
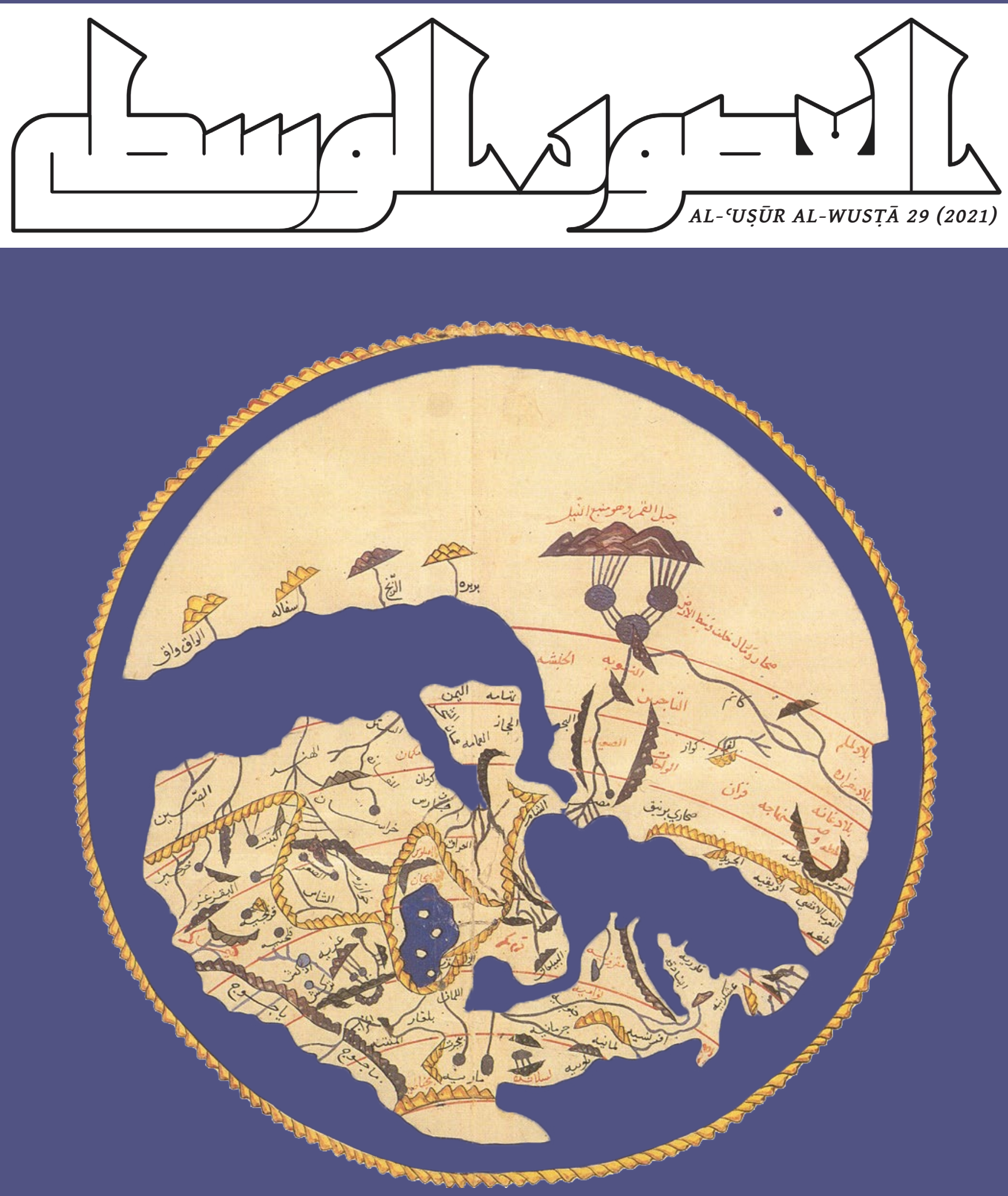

THE JOURNAL OF

MIDDLE EAST MEDIEVALISTS 
Middle East Medievalists (MEM) is an international professional non-profit association of scholars interested in the study of the medieval Middle East, expansively defined to include all geographies with prominent Muslim political, religious, or social presences between 500-1500 CE. MEM has two primary goals. The first is to increase the representation of medieval scholarship at scholarly meetings by co-sponsoring panels. The second is to foster communication among individuals and organizations with an interest in the study of the medieval Middle East.

Middle East Medievalists

MEM officially came into existence on 15 November 1989 at its first annual meeting, held in Toronto. As part of its effort to promote scholarship and facilitate communication among its members, MEM publishes al-'Ușūr al-Wusțā (The Journal of Middle East Medievalists).

\section{EDITORS \\ Antoine Borrut, University of Maryland \\ Matthew S. Gordon, Miami University \\ Alison Vacca, University of Tennessee, Knoxville}

\section{MANAGING EDITOR}

Christiane-Marie Abu Sarah, Erskine College

\section{BOOK REVIEW EDITORS}

Malika Dekkiche, University of Antwerp

Luke Yarbrough, University of California, Los Angeles (UCLA)

\section{EDITORIAL BOARD, $A L-{ }^{'} U S \bar{U} R$ AL-WUST $\bar{A}$ (THE JOURNAL OF MIDDLE EAST MEDIEVALISTS)}

Zayde Antrim, Trinity College

Sobhi Bouderbala, University of Tunis

Muriel Debié, École Pratique des Hautes Études

Fred M. Donner, University of Chicago

David Durand-Guédy, Independent Scholar

Nadia Maria El-Cheikh, American University of Beirut

Maribel Fierro, Consejo Superior de Investigaciones Científicas

Emma Gannagé, American University of Beirut

Denis Genequand, Site et Musée romains d'Avenches

Ahmet Karamustafa, University of Maryland

Étienne de La Vaissière, École des Hautes Études en Sciences Sociales

Stephennie Mulder, The University of Texas at Austin

Marina Rustow, Princeton University

Isabel Toral-Niehoff, Free University of Berlin

Alison M. Vacca, University of Tennessee, Knoxville

Peter Webb, Leiden University

\section{ISSN 1068-1051}

\section{COPYRIGHT AND PERMISSIONS}

This is an open access journal distributed under the terms of the Creative Commons Attribution-NonCommercialNoDerivatives 4.0 International License, which allows users to copy \& distribute the material in any medium or format in unadapted form only, for noncommercial purposes only, \& only so long as attribution is given to the original authors and source. To view a copy of this license, visit: http://creativecommons.org/licenses/by-nc-nd/4.0/

\section{BOARD OF DIRECTORS, MIDDLE EAST MEDIEVALISTS}

Stephennie Mulder, President

The University of Texas at Austin

Najam Haider, Vice President

Barnard College

Zayde Antrim, Secretary

Trinity College

Adam Talib, Board Member

Durham University

Arezou Azad, Board Member

University of Oxford

Khodadad Rezakhani, Board Member

Leiden University

Aurora González Artigao,

Graduate Student Representative

Consejo Superior de Investigaciones Científicas-

Spanish National Research Council, Madrid

Kader Smail, Graduate Student Representative

University of Maryland

\section{CONTACT INFORMATION AND WEBSITES}

Journal Submissions: aborrut@umd.edu

Website of the Middle East Medievalists: http://middleeastmedievalists.com/

Website of al- 'Ușūr al-Wusțā: https://www.middleeastmedievalists.com/ al-usur-al-wusta/

Become a member of the Middle East Medievalists: https://www.middleeastmedievalists.com/ membership-form/

Al- 'Ușūr al-Wusțā (Editorial Office)

Antoine Borrut, Editor

Department of History, University of Maryland

2115 Francis Scott Key Hall,

College Park, MD 20742-7315 USA 


\section{TABLE OF CONTENTS:}

Letter from the Editors

Antoine Borrut, Matthew S. Gordon, and Alison Vacca i-iii

\section{MEM AWARDS:}

Remarks by Michael Cook, Recipient of the 2020 MEM Lifetime Achievement Award. iv-ix

\section{ARTICLES:}

The Digraph اي in the Quranic Consonantal Text and the Identification of a New Letter Shape for Final Hē in the 7th to 8th Century Arabic Script Ahmad Al-Jallad $1-19$

A Preliminary Study of the Pseudo-Aristotelian Hermetica: Texts, Context, and Doctrines

Liana Saif. $20-80$

Created After, From, and For the Man? Development of Premodern Shi i Exegetic Discourse on the Creation of Woman

Katja von Schöneman

The Life of Christopher

Joshua Mugler

The Ribāt of Gurjī Khātūn ("the Georgian Lady"): New Data about Women Patrons, Chancery Practices, and Foundation Inscriptions in Seventh/Thirteenth-Century Saljuq Anatolia David Durand-Guédy

Mariun: An Exiled Queen's Pilgrimage and Death in Jerusalem

Gohar Grigoryan Savary

\section{REVIEW ESSAYS:}

Blurred Boundaries and Novel Normativities: The Jews of Arabia, the Quranic Milieu, and the "Islamic Judaism" of the Middle Ages (A Review of Aaron W. Hughes' Shared Identities: Medieval and Modern Imaginings of Judeo-Islam and Muslim and Jew: Origins, Growth, Resentment) Michael E. Pregill 256-302

Feeling Bad about Emotional History: The Case of Andalucismo (A Review of Charles Hirschkind's The Feeling of History: Islam, Romanticism, and Andalusia) Alejandro García-Sanjuán 


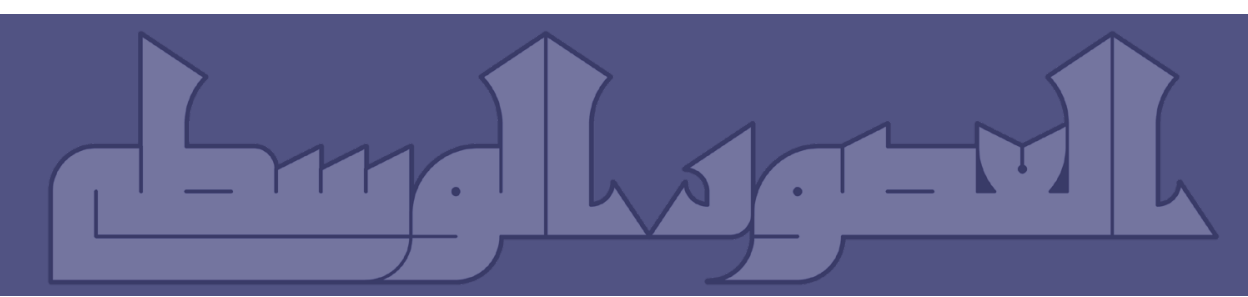

\section{TABLE OF CONTENTS (CONT.):}

\section{CONFERENCE REPORT:}

Pre-Modern Comparative Literary Practice in the Multilingual Islamic World(s)

(Oxford Comparative Criticism and Translation Research Centre, University of Oxford, 22-24 July 2021)

Clarissa Burt

\section{BOOK REVIEWS:}

Julián M. Ortega Ortega's La conquista islámica de la Península Ibérica: Una perspectiva arqueológica Xavier Ballestín

Eneko López Martínez de Marigorta's Mercaderes, Artesanos y ulemas:

Las ciudades de las coras de Ilbira y Pechina en época omeyan

Aurélien Montel

Challenging the Historiography of Philosophy, Science, and Religion through Greek-into-

Arabic Translations from Eleventh-Century Antioch (A Review of Alexandre M. Roberts' Reason and Revelation in Byzantine Antioch: The Christian Translation Program of Abdallah ibn al-Fadl)

Alberto Bardi

Konrad Hirschler's A Monument to Medieval Syrian Book Culture: The Library of Ibn 'Abd al-Hādī Caterina Bori 348-355

The Library of Arabic Literature Young Readers Series

(Philip Kennedy, Bilal Orfali, and Maurice Pomerantz, eds., Mā lidhdhat al-`ishq illā li-1-majānīn;

Philip Kennedy, Enass Khansa, and Bilal Orfali, eds., Hiyākat al-kalām; and Philip Kennedy,

Enass Khansa, and Bilal Orfali, eds., Lima ishtadda 'ishq al-insān li-hādhā al-(ālam?)

Philip Raad

Alejandro García Sanjuán's Yihad: La regulación de la guerra en la doctrina islámica clásica

Javier Albarrán

Ana Labarta's Anillos de la Península Ibérica, 711-1611

Maribel Fierro

Daniella Talmon-Heller's Sacred Place and Sacred Time in the Medieval Islamic Middle East

Kader Smail 369-373

Wendy M. K. Shaw's What Is "Islamic" Art? Between Religion and Perception

Sarah Slingluff. 


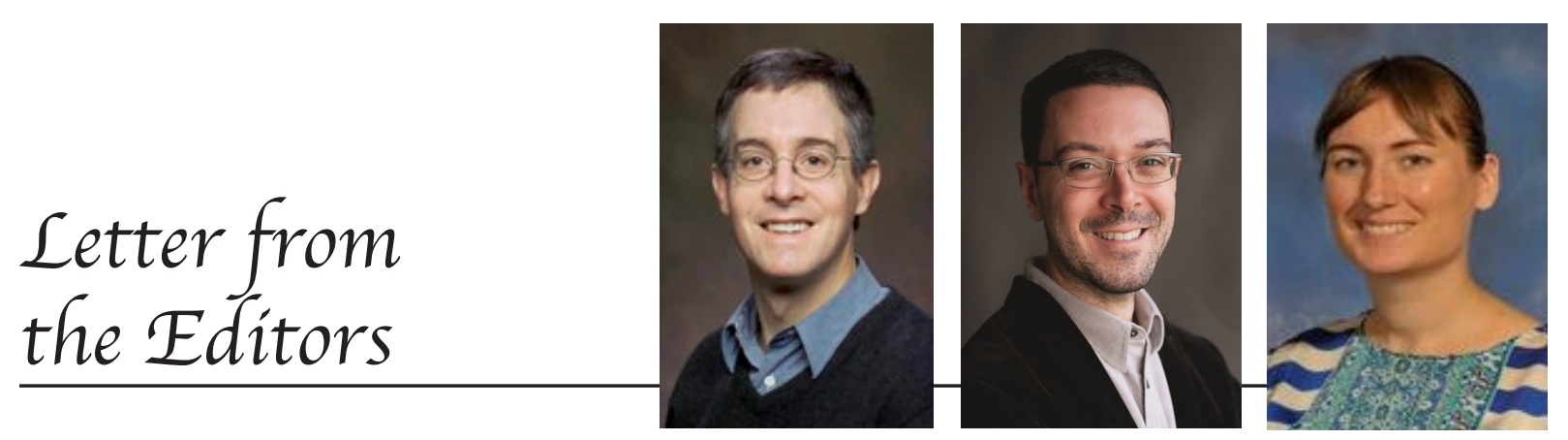

W e are very pleased to publish the newest issue of al- 'Ușūr al-Wustā $(U W)$. We remain, as ever, committed to the ideal of providing a venue for up-to-date scholarship in the disciplines of early and medieval Islamic, Arabic, and Middle East studies, while remaining a source of news and information on the current work of our colleagues and students.

On a personal note, the two of us, Antoine and Matthew, are delighted (and, yes, relieved) to announce that we will be turning over editorship of the journal to our esteemed colleagues Alison Vacca (UTK) and Zayde Antrim (Trinity College). To effect the transition, we asked Alison to join us in producing this issue (UW 29); Alison and Zayde will be taking over as coeditors from this point forward. We cannot think of two colleagues more likely to sustain the high standards of both scholarship and editing that we have pursued over these past years.
The editorial adventure of turning MEM's long-established bulletin into an online, peer-reviewed, and openaccess journal began almost a decade ago, when Antoine became secretary of MEM (November 2011) and Matthew MEM's president the following year. By then, MEM's bulletin was reaching its end. Although two new issues came out (in 2012 and 2014), it seemed clear that the bulletin-established in 1989 and expanded by Fred M. Donner from the 1990s on-was no longer sustainable in its original format in our digital age. MEM approved the idea of turning $U W$ into a full-fledged journal at the November 2013 MESA meeting in New Orleans. Antoine and Matthew volunteered to become coeditors, thus embarking on a journey whose many challenges we perceived dimly, if at all.

We presented the first issue of the newly conceived journal at the MESA meeting in Denver in November 2015, the same meeting at which Matthew stepped

(Photo of Antoine Borrut by Juliette Fradin Photography)

(c) 2021 Antoine Borrut, Matthew S. Gordon, and Alison Vacca. This is an open access article distributed under the terms of the Creative Commons Attribution-NonCommercial-NoDerivatives License, which allows users to copy and distribute the material in any medium or format in unadapted form only, for noncommercial purposes only, and only so long as attribution is given to the original authors and source. 
down as MEM's president. Seven years, forty-five articles, fifty-eight book reviews, and assorted other submissions later, we have published 2,261 pages. Along the way, after thousands of emails exchanged with authors and reviewers, the journal finally made its way to the Directory of Open-Access Journals and to a new home. As announced in our previous issue, and thanks to the efforts of Manan Ahmed Asif (Columbia University), $U W$ is now on a new platform, Academic Commons, a program of the Columbia University library system. We would like to direct all potential authors and contributors to that site (https://journals.library.columbia. edu/index.php/alusur/index).

Our efforts throughout would have fallen short had it not been for the contributions of four colleagues. Christiane-Marie Abu Sarah, now assistant professor of history at Erskine College, has served as managing editor from the onset and was instrumental to the success of the journal. We are deeply grateful for her consistent and excellent work. To Hanna Siurua, our lasting appreciation for equally consistent and fine editing. Warmest thanks, as always, to Malika Dekkiche (University of Antwerp) and Luke Yarbrough (UCLA), our book review editors, for again bringing together a set of extended reviews on topics in a variety of disciplines.

The new issue begins with a statement by Prof. Michael Cook, recipient of the 2020 Middle East Medievalists Lifetime Achievement Award, regarding his intellectual training and the fields to which he has devoted a rich and illustrious career as author, educator, and mentor. Among the many honors accorded to Prof. Cook in recent years was the Norwegian government's Holberg Prize (2014) and the Balzan Prize (2019), awarded by the International Balzan Prize Foundation in recognition of "the exceptional impact of [Professor Cook's] work on several research areas in Islamic Studies." Our previous issue featured a special dossier of six papers by emerging scholars in Arabic, Islamic, and Middle Eastern studies developed in the Holberg Seminar (2015-18), directed by Cook and Borrut alongside Jack Tannous (Princeton) and Khaled El-Rouayheb (Harvard).

What follows is a set of six full-length research articles on a range of topics. Each evinces the high quality of the scholarship of which our colleagues, in their respective disciplines, are capable. Ahmad al-Jallad has produced a well-illustrated and technical study of what he proposes was a particular orthographic feature of seventh- and eighth-century Arabic script. In an equally close study of the set of texts known typically as the pseudo-Aristotelian Hermetica, Liana Saif argues for a third/ ninth-century dating of these texts, which purport to record conversations between Aristotle and Alexander the Great. Katja von Schöneman, in a feminist, discourse-analytic reading, treats Arabic commentaries on Qur’ān 4:1 produced by twelve premodern $S^{-} \bar{i}^{\top} \overline{1}$ exegetes. Joshua Mugler's submission contains a study, translation, and edition of The Life of Christopher, a tenth-century GreekArabic Christian hagiography produced in Baghdad. This is our second Arabic edition, the first having been published by Jelle Bruning in 2020 (UW 28). In a study of women in the medieval and premodern Islamic world, David DurandGuédy's contribution examines an Arabic inscription from an Anatolian caravanserai 
built by the Georgian wife of a thirteenthcentury Rum Saljuq ruler. The final piece, by Gohar Grigoryan Savary, considers the life-and the problematic historiography that surrounds it-of Queen Mariun (d. 1377?), a significant figure of fourteenth-century Cilician Armenia and Mamluk Jerusalem.

The issue turns next to a pair of substantial review essays by, respectively, Michael Pregill and Alejandro GarcíaSanjuán. Pregill discusses two recent works by Aaron W. Hughes on "the JewishMuslim encounter" in the premodern and modern Islamicate world. García-Sanjuán, for his part, in a wide-angle reading of Charles Hirschkind's The Feeling of History: Islam, Romanticism, and Andalusia (University of Chicago Press, 2021), takes on the questions surrounding the legacy of Islamic Iberia in modern Spain. The two essays are then followed by a report on a conference, "Pre-modern Comparative Literary Practice in the Multilingual Islamic World(s)," organized by the Oxford Comparative Criticism and Translation Research Centre (OCCT) at the University of Oxford, 22-24 July 2022. Our thanks to Clarissa Burt (United States Naval Academy) for the report.

We close with the book review section. The nine reviews treat recent publications dealing with such topics as jihād as a legaldoctrinal issue; archaeology and the ArabIslamic conquest of Iberia; the Greek-to-
Arabic translation project of the medieval Islamic period; medieval Damascene book culture and letters; and new approaches to the study of Islamic art, as well as sacred space and sacred time in medieval Islam. We are forever grateful to those of our colleagues who took on the invaluable if sadly under-appreciated task of producing the reviews. As with the articles, the disciplinary topics of the publications treated in the reviews, alongside the expertise manifested by the reviews themselves, speak volumes of the vitality of the scholarly community to which we belong.

As is our custom, we close with the following two reminders.

First, we rely on your financial support. Again, although $U W$ is online, open access, and peer-reviewed, it is certainly not free. To cover the costs of publication and the work of our staff, among other expenses, you provide valuable support by keeping your membership in Middle East Medievalists up to date. For information on membership and the fund, please proceed to the MEM home page at:

https://www.middleeastmedievalists. com/membership-form/

Second, the full run of the journal, in its several iterations, is available online. To access the archive, please go to:

https://journals.library.columbia. edu/index.php/alusur/issue/ archive.

Sincerely, Antoine Borrut, Matthew Gordon, and Alison Vacca 


\title{
MEM Awards
}

\section{Remarks by the Recipient of the 2020 MEM Lifetime Achievement Award Given at the Annual Meeting of Middle East Medievalists (Online, 18 October 2020)}

\author{
Michael Cook \\ Princeton University \\ (mcook@princeton.edu)
}

$\mathrm{F}$ irst and foremost, let me say how much I appreciate the honor that Middle East Medievalists, its members and officers, are doing me in giving me this award. I'm very happy to be a link in a chain that includes scholars of the caliber of Wadad al-Qadi, Fred Donner, and Maribel Fierro, to name just a few of my predecessors. You asked me to speak for half an hour about two things in acknowledgment of the award: my career and the discipline in general. As to the discipline in general, I contributed my two cents of doom and gloom at a recent MESA panel organized by Antoine Borrut, ${ }^{1}$ and I do not want to get everyone depressed againeven though my remarks on that occasion included a cent of optimism. So what I will do is talk mainly about my career, and just come back briefly to the discipline at the end. The main interest of my career from the point of view of readers today is probably that it took shape under conditions very different from what we are now familiar with.

One thing I really like about our field is that if you ask people the simple question "How on earth did you get into this field?" you get so many different and often colorful answers. So here is mine. It begins with me about seven years old on a hill a few miles north of Izmir. Think of olive trees, vines, and some tents; this is an archaeological excavation led by my father and Ekrem Bey. Ekrem BeyEkrem Akurgal-was a good Kemalist, but like many of his generation he kept his notebooks in the Arabic script. This piqued my childish curiosity, and I asked him to write out the Arabic alphabet, which he

1. “The Future of the Field: 'Premodern' Islam at the Crossroads," MESA panel held on October 5, 2020, featuring also Profs. Matthew S. Gordon, Stephennie Mulder, Adam A. Sabra, and A. Holly Shissler.

(c) 2021 Michael Cook. This is an open access article distributed under the terms of the Creative Commons Attribution-NonCommercial-NoDerivatives License, which allows users to copy and distribute the material in any medium or format in unadapted form only, for noncommercial purposes only, and only so long as attribution is given to the original authors and source. 
did. I think I learnt the first two letters before I got bored and ran off to play (since then my work discipline has improved somewhat). I did not get around to learning the rest of the alphabet till I was nineteen and we were living in Bristol. This city had an old and well-stocked municipal library, in which I found and borrowed a copy of Cowan's textbook An introduction to Modern Literary Arabic. At that point I went down with mild pneumonia-it was a cold, wet, English winter-and I was feverish as I read through the first pages of the book, with the result that the Arabic words I learnt then are still suffused with a touch of delirium. Once I recovered I made more rapid progress, but there was one problem: the book could not tell me what the language actually sounded like. My solution was to acquire an enormous radio that was powerful enough to tune into Radio Cairo, though not very reliably. The book and the radio at least got me started. Later my teachers at Cambridge warned me that if you persist in trying to learn Arabic, the first fifteen years are the worst. Looking back on it several decades later, I am inclined to see that as British understatement.

But in telling the story of how I learnt the Arabic alphabet, I have skipped over something that matters for the development of my career. Between learning the first two letters and completing my knowledge of the alphabet I had made a rational choice-one of two I have made in the course of my academic career. By way of background, at the age of sixteen I was going to be a physicist, and it is still part of my self-image to believe that I could have made it as a fifth-rate physicist. In England in those days you had to specialize at a very early stage, and I had embarked on a track that focused on physics and math. Soon after I had a truly formative conversation with my math teacher, Mr. Unwin. He told me that as a mathematician I was all right, but nothing special. This was the most valuable piece of career advice I have ever been given, and the next day I switched to a track with a focus on history and English literature. I was not much good at the English literature, but I was some good at the history component. Now comes the rational choice. Somehow I figured out that if you brought an average talent to bear on mainstream history, you faced a lot of competition in an overpopulated field. (Perhaps I should explain that in those days mainstream history meant English and Western European history, with the Celtic fringe and the non-Western world evenhandedly excluded.) By contrast, I was thinking, if you were to learn a language or two and shift to the non-Western world, you would find yourself in a much less crowded part of the Western academy, with much more fresh ground to break. In retrospect I think I got that right, and it has been the foundation of my career.

Here, then, is how I executed my rational choice. I went up to Cambridge and first spent two years reading history, learning how state-of-the-art history was done. The highlights of those years were two people at whose feet I sat, Moses Finley and Michael Postan. In politics they were chalk and cheese, but they were both inspiringly intelligent lecturers. Then I went on to two years of Oriental studies, studying Turkish and Persian and some Arabic on the side. That was when I met Professor Arberry. He liked to see every student who was about to embark on Oriental Studies in the Middle Eastern 
field for a few minutes, but it tended to be a slightly awkward occasion because he did not have very much to say to the student. Fortunately I had been learning Persian grammar from an old copy of Sir William Jones's little book A Grammar of the Persian Language, and I was stuck on a sentence that I could not make syntactic sense of. So I pulled out the book and asked him about it. He took one look and immediately diagnosed the problem: the preposition bar had dropped out at the beginning of the sentence. I think he was tickled by the fact that a member of a barbarous generation such as mine should be learning Persian from an eighteenthcentury textbook, making this a fleeting moment of warmth and contact. It also taught me a philological lesson: try your hardest to make sense of the text in front of you, but do not forget the possibility that it may not in fact make sense. I applied that lesson a year or so later when reading Hāfiz and coming to the half-verse Zinda R $\bar{u} d-u$ bāgh kārān yād bād, "Let's remember the Zinda Rūd and the bāgh kārān." The Zinda Rūd is, of course, the river of Isfahan, but what are bāgh kārān? The English translators and the Bosnian commentator Sūdi said it meant "gardeners," but the Persian for "gardener" is bāghbān, not bāghkār. Now, as it happened, in another of our courses we were reading Rāwandī's Rāhat al-șudūr, and there we came upon an account of a garden in Isfahan called the Bāgh-i Kārān. So that was what Haāfiz was talking about. No doubt some Iranian scholar had pointed this out long before, but the experience of solving the problem gave me a bit of a high, and the hope that if I tried hard enough I could maybe be some good in the field I was entering. Again, I was fortunate in my teachers. There was
Dr. Hopkins (the father of Simon Hopkins), who took a real interest in his students in very practical ways-he looked at the abominable imitation of print in which we wrote Arabic and pushed us to learn ruq'a. And there was Turhan Gendjei, my teacher of Turkish, to whom I owed my awareness of Sūdì. He was a fine scholar, though he did not publish much. He never prepared the texts we read, and for the most part he did not need to. But it was the moments when he was puzzled that were the most valuable learning experience for me: we would be sitting in his study with his books on the shelves around us, and he would reach for the work of reference or the parallel passage that would solve the problem. That taught me a lot about what to do when you are stumped.

College is also about the people you meet in your own age group. Someone who made a big difference to my career was Roy Mottahedeh, who was in Cambridge on a fellowship. I remember puzzling with him about a word spelled $b-m-b$ in a Persian text of the early twentieth century. Today a beginner would have no trouble seeing in it the loan-word "bomb," but in those days you did not expect to see such things in the language of Hāfiz and Rāwandī. Roy was to play a big part in getting me to Princeton, but that comes later-first comes my time at the School of Oriental and African Studies.

I began my years at SOAS as a postgraduate student doing research under Bernard Lewis. This was economic history based on the Ottoman fiscal surveys of the fifteenth and sixteenth centuries. I was supposed to be writing a dissertation, but I never actually submitted it-which was not smart, but I got away with it, publishing my work as a book. Lewis then gave me 
a lectureship in economic history, but by then I was more interested in other things, so that I never really did much more economic history (apart from a rather juvenile chapter for the second edition of the Legacy of Islam²). I am not sure that was smart, either, but again I got away with it; nobody seemed to be very concerned to check up on what I was doing. I mention these things because they show you how lucky I was, not just in getting away with it, but also in having a decade in which I could cast around and experiment. For example, I wrote a book about Islam and the nation. I never published it, but this period of my life was fundamental in my formation.

Two people were really important to my development in that period. One was Albert Hourani at Oxford. He was genuinely interested in young scholars and their careers, and kept an eye on mine. Once when he went on leave he asked me to stand in for him and give a course of undergraduate lectures on early Islamic history. That was a subject I knew precious little about when I started, but by the end I was beginning to know my way around. The other person was Patricia Crone, with whom I did the only collaborative work I have done in my career. It is not that I think we were right in much of what we said, but it got me thinking creatively about a lot of things I have worked on ever since.

The final vignette of life at SOAS I want to give you is the découverte. It was Colin Heywood who instituted this. He has always been fascinated by Wittek; unlike me, he had met him. In Belgium in the 1930s Wittek and Lemerle had apparently established the principle of the découverte quotidienne: every day you had to make some discovery and submit it to your colleagues. In reviving this tradition we quickly decided that quotidienne was for gods and heroes, and met once a week instead. A group of us would gather over a bottle of wine after the administration had gone home and the building had gone quiet, and we would discuss some little discovery one of us had made. Colleagues like Robert Irwin, Sandy Morton, and David Morgan would be there. It was a little oasis of calm and camaraderie during Mrs. Thatcher's onslaught on Britain's universities. Inspiring as the découverte was, this was a good time to think of emigrating.

That brings me to my time at Princeton. Thanks to Abraham Udovitch and Roy Mottahedeh, I spent a spring semester at Princeton on approval, and a couple of years later, again thanks to them, I got an offer. Accepting it was the second rational choice of my career, but this time I did not need to do any figuring out. Altogether, the last thirty-four years have made a fantastic difference to my career. One aspect of this has been the scale of the available resources. It was my first day on the job when my chair told me that the department had a fund that needed to be spent by a certain date; could I think of a way to spend it? That was the first time I had ever heard anyone ask such a question. The change extended to my salary: from the start I was paid about twice my British salary. With spending habits shaped in Mrs. Thatcher's Britain, I have never quite

2. Michael Cook, "Economic Developments," in The Legacy of Islam, 2nd ed., ed. Joseph Schacht with C. E. Bosworth, 210-43 (Oxford: Clarendon, 1974). 
adapted to this. At the same time I had the good luck to find myself in a department that was very supportive of my scholarship and sheltered me from much of the waste of time and energy that goes into America's culture wars. I also had the good fortune to meet my wife, Kim Hegelbach, without whose reassuring presence in my life I would have been far less productive over these decades. But in academic terms the biggest change has been my role as a dissertation adviser. During my time at SOAS I had never once had a PhD advisee; since then I have had about as many as I have spent years at Princeton, roughly one $\mathrm{PhD}$ dissertation a year, not to mention other dissertations I have played a lesser role in. Most of the ones I have advised have been outside my comfort zone as a researcher. For example, the very first was about the fifteenth-century dream diary of a failed Sufi, and Sufism is definitely not my thing. But it was very interesting. If you think about it, everybody in the field goes on and on about successful Sufis, but here was a chance to see what you had to do to fail as a Sufi. I tried to get my student to put "failed Sufi" in the title of the book that came out of the dissertation, but he would not hear of it.

Right now I think I have five dissertations still in the oven. One is about what people got out of the Turāth in the twentieth-century Muslim worldor maybe just Egypt, since dissertations have a way of narrowing their focus. One is about tracing linkages through women in late Jāhilī and early Islamic society, going behind the patriarchal façade of the genealogists. One is about the Mongols and their client states in southern Iran, a basic point being that the Garmsir is so arid it is hard to cross, particularly for a Mongol army with all its horses and sheep. One is about state formation in the early modern Yemen: you have the Zaydi imamate tradition, and you have the Ottomans gatecrashing the Yemen till they are kicked out, so what was the Ottoman legacy in governance to the post-Ottoman Zaydi imamate? And one is about the law of $s a b b$-what is to be done when dhimmis vilify the Prophet. Here the drama lies in the evolution that takes place within the Hanafi law school, and incidentally it dramatizes how spurious the Pakistani blasphemy law is in Hanafi terms. So I guess the total number of dissertations I have advised could reach forty before I am done, a good Islamic number. They are obviously all very diverse, but there is one thing I can say about them in general. It seems my advisees genuinely believe $I$ have been doing them a big favor, or at least the ones who have submitted their dissertations so far have said so in their prefaces. I have no objection to this, and it is absolutely fine by me if they actually think that way. But the real truth is that they have been doing me a big favor: these dissertations are my continuing education program, and the older I get the more I need it.

The other thing I will say about them is that they have brought something significant home to me-it is a point I made at that MESA panel already mentioned. We are in a field where there is still an abundance of new ground to break. At that panel I used the case of dynastic monographs as an example; the genre is an old one, going back at least to Wellhausen's Arab Kingdom, yet there are many perfectly decent dynasties in Bosworth's handbook that have yet to receive monographic study. But here let me take the example of 
the study of the Qur'ān. If anything in our field was saturated with modern scholarly studies, this topic would be it. Indeed, for a long time I thought the study of the Qur'ān was saturated, and I would tend to steer students away from it. But the fact is that some of my former adviseesand not just my former advisees-have done dramatically new work in that field, making really impressive breakthroughs and showing how completely wrong I was in my expectations. So I guess one way to see this award is as encouragement to obsolesce gracefully.

My contacts with scholars in the early years of their careers have not, of course, been limited to Princeton graduate students. In particular, I have been lucky enough to find myself in receipt of funds that I was able to use to bring bright young scholars together in long-term seminars in which a central feature has been the exchange of feedback on their current work. One of these ventures was the Holberg Seminar, and the other, beginning last year, is the Balzan Seminar. ${ }^{3}$ Both have helped me, as well as the colleagues who generously participated in them, keep in touch with new and exciting scholarship in the field and play some part in shaping it. These seminars are yet another contribution to my continuing education program.

With all this I have not left myself much time to cover the discipline in general, and as I said at the beginning I do not want to get back into the doom and gloom. But what I said above about the new ground that is there for the breaking is one big point that an optimist could focus on. We are fortunate not to be in a field so saturated that the only way to make a splash is to be either utterly brilliant or utterly silly. So let me end by expressing the hope that we will get a continuing opportunity to break all this new ground. As a link in the chain of recipients of this award, I would like to think that that I will have successors as distinguished as my predecessors, and that in the future it will still be possible for scholars to have the luxury of spending a lifetime in this field, as I have been privileged to do.

3. On the Holberg Seminar, see the special dossier published last year in this journal: "Islamic History Broadly Conceived: A Tribute to Michael Cook and the Holberg Seminar," guest-edited by Sébastien Garnier, Matthew L. Keegan, and Pamela Klasova, Al- 'Ușūr al-Wusțā 28 (2020). A brief presentation of the Balzan Seminar, which focuses on the formation, maintenance, and failure of states in the Muslim world before 1800, can be found here: https://www.balzan.org/en/prizewinners/michael-cook/research-project-cook. 


\title{
The Digraph إى in the Quranic Consonantal Text and the Identification of a New Letter Shape for Final $H \bar{e}$ in the 7th to 8th Century Arabic Script*
}

\author{
Ahmad Al-Jallad \\ The Ohio State University
}

(al-jallad.1@osu.edu)

\begin{abstract}
This paper proposes a hitherto unrecognized orthographic practice in the Quranic consonantal text: use of the digraph إl, that is, alif + denticle, to represent the noninitial glottal stop, most often adjacent to the high vowels $\mathrm{i} / \overline{1}$ and less commonly in other environments. This feature leads to the identification of a new letter shape for the final hē in the early Islamic Arabic hand, originating in the Nabataeo-Arabic script, which in turn can explain a number of previously enigmatic spellings in the Quranic consonantal text.
\end{abstract}

\section{Introduction}

The Quranic consonantal text ${ }^{1}$ (henceforth QCT) contains several layers of historical Arabic orthography. Its foundation lies in the orthographic principles of the imperial

\footnotetext{
* I owe a great debt to Marijn van Putten for his help in locating examples of the orthographic peculiarities discussed in this paper and for finding supporting attestations in the manuscripts he is currently studying. I also thank Hythem Sidky for pointing me toward relevant examples in early Quranic codices. I made a short Facebook post on the identification of the new shape of the final he in a Quranic manuscript on March 30, 2018, and I thank Yüsef Gürsey and Mila Neishtadt for discussing the further applications of this letter shape with me there. All errors are my own.

Linguistic conventions:

* $=$ reconstructed pronunciation

$\mathrm{C}=$ consonant $\mathrm{V}=$ vowel

/ / = phonemic transcription

Details of cited pre-Islamic Arabic-script inscriptions are given in an index following the main body of this article.

1. This term refers to the theory that the extant Qurans go back to a single written archetype, conventionally labeled the 'Uthmānic Codex, and that the text was composed in a single dialect of Arabic. For the full elaboration

(c) 2021 Ahmad Al-Jallad. This is an open access article distributed under the terms of the Creative Commons Attribution-NonCommercial-NoDerivatives License, which allows users to copy and distribute the material in any medium or format in unadapted form only, for noncommercial purposes only, and only so long as attribution is given to the original authors and source.
} 
Aramaic writing tradition, ${ }^{2}$ inherited from Arabic's Nabataean forebear. These were followed by a variety of innovative spelling strategies that emerged after the Nabataean script was fully applied to the representation of the Arabic language. ${ }^{3}$ These innovations do not necessarily originate in the same place and time. The ever-growing corpus of pre-Islamic Arabic-script inscriptions suggests that the Nabataean Aramaic script did not develop directly into a single Arabic script but rather produced several lineages of Arabic scripts with their own orthographic practices and, sometimes, letter shapes. ${ }^{4}$ The establishment of Arabic as the language of an empire in the seventh century produced a homogenizing bottleneck, narrowing much of the variation found in pre-Islamic sources.

Older and newer orthographic practices exist side by side in the QCT and, to a lesser degree, in Classical Arabic orthography. The notation of internal long a illustrates this phenomenon. There is no attempt to indicate the long vowel internally in the extant sixth-century Arabic-script inscriptions, and there was no mater lectionis for internal $\bar{a}$ in the Nabataeo-Arabic and Nabataean scripts that preceded Arabic. ${ }^{5}$ The Quran in general agrees with this practice: long $\bar{a}$ is rarely indicated word-internally, with the exception of words belonging to the CāC pattern. ${ }^{6}$ A newer, plene orthographic practice that indicates $\bar{a}$ with alif in other environments seems to have emerged sometime in the seventh century. As van Putten has observed, ${ }^{7}$ the use of this new orthographic practice appears to be optional in the QCT: several words are written in both ways, sometimes according to the ancient orthography and other times with the innovative plene spelling. Certain core

of this theory, see the introductions to M. van Putten, "The Development of the Triphthongs in Quranic and Classical Arabic," Arabian Epigraphic Notes 3 (2017): 47-74; idem, "The Feminine Ending -at as a Diptote in the Qur'ānic Consonantal Text and Its Implications for Proto-Arabic and Proto-Semitic," Arabica 64, nos. 5-6 (2017): 695-705; idem, “'The Grace of God' as Evidence for a Written Uthmanic Archetype: The Importance of Shared Orthographic Idiosyncrasies," Bulletin of the School of Oriental and African Studies 82, no. 2 (2019): 271-88.

2. W. Diem, "Untersuchungen zur frühen Geschichte der arabischen Orthographie: I. Die Schreibung der Vokale," Orientalia, n.s., 48 (1979): 207-57, at 209-10.

3. This second layer is often called Higāzī-Meccan in the literature; see W. Diem, "Some Glimpses at the Rise and Early Development of Arabic Orthography." Orientalia, n.s., 45 (1976): 251-61, at 255. However, as we shall see in the following discussion, the orthographic innovations of this layer do not stem from a single source or period.

4. This idea is developed in A. Al-Jallad, “"Moge God Yazīd de Koning Indachtig Zijn': Nadere Beschouwingen over de Yazīd-Inscriptie en de Ontwikkeling van de Arabische Schriften," in Mohammad en de Late Oudheid, ed. J. van den Bent, F. van den Eijnde, and J. Weststeijn, 198-208 (Amsterdam: Verloren, 2018).

5. On the development of the Arabic script from its Nabataean forebear, see L. Nehmé, "A Glimpse of the Development of the Nabataean Script into Arabic Based on Old and New Epigraphic Material," in The Development of Arabic as a Written Language, ed. M. C. A. Macdonald, 47-88 (Oxford: Archaeopress, 2010). On Nabataean orthography, see J. Cantineau, Le Nabatéen (Osnabrück: Zeller, 1978); and on the orthography of Arabic words, especially those in the inscriptions of Hegrā, see J. Healey, The Nabataean Tomb Inscriptions of Mada'in Saleh (Oxford: Oxford University Press, 1993).

6. For example, the verb kāna is spelled كان more often than it appears, defectively, as كـ. Exceptions do exist: qāla is sometimes spelled قَ in early manuscripts.

7. For example, we find both عبده (Q 27:59) and عباده (Q 35:28) in the Cairo edition, and even greater variation once we compare spellings with internal ā across earlier manuscripts; see M. van Putten, Quranic Arabic: From its Hijazi Origins to its Classical Reading Traditions (Leiden: Brill, forthcoming). 
vocabulary items of the writing tradition, however, are not affected by the new spelling and continue to be written according to the old orthography, even to the present day; examples include the demonstratives 'this' هـذا / رحمن / ذلـ / raḥmān/.

This paper identifies a hitherto unrecognized orthographic practice in the QCT, which perhaps emerged in the period before the loss of the glottal stop ${ }^{8}$ and was phased out by the more phonetic writing principles of the main orthography of the Quran: use of the digraph إ, that is, alif + denticle, to represent the noninitial glottal stop, most often adjacent to the high vowels $i / \bar{i}$ and less commonly in other environments. This interpretation leads to the identification of a new letter shape for the hē in the early Islamic Arabic hand, originating in the Nabataeo-Arabic script, which in turn may explain a number of previously enigmatic spellings in the QCT.

\section{Identifying the ایى Digraph}

The following table presents all the examples known to me of the use of the digraph in the Cairo Edition and early Quranic manuscripts, along with the pronunciation of the words in which it occurs through various stages of the Arabic language.

Table 1: The Attestations of the Digraph 1 in the Cairo Edition \& Early Quranic Manuscripts ${ }^{9}$

\begin{tabular}{|c|c|c|c|}
\hline QCT spelling & $\begin{array}{l}\text { Proto-Arabic } \\
\text { pronunciation }\end{array}$ & $\begin{array}{l}\text { Classical Arabic } \\
\text { pronunciation }\end{array}$ & $\begin{array}{l}\text { Reconstructed QCT } \\
\text { pronunciation }^{10}\end{array}$ \\
\hline جات11 & * gi'tu & ği ${ }^{2} t u$ & guit \\
\hline جاي 12 & ${ }^{*} g i^{1} \mathrm{a}$ & $\check{g}^{\prime}{ }^{\prime} a$ & $g^{\prime} \bar{i}$ \\
\hline شات13 & *síitu & šitu & śit \\
\hline شاى14 & *śVy'un & šay & śi \\
\hline
\end{tabular}

8. Classical Nabataean orthography indicated the Arabic glottal stop with aleph, ', regardless of the quality of the following vowel. The loss of the use of alif to represent the glottal stop, hamz, in the QCT results from the loss of that phoneme in its dialect; M. van Putten, "Hamza in the Quranic Consonantal Text," Orientalia 86 no. 3 (2018): 93-120. As Diem ("Glimpses," 254) has suggested, there must have been a local writing tradition of Arabic in the Hijāz that devised an orthography closer to the pronunciation of the local dialect, without the hamz. Nevertheless, these new spellings remained in some cases in competition with the older practice of representing the etymological glottal stop with alif. For example, the word du 'afá'u 'weak' (masculine plural) is spelled both according to the old orthography as ضعفا (Q 9:91) with the final etymological glottal stop represented by the alif and according to an innovative, phonetic spelling as I ضعفو (Q 14:25; 40:47) with the glide resulting from the loss of the glottal stop in pronunciation represented, / $u^{\mathrm{c}} \mathrm{afāw}(\mathrm{u}) /$.

9. Manuscript sigla follow https://corpuscoranicum.de/.

10. This reconstruction is based on van Putten, "Grace of God."

11. Q 19:27, in MS Tübingen, Universitätsbibliothek, Ma VI 165, fol. 12r.

12. Q 39:69; Q 89:23.

13. Q 24:62, in MS Tübingen, Universitätsbibliothek, Ma VI 165, fol. 37V.

14. Q 18:23. 


\begin{tabular}{|c|c|c|c|}
\hline QCT spelling & $\begin{array}{l}\text { Proto-Arabic } \\
\text { pronunciation }\end{array}$ & $\begin{array}{l}\text { Classical Arabic } \\
\text { pronunciation }\end{array}$ & $\begin{array}{l}\text { Reconstructed QCT } \\
\text { pronunciation }\end{array}$ \\
\hline باسته15 & *bi’ayāti-hu & bi’ayāti-hī & biyayātVh \\
\hline لانتتا16 & *li'ayāti-nā & li-’ayāti-nā & liyayāt $(V) n \bar{a}$ \\
\hline باسم & *bi’awyāmin & bi’ayyāmin & biyayyām \\
\hline باسى & *bi’ayyi & bi’ayyi & biyayy \\
\hline باسد19 & *bi’aydin & biaydin & biyayd \\
\hline ما_20 ماع & ${ }^{*}$ mi'ata & mi'atin & mìyah \\
\hline باسكم & ${ }^{*}$ bi-’ayyi-kum $(u)$ & bi-’ayyi-kum & biyayyikum \\
\hline ساى22 & *suyi’a (or śî̉a) & $s \bar{i}^{\prime} a$ & sī (or siyy) \\
\hline سايل23 & *su'ila & sū'ila & sīla \\
\hline فاين24 & ${ }^{*}$ fa-in & fa-in & fayin \\
\hline ياس25 & ${ }^{*}$ yї̀asu & yay’asu & yVyas \\
\hline تاسو |26 & ${ }^{*} t \bar{i}$ ’asu & tay’asū & $t V y a s \bar{u}$ \\
\hline السواى27 & *sū’an & $a s-s \bar{u}^{\prime} a$ & $a s-s \bar{u}$ \\
\hline راسي28 & ${ }^{*}$ ru'yayi-ya & $r u^{\prime} y \bar{a}-y a$ & riyyāy \\
\hline لايلف29 & $*^{*} i_{-}$-ilāfi & li-’ilāfi (or li-’̄lāafi) & liyilāfi \\
\hline ملاهـم31، ملانه 30 & $\begin{array}{l}\text { *mala'i-hŭ, } \\
\text { *mala'i-hum }\end{array}$ & $\begin{array}{l}\text { mala’i-hī, } \\
\text { mala’i-him }\end{array}$ & malayi-h/hum \\
\hline نباى32 & $*_{n a b a j i}$ & naba’i & nabay(i) \\
\hline
\end{tabular}

15. Q 6:35.

16. Saray Medina 1a; Großer Korankodex Q $74: 16$.

17. Q 14:5.

18. Passim, Surat al-Raḥmān, MS Paris, BnF, Arabe 331, fol. 48v.

19. Q 51:47.

20. Passim in the Cairo Edition, but sometimes spelled مس in other manuscripts, e.g., Samarqand Q 8:66.

21. Q 68:6.

22. Samarqand Q 11:77; compare with the Cairo Edition: سى.

23. Samarqand Q 2:108; compare with the Cairo Edition: سلى

24. Q 3:144; 21:34.

25. Q 12:87.

26. Q 12:87.

27. Q 30:10.

28. Passim, Q 12:43, 100, MS London, British Library, Or. 2165, fols. 25r, 27 r.

29. Q 106:1; for this analysis, see van Putten, "Hamza," 110.

30. Q 7:103; 10:75; 11:97; 23:46; 28:32; 43:46.

31. Q 10:83.

32. Q 6:34. 


\section{Discussion}

This section describes the distribution of digraph ای l. Its relatively limited use suggests that it is an orthographic relic rather than a productive feature of the spelling system used to write the earliest Qurans.

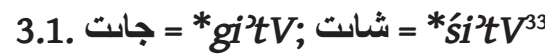

The third-person masculine singular of both of these verbs terminates in an alif in the

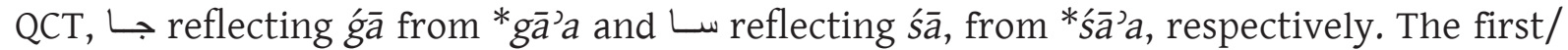
second-person form of these verbs in the synchronic dialect of the Quran, which had lost the glottal stop, must have been realized as git and śit, respectively, as in many modern dialects. The marginal spelling of these verbs with the digraph, however, indicates that the linguistic source of their orthography did not realize them with a simple medial $\bar{i}$. I suggest that this spelling emerged at a time when the glottal stop was still pronounced and the sequence las used to represent the noninitial glottal stop, in this case following an $i$-vowel.

\section{2. مآه = *mi’ah}

The enigmatic spelling of miah has been the subject of much debate, but no consensus has been reached as to what the alif-yā sequence is meant to signify. ${ }^{34}$ The pronunciations $m \bar{a}$ 'ah and mi'āh, found in some vocalized Quranic manuscripts, most certainly reflect artificial, secondary vocalizations based on the synchronic interpretation of the word's orthography. ${ }^{35}$ There is no etymological basis, from a comparative Semitic perspective or in the modern and ancient dialects of Arabic, for the vocalization of this word as anything other than mi'ah and, following the loss of the glottal stop, as miyah. In light of the discussion on above, the most natural explanation for this spelling is that it in fact reflects miah, using the digraph for the glottal stop following the $i$-vowel.

\subsection{Bi- and $L i$ - before Words Beginning with a Glottal Stop}

Several words with an initial glottal stop following the prepositions bi- and li- are written with the digraph, the same environment as above. ${ }^{36}$

33. These orthographic oddities were first recognized and commented on by Marijn van Putten on Twitter (https://twitter.com/PhDniX/status/976754498151514112), although he attempted no explanation of them.

34. The most widely cited opinion is that of Diem, "Untersuchungen," 102-namely, that the alif is preserved as a graphic archaism, and the yā following it reflects the contemporary pronunciation, miyah. This idea is followed by van Putten ("Hamza"), who terms it a mixed etymological spelling.

35. On these, see H. Sidky, "In Search of Lost Time: A Vocalized Muṣaf, Ibn Sāmir, and the Evolution of the Syrian Reading Tradition," forthcoming.

36. For previous treatments of this spelling, see van Putten, "Hamza," 109-11, and references therein. 
Table 2: The Digraph Following Prepositions

\begin{tabular}{|c|c|c|c|c|}
\hline ناست & • & دـ & اد & v \\
\hline bi’āyātin & $t$ & $\mathrm{y}$ & I & $b$ \\
\hline
\end{tabular}

\begin{tabular}{|c|c|c|c|c|}
\hline لـاسم & r & $د$ & اد & 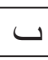 \\
\hline bi’ayyāmin & $\mathrm{m}$ & $\mathrm{y}$ & ) & $\mathrm{b}$ \\
\hline
\end{tabular}

\begin{tabular}{|c|c|c|c|}
\hline ساسى & 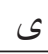 & اد & $\bullet$ \\
\hline bi-’ayyi & $\mathrm{y}$ & ) & $\mathrm{b}$ \\
\hline
\end{tabular}

\begin{tabular}{|l|l|l|l|l|}
\hline bi-’aydin & $د$ & \lrcorner & $د$ & $\bullet$ \\
\hline bi-l & $\mathrm{d}$ & $\mathrm{y}$ & 2 & $\mathrm{~b}$ \\
\hline
\end{tabular}

\begin{tabular}{|c|c|c|c|c|}
\hline بانكم & كم & $د$ & اد. & • \\
\hline bi-’ayyikum & $\mathrm{km}$ & $\mathrm{y}$ & 2 & $b$ \\
\hline
\end{tabular}

As van Putten has pointed out to me (personal communication), it is remarkable that in all such cases, a $y$ occurs later in the word. Perhaps this acted as an orthographic conditioning environment for the preservation of this archaic spelling, at least marginally. Alternatively, it is possible that the following $y$ blocked the loss of the glottal stop in this position in order to avoid the sequence yaya, a sort of dissimilation. If the glottal stop persisted longer in this environment than in others, this spelling would reflect a phonetic reality rather than being merely an instance of historical orthography.

\section{4. جاي =}

A noninitial glottal stop following the long vowel $\bar{i}$ is spelled using the digraph in the

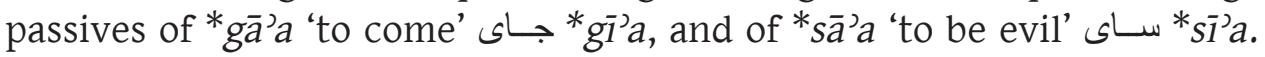

\section{5. شاى = Śs}

The reading traditions of the QCT vocalize the word for 'thing' only as šay', even when it is spelled سـاى. The modern dialects suggest that a by-form belonging to the fi ${ }^{1} 1$ pattern, rather than fa'l, existed; the interchange of these two patterns is well attested. ${ }^{37}$ In the dialect of Beirut, for example, the diphthong /ay/ remains intact; Proto-Arabic *baytun produces bayt, while the word for 'thing' is realized as $̌ \bar{s} \overline{\text { }}$. This must go back to an earlier *si $\bar{I}^{\text {' }}$ rather than *'say'. The Quranic spelling, in light of the previous identifications, suggests that its original dialect also exhibited a reflex of the fi 1 form, synchronically pronounced as si and historically as * ${ }^{*}{ }^{i}{ }^{2}$; the orthographic form wـ reflects the latter.

37. $\mathrm{Fal}^{\mathrm{l}} / \mathrm{fi}^{\mathrm{Cl}} \mathrm{by}$-forms are well attested in Arabic; for example, watrun, witrun 'single'; kasrun, kisrun 'bone with meat'; salmun, silmun 'reconciliation.' J. Fox, Semitic Noun Patterns (Winona Lake, IN: Eisenbrauns, 2003), 133. 


\subsection{The Spelling of the Glottal Stop with 1 before an I Vowel}

Although the most common environment for the spelling of the glottal stop with the digraph is after the vowel $i$, there are a few examples of it spelled as such in a closely related environment, before i: سـانل *su'ila; فاسن /fa-'in/; and the case forms ملاسـ /mala'i-hu/ and نباى /nabai/.

In at least one clear case, the noninitial glottal stop is rendered with $1: a s-s \bar{u} ' \bar{a}$ is spelled in Q 30:10, reflecting its complete emancipation from its original conditioning environment. However, one must note that the pronunciation of the alif maqșurah in the QCT was $\bar{e}$, and so the digraph may have been motivated by its proximity to this vowel, which was perhaps felt to be close to $\overline{1}$. The spelling of $r u^{3} y \bar{a}-y a$ with the digraph similarly points to the digraph's use outside of the environment of /i/, although again the contiguous $y$ may have played a role.

Also remarkable about the spelling السـواى is the fact that the $y$ of the digraph and the $y$ of the alif maqșürah are treated as one, as in words terminating in $y$ followed by a nisba ending, such as النيـن for al-nabiyyina (Q 2:61).

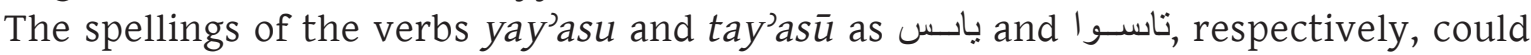
also reflect the use of the digraph outside the context of an $i$-vowel. But this is the case only if the vocalization of these verbs followed the Classical Arabic pattern in the dialect of the orthography. Prefix-conjugated verbs with the theme vowel /a/ (the vowel of the verb stem) have an $i$-vowel in the preformative prefix-the so-called Barths-Ginsberg law. ${ }^{38}$ If this law was operative in the dialect that gave rise to this spelling, these verbs would have been pronounced as $y \bar{i}$ as and $t \bar{i}$ 'as $\bar{u}$, the exact environment in which we would expect to encounter this spelling.

\section{The Background}

The evidence assembled above demonstrates that in the earliest stratum of Quranic orthography scribes had the option to employ the digraph إى to represent the noninitial glottal stop. The digraph was used most often after an $i$-vowel and marginally before one, and perhaps only once outside of that environment. The optional use of an orthographic device has several precedents in the Quran. As noted in the introduction, the representation of internal $\bar{a}$ with alif was almost entirely optional outside of the CāC environment. ${ }^{39}$ But in our case, the digraph إى, while certainly an innovation from the Nabataean perspective, must be construed as an archaism with regard to the synchronic dialect of the Quran and its

38. That is, yaf ${ }^{c} u l u$ and yaf $f^{\prime} i u$ but yif ${ }^{c} a l u$. on this law and its distribution in the Central Semitic languages, see J. Huehnergard, "Features of Central Semitic," in Biblical and Oriental Essays in Memory of William L. Moran, ed. A. Gianto, 155-203 (Rome: Pontificio Istituto Biblico, 1995). This law is still operative in the Najdi dialects of Arabic today; see B. Ingham, Najdi Arabic: Central Arabian (Amsterdam: J. Benjamins, 1994). And it seems to have been operative in the northern Old Arabic dialects as well, as evidenced by the spelling Elpav for yir'aw in an Arabic inscription written in Greek letters from the Jordanian Harrah; see A. Al-Jallad and A. al-Manaser, "New Epigraphica from Jordan I: A Pre-Islamic Arabic Inscription in Greek Letters and a Greek Inscription from North-Eastern Jordan," Arabian Epigraphic Notes 1 (2015): 51-70.

39. A notable exception is the spelling of $\mathrm{I}^{-}{ }^{2}$ verbs, which always have the alif. I thank Marijn van Putten for pointing this out to me. 
primary writing tradition, which had lost the glottal stop. This spelling must therefore stem from an orthographic tradition that, on the one hand, preserved the glottal stop in these environments but, on the other, had lost the means of using alif to represent it.

How did this come to be? Digraphs are not a component of Semitic alphabetic writing in general, so this practice was clearly not inherited directly from any antecedent script. I suggest that the digraph emerged in a "script-contact" situation. In order to fully appreciate this phenomenon, however, we should give some attention to the diversity of the Arabic script in the sixth century CE.

The corpus of sixth-century Arabic inscriptions and even earlier Nabataeo-Arabic inscriptions exhibits variation in both letterforms and orthographies. Focusing on just the sixth-century inscriptions, the following variation is attested:

The orthography of the word for 'I': In the Harrān inscription, the first-person pronoun is spelled ' $n$ '/'anā/, while in the Jebel Usays inscription it is spelled ' $n h$. This latter spelling is found in an unpublished pre-Islamic Arabic-script inscription from the Tabūk area as well. The spelling ' $n h$ most certainly goes back to the Nabataean rendering of this pronoun in Aramaic, which survives even into the Nabataeo-Arabic period as evidenced by the Tha'labah inscription. ${ }^{40}$

The use of wawation: Nabataean orthography marked final triptotic personal names/ nouns with a $w$, the so-called wawation. In Nabataeo-Arabic, this was generally retained in personal names, but in the sixth-century (and later) inscriptions, wawation is used differently from text to text. In the early Arabic-script inscriptions from Najrān, wawation is deployed in the expected way, whereas in the Jebel Usays inscription this feature is missing altogether. In the Yazīd inscription, wawation is applied to the diptotic name Yazid, suggesting an expansion of its usage. ${ }^{41}$

Letter shapes: Dots on $d \bar{a} l s$ and lunate rēs: The Nabataeo-Arabic inscriptions occasionally added a supralinear dot to the dāl, a relic of a phase when the glyphs for dāl and rē were identical; the dāl was distinguished by a dot on top, in contrast to the Syriac tradition, where the dot for the dālet was added below. The Yazìd inscription exhibits these dots on the dāls, while other sixth-century Arabic inscriptions do not. Moreover, we find two types of $r \bar{e}$ in the sixth-century inscriptions: a lunate form, as in the Jebel Usays inscription, and a linear rēe, as found in the Himà inscriptions and the sixth-century Arabic-script inscription of Dümat al-Jandal. ${ }^{42}$

These examples of diversity indicate that there was no unified orthography for Arabic in the pre-Islamic period. Different traditions must have evolved locally where the NabataeoArabic script was used. The chancelleries of different oases and tribal rulers could have

40. On this text, see U. Avner, L. Nehmé, and C. Robin, “A Rock Inscription Mentioning Tha'laba, an Arab King from Ghassān,” Arabian Archaeology and Epigraphy 24, no. 2 (2013): 237-59.

41. See Al-Jallad, "Yazīd-Inscriptie," 197-98.

42. Ibid., 199-200. 
developed their own particularities of writing, and these coexisted until the emergence of the Umayyad state and the top-down unification of the Arabic script. ${ }^{43}$ Script contact must be assumed for this period, as writing was used to send letters not only to one's own kinsmen but also to people from neighboring groups, who may have had slightly different ways of writing Arabic. This situation forms the context for the scenario I develop below to account for the emergence of the digraph ایى.

In principle, orthographic developments emerge in an environment that allows for the reanalysis of a fixed, older spelling to produce a new one-a point of diffusion. If we look to the distribution of this digraph in the QCT, it is clear that it was most associated with the sequence $i^{3}$, and indeed, the only word that is more often than not written with the digraph, even to this day, is ماـ 'one hundred.' This stability suggests that the spelling of this word was fixed and widely adopted at a very early point in the history of the Arabic script. The number one hundred is our "patient zero," so to speak.

While the number one hundred is most likely to have been the model upon which the spelling of the glottal stop with اي was based, this does not explain why the digraph was used to represent the glottal stop in this word to begin with. The numeral is well attested in pre-Islamic Nabataean and Nabataeo-Arabic inscriptions, yet in all cases it is spelled $m^{\prime} h / t$, without a denticle, matching its etymology and pronunciation. ${ }^{44}$ It is at this point that we should turn our attention to the paleography of the final he in Nabataeo-Arabic. The letter had multiple forms in the Nabataeo-Arabic hand-one form had the denticle of the $h$ on top of its loop, while another form had it on the base line to its right.

Figure 1: Shapes of the $H \bar{e}$ in Nabataeo-Arabic ${ }^{45}$

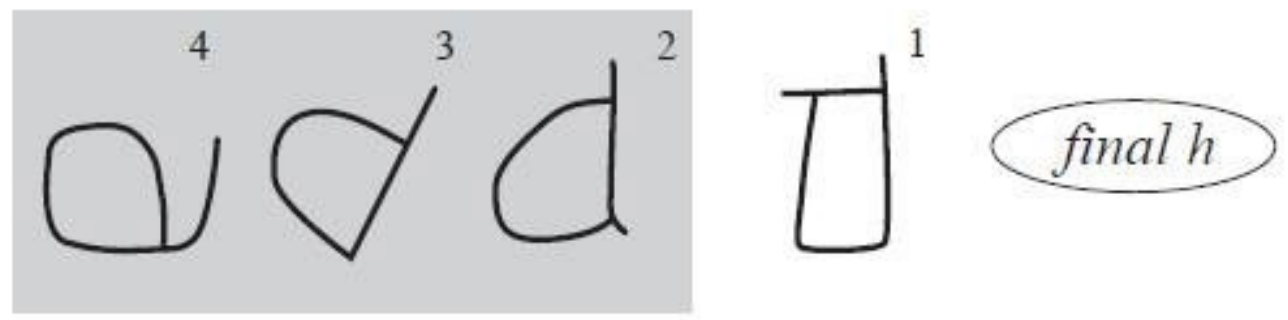

43. On the scenario of the Arabic script evolving gradually from Nabataean at the courts of tribal chiefs in Northwest Arabia, see L. Nehmé, "Epigraphy on the Edges of the Roman Empire: A Study of the Nabataean Inscriptions and Related Material from the Darb Al-Bakrah, Saudi Arabia, 1st-5th Century AD” (Mémoire scientifique d'habilitation à diriger des recherches, École pratique des hautes études, 2013).

44. This evidence is assembled in L. Nehmé, "Aramaic or Arabic? The Nabataeo-Arabic Script and the Language of the Inscriptions Written in This Script," in Arabic in Context: Celebrating 400 Years of Arabic at Leiden University, ed. A. Al-Jallad, 75-89 (Leiden: Brill, 2017), 88-90.

45. Nehmé, "Glimpse," 49. 
Figure 2: Example of a Denticled Hē in Nabataeo-Arabic (with the First Line's Final Word Reading 'sylh) ${ }^{46}$

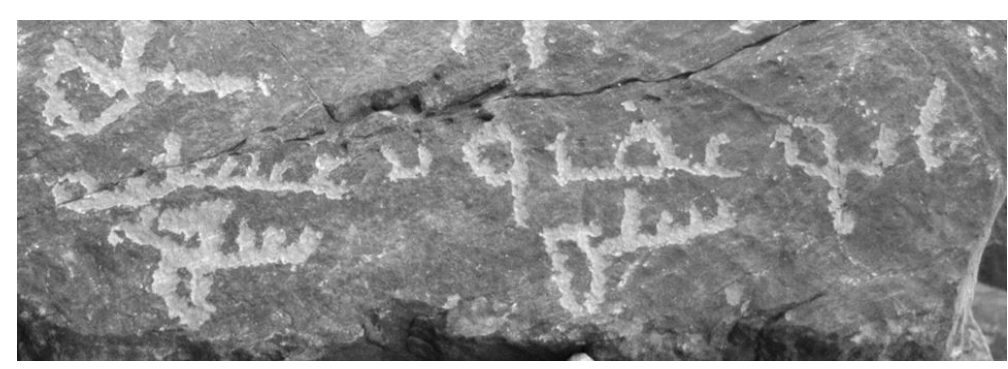

The latter form survived well into the period of the sixth-century Arabic script, as we find it in the spelling of the word 'iläh at least twice.

Figure 3: Umm al-Jimāl Inscription (with the First Line Reading ' $\left.b d{ }^{\prime} 1-1 h\right)^{47}$
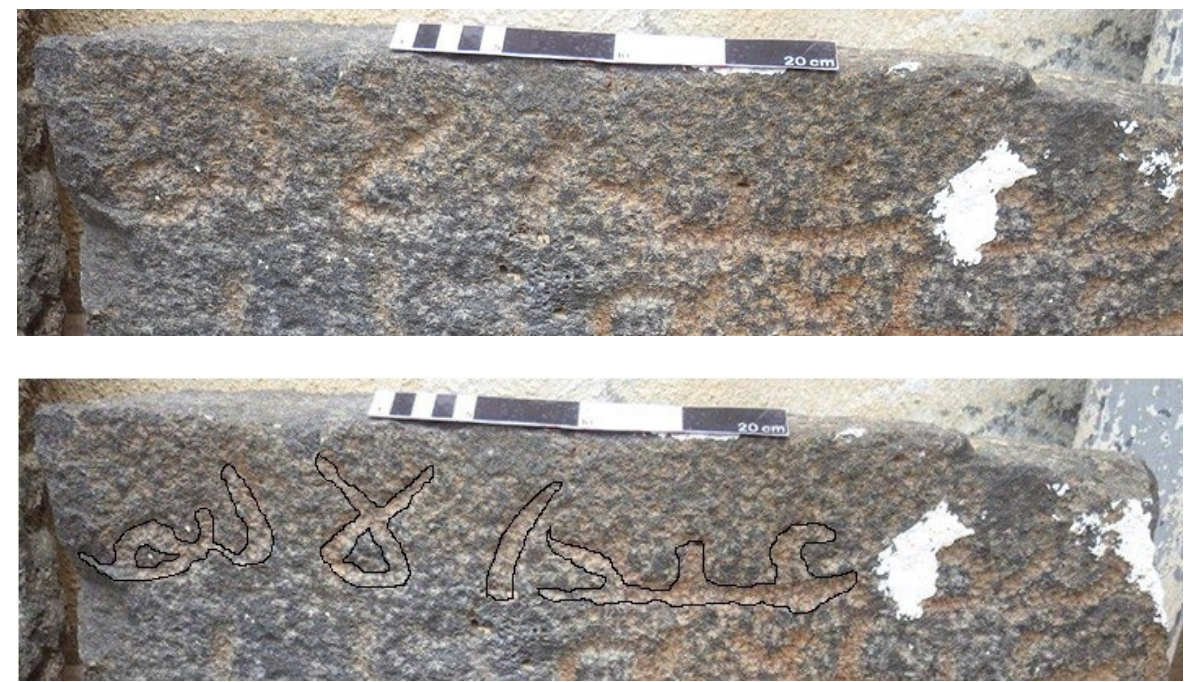

Figure 4: Unpublished Graffito from Farīq al-Ṣahrā (\#5); 'lh = 'ilāh..$^{48}$

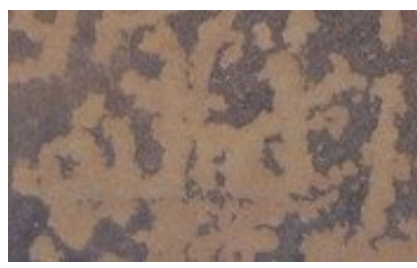

46. Nehmé, “Glimpse," UJadh 299.

47. L. Nehmé, "New Dated Inscriptions (Nabataean and Pre-Islamic Arabic) from a Site near Al-Jawf, Ancient Dūmah, Saudi Arabia," Arabian Epigraphic Notes 3 (2017): 121-64.

48. The original photograph can be found here: https://alsahra.org/2017/09/شقشعربية-بكنة-نبطيـة/ (accessed June 17, 2021). 
To most modern eyes, the spelling of 'ilāh in the two Arabic inscriptions above looks more like 'lyh, with a denticle before the $h$. Although it may be tempting to argue for 'imālah in these cases-that is, a graphic representation of the $\bar{e}$ allophone of ${ }^{*} \bar{a}-$ we should note that the particular shape of the $h$, the loop without a tooth on top, prevents us from interpreting the denticle before the loop as a separate letter: it is part of the $h$.

In a lecture I gave on this subject, ${ }^{49}$ I hypothesized that such a letterform must have persisted into the Islamic period, for reasons we shall see below. Shortly afterward, van Putten kindly shared with me a fascinating discovery he made while studying the pre-750 CE Quranic manuscript DAM 01-29.1 that confirms my hypothesis. The word 'âhirah is spelled with a final $\backsim$, where the he lacks a tooth on top of the loop and is preceded by a denticle. This can only reflect the ancient shape of the he discussed above.

\section{Figure 5: Al-āhirah Spelled with a Denticled Hēe, الاخربـ \\ (DAM 01-29.1, fol. 3v, I. 2 [Q 3:45])}

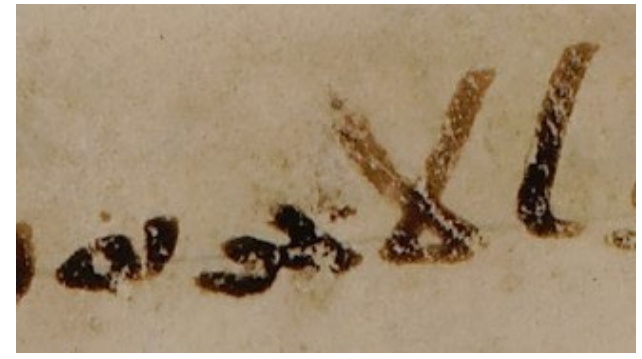

I subsequently noticed the denticled $h \bar{e}$ in an early Islamic inscription from the area of Medina..$^{50}$ Although this text is undated, its paleography suggests that it was produced sometime after the second Islamic century, indicating that the digraph survived marginally, and was perhaps restricted to certain formulae.

Figure 6: Malā'ikatu-hū

(Source: @Mohammed93athar).

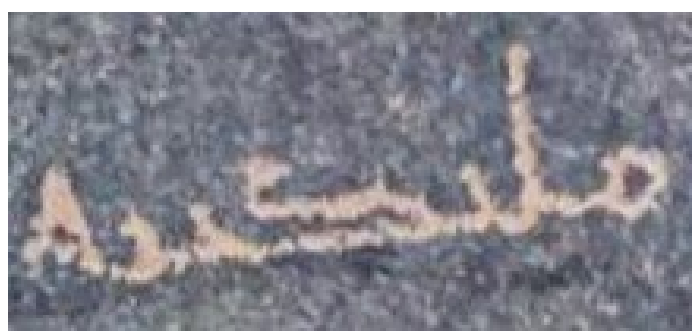

49. Delivered at the "Reading the Rasm" workshop held at Leiden University on December 3, 2018.

50. This text was posted online by Abū 'Abd Allāh al-Mughadhdhawī on his famous Twitter account, Nawādir al-āthār wa-1-nuqūsh (@Mohammed93athar: https://twitter.com/mohammed93athar/status/ 1088434910254247936). 


\section{Scenario}

The word "one hundred" was certainly frequent in economic documents and in dating formulae. Since the spelling of this word in pre-Islamic times was always $m$ ' $h$, what if the denticle of the Quranic ماس and that of later Arabic orthography is, at least in origin, no $y$ at all? Could we not interpret this word as simply a continuation of the spelling $m^{\prime} h$, consisting of three letters? If so, then the final denticle, frozen in Arabic orthography, is not a denticle but part of the final shape of the $h$, similar to the one found in the Umm al-Jimāl inscription and in the Quranic MS DAM 01-29.1. In other words, the shape - is simply one of the various forms of final $h$ in the pre-Islamic Arabic scripts that continued, albeit marginally, into the Islamic period.$^{51}$ For reasons that are lost to us now, this spelling of "one hundred" gained traction and was frozen graphically as a numerogram, as it is in the orthography of Arabic today. Now, if this gram spread to a writing tradition of Arabic that made use of another form of final $h$, scribes could have easily mistaken the denticle of the final he for a separate letter, misparsing and graphically reinterpreting it as And since it was pronounced as mi'ah, scribes could have inferred that the sequence was a way to spell the noninitial glottal stop. The distribution of this spelling suggests that it was always an optional strategy to represent this sound, and that it diffused by analogy to phonetically similar environments, but not exclusively to them. This theory explains the fact that the majority of the digraph's attestations occur in the vicinity of an $i / \overline{1}$ vowel, and usually in the exact phonetic environment of $i^{3} .^{52}$

Why would scribes devise a new way of representing the glottal stop if the Nabataean and Nabataeo-Arabic script already had a method to do so with alif? The answer, I think, lies in understanding the diffusion of Arabic writing traditions. The main orthographic stratum in the Quran clearly reflects a dialect that lost the glottal stop. What if the Arabic script spread from this starting point to a group that retained the stop? This, in fact, has already happened once in the Islamic period, namely, in writing Classical Arabic with Hijāzì orthography. Scribes may have abstracted from the spelling of ماسـ a plene method of rendering the glottal stop, a sound their language had but that was not represented in Hijāzī orthography.

The emergence of a new orthographic practice based on the reinterpretation of a fixed spelling according to synchronic pronunciation finds an exact parallel in the development of another optional spelling strategy, the representation of internal $\bar{a}$ with alif. Diem explains the emergence of the use of the alif to spell word-internal $\bar{a}$ as follows. ${ }^{53}$ Words with an etymological glottal stop preceding the short /a/ would have been pronounced as $\bar{a}$, leading to the synchronic interpretation that internal alif signaled the vowel $\bar{a}$. The fact that this spelling in QCT orthography was most consistently applied to CāC nouns seems to imply

51. I thank Mila Neishtadt for pointing out the possible use of the denticled he for the spelling of the word "one hundred" and both her and Marijn van Putten for the rich discussion with me on my Facebook post of March 30, 2018.

52. The fact that we have no reproductions of this spelling in the exact phonetic environment, namely glottal stop $+h$, has probably to do with the rarity of this sequence and the limited corpus available to us.

53. Diem, “Glimpses," 258-59. 
that the point of diffusion was spellings of $\mathrm{Ca}^{\mathrm{C}} \mathrm{C}$ nouns, from which the practice expanded to represent internal $\bar{a}$ in all environments.

Original pronunciation: rảs || orthographic representation راس: internal alif = consonantal'

Loss of glottal stop: rās \| orthographic representation راس: internal alif $=\bar{a}$

\section{Figure 7: The Development of the Digraph ${ }^{54}$}

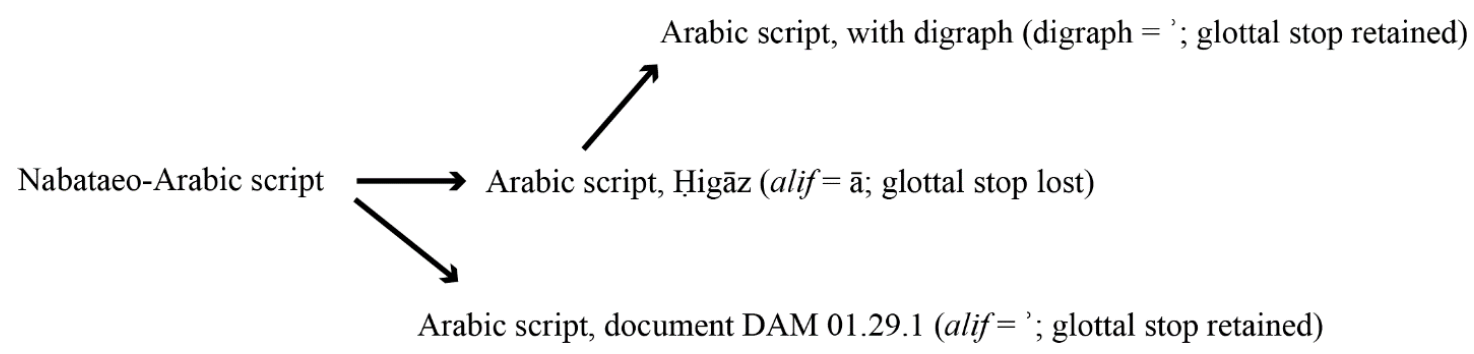

The digraph ایى appears to be an embryonic attempt to indicate the internal glottal stop in a writing tradition that kept this sound but used Hijāzī orthography, which lacked a graphic means of representing it. It is impossible to reconstruct, at the current moment, why it was employed marginally in the writing of the Quranic archetype and later documents. Despite the fact that most later reading traditions had the need to represent the wordinternal glottal stop, it is clear that the main tradition of writing Arabic, following the reforms of 'Abd al-Malik, did not employ the digraph. The occasions on which it was used in the Quranic archetype and other early manuscripts became orthographic relics, similar to the spelling of ماسـ today, the purpose of which was no longer understood. Perhaps the introduction of the method of marking the glottal stop with supralinear diacritics finally extinguished any lingering use of the digraph in the writing of Arabic.

\section{The Archaic Final $H \bar{e}$}

The emergence of the digraph was based on the graphic reinterpretation of the archaic final $h \bar{e}$ in the word ماسـ. The same archaic form seems to have been frozen graphically in the spelling of the word Torah in Q 3:3 (and passim) as has been the subject of much speculation, with suggested explanations ranging from spontaneous 'imālah (the raising of $\bar{a}$ to $\bar{e}$ ) to the contamination of the word tōrāh and

54. DAM 01-29.1 is an early Quran manuscript that, as G.-R. Puin observed, spelled the glottal stop on occasion with the ', continuing the older Nabataean practice; see Puin, "Vowel Letters and Ortho-Epic Writing in the Qur'ān," in New Perspectives on the Qur'ān: The Qur'ān in Its Historical Context 2, ed. G. S. Reynolds, 147-90 (New York: Routledge, 2011), 170. This is the same document that used the archaic final he in the word al-āhirah, cited above, further indicating that the alif spelling is ancient rather than a later and coincidental development.

55. I thank Yüsef Gursey for suggesting the possible application of the allograph of final he to this word in a Facebook post of March 30, 2018. 
'oraytāis ${ }^{56}$ both of these are wholly unconvincing, and the latter especially strains credulity. A simpler solution presents itself in light of the interpretation of the word ماـه : the spelling of tōrāh consists of four letters and not five, the final denticle and loop being simply the archaic form of the hē. This produces the expected spelling of /tōrāh/, twrh.

\begin{tabular}{|c|c|c|c|}
\hline$\omega$ & $\jmath$ & $g$ & $\bullet$ \\
\hline$h$ & $r$ & $w$ & $t$ \\
\hline
\end{tabular}

While this spelling made its way into the Quranic archetype, another rather common spelling that did not lends itself to a similar interpretation. A number of times, the word for "god," 'ilāh, is spelled in early manuscripts as السـ.57 This has usually been interpreted as a plene spelling of 'imālah, reflecting the pronunciation of ${ }^{*} \bar{a}$ as $\bar{e} \cdot .^{58}$ Although this explanation is in theory plausible ${ }^{59}$ it is striking that such a spelling occurs with any frequency only in this word. This suggests to me that we most likely have another example of the archaic he graphically frozen in the high-frequency word 'ilāh, mirroring the pre-Islamic examples identified above.

In contrast to السه, there are two examples provided by Puin of the denticle's representing a long ā: in the word riğāl, spelled رجـل in Q 72:6 in DAM 01-28.1 and DAM 01-29.1, ${ }^{60}$ and in the word ' $i b \bar{a} d$, spelled عبد in Q 40:31 in DAM 01-29.1. The latter occurs in a rhyme position, where the rhyme is formed with the syllable $\overline{\mathrm{a}} \mathrm{C \#}$. Given that both of these spellings occur very infrequently, and never in the pre-Islamic period, there is no reason to assume that they reflect an ancient practice. They could have emerged in the scribal milieu of Quranic copying, perhaps being the innovation of a small group. In any case, I do not believe they are related to the denticled he. Their interpretation lies in the phenomenon of orthographic reanalysis in the wake of language contact.

The original language of the QCT had a distinct reflex of the triphthong *ayV: it was pronounced as $\bar{e}$ and rhymed separately from the alif mamdu $\overline{d a h} .{ }^{61}$ However, by the time Qurans were being copied, the text was read in dialects that realized the reflex of *aya as $\bar{a}$. The orthographic mismatch allowed for the emergence of a new orthographic convention. But let us first illustrate the scenario:

س $=$ QCT original: banē-hā

= some late seventh/eighth century readings: banā-hā

56. For a complete discussion of the opinions on this subject, see Diem, “Untersuchungen," 248-50.

57. Puin, "Vowel Letters," 168.

58. Ibid.; but F. Deroche, in La transmission écrite du Coran dans les débuts de l'islam: Le codex ParisinoPetropolitanus (Leiden: Brill, 2008), views it simply as a mater lectionis for $\bar{a}$.

59. Puin also cites the spelling of Q 4:3 طـاب in the Cairo Edition as طيب in the Samarkand codex, but this may be explained by a different reflex-the collapse of the medial triphthongs; see van Putten, "Triphthongs," 49-50, 69. It is reported that in the ancient Hijāzi dialect, this very verb was realized as tēeba. Nevertheless, the scenario developed for the spelling of $\bar{a}$ with the denticle could account for the pronunciation tāa even here.

60. The latter attestation was recently identified by van Putten.

61. On the outcome of the triphthongs in the QCT, see van Putten, "Triphthongs." 
Just as one could extrapolate from the spelling ماسـ that the alif-denticle combination represented ', it is possible to deduce from such QCT spellings that word-internal a could be spelled with a denticle-but only in a dialect that had no 'imālah; in other words, a dialect that did not realize the reflex of the triphthong as $\bar{e}$. If this innovation indeed emerged in such a scribal context, it never truly took off, and the practice was quickly marginalized by the internal alif spelling.

\section{Concluding Remarks}

I hope to have shown that an archaic strand of Quranic orthography made use of the digraph to represent the glottal stop in a noninitial position. This peculiar method of spelling emerged in a situation of script contact, where the graphically frozen spelling

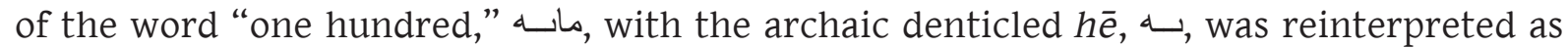
consisting of four letters, I I , with l representing the glottal stop. From this point, the use of the digraph spread to the representation of this sound in similar environments. Moreover, relics of the archaic final hē explain the enigmatic spelling of the word tōrāh and the supposedly 'imālah'ed spelling of the word 'ilāh in several early manuscripts.

This study brings into relief an important issue in the study of the language of the Quran: its layered orthography. Although the text is generally consistent in its spellings, the significant variation on its margins harkens back to a period before Arabic orthography was standardized..$^{62}$ For this reason, the desire to devise rules to account for every spelling in the Quran is perhaps misguided; only a historically informed approach, with due consideration of the diversity of Arabic scripts and spelling strategies in the pre-Islamic period, can fully explain its many orthographic enigmas.

62. For a discussion on the possible timing of the standardization of Arabic orthography as we know it, see C. Robin, "La réforme de l'écriture arabe à l'époque du califat médinois," Mélanges de l'Université Saint-Joseph 59 (2006): 319-64. 


\section{Index of Early Arabic Inscriptions Cited}

Ḥarrān inscription: Monumental bilingual Arabic-Greek inscription from Ḥarrān, Syria, dated to $568 \mathrm{CE}$; for the latest edition, see Macdonald's commentary in Z. T. Fiema et al., "Provincia Arabia: Nabataea, the Emergence of Arabic as a Written Language, and GraecoArabica," in Arabs and Empires before Islam, ed. G. Fisher, 373-433 (Oxford: Oxford University Press, 2015).

Jebel Usays inscription: A small rock graffito at Jebel Usays in southern Syria, dated to 528 CE; for the latest edition, see Macdonald's commentary in Fiema et al., "Provincia Arabia."

Hiimà (Najrān) pre-Islamic Arabic inscriptions: A collection of pre-Islamic Arabic-script inscriptions from the region of Najrān, the earliest dating to $470 \mathrm{CE}$. On these texts, see C. J. Robin, A. I. al-Ghabbān, and S. F. al-Sa'īd, "Inscriptions antiques de la région de Najrān (Arabie séoudite méridionale): Nouveaux jalons pour l'histoire de l'écriture, de la langue et du calendrier arabe," Comptes rendus des séances de l'Académie des inscriptions et belleslettres 3 (2014): 1033-1128.

Dūmah sixth-century Arabic inscription: A Christian Arabic-script graffito from the region of Dūmat al-Jandal, northern Saudi Arabia; see L. Nehmé, "New Dated Inscriptions (Nabataean and Pre-Islamic Arabic) from a Site near Al-Jawf, Ancient Dūmah, Saudi Arabia," Arabian Epigraphic Notes 3 (2017): 121-64.

Umm al-Jimal inscription: A pre-Islamic Arabic-script inscription, undated. For the latest discussions, see R. Hoyland, "Mount Nebo, Jabal Ramm, and the Status of Christian Palestinian Aramaic and Old Arabic in Late Roman Palestine and Arabia," in The Development of Arabic as a Written Language, ed. M. C. A. Macdonald, 29-46 (Oxford: Archaeopress, 2010), 40, and Nehmé, "New Dated Inscriptions."

Yazīd inscription: An early Christian Arabic inscription from the region of Qașr Burqu in Northeastern Jordan; see Y. Shdaifat, A. Al-Jallad, Z. al-Salameen, and R. Harahsheh, "An Early Christian Arabic Graffito Mentioning 'Yazīd the King," Arabian Archaeology and Epigraphy 28, no. 2 (2017): 1-10. 


\section{Quranic manuscripts sigla}

BnF Arabe 331, Paris (+ Ms. Leiden Or. 14.545b +Ms. Leiden Or. 14.545c), 58 folios; first Islamic century.

Samarkand Kodex (Faksimiledruck): Berlin, Staatsbibliothek, 353 folios; dated to about 700-850.

British Library, Or. 2165, 121 folios; second half of the first Islamic century.

Großer Korankodex: Kairo, al-Maktaba al-Markaziyya li-l-Makhțūțāt al-Islāmiyya, 1087 folios; not before 700 .

Saray Medina 1a: Istanbul, Topkapı Sarayı Müzesi M1, 308 folios; late first/early second century.

Tübingen, Universitätsbibliothek, Ma VI 165, 77 folios; second half of the seventh century CE. 


\section{Bibliography}

Al-Jallad, A. “'Moge God Yazīd de Koning Indachtig Zijn': Nadere Beschouwingen over de Yazīd-Inscriptie en de Ontwikkeling van de Arabische Schriften.” In Mohammad en de Late Oudheid, edited by Josephine van den Bent, Floris van den Eijnde, and Johan Weststeijn, 198-208. Amsterdam: Verloren, 2018.

-- - and A. al-Manaser. "New Epigraphica from Jordan I: A Pre-Islamic Arabic Inscription in Greek Letters and a Greek Inscription from North-Eastern Jordan." Arabian Epigraphic Notes 1 (2015): 51-70.

Avner, U., L. Nehmé, and C. J. Robin. "A Rock Inscription Mentioning Tha'laba, an Arab King from Ghassān." Arabian Archaeology and Epigraphy 24, no. 2 (2013): 237-59.

Cantineau, J. Le Nabatéen. Paris, 1930/1932. Reprint. Osnabrück: Zeller, 1978.

Déroche, F. La transmission écrite du Coran dans les débuts de l'islam: Le codex ParisinoPetropolitanus. Leiden: Brill, 2008.

Diem, W. "Some Glimpses at the Rise and Early Development of Arabic Orthography." Orientalia, n.s., 45 (1976): 251-61.

---. "Untersuchungen zur frühen Geschichte der arabischen Orthographie: I. Die Schreibung der Vokale.” Orientalia, n.s., 48 (1979): 207-57.

Fiema, Z. T., A. Al-Jallad, M. C. A. Macdonald, and L. Nehmé. "Provincia Arabia: Nabataea, the Emergence of Arabic as a Written Language, and Graeco-Arabica." In Arabs and Empires before Islam, edited by G. Fisher, 373-433. Oxford: Oxford University Press, 2015.

Fox, J. Semitic Noun Patterns. Winona Lake, IN: Eisenbrauns, 2003.

Healey, J. The Nabataean Tomb Inscriptions of Mada'in Saleh. Journal of Semitic Studies Supplement 1. Oxford: Oxford University Press, 1993.

Hoyland, R. "Mount Nebo, Jabal Ramm, and the Status of Christian Palestinian Aramaic and Old Arabic in Late Roman Palestine and Arabia." In The Development of Arabic as a Written Language, edited by M. C. A. Macdonald, 29-46. Oxford: Archaeopress, 2010.

Huehnergard, J. "Features of Central Semitic." In Biblical and Oriental Essays in Memory of William L. Moran, edited by A. Gianto, 155-203. Rome: Pontificio Istituto Biblico, 1995.

Ingham, B. Najdi Arabic: Central Arabian. Amsterdam: J. Benjamins, 1994.

Nehmé, L. "Aramaic or Arabic? The Nabataeo-Arabic Script and the Language of the Inscriptions Written in This Script." In Arabic in Context: Celebrating 400 Years of Arabic at Leiden University, edited by A. Al-Jallad, 75-89. Leiden: Brill, 2017.

-- - "Epigraphy on the Edges of the Roman Empire: A Study of the Nabataean Inscriptions and Related Material from the Darb Al-Bakrah, Saudi Arabia, 1st-5th Century AD." 
Mémoire scientifique d'habilitation à diriger des recherches, École pratique des hautes études, 2013.

--C. "A Glimpse of the Development of the Nabataean Script into Arabic Based on Old and New Epigraphic Material." In The Development of Arabic as a Written Language, edited by M. C. A. Macdonald, 47-88. Oxford: Archaeopress, 2010.

-_- "New Dated Inscriptions (Nabataean and Pre-Islamic Arabic) from a Site near Al-Jawf, Ancient Dūmah, Saudi Arabia.” Arabian Epigraphic Notes 3 (2017): 121-64.

Puin, G.-R. 2011. "Vowel Letters and Ortho-Epic Writing in the Qur'ān." In New Perspectives on the Qur'ān: The Qur'ān in Its Historical Context 2, edited by G. S. Reynolds. New York: Routledge, 2011.

Robin, C. "La réforme de l'écriture arabe à l'époque du califat médinois." Mélanges de l'Université Saint-Joseph 59 (2006): 319-64.

-- , A. I. al-Ghabbān, and S. F. al-Sa'īd. “Inscriptions antiques de la région de Najrān (Arabie Séoudite méridionale): Nouveaux jalons pour l'histoire de l'écriture, de la langue et du calendrier arabe." Comptes rendus des séances de l'Académie des inscriptions et belleslettres 3 (2014): 1033-1128.

Shdaifat, Y., A. Al-Jallad, Z. al-Salameen, and R. Harahsheh. "An Early Christian Arabic Graffito Mentioning 'Yazīd the King."' Arabian Archaeology and Epigraphy 28, no. 2 (2017): 1-10.

Sidky, H. "In Search of Lost Time: A Vocalized Muṣhaf, Ibn Sāmir, and the Evolution of the Syrian Reading Tradition." Forthcoming.

van Putten, M. "The Development of the Triphthongs in Quranic and Classical Arabic." Arabian Epigraphic Notes 3 (2017): 47-74.

- - . "The Feminine Ending -at as a Diptote in the Qur'ānic Consonantal Text and Its Implications for Proto-Arabic and Proto-Semitic." Arabica 64, nos. 5-6 (2017): 695-705.

- - . “The Grace of God' as Evidence for a Written Uthmanic Archetype: The Importance of Shared Orthographic Idiosyncrasies." Bulletin of the School of Oriental and African Studies 82, no. 2 (2019): 271-88.

-C-. “Hamza in the Quranic Consonantal Text.” Orientalia 86, no. 3 (2018): 93-120.

---. Quranic Arabic: From its Hijazi Origins to its Classical Reading Traditions (Leiden: Brill, forthcoming). 


\title{
A Preliminary Study of the Pseudo-Aristotelian Hermetica: Texts, Context, and Doctrines*
}

\author{
LIANA SAIF \\ University of Amsterdam
}

(1.w.i.saif2@uva.nl)

\begin{abstract}
The pseudo-Aristotelian Hermetica are an understudied yet influential group of texts surviving in Arabic that claim to record conversations between Aristotle and Alexander the Great. I propose a ninth-century dating for these texts on the basis of textual and contextual evidence. In them, Aristotle instructs Alexander on two major subjects to aid his royal pupil's military career and personal life: the cosmos, the genesis of everything in it, and astral magic. This study provides a preliminary analysis of the texts' manuscripts and content, discussing what makes them Aristotelian and Hermetic and highlighting the resonances of Zoroastrian astro-cosmogenic doctrines.
\end{abstract}

7 he pseudo-Aristotelian Hermetica (hereafter PsAH) are a group of texts surviving in Arabic that claim to record conversations between Aristotle and Alexander the Great. In these conversations, Aristotle instructs Alexander about the cosmos, the comingto-be of everything in it, and astral magic-more precisely, talismanry, rituals for attracting the spiritual and planetary forces of the cosmos, the creation of amulets, and extensive astrological rules. The purpose of the instruction is to support Alexander's military career and personal life. Aristotle claims to have received this knowledge from Hermes Trismegistus. There are very few studies dedicated to these fascinating and influential texts; therefore, this article offers a preliminary study of the PsAH that introduces the texts and their contexts systematically.

\footnotetext{
*I am indebted to Charles Burnett for his support and guidance, which proved indispensable for this article, and to my friend A.O.M. for his generosity with manuscripts. I am also grateful to the anonymous reviewers of this submission, who provided detailed and generous feedback, and to Travis Zadeh for his encouragement and guidance with primary and secondary sources. Finally, I extend my gratitude to Mariano Errichiello and Julian Strube for their constructive comments..

(c) 2021 Liana Saif. This is an open access article distributed under the terms of the Creative Commons Attribution-NonCommercial-NoDerivatives License, which allows users to copy and distribute the material in any medium or format in unadapted form only, for noncommercial purposes only, and only so long as attribution is given to the original authors and source.
} 
We can identify the following constituent treatises within the PsAH cluster: al-Istimākhīs, ${ }^{1}$ al-Isțimāțīs ${ }^{2}$ al-Hādhìțūs, and al-Ustuwatțās. ${ }^{3}$ Together, they seemed to have formed a single work entitled Kitāb 'Ilal al-rūhāaniyyāt. To these we can add al-Madịtīs (which is an abridgment of Kitāb 'Ilal al-rūḥāniyyāt), Kitāb al-Shu'rā al-yamāniyya, and Dhakhīrat Iskandar. Modern scholarship has been bedeviled by a great deal of confusion about the spellings of these titles in manuscripts and secondary sources, which has prevented scholars from seeing the various connections between the texts that show them to have been part of a larger corpus. Nevertheless, the designation "pseudo-Aristotelian Hermetica" and the abbreviation used here, PsAH, must not lead us to overemphasize the homogeneity of the texts, for three reasons. First, a more thorough inspection of the surviving manuscripts is required to confirm the works' textual stability. Second, the constituent texts have been grouped in divergent ways, as evinced by some manuscripts and their careers, and sometimes compiled with non-PsAH texts into clusters that had separate trajectories, as in the case of what I refer to below as the PSAH Cycle and Kitāb Clal al-rūhāniyyāt. Third, two of the texts identified here as pseudo-Aristotelian and Hermetic-namely, Kitāb al-Shu'rāa al-yamāniyya and Dhakhïrat Iskandar-are later compositions that drew on what had become a dynamic Islamic philosophical and scientific tradition espousing the doctrines of Aristotle and Hermes.

The importance of the PsAH as a major source of elements that became ubiquitous in and fundamental to the medieval occult sciences cannot be overstated. Their influence is visible in the rūhāniyyāt, talismanic practices, and astral causality in Maslama al-Qurțubī's Ghāyat al-ḥakim, in the magic and astrology of Rasāill Ikhwān al-Șafă', and the science of letters ('ilm al-ḥurūf) of Aḥmad al-Būnī in the thirteenth century and 'Abd al-Raḥmān al-Bisțāmī in the fifteenth, among others. ${ }^{4}$ As a pivotal current in Islamic intellectual culture, the occult sciences coproduced and enriched knowledge about nature, the cosmos, and their forces. Therefore, it is not hard to see the significance of the PsAH beyond the occult sciences in Islamic intellectual history as a whole. What Paul Magdalino and Maria Mavroudi have said about Byzantine culture extends to Islamic culture: "Intellectual engagement with the occult was rooted in, or sought to cohere with, the philosophical systems of Greco-Roman antiquity.... The learned practitioners of the occult had a basic general education, including philosophy, and tended to combine their special expertise with a variety of intellectual interests, which made it appropriate to describe them as philosophoi." Similarly, hakim (sage or philosopher) designated occult scientists in medieval Islamic intellectual culture.

1. Based on MS London, British Library, Delhi Arabic 1946, fol. 1v. In MS Oxford, Bodleian, Marsh 556, fol. 111r, it is vowelized as al-Ișțamākhus, الإصطَماخُس .

2. Based on Marsh 556, fol. 4r. In Delhi Arabic 1946, fol. 32v it is found as al-Ișțimātīs, الاصطماطيس.

3. Following the vowelisation in Arabe 2577, fol. 1r; in Delhi Arabic 1946, fol. 32r it is found as al-Isnūtāas, الاسنوطاس.

4. L. Saif, "From Ġāyat al-Hakīm to Šams al-Macārif: Ways of Knowing and Paths of Power in Medieval Islam," Arabica 64 (2017): 297-345, at 306-9, 330-31.

5. P. Magdalino and M. Mavroudi, "Introduction," in The Occult Sciences in Byzantium, ed. P. Magdalino and M. Mavroudi, 11-38 (Geneva: La pomme d'or, 2006), 13. 
Magic and alchemy, in particular, were considered the epitome of wisdom (hikma). The Islamic reception of Aristotle was, in reality, that of a master philosopher, sage, and mage, as demonstrated by the so-called Theology of Aristotle. The work is, in fact, an Arabic paraphrase of Plotinus's Enneads IV-VI along with Porphyry's commentary, which turns Aristotle into a sage of high Neoplatonism. Moreover, the pseudo-Aristotelian Sirr al-asrār (The secret of secrets, lat. Secretum secretorum) cemented Aristotle's image as a mage with consummate knowledge of occult properties, astral influences, and talisman construction. Along with the PsAH, these texts helped establish a Hermetized and Neoplatonized Aristotelianism that became definitive of Islamic scientific, philosophical, and religious knowledge pertaining to the universe, generation and corruption, and the place of human beings in the cosmos.

In this article, I first identify the constituent treatises of the PsAH and their relationships to one another. I then argue for a ninth-century date for their production on the basis of citations in texts influenced by them as well as contextual considerations, especially the coinciding of their composition with the codification of Zoroastrianism in texts such as the Bundahishn and Dēnkard. These texts could have familiarized the author or authors of the PsAH or their intellectual atmosphere with astro-prophetical cycles and the cosmic networks revolving around the "spiritual beings" known as rūhāniyyāt. Moving to the content, I show how the philosophical and magical background of the PsAH demonstrates a consequential melding of Aristotelian hylomorphism and causality with what was perceived as "Hermetic" theurgic and astro-magical aspects.

\section{The Texts and Manuscripts}

The first step toward understanding the pseudo-Aristotelian Hermetic corpus is to draw a circle around its known and surviving constituent treatises-a real challenge considering the scattered manuscripts, widespread confusion about the titles, and the lack of dedicated studies. The PsAH were widely known in the Islamic world, especially during the medieval and early modern periods, but the titles were often confused. Ibn Abì Ușaybica (d. 668/1270), in 'Uyūn al-anbā' fị tabaqāt al-ațibbā' (The choicest reports on the classes of physicians), mentions several PsAH texts in a chapter dedicated to the works of Aristotle. One of these is "al-Isțimākhīs, composed when he [Alexander] wished to leave the Land of Rūm," exactly as described in the prologue of al-Isțimākhīs. He also mentions Kitāb al-Malāțis, a certain "Kitāb al-Ismātālīss," and "a book for Alexander on the rūhāniyyāt and their actions in the climes," which is possibly a reference to al-Isțimātīis and its discussion of the seven climes. ${ }^{6}$ Under a section on Hermes's writings on "nīranjs, ${ }^{7}$ occult properties, and talismans," Ibn al-Nadīm (d. 380/990) lists "Kitāb al-Harịtūs on nīranjs, trees, fruits, oils, and grasses";

6. Ibn Abī Ușaybi`a, 'Uyūn al-anbā’ fi țabaqāt al-ațibbā', ed. N. Riḍā (Beirut: Dār Maktabat al-Hayyāt, n.d.), 105; online ed., E. Savage-Smith, S. Swain, and G. J. van Gelder, eds., A Literary History of Medicine (Leiden: Brill, 2020), https://doi.org/10.1163/37704_0668IbnAbiUsaibia.Tabaqatalatibba.lhom-ed-ara1.

7. In occult literature "nīranjs" refer to magical concoctions made from organic material. It is claimed that they cultivate a sort of "spiritual force" that overpowers that of animals and people. They are often ingested or suffimigated. They are discussed in more detail in section IV.5. 
this is al-Hādhitūus, which has chapters on these precise genres. Under Hermes's writings on alchemy, Ibn al-Nadīm lists "al-Hārịtūus" again, as well as al-Malātīs, "al-Isțimākhis," and a certain Kitāb al-Salmātīis. ${ }^{8}$

In a section of his Tārīkh discussing Alexander the Great, Ibn Khaldūn (732-808/13321406) mentions al-Isțimākhīs, which contains "the ancient devotions" (al-cibāda al-ūlā). He notes that "the people of the seven climes used to worship the[ir] planet, for each clime has a planet to which they prostrate, suffumigate, make sacrifices, and slaughter. The rūhāniyya of this planet manages their affairs, they claim." The "ancient devotions" is likely to be a reference to the laws of the first sage-prophets in al-Isțimātîs. Discussion of the seven climes can also be found in al-Ustuwatțās and al-Isțimātīis. Ibn Khaldūn does make reference to "Kitāb al-Isțimāțīs, which contains [information on] conquering cities and fortresses by talismans and [astrological] judgment; among them are talismans to bring down rain and to draw water." This is an appropriate description of the contents of this text. He also mentions a "Kitāb al-Ishțurțās on elections according to the procession of the moon through the mansions and applications," which is likely to be a reference to al-Ustuwwatțās. And he adds "other books on the benefits and occult properties of animal parts, stones, trees, and grasses," which recalls the content of al-Hādhìțūs. ${ }^{9}$

Ibn Khaldūn's description is worded similarly to that of the Coptic historian Jirjis al-Makin (602-672/1205-1273) in his al-Majmü $\bar{u}^{c}$ al-mubārak (The blessed compendium):

Aristotle interpreted the books of Hermes, the first Egyptian sage, and he translated them from the Egyptian tongue to the Greek. He explained the knowledge, judgments, and talismans therein. One of these [books] is Kitāb al-Isțimākhīs, and it contains the devotions of the first peoples. He mentions in it that the people of the seven climes used to worship the seven planets; and in every clime they worshipped one of these planets, prostrating, suffumigating, making sacrifices, and slaughtering to it. The rūhāniyya of this planet appeared to its clime and addressed [its people], fulfilling their needs in all that they seek. One of these [books] is Kitāb al-Isțimāțīs, which contains [information] on conquering cities, fortresses, strongholds, and seizing kingdoms with the talismans and judgments they make. Among them are talismans that bring down rain and water to them in thirsty deserts and dry wildlands. There is also Kitāb al-Ustuwatțās. ${ }^{10}$

Hājjī Khalīfa (1017-1608/1609-1657), in Kashf al-ẓunūn, lists some of the PsAH texts: al-Hārițūs (this is likely al-Hādhìtūs) and al-Malātî̀s. ${ }^{11}$ He also mentions "the book on attracting the rūhāniyya of animals from the writings of Hermes, interpreted by Aristotle. It is the book named al-Madātiss." This is a description of the contents of the text known as Istijlāb rūhāniyyāt al-bahāim (On attracting the rūhāniyyāt of animals)-also referred

8. Ibn al-Nadīm, al-Fihrist (Beirut: Dār al-Ma'rifa, n.d.), 434, 496.

9. Ibn Khaldūn, Tārīkh Ibn Khaldūn, ed. Kh. Shihāda and S. Zakkār, 7 vols. (Beirut: Dār al-Fikr, 2000), 2:223-24.

10. MS Oxford, Bodleian Library, Huntington 188, fol. 131r.

11. Ḥājjī Khalīfa, Kashf al-ẓunūn, ed. M. Sh. Yāltaqāyā and R. B. al-Kalīsī, 2 vols. (Beirut: Dār Ihyā̄a al-Turāth al-`Arabì, n.d.), 1:657-58. 
to in the text as al-Madhātīis ${ }^{12}$ which constitutes a chapter in al-Ustuwatțās. ${ }^{13}$ Other texts mentioned include an "al-Isțālīs," an "al-Isfūțās," al-Isțimāțīs, ${ }^{14}$ the al-Malāțīs al-akbar, al-Ustuwatțās, a certain al-Hāwițūs, a "book of the moon by Hermes the Sage, which [contains material] on occult properties and talismans that consider the advent of the moon and its progression in the mansions," 15 and, finally, "epistles by Aristotle to his son and to Alexander on managing the kingdom and on magic, too." Hạjjì Khalīfa also mentions "Kitāb al-Rūhāniyyāt and their actions in the climes" by Aristotle. ${ }^{16}$

Modern scholars have identified some of the PsAH's constituent treatises, often confusing the titles, and supplementing their identification with reference to other sources, especially the lists of Ibn al-Nadīm and Hājjī Khalīfa. For example, in Aristoteles Arabus, F. E. Peters identifies five separate texts: al-Isțimākhīs, al-Isțimāțis, al-Malāțīs (equating it with al-Madīțīs), the K. 'Ilal al-rūhāniyyāt, and Dhakhīrat Iskandar. ${ }^{17}$ In Geschichte des Arabischen Schrifttums, Fuat Sezgin lists al-Shu'rā and K. 'Ilal al-rūhāniyyāt under the heading "Astronomy, Astrology, and Magic"18 and includes under Aristotelian works al-Isțimākhīs, al-Ustuwwatțās (which he deems identical to al-Isțimātịis), al-Malāțīs or al-Miyalātīs, and Dhakhïrat Iskandar. ${ }^{19}$ In Die Natur- und Geheimwissenschaften im Islam, Manfred Ullmann identifies as separate texts al-Isțimākhīs, al-Isțimāțīs, al-Ustuwațtās, al-Madītīs, al-Hādhìtūus, and Dhakhïrat Iskandar. ${ }^{20}$ As noted earlier, very little research has tackled the problem of the titles. The result is that certain treatises have been considered separate works even though they are in fact interconnected.

Nevertheless, 'Abd al-Raḥmān Badawī edited the passages about the Perfect Nature (al-țibā' al-tāmm) from al-Isțimākhìs on the basis of MS Cairo, Dār al-kutub, 4291, fols. 136r137r. ${ }^{21}$ Recently, Kevin van Bladel has drawn attention to the PsAH in his investigations into Hermes, Hermetic writings, and their circulation. ${ }^{22}$ Charles Burnett has uncovered a case of twelfth-century reception of $K$. 'Ilal al-Rühāniyyāt in the Latin West in the form of a paraphrase entitled Liber Antimaquis, ${ }^{23}$ mentioned in De essentiis by Hermann of Carinthia,

12. Not to be confused with al-Madītīs described below.

13. Ibid., 2:1389.

14. Ibid., 2:1390.

15. Ibid., 2:1463.

16. Ibid., 2:1421.

17. F. E. Peters, Aristoteles Arabus: The Oriental Translations and Commentaries of the Aristotelian Corpus (Leiden: Brill, 1968), 58-59.

18. Sezgin, Geschichte des Arabischen Schrifttums, 9 vols. (Leiden: Brill, 1967-2000), 4:41-42.

19. Ibid., 4:40-42; 7:102-3.

20. M. Ullmann, Die Natur- und Geheimwissenschaften im Islam (Leiden: Brill, 1972), 374-77, 394-95.

21. 'A. Badawī, al-Insāniyya wa-1-wujūdiyya fĩ al-fikr al-'arabī (Cairo: Maktabat al-Nahụa al-Miṣriyya, 1947), $177-84$.

22. K. van Bladel, The Arabic Hermes: From Pagan Sage to Prophet of Science (Oxford: Oxford University Press, 2009), 101-2, 114, 178, 224.

23. MS London, British Library, Sloane 3854 (fifteenth century), fols. 105v-110v ("The Book of the Spiritual Works of Aristotle, or the book Antimaquis, which is the book of secrets of Hermes: wonderful things can be accomplished by means of this book and it is the ancient book of the seven planets"); L. Thorndike, A History 
who worked in the twelfth century and also translated several Arabic astrological works, including ones by Abū Ma'shar al-Balkhī (c. 171-c.272/787-886). ${ }^{24}$ On the basis of MS Oxford, Bodleian, Marsh 556 (al-Madițis) and MS Paris, BnF, Arabe 2577, Burnett has provided an analysis of the interconnections among these texts and their influence on the magic blockbuster Ghāyat al-hakim (The goal of the sage) and its Latin reception. ${ }^{25}$

In the rest of this section, I introduce the constituent texts of the PsAH, highlighting cross-references among the texts and historical evidence that attests to their relative cohesion. The list of manuscripts consulted is not exhaustive. For the next stage of research, which should include producing a critical edition of the PsAH, a more comprehensive survey of manuscripts is necessary. All the manuscripts consulted are listed in the Appendix.

\section{The PsAH Cycle}

The manuscripts consulted show that certain pseudo-Aristotelian Hermetic texts traveled together. This cluster includes treatises that are not pseudo-Aristotelian or Hermetic but reflect the same themes-namely, amulets, talismans, and the occult properties of stones. In this article, I refer to this combination of texts as the PSAH Cycle. I shall begin with the pseudo-Aristotelian Hermetic texts and then move to the others.

The pseudo-Aristotelian Hermetica are framed as lessons to Alexander the Great and commentaries on Hermetic knowledge by Aristotle, composed over a period of time at different stages of various military campaigns. The first composition is al-Isțimākhīs, which begins as follows:

This is Kitāb al-Isțimākhīs [on knowledge] received from Hermes and composed by Aristotle the Sage to Alexander when he wished to exit the land of Rūm [for a military campaign] to the eastern lands (ard al-mashriq). This was during the fourth year of his rule. $^{26}$

The text consists mainly of instructions for talismans and amulets for securing military success, but it also contains an introduction to the central concept of the Perfect Nature

of Magic and Experimental Science: During the First Thirteen Centuries of our Era, vol. 2 (London: Macmillan, 1923), 260.

24. C. Burnett, "Hermann of Carinthia and the Kitāb al-Isțamāțīs: Further Evidence for the Transmission of Hermetic Magic," Journal of the Warburg and Courtauld Institutes 44 (1981): 167-69; idem, “Aristoteles/Hermes: Liber Antimaquis," in Hermetis Trismegisti Astrologica et Divinatoria, ed. P. Lucentini et al., 179-221 (Turnhout: Brepols, 2001); idem, "The Establishment of Medieval Hermeticism," in The Medieval World, ed. P. Linehan and J. L. Nelson, 111-30 (London: Routledge, 2001). See also S. Page, Magic in the Cloister: Pious Motives, Illicit Interests, and Occult Approaches to the Medieval Universe (University Park, PA: Penn State University Press, 2013), 94-95, where Page draws attention to the commonalities in "visionary framework" and practices between the PsAH and the medieval Liber de essentia spiritum by a Sevillian author. See also B. Láng, Unlocked Books: Manuscripts of Learned Magic in the Medieval Libraries of Central Europe (University Park, PA: Penn State University Press, 2008), 105-6.

25. C. Burnett, “Tābit ibn Qurra the Harrānian on Talismans and the Spirits of the Planets," La corónica: A Journal of Medieval Hispanic Languages, Literatures, and Cultures 36, no. 1 (2007): 13-40.

26. MS London, British Library, Delhi Arabic 1946, fol. 1v. 
(al-țibā' al-tāmm), which is a rūhāniyya-a "spiritual" being-that watches over the philosopher/sage and belongs to her/his ruling planet, acting as a guide to wisdom and selfcultivation. Al-Isțimākhīs also includes the famous story of the discovery of the Hermetic Emerald Tablet in a dark crypt. These parts of the text are discussed in more detail below.

Another text that appears in the PsAH Cycle is a part of (min) Kitāb al-Isțimāțis. It is stated that al-Isțimātīis was composed after al-Isțimākhīs:

From Kitāb al-Isțimāțīs, composed by Hermes in (fi) 'Ilal al-rūhāniyyāt, divided according to the seven climes and their nature, operations, and substances. This is the book wherein Aristotle the Sage explains the causes of the rūhāniyyāt, their activities, their substances, and their differences across the seven climes and according to the seven planets. ${ }^{27}$

The next major constituent treatise of the PsAH is al-Ustuwatțās, a section of which appears in the PsAH Cycle under the title Kitāb Istijlāb rūhāniyyāt al-bahāim. According to its prologue, it is also referred to as "al-Madātīis". ${ }^{28}$ Nevertheless, at the end of the text, we read: "This is the end of what the Sage described in Kitāb al-Ustuwatțās." ${ }^{29}$ This seems to be, then, a chapter from al- Ustuwatțās. The text begins as follows:

The book of attracting the rūhāniyyāt of all animals according to the words of Hermes, interpreted by Aristotle. It is the book titled al-Madātīis. When I read this book, I found in it these four amulets (khirz) mentioned and praised by Hermes. ${ }^{30}$

Another part of the Kitāb al-Ustuwațtās is included in the Cycle. It is a chapter from “al-Ishnūṭās" (الاشـنوطاس) according to MS Delhi Arabic 1946, fol. 85v and MS Arabe 221, fol. 60r; however, the content seems like a continuation of the episode of Admānūs's learning from Hādūs about the conditions for magical practice which we encounter in al-Ustuwatțās (الأسـتوطّاس). It is only a matter of scribal variation in dotting; so it seems to be a chapter of al-Ustuwatțās. In the prologue, we read:

This is a chapter (fașl) from the book of al-Ustuwattāas. Aristotle the Sage said: in his education of Admānūs in the hidden secrets and the subtle spiritual actions, the first thing Hādūs taught him in the secrets of the stars was the clarification of the twentyeight mansions. These are the stations which constitute the first division, knowledge, and roots of the entirety of the first edifice. ${ }^{31}$

Other manuscripts, discussed below, contain additional parts of al-Ustuwatțās, indicating that it is one of the major constituent texts of the PsAH corpus as a whole.

\footnotetext{
27. Ibid., fol. 32v.

28. Ibid., fol. $21 \mathrm{v}$.

29. Ibid., fol. 32r (in the text it is dotted as الاسنوطاس).

30. Ibid., fol. $21 \mathrm{v}$.

31. Ibid., fol. $85 \mathrm{v}$.
} 
An interesting reiteration of al-Ustuwatțās is associated with the scholar and grammarian Sirāj al-Dīn Abū Ya'qūb al-Sakkākī (555-626/1160-1229), and it appears in MS Tehran, Majlis-i Shūrā-yi Millī, no. 4752 (fols. 1r-42v). In addition to Dhakhïrat Iskandar and another text on stones, which is described below, this manuscript includes the third bāb, entitled al-Isqūtāas, from al-Sakkākī's magic text al-Kitāb al-Shāmil fị al-baḥr al-kāmil (The Comprehensive Book on the Perfect Sea). ${ }^{32}$ Like all the PsAH texts identified here, al-Isqūtās-also called Kitāb al-Manlāțīs Istūtạțīs in the Kitāb al-Shāmil-is set within a historical narrative. A sanad is given, which begins with al-Sakkākī and ends with a certain Shakārkun Madīlā al-Mūṣilī in al-Kitāb al-Shāmil in the SOAS manuscript, and with Yazīd al-Mūṣilī in the Majlis manuscript. In the narrative, this al-Mūsili has arrived in Egypt and has been admitted to the company of its ruler Ahmad b. Tūlūn. ${ }^{33}$ There he finds an old shaykh dressed as a priest talking about the wonders and uncanny elements of ancient knowledge to a group of listeners. When asked about his sources, the shaykh mentions a single book that he

inherited from his forefathers, containing several parts, retrieved from the treasuries of Khosraw I by Kanaka the Indian, ${ }^{34}$ a master of conjunctions, who counted it among the Hermetic books (al-kutub al-hirmisiyya) translated by Aristotle and known as Kitāb Mīlatịis al-akbar. It is a book that contains a description of the [lunar] mansions, twentyeight of them, their natures and properties, and the names of the angels in charge, their suffumigations, and the niranjs made under them.

Ibn Ṭūlūn expresses interest in obtaining a copy of the book for his treasury. The shaykh responds by handing him this very book. Ibn Ṭūlūn then orders a man called Sahl b.

32. For the entire Kitāb al-Shāmil, I have consulted MS London, SOAS, no. 46347, fol. 2r. See M. Noble, Philosophising the Occult: Avicennan Psychology and the Hidden Secret of Fakhr al-Dîn al-Râzî (Hamburg: de Gruyter, 2021); T. Zadeh, "Commanding Demons and Jinn: The Sorcerer in Early Islamic Thought," in No Tapping around Philology: A Festschrift in Honor of Wheeler McIntosh Thackston Jr.'s 70th Birthday, ed. A. Korangy and D. J. Sheffield (Wiesbaden: Harrassowitz, 2014), 131-60. Emily Selove at the University of Exeter is the Principal Investigator of the Leverhulme-funded research project "A Sorcerer's Handbook," which will produce an edition, a translation, and a literary study of al-Sakkākī's text.

33. Interestingly, there seems to be a proximity between the family of Ibn Ṭūlūn to magic. It is mentioned in Ghāyat al-hakìm, where we learn that in a commentary on an aphorism belonging to Ptolemy's Centiloquium/ The Fruit by Aḥmad b. Yūsuf the secretary, there is a story set in the time of Khmārūwīh b. Aḥmad b. Țūlūn in Egypt about a Byzantine resident of Egypt who was able to save a boy from a scorpion sting with a magical seal, was used to stamp a piece of frankincense that was then given to the afflicted to drink. It received its powers from the planets in a specific configuration. Maslama b. Qāsim al-Qurțubī, Picatrix: Das Ziel des Weisen, ed. H. Ritter (Leipzig: B. G. Teubner, 1933), 54-55.

34. Many astrological works are attributed to the semilegendary Kanaka, whose name, meaning gold in Sanskrit, is often invoked in works dedicated to the astral sciences (astrology, astronomy, and talismanry). He is described by Pingree as "a favorite symbol used by intellectuals of the Islamic tradition to indicate the partial dependence of some of their sciences upon Sanskrit sources." Pingree links him to Sassanian intellectual culture and suggests he learned astrology in the Abbasid context, holding a position in the caliphal court. Several treatises are attributed to Kanaka; see J.-C. Coulon, La magie en terre d'islam au Moyen Âge (Paris: CTHS, 2017), 108-10, 150, 159; Sezgin, Geschichte des arabischen Schrifttums, 7:94-97; Ullmann, Natur- und Geheimenwissenschaften, 289-301; D. Pingree, From Astral Omens to Astrology, from Babylon to Bīkāner (Rome: Istituto italiano per l'Africa e l'Oriente, 1997), 51-62. 
Mahīdān to translate it. ${ }^{35}$ What follows is the text of this PsAH work, which includes another interesting narrative that explicitly sets this text apart from al-Ustuwatțās and asserts an Indian provenance for its content:

Kanaka the Indian said: This is the book I translated from [another work by] my esteemed sire Aristotle when I was composing my book describing the planetary rūhāniyyāt and their activity, influences, actions, and properties. I was so thorough I did not leave anything unmentioned. This has been obtained from the lights of the esteemed Hermes, tripled in abundant wisdom that emanates over me and those like me. It occurred to me to mention the lunar mansions and their rūhāniyyāt, their properties, the nīranjs made under them, alchemical operations (tadbīr al-șan'a), and descriptions of fatal poisons, so that this book would be comprehensive in knowledge and operations, unlike al-Ustuwatțās and the rest of my books. I could not find anything like this with me, and I found it strange that I have overlooked this matter. Time passed in investigation and thought about this, until I found myself in the army of the philosopher-king (al-malik al-faylasüf) and pupil (tilmìdh) ${ }^{36}$ Alexander, son of Philip the Greek, [heading] to the land of India. He requested at its threshold all the old books by the ancient sages. So I brought to him many books on all kinds of verified occult sciences (al-'ulüm al-haqiqua al-khafiyya). Among them was a book penned by Idriyās. He (Kanaka) said: Upon reading it I realized that it contained what had been weighing on my mind regarding the mansions, their properties, and what is done under each mansion. I mention their rūhāaniyyāt as I recall them from Hermes Trismegistus, combining all that I had come across. So I thanked the Cause of all causes, the Creator of all creatures, for inspiring in me wisdom and spiritual insight (al-khātir al-rūḥānī). ${ }^{37}$

This narrative elicits couple of important observations. First, the PsAH, and the al-Ustuwatțās in particular, are depicted here as a standard to follow and adapt to the occult practices of the thirteenth century. Indeed, the text is similar to al-Ustuwatțās in its description of the magical operations of the lunar mansions, but the practices prescribed by the two texts are different, and the rūhāniyyāt in this text are more like angels with Hebraic names. Second, the PSAH were legitimized and sensationalized by their insertion into a "historical imaginary," which is understood here as a shared understanding of the past created by various discourses-political, religious, scientific, philosophical, literary, and so on-which shapes the way in which a community relates to its immediate and ancient past and to its entanglements with different groups. In the case of the PsAH, this historical imaginary is one that reconstructs and celebrates a dynamic Islamic culture that hybridizes Persian, Indian, and Greek heritage.

\footnotetext{
35. SOAS 46347, fols. 30v-31v.

36. It is likely that the definite article is missing. Al-tilmìdh means "the student," not "student of," indicating Alexander's tutelage under Aristotle.

37. SOAS 46347, fols. $31 \mathrm{v}-32 \mathrm{r}$.
} 
The last pseudo-Aristotelian Hermetic treatise found in the Cycle is Kitāb al-Hādhịtūs. Aristotle is absent from this text, but a cross-reference in the aforementioned al-Istijlāb ${ }^{38}$ confirms its belonging to the PsAH, "according to what was described by Hermes." ${ }^{9}$ Furthermore, an anonymous translator is mentioned.

The text begins as follows:

This Kitāb al-Hādhịtūs is the book that God, powerful and exalted, taught Adam.

When He forced him to descend from Paradise, he taught him every beneficial thing, and every craft with which he could make good his land..$^{40}$

The narrative about Admānūs (Adam) in this text is consistent with the rest of the corpus and provides a complementary trajectory by describing the magical knowledge that Admānūs received from the demiurge Hādūs (see below). The creation of Admānūs is described in other texts of the PsAH.

Four other works, which do not belong to the pseudo-Aristotelian Hermetica, also found their way into the Cycle. The first is the Giranis, which is attributed to Hermes but does not feature Aristotle. It is concerned with the occult properties of natural things and is organized alphabetically. ${ }^{41}$ The work is an Arabic translation of an early Greek version of the Kyranides that has not survived. It may have differed from the traditional Greek versions. ${ }^{42}$ As ToralNiehoff notes, this may be called the earliest Arabic translation of a Hellenistic text on magic. She also highlights the work as evidence of medieval Islamic intellectual knowledge of ancient magic and of Muslims' ability to contextualize such knowledge successfully. ${ }^{43}$ The latter is attested by the work's inclusion among the pseudo-Aristotelian Hermetic texts, which demonstrates a medieval conceptualization of a wider magical "hermetic" tradition. ${ }^{44}$

We also find in the Cycle a treatise entitled Kitāb al-Ahjār (The Book of Stones). Although the work begins abruptly, a title is given in the conclusion. In content, the text is almost identical to another collection of stone and ring magic, MS Istanbul, Süleymaniye, Ayasofya 3610 , fols. $1 \mathrm{v}-143 \mathrm{r}^{45}$ The compiler of this manuscript claims to have relied on several books "that describe some of the writings of the Light of Knowledge, Aristotle the Sage, retrieved from the book by Hermes the Sage" (fol. 2r). This makes it a pseudo-Aristotelian Hermetic

38. The treatise on attracting animals that forms part of al-Ustuwwatțās, see above and the appendix.

39. Delhi Arabic 1946, fol. 85r.

40. Ibid., fol. 53 r.

41. This text was edited and studied by Isabel Toral-Niehoff on the basis of MS Oxford, Bodleian, Arab d. 221 in Kitab Giranis: Die arabische Übersetzung der ersten Kyranis des Hermes Trismegistos und die griechischen Parallelen (Munich: Herbert Utz, 2004).

42. Toral-Niehoff, Kitab Giranis, 37-38.

43. Toral-Niehoff, Kitab Giranis, 16.

44. A.-J. Festugière, ed., La révélation d'Hermès Trismégiste, vol. 1: L'astrologie et les sciences occultes (Paris: Les belles lettres, 1989), 201-16.

45. This is a royal manuscript copied for the treasury of Sultan Abū al-Nașr Sayf al-Dīn al-Ashraf Qaytbay (r. 1468-96); see fol. 1r. The colophon dates the manuscript to the beginning of Sha'bān 888/September 1483. 
text. However, in the version of the text found in the PsAH Cycle the reference to Aristotle and Hermes is absent since the first half of the text is missing.

Kitāb al-Ahjār is followed in the Cycle by Kitāb 'Uțārid b. Muhammad al-Muhāaib fí manāfi ‘ al-ahjār wa-l-khiraz wa-țillismātihā wa-khawātim al-kawākib al-sab`a (The Book of 'Uțārid b. Muḥammad al-Muhāsib on the Benefits of Stones, Amulets, and Their Talismans, and the Rings of the Seven Planets), according to the title given at the text's conclusion. ${ }^{46}$ The PsAH Cycle includes only the last part of the actual text attributed to 'Uțārid on the construction of planetary rings. The first part of the work is found in the stone magic collection MS Paris, BnF, Arabe 2775 (second text, fols. 102r-114r) and in the second part of Ayasofya 3610 (fols. 44v-168v). Moreover, a version of 'Uțārid's work appears in MS Tehran, Majlis-i Shūrā-yi Millī, fols. 80r-88v, the same Persian manuscript that contains the third bāb (al-Isqūțās) of al-Sakkākī's Shāmil (fols. 43r-79v), discussed above, as well as the pseudoAristotelian Dhakhirat Iskandar (fols. 1r-42v). ${ }^{47}$ The ubiquity of the PsAH in all kinds of compilations on the theme of the occult properties of stones, talismans, and niranjs testifies to their deep impact on Arabic- and Persian-language audiences interested in the occult sciences.

'Uțārid b. Muhammad is described by Ibn al-Nadīm as an astrologer and an astronomer. ${ }^{48}$ In Arabe 2775 we read that 'Uțārid was inspired to write his own work on stones by a certain book of the same genre by Hermes that constitutes one of "the treatises (alșuhuf) known [collectively] as Üjāyaq $\overline{1}{ }^{49}$ which bring together writings on stones, trees, and all animals whose benefits I ('Uțārid) found in the Book of the Seven Talismans of Wisdom (Kitāb al-Ṭillismāt li-l-ḥikma al-sab'a)." "Uțārid claims to have gathered in his work all writings on stone magic "by the Arabs." ${ }^{50}$ In Arabe 2775, we also find a text containing

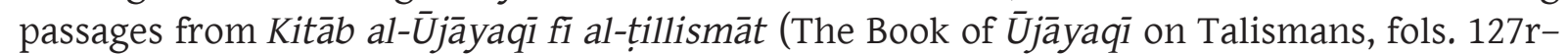
131r). In Ayasofya 3610, the Üjāyaqi is a corpus of writing (mushaf) which contains "a book on temples and stones" (kitāb al-barābī wa-l-aḥjār), but we do not find any actual discussion of temples in either Ayasofya 3610 or Arabe 2775. However, there is a similar discussion in another stone magic collection in MS Cambridge, Dd. 4. 28, ${ }^{51}$ in a treatise titled Mușhaf Hirmis al-Harāmisa (The Book of Hermes of the Hermae, fols. 100r-119v), described as "the second book that covers the kinds of stones and their minerals, and wherein there is [a discussion of] their benefits, explained clearly, and wherein he also mentions several temples" (fol. 100v). There is no reference here to the Üjāyaqī. A text attributed to Hermes

46. On the astral scientist 'Uțārid b. Muhammad al-Ḥāsib (fl. ninth-tenth century) and for comparisons of his work with Ghāyat al-ḥakìm on the basis of MS Madrid, El Escorial, no. 939, fols. 16v-17v, see M. J. Parra Pérez, "El 'Sirr al-asrār' de 'Uțārid b. Muḥammad al-Ḥāsib y sus aforismos," Anaquel de estudios árabes 20 (2009): 165-86.

47. See more on these two texts below.

48. Ibn al-Nadìm, al-Fihrist, 387; Sezgin, Geschichte des arabischen Schrifttums, 5:254; 6:161; 7:137.

49. MS Paris, BnF, Arabe 2775, fol. 102v. In MS Istanbul, Süleymaniye, Ayasofya 3610, fol. 144v, the book's title is given as: إِرْخَانِيقي

50. MS Paris, BnF, Arabe 2775, fols. $102 \mathrm{v}-103 \mathrm{v}$.

51. This manuscript carries the title Kitāb Azmār al-afkār fi jawāhir al-ahjār (the divulsion of ideas on the precious stones) It was sponsored for the treasury of al-Malik al-Nāṣir Nāṣir al-Dīn Muhammad b. Qalāwūn (r. 1293-94, 1299-1309, 1310-41). The manuscript ends abruptly. 
with that title perhaps once existed, containing the material in Mușhaf Hirmis al-Harāmisa, the material in 'Uțārid's text (in Arabe 2775 and Ayasofya 3610), and Kitāb al-Ūjāyaqī fi al-tillismāt (Arabe 2775). ${ }^{52}$

The final text in the PsAH Cycle is al-Kitāb al-majmū' fi khawāṣs al-ahjāar (The Collection Concerning the Occult Properties of Stones), which contains Kitāb Ma'rifat al-hijāra wa-khāșsiyatihā wa-nuqūshihā (On the Knowledge of Stones, Their Occult Properties, and Their Inscriptions) taken from al-Hādhițūs by the first Hermes, ${ }^{53}$ as well as other books (mașāhif). The text begins as follows:

This is the book on the knowledge of stones, their occult properties and inscriptions, what is made from them, and these things with which its practice is accompanied, retrieved from Kitāb al-Hādhìtūs by the first Hermes and the books of wisdom (mașāhif al-hikma). ${ }^{54}$

One of the five texts featured in this collection is referred to as bāb mahakkāt al-ahjār min kalām Aristotle wa-ghayrihi ("a chapter on the pulverulence of stones from the writings of Aristotle and others")..$^{55}$ Its content is identical with that of a section called dhikr mahakkāt al-hijār al-sab`a ("reference to the pulverulence of the seven stones") in Cambridge, Dd. 4. 28, fols. 120r-122r. Both are based on the sayings of a sage named Funțus.

\section{Kitāb 'llal al-Rūhāniyyāt and More of al-Ustuwatțās}

According to the manuscript evidence, $K$. 'Ilal al-rūhāniyyāt is known as a two-part composition, comprising a text from al-Ustuwatțās and a second part, which lacks a title. The text from al-Ustuwațtās, which constitutes the first half of $K$. 'Ilal al-rūhāniyyāt, is concerned with the ontological links between the macrocosm and the microcosm, Aristotelian hylomorphism and the generation of the terrestrial world, the celestial structure of the cosmos, and the role of the rūhāniyyāt in the administration of the celestial,

52. Arabe 2775 also contains "The Scintillating Pearls on the Properties of Stones and Minerals" (al-La'āli' al-muḍī’a fị khawāșs al-jawāhir wa-1-ahjār) by Aḥmad al-Tīfāshī (1184-1253) (fol. 1v), a book on the properties of stones by Hunayn b. Ishāq (fol. 76v), a book by Hermes on the occult properties of stones (fol. 161v), and an epistle on ancient opinions concerning stones, heavily featuring Aristotelian writings on stones (fol. 131v).

53. Abū Ma'shar al-Balkhī describes three different figures named Hermes in a surviving portion of his lost Kitāb al-Ulüf. The first Hermes was identified as Idrīs and is presented as an antediluvian prophet who constructed Egyptian temples. His father is Gayōmard. He is a consummate astronomer/astrologer and the first physician. The second Hermes is Babylonian who excelled in medicine, philosophy, and mathematics. Pythagoras is his pupil. The third Hermes of Abū Ma'shar lived in Egypt after the Flood. He is skilled in drugs and poisons and composed books on alchemy and precious stones. K. van Bladel, "Hermes and Hermetica", in Encyclopaedia of Islam THREE, ed. Kate Fleet, Gudrun Krämer, Denis Matringe, John Nawas, Everett Rowson (Leiden: Brill, online on 11 October 2021 http://dx.doi.org/10.1163/1573-3912_ei3_COM_23130; van Bladel, Arabic Hermes, 27 esp. n. 21, 28, 31-32; D. Pingree, The Thousands of Abū Ma'shar (London: Warburg Institute, 1968); C. Burnett, "The Legend of the Three Hermes and Abū Ma'shar's Kitāb al-Ulūf in the Latin Middle Ages," Journal of the Warburg and Courtauld Institutes 39 (1981): 231-34; D. Pingree, From Astral Omens to Astrology, from Babylon to Bīkāner (Rome: Istituto italiano per l'Africa e l'Oriente, 1997), 53-54.

54. Delhi Arabic 1946, fol. 126r.

55. Ibid., fol. 154r.

Al-'Ușūr al-Wusțā 29 (2021) 
terrestrial, and human worlds. It also discusses the creation of Admānūs and Haywānus, and the lunar mansions and associated nirranjs. It thus perfectly matches the content of al-Ustuwatțās in the PsAH Cycle (see above). In addition, it complements the content of al-Hādhịtūs, which describes itself as "the book that God, powerful and exalted, taught Adam." ${ }^{66}$ The same divine lessons to Admānūs are covered in the part of al-Ustuwatțās found in Kitāb Ilal al-rūhāniyyāt. In the second part, we read that K. Ilal al-rūhāniyyāt is in fact a translation, and we are given a summary of the second part's contents:

Hunayn b. Ishāa said: Among the books of Aristotle that we have found and I have translated from the Greek tongue to the Arabic is Kitāb Ilal al-rūhāniyyāt by Hermes. It is divided according to the seven climes, their nature, and their operations. This is the book wherein Aristotle explains the causes of the rūhāniyyāt, the nīranjs, their substances, and their differences, distributed among the seven climes. For Alexander asked Aristotle the Sage [for this information] when he had just completed Kitāb alIsțimākhīs, which he had explained to him during his march to Persia. ${ }^{57}$

The reported contents of this part of $K$. 'Ilal al-rūhāniyya and the stated chronology of its composition indicate that it is al-Isțimātīs, which, according to the prologue found in the PSAH Cycle, is likewise organized "according to the seven climes and their nature, operations, and substances" and treats "the causes of the rūhāniyyāt, their activities, their substances, and their differences across the seven climes and according to the seven planets." ${ }^{8}$

The texts' own narratives and the cross-references established by this study demonstrate the unity between the texts of the PsAH Cycle and the Kitāb Ilal al-rūhāniyyāt. We can conclude that the first text written was al-Isțimākhīs, followed by al-Isțimāțīs. Al-Ustuwatțās was part of a larger Hermetic work called K. 'Ilal al-rūhāniyyāt. It is not a farfetched possibility that al-Isțimākhīs, al-Isțimāțīs, al-Ustuwațtās, and al-Hādhìțūs are all parts of the larger K. Ilal al-rūhāniyyāt. It remains unclear whether they were written all at once or over a period of time, but together they constitute the core texts of a pseudo-Aristotelian Hermetic corpus, containing a comprehensive and consistent cosmology according to which the world is ruled by God and a demiurge, unique genesis myths, planetary reverence, and magical and theurgic practices set within this world.

\section{Al-Madītīs}

The work known as al-Maditịs is an abridged reformulation of the content of the PsaH core texts. The text begins as follows:

This is the book of Hermes on the operations pertaining to moving animals (fi sanājic al-ḥayawān al-mutaḥarrika). It is the one he called Kitāb al-Madītīs, interpreted by

\footnotetext{
56. Ibid., fol. 53r.

57. MS Paris, BnF, Arabe 2577, fol. 38r.

58. Delhi Arabic 1946, fol. 32v.
} 
Aristotle the Sage, and mentioned by Aristotle to Alexander the King in al-Isțimāțīs. ${ }^{59}$

According to the text, al-Maditịs is the title given to the work by Aristotle, who interpreted the knowledge revealed to Hermes about the secrets of creation obtained in a dark crypt. ${ }^{60}$ This is the same story as that which we find in al-Isțimākhīs, where Hermes meets his personal rūhāniyya, known as the Perfect Nature. ${ }^{61}$ The text proceeds to summarize some content from al-Isțimākhīs. Elsewhere, more textual history is given, clearly delineating the relationship between al-Maditịis and other texts of the PsAH:

Aristotle said: You are satisfied only with the most extensive research and analysis (al-bahth wa-l-istiqșā'). Yes, through it I have found the description of these things, the niranjs, and the employment of wet and dry organs ( $\left.a^{c} d \bar{a}^{j}\right)$ that the maker of niranjs needs. These are their hidden secrets that, along with [all] its aspects, were not possible to recount [here] because of their length. I dedicated a book to these [things] and named it Kitāb al-Asrār [The Book of Secrets], and I specified in it the times and hours that the practitioner of these nirranjs needs to keep. [. . .] The Sage omitted mention of these in their [suitable] place to avoid prolongation [. . .], so he placed them all in a single book and named it Kitāb al-Ustuwatțās, ${ }^{62}$ which is translated as "the secrets" (al-asrār). He also added into this book all the secrets needed from of Kitāb al-Istimākhīs and Kitāb al-Isțimāțīs, ${ }^{63}$ the book that compiles the secrets the practitioner of nirranjs needs. This the Sage described in "the Book of the Qualities of Moving Animals." This book is completed by the aid of God and His kindness. This is the book named al-Maditịs, Aristotle's interpretations for Alexander the Great. ${ }^{64}$

The book continues with content from al-Isțimākhīs.

\section{Dhakhïrat Iskandar (The Treasury of Alexander)}

Dhakhirat Iskandar deals with astrology and the principles of astral influences, talismanry, occult properties, and alchemy. Ana Maria Alfonso-Goldfarb studied the work and, with Safa Abou Chahla Jubran, produced a translation into Portuguese on the basis of MS Madrid, El Escorial no. 947 (which also contains Ghāyat al-ḥakìm), and MS Berlin, Staatsbibliothek zu Berlin, Wetzstein II 1209, fols. 1v-42v (see Appendix). ${ }^{65}$

Dhakhirat Iskandar is one of the most popular of all the pseudo-Aristotelian Hermetica, circulating widely in Persian translations. ${ }^{66}$ It begins thus:

59. MS Oxford, Bodleian, Marsh 556, fol. 5r.

60. Ibid., fol. $5 \mathrm{v}$.

61. Delhi Arabic 1946, fols. 4v-5r.

62. الاسطوطاس.

63. الاسطماطيس ,الاسطماخيس.

64. Marsh 556, fol. 110v.

65. A. M. Alfonso-Goldfarb, Livro do Tesouro de Alexandre: Um estudo de hermética árabe na oficina da história de ciência, trans. Alfonso-Goldfarb and S. Abou Chahla Jubran (Petrópolis: Editora Vozes, 1999), $23-25$.

66. C. A. Storey, Persian Literature: A Bio-Bibliographical Survey, vol. 2, part 3 (Leiden: Brill, 1977), 457-58. 
Al-Amir al-Mu'tașim had heard that there was an ancient monastery associated with Antiochus, pupil of Alexander Dhū al-Qarnayn, son of Philip the Greek. Antiochus had built and fortified it, appointing a group to service it and to safeguard a house in it that they claim to contain some of the relics $(\bar{a} y \bar{a} t)^{67}$ of the prophets and their remains. For the sake of the group responsible for maintaining the monastery, Antiochus sponsored (waqqafa 'alā) several estates, and he wrote down for them records that he notarized in Byzantium (thabattahā fi Rümiyya al-Kubrā) to preserve its contents, establish covenants with the Byzantines and Greeks so that they would not allow anyone to target them or to obstruct that which he had sponsored for them, and prevent the opening of the gate to the house of the remains to honor [anyone]. So al-Mu'tasim sent a message to the people of this monastery, ordering them to allow him [to enter] the house of the remains. He said: "If this house contains nothing but the remains of prophets, as you claim, we will not usurp it or damage what is in there. If it contains money or books of wisdom, there would be no benefit in leaving them sealed there after the death of their owners. We are more entitled to them." 68

Eventually, according to the narrative, al-Mu'tașim also guaranteed the safety of the monastery attendants' lives and property, and they trusted him. Then he dispatched the intelligence courier al-Malik b. Yahyā, the astrologer 'Alī b. Ahmad, and the engineer Muhammad b. Khālid to search this monastery, but to no avail; they found nothing. Muhammad b. Khālid suspected that the attendants had transferred the objects somewhere else. The latter protested and nearly convinced him and al-Mu'tașim that nothing had been hidden. After this event, al-Mu'tașim saw in a dream the caliph al-Ma'mūn telling him that in this house he should find "the treasury of Alexander Dhū al-Qarnayn and the knowledge of Aristotle and Hermes the Great." As soon as he woke up, he called for Muhammad b. Khālid and ordered him to destroy the walls and their foundations. Eventually, the searchers found a copper box covered with Hematite (al-hadìd al-șinì), and inside it was a box made of red gold, locked with a golden key hanging from a golden chain. On the box was writing in Greek script, and inside it was a 360-page golden book whose pages were also made of red gold. Every page had twelve lines, written sometimes in Greek and sometimes in Latin script. This was the treasury of Alexander. To honor Muhammad b. Khālid, the treasury's finder, al-Mu'tașim tasked him with writing the prologue to this highly sought-after and treasured work. The prologue claims that the text was discovered after the sack of Amorium in 223/838. ${ }^{69}$ The theologian Ibn Taymiyya (661-728/1263-1328) knew the Dhakhira and considered it a book on the astral religion of the Sabians, among whose adherents he counted Aristotle. ${ }^{70}$ There is no reference in the work to any of the other titles of the PsAH, but its contents match their magical concerns and practices.

67. Damage in IO Islamic 673, fol. 1v, obscures the word آيـات (āyāt). On close inspection, however, it seems to be آلات (ālāt), "possessions", which is found in MS Tehran, Majlis-i Shūrā-yi Millī, no. 4752, fol.1r.

68. MS London, British Library, IO Islamic 673, fols. 1v-2r.

69. IO Islamic 673, fols. $1 \mathrm{v}-5 \mathrm{r}$.

70. Ibn Taymiyya, Dar’ ta āruḍ al-`aql wa-1-naql, ed. M. R. Sālim, 10 vols. (Riyadh: Imam Mohammad Ibn Saud Islamic University, 1991), 1:312. 
In the tenth-century magic handbook Ghāyat al-hakim, the work's author, Maslama al-Qurțubī (d. 353/964), mentions a work by Aristotle called al-Malāțīs containing nìranjs made by Kinas al-Hindī, about whom Alexander the Great had inquired. According to al-Qurțubī, Kīnās had been known as al-Rūhānī ("the theurgist") and had reached the age of 540 under the emperor Hadrian. Al-Qurțubi goes on to provide numerous recipes from al-Malātīis over two chapters. ${ }^{71}$ This Kinas and his nïranjs are also mentioned in al-Madịtīis. ${ }^{72}$ Nevertheless, beyond such superficial similarities, nothing substantiates a real connection between al-Malātīs and al-Madītīs. ${ }^{73}$ The title al-Malātīs is likewise mentioned in the alchemical work Tadbīr Hirmis al-Harāmisa and seems to be foundational to it. ${ }^{74}$

The abovementioned third $b \bar{a} b$ of al-Kitāb al-Shāmil claims to contain a certain al-Mīyālātịis al-akbar and says to contain "a description of the [twenty-eight lunar] mansions ...., their natures and properties, and the names of the angels in charge, their suffumigations, and the niranjs made under them" ${ }^{75}$ The work continues with the exposition of the mansions according to this al-Mīyālātīis. ${ }^{76}$ The content is different from that of the Dhakhira and the Ghāya. Al-Malāțīs al-akbar/Dhakhïrat Iskandar is thus likely to be a later work that elaborates Aristotelian-Hermetic magical and alchemical practice.

\section{Al-Shưrāa al-Yamāniyya or Aḥkām Ṭulū' al-Shu'rāa al-Yamāniyya}

The text known as al-Shu'rā al-yamāniyya is a popular, predominantly astrological text on prognostication by the star Sirius. The prologue claims that it is based on a text by Hermes, The Treasured Book (al-Kitāb al-Makhzūn), on which Aristotle drew and which he interpreted. It was translated into "the ancient tongue" 77 by Nafțuya the Sage, and in MS Paris, BnF, Arabe 2578, we are told that it was known to Wahb b. al-Munabbih (34-109/654728), the author of a sacred history entitled Qișaș al-anbiyā' (Stories of the Prophets). ${ }^{78}$ Edgar Blochet saw no reason to contradict this claim and proposed a Greek or Syriac origin for the work. He went as far as stating that al-Shu'rā was the basis for the part of Arabe 2577 that contains al-Ustuwațțās and K. Tlal al-rūḥāniyyāt, an opinion accepted by Sezgin. ${ }^{79}$ However, a comparison of the works does not support this assertion. The cosmology and

71. Al-Qurțubī, Picatrix, ed. Ritter, 248-85; Sezgin, Geschichte des arabischen Schrifttums, 7:66.

72. Marsh 556, fol. 47r. On Kīnās and nīranjs, see Sezgin, Geschichte des arabischen Schrifttums, 7:66; Ullmann, Natur- und Geheimwissenschaften, 367-68.

73. Ullmann, Natur- und Geheimwissenschaften, 366-67.

74. P. Carusi, "Alchimia ermetica e arte del vetro: Il Tadbīr Harmis al-Harāmisa," Quaderni di studi arabi 10 (1992): 175-200, at 176-78; Ullmann, Natur- und Geheimwissenschaften, 168, 366-68; Sezgin, Geschichte des arabischen Schrifttums, 4:39 (no. 3).

75. MS, London, British Library, Delhi Arabic 1915, fols. 91r-91v; SOAS 46347, fols. 30v-31v.

76. SOAS 46347, fols. 31r-59v.

77. In MS Paris, BnF, Arabe 2578, fol. 1v: "the ancient book," kitāb.

78. Arabe 2580 , fol. $1 \mathrm{v}$.

79. E. Blochet, "Études sur le Gnosticisme musulman," Rivista degli studi orientali 4, no. 1 (1911): 47-79, at 57-58; see also Sezgin, Geschichte des arabischen Schrifttums, 4:35. 
content of K. 'Ilal al-rūḥāniyyāt (which, as we have seen, included al-Ustuwațțās) differ considerably from those of al-Shu'rā despite their common astrological concerns, so the latter seems more like a sister text to the former rather than its basis.

\section{Dating the Pseudo-Aristotelian Hermetica}

For dating purposes, we are fortunate that the PsAH were influential on some major early texts on magic, in which they are cited by name. In some recensions of the tenth-century esoteric encyclopedia of Ikhwān al-Ṣafā' known as Rasāill Ikhwān al-Șafā') (The Epistles of the Brethren of Purity), reference is made to al-Ustuwatțās as the source of the epistle's discussion of the lunar mansions. ${ }^{80}$ The Rasā'il were written in Iraq in the first half of the tenth century, thus giving a terminus ante quem for al-Ustuwatțās. ${ }^{81}$ To this we can add references made in one of the best-known texts on astral magic in Arabic, Ghāyat al-hakìm, which was written in 348/959 according to its Andalusian author, Maslama al-Qurțubi, who traveled to the eastern domains, including Iraq. ${ }^{82}$ Another possible clue to the date of the PsAH comes from one of the treatises themselves, namely, the version of al-Isțimātīis found as the second part of K. Ilal al-rūhāniyyāt in Arabe 2577 and MS Manisa, National Library of Manisa, no. 1461. That text claims that the prominent translator Hunayn b. Ishāq (d. 260/873) had come across the text among works written by Aristotle and translated it from Greek into Arabic. ${ }^{83}$ If this is true, we have a terminus post quem for the text. However, the putative role of Hunayn b. Ishāq is one of the apocryphal elements of the PsAH texts alongside the attribution of the texts to Aristotle and the attribution of Aristotle's knowledge to Hermes. No such translation by Hunayn is recorded in historical accounts, and I have found no evidence of the work's Greek origins or references to it in ancient texts. The mention of Hunayn is reminiscent of the attribution to him of the aforementioned book on stones in Arabe 2775 and of the translation of Kitāb Nawāmīs Aflātun (The Secrets of Plato, known in Latin as Liber Vaccae), a ninth-century work mentioned in the early

80. Ikhwān al-Șafā', Rasā’il Ikhwān al-Ṣafā', 4 vols. (Beirut: Dār Șādir, 2008), 4:443-45; MS Istanbul, Süleymaniye, Atıf Efendi 1681, fols. 572a-576a; MS Manisa, National Library of Manisa (Genel Kitaplik), no. 1461, fols. $18 \mathrm{v}-25 \mathrm{v}$.

81. According to Maribel Fierro, "it is safe to conclude that they were written before 325/936"; M. Fierro, "Bāṭinism in al-Andalus: Maslama b. Qāsim al-Qurțubī (d. 353/964), Author of the Rutbat al-Hakìm and the Ghāyat al-Hakim (Picatrix)," Studia Islamica 84 (1996): 87-112. If the text's reference to 'Īd Ghadir points to the public commemoration of Ghadir Khumm started by the Buyids, the terminus post quem should be 945 , the year the Buyids took over Baghdad. This is supported by Abū Hayyān al-Tawhịīìs account of the Ikhwān al-Ṣafā̄'s being active under the Buyids; see A. Hamdani, "Abū Ḥayyān al-Tawhīìi and the Brethren of Purity," International Journal of Middle East Studies 9, no. 3 (1978): 345-5. See also G. de Callataÿ, "Magia en al-Andalus: Rasāil Ikhwān al-Ṣafā', Rutbat al-ḥakīm y Ghāyat al-ḥakīm (Picatrix)," al-Qanțara 34, no. 2 (2013): $297-344$.

82. Al-Qurțubī, Picatrix, ed. Ritter, 1.

83. Arabe 2577, fol. 38r. 
tenth-century Kitāb al-Tajmī̄ (The Book of Assemblage) attributed to Jābir b. Hayyān. ${ }^{84}$ All of this lends greater support to a ninth-century dating.

In one manuscript of al-Shu'rā al-yamāniyya (Arabe 2578, fol. 1v), the reader is told that Wahb b. al-Munabbih knew the text as he was an expert on the subject of astral influences. The suggestion that al-Shu'rā was composed in the eighth century is tempting, especially if it was indeed translated from Middle Persian. However, this reference to Wahb is absent from the rest of the manuscripts consulted. Further, there is nothing to suggest that the claim is true, although the association with Wahb is interesting; existing fragments of his Kitāb al-Mabādi' (The Book of Principles) indicate his interest in astral knowledge, and this is confirmed by some accounts. ${ }^{85}$

Blochet argues that "the political horizon" of the Shu'rā's author is that of the first Mamluk sultans, thus suggesting a twelfth- to fourteenth-century Egyptian origin. He supports his argument with the geographic names that appear in the text-namely, Rūm, Syria, Constantinople the Great, Maghreb, Algeria and Kairouan, Nūba, Abyssinia, India and Sind, China, and the countries of the Turks and Kiptchak. ${ }^{86}$ The claim remains highly speculative and unconvincing. The perceived Egyptian connection rests on the fact that the text provides predictions for the flooding of the Nile, but interest in this topic was hardly limited to Mamluk-era Egyptians; it was also a concern for the Abbasids, whose centralized taxation systems and extensive administrative reach encompassed Egypt. The flooding of the Nile would have been a significant event also for other dynasties in other periods. Nevertheless, like the Dhakhïra, the Shu'rā is not cited in early texts as the rest of the PsAH are, and neither work contains cross-references to other PsAH texts. This means that they cannot be set firmly in the ninth century, unless we take at face value the references to the ninth-century sack of Amorium in the Dhakhïra and to Wahb b. Munabbih, who was active in the eighth century, in the Shu'rā. Without further evidence, the dating of these two texts remains open to challenge.

84. L. Saif, "The Cows and the Bees: Arabic Sources and Parallels for Pseudo-Plato's Liber Vaccae (Kitāb al-Nawāmīs)," Journal of the Warburg and Courtauld Institutes 79 (2016): 1-47. David Pingree considers the Liber Vaccae a Sabian text on the basis of a passage that describes the convictions of the masters of secrets (nawāmīs), opfices aneguemis; however, nowhere in the passage are Sabians mentioned. D. Pingree, "The Șābians of Harrān and the Classical Tradition," International Journal of the Classical Tradition 9, no. 1 (Summer 2002): 8-35, at 34-35; M. Van der Lugt, “'Abominable Mixtures': The Liber Vaccae in the Medieval West, or the Dangers and Attractions of Natural Magic," Traditio 64 (2009): 229-77, at 229, 232-33; D. N. Hasse, "Plato Arabico-Latinus: Philosophy-Wisdom Literature-Occult Sciences," in The Platonic Tradition in the Middle Ages: A Doxographic Approach, ed. S. Gershwin and M. J. F. M. Hoenen, 31-66 (Berlin: de Gruyter, 2002), 53-54; D. Pingree, "Plato's Hermetic Book of the Cow," in Il Neoplatonismo nel Rinascimento, ed. P. Prini, 133-45 (Rome: Istituto della Enciclopedia Italiana, 1993), 133-34.

85. Sezgin, Geschichte des arabischen Schrifttums, 7:99; R. G. Khoury, "Un fragment astrologique inédit attribué à Wahb b. Munabbih," Arabica 19, no. 2 (1972): 139-44; N. Abbott, "Wahb b. Munabbih: A Review Article," Journal of Near Eastern Studies 36, no. 2 (1977): 103-12; A.-L. De Prémare, "Wahb b. Munabbih, une figure singulière du premier islam," Annales: Histoire, Sciences Sociales 3 (2005): 531-49.

Blochet, "Études sur le Gnosticisme musulman," 57-58; see also Sezgin, Geschichte des arabischen Schrifttums, 4:35-35.

86. Blochet, "Études sur le Gnosticisme musulman," 61-62. 
The dating of certain PsAH texts has been connected to the dating of the better-known Sirr al-khaliqa (The Secret of Creation) by pseudo-Apollonius, a "hermetic" cosmological text concerned mostly with the etiology of all created and generated things, from angels to minerals, with pronounced astrological undertones. The real Apollonius (Bālīnās) was known as "the master of talismans," according to various Arabic sources. ${ }^{87}$ In this work, a Christian priest called Sājiyūs from Nablus is mentioned as the translator of "Kitāb al-"Ilal" which was the title of the book which was given to Apollonius by the Perfect Nature (al-tib $\bar{a}^{c}$ al-tāmm) in the dark crypt from which he also retrieved the Emerald Tablet. ${ }^{88}$

The first part, or introduction, of Sirr al-Khaliqa is a commentary by the priest establishing the truth of monotheism (a theme that is continued in the following part), and it contains an interpretation of twenty-two divine names. ${ }^{89}$ The priest identifies himself as a Rūmī (Byzantine) and positions his beliefs about the nature of God in contrast to those of the Brahmins, who caused the Indians to deviate from the words of the Buddha, believing that God is a body of light. He also denounces the Sabians for believing that God mixes with his creation. ${ }^{90}$ Minor interventions by a Muslim editor, such as prayers upon the Prophet Muhammad as section starters and conclusions, are found through the text. ${ }^{91}$

Ursula Weisser, Martin Plessner, and Hellmut Ritter have identified several parallels between al-Ustuwațtās, al-Isțimāțis, and Sirr al-khalìqa, especially the division of causes into four types ${ }^{92}$ and the story of the dark crypt in which the existence of the Perfect Nature is revealed and the Emerald Tablet. ${ }^{93}$ Thus, the dating of one can shed light on the dating and context of the other and locates its place in a particular intellectual tradition or religious current.

Plessner was hesitant to ascribe a pre-Islamic origin to Sirr al-khaliqa, although he considered it older than the PsAH treatises. Weisser argued that the author of Sirr al-khaliqa used "a pre-Islamic version" of al-Isțimātīs..$^{94}$ She concluded, on the basis of brief and speculative linguistic comparisons, that both texts had a non-Arabic origin. Zimmermann, in his review of Weisser's monograph, asserted that Weisser was right in arguing that Sirr al-khalīqa depends on al-Isțimāțis, but wrong in suggesting that the borrowing took place

87. M. K. Zanjani Asl, "Sirr al-khaliqqa and Its Influence in the Arabic and Persianate World: 'Awn b. al-Mundhir's Commentary and Its Unknown Persian Translation," al-Qanțara 37, no. 2 (2016): 435-73, at 437-40.

88. Ps. Apollonius of Tyana, Buch über das Geheimnis der Schöpfung und die Darstellung der Natur (Buch der Ursachen), ed. U. Weisser (Aleppo: Institute of the History of Arab Science, University of Aleppo, 1979), 100.

89. Ps. Apollonius, Geheimnis der Schöpfung, 1-50, 53-65.

90. Ps. Apollonius, Geheimnis der Schöpfung, 63-65; U. Weisser, Das Buch über das Geheimnis der Schöpfung von Pseudo-A pollonius von Tyana (Berlin: de Gruyter, 1980), 82-83.

91. Ps. Apollonius, Geheimnis der Schöpfung, 99-100.

92. Ps. Apollonius, Geheimnis der Schöpfung, 13-14; cf. al-Ustuwatțās, Arabe 2577, fols. 2r-3r.

93. Ps. Apollonius, Geheimnis der Schöpfung, 5-7; cf. al-Isțimākhīs, Delhi Arabic 1946, fols. 4r-5v. For the parallels, see Weisser, Das Buch über das Geheimnis der Schöpfung, 55, 68-69; M. Plessner, "Neue Materialien zur Geschichte der Tabula Smaragdina," Der Islam 16 (2009): 77-113, at 93-95; Maslama al-Qurțubi, Picatrix: Das Ziel des Weisen; Translated to German from the Arabic, trans. and ed. H. Ritter and M. Plessner (London: Warburg Institute, 1962), 198-202. See also van Bladel, Arabic Hermes, 124-25, 158-61, 170-71, 178-79.

94. Weisser, Das Buch über das Geheimnis der Schöpfung, 69. 
at a "pre-Arabic" stage. In his view, it was more probable that it was the "Arabic version" of al-Istimātīs that had been used in the compilation of the Arabic version of Sirr al-khaliqqa. ${ }^{95}$

There is no reliable information that suggests a pre-Islamic origin for either Sirr al-khaliqa or the PsAH. Their pseudo-epigraphic nature places them within a widespread tradition of (mis)attributions common in the ninth and tenth centuries. Applying the principle of Occam's razor, Sirr al-khaliqa is more likely a text composed or heavily paraphrased by the priest Sājiyūs and a Muslim redactor, whose touches are present throughout the text. As Weisser herself has pointed out, it is difficult to differentiate the "original" text from these intrusions. ${ }^{96}$ The author knew al-Isțimāțis and al-Isțimākhīs, and Sirr al-khalīqa was where he transferred, negotiated, rejected, and Christianized some of their doctrines. This becomes even more evident when we look at his discourse on monotheism and his take on the rūhāniyyāt, which he calls rūhāniyyūn.

The author of Sirr al-khāliqa criticizes the Sabians, "the people (așhāb) of trees," "the people of the Sun," "the people of the stars," idolaters, "the people of the natures (așhāb al-țabā'ic)," and others who claim that God has a partner in creation. ${ }^{97}$ He challenges a particular group of people on their belief that "the First Creator authorized some of his creatures to create" 98 -a belief reminiscent of the power given to Hādūs by the

95. F. W. Zimmermann, review of Das Buch über das Geheimnis der Schöpfung by Weisser, Medical History 25 (1981): 439-40; J. Ruska, Tabula Smaragdina: Ein Beitrag zur Geschichte der Hermetischen Literatur (Heidelberg: Carl Winter's Universitätsbuchhandlung, 1926), 67. Antoine Isaac Silvestre de Sacy believed Sirr al-khāliqa to be an originally Greek work penned by the Christian priest Sājiyūs and subsequently translated into Syriac and expanded anonymously. This Syriac version was then translated into Arabic by a Muslim who added Islamic linguistic elements (Weisser, Das Buch über das Geheimnis der Schöpfung, 8). François Nau, on the other hand, contended that the text's "essence" was indeed attributable to Apollonius of Tyana, although it had undergone many redactions. He identified the translator into Syriac as Sergios (d. 536) from Ras al-Ayn in Syria and argued that Hunayn b. Ishāq was the translator into Arabic; see, Ibid., 9. Julius Ruska was of the opinion that the work had been produced between the sixth and eighth centuries in northeast Persia; he remained uncertain about a Greek original and was inclined to consider Sājiyūs the invention of a Muslim redactor; see, J. Ruska, Tabula Smaragdina: Ein Beitrag zur Geschichte der Hermetischen Literatur (Heidelberg: Carl Winter's Universitätsbuchhandlung, 1926), 122-27, 129. Martin Plessner saw a pre-Islamic origin unlikely; see, Martin Plessner, "Neue Materialien zur Geschichte der Tabula Smaragdina," Der Islam 16 (2009): 77-113. Paul Kraus suspected that the author, who belonged to Hellenized circles in Syria, adapted an early translation into Arabic, with a final redaction under the caliph al-Ma'mūn; see, P. Kraus, Jābir ibn Hayyān: Contribution à l'histoire des idées scientifiques dans l'islam, vol. 1: Le corpus des écrits Jābiriens (Cairo: French Institute of Oriental Archaeology, 1943), 290-303. Louis Massignon deemed it the work of a "heterodox Muslim" under al-Ma'mūn, based on a "hermetic prototype"; see, L. Massignon, "Inventaire de la littérature hermétique arabe," in Festugière, La révélation d'Hermès Trismégiste, 1:384-400, at 395. Ruska, meanwhile, concluded that "the Arabic Hermetic writings"-by which he meant the PsAH-are not based on Coptic or Greek models but rather were created in the tenth or eleventh century on the basis of borrowings from Ghāyat al-hakim, which at that time was erroneously attributed to the mathematician Maslama al-Majrìtī (950-1007); see, J. Ruska, Tabula Smaragdina: Ein Beitrag zur Geschichte der Hermetischen Literatur (Heidelberg: Carl Winter's Universitätsbuchhandlung, 1926), 67.

96. Weisser, Das Buch über das Geheimnis der Schöpfung, 69.

97. Ps. Apollonius, Geheimnis der Schöpfung, 35-37.

98. Ibid., 46. 
"First Creator" in al-Isțimātīis. Furthermore, he refers to Adam as Admānūs, the name used across the PsAH, and describes him, along with Lucifer (Ibliss), as the first sinner..$^{99}$

In a subsequent section, "On the Creation of Angels," the author describes angels as "the luminescent intelligences" (al-arwāh al-mutafakkira al-nā'ira). The higher ones, he says, are created from simple fire, water, or air, but not from earth, as that is too terrestrial for their sublime nature. Such beings also include jinn, devils (shayāțin), "dwellers of the air, fire, sea and land," and the rūhāniyyūn of the two luminaries (the sun and the moon), planets, stars, and spheres who govern celestial and terrestrial affairs. ${ }^{100}$ Unlike the PsAH, Sirr al-khaliqa seeks to "demystify" the nature of these beings, repeatedly stressing that though they are immortal, but like animals and plants, they emerge from the elements, not from ether or through some other cosmogenic forces. ${ }^{101}$ The author goes on to describe the traits and responsibilities of the planetary rūhāniyyūn, which include fighting off rebellious devils (maradat al-shayātīn). Interestingly, the role of guardian angels (al-hāfizūun) over children is given to mercurial rūhāniyyūn. ${ }^{102}$ Lunar rūhāniyyūn are assigned to guard the stars from the evil Shițāìl (Lucifer) and his progeny, who eavesdrop on the Higher Assembly, that is, the solar rūhāniyyūn. ${ }^{103}$ This recalls Quran 37:6-8: "We have adorned the low heavens with embellishing planets (6) as protection from every rebellious devil (shayțān mārid) (7) so they may not eavesdrop on the Higher Assembly, pelted from every side (8)." Moreover, the author provides a peculiar angelic hierarchy. The two highest classes of supra-solar angels are what he refers to as Samūrā and the Carriers (al-hamala), and below them are the subsolar Karūbā and the Treasurers (khazana). Their description contains similarities, albeit unsystematic ones, with Christian angelology. The Karūba are likely to be the cherubim; both groups are described as having four wings. The Samūrā occupy a position similar to that of the seraphim, but they have zoomorphic appearances (the faces of oxen, lions, and eagles, in addition to human faces), a feature traditionally associated with the cherubim. The Carriers are reminiscent of the Quranic hamalat al-'arsh (the Carriers of the Throne), who, like the Christian Thrones, occupy a high station. The Treasurers-the lowest category of angels according to Sirr al-khaliqa-recall the Dominations. ${ }^{104}$ This angelic hierarchy is different to the Celestial Hierarchy of pseudo-Dionysius the Areopagite (fifth-early sixth century), which was translated as part of the Corpus Dionysiacum in 1009 by 'Alī 'Īsā b. Ishạa of Emesa. ${ }^{105}$ However, Christian medieval angelology coalesced and was formalized in the thirteenth century, when reflections on the angels' metaphysical nature came to rely more heavily on Aristotelian problems and categories. Sirr al-khaliqa's reworking of Christian

\footnotetext{
99. Ibid., 47-48.

100. Ibid., 161-56.

101. Ibid., 155-58.

102. Ibid., 169.

103. Ibid., 166, 178-79.

104. Ibid., 179-84.
}

105. A. Treiger, “The Arabic Version of Pseudo-Dionysius the Areopagite's 'Mystical Theology,' Chapter 1: Introduction, Critical Edition, and Translation," Le Muséon 120, nos. 3-4 (2007): 365-93. 
angelology can be seen to reflect an important moment before its standardization, when scholastics were developing "their ideas about angels and the creation in response to Arab and Greek ideas about intelligences and the origins of the world." 106 The Sirr al-khaliqa's major objectives were spurred by ideas about the rühāniyyāt found in al-Isțimāțīs and al-Isțimākhiss, which supports the conclusion that the latter two texts preceded Sirr al-khalīqa. ${ }^{107}$

Before the tenth century, although references to Apollonius as a master of talismans and philosopherabound, directcitations of Sirral-khaliqqa are very rare, and even whereits influence has been detected, the evidence has fallen short. ${ }^{108}$ A notable exception is the Jābirian corpus, specifically Kitāb al-Ahjār 'alā ra'̄i Bālīnās (The Book of Stones According to Apollonius) and

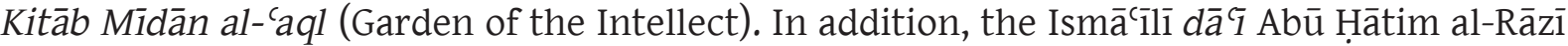
(d. 322/935) claims in his Kitāb al-Nubuwwa (The Book of Prophecy) that Sirr al-Khalìqa was apocryphal and had been written in the time of al-Ma'mūn (r. 196-201/813-833). However, this statement is too obscure to be accorded much weight, especially given the literary genre of the work that contains it-namely, a debate between Abū Hâtim al-Rāzì and Abū Bakr b. Zakariyā al-Rāzī (251-313/865-925). ${ }^{109}$

Accepting the Jābirian corpus as the late ninth- or early tenth-century product of a collective united by a conception of a Jābirian program of knowledge centered on the occult sciences, especially alchemy and magic, ${ }^{110}$ and further accepting 959 as the time of composition of the Ghāya, ${ }^{111}$ which cites the PsAH and the Jābirian Kitāb al-Nukhab (The Compendium) - the latest treatise in the corpus - we may place the PsAH, Kitāb al-Nukhab, and Kitāb al-Ahjār chronologically before the Ghāya. There is no evidence of the influence of Sirr al-khaliqa on the Ghäya, which is not surprising given their different contents and especially their disparate positions on the rūhāniyyāt; in addition, perhaps they were

106. D. Keck, Angels and Angelology in the Middle Ages (Oxford: Oxford University Press, 1998), 71.

107. Risālat Bālīnās al-Hakìm fi ta’thīr al-rūhāniyyāt, MS Madrid, El Escorial, no. 921; Kitāb Ṭalāsim Bālīnās al-akbar, MS Paris, BnF, Arabe 2250, fols. $84 \mathrm{r}-134 \mathrm{v}$. The latter title is also given for MS Berlin, Petermann I 66, fols. $41 \mathrm{v}-74 \mathrm{r}$, which has the same prologue as the aforementioned Madrid manuscript. The rest of its contents are an amalgam of material from the PsAH. On Kitāb Ṭalāsim Bālīnās al-akbar, its Greek background, and the two manuscripts, see L. Raggetti, “Apollonius of Tyana's Great Book of Talismans," Nuncius 34 (2019): 155-82. The rūḥāniyyāt in Risālat Bālīnās al-Hakìm fi ta’thīr al-rūhāniyyāt (The Epistle of Apollonius the Sage on the Influences of the Rūhāniyyāt) are construed in a way that is more aligned with their depiction in the PsAH, whereas in Kitāb Țalāsim Bālīnās al-akbar (The Great Book of Talismans by Apollonius), the spiritual agents are angelic (malak) with Hebrew names such as Ishmiyāl and Hirbīl.

108. For direct references from the early tenth century, especially by Ismācîlī dā $c_{1}$ s, see Zanjani Asl, "Sirr al-khalīqa and Its Influence."

109. Jābir b. Hayyān, Mukhtār rasā’il Jābir b. Hayyān, ed. P. Kraus (Cairo: Maktabat al-Khānjī, 1936), 126, 223; S. N. Haq, Names, Natures, and Things: The Alchemist Jābir ibn Hayyān and His "Kitāb al-Ahjār" (Dordrecht: Kluwer, 1994), 29-30; Sezgin, Geschichte des arabischen Schrifttums, 4:77-88.

110. P. Kraus, Jābir ibn Hayyān: Contribution à l'histoire des idées scientifiques dans l'islam, vol. 1: Le corpus des écrits Jābiriens (Cairo: French Institute of Oriental Archaeology, 1943), xxiii-xxvi, xxxiv-xxv.

111. As indicated by the manuscripts; see also Fierro, "Bāținism in al-Andalus," 97. 
composed too closely together in time for one to have influenced the other. We are thus left with two possible scenarios:

\section{Scenario 1:}

PsAH (early ninth century) $\rightarrow$ Sirr al-khalīqa (mid- to late ninth century) $\rightarrow$ al-Nukhab and al-Ahjār (early tenth century) $\rightarrow$ Ghāya (mid-tenth century)

This scenario places Sirr al-khaliqqa in or near the time of al-Ma'mūn's reign. If one accepts Sezgin's and Haq's objections to Kraus's dating of the Jābirian corpus and their alternative dating of it to the eighth century, a different, ${ }^{112}$ less likely, scenario emerges in which the $\mathrm{PsAH}$ is a seventh- or eighth-century composition and Sirr al-khaliqa is written shortly after it:

\section{Scenario 2:}

PsAH (seventh-eighth century) $\rightarrow$ Sirr al-khaliqa (seventh-eighth century) $\rightarrow$ al-Nukhab and al-Ahjār (eighth century) $\rightarrow$ Ghāya (mid-tenth century)

There is no evidence of the influence of the PsAH on the magic or worldview of the Jābirian corpus. Al-Kindī (d. between 252-260/866-873) and Thābit b. Qurra (d. 288/901), both of whom wrote on magic, also show no knowledge of the PsAH in their writings, ${ }^{113}$ and neither does Abū Ma'shar al-Balkhī, who took a deep interest in the legend of Hermes. Their neglect of the PsAH could mean that these texts were not produced as early as the seventh or eighth centuries; however, it is just as likely to be indicative of the diversity of magic traditions in these foundational periods in the history of the Islamic occult sciences.

In dating the PsAH, some contextual considerations are necessary, especially given the absence of a smoking gun. The first of these is the trend of Hermetic enthusiasm witnessed in and around the ninth century. Among the Hermetic works translated from Greek to Middle Persian were a treatise known by its Latin title De stellis beibeniis and translated into Arabic as Kitāb Asrār al-nujūm (The Book of Astral Secrets), which David Pingree dates to 505, and Kitāb Hirmis fì tahāwīl sinì al-mawālīd (The Book of Hermes on the Revolutions of the Years of the Nativities), which was translated from Persian into Arabic. ${ }^{114}$ The eighth-century astrologer-translator Abū Sahl b. Nawbakht (eighth century) in his now lost Kitāb al-Nhmt $t^{3} n^{115}$ and the great astrologer Abū Ma'shar in his Kitāb al-Ulüf (The Book

112. Sezgin, Geschichte des arabischen Schrifttums, 4:191-213; Haq, Names, Natures, and Things, 19-29.

113. M.-Th. d'Alverny and F. Hudry, "Al-Kindi: De radiis," Archives d'historie doctrinale et littéraire du Moyen Âge 41 (1974): 139-260; G. Bohak and C. Burnett, Thābit ibn Qurra on Talismans and Pseudo-Ptolemy on Images 1-9: A Reconstruction Based on the Judaeo-Arabic and Latin Texts, Together with the "Liber Prestigiorum Thebidis" (forthcoming); C. Burnett and G. Bohak, "A Judaeo-Arabic Version of Tābit ibn Qurra's De Imaginibus and Pseudo-Ptolemy's Opus Imaginum," in Islamic Philosophy, Science, Culture, and Religion: Studies in Honor of Dimitri Gutas, ed. F. Opwis and D. Reisman, 179-200 (Leiden: Brill, 2012).

114. Van Bladel, Arabic Hermes, 28; D. Pingree, "Classical and Byzantine Astrology in Sasanian Persia," Dumbarton Oaks Papers 43 (1989): 227-39.

115. I follow Van Bladel and use the name Nhmt'n (with short vowels unknown) since "it has never been satisfactorily explained, though presumably it masks a distorted Middle Persian or other Iranian word; see, Van Bladel, Arabic Hermes, 30-31, and n. 37. 
of Thousands) further articulated and popularized a "historical" narrative for Hermes the Sage. ${ }^{116}$ As van Bladel writes: "References to Hermes and Zoroaster in such works illustrate for us one aspect of the intellectual milieu of the third century, when Hermetic texts were said by our Arabic sources to have been transmitted to the Persian Empire." ${ }^{117}$ In a recent article, van Bladel demonstrates the frustration expressed by the astrologer al-Birūni (d. after 442/1050) in Ifrād al-maqāl fị amr al-zilāl (The Special Treatise on the Subject of Shadows) about books on alchemy and talismans parading as authentic texts by Hermes. Al-Bīrūnī was familiar with the works of eighth- and ninth-century Arabic astrologers who used and cited astrological books attributed to Hermes. ${ }^{118}$

The upswell of interest in Hermes not only supports a ninth-century date for the PsAH but also demonstrates the entanglement of Zoroastrian ideas, especially concerning astrology, with intellectual and religious thought in the ninth century in the eastern domains of the Islamic Mediterranean, including the eastern and southern frontiers of Byzantium. Such entanglement is also an evident feature of the PsAH. Furthermore, between the eighth and tenth centuries, the rate of conversion from Zoroastrianism to Islam or to other Zoroastrian subaltern currents was high. ${ }^{119}$ Moreover, the early Abbasids sought to create a new Islamic polity that borrowed some elements from Persian Zoroastrian traditions, and this aim manifested in the administrative power of the Barmakid family and the employment of Zoroastrian leaders for projects of translation from Middle Persian to Arabic. ${ }^{120}$ In the case of astrology, Pingree argues that early Abbasid knowledge "was largely Sasanian and Greek in origin with Indian material entering in through its being intermingled with the Greek and Iranian elements in Sasanian astrology, while most of the practicing astrologers of the late eighth and early ninth centuries were Iranian." ${ }^{21}$ Finally, it was during the ninth

116. Van Bladel, Arabic Hermes, 27 esp. n. 21, 28, 31-32; D. Pingree, The Thousands of Abü Ma'shar (London: Warburg Institute, 1968); C. Burnett, “The Legend of the Three Hermes and Abū Ma'shar's Kitāb al-Ulūf in the Latin Middle Ages," Journal of the Warburg and Courtauld Institutes 39 (1981): 231-34.

117. Van Bladel, Arabic Hermes, 47.

118. K. van Bladel, “Al-Bīrūnī on Hermetic Forgery," Gnosis:Journal of Gnostic Studies 3 (2018): 54-66, at 58, 63. The following is al-Bīrūnī's statement as translated by van Bladel: "I do not say this to defame Hermes, for it is he who occupied such a position with respect to wisdom that the Greeks counted him among the prophets. He transmitted the sciences of the Chaldaeans to Egypt, and the Chaldaeans-the people of Babylon-were so evidently advanced in the sciences that they were called sorcerers on that account, even if nothing is extant of their sciences today apart from their conception of the motion of the celestial sphere-which bespeaks a continuous care in observing it for millennia-and the traditions related from them by practicing astronomers, Ptolemy and others. Nevertheless, the books of Hermes, and the books of alchemy and talismans, suffer from an affliction: that fakers are devoted to composing and forging them, imputing them to the Sages."

119. T. Daryaee, "Zoroastrianism under Islamic Rule," in The Wiley Blackwell Companion to Zoroastrianism, ed. M. Stausberg, Y. S.-D. Vevaina, and A. Tessmann, 103-18 (Chichester: Wiley Blackwell, 2015), 104 and 108; J. K. Choksy, "Zoroastrians in Muslim Iran: Selected Problems of Coexistence and Interaction during the Early Medieval Period," Iranian Studies 20, no. 1 (1987): 17-30, at 21.

120. Daryaee, "Zoroastrianism under Islamic Rule," 107; D. Gutas, Greek Thought, Arabic Culture: The Graeco-Arabic Translation Movement in Baghdad and Early 'Abbāsid Society (2nd-4th/8th-10th Centuries) (London: Routledge, 1998), 29, 45-51, 136.

121. Pingree, From Astral Omens to Astrology, 41. 
century that a significant number of Zoroastrian Middle Persian texts were taking shape as canon. ${ }^{122}$ The Dēnkard and the Bundahishn were part of "a new didactic, apologetic and polemic literature" produced in this period. ${ }^{123}$

Recently, Emily Cottrell and Micah Ross challenged the "Middle Persian hypothesis" of Pingree, who, in a series of publications instrumentalized the discovery of an Arabic version of Dorotheus's Pentabiblos to overemphasize, according to Cottrell and Ross, the role of a Persian intermediary between Greek astrology and its Arabic reception. ${ }^{124}$ Pingree based his claim on a report by Ibn Nawabakht found in Ibn al-Nadim's Fihrist. Cottrell and Ross questioned the strength of Pingree's evidence and concluded that there is no strong support for the claim that a third-century project of translating scientific texts into Persian paved the way for the Arabic reception of Greek ideas, as Pingree argued. ${ }^{125}$ It is not the aim of the present article to insert the PsAH within some fixed line of transmission, whether directly from Greece or through an intermediate. However, what the narratives and reports of Ibn Nawabakht, Ibn al-Nadim, and others do provide is an insight into how Islamic culture in the ninth and tenth centuries envisioned its scientific and intellectual heritage. It is this heritage and historicization that is internalized in the PsAH, whether by a trajectory of textual and material transmission or by naturalization. It remains true that the PsAH are the product of a dynamic atmosphere of translation activity, hermetic fervor, and codification of Middle Persian Zoroastrian religious texts, whether they contain Greek influences or not. ${ }^{126}$

\section{Aristotelian, Hermetic, or Sabian?}

Around one hundred pseudo-Aristotelian works were in circulation in the Middle Ages. These works were overwhelmingly concerned with the occult sciences, including alchemy,

122. Daryaee, “Zoroastrianism under Islamic Rule,” 109-10; Choksy, “Zoroastrians in Muslim Iran,” 18, 20.

123. J. C. Bürgel, "Zoroastrianism as Viewed in Medieval Islamic Sources," in Muslim Perceptions of Other Religions: A Historical Survey, ed. J. Waardenburg (New York: Oxford University Press, 1999), 202-12, at 203.

124. D. Pingree, "Classical and Byzantine Astrology in Sasanian Persia," Dumbarton Oaks Papers 43 (1989): 227-39; Pingree, From Astral Omens to Astrology, 39-50.

125. E. J. Cottrell and M. T. Ross, "Persian Astrology: Dorotheus and Zoroaster, According to the Medieval Arabic Sources (8th-11th Century)," in Proceedings of the Eighth European Conference of Iranian Studies, vol. 1: Studies in Pre-Islamic Iran and on Historical Linguistics, ed. P. B. Lurje, 87-105 (Saint Petersburg: State Hermitage Publishers, 2019).

126. Cottrell and Ross show that the "Middle Persian hypothesis" focused on a reference to the Almagest of Ptolemy in book 4 of the Dēnkard but neglected the fact that "the megistik ì hrōmāy" (the Megistik, or "Romans," among the Greeks), referred to Ptolemy's work by its Arabic title, not its Greek one (Syntaxis). They also point out that book 4 of the Dēnkard, like Ibn Nawbakht, indicated that the growing interest in science came from Khosraw Anūshirwān, so the hypothesis of a third-century Persian intervention was unnecessary. Ptolemy was known at the sixth-century Sasanian court from testimonies describing the comparison of the Indian and Ptolemaic coordinates that led to the creation of the Zij al-Shahriyar. Cottrell and Ross, "Persian Astrology," 90. This information lends an element of credence to the historical narrative in al-Sakkākī's Shāmil about Aḥmad b. Ṭulūn's guest, who displays a single book retrieved from the treasuries of Khosraw I by "Kanaka the Indian" (see above). 
chiromancy, and physiognomy. ${ }^{127}$ Some of these works were renowned and influential, such as Kitāb al-Siyāsa fì tadbīr al-ri'āsa (The Book of Governance and Administration), which purports to be an epistle from Aristotle to Alexander the Great, offering political, moral, and dietary advice. Known in the tenth century, the work (mentioned earlier in this article) is often referred to by its subtitle Sirr al-asrār, which is also the title of the last chapter concerned with astral magic. ${ }^{128}$ It was known in Latin Europe as Secretum secretorum. Other pseudo-Aristotelian texts include the Chiromantia and the Physiognomia. ${ }^{129}$ The PsAH are related to this genre in their shared subject matter and historical proximity in the form in which we know them-that is, as Arabic productions. Many of the pseudo-Aristotelian (not necessarily Hermetic) texts also take the form of epistles or instructions to Alexander the Great and, more generally, belong to the "mirrors for princes" genre.

More significantly, the PsAH contain theories and concepts that are Aristotelian, in particular the discussion of causality in K. Ilal al-rūhāaniyyāt and the link (ittiṣāl) between the macrocosm and the microcosm:

The first cause is the cause for the sake of which the thing comes to be, and the second cause is the thing for the purpose of which the thing comes to be. An example of this is the jeweller who works a [metal] sheet into a ring. If someone asks about its element ('unșuruh), the metal sheet would be the answer. If someone asks about its cause, it is

127. C. B. Schmitt and D. Knox, Pseudo-Aristoteles Latinus: A Guide to Latin Works Falsely Attributed to Aristotle before 1500 (London: Warburg Institute, 1985), 4; L. Thorndike, "The Latin Pseudo-Aristotle and Medieval Occult Science," Journal of English and Germanic Philology 21, no. 2 (1922): 229-58, at 231; idem, History of Magic, 2:246-78; S. J. Williams, "Defining the Corpus Aristotelicum: Scholastic Awareness of Aristotelian Spuria in the High Middle Ages," Journal of the Warburg and Courtauld Institutes 58 (1995): 29-51.

128. M. Manzalaoui, “The Pseudo-Aristotelian 'Kitāb Sirr al-asrār': Facts and Problems,” Oriens 23/24 (1974): 147-257, at 158-59; Thorndike, History of Magic, 2:249, 257-58, 268-78; pseudo-Aristotle, al-Ușūl al-yūnāniyya li-l-nazariyyāt al-siyāsiyya fị al-islām, ed. 'A. Badawī (Cairo: Maktabat al-Nahḍa al-Miṣriyya, 1954), 69. On the influence, circulation, and structure of this text, see M. Grignaschi, "L'origine et les métamorphoses du Sirr al-asrâr," Archives d'histoire doctrinale et littéraire du Moyen Âge 43 (1976): 7-112; idem, "La diffusion du Secretum Secretorum dans l'Europe occidentale," Archives d'histoire doctrinale et littéraire du Moyen Âge 48 (1980): 7-70; idem, "Remarques sur la formation et l'interprétation du Sirr al-asrâr," in Pseudo-Aristotle's "The Secret of Secrets": Sources and Influences, ed. W. F. Ryan and C. B. Schmitt, 3-33 (London: Warburg Institute, 1982); S. J. Williams, "The Early Circulation of the Pseudo-Aristotelian 'Secret of Secrets' in the West," in Le scienze alla corte di Federico II, ed. M. R. McVaugh and V. Pasche, 127-44 (Turnhout: Brepols and Florence: SISMEL, 1994); K. van Bladel, "The Iranian Characteristics and Forged Greek Attributions in the Arabic Sirr al-Asrar (Secret of Secrets)," Mélanges de l'Université Saint-Joseph 57 (2004): 151-72; M. Maróth, “The Correspondence between Aristotle and Alexander the Great: An Anonymous Greek Novel in Letters in Arabic Translation," Acta Antiqua 45 (2001): 231-315; D. Gutas, "Review Article: On Greco-Arabic Epistolary "Novels,"” Middle Eastern Literature 12 (2009): 59-70; W. F. Ryan and M. Taube, The Secret of Secrets: The East Slavic Version (London: Warburg Institute, 2020).

129. Schmitt and Knox, Pseudo-Aristoteles Latinus, v-vi. A translation of a pseudo-Aristotelian physiognomy is attributed to Hunayn b. Ishāq. The Greek original is dated to about $300 \mathrm{BCE}$, and it was translated into Latin in the thirteenth century by Bartholomaeus de Messana; see S. Vogt, Aristoteles: Opuscula VI: Physiognomonica (Berlin: Akademie Verlag, 1999), 197; R. Forester, Scriptores Physiognomonici, Graeci et Latini, vol. 1 (Leipzig: B. G. Teubner, 1893), vii-cxcii, 4-91. 
the smithing of the jeweller. If it is asked "for what purpose is it created?", for wearing it is said. Altogether, the principles in this are four-fold: the cause (illa), the instrument (sabab), the action, and the agent. [. . .] He said: the action indicates the agent; the action is connected to the agent in a manifest manner, unhidden, since there is no action without the agent, and every agent indicates the action. To the agent is the action of motion; motion produces heat. ${ }^{130}$

According to the 'Ilal, the genesis of the cosmos was a result of the primordial principles of action, motion, heat, and cold. Action resulted from motion producing heat, from which emerged the masculine principle, whereas stillness generated coldness, the feminine principle; "the four elements came together in couples (muqtarina), and these were the mother elements." 131

Astral causality and its Aristotelian elements are not unique to the PsAH. Although K. 'Ilal al-rūhāaniyyāt does not divulge its sources, by the ninth century these ideas had permeated cosmological discussions via influential works that formulated an astrologized ontology and cosmogony based on the theories of generation and corruption and the nature of the heavens found in Aristotelian works.

I have argued elsewhere that applying Aristotelian causality to explain astral influences, in the explicit context of astrology in theory and practice, and the relationship between the world above and the world below is a deeply influential development in medieval Islam, primarily systematized by the most prominent astrologer Abū Ma'shar al-Balkhī and his teacher al-Kindī. Adopting the Aristotelian epistemological stance, Abū Ma'shar perceived the heavenly bodies as causes of generation and corruption, and it was precisely because of their causal role that resemblances occurred in nature. In Physics, Aristotle explains that the study of nature is an inquiry into causes from their effects. By adopting this basis for astrological investigation, Abū Ma'shar famously established astrology as a part of natural philosophy in the Aristotelian sense and as a science that reveals causes through the observation of effects. In his Kitāb al-Madkhal al-kabīr ilā cilm aḥkām al-nujūm (Great Introduction to Astrology), the planets themselves are given a generative role as agents and efficient causes, responsible for the perpetual link between the celestial world and the sublunary world below. Abū Ma'shar writes that "the terrestrial world is connected to the celestial world and its motions by necessity. Therefore, due to the power of the celestial world and the celestial motions, terrestrial things, generated and corruptible, are affected." They are affected specifically by the heat produced by the motions of the celestial bodies, which causes transformation-including corruption-of generated things. In On Generation and Corruption, Aristotle attributes the coming to be and passing away of things to the circular motions of the heavens. In Meteorology, he also explains that elementary transformations take place because the celestial bodies emit heat that affects the sublunary world. According to Abū Ma'shar, the celestial bodies cause transformations

130. Arabe 2577, fols. 2 r-3r.

131. Ibid., fol. 3r. 
in the sublunary world (tataghayyar, hadath istihàlāt), which consequently experiences generation and corruption (sarā fihā al-kawn wa-l-fasād). ${ }^{132}$

Before Abū Ma'shar, al-Kindī also assigned the heavenly bodies a generative and causal role in two treatises, al-Ibāna 'an al-cilla al-făcila al-qarība li-1-kawn wa-l-fasād (On the Explanation of the Proximate Cause of Generation and Corruption) and al-Ibāna 'an sujūd al-jurm al-aqșā (On the Explanation of the Bowing of the Outermost Body). The notion of astral causation can be found in the latter work, which is addressed to the son of the caliph al-Mu'tașim as a response to the question regarding the meaning of the Quranic verse that states that the stars and the trees bow down. The philosopher explains that the act of prostration described in the verse is not literal but rather indicates the stars' casting of influence to the earth and being causes of the generation of all terrestrial things. Therefore, the sacred order of the stars and the planets is not an arbitrary arrangement of signs but an order of causes. In al-Ibāna 'an al-'illa, al-Kindī explains that the planets and their motions are the origin of everything that exists in the sublunary world. ${ }^{133}$

Before both al-Kindī and Abū Ma'shar, however, a prolific commentator on Aristotle, Alexander of Aphrodisias, who was active in the late second and early third century, also attributed to the motions of the celestial spheres a role in causing and maintaining the terrestrial-celestial link. Alexander begins his Fì mabādi’ al-kull bi-ḥasab ra'ī Aristūtālīs (The Principles of the Whole According to the Opinion of Aristotle) by establishing his Aristotelian epistemological stance: there are instruments (sabab) and causes ( $i 11 a)$, and the earliest cosmogonical simple principles are the causes that account for the behavior of generated things and their motions by internal and external principles. ${ }^{134}$ In $K$. "Ilal al-rūhāniyyāt, a similar distinction is made: the link (ittișāl) between the macrocosm and the macrocosm "stems from an instrument and a cause. The cause is twofold and the instrument is singular. The instrument of the thing is that from which it originates. The cause is twofold: the cause of the thing before it comes to be and the cause of the thing after it comes to be." ${ }^{135}$ Alexander emphasizes that the motions of the higher spheres are linked (muttașila) to the divine bodies (including the celestial bodies) and the sublunary world. ${ }^{136}$ This necessitates the existence of a hypostatic chain, at the top of which is the Prime Mover to whom the Intellect aspires, mobilized by a perfect, circular, pneumatic motion toward Perfection for the sake of the Good. ${ }^{137}$ The Intellect imparts motion to the sphere of the fixed stars, which in turn imparts motion to the planets, which, with their

132. L. Saif, The Arabic Influences on Early Modern Occult Philosophy (Basingstoke: Palgrave Macmillan, 2015), passim.

133. Saif, Arabic Influences, 17.

134. Alexander of Aphrodisias, On the Cosmos: Arabic Text with English Translation, Introduction, and Commentary, ed. and trans. C. Genequand (Leiden: Brill, 2001), 42.

135. Arabe 2577, fols. 2 r-3r.

136. Alexander of Aphrodisias, On the Cosmos, 66, 112-14.

137. Ibid., 68, 96-98. 
varying movements, cause the potential for and actualization of transformation, including generation and corruption. ${ }^{138}$

A statement in K. Tlal al-rūḥāniyyāt recalls a particularly Alexandrian doctrine:

All things are both active (fácil) and passive (munfacil), for all things begin as a result of an agent ( $f a$ cil); the agent signifies the action, and the action signifies the thing that is acted upon ( $\left.\operatorname{maf}^{c} \bar{u} l\right)$. The thing acted upon indicates its agent; therefore, the thing that is acted upon indicates how it is 'enacted upon' in explaining the action and the agent. ${ }^{139}$

In Fi al-mabādi', Alexander notes that "among the things in it [the world] there are those that are agents only (fácil); some are passive (munfa'il) only; and some are both agent and passive. This is how some are ready to connect and remain with one another (yatahayya' an yattașil ba'duhā bi-ba'd wa-yalzam ba' ${ }^{\prime}$ uha $b a^{\prime} d$ d)." ${ }^{\prime 140}$ This is a departure from Aristotle, for whom everything that moves is moved by something else and, as Charles Genequand explains, the inner nature of the elements cannot be the efficient cause of their motion. ${ }^{141}$

It is important to recognize, however, that this astrologization of generation and corruption that emerges from late Aristotelian traditions is characterized by the assimilation of (neo-)Platonic doctrines, from the discussion of hypostatic structures to the application of the psychological theory of De anima to the ensouled stars and planets. ${ }^{142}$ This crucial aspect is discussed below in the context of the animated and animating principles of the cosmos, especially the PsAH's rūhāniyyāt. For now, it is sufficient to stress the philosophical framework of PsAH, which is reliant on Aristotelian notions of causality.

The model of a conversation between Aristotle and Alexander, the subject matter, and the philosophical rationale for the connection between the macrocosm and the microcosm place the PsAH firmly within the pseudo-Aristotelian genre. The magical and theurgic elements are supported by the astrologization of Aristotelian causality via the reconciliation of Aristotle and Hermes, whose works are presented as the source of the former's knowledge. The content is thus in this sense "Hermetic," but this does not imply that the PsAH embody a transhistorical body of fixed dogma or a set of doctrines uniting texts and thinkers in various languages across time and space under the anachronistic rubric of hermeticism/ hermetism, as Bladel insists in The Arabic Hermes. ${ }^{143}$ Nonetheless, the PsAH do constitute a substantial body of texts with a thematic and mythic consistency that lends itself to the construction of a medieval Arabic "hermeticism" constructed by medieval agents as filling the pages of "hermetic books" (al-kutub al-hirmisiyya). This level of coherence invited

138. Ibid., 86, 112, 120.

139. Arabe 2577, fol. 2v.

140. Alexander of Aphrodisias, On the Cosmos, 114 (my translation, for the sake of accuracy).

141. Ibid., 7, 62-64.

142. Ibid., 6.

143. A.D. Nock, "A New Edition of the Hermetic Writings," Journal of Egyptian Archaeology 11, no. $3 / 4$ (1925): 126-37, at 177; van Bladel, Arabic Hermes, 17-22. 
many medieval and early modern thinkers to associate the PsAH with a single religious group-namely, the Sabians, as discussed below.

Most scholarship touching on the texts of the PsAH identifies them as "technical hermetica," since they contain magical, astrological, and alchemical instructions, to distinguish them from "philosophical Hermetism" as encapsulated in the Corpus Hermeticum, which is a product of Roman Egyptian society that synthesized Greek and Egyptian views. ${ }^{144}$ Some go as far as to describe the "technical hermetica" as "religious" in contrast to the Corpus Hermeticum, which is seen as the "philosophical" counterpart largely on the basis of the assessment by the Dominican friar Andre-Jean Festugière, who dissociated the latter from any "religious" doctrine. ${ }^{145}$ This dyadic approach echoes the misleading yet tenacious binary imposed on "Hermetic" magic, which is divided into natural and ceremonial magic. ${ }^{146}$ It lies behind Pingree's search for the sources of the "Neoplatonic justifications" found in the Ghàyat al-hakim's description of the pagan practice of statue vivification. He admits to not understanding how "neutral" non-corporeal celestial forces (rūhāniyyāt) were conceived in opposition to the "divine and demonic beings" that are represented in ancient amulets. As a result, he proposes that the practice originated in Sabian-Harrānian anxieties about their reputation as "practitioners of the black arts" whoaccording to Pingree-produced a large body of pseudo-Hermetic and pseudo-Aristotelian texts, although the evidence for this link is lacking. He suggests that "unpublished Hermetic texts such as the Kitāb al-Isțimākhīs" could shed light on the relationship between the Sabians-Harranians and the PsAH. ${ }^{147}$ For Pingree, the PsAH are thus "scientific texts more characteristic of Sabians," 148 which neutralized "the nauseous details of psychic magic" in ways that would leave someone like Plato "horrified to learn what ends his philosophy has been made to serve." 149

It is important to recognize that the PsAH are different from the Greek Hermetica. The PsAH belong to a large group of texts attributed to Hermes that "are later works originally composed in Arabic. Yet even where the texts themselves are not of ancient origin, the idea of Hermes is." ${ }^{150}$ The Corpus Hermeticum usually refers to the philosophical corpus that was celebrated in the fifteenth century and translated by Marsilio Ficino (1433-99) into Latin. Many "technical" Greek Hermetica, such as Iatromathematica and To Asclepius on the Plants of the Seven Planets, remain unstudied. As Christian H. Bull has pointed out, the distinction between a technical and a philosophical corpus is false even from the point

144. Van Bladel, Arabic Hermes, 7; G. Fowden, The Egyptian Hermes: A Historical Approach to the Late Pagan Mind (Princeton, NJ: Princeton University Press, 1993 [first ed. 1986]), 69-74.

145. P. Lucentini and V. P. Compagni, "Hermetic Literature I: Antiquity," in Dictionary of Gnosis and Western Esotericism, ed. W. Hanegraaff, 517-29 (Leiden: Brill, 2005), 487-88, 499; Festugière, La révélation d’Hermès Trismégiste, 1:81-87; 2:50.

146. A. Sannino, "From Hermetic Magic to the Magic of Marvels," in The Routledge History of Medieval Magic, ed. S. Page and C. Rider, 153-68 (London: Routledge, 2019), 154.

147. Pingree, "Șābians of Harrān," 15.

148. Ibid., 30.

149. Ibid., 33.

150. Van Bladel, Arabic Hermes, 10. 
of view of the traditional Egyptian traditions from which the Greek Hermetica emerged. ${ }^{151}$ The PsAH's emphasis on technical instructions should not distract from its philosophical and cosmological elements, laid out in K. 'Ilal al-rūḥāniyyāt. Especially given the PsAH's consistent mythology and cosmological framework, which render them even more unique; the PsAH are the most reliable sources for the construction of the Arabic Hermes.

It is tempting to surmise that the PsAH were codified texts belonging to a certain group. Historically, as noted above, they have been associated with the Sabians. For example, Moses Maimonides (1138-1204) writes in Dalālat al-hāàinin that Kitāb al-Isțimākhīs is commonly "attributed to Aristotle, [but] he is free of this (hāshāh) [. . .] and another one is attributed to Aristotle [.. . ] Those that I mention to you are all scriptures (asfär) of the idol worshippers that were made available in the Arabic tongue." ${ }^{152}$ For him, al-Isțimākhīs belongs to the Sabians, who believe that there is no God and that only the planets deserve reverence. ${ }^{153}$ As mentioned earlier, Ibn Taymiyya knew the Dhakhira and considered it a book of the Sabians, among whom he counted Aristotle. ${ }^{154}$ Many scholars have tackled the question of the identity of the Sabians, and this is not the place to recount their arguments; suffice it to say that the term emerged from a heresiographical and polemical discourse and has been used to refer to various groups that revered and practiced complex devotions to the planets and the stars. ${ }^{155}$

Nevertheless, historical sources contain many references alluding to practices similar to those described in the PsAH, particularly within discussions of the Sabians, and it is worth mentioning some of these. Al-Shahrastānī (d. 548/1153), in his Kitāb al-Milal wa-1nihal (The Book of Sects and Creeds), notes that according to the Sabian madhhab (set of

151. C. H. Bull, The Tradition of Hermes Trismegistus: The Egyptian Priestly Figure as a Teacher of Hellenized Wisdom (Leiden: Brill, 2018), 280, 370-71; Cottrell is critical of van Bladel's exclusion of the Alexandrian Hermetica represented by the Corpus Hermeticum, which, she argues, is cited in medical works and in particular by Hippocrates and Galen, whose Syriac and Arabic translations circulated already in the ninth century; E. Cottrell, "L'Hermès Arabe de Kevin van Bladel et la question du rôle de la literature Sassanide dans la presence d'écrits hermètiques et astrologiques en langue arabe," Bibliotheca Orientalis 72 (2015): 336-401.

152. Moses Maimonides, Dalāìl al-ḥāìīn, ed. Ḥ. Atāy (Cairo: Maktabat al-Thaqāfa al-Dīniyya, n.d.), 588.

153. Ibid., 588.

154. Ibn Taymiyya, Dar’ ta ‘̄âu, 1:312.

155. The Sabians are mentioned three times in the Quran, at 2:26, 5:69, and 22:17. The first mention (Q 2:26) reads: "Indeed, those who believed and those who were Jews or Christians or Sabians-those who believed in God and the Last Day and did righteousness-will have their reward with their Lord, and no fear will there be concerning them, nor will they grieve." This reference has puzzled historians, and there are no sources contemporary to the Quran that mention the Sabians, so it is not possible to be certain of their identity. For a good summary of research on the Sabians from historical and etymological perspectives, see T. Green, City of the Moon God: Religious Traditions of Harran (Leiden: Brill, 1992), 3-6, 101-8; F. de Blois, "Sabians," in Encyclopaedia of the Qur'ān, ed. J. Dammen McAuliffe (Leiden: Brill, online), http://dx.doi.org/10.1163/18753922_q3_EQSIM_00362. For a detailed critique of “uncontrolled historical speculation" about the Harranians' being Sabians, see van Bladel, Arabic Hermes, 65-82. For an example of such outdated speculation, see A. E. Affifi, "The Influence of Hermetic Literature on Moslem Thought," Bulletin of the School of Oriental and African Studies 13, no. 4 (1951): 840-55, at 842-43; M. Noble, "Sabian Astral Magic as Soteriology in Fakhr al-Dīn al-Rāzī's al-Sirr al-Maktum," in Islamicate Occult Sciences in Theory and Practice, ed. L. Saif, F. Leoni, M. Melvin-Koushki, and F. Yahya, 207-29 (Leiden: Brill, 2020). 
convictions) the rūhāniyyāt, who receive their power from God, are the governors of all affairs in the world below. ${ }^{156}$ Indeed, he calls the Sabians "the people of the rūhanniyyāt" (așhāab al-rūḥāniyyāt). ${ }^{157}$ According to al-Shahrastānī, the Sabians were experts in the construction of planetary temples, divination, astrology, and incantations; they wrote books on rings (khawātìm), occult properties (khawāș̣), and images (șuwar). ${ }^{158}$ So far, the description does not warrant jumping to the attractive conclusion that al-Shahrastānī is referring to the group that produced the PsAH. However, he makes a striking statement that does recall K. "Ilal al-rūhāniyyāt in the first part called al-Ustuwațtās : "They say the celestials are the fathers and the elements are the mothers." ${ }^{159}$ In this part of $K$. . Ilal al-rūhāniyyāt, as described earlier, the genesis of the cosmos is said to have resulted from the primordial principles of action, motion, heat, and cold, with motion and heat giving rise to the masculine principle and stillness and coldness giving rise to the feminine one. Here, too, there is an explicit reference to procreation: "The four elements came together in couples (muqtarina), and these were the mother elements."160

Al-Mas' $\bar{u} d \bar{i}$ (d. 345/956), in his Murūj al-Dhahab (Meadows of Gold), gives a similar description of the practices of the Sabians and their belief in the rūhāniyyāt. However, a fascinating passage describes a belief concerning the periods of zodiacal sovereignty (discussed in detail below) that, as far as I am aware, is found only in al-Ustuwatțās. According to al-Mas' $\bar{u} d \overline{1}$, a group of people conceived of the time leading up to the end of the world in the following way:

The sovereignty of that time will be for Virgo, which is 7,000 years [long], and this is the age of the human world, with Jupiter aiding Virgo in governance [...] They claimed that the sovereignty of the sign of Aries is 12,000 years; the sovereignty of Taurus is 11,000 years; the sovereignty of Gemini is 10,000 years; the sovereignty of Cancer is 9,000 years; the sovereignty of Leo is 8,000 years; the sovereignty of Virgo is 7,000 years; the sovereignty of Libra is 6,000 years; the sovereignty of Scorpio is 5,000 years; the sovereignty of Sagittarius is 4,000 years; the sovereignty of Capricorn is 3,000 years; the sovereignty of Aquarius is 2,000 years; and the sovereignty of Pisces is 1,000 years. The total is 78,000 years. ${ }^{161}$

This view is identical to the description of the periods of zodiacal sovereignty in alUstuwațtās, discussed below. ${ }^{162}$ The overlap is probably an indication of al-Shahrastānīs and al-Mas' 'ū dì's knowledge of the PsAH, adopting the common narratives about their connection to the beliefs and identity of the Sabians.

156. Al-Shahrastānī, al-Milal wa-1-niḥal, ed. M. b. F. Badrān, 2 vols. (Cairo: Maktabat al-Anjilū al-Mișriyya, n.d.), 2:8.

157. Ibid., 2:7.

158. Ibid., 2:8, 30-31, 52-53, 61.

159. Ibid., 2:8.

160. Arabe 2577, fol. 3 r.

161. Al-Mas'̄̄ùī, Murūj al-dhahab, ed. K. H.. Mar`ī, 4 vols. (Beirut: al-Maktaba al-`Așriyya, 2005), 2:170.

162. Arabe 2577, fol. 7r-V. 
None of the PsAH texts refer to themselves as Sabian or Harrānian. However, that they were viewed related is exhibited in MS Leiden, Leiden University, Or. 1235. It includes a collection of treatises that share the themes of the PsAH, such as a treatise on suffumigation and planetary rings attributed to Țamțam al-Hindi which cites Aristotle in multiple places. It also contains parts of both al-Ustuwațtās and al-Isțimāțis. In addition, one finds a treatise entitled "The Secrets of the Sabians on Knowing the Hours of Transformations (al-qalb)" which describes magical operations such as for making planetary rings and talismanic engravings. The title of the text is not a reliable indication of a "Sabian" identification or origin, as it could have been given by the work's compiler or scribe on the basis of a perceived association. There is no reference to Sabians in the text itself. Calling the PsAH Sabian would thus be misleading. The most defining feature of the PsAH remains the texts' apocryphal attribution to Aristotle and Hermes, which is used to justify the amalgamation of Aristotelian causality and hylomorphism with Perso-Arabo-Hermetic astrological and magical materials.

The nature of the Sabian religion is understandably very intriguing, but we must rein in our enthusiasm, which might lead us to see Harrān and the Sabians where they are not present. For example, in some manuscripts of al-Shu'rā al-yamāniyya, the astral sciences are said to be the special knowledge of the people of Harrān (ahl al-Harrān); ${ }^{163}$ in other manuscripts, they are associated with the people of India (ahl al-Hind). ${ }^{164}$ The rush to identify Sabian Harranian rituals led Hellmut Ritter to misread the month of Huzayrān as Ḥarrān in the Ghāyat al-ḥakīm's description of a Sabian rite of passage (imtīhān al-ghilmān) even though the manuscripts show the name of the month consistently, with the result that he and others who viewed the Sabian rituals described in the Ghāya as Harrānian. ${ }^{165}$

\section{The Astrological Cosmogony of the PsAH and Its Zoroastrian Resonances}

The practical astrology of the PsAH, which includes rules of practice (exaltations, houses, lunar mansions, aspects, etc.), is, for the most part, Greek. Other sources have been noted; for example, Burnett and Pingree highlight Indo-Persian influences on the PsAH's conception of the lunar mansions and show that it reflects the Nakșatrāni of classical Indian astrology. ${ }^{166}$ However, astral/astrological theories in the PsAH underlie the structuring

163. Arabe 2580, fol. $1 \mathrm{v}$.

164. Arabe 2578 , fol $1 \mathrm{v}$.

165. Al-Qurțubī, Picatrix, ed. Ritter, 226. In preparing an English translation of the Ghāya, I consulted twentyfour manuscripts, all of which mention Huzayrān, not Ḥarrān, in this section. See, for example, MS Istanbul, Süleymaniye, Hamidiye 852, fol. 99v; MS Dublin, Chester Beatty, Ar. 3313, fol. 151v. The mistake is reproduced in G. Bing's foreword to the German translation (p. i), in the introduction by Ritter and Plessner (pp. 22, 31-32), and in the translation itself (p. 238): al-Qurțubī, Picatrix, ed. Ritter and Plessner; also reproduced in Green, City of the Moon God, 187, 213.

166. C. Burnett, "Arabic, Greek, and Latin Works on Astrological Magic Attributed to Aristotle," in PseudoAristotle in the Middle Ages: The Theology and Other Texts, ed. J. Kraye, W. Ryan, and C. Schmitt, 84-96 (London: Warburg Institute, 1986), 84-96, 87; A. Panaino, "Between Astral Cosmology and Astrology: The Mazdean Cycle of 12,000 Years and the Final Renovation of the World," in The Zoroastrian Flame: Exploring Religion, History and Tradition, ed. A. Williams, S. Stuart, and A. Hintze, 113-33 (London: Bloomsbury, 2016), 121-22. 
of the cosmos, its primordial creation activity, and the volitional causality that governs its affairs. It is in this type of astrological cosmogeny that we find Zoroastrian influences. This is not surprising when we consider the time that I have proposed for the production of these texts: the ninth century. Many scholars have clarified the Zoroastrian/Middle Persian link with "pseudo-Hermetic" works, especially in the minds of Muslim intellectuals. ${ }^{167}$

My comparison between the doctrines of the PsAH and Zoroastrianism is not meant to imply that the former represent a variety of Zoroastrianism. Rather, as stressed earlier, I am interested in the historical imaginary that encompasses and assimilates variegated doctrines and ideas (dualism, creation myths, demiurges, spirits, etc.) into narratives that feed societal, intellectual, and political aspirations by linking the past to the present. ${ }^{168}$ It is not unusual to encounter local traditions and belief systems in the ninth century that are reminiscent of Zoroastrianism but do not correspond to it. Influential ideas from Zoroastrianism were absorbed into a wider historical imaginary that also encompassed ideas originating with other local traditions, thus creating entangled identities. ${ }^{169}$

It is the astrological cosmogony of the PsAH that carries the most fascinating elements of these texts:

1. The crucial role of cosmogenic and cosmological cycles

2. The story of the creation of humans by the demiurge Hādūs

3. The seven sage-prophets

4. The system of volitional causality whose agents are the rūhāniyyāt, "spiritual entities"

5. Magical practice

All five elements are found in the PsAH, as well as in the summary text, al-Madittîs.

\section{Cosmological Cycles}

In the first part of K. 'Ilal al-rūhāniyyāt entitled al-Ustuwațțās Aristotle introduces an unusual zodiacal cycle: "He [God] assigned to each sign a period of sovereignty, and this is so because for every beginning there is a conclusion, and the beginning of a thing denotes its conclusion and its end." 170 He then proceeds to list these periods of sovereignty, which he uncovered through his efforts to comprehend the "hidden, protected secrets" (istakhrajtuhu min al-asrār al-mughayyaba al-maknūna): Aries: 12,000 years; Taurus: 11,000 years; Gemini: 10,000 years; Cancer: 9,000 years; Leo: 8,000 years; Virgo: 7,000 years; Libra 6,000 years; Scorpio: 5,000 years; Sagittarius: 4,000 years; Capricorn: 3,000 years;

167. Sezgin, Geschichte des arabischen Schrifttums, 4:35-36; van Bladel, Arabic Hermes, passim.

168. On the question of what makes a doctrine or a religion Zoroastrian, see P. Crone, The Nativist Prophets of Early Islamic Iran: Rural Revolt and Local Zoroastrianism (Cambridge: Cambridge University Press, 2012), 318-20.

169. Ibid., 23-27.

170. Arabe 2577, fol. 7r. 
Aquarius: 2,000 years; Pisces: 1,000 years. These periods add up to a cycle of 78,000 years, whose end marks "the conclusion of the macrocosm and the dissolution of its parts." ${ }^{171}$

Furthermore, these periods of zodiacal sovereignty mark stages in the generation of earth's creatures. Citing Hermes's al-Kitāb al-Makhzūn, Aristotle explains that during the reigns of Aries, Taurus, and Gemini-that is, during the first 33,000 years-moving animals did not exist, nor was there a rūhāniyya population on earth ('imāra rūhāniyya). Instead, the stars were working their influences in the belly of the earth, preparing for the emergence of plants. When the sovereignty of Cancer began,

the rūhāniyyāt of the stars gained strength in their courses and sustenance drew itself up, as did the sphere, rounded in its course. [When] the signs became strong in their qualities, the rūhāniyya of life poured down and caused to emerge the manifest action (al-zāhir) from the invisible and hidden (al-khafiyy al-bāțin) action. God, powerful and exalted ('azza wa-jall), created (kawwana) aquatic beings and the insects of the earth during the entirety of Cancer's cycle. ${ }^{172}$

During Leo's sovereignty, four-legged animals multiplied. Under Virgo, God created from Virgo's rūhāniyya the first man and the first woman, Admānūs and Haywānus. ${ }^{173}$ During the sovereignty of Libra, birds were created. Al-Madītīs recounts the same story, adding that at the end of this cosmic cycle, the universe will return to "its first state of being" (ila kawnihi al-awwal). ${ }^{174}$

This description of a 78,000-year cosmic cycle (in other words, the age of the universe) is unique to the PsAH. The Persian system of the fardār, which was known in Hebrew, Arabic, and Latin, refers to a sequence of seventy-five-year periods. In the ninth century, Abū Ma'shar expanded the range and added the "big fardār," a period of seventy-eight years ruled successively by the twelve signs with the same order and pattern of decreasing reigns as we find in al-Ustuwatțās. He also outlined a "middle fardār," a cycle of 675 years containing nine individual fardārs of seventy-five years each, and a "small fardār," a period of seventy-five years divided among the seven planets and the lunar nodes known as the Head and Tail of the Dragon in the order of their exaltation. ${ }^{175}$ The astrologer al-Bīrūnī, in his Qānūn al-mas' $\bar{u} d \bar{i}$ (the canon of al-mas' $\bar{u} d \overline{1}$ ), also recognized these periods. As Pingree has shown in his reconstruction of Abū Ma'shar's lost Kitāb al-Ulūf, the fardār periods are elements of "a complex system of cycles which determine the dominant planetary or zodiacal influences at any particular point in time"-a system that Islamic astrology inherited from Sasanian Persia. ${ }^{176}$

171. Ibid., fol. $7 \mathrm{r}-\mathrm{v}$.

172. Ibid., fols. $7 \mathrm{v}-8 \mathrm{r}$.

173. Ibid., fol. $8 \mathrm{r}$.

174. Marsh 556, fol. 10v.

175. Abraham Ibn Ezra, The Book of the World, ed. and trans. S. Sela (Leiden: Brill, 2010), 21-22 and n. 115.

176. Pingree, Thousands of Abū Ma'shar, 15-32. Godefroid de Callataÿ and I discuss the cycles in the PsAH and their medieval reception in greater detail in "Astrological and Prophetical Cycles in the Pseudo-Aristotelian Hermetica and Other Islamic Esoterica," in Bilan et perspectives des études sur les encyclopédies médiévales, 
Moreover, the PsAH's 78,000-year cycle is reminiscent of the Zoroastrian cosmic cycle of 12,000 years, divided into twelve equal periods of zodiacal sovereignty as discussed in the Bundahishn. The cosmic duel between Ohrmazd and Ahreman took place during this cycle. ${ }^{177}$ The earliest phase of creation covered the first 3,000 years of the mēnōg state, denoting the realm of mental existence, which is the realm of "spirit." ${ }^{178}$ This was followed by another 3,000 years, in which Ahreman was sent into a dormant state by Ohrmazd by means of a prayer known as Ahunwar. Rising from his sleep, Ahreman attacked creation. This event marked the beginning of the 6,000-year period of the gētig realm, which is the "living" and "physical" dimension of existence. It was in this phase that the astral bodies were set in motion. ${ }^{179}$ The first 3,000 years of the gētig concluded with the revelation of the Mazdean faith to Zoroaster, whereas the final period of 3,000 years will witness, at the end of each millennium, the birth of one of the three sons of Zoroaster. They will announce the liberation from the darkness, and with the birth of the third son-the Revitalizer par excellence, the Sōshāns-the destruction of Ahreman will take place. The stars were set in motion after Ahreman's invasion. ${ }^{180}$ Panaino notes of the 12,000 year-cycle that "the elaboration of this doctrine represents one of the most original and radical innovations developed by the Iranian speculative mind in the course of history." ${ }^{181}$

Thus, in the Bundahishn we have a period of primordial cosmic activity divided into 12,000 years of zodiacal sovereignty, but these periods of sovereignty differ from the PsAH's periods of zodiacal sovereignty in their fixed lengths of 1,000 years per sign. Since the PsAH were composed in a place of intense ideological exchange with recently codified Zoroastrian texts, we can discern the fusion of two originally Persian ideas in themAbū Ma'shar's modification of the fardār into a period of seventy-eight years ruled by twelve signs in the now familiar descending order, and the cycle of 12,000 years with each millennium under the protection of a particular zodiacal sign. The adoption of these ideas did not necessarily happen consciously; it may have been the result of these influential astrological ideas coalescing and reforming in accordance with the cultural and intellectual context. By their nature, these ideas lend themselves to reinvention since, as Panaino remarks, "these patterns are not strictly astrological, being purely symbolical and based on a simple proportional comparison, in which a single month corresponds to 1,000 years." 182

ed. G. de Callatä̈, M. Cavagna, B. van den Abeele, and F. van Haeperen (Louvain la Neuve: Université catholique de Louvain, Publications de l'Institut d'études médiévales, forthcoming). See also E. Kennedy, "Ramifications of the World-Year Concept in Islamic Astrology," in Proceedings of the Tenth International Congress of the History of Science, 23-43 (Paris: Hermann, 1962), 26-30; G. de Callataÿ, Annus Platonicus: A Study of World Cycles in Greek, Latin and Arabic Sources (Louvain: Peeters, 1996).

177. A. Panaino, "Cosmologies and Astrology," in Stausberg, Vevaina, and Tessmann, Wiley Blackwell Companion to Zoroastrianism, 235-58, at 238.

178. Ibid., 236; The Bundahišn: The Zoroastrian Book of Creation; A New Translation, trans. D. Agostini and S. Thrope (New York: Oxford University Press, 2020), 3-5, 40-42, 18-26 (the celestial world of the Bundahishn).

179. Panaino, "Cosmologies and Astrology," 236, 239.

180. Ibid., 237-38, 240; Panaino, "Between Astral Cosmology and Astrology," 114-15; Bundahišn, 40-50.

181. Panaino, "Between Astral Cosmology and Astrology," 116.

182. Ibid., 117. 
Classical astrology was not yet practiced in the second millennium BCE; it entered Iran in Parthian times and became current, with some adaptations, in the Sasanian period. ${ }^{183}$ Edward Kennedy and Pingree conclude that astrologers of the Islamic era such as Māshā’allāh "superposed the conjunction astrology upon a Zoroastrian millennial cosmology in which the duration of the universe is to be 12,000 years." 184 Abū Ma'shar's application of the fardār system and its cosmic amplification in the PsAH are cases of the astrologization trend seen in the Bundahishn's 12,000 cycles.

\section{Adam, Eve, and the Demiurge}

More signs of the aforementioned ideological convergence can be seen in the story of the creation of Admānūs (Adam) and Haywānus (Eve) under the rule of Virgo (7,000-yearlong cycle) and of the demiurge who creates them. According to this story, when all the planets were in their exaltations, "they lifted their resolve (himma) to the highest sphere, which is their governor, asking for a corporeal creation (khilqa jismāniyya) into which their rūhāniyyāt may pour, so they may direct it. As a result of this resolve, a pure, strong, angelic spirit was generated (fa-tawallada min tilk al-himma rūhan qawiyyan malakan naqiyyan), called Hādūs." ${ }^{185}$ Hādūs, the story goes, created the first man from hundreds of celestial rūhāniyyāt, giving him the form of the macrocosm. At first, Admānūs was "like animals, not cognizant of anything (lā ya'qil shay')," but then Hādūs lifted Admānūs's resolve to the Creator, exalted and high (al-Bāri', jalla wa- $\left.{ }^{-} a l \bar{a}\right)$ and connected it to the stars and planets because of their innate spirits (arwāh) of intellect ('aql), logic (manțiq), and thought (fikr). In the moment in which the first man was created, the planets were occupying their exaltations and pouring into him their benefic influences, except for Saturn, which was in the exaltation of Mars and thus handed down the Major Misfortune (al-nahs al-kabir) that could be suffering in general or specifically death. ${ }^{186}$

The concept of the demiurge was available through Plato's Timaeus, which had been translated by Ibn al-Bițīq and possibly revised and translated again by Hunayn b. Ishāa. ${ }^{187}$ According to this work, the universe is created and maintained by a purposeful, and beneficent agency. It is the handiwork of a divine craftsman, the demiurge, who bestows

183. Panaino, "Cosmologies and Astrology," 241, 245.

184. E. Kennedy and D. Pingree, The Astrological History of Māshāallāh (Cambridge, MA: Harvard University Press, 1971), vii. See also E. G. Raffaelli, “Astrology and Religion in the Zoroastrian Pahlavi Texts," Journal Asiatique 305, no. 2 (2017): 171-90, at 180.

185. Arabe 2577, fol. $8 \mathrm{v}$.

186. Ibid., fol. 8 bis $r$.

187. On the reception of Plato in the Arabic-speaking world, see F. Rosenthal, "On the Knowledge of Plato's Philosophy in the Islamic World," Islamic Culture 14 (1940): 387-422; R. Walzer, "Platonismus in der islamischen Philosophie (arabische Übersetzung aus dem griechischen)," in Antike und Orient im Mittelalter: Miscellanea Mediaevalia 1, 179-95 (Berlin: de Gruyter, 1962); D. Gutas, "Platon: Tradition arabe," in Dictionnaire des philosophes antiques, vol. 5, ed. R. Goulet, 845-63 (Paris: CNRS, 2012); R. Arnzen, "Plato's Timaeus in the Arabic Tradition: Legend-Testimonies-Fragments," in Il Timeo: Esegesi greche, arabe, latine, ed. F. Celia and A. Ulacco, 181-267 (Pisa: Pisa University Press, 2012). 
mathematical order on primordial chaos to generate the ordered cosmos. The universe and all its parts are arranged to produce good effects. In Plato's view, this arrangement is not fortuitous but rather the outcome of the deliberate intent of the Intellect (nous), represented by the craftsman who designs and constructs a world that is as excellent as its nature permits it to be. ${ }^{188}$ The demiurge here is identical to Nous in Plato's Philebus, too. ${ }^{189}$ However, there is nothing in the PsAH that evokes any recognizably Platonic interpretation of the demiurge's nature or its activity.

The Asclepius's famed demiurge, by contrast, rings a bell:

Pouring down Essence and taking Matter up, drawing both round himself and to himself all things, and from himself giving all things to all. For he it is whose goodly energies extend not only through the Heaven and the Air, but also onto Earth, right down unto the lowest Depth and the Abyss. And if there be an Essence which the mind alone can grasp, this is his substance [.. .] But whence this [Substance] doth arise, or flows forth, he, [and he] only, knows. [.. .] The reins are Life, and Soul, and Spirit, Deathlessness, and Genesis. ${ }^{190}$

However, the Asclepius-known in late antiquity as The Perfect Discourse-was translated into Latin and Coptic but does not seem to have been known in Arabic, ${ }^{191}$ which reduces the likelihood of its being among the sources of influence on the PsAH.

Of course, the Zoroastrian demiurge of the Bundahishn is a possible inspiration, especially if the production of the Bundahishn coincided with the composition of the PsAH. But the demiurge of the PsAH appears after the creation of the stars and the earth; therefore, he is not responsible for all creation, only for the creation of human beings. He does not appear to be responsible for the emergence of birds in the following period of sovereignty, that of Libra. Moreover, Hādūs is neutral in comparison to the Zoroastrian demiurge, ${ }^{192}$ although his intentionality is not clear, for Saturn, unlike all the other planets, was not in its exaltation at the moment Hādūs created Admānūs, and we do not know whether it was by Hādūs's choice that misfortune and death were astrologically introduced into the life of the first humans. Furthermore, Zoroastrianism's strict duality is absent from the PsAH.

Nevertheless, we still find a parallel with some Zoroastrian doctrines. In the 12,000year cycle in the Bundahishn, it was in the period of gētig, from the seventh millennium onward and after Ahreman's irruption, that the whole celestial sphere was put in motion. With the beginning of the gumēzishn (the mixed state of good and evil in the

188. D. Zeyl and B. Sattler, "Plato's Timaeus," in The Stanford Encyclopedia of Philosophy, summer 2019 ed., ed. E. N. Zalta, https://plato.stanford.edu/archives/sum2019/entries/plato-timaeus.

189. S. Menn, "Aristotle and Plato on God as Nous and as the Good," Review of Metaphysics 45, no. 3 (1992): $543-73$, at 546.

190. G. R. S. Mead, ed. and trans., Thrice-Greatest Hermes: Studies in Hellenistic Theosophy and Gnosis, vol. 1 (London: Theosophical Publishing Society, 1906), 269-71.

191. Van Bladel, Arabic Hermes, 133.

192. Panaino, "Cosmologies and Astrology," 235. 
material world), ${ }^{193}$ the domination of the new millennium passed to Libra, the sign representing the most significant point of astrological depression, but also Saturn's place of exaltation. ${ }^{194}$ Thus, Kēwān (Saturn), the most dangerous of the planetary demons, became the lord of that millennium and, after thirty years, decreed the death of the first man, Gayōmard. ${ }^{195}$ In the PsAH, the sovereign of the millennium in which the first man appears is Virgo, whose ruler is traditionally Mercury. In the horoscope of Gayōmard given in the Bundahishn, all the seven planets were in their exaltation except for Mercury, which was in its fall in Pisces, rather than in Virgo, the ruling sign of that millennium according to the PsAH. ${ }^{196}$ The same principle is at work in the Bundahishn: one planet is off and disordered, and this explains astrologically the presence of suffering, death, and evil. In the PsAH, the malefic nature of Saturn is responsible for confusion (hïra), mutability (taghyir), and sadness (huzn), whereas in the Bundahishn it is Saturn, the ruler of this period, that introduces death, and a malefic Mercury may signal a troubled existence. ${ }^{197}$

As for Haywānūs, she was created to distract Admānūs from his fascination with Hādūs. According to the story, Admānūs was hopelessly fixated on the mighty Hādūs, finding solace in the latter's presence. The demiurge then decided to strike Admānūs with his hand between the shoulders, "grabbing from him" something spiritual and something corporeal. Giving some of his own power to strengthen the rūhāniyya of resolve (al-himma), he created Haywānūs as the embodiment of the feminine principle (fa-khalaqa minhu Haywānūs bi-1-unūtha). This caused Admānūs to pay attention to her and find solace in her, and they thus "came together through masculinity and femininity, as a result of which she gave birth to the human race." 198 It is difficult, at this stage, to identify the origins of this fascinating narrative despite the shallow similarities with the story of Adam and Eve. From our description thus far, the similarity between Admānūs and Gayōmard lies in their monogenesis and the astrological background of their birth; in addition, as Yishai Kiel observes:

The convergence of Adam and Gayōmard as a First Man figure is found, in fact, already in central Manichaean works written in Iranian languages from the third century onwards. Rather than identifying Adam and Eve with Mašī and Mašyānī (the first human couple and the descendants of Gayōmard), Mani identifies Gayōmard (Manichaean Middle Persian, Gēhmurd) with Adam and, leaving out Mašì, he identifies Mašyānī (Manichaean Middle Persian, Murdiyānag) with Eve. The use of Zoroastrian mythology in central Manichaean works reflects the attempt on the part of Mani and his followers

193. Bundahišn, 5, 7, 14.

194. Ibid., 41.

195. Panaino, "Cosmologies and Astrology," 240; Bundahišn, 49.

196. Bundahišn, 35-39.

197. Arabe 2577, fols. 6v, 8v, 9v, 13v; A. Panaino, "Saturn, the Lord of the Seventh Millennium," East and West 46, nos. 3-4 (1996): 235-50, at 238-40; Raffaelli, "Astrology and Religion," 180; Panaino, "Cosmologies and Astrology," 250-51; idem, "Between Astral Cosmology and Astrology,” 121.

198. Arabe 2577 , fols. $12 \mathrm{v}-13 \mathrm{r}$. 
to package the Manichaean message in a manner that would be more agreeable and familiar to local adherents to Zoroastrianism. ${ }^{199}$

Kiel's objective in his article was to present the Talmudic story of Adam and Eve in light of Zoroastrian and Manichean doctrines. However, the similarities that he establishes concern elements that are absent from the creation myth of the PsAH-namely, sex with demons and atonement with abstinence. Nevertheless, it is possible that such accumulative processes of doctrinal merging resulted in the Admānūs-Gayōmard hybrid in the PsAH.

\section{The Seven Sage-Prophets}

The celestial being Hādūs not only created the first man and woman but also introduced Admānūs to the sciences: he taught him logic and "the occult sciences and subtle operations" (al-'ulūm al-khafiyya wa-l-a'māl al-lațīfa). ${ }^{200} \mathrm{He}$ also taught him about animals, their anatomy and the flow of certain rūhāniyyāt within them, and what they are good for. Then Hādūs gave him knowledge of plants and minerals. Aristotle mentions "the secrets of the four sciences and their causes, the secrets of medicine and its causes, and the secrets of the elements and their composition." ${ }^{201}$ It is not clear what is meant by the four sciences; however, given the mention of the occult sciences earlier we can assume them to be magic, astrology, alchemy, and divination. This first knowledge of nature was thus revealed to human beings by the demiurge before he "ascended away" (murtafic canka) from Admānūs and Haywānus, requesting that they populate the earth with their progeny. ${ }^{202}$ One of their offspring is Shìtālūs, who is mentioned in al-Hādhìtūs and whom Hādūs "clothes" with Admānūs's "spiritual garments" (innī urīd an ulbisuhu libāsaka li-l-rūḥāniyya). ${ }^{203}$

The knowledge imparted by Hādūs was not maintained by Admānūs's descendants. As a result, seven sage-prophets were possessed by the rūhāniyyāt of their climes and planets. These rūhāniyyāt brought religious laws and rituals (tusharric al-adyān wa-1(ibādāt). ${ }^{204}$ Reporting Hermes's teachings, Aristotle explains that the rūhāniyya of each planet, possesses a "sage" (hakim) who emerges at the beginning of every millennium and bestows wisdom on the people of his clime. At the end of each millennium, the rūhanniyya assigned to the sage ascends, and a new millennium with a new sage begins. The reason for this process is that the highest sphere shifts by one degree every 1,000 years. When the prophetic rūhanniyya is generated from that sphere, it descends to the realm of the planets and generates another rūhāniyya, which then generates twelve more, corresponding to the signs of the zodiac. ${ }^{205}$ Each sage-prophet teaches the people of his clime about their

199. Y. Kiel, "Creation by Emission: Reconstructing Adam and Eve in the Babylonian Talmud in Light of Zoroastrian and Manichaean Literature," Journal of Jewish Studies 66, no. 2 (2015): 300-301.

200. Arabe 2577, fol. $13 \mathrm{r}$.

201. Ibid., fols. $14 \mathrm{v}-16 \mathrm{r}$.

202. Ibid., fol. $16 \mathrm{v}$.

203. Delhi Arabic 1946, fol. 55v.

204. Arabe 2577, fol. 54r.

205. Ibid., fol. $23 \mathrm{v}$.

Al- 'Ușūr al-Wusțā 29 (2021) 
practical obligations to the rūhāniyyāt of the planet (including sacrifices, nìranjs, poisons, talismans, rings, idols, and the names of the rūhāniyyāt). ${ }^{206}$

Human history structured by a millennial scheme, the eschatological role of immortal kings and heroes, and the intervention of deities are major elements of Zoroastrian religious traditions. ${ }^{207}$ According to the Mazdean tradition, the history of humankind covers six millennia from the First Man, Gayōmard, to the last of the three future saviors, Sōshāns. The Mazdean cosmic cycle has been variously said to consist of $12,000,9,000$, or even 7,000 years, but the latter number is found only in Islamic texts. ${ }^{208}$

Enrico Raffaelli notes that the Byzantine millenary chronocratoria system has Saturn first and then the other planets in the order of Hellenistic astronomy, each ruling over one millennium of history. Such a system is missing from the Bundahishn, which has the 12,000-year cycle discussed above. Nevertheless, Arabic sources mention some Mazdean chronologies, which most likely date from the Sasanian period, according to which the key part of world history lasts for 7,000 years. Furthermore, a planetary chronocratoria system is attributed to the Persians by al-Sijzì (ca. 334-411/945-1020) in his Muntakhab kitāb al-Ulüf (The Abridgment of the Book of Thousands). ${ }^{209}$

Astrological sacred history is present in the ninth-century Zoroastrian text Dēnkard, which mentions twelve astrologers named after the twelve zodiac signs. This story is referenced in Arabic sources; however, in the tenth-century historical bibliography, al-Fihrist, of Ibn al-Nadim, the same story is modified to feature seven astrologers corresponding to the seven planets and Hermes as the representative of Mercury. This association proved very influential on the Arabic constructions of the legend of Hermes. ${ }^{210}$ The content of the PsAH was the product of a setting in which these Hellenistic and Persian doctrines of astrological cycles were accessible and influential, leading to their incorporation into the cosmological framework of the PsAH.

\section{Rūḥāniyyāt}

The volitional causality of the PsAH's cosmos is based on the activity of the rūhāniyyāt, the spiritual agents who determine the qualities of natural things, including human beings, and transmit astral influences. "Volitional causality" is a term I have employed elsewhere to describe the network created by these spiritual agents that penetrates the celestial and terrestrial worlds, carrying down and putting into action the will of God. These spiritual agents are "immanent principles-beings manifesting divine plenitude and profusion," the core of the universe's nonmechanistic efficiency. ${ }^{211}$ As we saw earlier, the creation of the first man was the result of this volitional causality via the demiurge.

\footnotetext{
206. Ibid., fols. $54 \mathrm{v}-98 \mathrm{v}$.

207. Panaino, "Cosmologies and Astrology," 260.

208. Ibid., 250-51; Pingree, From Astral Omens, 39-40.

209. Raffaelli, “Astrology and Religion," 180-81.

210. Van Bladel, “Al-Bīrūnī on Hermetic Forgery," 59; idem, Arabic Hermes, 31-32.

211. Saif, The Arabic Influences, 4, 172, 181.
} 
Events in the world below are inclined by the influences of the rūhāniyyāt and tuned by the planetary and astral configurations through which their agency flows. It is not an exaggeration to say that by and large, medieval and early modern magical traditions, from Ghāyat al-ḥakim through the works of the arch-mage Ahmad al-Būni to contemporary practices and writings, have been permeated by the rūhāniyyāt. However, as their sources were typically not identified, they were often confused with the more traditional "spirits," and this association solidified over time. Consequently, in later literature they became interchangeable with jinn or angels or were given a special status within a more expressly Islamic cosmology. ${ }^{212}$

The rūhāniyyāt permeate all the treatises that make up the PsAH. We are told that when God first "established the secrets of the macrocosm in the microcosm," there was nothing physical-no bodies, substances, or accidents in the microcosm. ${ }^{213}$ What the microcosm had was "spiritual (rūhāniyya) parts connected with one another." ${ }^{14}$ As noted earlier, the genesis of the observable cosmos is explained as the result of the primordial principles of action, motion, heat, and cold. These produce the masculine and feminine principles, which in turn give rise to primordial elements (usțuqușșāt), which are "the fundamentals (ușūl) from which spiritual and physical things are generated." ${ }^{215}$ Thus, there are three principles of creation: corporeality, the spiritual dimension (rūhāniyya), and their "partnership" (shirka). The corporeality of the macrocosm manifests in the variation of forms, the spiritual dimension is the decreed life (al-hayāt al-muqaddara), and their partnership comprises "actions influencing the bodies from the spiritual dimension" through the mediation of the seven planets. ${ }^{216}$ About the rūhāniyyāt, we read: "The highest sphere is the governor (mudabbir) by its essence (bi-dhātihi), and from it the rūhāniyyāt of good and evil pour downward to the bodies by the authority of the rühāniyya of the highest-that is, the highest sphere." These rūhāniyyāt flow through the planets and the microcosm, multiplying and branching as they descend. ${ }^{217}$ Every event results from their actions. However, their very nature is determined by the primordial elements, the principles of heat/masculinity and cold/femininity. There are rūḥāniyyāt of planets, zodiac signs, physical attributes, cognitive faculties, animals, plants, minerals, climes, and so on. By means of the rūhāniyyāt, the microcosm and the terrestrial world are connected to the celestial world and the macrocosm. ${ }^{218}$

A particular rūhāniyya takes center stage in the life of the mage/sage/king. This is the personal rūhāniyya, about which we learn in al-Isțimākhīs. Aristotle advises Alexander the Great as follows:

\footnotetext{
212. Saif, "From Ġāyat al-Hakìm."

213. Arabe 2577, fol. 1v.

214. Ibid., fol. $2 \mathrm{v}$.

215. Ibid., fol. $3 r$.

216. Ibid., fol. $3 \mathrm{v}$.

217. Ibid., fol. $4 \mathrm{r}-\mathrm{v}$.

218. Ibid., fols. $7 v-12 v$.
} 
The first thing you ought to begin with in your affairs is to look to your governing rūhāniyya, whose parts are linked with your star and who is devoted to you and [looks] after you by directing the rulership of your star. This is the Perfect Nature (al-țibā'al-tāmm), mentioned by Hermes in his book. For he said that if the microcosm, the human being, is perfect in nature, his heart is like the stable disk of the Sun in the sky, which extends her rays over all horizons. Likewise, the Perfect Nature takes the role of an intermediary in the heart, and so its rays pass through and come into contact with the faculties of subtle wisdom; then the rays attract these powers of wisdom until they establish them in the heart where they belong, the way the rays of the Sun attract the powers of the world and raise them into the air. Socrates the Sage said: The Perfect Nature is the Sun of the sage and his origin. Hermes was asked: By what means does he [the sage] bring down wisdom? He said: By means of the Perfect Nature. He was asked: What is the key of wisdom? He said: The Perfect Nature. He was asked: What is the Perfect Nature? He said: The rūhāniyya of the philosopher, which is connected to his star and its governor, unlocking for him the latches of wisdom and teaching him all that puzzles him, inspires him with its own awareness (șawābuhā) and hands him the key to its [wisdom] gates in sleep and in wakefulness. ${ }^{219}$

This advice is followed by a story similar to the narrative about the extraction of the Emerald Tablet in the Sirr al-khaliqa. Instead of the tablet, the name of the Perfect Nature that is revealed: ${ }^{220}$

Hermes said: When I wanted to retrieve the science and methods of the causes of creation, I stumbled upon a dark crypt filled with shadows and winds. I could not see anything because of its darkness, and no lamp could be kindled because of the abundance of winds. In my sleep, a visitor came in the most beautiful form. He said: Take a fire and place it inside a clear glass container, and it will show you [the way]. Enter the crypt, dig in its center, and extract from it a statue with a built-in talisman. If you remove this statue, the wind will dissipate, and you shall see the crypt and it will be illuminated for you. Then dig in its four corners and you shall retrieve the science of all creation, the science of nature, and the genesis of all things and their ways. I asked him: And you; who are you? He answered: Your Perfect Nature. If you wish to see me, call me by my name: Bmāghīs, Fqdīsūghdās, Wghdās, Nūfāghādīs. ${ }^{221}$

These four, the text tells us, are the "letters of the names of this rūhāniyya."222 The Perfect Nature then teaches Hermes the ritual to summon it. There is no magic without the rūhāniyyāt, and there is no wise and victorious philosopher or king without the Perfect Nature. ${ }^{223}$

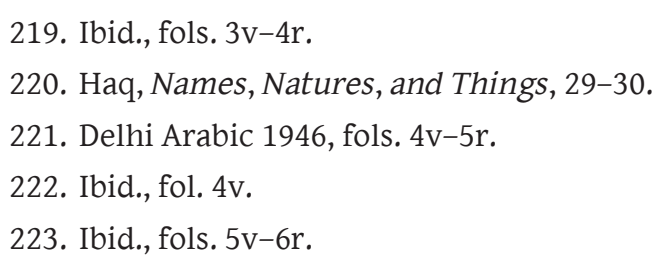


I have argued elsewhere that the rūhāniyyāt are akin to or even a reformulation of the Greek daemones. The Neoplatonic chain of divine beings consists of God, daemons, heroes, and souls. Daemons are "the common bond that connects gods with souls, and that causes their linkage to be indissoluble. They bind together a single continuity from top to bottom." The bond between the daemons and the gods is generative, too, as the former "receive from the gods on high the causal principles of all these things" and, subjecting themselves to the goodness of the gods, cause "the formless to shine forth in forms." ${ }^{224}$ Through the influence of the Arabic sources that they knew, such as Ghāyat al-hakim, known in Europe in its Latin translation, Picatrix, ${ }^{225}$ European natural philosophers, occultists, and esotericists depaganized the daemons, rendering them more palatable to Christian thinkers. ${ }^{226}$ Some European medieval and early modern natural philosophers and occultists encountered "daemones" in Iamblichus's De mysteriis aegyptiorum, chaldaeorum, assyriorum (On the Mysteries of the Egyptians, Chaldeans, and Assyrians), a paraphrase of which was completed by the priest, mage, and philosopher Marsilio Ficino in 1497. Ficino also translated and published in 1497 Porphyry's De abstinentia ab esu animalium (On Abstinence from Killing Animals). Other sources include Plato's Symposium on Love and Ficino's commentary on it, Cratylus, as well as the Timaeus. ${ }^{227}$ Furthermore, the Perfect Nature recalls the personal daemon from Apuleius's On the God of Socrates (De deo Socratis). When the creation of a human soul takes place, a daemon is assigned to guard and watch over it. This daemon is a genius who communicates through signs, inspiration, and dreams in order to guide human beings by inclining towards one action or event, or to forewarn them of harms. ${ }^{228}$

\section{Magical Practice}

The magical instructions and practices across the PsAH are consistent in terms of ritual types, construction formats, and conditions of practice. All treatises in the corpus save the Dhakhira claim that these rituals and operations belong to the knowledge Hādūs endowed on Admānūs. The agents of efficaciousness are the rūhāniyyāt and the occult properties of animals, plants, minerals, and stones. ${ }^{229}$ The magic of the PsAH includes talismans, the organic concoctions referred to as nìranjs, invocations to the rūhāniyyāt, suffumigations, sacrifices, magic rings, poison antidotes, and magic connected to the lunar mansions.

Niranj originally refers to a type of Zoroastrian prayer known in Middle Persian as nērang, commonly, and shakily, translated as "incantation." A nīranj identifies "the forces that shape and animate existence, whether spiritual (mēnōg) or physical (gètīg)."

224. Ibid., 187.

225. Ibid., 179-81; D. Pingree, "From Hermes to Jābir and the Book of the Cow," in Magic and the Classical Tradition, ed. C. Burnett and W. F. Ryan, 19-28 (London: Warburg Institute, 2006), 21.

226. Saif, Arabic Influences, 189-94.

227. Saif, Arabic Influences, 186-89.

228. Ibid., 179 and n. 60.

229. Delhi Arabic 1946, fol. 12r.

230. R. E. Payne, A State of Mixture: Christians, Zoroastrians, and Iranian Political Culture in Late Antiquity (Oakland: University of California Press, 2015), 86-89; M. Boyce, "Pāydāb and Nērang: Two Pahlavi Terms 
In addition, it denotes standard formulas to be uttered on specific occasions, such as after killing noxious creatures and sneezing. The word has proven difficult to translate precisely given its use in different contexts of Zoroastrian cultic practice and its Islamic appropriation. Other known nērangs have similar purposes as the nïranjs we encounter in the PsAH: they are recited to defeat sorcerers, give courage, restore a relationship between a husband and a wife, and promote healing. ${ }^{231}$ Panaino discusses two nērangs, one in Middle Persian and the other in Pazend. They contain an invocation of the most important stars and planets of the Zoroastrian tradition. ${ }^{232}$ The first of the two is aimed at tying the mouths of demons, tyrants, sinners, thieves, murderers, and oppressors: "In the name of God (Yazd) in the name of the brave Fredon, in the name of the star Tishtar (Sirius), in the name of the star Sadwes (Fomalhaut), in the name of the star Wanand (Vega), in the name of the stars Haftoring (Ursa Major)." The day of the operation is specified: "In the name of Ohrmazd, the creator, on the day of Spandarmad, in the month of Spandarmad, I have tied down [. . .]"233 The second neerang cures fevers and other afflictions caused by demons and the evil eye "by the powers of the stars and the planets."234

In the PsAH, the niranj is not identified with Zoroastrians; however, it is a staple medieval magical object, seen in the Ghāya, Rasā'il Ikhwān al-Ṣafă', and al-Sakkākī's Shāmil and appearing in Ibn Sīnā's al-Ishārat wa-1-tanbīhāt as well as in myriad unstudied manuscripts. ${ }^{235}$ It is possible that its ubiquity is the result of a direct co-optation of Zoroastrian practices, but it is more realistic to view this "influence," discussed at length in this section and encapsulated by the PsAH, as an indication that a cosmography and a set of practices that were once deeply Iranian were naturalized by the ideological dynamism of the eastern Islamic domains, reaching al-Andalus and Latinate Europe.

Burnett has drawn attention to the nature of the niranjs in the PsAH within the Arabic tradition and the way in which they passed into the Latin world through translations of some PsAH treatises such as al-Istijlāb (from al-Ustuwatțās) and a portion of al-Madītīs known as Antimaquis, as well as through the translation of Ghāyat al-hakìm, Herman of

Further Considered," Bulletin of the School of Oriental and African Studies 54, no. 2 (1991): 281-29, at 284-85; M. Stausberg, "Monday-Nights at the Banaji, Fridays at the Aslaji: Ritual Efficacy and Transformation in Bombay City," in Zoroastrian Rituals in Context, ed. M. Stausberg, 653-718 (Leiden: Brill, 2004), 666.

231. C. Burnett, "Nīranj: A Category of Magic (Almost) Forgotten in the Latin West," in Natura, scienze e socièta medievali: Studi in onore di Agostino Paravicini Bagliani, ed. C. Leonardo and F. Santi, 37-66 (Florence: SISMEL, 2008), 37-38; F. M. Kotwal and P. G. Kreyenbroek, "Prayer," in Stausberg, Vevaina, and Tessmann, Wiley Blackwell Companion to Zoroastrianism, 333-43, at 341; J. J. Modi, "A Few Parsee Nîrangs (Incantations or Religious Formulae)," in Anthropological Papers Read before the Anthropological Society of Bombay, part 3, 52-71 (Bombay: Nabu Press, 1924), 55-56.

232. A. Panaino, "Two Zoroastrian Nērangs and the Invocations to the Stars and the Planets," in The Spirit of Wisdom (Mēnōg ì Xrad): Essays in Memory of Ahmad Tafazzoli, ed. T. Daryaee and M. Omidsalar, 196-218 (Costa Mesa, CA: Mazda Publishers, 2004), 196-97, 206-7.

233. Ibid., 198-99.

234. Ibid., 200-201.

235. Ibid., 207, 209-10; SOAS 46347, fols. 30v-31r; Noble, Philosophising the Occult, 22-23; L. Saif, "A Study of Ikhwān al-Ṣafā’’s Epistle on Magic, the Longer Version (52b)," in Saif et al., Islamicate Occult Sciences, 162-206, at $187-88$. 
Carinthia's De essentiis (which contains a reference to "data neiringet initia" attributed to Aristotle), and the Liber Lune secundum Aristotelem. ${ }^{236}$

\section{Conclusion}

The aim of this article was to present the pseudo-Aristotelian Hermetica as a recognizable corpus unified by cross-references among its constituent texts, the historical narrative articulated across them, and their consistent cosmological and mythic foundations. Drawing on both internal and external evidence, I have argued for a ninth-century provenance. A clear and systematic introduction to this dense corpus required first disentangling the confusion about the titles and number of the constituent treatises through a careful reading of the texts. The major texts of the PsAH are al-Isțimākhīs, al-Istimātīis, al-Ustuwatțās, and al-Hādhịtūs, all of which are likely to be parts of a larger work entitled K. Ilal al-rūhāniyyāt. There also exists an abridgment of the latter work, entitled al-Madițis. We are aware of two additional texts that can be considered pseudo-Aristotelian and Hermetic but that were composed much later, modeled on the aforementioned texts; these are Dhakhirat Iskandar and al-Shu'rā al-yamāniyya.

What makes the PsAH unique is their content. Magical recipes and planetary rituals are woven into a creation myth according to which a demiurge, Hādūs, teaches Admānūs the sciences and doctrines required to cultivate his soul, intellect, and progeny and to secure prosperity for human civilization. The first sciences revealed to Admānūs, given their necessity for survival, are the occult sciences, knowledge of natural properties, and medicine. However, the generations after Admānūs went astray, so seven sage-prophets, embodying planetary rühaniyyāt, appear in successive epochs to different peoples to reestablish law and wisdom. Creation and generation-and their counterparts, cosmic collapse and corruption-as well as prophecy and revelation are structured by astrological cycles. I have shown the considerable extent to which these ideas demonstrate the blending of Zoroastrian notions, especially astrological ones, with Greek ideas in the PsAH corpus.

The prologues of the PsAH texts, examined in detail here, reveal that the entire corpus is located within a historical imaginary, which consolidates Aristotle and Hermes Trismegistus philosophically and doctrinally. Alexander the Great becomes a model of a sagacity that links the understanding of the celestial world with that of the terrestrial, the divine with the mundane.

The philosophisation of the occult through the Hermes-Aristotle-Alexander triad proved profoundly influential and forms the basis for the cosmological and philosophical principles of major occult texts such as Ghāyat al-ḥakīm, Rasā'il Ikhwān al-Ṣafā', al-Sakkākī's al-Kitāb al-Shāmil, and the works of Aḥmad al-Būnī. This trend highlights a closely interrelated canon of early medieval Islamic occult sciences that include the Jâbirian corpus, the pseudo-Apollonian Sirr al-khaliqa, and other important but understudied works. ${ }^{237}$

236. Burnett, "Nirranj," 44-66, where the Liber Lune secundum Aristotelem is edited and translated.

237. The influence of the PsAH is also evident in Kitāb Sharāsīm al-hindiyya, currently being studied by JeanCharles Coulon, who is also preparing a critical edition. See J.-C. Coulon, "The Kitāb Sharāsīm al-Hindiyya and Medieval Islamic Occult Sciences," in Saif et al., Islamicate Occult Sciences, 317-79. 
The influential esotericist and lettrist 'Abd al-Raḥmān al-Bisțāmī (d. 858/1454) presents at the beginning of his Shams al-āfāq (The Sun of the Horizon) an extensive reading list on occult sciences, which includes Kitāb al-Ishnūțās (al-Ustuwațțās), al-Isțimākhīs, al-Hādhìțūsh (al-Hādhịtūs), and al-Malātīis, in addition to texts attributed to Kīnās, Ghāyat al-hakìm, and the works of al-Būnī, among others. ${ }^{238}$ Therefore, by giving the PsAH its due attention, we become better equipped to understand the diversity of ideas, practices, and sources in a foundational period in the history of the Islamic occult sciences, namely, the eighth to tenth centuries, which continued to echo in later periods. The deep influence of these ideas is not restricted to the realm of the occult sciences but also infiltrated the wider discourse on wisdom and the production of knowledge about the universe, its forces, and the place of human beings in the cosmos.

The overall objective of this article has been to catalyze scholarly interest in the PsAH. A more exhaustive analysis of the available manuscripts is needed to support the essential undertaking of editing and translating the PsAH, which would make more widely available a hitherto unnoticed corpus arising from a community active under Islamic rule with unique myths, cosmology, and practices. The striking parallels between the contents of the PsAH and later descriptions of Sabian doctrines and rituals deserve further attentionnot necessarily for the purpose of identifying who the Sabians actually were but as a genealogical approach to Sabian religion as a construct instrumentalized in the formation of an Islamic cultural identity by means of relating and othering, as we see in al-Shahrastānī's al-Milal wa-l-nihal. The PsAH invites us to consider the relationship it has with ancient local sets of beliefs that relate to Zoroastrianism such as the "Ghulāt" and "the specific complex of Syro-Mesopotamian Gnostic traditions [that] likely contributed to the religious milieu out of which Ghulāt thought emerged;" ${ }^{239}$ this becomes more pressing when we consider the role of the demiurge in the world of the PsAH. Another subject for future investigation is the reception and circulation of the PsAH within the Islamic world and beyond from the perspective of manuscript studies, intellectual history, history of science, and material culture, in order to get closer to understanding the communities from which these texts emerged and the traditions that were shaped by them.

238. 'Abd al-Raḥmān al-Bisțāmī, Shams al-āfāq fi cilm al-ḥurūf wa-l-awfāq, MS London, British Library, no. 7494, fols. 3r-6r; see also N. Gardiner, "Books on Occult Sciences," in Treasures of Knowledge:An Inventory of the Ottoman Palace Library (1502/3-1503/4), vol. 1: Essays, ed. G. Necipoğlu, C. Kafadar, and C. H. Fleischer, 735-66 (Leiden: Brill, 2019); J.-C. Coulon, "Building al-Būnī's Legend: The Figure of al-Būnī through 'Abd al-Rahmān al-Bisțāmī’s Shams al-Āfāq," Journal of Sufi Studies 5, no 1 (2016): 1-26.

239. Crone, The Nativist Prophets of Early Islamic Iran, 22-27, 191- 215; M. Asatryan and D. Burns, "Is Ghulāt Religion Islamic Gnosticism? Religious Transmissions in Late Antiquity," in Le Ésotérisme shi'ite: ses racines et ses prolongement, ed. M.A. Amir-Moezzi, M. de Cillis, D. de Smet, and O. Mir-Kasimov (Turnhout: Brepols, 2016), 55-86. 


\section{Appendix: Manuscripts Consulted}

\section{The Pseudo-Aristotelian Hermetic Cycle}

Complete manuscripts:

- MS Oxford, Bodleian, Arab d. 221, fols. 1r-82r. The sequence of folios is disordered. Dated 417/1026. A. F. L. Beeston has challenged the dating, arguing that the text is instead an early fourteenth-century composition. ${ }^{240}$ Isabel Toral-Niehoff, however, has proposed $921 / 1515$ as a terminus ante quem on the basis of repeated notes within the text that are dated between $921 / 1515$ and $933 / 1527 .^{241}$

- MS London, British Library, Delhi Arabic 1946, fols. 1v-200r. Undated. Estimate: late nineteenth century.

- MS Tonk, Rajasthan, Maulana Abul Kalam Azad Arabic Persian Research Institute, no. 2142. Described by Isabel Toral-Niehoff and Hans Daiber. ${ }^{242}$ Despite several attempts, I, like Toral-Niehoff and Daiber, was unable to gain access to this manuscript. ${ }^{243}$

The constituent treatises of the Cycle are the following:

a. Al-Isțimākhīs (PsAH), fols. 1v-21r in Delhi Arabic 1946.

b. Kitāb Istijlāb rūhāniyyāt al-bahā’im (On Attracting the Rūhāniyyāt of Animals, PsAH), fols. 21v-32r in Delhi Arabic 1946. Also referred to as al-Madātīs, according to the prologue. ${ }^{244}$ At the end of the text, we read: "This is the end of what the Sage described in K. al-Ustuwațtās." ${ }^{245}$ It thus seems to be a chapter of al-Ustuwatțās (see also "e" below).

c. From (min) Kitāb al-Isțimāțīs (PsAH), fols. 32v-52v in Delhi Arabic 1946.

d. Kitāb al-Hādhìtūu (PsAH), fols. 53r-85r in Delhi Arabic 1946. Aristotle is absent, but the text's identity is confirmed by a cross-reference in al-Istijlāb: "according to what was described by Hermes." ${ }^{446}$ An anonymous translator is mentioned.

e. Another chapter from al-Ustuwatțās (PsAH), fols. 85v-92v in Delhi Arabic 1946 (see also "b" above).

f. Giranis (not PsAH), fols. 93r-115v in Delhi Arabic 1946.

240. A. F. L. Beeston, “An Arabic Hermetic Manuscript,” Bodleian Library Record 7, no. 1 (1962): 20-23.

241. Toral-Niehoff, Kitab Giranis, 28.

242. Toral-Niehoff, Kitab Giranis, 29; H. Daiber, "New Manuscript Findings from Indian Libraries," Manuscripts of the Middle East 1 (1986): 26-48, at 39, no. 156.

243. The catalog can be accessed here: http://www.maapritonk.nic.in/pdf/A-handlist-of-Arabic-Mss.pdf.

244. Delhi Arabic 1946, fol. 21v.

245. Ibid., fol. 32r.

246. Ibid., fol. $85 \mathrm{r}$.

Al- 'Ușūr al-Wusțā 29 (2021) 
g. Kitāb al-Ahjār (The Book of Stones, not PsAH), fols. 116r-119r in Delhi Arabic 1946. The title is given at the end; the text begins abruptly. Identical in content to the stone- and ring-magic collection in MS Istanbul, Süleymaniye, Ayasofya 3610, fols. $1 \mathrm{v}-143 \mathrm{r} .^{247}$

h. Kitāb 'Uțārid b. Muḥammad al-Muḥāsib fị manāfi' al-aḥjār wa al-khiraz wa țillismātihā wa khawatim al-kawākib al-sab'a (The Book of 'Uțārid b. Muhammad al-Muhāsib on the Benefits of Stones, Amulets, and Their Talismans, and the Rings of the seven planets, not PsAH), fols. 119r-126r in Delhi Arabic 1946. The title is given at the text's conclusion. The PSAH Cycle includes only the last part of the actual text attributed to 'Uțārid on the construction of planetary rings. The second text in the stone-magic collection MS Paris, BnF, Arabe 2775 (fols. 102r-114r) and the second part of Ayasofya 3610 (fols. 44v-168v) contain the first part of 'Uțārid's work.

i. Al-Kitāb al-majmū' fi khawāșș al-ahjār (The Collection Concerning the Occult Properties of Stones, not PsAH), which contains Kitāb Ma'rifat al-ḥijāra wa-khāș̣iyatihā wa-nuqūshihā (On the Knowledge of Stones, Their Occult Properties, and Their Inscriptions) taken from al-Hādhịtūs (see "d" above) by the First Hermes and other books (mașāhif); fols. 126r-197r in Delhi Arabic 1946. One of the five texts featured in this collection is referred to as "bāb mahakkāt al-ahjār min kalām Aristotle wa-ghayrihi" ("a chapter on the pulverulence of stones from the writings of Aristotle and others," fol. 154r), which is identical to a section called "dhikr mahakkāt al-hijār al-sabca" ("reference to the pulverulence of the seven stones") in MS Cambridge, Dd. 4. 28., fols. 120r-122r. Both are based on sayings by a sage named Funțus.

\section{Kitāb Tlal al-rūḥāniyyāt and al-Ustuwațtās}

Complete manuscripts:

- MS Paris, BnF, Arabe 2577, fols. 35v-104r. Undated. Estimate: fourteenth century. Al-Ustuwatțās on fols. 1v-34r; al-Isțimāțīs on fols. 35v-104r. In this manuscript, fols. 104r-105r contain sections from Kitāb Nawāmīs Aflāțūn, known in Latin as Liber Vaccae or Liber Aneguemis.

- MS Manisa, National Library of Manisa (Genel Kitaplik), no. 1461. Dated 771/1370. Al-Ustuwatțās: fols. 1v-25v; Ps.2: fols. 26v-72r.

Incomplete manuscripts:

- MS Berlin, Staatsbibliothek zu Berlin, Petermann I 66. Eighteenth century, according to the catalog. Parts from al-Isțimātīs are found in fols. $41 \mathrm{v}-73 \mathrm{v}$.

247. This is a royal manuscript copied for the treasury of Sultan Abū al-Nașr Sayf al-Dīn al-Ashraf Qaytbay (r. 1468-96); see fol. 1r. The colophon dates the manuscript to the beginning of Sha'bān 888 AH (September 1483). 
- MS Leiden, Leiden University, Or. 1235. Undated. This is a collection of treatises on the subject of planetary talismans and invocations from various works, including al-Ustuwațtās on fols. $9 \mathrm{r}-17 \mathrm{v}, 35 \mathrm{r}-38 \mathrm{v}$, and $52 \mathrm{r}$, and an abridgment by Ibn Wașif of Kitāb al-Mīlāțis "described by Kīnās" on fols. 76v-101r (see below under Kitāb al-Mīlātīs al-akbar).

\section{Al-Maditīis}

- MS Oxford, Bodleian, Marsh 556, fols. 4r-152r. The date has been scratched off. This is an abridged reformulation of K. 'Ilal al-rūhāniyyāt.

\section{Dhakhïrat al-Iskandar (The Treasury of Alexander)}

Complete manuscripts:

- MS London, British Library, IO Islamic 673, fols. 1v-59r. The date has been scratched off.

- MS Berlin, Staatsbibliothek zu Berlin, Wetzstein II 1209, fols. 1v-42v.

Incomplete manuscripts:

- MS Tehran, Majlis-i Shūrā-yi Millī, no. 4752, fols. 1r-42v, under the title Kitāb Milātīs al-akbar. This manuscript includes the third bāb, entitled al-Isqūtās (al-Ustuwațțās?), from al-Kitāb al-Shāmil fị al-baḥr al-kāmil (The Comprehensive Book on the Perfect Sea), a magic text by Sirāj al-Dīn Abū Yacqūb al-Sakkākī (1160-1229).

\section{Al-Shu'rāà al-yamāniyya or Aḥkām țulü cal-shu'rāa al-yamāniyya}

Complete manuscripts:

- MS Paris, BnF, Arabe 2578, fols. 1v-38v.

- MS Paris, BnF, Arabe 2579, fols. 1v-13v.

- MS Paris, BnF, Arabe 2580, fols. 2v-16v. ${ }^{248}$

248. Many other manuscripts of this work exist, including MS Tehran, Majlis 6451/3, 4448/7; MS Leipzig, Vollers 831; and MS Princeton, Islamic Manuscripts, Garrett no. 547H. 


\section{Bibliography}

Abbott, N. "Wahb b. Munabbih: A Review Article." Journal of Near Eastern Studies 36, no. 2 (1977): 103-12.

Affifi, A. E. "The Influence of Hermetic Literature on Moslem Thought." Bulletin of the School of Oriental and African Studies 13, no. 4 (1951): 840-55.

Alexander of Aphrodisias. On the Cosmos: Arabic Text with English Translation, Introduction, and Commentary. Edited and translated by C. Genequand. Leiden: Brill, 2001.

Alfonso-Goldfarb, A. M. Livro do Tesouro de Alexandre: Um estudo de hermética árabe na oficina da história de ciência. Translated by A. M. Alfonso-Goldfarb and S. Abou Chahla Jubran. Petrópolis: Editora Vozes, 1999.

d'Alverny, M.-Th., and F. Hudry. "Al-Kindi: De radiis." Archives d'historie doctrinale et littéraire du Moyen Âge 41 (1974): 139-260.

(Pseudo-)Apollonius of Tyana. Buch über das Geheimnis der Schöpfung und die Darstellung der Natur (Buch der Ursachen). Edited by U. Weisser. Aleppo: Institute of the History of Arab Science, University of Aleppo, 1979.

(Pseudo-)Aristotle. Al-Ușūl al-yūnāniyya li-1-nazariyyāt al-siyāsiyya fì al-islām. Edited by 'A. Badawī. Cairo: Maktabat al-Nahḍa al-Mișriyya, 1954.

Arnzen, R. "Plato's Timaeus in the Arabic Tradition: Legend-Testimonies-Fragments." In Il Timeo: Esegesi greche, arabe, latine, edited by F. Celia and A. Ulacco, 181-267. Pisa: Pisa University Press, 2012.

Asatryan M. and Burns, D. "Is Ghulāt Religion Islamic Gnosticism? Religious Transmissions in Late Antiquity." In Le Ésotérisme shi'ite: ses racines et ses prolongement, edited by M.A. Amir-Moezzi, M. de Cillis, D. de Smet and O. Mir-Kasimov (Turnhout: Brepols, 2016), 55-86.

Badawī, 'A. Al-Insāniyya wa-l-wujūdiyya fị al-fikr al-'arabī. Cairo: Maktabat al-Nahḍa al-Mișriyya, 1947.

Beeston, A. F. L. “An Arabic Hermetic Manuscript.” Bodleian Library Record 7, no. 1 (1962): 20-23.

Blochet, E. "Études sur le Gnosticisme musulman." Rivisita degli studi orientali 4, no. 1 (1911): $47-79$.

de Blois, F. “Sabians.” In Encyclopaedia of the Qur’ān, ed. J. Dammen McAuliffe. Leiden: Brill, online. http://dx.doi.org/10.1163/1875-3922_q3_EQSIM_00362. 
Bohak, G., and C. Burnett. Thābit ibn Qurra on Talismans and Pseudo-Ptolemy on Images 1-9: A Reconstruction Based on the Judaeo-Arabic and Latin Texts, Together with the "Liber Prestigiorum Thebidis" (forthcoming).

Boyce, M. "Pāydāb and Nērang: Two Pahlavi Terms Further Considered." Bulletin of the School of Oriental and African Studies 54, no. 2 (1991): 281-29.

Bull, C. H. The Tradition of Hermes Trismegistus: The Egyptian Priestly Figure as a Teacher of Hellenized Wisdom. Leiden: Brill, 2018.

The Bundahišn: The Zoroastrian Book of Creation; A New Translation. Translated by D. Agostini and S. Thrope. New York: Oxford University Press, 2020.

Bürgel, J. C. "Zoroastrianism as Viewed in Medieval Islamic Sources." In Muslim Perceptions of Other Religions: A Historical Survey, edited by J. Waardenburg, 202-12. New York: Oxford University Press, 1999.

Burnett, C. "Arabic, Greek, and Latin Works on Astrological Magic Attributed to Aristotle." In Pseudo-Aristotle in the Middle Ages: The Theology and Other Texts, edited by J. Kraye, W. Ryan, and C. Schmitt, 84-96. London: Warburg Institute, 1986.

-_- "Aristoteles/Hermes: Liber Antimaquis." In Hermetis Trismegisti Astrologica et Divinatoria, edited by P. Lucentini et al., 179-221. Turnhout: Brepols, 2001.

-_-. "The Establishment of Medieval Hermeticism." In The Medieval World, ed. P. Linehan and J. L. Nelson, 111-30. London: Routledge, 2001.

-_-. "Hermann of Carinthia and the Kitāb al-Isțamāțīs: Further Evidence for the Transmission of Hermetic Magic." Journal of the Warburg and Courtauld Institutes 44 (1981): 167-69.

-_- "The Legend of the Three Hermes and Abū Ma'shar's Kitāb al-Ulūf in the Latin Middle Ages." Journal of the Warburg and Courtauld Institutes 39 (1981): 231-34.

-_-. "Nìranj: A Category of Magic (Almost) Forgotten in the Latin West." In Natura, scienze e socièta medievali:Studi in onore di Agostino Paravicini Bagliani, edited by C. Leonardo and F. Santi, 37-66. Florence: SISMEL, 2008.

-_-. "Tābit ibn Qurra the Harrānian on Talismans and the Spirits of the Planets." La corónica: A Journal of Medieval Hispanic Languages, Literatures, and Cultures 36, no. 1, (2007): 13-40.

- - - and G. Bohak. "A Judaeo-Arabic Version of Tābit ibn Qurra's De imaginibus and PseudoPtolemy's Opus imaginum." In Islamic Philosophy, Science, Culture, and Religion: Studies in Honor of Dimitri Gutas, edited by F. Opwis and D. Reisman, 179-200. Leiden: Brill, 2012.

de Callatä̈, G. Annus Platonicus: A Study of World Cycles in Greek, Latin and Arabic Sources. Louvain: Peeters, 1996. 
-—-. "Magia en al-Andalus: Rasā'il Ikhwān al-Ṣafā', Rutbat al-ḥakīm y Ghāyat al-ḥakīm (Picatrix)." Al-Qanțara 34, no. 2 (2013): 297-344.

and L. Saif. "Astrological and Prophetical Cycles in the Pseudo-Aristotelian Hermetica and Other Islamic Esoterica." In Bilan et perspectives des études sur les encyclopédies médiévales, edited by G. de Callataÿ, M. Cavagna, B. van den Abeele, and F. van Haeperen. Louvain la Neuve: Université catholique de Louvain, Publications de l'Institut d'études médiévales, forthcoming.

Carusi, P. "Alchimia ermetica e arte del vetro: Il Tadbīr Harmis al-Harāmisa." Quaderni di studi arabi 10 (1992): 175-200.

Choksy, J. K. "Zoroastrians in Muslim Iran: Selected Problems of Coexistence and Interaction during the Early Medieval Period." Iranian Studies 20, no. 1 (1987): 17-30.

Cottrell, E. J. “L'Hermès Arabe de Kevin van Bladel et la question du rôle de la literature Sassanide dans la presence d'écrits hermètiques et astrologiques en langue arabe." Bibliotheca Orientalis 72 (2015): 336-401.

- - - and M. T. Ross. "Persian Astrology: Dorotheus and Zoroaster, According to the Medieval Arabic Sources (8th-11th Century)." In Proceedings of the Eighth European Conference of Iranian Studies, vol. 1: Studies in Pre-Islamic Iran and on Historical Linguistics, edited by P. B. Lurje, 87-105. Saint Petersburg: State Hermitage Publishers, 2019.

Coulon, J.-C. "Building al-Būnī's Legend: The Figure of al-Būnī through 'Abd al-Raḥmān al-Bisțāmī’s Shams al-Āfāq." Journal of Sufi Studies 5, no 1 (2016): 1-26.

-_-. "The Kitāb Sharāsīm al-Hindiyya and Medieval Islamic Occult Sciences." In Islamicate Occult Sciences in Theory and Practice, edited by L. Saif, F. Leoni, M. Melvin-Koushki, and F. Yahya, 317-79. Leiden: Brill, 2020.

-_- La magie en terre d'islam au Moyen Âge. Paris: CTHS, 2017.

Crone, P. The Nativist Prophets of Early Islamic Iran:Rural Revolt and Local Zoroastrianism. Cambridge: Cambridge University Press, 2012.

Daiber, H. "New Manuscript Findings from Indian Libraries." Manuscripts of the Middle East 1 (1986): 26-48.

Daryaee, T. “Zoroastrianism under Islamic Rule.” In The Wiley Blackwell Companion to Zoroastrianism, edited by M. Stausberg, Y. S.-D. Vevaina, and A. Tessmann, 103-18. Chichester: Wiley Blackwell, 2015.

Festugière, A.-J., ed. La révélation d'Hermès Trismégiste, vol. 1: L’astrologie et les sciences occultes. Paris: Les belles lettres, 1989.

Fierro, M. "Bāținism in al-Andalus: Maslama b. Qāsim al-Qurțubī (d. 353/ 964), Author of the Rutbat al-Hakìm and the Ghāyat al-Hakìm (Picatrix)." Studia Islamica 84 (1996): 87-112. 
Forester, R. Scriptores Physiognomonici, Graeci et Latini. Volume 1. Leipzig: B. G. Teubner, 1893.

Fowden, G. The Egyptian Hermes: A Historical Approach to the Late Pagan Mind. Princeton, NJ: Princeton University Press, 1993.

Gardiner, N. "Books on Occult Sciences." In Treasures of Knowledge: An Inventory of the Ottoman Palace Library (1502/3-1503/4), vol. 1: Essays, edited by G. Necipoğlu, C. Kafadar, and C. H. Fleischer, 735-66. Leiden: Brill, 2019.

Green, T. City of the Moon God:Religious Traditions of Harran. Leiden: Brill, 1992.

Grignaschi, M. "La diffusion du Secretum Secretorum dans l'Europe occidentale." Archives d'histoire doctrinale et littéraire du Moyen Âge 48 (1980): 7-70.

-_- "L'origine et les métamorphoses du Sirr al-asrâr." Archives d'histoire doctrinale et littéraire du Moyen Âge 43 (1976): 7-112.

-_- "Remarques sur la formation et l'interprétation du Sirr al-asrâr." In Pseudo-Aristotle's "The Secret of Secrets": Sources and Influences, edited by W. F. Ryan and C. B. Schmitt, 3-33. London: Warburg Institute, 1982.

Gutas, D. Greek Thought, Arabic Culture:The Graeco-Arabic Translation Movement in Baghdad and Early 'Abbāsid Society (2nd-4th/8th-10th Centuries). London: Routledge, 1998.

-_-. "Platon: Tradition arabe." In Dictionnaire des philosophes antiques, vol. 5, edited by R. Goulet, 845-63. Paris: CNRS, 2012.

--_. "Review Article: On Greco-Arabic Epistolary 'Novels." Middle Eastern Literature 12 (2009): 59-70.

Ḥājjī Khalīfa. Kashf al-ẓunūn. Edited by M. Sh. Yāltaqāyā and R. B. al-Kalīsī. 2 vols. Beirut: Dār Ihyā̄' al-Turāth al-`Arabī, n.d..

Hamdani, A. "Abū Hayyān al-Tawhīidī and the Brethren of Purity." International Journal of Middle East Studies 9, no. 3 (1978): 345-53.

Hasse, D. N. "Plato Arabico-Latinus: Philosophy-Wisdom Literature-Occult Sciences." In The Platonic Tradition in the Middle Ages: A Doxographic Approach, edited by S. Gershwin and M. J. F. M. Hoenen, 31-66. Berlin: de Gruyter, 2002.

Haq, S. N. Names, Natures, and Things: The Alchemist Jābir ibn Hayyān and His "Kitāb al-Ahjār" (Book of Stones). Dordrecht: Kluwer, 1994.

Ibn Abī Ușaybica. 'Uyūn al-anbā' fi țabaqāt al-ațibbā'? Edited by N. Riḍā. Beirut: Dār Maktabat al-Ḥayyāt, n.d.

Ibn Ezra, Abraham. The Book of the World. Edited and translated by S. Sela. Leiden: Brill, 2010. 
Ibn Hayyān, Jābir. Mukhtār rasāìil Jābir b. Hayyān. Edited by P. Kraus. Cairo: Maktabat al-Khānjī, 1936.

Ibn Khaldūn. Tārīkh Ibn Khaldūn. Edited by Kh. Shiḥāda and S. Zakkār. 7 vols. Beirut: Dār al-Fikr, 2000.

Ibn al-Nadīm. Al-Fihrist. Beirut: Dār al-Ma'rifa, n.d.

Ibn Taymiyya. Dar’ ta'āruḍ al-'aql wa-1-naql. Edited M. R. Sālim. 10 vols. Riyadh: Imam Mohammad Ibn Saud Islamic University, 1991.

Ikhwān al-Ṣafā’. Rasā’il Ikhwān al-Ṣafā’. 4 vols. Beirut: Dār Șādir, 2008.

Keck, D. Angels and Angelology in the Middle Ages. Oxford: Oxford University Press, 1998.

Kennedy, E. "Ramifications of the World-Year Concept in Islamic Astrology.” In Proceedings of the Tenth International Congress of the History of Science, 23-43. Paris: Hermann, 1962.

--_ and D. Pingree. The Astrological History of Māshā'allāh. Cambridge, MA: Harvard University Press, 1971.

Khoury, R. G. "Un fragment astrologique inédit attribué à Wahb b. Munabbih.” Arabica 19, no. 2 (1972): 139-44.

Kiel, Y. "Creation by Emission: Reconstructing Adam and Eve in the Babylonian Talmud in Light of Zoroastrian and Manichaean Literature." Journal of Jewish Studies 66, no. 2 (2015): 300-301.

Kotwal, F. M., and P. G. Kreyenbroek. "Prayer." In The Wiley Blackwell Companion to Zoroastrianism, edited by M. Stausberg, Y. S.-D. Vevaina, and A. Tessmann, 333-43. Chichester: Wiley Blackwell, 2015.

Kraus, P. Jābir ibn Hayyān: Contribution à l'histoire des idées scientifiques dans l'islam, vol. 1: Le corpus des écrits Jābiriens. Cairo: French Institute of Oriental Archaeology, 1943.

Láng, B. Unlocked Books: Manuscripts of Learned Magic in the Medieval Libraries of Central Europe. University Park, PA: Penn State University Press, 2008.

Lucentini, P., and V. P. Compagni. "Hermetic Literature I: Antiquity.” In Dictionary of Gnosis and Western Esotericism, edited by W. Hanegraaff, 517-29. Leiden: Brill, 2005.

Magdalino, P., and M. Mavroudi. "Introduction." In The Occult Sciences in Byzantium, edited by P. Magdalino and M. Mavroudi, 11-38. Geneva: La pomme d'or, 2006.

Manzalaoui, M. “The Pseudo-Aristotelian 'Kitāb Sirr al-asrār': Facts and Problems." Oriens 23/24 (1974): 147-257. 
Maróth, M. "The Correspondence between Aristotle and Alexander the Great: An Anonymous Greek Novel in Letters in Arabic Translation.” Acta Antiqua 45 (2001): 231-315.

Massignon, L. "Inventaire de la littérature hermétique arabe." In La révélation d'Hermès Trismégiste, vol. 1: L'astrologie et les sciences occultes, edited by A.-J. Festugière, 384-400. Paris: Les belles lettres, 1989.

al-Mas' ū ${ }^{\complement} \overline{1}$, Abū al-Hasan 'Alī. Murūj al-dhahab. Edited by K. H.. Mar'ī. 4 vols. Beirut: al-Maktaba al-'Așriyya, 2005.

Mead, G. R. S., ed. and trans. Thrice-Greatest Hermes: Studies in Hellenistic Theosophy and Gnosis. Volume 1. London: Theosophical Publishing Society, 1906.

Menn, S. "Aristotle and Plato on God as Nous and as the Good." Review of Metaphysics 45, no. 3 (1992): 543-73.

Modi, J. J. “A Few Parsee Nîrangs (Incantations or Religious Formulae).” In Anthropological Papers Read before the Anthropological Society of Bombay, part 3, 52-71. Bombay: Nabu Press, 1924.

Moses Maimonides.Dalālat al-ḥā’irīn. Edited by Ḥ. Atāy. Cairo: Maktabat al-Thaqāfa al-Dīniyya, n.d.

Noble, M. Philosophising the Occult: Avicennan Psychology and the Hidden Secret of Fakhr al-Dîn al-Râzî. Hamburg: de Gruyter, 2021.

--C. "Sabian Astral Magic as Soteriology in Fakhr al-Dīn al-Rāzī’s al-Sirr al-Maktum." In Islamicate Occult Sciences in Theory and Practice, edited by L. Saif, F. Leoni, M. Melvin-Koushki and F. Yahya, 207-29. Leiden: Brill, 2020.

Nock, A. D. "A New Edition of the Hermetic Writings." Journal of Egyptian Archaeology 11, no. 3/4 (1925): 126-37.

Page, S. Magic in the Cloister: Pious Motives, Illicit Interests, and Occult Approaches to the Medieval Universe. University Park, PA: Penn State University Press, 2013.

Panaino, A. "Between Astral Cosmology and Astrology: The Mazdean Cycle of 12,000 Years and the Final Renovation of the World." In The Zoroastrian Flame: Exploring Religion, History and Tradition, edited by A. Williams, S. Stuart, and A. Hintze, 113-33. London: Bloomsbury, 2016.

-_- "Cosmologies and Astrology." In The Wiley Blackwell Companion to Zoroastrianism, edited by M. Stausberg, Y. S.-D. Vevaina, and A. Tessmann, 235-58. Chichester: Wiley Blackwell, 2015.

-_-. "Saturn, the Lord of the Seventh Millennium." East and West 46, nos. 3-4 (1996): 235-50. 
--C. "Two Zoroastrian Nērangs and the Invocations to the Stars and the Planets." In The Spirit of Wisdom (Mēnōg ì Xrad): Essays in Memory of Ahmad Tafazzoli, edited by T. Daryaee and M. Omidsalar, 196-218. Costa Mesa, CA: Mazda Publishers, 2004.

Parra Pérez, M. J. “El ‘Sirr al-asrār' de 'Uțārid b. Muhammad al-āsib y sus aforismos.” Anaquel de estudios árabes 20 (2009): 165-86.

Payne, R. E. A State of Mixture: Christians, Zoroastrians, and Iranian Political Culture in Late Antiquity. Oakland: University of California Press, 2015.

Peters, F. E.Aristoteles Arabus:The Oriental Translations and Commentaries of the Aristotelian Corpus. Leiden: Brill, 1968.

Pingree, D. "Classical and Byzantine Astrology in Sasanian Persia." Dumbarton Oaks Papers 43 (1989): 227-39.

-- . From Astral Omens to Astrology, from Babylon to Bīkāner. Rome: Istituto italiano per l'Africa e l'Oriente, 1997.

-- - "From Hermes to Jābir and the Book of the Cow." In Magic and the Classical Tradition, edited by C. Burnett and W. F. Ryan, 19-28. London: Warburg Institute, 2006.

- - . "Plato's Hermetic Book of the Cow." In Il Neoplatonismo nel Rinascimento, edited by P. Prini, 133-45. Rome: Istituto della Enciclopedia Italiana, 1993.

- - . "The Șābians of Harrān and the Classical Tradition." International Journal of the Classical Tradition 9, no. 1 (2002): 8-35.

---. The Thousands of Abū Ma'shar. London: Warburg Institute, 1968.

Plessner, M. “Neue Materialien zur Geschichte der Tabula Smaragdina.” Der Islam 16 (2009): 77-113.

De Prémare, A.-L. "Wahb b. Munabbih, une figure singulière du premier islam." Annales: Histoire, Sciences Sociales 3 (2005): 531-49.

al-Qurțubī, Maslama b. Qāsim. Picatrix: Das Ziel des Weisen, edited by H. Ritter. Leipzig: B. G. Teubner, 1933.

al-Qurțubī, Maslama, Picatrix: Das Ziel des Weisen; Translated to German from the Arabic, edited and translated by H. Ritter and M. Plessner. London: Warburg Institute, 1962.

Raggetti, L. “Apollonius of Tyana's Great Book of Talismans.” Nuncius 34 (2019): 155-82.

Raffaelli, E. G. "Astrology and Religion in the Zoroastrian Pahlavi Texts." Journal Asiatique 305, no. 2 (2017): 171-90.

Rosenthal, F. "On the Knowledge of Plato's Philosophy in the Islamic World." Islamic Culture 14 (1940): 387-422. 
. "Platonismus in der islamischen Philosophie (arabische Übersetzung aus dem griechischen)." In Antike und Orient im Mittelalter: Miscellanea Mediaevalia 1, 179-95. Berlin: de Gruyter, 1962.

Ruska, J. Tabula Smaragdina: Ein Beitrag zur Geschichte der Hermetischen Literatur. Heidelberg: Carl Winter's Universitätsbuchhandlung, 1926.

Ryan, W. F., and M. Taube. The Secret of Secrets: The East Slavic Version. London: Warburg Institute, 2020.

Saif, L. The Arabic Influences on Early Modern Occult Philosophy. Basingstoke: Palgrave Macmillan, 2015.

-- - "The Cows and the Bees: Arabic Sources and Parallels for Pseudo-Plato's Liber Vaccae (Kitāb al-Nawāmīs)." Journal of the Warburg and Courtauld Institutes 79 (2016): 1-47.

-_-L. "From Ġāyat al-Hakīm to Šams al-Macārif: Ways of Knowing and Paths of Power in Medieval Islam.” Arabica 64 (2017): 297-345.

Saif, L. “A Study of Ikhwān al-Șafā̄'s Epistle on Magic, the Longer Version (52b)." In Islamicate Occult Sciences in Theory and Practice, edited by L. Saif, F. Leoni, M. Melvin-Koushki and F. Yahya, 162-206. Leiden: Brill, 2020.

Sannino, A. "From Hermetic Magic to the Magic of Marvels." In The Routledge History of Medieval Magic, edited by S. Page and C. Rider, 153-68. London: Routledge, 2019.

Savage-Smith, E., S. Swain, and G. J. van Gelder, eds. A Literary History of Medicine. Leiden: Brill, 2020. https://doi.org/10.1163/37704_0668IbnAbiUsaibia.Tabaqatalatibba.lhomed-ara1.

Schmitt, C. B., and D. Knox. Pseudo-Aristoteles Latinus: A Guide to Latin Works Falsely Attributed to Aristotle before 1500. London: Warburg Institute, 1985.

Sezgin, F. Geschichte des arabischen Schrifttums. 9 vols. Leiden: Brill, 1967-2000.

Sezgin, U. "Pharaonische Wunderwerke bei Ibn Wașîf Aș-Șāb’ und al-Mas'ūdī." Zeitschrift für Geschichte der arabisch-islamischen Wissenchaften 9 (1994): 229-91.

al-Shahrastānī, Abū al-Fatḥ Muhammad. Al-Milal wa-l-niḥal. Edited by M. b. F. Badrān. 2 vols. Cairo: Maktabat al-Anjilū al-Mișriyya, n.d.

Stausberg, M. "Monday-Nights at the Banaji, Fridays at the Aslaji: Ritual Efficacy and Transformation in Bombay City." In Zoroastrian Rituals in Context, edited by M. Stausberg, 653-718. Leiden: Brill, 2004.

Storey, C. A. Persian Literature: A Bio-Bibliographical Survey. Volume 2, part 3. Leiden: Brill, 1977. 
Thorndike, L. A History of Magic and Experimental Science: During the First Thirteen Centuries of our Era. Volume 2. London: Macmillan, 1923.

--C. "The Latin Pseudo-Aristotle and Medieval Occult Science." Journal of English and Germanic Philology 21, no. 2 (1922): 229-58.

Toral-Niehoff, I. Kitab Giranis: Die arabische Übersetzung der ersten Kyranis des Hermes Trismegistos und die griechischen Parallelen. Munich: Herbert Utz, 2004.

Treiger, A. "The Arabic Version of Pseudo-Dionysius the Areopagite's 'Mystical Theology,' Chapter 1: Introduction, Critical Edition, and Translation." Le Muséon 120, nos. 3-4 (2007): 365-93.

Ullmann, M. Die Natur- und Geheimwissenschaften im Islam. Leiden: Brill, 1972.

van Bladel, K. The Arabic Hermes: From Pagan Sage to Prophet of Science. Oxford: Oxford University Press, 2009.

-- . "Hermes and Hermetica." In Encyclopaedia of Islam THREE, ed. Kate Fleet, Gudrun Krämer, Denis Matringe, John Nawas, Everett Rowson. Leiden: Brill, online http:// dx.doi.org/10.1163/1573-3912_ei3_COM_23130

-—-. "Al-Bīrūnī on Hermetic Forgery." Gnosis: Journal of Gnostic Studies 3 (2018): 54-66.

--C. "The Iranian Characteristics and Forged Greek Attributions in the Arabic Sirr al-Asrar (Secret of Secrets)." Mélanges de l'Université Saint-Joseph 57 (2004): 151-72.

Van der Lugt, M. “'Abominable Mixtures': The Liber Vaccae in the Medieval West, or the Dangers and Attractions of Natural Magic." Traditio 64 (2009): 229-77.

Vogt, S. Aristoteles: Opuscula VI: Physiognomonica. Berlin: Akademie Verlag, 1999.

Weisser, U. Buch über das Geheimnis der Schöpfung und die Darstellung der Natur. Aleppo: University of Aleppo, 1979.

-- - Das Buch über das Geheimnis der Schöpfung von Pseudo-A pollonius von Tyana. Berlin: de Gruyter, 1980.

Williams, Steven J. "Defining the Corpus Aristotelicum: Scholastic Awareness of Aristotelian Spuria in the High Middle Ages." Journal of the Warburg and Courtauld Institutes 58 (1995): 29-51.

---. "The Early Circulation of the Pseudo-Aristotelian 'Secret of Secrets' in the West." Le scienze alla corte di Federico II, edited by M. R. McVaugh and V. Pasche, 127-44. Turnhout: Brepols and Florence: SISMEL, 1994.

Zadeh, T. "Commanding Demons and Jinn: The Sorcerer in Early Islamic Thought." In No Tapping around Philology: A Festschrift in Honor of Wheeler McIntosh Thackston Jr.'s 
70th Birthday, edited by A. Korangy and D. J. Sheffield, 131-60. Wiesbaden: Harrassowitz, 2014.

Zanjani Asl, M. K. "Sirr al-Khaliqa and Its Influence in the Arabic and Persianate World: 'Awn b. al-Mundhir's Commentary and Its Unknown Persian Translation." Al-Qanțara 37, no. 2 (2016): 435-73.

Zeyl, D., and B. Sattler. "Plato's Timaeus." In The Stanford Encyclopedia of Philosophy, summer 2019 ed., edited by E. N. Zalta. https://plato.stanford.edu/archives/sum2019/ entries/plato-timaeus/.

Zimmermann, F. W. Review of Das Buch über das Geheimnis der Schöpfung von PseudoA pollonius von Tyana, edited by U. Weisser, Medical History 25 (1981): 439-40.

\section{All Manuscripts Mentioned:}

Compilation containing al-Isțimāțīs, Kitāb Bālinās li-ibnihi, and other untitled texts: MS Berlin, Staatsbibliothek zu Berlin, Petermann I 66.

Compilation of texts on stones: MS Paris, BnF, Arabe 2775.

Dhakhïrat al-Iskandar: MS Madrid, El Escorial, no. 947.

Dhakhïrat al-Iskandar: MS London, British Library, IO Islamic 673.

Dhakhïrat al-Iskandar: MS Berlin, Staatsbibliothek zu Berlin, Wetzstein II 1209.

Ghāyat al-ḥakīm: MS Istanbul, Süleymaniye, Hamidiye 852.

Ghāyat al-ḥakim: MS Dublin, Chester Beatty, Ar. 3313.

Kitāb Azmār al-afkār fị jawāhir al-ahjār: MS Cambridge, Dd. 4. 28.

Kitāb Hirmis al-Harāmisa (al-Shứrā al-yamāniyya): MS Paris, BnF, Arabe 2578.

Kitāb Hirmis al-Harāmisa (al-Shứrā al-yamāniyya): MS Paris, BnF, Arabe 2579.

Kitāb Hirmis al-Harāmisa (al-Shứrā al-yamāniyya): MS Paris, BnF, Arabe 2580.

Kitāb Ilal al-rūḥāniyyāt: MS Paris, BnF, Arabe 2577.

Kitāb 'Ilal al-rūhāniyyāt: MS Manisa, National Library of Manisa (Genel Kitaplik), no. 1461.

Kitāb Milāțis al-akbar and others: MS Tehran, Majlis-i Shūrā-yi Millī, no. 4752.

Kitāb al-Jawāhir wa-l-ahjā̄r: MS Istanbul, Süleymaniye, Ayasofya 3610.

Kitāb Ṭalāsim Bālīnās al-akbar: MS Paris, BnF, Arabe 2250.

Liber Antimaquis: MS London, British Library, Sloane 3854. 
Al-Madịtīs: MS Oxford, Bodleian, Marsh 556.

al-Majmū` al-mubārak: MS Oxford, Bodleian, Huntington 188.

PsAH Cycle: MS Oxford, Bodleian, Arab d. 221.

PSAH Cycle: MS London, British Library, Delhi Arabic 1946.

PsAH Cycle: MS Tonk, Rajasthan, Maulana Abul Kalam Azad Arabic Persian Research Institute, no. 2142.

Rasā'il Ikhwān al-Ṣafā’: MS Istanbul, Süleymaniye, Atıf Efendi 1681.

Risālat Bālīnās al-Hakīm fi ta’thīr al-rūḥāniyyāt: MS Madrid, El Escorial, no. 921.

Shams al-āfāq fì cilm al-ḥurūf wa-l-awfāq by 'Abd al-Raḥmān al-Bisṭāmī: MS London, British Library, no. 7494.

al-Shu'rāa al-yamāniyya: MS Tehran, Majlis-i Shūrā-yi Millī, no. 6451/3.

al-Shu'rāa al-yamāniyya: MS Tehran, Majlis-i Shūrā-yi Millī, no. 4448/7.

al-Shu'rāa al-yamāniyya: MS Leipzig, Vollers 831.

al-Shứrā al-yamāniyya: MS Princeton, Islamic Manuscripts, Garrett no. 547H.

Sirr al-asrār by 'Uțārid b. Muḥammad al-Ḥāsib: MS Madrid, El Escorial, no. 939.

al-Ustuwațtās and others: MS Leiden, Leiden University, Or. 1235. 


\title{
Created After, From, and For the Man? Development of Premodern Shici Exegetic Discourse on the Creation of Woman*
}

\author{
KATJA VON SchÖNEMAN \\ University of Helsinki, Finland
}

(katja.von.schoneman@helsinki.fi)

\begin{abstract}
This article examines the diachronic development of Shici exegetic discourse on the sentence Khalaqakum min nafs wāhiida wa-khalaqa minhā zawjahā ("created you from a single soul and created its mate from it") in the Quranic verse 4:1, customarily read as describing the creation of the first couple, Adam and Eve. Applying feminist discourse analysis and focusing on the Arabic-language commentaries of twelve premodern Imāmi exegetes from the third/ninth to the eleventh/seventeenth century, my study reveals that the medieval commentary material both accumulated and transformed along a hermeneutical trajectory comprising three distinctive discursive stages. The first stage established the lore on Eve's creation in dismissive terms, and the second strengthened these misogynous views to make the potential substance of Eve's creation even more negligible. This concept was further expanded in the third discursive stage, in which the weak woman, inclined toward the material and the corporal, was seen as created to provide service and entertainment for the man. Her creation was thus used to justify gender hierarchy, even the seclusion of women.
\end{abstract}

\section{Introduction: The Creation of Woman in the Quran and the Islamic Interpretive Tradition}

There is no unitary passage describing the creation of humankind in the Quran. Instead, individual verses in several chapters give hints about the creation of the primordial human beings, Adam (Ádam) and his spouse. The Quran describes humankind as created from clay, mud, dust, or fluid, ${ }^{1}$ and from a single soul. ${ }^{2}$ Five verses also mention the creation of

\footnotetext{
* I wish to express my gratitude to Ilkka Lindstedt, Mulki Al-Sharmani, and Amina Inloes for their precious comments on an earlier draft of this article.

1. Q 6:2 (clay); 7:12 (clay); 15:26 (clay, mud); 15:28 (clay, mud); 16:4 (drop); 22:5 (dust/drop); 23:12 (clay); 25:54 (water); 32:7 (clay); 35:11 (dust/drop); 38:71 (clay); 40:67 (dust/drop); 55:14 (clay); 76:2 (drop); and 86:6 (water).

2. Q $4: 1 ; 6: 98 ; 7: 189 ; 31: 28$; and $39: 6$.

(c) 2021 Katja von Schöneman. This is an open access article distributed under the terms of the Creative Commons Attribution-NonCommercial-NoDerivatives License, which allows users to copy and distribute the material in any medium or format in unadapted form only, for noncommercial purposes only, and only so long as attribution is given to the original authors and source.
} 
the first human's mate. ${ }^{3}$ The best-known one, often understood as the portrayal of human creation, is found in the beginning of Sürat al-Nisā', "Chapter of women," which depicts the creation of people from a single soul, nafs wāhida, and the creation from it of its mate, zawj, so that they would multiply into numerous men and women. ${ }^{4}$ However, none of these passages explicitly address the creation of the first woman, later named as Eve (Arabicized as $H a w w \bar{a})$ in the Islamic interpretive tradition. Furthermore, the Quran does not clarify either the way or the substance from which the first woman was created.

Quranic exegesis, tafsir , developed rapidly during the first centuries of Islam. This interpretive knowledge was constructed from a variety of sources and eventually compiled into literary format by Muslim exegetes (mufassirūn). Prophetic traditions, or hadiths, highly valued especially in Sunni Islam, were often used to explain the scripture. In Shici exegesis, the emphasis was first on ta'wìl, the shedding of light on the esoteric (bātin) meaning of the exoteric (zāhir) part of the scripture; this spiritual exegesis was often sectarian and political. The Imāmī (i.e., Twelver) interpretive tradition imbibed the tafsīr style prevalent in Sunni exegesis, and narrations (sg. khabar; pl. akhbār) from the infallible imams became the core of Shici interpretation. ${ }^{5}$ These narrations were used systematically to explain the Quranic message particularly in tradition-based exegesis, tafsir bi-1-ma'thür. ${ }^{6}$

Premodern exegetes kept building upon earlier exegetic knowledge, so the interpretative knowledge both accumulated and transformed in their Quranic commentaries. ${ }^{7}$ The lore

3. Q $4: 1 ; 7: 189 ; 30: 21 ; 39: 6$; and $42: 11$.

4. "O mankind! Be wary of your Lord, who created you from a single soul and created its mate from it (khalaqakum min nafs wāhida wa-khalaqa minhā zawjahā), and from the two of them, scattered numerous men and women"; Q 4:1 in The Qur’ān, trans. 'Ali Qulī Qarā’̄i (London: Islamic College for Advanced Studies Press, 2004), 105. The word nafs, "soul," in the verse is grammatically feminine, whereas the word zawj, "mate," is masculine-so grammatically speaking, God created a feminine soul and from her/it He created her/its masculine mate. For details, see R. Hassan, "Made from Adam's Rib? The Woman's Creation Question," Al-Mushir 27 (1985): 124-55.

5. M. Pregill, "Exegesis," in Routledge Handbook on Early Islam, ed. H. Berg, 98-125 (Abingdon: Routledge, 2018), 105-9; S. Rizvi, "Twelver Shī'ī Exegesis," in The Oxford Handbook of Qur'anic Studies, ed. M. A. Abdel Haleem and M. A. A. Shah, 708-20 (Oxford: Oxford University Press, 2020); D. Steigerwald, “Twelver Shī'ī Ta'wīl," in The Blackwell Companion to the Qur'ān, ed. A. Rippin, 372-85 (Hoboken, NJ: Wiley, 2006). These narrations were also folded into codices, specifically the compilation known as al-kutub al-arba'a, "the Four Books." One of these four collections of traditions is Man lā yahụuruhu al-faqīh by Shaykh al-Ṣadūq (d. 381/991), perhaps better known as Ibn Bābawayh. He also wrote 'Ilal al-sharā'ic wa-l-ahkām wa-l-asbāab, which is repeatedly cited in connection with the exegetic accounts examined in this article. For more information, see R. Gleave, "Between Hadīth and Fiqh: The 'Canonical' Imāmī Collections of Akhbār," Islamic Law and Society 8 (2001): 350-82. Shici hadiths concerning the creation of woman are comprehensively discussed by A. Inloes in Women in Shi'ism: Ancient Stories, Modern Ideologies (Piscataway, NJ: Gorgias Press, 2020), 57-136.

6. Steigerwald, "Twelver Shī̄ī Ta’wìl," 380-82. Tafsīr bi-1-ma’thūr was also characteristic of Sunni exegesis of the time. This approach represents the first of the two major schools in later Imāmī theology, Akhbārī and Ușūlī, of which the latter gives more space for ijtihād, or personal reasoning (see, e.g., Steigerwald, "Twelver Shīîi Ta’wìl," 380-81). Admittedly, this is a simplification of the origins of tafsīr literature, for further discussion on which see, e.g., N. Sinai, “The Qur'anic Commentary of Muqātil b. Sulaymān and the Evolution of Early Tafsīr Literature," in Tafsir and Islamic Intellectual History: Exploring the Boundaries of a Genre, ed. A. Görke and J. Pink (Oxford: Oxford University Press, 2014), 113-43.

7. Pregill, “Exegesis," 108. 
of coexisting cultures and religions naturally affected this process. For instance, Muslim scholars seem to have been familiar with biblical narratives, and some details-such as the Hebrew Bible's depiction of the substance of Eve's creation as one of Adam's ribs-were absorbed into the Islamic interpretive tradition. ${ }^{8}$ In addition, the selection of traditions in each compilation was determined by individual choices, reflecting the exegete's own context and concerns.

The development of the Islamic interpretive tradition with respect to the creation of woman has been previously studied, although often with only marginal remarks concerning the Shici tradition. ${ }^{9}$ Individual premodern Imāmī scholars' exegetic accounts addressing this topic have been referred to in a number of studies, ${ }^{10}$ and the matter has been examined focusing on exegetic material outside the tafsir literature. ${ }^{11}$ Furthermore, modern Shici exegeses concerning the creation of woman have been addressed sporadically. ${ }^{12}$ Eve in Imāmì commentaries has also been dealt with in some studies focusing on the early events

8. See, e.g., K. Bauer, "Room for Interpretation: Qur'anic Exegesis and Gender" (PhD diss., Princeton University, 2008), 29-31; C. Bronson, "Imagining the Primal Woman: Islamic Selves of Eve" (PhD diss., University of Chicago, 2012), 124; eadem, "Eve in the Formative Period of Islamic Exegesis: Intertextual Boundaries and Hermeneutic Demarcation," in Görke and Pink, Tafsīr and Islamic Intellectual History, 27-61, at 30-34; Hassan, "Made from Adam's Rib"; eadem, "The Issue of Woman-Man Equality in the Islamic Tradition," in Women's and Men's Liberation, ed. L. Grob et al., 65-82 (New York: Greenwood Press, 1991), available at http://riffathassan. info/wp-content/uploads/2014/03/The_Issue_of_Woman-Man_Equality_in_the_Islamic_Tradition1.pdf; Pregill, "Exegesis," 105-8; R. Tottoli, "The Corpora of Isrā'sliyyāt," in Abdel Haleem and Shah, Oxford Handbook of Qur'anic Studies, 682-92.

9. Bauer, "Room for Interpretation," 24-57; eadem, Gender Hierarchyin the Qurāan:Medieval Interpretations, Modern Responses (Cambridge: Cambridge University Press, 2015), 101-36; Bronson, "Imagining the Primal Woman," 107-57; Hassan, "Made from Adam's Rib," 124-55; R. Osman, Female Personalities in the Qur'an and Sunna:Examining the Major Sources of Imami Shi i Islam (New York: Routledge, 2015), 15-42; K. von Schöneman, “"Confine Your Women!': Diachronic Development of Islamic Interpretive Discourse on the Creation of Woman," Hawwa (published online ahead of print, October 2020, https://doi.org/10.1163/15692086-BJA10010): 1-45; B. Stowasser, Women in the Quran: Traditions and Interpretation (New York: Oxford University Press, 1996), 25-38.

10. H. Arpaguş, "The Position of Woman in the Creation: A Qur'anic Perspective," in Muslima Theology: The Voices of Muslim Women Theologians, ed. E. Aslan et al., 115-32 (Frankfurt am Main: Peter Lang, 2013); Bauer, Gender Hierarchyin the Qur'ān, 123-29; A. Geissinger, Gender and Muslim Construction of Exegetical Authority: A Rereading of the Classical Genre of Qur'an Commentary (Leiden: Brill, 2015), 39-41; K. Kueny, "Reproducing Power: Qur'ānic Anthropogonies in Comparison," in The Lineaments of Islam: Studies in Honor of Fred McGraw Donner, ed. P. M. Cobb, 235-60 (Leiden: Brill, 2012); J. Smith and Y. Haddad, "Eve: Islamic Image of Woman," Women's Studies International Forum 5 (1992), 135-44. In addition, Fāțimid Ismācīlī interpretations have been addressed in K. Bauer, "Spiritual Hierarchy and Gender Hierarchy in Fāțimid Ismā̄īlī Interpretations of the Qur'an,” Journal of Qur'anic Studies 14 (2012): 29-46.

11. M. Dhala, "Five Foundational Women in the Qur'an: Reading their Stories from a Shia Female Perspective," Berkeley Journal of Religion and Theology 5 (2019): 3-26; Z. Hadromi-Allouche "Creating Eve: Feminine Fertility in Medieval Islamic Narratives of Eve and Adam," in In the Arms of Biblical Women, ed. J. Greene and M. Caspi, 27-64 (Piscataway, NJ: Gorgias Press, 2013); Inloes, Women in Shi'ism, 57-136; M. Kister, “Adam: A Study of Some Legends in 'Tafsir' and 'Hadit' Literature," Israel Oriental Studies 13 (1993): 113-74, at 143-47; idem, "Legends in Tafsir and Hadīth Literature: The Creation of Ādam and Related Stories," in Approaches to the History of the Interpretation of the Qur'ān, ed. A. Rippin, 82-114 (Piscataway, NJ: Gorgias Press, 2013), 110-14.

12. Arpaguş, "Position of Woman," 115-32; S. Hasyim, Understanding Women in Islam: An Indonesian Perspective (Jakarta: Solstice, 2006), 25-51. 
of humankind after the creation of woman. ${ }^{13}$ However, most studies addressing the primal woman and her creation in the Islamic interpretive tradition discuss exclusively the Sunni tradition. ${ }^{14}$ The diachronic development of Imāmī exegesis is considered in only a few studies. ${ }^{15}$ Of these, Karen Bauer's work provides an important discussion regarding the exegetic trends in Imāmī interpretation.

\section{Material and Methods}

This study explores the evolution of the exegetic discourse concerning the creation of woman in premodern Imāmī commentaries on the Quran. I identified a total of thirteen verse-by-verse commentaries, as opposed to works of thematic exegesis, in Arabic that address the sentence Khalaqakum min nafs wāhida wa-khalaqa minhā zawjahā in the first verse of Sürat al-Nisā' (Q 4:1). My search spanned the period from the third/ninth to the eleventh/seventeenth century-that is, from the formative period of Shici Islam up to the beginning of the modern era. My primary sources consist of the works of twelve premodern Imāmī scholars: Furāt al-Kūfì (d. early fourth/tenth century), 'Alī b. Ibrāhīm al-Qummī (d. after 307/919), Muhammad b. Mas'ūd al-'Ayyāshī (d. 319/932), Abū Ja'far Muhammad al-Ṭūsī (d. 460/1067), Abū 'Alī al-Faḍl al-Ṭabrisī (d. 548/1153-two separate commentaries), Muhammad al-Shaybānī (d. seventh/thirteenth century), Abū al-Fayḍ al-Nākūrī (d. 1004/1595), 'Abd 'Alī b. Jum'a al-'Arūsī al-Huwayzì (d. between 1080/1669 and 1105/1693),16 Muhsin al-Faỵ̣ al-Kāshānī (d. 1091/1680), Hāshim al-Baḥrānī (d. 1107/1696), Nūr al-Dīn al-Kāshānī (d. 1115/1703), and Mìrzā Muḥammad al-Mashhadī (d. 1125/1713). Given the discursive nature of Quranic commentaries, it is justifiable to focus on commentaries in a single language; therefore, I selected only Arabic-language works and excluded premodern Persian commentaries, a few of which exist in verse-by-verse format. ${ }^{17}$ I found no verse-by-

13. H. Abugideiri, "Allegorical Gender: The Figure of Eve Revisited," American Journal of Islamic Social Sciences 13 (1996): 518-36; K. Ruffle, “An Even Better Creation: The Role of Adam and Eve in Shici Narratives about Fatimah al-Zahra," Journal of the American Academy of Religion 81 (2013): 791-819.

14. For a concise review on this literature, see von Schöneman, “Confine Your Women!," 14-15.

15. Bauer, "Room for Interpretation" and Gender Hierarchy in the Qurān, 101-36; Bronson, "Imagining the Primal Woman"; and "Eve in the Formative Period." Bauer examines the commentaries of three Imāmī exegetes and mentions four others in connection with her analyses. Bronson, on the other hand, focuses on formative Sunni exegesis. The most comprehensive excursions into the Shici interpretive tradition concerning the creation of woman are provided by Inloes (Women in Shi'ism, 57-136) and Osman (Female Personalities, 15-42).

16. Some studies (e.g., those of Bauer and Osman) report a much later date for his death, but my estimate is based on comprehensive research performed by Todd Lawson, reported in his "Akhbārī Shi'ī Approaches to Tafsīr," in Approaches to the Qur’ān, ed. G. R. Hawting and A. Shareef, 173-210 (London: Routledge, 1993). This detail is significant in evaluating the interrelation between the commentaries in the third discursive stage of my study, since Lawson's dating makes al-Huwayzi’s the first commentary in this stage. Bauer ascribes-mistakenly, I believe-to Muhsin al-Fayḍ al-Kāshānī many traditions that seem to have been first presented by al-Huwayzī.

17. Two of them-Abū al-Futūḥ al-Rāzī's (d. sixth/twelfth century) Rawḍ al-jinān wa-rawh al-janān and Mullā Fatḥ Allāh Kāshānī's (d. 988/1580) Manhaj al-ṣādiqīn fị ilzām al-mukhālifin-have been consulted for reference. However, they do not add much to the specific narrative concerning the creation of woman. 
verse Arabic commentary literature representing other branches of Shici Islam from this time period. ${ }^{18}$ All translations from Arabic into English provided in the analyses are mine.

The methodological framework of the present study can be defined as feminist discourse analysis, influenced by both poststructuralist and social constructionist thought. According to the latter, the way people understand the categories and concepts of the world is determined by time and place-that is, by their socially constructed cultural context. ${ }^{19}$ Gender can be seen as a social construct built through discourse, whether spoken or written. ${ }^{20}$ Dominant gender ideologies are formed and sustained within particular communities, ${ }^{21}$ including premodern Muslim societies.

In poststructuralist thought, meanings expressed by language are unsettled, so they transform diachronically and in close connection with the social context of their use. ${ }^{22}$ The process of meaning-making creates, preserves, and modifies representations of power, ${ }^{23}$ presumably in conjunction with gender asymmetry as well. Both contextuality and plasticity are substantial aspects in this article, as it examines literature composed centuries ago in a specific religious community yet based on an interpretive tradition formed over a long period of time. An essential starting point of my analysis is the fact that these exegetic texts were not born in a vacuum. Instead, they were produced in the midst

18. It should be noted that the theme of human creation has also been addressed in some thematic commentaries, not only in the verse-by-verse ones included in this study.

19. V. Burr, Social Constructionism, 3rd ed. (London: Routledge, 2015), 1-4.

20. J. Sunderland, Gendered Discourses (Basingstoke: Palgrave Macmillan, 2004), 11. Feminism as a theory and a method is related to consciousness of patriarchy, sexism, and social justice, in particular. For feminist approaches to the study of religion, in general, see Sue Morgan's thorough review on the topic in "Feminist Approaches," in Approaches to the Study of Religion, ed. P. Connolly, 42-72 (London: Continuum, 1999). She defines a feminist approach as a "critical transformation" of theoretical perspectives that introduces gender as a primary analytical category. The critical dimension of such inquiry addresses "religion with its historical perpetuation of unjust, exclusionary practices that have legitimated male superiority in every social domain." Morgan correctly notes that feminism is not a homogenous concept; instead, it comprises a vast range of perspectives. What is common to these approaches, however, is the critique of patriarchy-that is, institutionalized systems of male dominance (Morgan, "Feminist Approaches," 42-43).

21. See, e.g., M. Lazar, "Feminist Critical Discourse Analysis: Articulating a Feminist Discourse Praxis 1," Critical Discourse Studies 4 (2007): 141-64, at 147. A feminist approach to examining premodern Islamic texts has been described by Sa'diyya Shaikh in connection with her study on certain hadiths as one that addresses Muslim religio-cultural texts representing "dominant conceptions of gender and the category of woman" within the premodern Muslim legacy and examines how they later become ideologically useful in determining "religious ideals of gender"; S. Shaikh, "Knowledge, Women and Gender in the Hadith: A Feminist Interpretation," Islam and Christian-Muslim Relations 15 (2004): 99-108, at 100. In this study, the feminist dimension is about rendering gender ideology transparent and concomitantly providing a forum for feminist hermeneutics, that is, for tracing and deconstructing patriarchy in religious texts by exploring the narratives and discourses used to construct, embody, and sustain gender hierarchy. For feminist hermeneutics in Islamic studies, see, e.g., N. Jeenah, “Towards an Islamic Feminist Hermeneutic," Journal for Islamic Studies 21 (2008): 36-70.

22. Burr, Social Constructionism, 61-63; N. Fairclough, Critical Discourse Analysis: The Critical Study of Language (London: Longman, 1995), 189.

23. N. Fairclough, Analysing Discourse: Textual Analysis for Social Research (London: Taylor and Francis, 2004), 9. 
of eloquent communication between the Islamic interpretive tradition and lived religion, albeit admittedly among the scholarly elite.

The concept of "discourse" can be defined, for instance, as a way to observe how the world is (re)constructed by language use. ${ }^{24}$ Discourse can normalize perceptions of gender by ${ }^{25}$ for example, creating and sustaining inequality or upholding unjust categorizations. Language use is always located in a particular time and space, so discourse is both engendered and construed historically. ${ }^{26}$ It is also intertextual by nature. ${ }^{27}$ In the present article, I examine these aspects by identifying the evolution of Muslim exegetic discourse as a way of constructing, embodying, and sustaining gender hierarchy in a certain form of language use and a distinctive genre of texts: tafsir $^{28}$

Discourse analysis is not a fixed approach with concrete analytical utensils. It is better characterized as providing a multidisciplinary framework for exploring discursive praxes influencing or representing social structures. This is done by combining textual analysis with other forms of social studies. ${ }^{29}$ The focal point is typically the ways in which power and inequality manifest in and are constituted by the discourse of a given context; thus, discourse analysis may serve as a tool in finding injurious rhetoric concerning gender matters. ${ }^{30}$ Power is an important concept in this study, as I seek to identify the exegetic features employed to preserve gender-based social inequality in Muslim scholarly discourse.

The framework of discourse analysis has been recently used in many fields of academia, including religious studies. ${ }^{31}$ For instance, it has been utilized to address the way biblical interpretations are formed and discussed in a specific context, as well as the subjectivity of the interpreter. ${ }^{32}$ Discourse analysis has also been applied to Quranic studies, particularly in comparing translations that are thought to necessarily represent the translators' interpre-tations, ${ }^{33}$ and in research on the Shici interpretive tradition

24. Sunderland, Gendered Discourses, 6-7.

25. J. Butler, Bodies That Matter: On the Discursive Limits of "Sex" (Abingdon: Routledge, 1993), 1.

26. R. Wodak, "What CDA Is About: A Summary of Its History, Important Concepts and Its Developments," in Methods of Critical Discourse Analysis, ed. R. Wodak and M. Meyer, 1-13 (London: Sage, 2001).

27. R. Wodak, Gender and Discourse (London: Sage, 1997), 6.

28. Every text is language use, and as such a potential target of discourse-analytic exploration.

29. N. Fairclough, Discourse and Social Change (Cambridge: Polity Press, 1992), 12-36.

30. Sunderland, Gendered Discourses, 11.

31. E.g., T. Hjelm, "Discourse Analysis," in The Routledge Handbook of Research Methods in the Study of Religion, ed. S. Engler and M. Stausberg, 134-50 (Abingdon: Routledge, 2011).

32. T. Warhol, "Gender Constructions and Biblical Exegesis: Lessons from a Divinity School Seminar," in Language and Religious Identity: Women in Discourse, ed. A. Jule, 50-72 (Basingstoke: Palgrave Macmillan, 2007), 51-52; for an illustrative case study of the phenomenon, see the entire article by Warhol.

33. E.g., D. T. Bazargani, “A comparative Study on Two Translations of the Holy Qur'an: A Critical Discourse Analysis Approach,” Translation Studies 12 (2015): 49-64; A. Sideeg, "Traces of Ideology in Translating the Qurān into English: A Critical Discourse Analysis of Six Cases across Twenty Versions," International Journal of A pplied Linguistics and English Literature 4 (2015): 214-26. 
outside the genre of tafsīr. ${ }^{34}$ Tafsir has in fact been characterized as discourse analysis by its very nature. ${ }^{35}$

Aiming to evaluate the diachronic development of the exegetic discourse identifiable in Quranic commentaries, my study also benefits from a genealogical approach. This use of the concept of genealogy was introduced by Friedrich Nietzsche and later made famous in reconstructing historical trajectories by Michel Foucault. ${ }^{36}$ Genealogy tackles the role of power in shaping human understanding, further improving the discourse-analytic framework when applied to historical literary sources, in particular. ${ }^{37}$ Every new text is affected by other texts cultivated before it. Tafsī has been described as an inherently genealogical tradition, ${ }^{38}$ and genealogical discourse analysis has been used to examine both Sunni Islamic and Jewish interpretive traditions. ${ }^{39}$ It is thus reasonable to assume that it would be useful also for investigating the evolution of Imāmì discourse on the creation of woman.

This study strives to demonstrate the all-encompassing patriarchal ethos of the premodern interpretive tradition by pointing out notions that represent and generate the gender-based hegemony prevalent in the exegetes' context. First, I uncover the content and linguistic features of the interpretative accounts likely to portray gender aspects and attitudes. Second, as a particular account is naturally a product of material selection, I discuss the narrations chosen by the exegetes in conjunction with preceding commentaries, carefully noting their individual opinions. Third, I track the accrual of misogynous details during the development of the interpretive discourse on the creation of woman. Importantly, my study develops the previous application of genealogical and discourseanalytic methodology by Omaima Abou-Bakr in connection with another Quranic verse. ${ }^{40}$ I have elsewhere applied this approach to Sunni and Jewish exegetic discourses regarding

34. E.g., S. Rizwan, "Religion, Ideology and Discourse: A Critical Discourse Analysis of Majlis-e-Hussain," Journal of Islamic and Middle Eastern Multidisciplinary Studies 1 (2011): 1-35; F. Jawad and N. Othman, "A Critical Discourse Analysis of Risalat al-Huquq of Imam Ali al-Sajjad," Majallat al-`ulūm al-insāniyya 24 (2017): 50-69.

35. M. Nordin, "'Ilm al-Tafsir and Critical Discourse Analysis: A Methodological Comparison," Journal of Language Studies 15 (2015): 129-42.

36. M. Saar, "Genealogy and Subjectivity," European Journal of Philosophy 10 (2002): 231-45, at 231-33; Gary Gutting, Foucault: A Very Short Introduction (Oxford: Oxford University Press, 2005), 50-58.

37. S. Anaïs, "Genealogy and Critical Discourse Analysis in Conversation: Texts, Discourse, Critique," Critical Discourse Studies 10 (2013): 123-35.

38. W. Saleh, The Formation of the Classical Tafsïr Tradition:The Qur'ān Commentary of al-Tha labī (Boston: Brill, 2004), 14-16.

39. O. Abou-Bakr, "The Interpretive Legacy of Qiwamah as Exegetical Construct," inMenin Charge? Rethinking Authority in Muslim Legal Tradition, ed. M. Al-Sharmani et al., 44-64 (Oxford: Oneworld, 2015); von Schöneman, “"Confine Your Women!"; eadem, "Evolution of Rabbinic Discourse on the Creation of Woman in Late Antiquity" (MA thesis, University of Helsinki, 2019), available at https://helda.helsinki.fi/handle/10138/306271.

40. Abou-Bakr, "Interpretive Legacy." Abou-Bakr examines the accumulation of gender notions in exegeses on the first part of the Quranic verse 4:34 and the evolution of the original term qawwāmūn into the patriarchal construct of qiwāma within the evolving chronological context of Quranic commentaries representing different tafsir approaches. 
the creation of woman. ${ }^{41}$ I will demonstrate the significance of this methodology in highlighting the genealogical character of the Imāmi exegetic discourse-that is, the ways in which layers of interpretation are built upon one another and shifts and additions take place within the boundaries of the interpretive community.

\section{Analysis: Development of Imāmī Exegetic Discourse}

\section{Setting the Scene: Constituting the Imāmī Tradition Corpus (Third-Fourth/Ninth-Tenth Centuries)}

The development of Imāmì exegesis concerning the creation of woman can be roughly divided into three distinct discursive stages defined, respectively, by the constituting of the Shici exegetic corpus, reassertion of the interpretive tradition, and affluent hermeneutics and augmentations. The first stage represents the formative, "preclassical" period of Imāmī tafsir, and it is preserved in the compilations of the second-generation exegetes, who lived in the third/ninth and fourth/tenth centuries. The three pre-Buyid exegetes, who exemplify this first discursive stage, are Furāt al-Kūfī, 'Alī b. Ibrāhīm al-Qummī, and Muhammad b. Mas' $\overline{\mathrm{u}} \mathrm{d}$ al-'Ayyāshī. They transmitted traditions from the disciples of the infallible imams of Twelver Shici Islam, generally without adding their own comments.

The first discursive stage established the core of Imāmi interpretations of the Quranic verse at issue. In his commentary, al-Kūfi offers a singular interpretation of $Q$ 4:1 that reflects the efforts at the time to establish the identity of the Imāmī community. 'Alī b. Ibrāhīm al-Qummī, by contrast, presents only the view known mainly from the Sunni interpretive tradition: Eve was created from the lowest rib of Adam. Finally, al-'Ayyāshi explains the same passage with reference to several traditions according to which Eve was created in diminutive terms either from Adam's smallest rib or from a leftover portion of the clay used to fashion him. She was created from Adam, which makes her hanker after men. This is, for al-'Ayyāshī, the reason to keep women indoors. In what follows, I will elaborate on the interpretations of each exegete.

\subsection{Abū al-Qāsim Furāt b. Ibrāhīm b. Furāt al-Kūfì (d. Early Fourth/Tenth Century)}

The compilation known as Tafsīr Furāt al-Kūfi represents tradition-based exegesis: its narrations generally go back to the fifth and sixth imams as well as the disciples of the first imam, 'Alī b. Abī Țālib (d. 40/661). ${ }^{42}$ It was authored at the end of the third/ninth century by Furāt al-Kūfi, an important Shici hadith scholar and exegete, albeit apparently the least known of the commentators from this discursive stage. ${ }^{43}$ The commentary reflects the author's association with esoteric mysticism, which is evident in the following account as well.

\footnotetext{
41. Von Schöneman, “'Confine Your Women!”; eadem, "Evolution of Rabbinic Discourse.”

42. M. Bar-Asher, Scripture and Exegesis in Early Imami-Shiism (Boston: Brill, 1999), 29-32.

43. M. A. Amir-Moezzi, "Furāt b. Furāt al-Kūfi," in Encyclopaedia of Islam, 3rd ed., ed. K. Fleet et al. (Leiden: Brill Online).
} 
Furāt al-Kūfi presents one long tradition with a thorough isnād (chain of transmitters) concerning $Q$ 4:1. It begins with a narration allegedly transmitted from the sixth imam, Ja'far b. Muhammad al-Șādiq (d. 148/765), and originally attributed to no less than the Prophet himself: "God created me and the people of my house from a piece of clay" (khalaqanì wa-ahl baytī min țina). It further describes this ahl al-bayt, here referring to the Shica, as illuminating the world with the light they have preserved since the creation. The tradition then warns the faithful against going astray and reminds them of the reward in the hereafter. ${ }^{44}$

This interpretation is a remarkable deviation from those presented in other Quranic commentaries of the time, particularly in that it does not connect the original verse with the creation of the primordial couple, Adam and Eve. Instead, it associates the passage with the creation of ahl al-bayt, apparently reflecting the author's context, which was dominated by the formation of the concept of imāmiyya between the minor and major occultations of the twelfth imam (264-329/874-941) and the central role of al-Küfi's home city of Kufa as a firm Imāmī stronghold with a distinctive religious literature. ${ }^{45} \mathrm{Al}-\mathrm{Ku} f 1$ does not, however, elaborate on this theme explicitly. Instead, his account-and the discussion that follows it-connects the creation with righteousness, guidance, and salvation. Furthermore, it mentions the substance of human creation as "clay" (tinna). ${ }^{46}$ However, al-Kūfi does not distinguish between different phases of human creation, and he thus does not address the creation of woman specifically.

\subsection{Abū al-Hasan 'Alī b. Ibrāhīm al-Qummī (d. after 307/919)}

'Alī b. Ibrāhīm al-Qummī was a multitalented scholar who authored about a dozen books, the most important one being his tradition-based exegesis. Al-Qummi's interpretation of Q 4:1 is brief, as is his tafsīr in general. He laconically states that khalaqakum min nafs wāhida refers to the creation of Adam, whereas khalaqa minhā zawjahā refers to that of Eve, and that the latter was created from the former's lowest rib (min asfal aḍla cihi). ${ }^{47}$ The terminology chosen resembles that of Ibn Abi Hātim (d. 327/938), a contemporary Sunni commentator, who also specified that the rib in question was the lowest one. ${ }^{48}$ It is remarkable that by tracing Eve to Adam's rib, al-Qummī diverges from most other Imāmī sources, which opt for "clay" as the origin of woman, as I will show below. In fact, it seems

44. Furāt al-Kūfî, Tafsīr Furāt al-Kūfi, ed. M. al-Kāẓim (Beirut: Mu’assasat al-Tārīkh al-'Arabī, 2011), 1:101-2. In this edition, the traditions have been organized according to Quranic verses.

45. Bar-Asher, Scripture and Exegesis, 6-9; for an extensive introduction to the time period and the pre-Buyid exegetes representing the era, see the entire study.

46. Interestingly, this tradition evokes the well-known Imāmī conception of the different locations of clayrepresented by the Quranic terms cilliyyūn and sijjin-used for the creation of the imams and their enemies; see, e.g., M. A. Amir-Moezzi, The Divine Guide in Early Shi'ism: The Sources of Esotericism in Islam (Albany: State University of New York Press, 1994), 38-41.

47. 'Alī b. Ibrāhīm al-Qummī, Tafsīr al-Qummī, ed. Ṭ. al-Mūsawī al-Jazāirīī (Najaf: Maṭba'at al-Najaf, 1966), $1: 130$.

48. Cf. Ibn Abī Ḥātim al-Rāzī, Tafsīr al-Qur’ān al-'aẓìm, ed. A. M. al-Ṭayyib (Mecca: Maktabat Nizār Muṣțafā al-Bāz, 1999), 3:852. 
that his understanding of this Quranic verse is mainly influenced by Sunni conceptions of its meaning. Unlike his contemporary al-Kūfi, al-Qummì does not use his explication of this particular passage to promote the development of Imāmī identity. However, in many other parts of his commentary, al-Qummī emphasizes the superiority of the Prophet's family and his descendants, as well as the infallible imams, hence affirming the core of Imāmi ideology. ${ }^{49}$

\subsection{Abū al-Naḍr Muḥammad b. Mas'ūu al-'Ayyāshī (d.319/932)}

The third exegete of this discursive stage, Muhammad b. Mas' $\bar{u} d$ al-'Ayyāshī, made important contributions to Imāmī jurisprudence and hadith studies as well as Arabic literature. His most famous work, extensively cited by later exegetes, is his Tafsir, which was written during the early fourth/tenth century. ${ }^{50}$ His agenda is characterized by polemics against rational, or opinion-based, interpretation of the Quran (tafsir bi-l-ra'y). ${ }^{1}$ The style of Tafsīr al-'Ayyāshī clearly follows tradition-based exegesis and has much in common with the exegesis of the legendary Sunni scholar of the time, Abū Ja'far Muhammad al-Tabarī (d. 310/923). The main difference lies in the chains of transmitters: al-'Ayyāshī's seem to be sect-selective, pointing to the emergence of this feature already at such an early stage of Islamic history.

In the beginning of his interpretation of the passage, al-'Ayyāshī cites a tradition ascribed to Imam 'Alī. According to this tradition, Eve was created from a tiny rib in Adam's side (qușayrā janb Ādam), which was actually the smallest rib (al-dil' al-aṣghar), when he was resting. ${ }^{52}$ Both the term qușayrā, a diminutive form of qașīr ("short"), and the idea of Adam sleeping while Eve is being formed are also present in al-Tabarī's commentary on the same Quranic passage. ${ }^{53}$ Adding diminutive elements to the narrative clearly presents Eve as an inferior being as compared to Adam. This tradition also appends details from the biblical Garden of Eden narrative, which was quite common among contemporary Sunni commentators, indicating that scholarly works circulated freely and widely at this point of sectarian development.

Al-'Ayyāshī then cites the sixth imam, Ja'far b. Muhammad al-Ṣādiq: "God created Adam from water and clay, so the zeal (himma) of his son is in water and clay. God created Eve from Adam, so men are the zeal of women (fa-himmat al-nisā' al-rijāl). So, fortify them [fem.] in the[ir] homes (hașșinūhunna fi al-buyūt)!"54 Notably, this narration resembles

49. Bar-Asher, Scripture and Exegesis, 39-45.

50. Bar-Asher, Scripture and Exegesis, 56-63.

51. J. McAuliffe, "Quranic Hermeneutics: The Views of al-Ṭabarī and Ibn Kathīr," in Rippin, Approaches to the History, 46-62, at 48.

52. Muhammad b. Mas' '̄ùd al-`Ayyāshī, Tafsīr al-`Ayyāshī, ed. H. Rasūlī Maḥallātī (Beirut: Mu’assasat al-A`lamī, 1991), 1:241.

53. Abū Ja`far Muḥammad al-Ṭabarī (d. 310/923), Jāmi` al-bayān 'an ta’wīl āy al-Qur’ān (Cairo: Dār Hijr, 2001), 6:341.

54. Tafsīr al-`Ayyāshī, 1:241. Cf. Bauer's translation in Gender Hierarchy in the Qur’ān, 124. The zeal of men for water and clay possibly refers to agriculture. 
a tradition that was probably initiated in early classical Sunni exegesis by Ibn Abī Ḥātim and that reappears more than 400 years later in the influential commentaries of Ibn Kathir (d. 774/1373) and Jalāl al-Dīn al-Suyūṭi (d. 911/1505), which recommend keeping women indoors on the basis of similar reasoning. ${ }^{55}$ It is also repeated in the Shici tradition after al-'Ayyāshī by, for example, al-Ḥuwayzī, Muḥsin al-Fayḍ, and al-Bahrānī in the eleventh/ seventeenth century, as will be seen below.

The next two traditions cited in al-'Ayyāshī's work, which consolidate the understanding of $\mathrm{Q} 4: 1$ in connection with human creation and the primordial beings, depict an ideal of marriage, often seen as one between first cousins. Although the vivid stories about the respective marriages of Adam's sons with a houri and a jinn and the subsequent marriage between the respective offspring of the two unions do not add details on the matter of female creation, they reveal a major endeavor of the Imāmī exegetic corpus on this particular Quranic verse: to solve the logical puzzle concerning the procreation of Adam's children. The matter was further elaborated upon in subsequent Shici commentaries, but this topic lies outside the focus of my article and is thus not discussed here.

The final tradition al-'Ayyāshī's commentary introduces is an alternative view, attributed to the fifth imam, Abū Jacfar al-Bāqir (d. 114/732), concerning the material from which Eve was created. The imam is quoted as saying that when people say that God created her from one of Adam's ribs (min dil' min aḍlā' $\bar{A} d a m$ ), they are lying. The Imam marvels at the claim: as if God were incapable of creating her from anything but a rib! A similar speculation was later presented by the Sunni commentator Fakhr al-Dīn al-Rāzì (d. 606/1210) in his al-Tafsīr al-kabir , arguing that since God is capable of creating Adam from dust, He must be capable of creating Eve from dust as well, ${ }^{56}$ but this argument was not commonly reproduced in later Sunni commentaries. In the Shici interpretive tradition, however, it was widely known and has been often repeated since.

Al-'Ayyāshī goes on to quote a statement from the Prophet, transmitted by Imam al-Bāqir from a member of ahl al-bayt: "God, Blessed and High, took a handful of clay and mixed it with His right hand-and both of His hands are right [hands]-and created Adam from it. And there was some leftover clay (fadalat fadla min al-țin), from which He created Eve." 57

Al-'Ayyāshī's interpretation of Q 4:1 represents the beginning of a long-lasting tension in Imāmì exegesis between two incompatible views, each supported by traditions attributed to the imams: Eve was created from a rib or from the same clay as Adam. Although some

55. Cf. Ibn Abī Ḥātim, Tafsīr, 3:852; 'Imād al-Dīn Ismā'īl b. Kathīr, Tafsīr al-Qur’ān al-'aẓīm, ed. M. S. Muhammad et al. (Cairo: Mu’assasat Qurțuba, 2000), 3:333; and Jalāl al-Dīn al-Suyūțî, al-Durr al-manthūr fí tafsīr al-ma’thūr, ed. 'A. M. al-Turkī (Cairo: Markaz al-Hajr, 2003), 4:209. Osman cites an editorial note from a Shici hadith collection according to which this might have been meant allegorically: "houses" actually mean "husbands"-women should be made safe through marriage so that their inborn zeal toward men would not lead them away from the right path (Osman, Female Personalities, 28). Inloes gives an insightful summary of the features of this tradition in her Women in Shi'ism, 81.

56. Cf. Fakhr al-Dīn al-Rāzì, al-Tafsīr al-kabīr wa-mafātīh al-ghayb (Beirut: Dār al-Fikr, 1981), 9:167. It is possible that al-Rāzì was influenced by Shici thought, which his commentary may also reflect.

57. Tafsīr al-`Ayyāshī, 1:242. Cf. Bauer's translation of a similar passage in Gender Hierarchy in the Qur’ān, 124. 
individual exegetes endorsed one or the other of these views, Imāmī commentators generally remained silent on the matter until the eleventh/seventeenth century. ${ }^{58}$ Meanwhile, the Sunni interpretive tradition stuck firmly to the view that the initial soul was Adam and the mate made from it was Eve, created from Adam's rib..$^{59}$ It is tempting to speculate that the Imāmi exegetes who opted for the clay explanation-instead of the rib theory favored by the Sunnis-sought deliberately to distinguish Imāmī exegesis from its Sunni counterpart. This position may have been part of the distinct Imāmī identity that took shape in the period between the occultations of the twelfth imam.

\section{Reasserting the Interpretive Tradition (Fifth-Seventh/Eleventh-Thirteenth Centuries)}

The classical period of Imāmī exegesis, represented by the third generation of exegetes, encompasses the span from the fifth/eleventh to the seventh/thirteenth century. Shic $i$ commentators-including the three exegetes studied from this period, namely, Abū Ja'far Muhammad al-Ṭūsī, Abū 'Alī al-Faḍl al-Ṭabrisī, and Muḥammad al-Shaybānī-drew on previous traditions, Sunni and Shici alike, in their work. ${ }^{60}$ This phase constitutes the second discursive stage of Imāmī exegesis on the creation of woman, and it is defined by efforts to entrench the views on the matter articulated in the first stage. The scholars of this period worked in an environment that can be seen as the golden age of the Shica, during and after the reigns of the Buyid (322-447/934-1062) and Fatimid (297-555/909-1171) dynasties, and it is plausible that they felt quite free to express their doctrinal beliefs in their scholarly works. Nevertheless, in their writings the tiny rib allegedly used for the creation of woman is not only the lowest and smallest one, as in the preceding stage, but sinister and the farthest one as well. In addition, the rib is further described as crooked, and its crookedness symbolizes the wariness with which men should deal with women. The following sections elucidate the details of each commentary's account.

\subsection{Abū Ja'far Muhammad b. Hasan al-Ṭūsī (d. 460/1067)}

Abū Ja'far Muhammad al-Ṭūsī is one of the most influential Shici scholars of all time. Besides being a prolific writer, he is also considered the founder of Imāmi jurisprudence. He worked under the Shici-favoring Buyid dynasty and authored two of the four most famous Imāmī hadith collections. ${ }^{61}$ In his Quranic commentary, al-Tibyān fì tafsīr al-Qur’ān, al-Ṭūī starts his explication on verse Q 4:1 with matters pertaining to the latter part of the verse. He then proceeds to the passage of interest here, asserting that according to all commentators, God created His creation from a single soul, and this soul was Adam.

58. Bauer, "Room for Interpretation,” 39; eadem, Gender Hierarchy in the Qur’ān, 125.

59. E.g., von Schöneman, “"Confine Your Women!"”

60. Ayoub, “The Speaking Qur’ān and the Silent Qur’ān: A Study of the Principles and Development of Imāmī Tafsir ," in Rippin, Approaches to the History, 177-98, at 185. For a thorough introduction to the era and the context of these exegetes, see C. Baker, Medieval Islamic Sectarianism (Amsterdam: Arc Humanities Press, 2019).

61. I.e., al-kutub al-arba`a; M. A. Amir-Moezzi, "Al-Ṭūsī, Muhammad b. al-Hasan," in Encyclopaedia of Islam, 2nd ed., ed. P. J. Bearman et al., 10:745-46 (Leiden: Brill, 1954-2009). For an introduction to the Buyid dynasty, see Baker, Medieval Islamic Sectarianism, 1-15. 
Al-Ṭūsi goes on to say that God's saying khalaqa minhā zawjahā refers to Eve, and he claims that most commentators subscribe to the view that she was created from one of Adam's ribs. ${ }^{62}$ Interestingly, al-Ṭūsi appeals to an existing scholarly consensus, possibly encompassing Sunni as well as Shici commentators, which may seem surprising given his Imāmì-majority context.

Next, al-Ṭūsī quotes a tradition from Imam al-Bāqir: God created woman from a leftover of the clay from which He had created Adam. He then argues that although the term "soul" is grammatically feminine, its meaning here is masculine, and the masculine form of the phrase-nafs wāhid-would be correct, as well. ${ }^{63}$ Al-Ṭūī thus seems to settle on the interpretation that the woman, too, was created from clay, albeit only a leftover portion of it. The concept of leftover material was already introduced in al-'Ayyāshī's interpretation, but al-Ṭūsĩ confirms this Imāmī conception by allowing potential alterations to the grammatical structure of the Quranic text, concomitantly emphasizing the primacy of a male being.

\subsection{Abū 'Alī al-Fạ̣l b. al-Hasan al-Ṭabrisī (d. 548/1153)}

Al-Ṭabrisi is perhaps the best known premodern Shici exegete. Although his main teacher was a student of al-Ṭūsī, he was also taught by Sunni scholars. Al-Ṭabrisī wrote two commentaries, of which the briefer one is called Jawāmi ‘ al-jāmi` fi tafsīr al-Qur’ān al-majīd. Concerning $Q$ 4:1, the commentary addresses the soul, nafs, which God brought into being from soil, subsequently creating Eve from one of its ribs. Al-Tabrisī also quotes a saying by the Prophet, according to which God created people from Adam's soul and then created their mother, Eve, from it. ${ }^{64}$ It is noteworthy that al-Ṭabrisī uses a feminine suffix $(-h \bar{a})$ for "it," most likely referring to the feminine noun nafs.

The more comprehensive of al-Ṭabrisī's Quran commentaries, Majma' al-bayān fì tafsīr al-Qur'ān, is probably the most authoritative premodern Imāmī commentary. ${ }^{65}$ After elaborating at length on other parts of verse $Q 4: 1$, following quite closely the commentary of al-Ṭūsì, al-Ṭabrisī presents a tradition explicating the passage khalaqakum min nafs wăhida. He states that according to all interpreters, the "soul" denotes Adam, despite the feminine form of the word, and as evidence he quotes the words of a poet:

Your father is a successor whom another bore (abūka khalifa waladathu ukhrā), and you are the successor of that perfection (wa-anta khalifat dhāka al-kamāl). ${ }^{66}$

62. Abū Ja`far Muhammad al-Ṭūsī, al-Tibyān fì tafsīr al-Qur’ān, ed. A. Sh. al-Amīn and A. H. Qașīr (Najaf: Maktabat al-Amīn, 1989), 3:99.

63. Al-Ṭūsī, al-Tibyān, 3:99; cf. Tafsīr al-`Ayyāshī, 1:242. Correspondingly in Sunni tafsīr, e.g., al-Ṭabarī, Jāmi` al-bayān, 6:339-40.

64. Faụl b. al-Hasan al-Ṭabrisī, Jawāmi` al-jāmic fî tafsīr al-Qur’ān al-majīd (Qum: Mu’assasat al-Nashr al-Islāmī, 2003), 1:368.

65. E. Kohlberg, “Al-Ṭabrisī (Ṭabarsī), Amīn al-Dīn,” in Encyclopaedia of Islam, 2nd ed., 10:40-41. For extensive information both on Majma' al-bayān and on its author, see B. Fudge, Qur'anic Hermeneutics: Al-Tabrisi and the Craft of Commentary (London: Routledge, 2012).

66. Faụl b. al-Ḥasan al-Ṭabrisī, Majma‘ al-bayān fì tafsīr al-Qur’ān (Beirut: Dār al-Murtaḍā, 2006), 3:7. 
The feminine-looking noun for "successor," khalifa, ${ }^{67}$ is used in connection with the grammatically masculine "father," $a b \bar{u}$, and the masculine second-person pronoun anta. That the addressee is masculine is confirmed by the use of the masculine suffix -hu in the first sentence ${ }^{68}$ Like al-Ṭūsì, al-Ṭabrisī points out that a masculine attribute, wāhid, for the single soul would have been correct as well. ${ }^{69}$

Al-Ṭabrisī then asserts that most commentators agree that khalaqa minhā zawjahā means that Eve was created from one of Adam's ribs. This interpretation, he claims, is further supported by a saying of the Prophet: "The woman was created from a rib (khuliqat al-mar'a min dil $)^{\prime}$. If you straighten it, you break her, but if you leave her crooked, you will find her pleasant (istamta'ta bihā)."70 This narration is remarkably similar to that repeated in Sunni commentaries in that al-Tabrisî's exegesis also contains modified versions of some Sunni hadiths whose reliability and soundness, however, have been heavily criticized by the Muslim feminist scholar Riffat Hassan. ${ }^{71}$ The tradition depicts women as disconsolately crooked, perhaps even as persons with contorted morality.

In sum, although al-Ṭabrisī follows his predecessor al-Ṭūsì quite closely, he ends with a statement indicating that the substance of Eve's creation was the lowest rib of Adam. ${ }^{72}$ It is noteworthy that although al-Tabrisī was working in an environment shaped by Shici domination in Iran, he concludes his explication of Q 4:1 with this apparently Sunni claim. This marks as a clear shift in the conception of the primordial couple's creation, and it contributes to the consolidation of the image of woman as derivative and subordinate. It is possible that this shift reflects the supposed "Sunni revival" that followed the so-called Shici century, ${ }^{73}$ and that the political environment of Sunni resurgence might have pushed Imāmī exegetes to take Sunni conceptions more emphatically into account.

67. Feminine-looking since it concludes in a tā’ marbūța.

68. In fact, the first part of the poem is also cited by Sunni exegetes in support of similar reasoning; see, e.g., al-Ṭabarī, Jāmi ' al-bayān, 6:339-40; Abū al-Hasan 'Alī b. Aḥmad al-Wāhiidī (d. 468/1076), Tafsīr al-basịt (Riyadh: Wizārat al-Ta'līm al-'`̄'lì, 2010), 6:281; al-Rāzì, al-Tafsīr al-kabīr, 9:166.

69. Al-Ṭabrisī, Majma' al-bayān, 3:7; cf. al-Ṭūsī, al-Tỉbyān, 3:99.

70. Al-Ṭabrisī, Majma' al-bayān, 3:7. For similar passages in Sunni exegeses of the time, see, e.g., al-Wāhiidī, Tafsīr al-basịt, 6:282; al-Rāzī, al-Tafsīr al-kabìr, 9:167. A comparable tradition, which notes that the woman is "like a rib," can also be found among Shici traditions, albeit not in connection with the creation. For example, Abu Ja'far al-Kulaynī (d. 329/941) and Ibn Bābawayh attribute this comment to the Prophet as reported by the sixth imam: Muḥammad b. Ya'qūb al-Kulaynī, al-Kāfì (Tehran: Dār al-Kutub al-Islāmiyya, 1947), 5:513; Muhammad b. 'Alī b. al-Husayn b. Bābāwayh al-Qummī, Man lā yahựuhu al-faqīh (Qum: Jamā'at al-Mudarrisīn fì al-Hawza al-'Ilmiyya, 1885), 3:439-40. Interestingly, as Inloes notes (Women in Shi'ism, 62), Ibn Bābawayh expresses doubt in the report's soundness .

71. Hassan, "Made from Adam's Rib"; cf. al-Wāḥidī, Tafsīr al-basīt, 6:281; al-Rāzī, al-Tafsīr al-kabīr, 9:167; Muḥammad b. Aḥmad al-Qurțubī, al-Jāmi` li-aḥkām al-Qur’ān (Beirut: al-Risāla, 2000), 6:6. Osman argues that the view of woman as irredeemably crooked is fundamentally against the Quran and its verse 95:4, which says that humans have been created fi ahsan taqwim, "in the best of forms" (Osman, Female Personalities, 27-28).

72. Al-Ṭabrisī, Majma' al-bayān, 3:7; cf. al-Ṭūsī, al-Tỉbyān, 3:99.

73. For a concise introduction to these somewhat debated concepts, see Baker, Medieval Islamic Sectarianism, 1-15. For the broader debate regarding the concept of a "Sunni revival," see S. Mulder, The Shrines of the 'Alids in Medieval Syria (Edinburgh: Edinburgh University Press, 2014), 16, n. 16. 


\subsection{Muhammad b. al-Hasan al-Shaybānī (d. seventh/thirteenth century)}

Muḥammad b. al-Ḥasan al-Shaybānī is a little-celebrated character among premodern Shici exegetes. In fact, the manuscript attributed to him does not mention his name at all. However, his name and his authorship of the book bearing the title Nahj al-bayān can kashf ma'ānì al-Qur'ān is given in another contemporary work. ${ }^{74}$ In his Quranic commentary, al-Shaybānī interprets the passage in question rather briefly. He first states, citing Imam al-Șādiq, that khalaqakum min nafs wāhida means that humankind was created "from Adam," who was thus named because he was created from the surface of the earth (adim al-arḍ). ${ }^{75}$ Next, al-Shaybānī interprets khalaqa minhā zawjahā as referring to Eve. She was named Hawwā' because she was created from a living thing (hayy). According to al-Shaybānī, God created her from a rib on Adam's left side (dil cal-yasār), and this tiny rib was among the last ones (al-quṣayrā ākhir al-aḍlāc). Furthermore, Eve was called "a woman" (imra'a) because she was created from the man $\left(a l-m_{a r}\right){ }^{76}$

The diminutive term qușayrā in al-Shaybānī's account was also used by al-'Ayyāshī a few hundred years earlier; in addition, it is frequently repeated in medieval Sunni commentaries. By contrast, al-Shaybānī's use of yasār is not replicated in any other commentary analyzed here. This is thus the first, but not the last, account to specify that the tiny rib from which Eve was created came from Adam's left side and to describe it in sinister and negative terms. Furthermore, the rib's being one of the last ones, ākhir al-aḍlā', is a novel elaboration, although many other dismissive attributes have already been applied by this stage of the interpretive discourse. Notably, both the Arabic term used for "woman" and Eve's proper name are explained by her derivative creation from the man. Together, these discursive features serve to consolidate an understanding of women as fundamentally reliant on and subservient to men. This view could reflect the Sunni shift in Middle Eastern power relations in this period after the transient success of Shici thought among the leaders.

\section{Blossoming of the Lore: An Affluence of Hermeneutics (Tenth-Eleventh/Sixteenth- Seventeenth Centuries)}

The concept of Eve's creation is elaborated and expanded on in the third discursive stage of Imāmī exegetic discourse, examined here through the explications of Abū al-Fayd al-Nākūrī, 'Abd 'Alī b. Jum'a al-'Arūsī al-Ḥuwayzī, Muḥsin al-Fayḍ al-Kāshānī, Hāshim al-Baḥrānī, Nūr al-Dīn al-Kāshānī, and Mīrzā Muḥammad al-Mashhadī, most of whom worked under the rising Safavid dynasty, which adopted Imāmī doctrine as the state religion. The commentaries produced in this majority context are often polemical, accentuating sectarian

74. Ḥ. Dargāhī, introduction to Muḥammad b. al-Ḥasan al-Shaybānī, Nahj al-bayān 'an kashf ma'ānī al-Qur'ān, ed. H.. Dargāhī (Qum: Nashr al-Hādī, 1958-99), 1:ḥā'.

75. Al-Shaybānī, Nahj al-bayān, 2:108.

76. Al-Shaybānī, Nahj al-bayān, 2:108. The word imra’a, translated as "woman," can be read as a derivative of the word mar' used, in this sentence, for "man." This tradition is also presented by the Sunni exegete Abū al-Layth al-Samarqandī in his Baḥr al-'ulūm, ed. 'A. M. Mu'awwad et al. (Beirut: Dār al-Kutub al-'Ilmiyya, 1993), 1:328-29. The reasoning resembles that seen in Genesis 2:23, in which the primal man names the newly born female creature a "woman" (Heb.ishsha) because she was taken from "man" (Heb.ish). 
elements. The accounts of the creation of woman presented by these exegetes frequently develop the previously constructed narrative further, mainly by introducing misogynous conclusions concerning the status of women. They also add dismissive attributes to the rib they portray as Eve's origin and assert that she was made to satisfy Adam's diverse desiresto provide him with entertainment, service, and sexual favors. Moreover, Muhsin al-Fayd reconciles the competing views regarding the substance of Eve's creation by pointing out that the respective essences of men and women are fundamentally different, hence probably strengthening the late Safavid tendency toward gender segregation. Details regarding Eve's creation from an interior and sinister part of Adam are used to justify the gendered duties and rights of women and men. The following sections analyze the interpretations provided by the six exegetes from this discursive stage in detail.

\subsection{Abū al-Fayḍ al-Fayḍ̂i al-Nākūrī (d. 1004/1595)}

Al-Nākūrī was an Indian polymath who made diverse contributions to politics, poetry, study of history, and exegetics. ${ }^{77}$ His Quranic commentary, called Sawātị ${ }^{\complement}$ al-ilhām fì tafsīr kalām al-malik al-'allām, comments on the relevant Quranic passage quite briefly. Al-Nākūrī states that khalaqakum means "He formed you" (șawwarakum), and min nafs wāhida means that people have a single origin, "your father Adam." Khalaqa minhā zawjahā, according to al-Nākūrī, indicates that Adam's spouse is "your mother Eve," and she was born of Adam's shoulder blade, milāt Âdam. ${ }^{78}$ Al-Nākūrī's specification of a shoulder blade as Eve's origin is a remarkable deviation from all other traditions, which claim she was fashioned from a rib, but it, too, traces Eve's substance to one of Adam's bones. The shoulder blade claim does not, to my knowledge, have a parallel in the texts of any Abrahamic religion. However, this peculiar detail is not repeated in later exegetic accounts. It is possible that it reflects the context of the author, who lived in the borderland of Islamic civilization.

\section{2. 'Abd 'Alī b. Jum'a al-'Arūsī al-Huwayzī (d. between 1080/1669 and 1105/1693)}

'Abd 'Alī al-Huwayzì was a hadith scholar and exegete who was based in Shiraz, a major Iranian city under Safavid rule. ${ }^{79} \mathrm{He}$ held the view that traditions are essential to understanding the meaning of the Quran, and he is believed to have initiated the Akhbāri method of tafsir. ${ }^{80}$ Thus, al-Huwayzī inaugurates a series of several exegetes identified as representatives of the so-called Akhbārī school of exegesis. ${ }^{81}$ His Tafsīr nür al-thaqalayn, completed by $1065 / 1655$, contains a vast variety of traditions, including several on the

77. M. al-Shīrāzī, introduction to Abū al-Fayḍ al-Nākūrī, Sawāți ${ }^{\complement}$ al-ilhām fì tafsīr kalām al-malik al-`allām, ed. M. al-Shīrāzì (Iran: n.p., 1996), 1:113-17.

78. Al-Nākūrī, Sawāți al-ilhām, 2:6.

79. For an extensive introduction to the Safavid dynasty, see A. Newman, Safavid Iran: Rebirth of a Persian Empire (London: I. B. Tauris, 2006).

80. Lawson, "Akhbārī Shi'ī Approaches to Tafsīr," 178-80.

81. R. Gleave, Scripturalist Islam: The History and Doctrines of the Akhbārī Shī ī School (Leiden: Brill, 2007), 154. 
matter of human creation as discussed in Q 4:1. It is the most meticulous of the premodern Shici commentaries analyzed in this study.

Al-Huwayzi begins his discussion with a tradition claiming that the name of Eve as well as the Arabic word for woman (imra'a) are dependent on her derivative creation, as already argued by al-Shaybānī hundreds of years earlier, ${ }^{82}$ and that women were called "women" (nisā') because there was no intimacy (uns) for Adam except for Eve. ${ }^{83}$ Like many other exegetes, al-Ḥuwayzī repeats earlier traditions from Tafsīr al-'Ayyāshī and elaborates at length on the procreation of the first couple's children, mainly providing evidence against the possibility that sibling marriage was involved. Returning to the details of human creation, al-Huwayzi adds new attributes to the rib from which Eve was made via a narration ascribed to Imam al-Ṣādiq: Eve was created from Adam's farthest left-hand rib (diil $\bar{A}$ dam al-yusrā al-aqșā). ${ }^{84}$ With the added attribute aqșā, the first woman becomes even more marginal. Notably, al-Huwayzī also uses the attribute yusrā, which is usually interpreted and translated as "left" but which also has a potential negative connotation as sinister. ${ }^{85}$ In the narration, the Imam goes on to criticize theologians who insinuate that God did not have the ability to create a spouse for Adam from anything but his ribwhich implies that Adam married a part of himself. ${ }^{86}$ Instead, the Imam describes Eve's creation thus:

When God-blessed and exalted be He-created Adam from clay, He asked the angels [to prostrate before Adam], so they prostrated before him. God cast a slumber upon him, and then He contrived (ibtada'a) a creation for him [Adam], making her in the hole between his knees (ja'alahā fi maw dị al-nuqra allatì bayna rukbatayhi). This is why the woman is subordinate to the man (taba' 1 i-1-rajul). ${ }^{87}$

The verb ja'ala in this passage can be understood to denote the creation of something from a preexisting thing, so a reader may get the impression that the first woman was extracted from the man, further strengthening the idea of male primality, even supremacy. ${ }^{88}$ Most importantly, the narration adds new details: the first woman was made in a mysterious

82. 'Abd 'Alī al-Huwayzì, Tafsīr nūr al-thaqalayn, ed. H. al-Rasūlī al-Mahallātī (Qum: Maṭba'at al-'Ilmiyya, 1980), 1:429; cf. al-Shaybānī, Nahj al-bayān, 2:108.

83. Al-Huwayzī, Nūr , 1:430; the words "women" and "intimacy" share two consonants, nūn and sīn.

84. Al-Huwayzī, Nūr, 1:430.

85. For the negative connotation, see Q 90:8-20.

86. Al-Huwayzī, Nūr, 1:430; cf. Tafsīr al-`Ayyāshī, 1:242. Elsewhere in his commentary al-Huwayzī suggests that the rib narrative is weak, as noted by Osman (Female Personalities, 17).

87. Al-Huwayzī, Nūr, 1:430-31. Cf. Bauer's translation of a similar passage from Muhsin al-Fayḍ al-Kāshānī's commentary in Gender Hierarchy in the Qur’ān, 126.

88. See A. Wadud, Qur'an and Woman: Rereading the Sacred Text from a Woman's Perspective (New York: Oxford University Press, 1999), 18-19. Osman seems to disagree on the basis of another meaning of jacala, "to change something from its previous state" (Osman, Female Personalities, 38, n. 35). However, Zohar HadromiAllouche reads a similar passage, also attributed to Imam al-Ṣādiq, in Quṭb al-Dīn al-Rāwandỉ’s (d. 573/1177) Qișas al-anbiyā' to mean that the creation of Eve was a totally new creation (Hadromi-Allouche, "Creating Eve," 38). 
place associated with the man, and this origin is closely connected to her position in society. The creation of the first woman is thus used to justify the oppression of all women. The peculiar narration goes on to describe Adam and Eve meeting one another and the purpose of her creation:

Adam said thereupon: O Lord, who is this good creation, who kept me company and whom I look at? God said: O Adam, this is my servant (amatī) Eve; would you like her to be with you so that she may entertain you (tu'nisuka), speak with you, and carry out your command (ta'tamiru li-amrika)? [Adam] said: Yes, Lord, and for that I owe You thanks and praise. God, Glorious and Almighty, said: Ask me for her hand as she is my servant, and she is also suitable for you as a spouse for [your] desire[s] (zawja li-1-shahwa). Then God set desire in him, and before that He had taught Adam the knowledge. ${ }^{89}$

The purpose of the creation of woman thus seems to be to provide entertainment and service for the man. She is the object of the man's lust, and she lacks knowledge. According to Rawand Osman, this distinction has given rise to the view that Adam is the higher soul and Eve is the lower one. This interpretation, Osman argues, is contrary to the original Quranic meaning of nafs. She further proposes that the depiction of the spouses in this narrative does not represent the Quranic meaning of zawj, which refers to an equal spouse. ${ }^{90}$

The story continues:

[Adam] said: O Lord, I ask You for her hand. And what is Your wish (rị̣āka) concerning this? [God] said: My wish is that you teach her the characteristics of my religion. [Adam] said: I owe You that if You wish that, O Lord! [God] said: I wished it and I married her to you, so she is joined to you. [Adam] said: Come to me! She said: No; you come to me! So God, Glorious and Almighty, ordered Adam to go to her and he went. Had he not done it, the women would go to ask [for men's] hand[s] for themselves. ${ }^{91}$

Eve's insistence that Adam go to her matches the conventional practice of patriarchal traditions, in which it is generally the man who goes to the woman to propose marriage. At the same time, this detail provides a rationale for the customs of its context: women are not to initiate matrimonial proposals, purely because of the events during the creation. In addition, this tradition contains the key elements of an Islamic marriage-a dower

89. Al-Huwayzī, Nūr, 1:431. Cf. Bauer, Gender Hierarchy in the Qur’ān, 126. The eleventh/seventeenthcentury Imāmī scholar al-Majlisī (d. 1111/1698) gives a similar account in his monumental collection of Imāmī traditions, most likely influencing subsequent Quranic interpretations, although with some differences: God created Eve in Adam's shape and showed her to him when he was asleep-this was the first dream on earth. When Adam woke up, Eve was sitting close to his head. When he asked who she was, God identified her as the person Adam had seen in his dream. Muhammad Bāqir al-Majlisī, Bị̂̄ār al-anwār: al-Jāmi a li-durar akhbār al-a'imma al-aṭ̂ār (Beirut: Dār Iṇyā' al-Turāth al-'Arabī, 1983), 11:115.

90. Osman, Female Personalities, 25. In addition, Inloes argues that the terminology clearly connects Eve to slavery (Women in Shi'ism, 87).

91. Al-Ḥuwayzī, Nūr, 1:431. Cf. Bauer, Gender Hierarchy in the Qur’ān, 126. 
(teaching religion) and a guardian (God). The presence of elements reflecting gender hierarchy in this tradition prompted Amina Inloes to characterize it as an instance of "Abbāsid-style slave-wife barter." ${ }^{2}$ It is indeed surprising that this tradition, attributed to one of the most frequently cited imams, is not taken into account in any of the previous commentaries.

A bit later in his commentary, al-Huwayzì quotes a prophetic tradition according to which the Messenger of God was asked whether Adam was created from Eve or Eve from Adam, and he responded:

Eve was created from Adam; had Adam been created from Eve, divorce would be in the hands of women, not of men. So, was she created from his entirety or from some [part] of him? From some [part] of him; had she been created from his entirety, women could be punished like men are. And from his exterior or his interior? From the interior; had she been created from his exterior, the women would be unveiled like the men are. Therefore, women became covered. And from his right or his left (shimālihi)? From his left; had she been created from his right, the female's part of the inheritance would be like that of the male. Therefore, it became a portion for women and two portions for men. And the testimony of two women is like that of one man. So from what was she created? He said: From the clay that was left over from his left-hand rib (min al-țina allatī fadalat min dil cihi al-aysar). ${ }^{33}$

Al-Huwayzi is the first commentator thus far to use the word shimāl for the left side. ${ }^{94}$ He also uses the word aysar, which can be translated to mean "left" as well as "more negligible"; the latter translation adds a negative nuance to the depiction of women. Significantly, this narration also seems to justify the hierarchical duties and rights of men and women, which may be considered the very basis of gender inequality. It also further diminishes the substance of Eve's creation: it is here the leftover clay from the creation of Adam's left-hand rib, not the whole of Adam. This tradition, like the next one, encapsulates the Imāmī views on the creation of woman by encompassing the key elements of the clay, the rib, and the secondary creation of the woman. ${ }^{95}$ In fact, it has been suggested that being created from such leftovers can be read as worse than being created from a rib. ${ }^{96}$

According to a tradition attributed to Imam 'Alì, men were created from the earth, so they are interested in the earth, whereas women were created from men, so their interest is in men. 'Alī thus declares: "Imprison your women, O community of men!" (fa-ihbisisu nisā’akum yā ma (āshir al-rijāl). Some earlier Imāmī commentaries already conveyed a similar command, but al-Huwayzī's is the first Imāmī commentary to use the same verb,

92. Inloes, Women in Shi'ism, 69; see also her summary of the tradition's misogynous elements at 74-75. For Bauer's discussion on a similar passage, see "Room for Interpretation," 43; Gender Hierarchy in the Qur’ān, 127.

93. Al-Huwayzī, Nūr, 1:434.

94. At least one Sunni commentator uses the same term; see Abū Ḥayyān al-Andalusī, Tafsīr al-baḥr al-muhịt, ed. A. 'Abd al-Mawjūd et al. (Beirut: Dār al-Kutub al-'Ilmiyya, 2001), 3:163.

95. Al-Huwayzī, Nūr, 1:434.

96. Inloes, Women in Shi'ism, 128. 
habasa, that appears in several Sunni commentaries ${ }^{97}$ The overlap may indicate the fluidity of exegetic networks, which may have been less sect-selective than we tend to assume. Invoking an alternative version of an earlier tradition calling for the seclusion of women may also reflect the observed trend toward the imposition of more restrictions on women during the second half of the Safavid era, possibly because of increasing urbanization and clericalization..$^{98}$

\subsection{Muhammad b. Murtaḍā Muḥsin Faỵ̣ al-Kāshānī (d. 1091/1680)}

Mullā Muḥsin al-Fayḍ al-Kāshānī is a well-known religious scholar of Safavid Iran. He was also the son-in-law of the influential Imāmī philosopher Mullā Ṣadrā (d. 1050/1635), who may have influenced Mullā Muhsin's conceptions of gender. He studied various Islamic disciplines and later produced a wide variety of religious literature, including a multivolume Quranic commentary called Kitāb al-Șāfî fì tafsīr al-Qur'ān, which he completed in 1075/1664. ${ }^{99}$ His interpretation of the relevant sentence in Q 4:1 starts with the assertion that min nafs wāhida means Adam, and khalaqa minhā zawjahā means Eve. Muhsin then invokes a long list of previous traditions on the matter, including contradictory traditions mentioning either a rib or leftover clay as the substance of female creation. ${ }^{100}$ Many of these accounts echo the Hebrew Bible, which seems to have influenced the Islamic-including Shici-interpretive tradition in relation to the story of human creation. ${ }^{101}$ Muhsin al-Fayd also reproduces a long narration very similar to that previously provided by al-Huwayzi in which God creates Eve in the hole between Adam's hips (bayna warkayhi) to serve and entertain Adam. ${ }^{102}$ Although the location of the hole in Muhsin al-Fayḍ's account differs

97. Al-Huwayzī, Nūr, 1:434; cf. Ibn Abī Hātim, Tafsīr, 3:852; Ibn Kathīr, Tafsīr, 3:333; al-Suyūțī, al-Durr al-manthür, 4:209. This tradition, with the same verb, can already be found in the fourth/tenth-century compilation al-Kāfí, but somewhat surprisingly it does not appear in Imāmī exegetic material before al-Huwayzī.

98. R. Matthee, "From the Battlefield to the Harem: Did Women's Seclusion Increase from Early to Late Safavid Times?," in New Perspectives on Safavid Iran: Empire and Society, ed. C. Mitchell, 99-120 (London: Routledge, 2010), 110. However, Matthee notes that the conventional conception of women's diminishing public role during this period should be revisited and the complexity of the issue acknowledged.

99. W. C. Chittick, "Muḥsin-i Fayḍ-i Kāshānī," in Encyclopaedia of Islam, 2nd ed., 7:475-76.

100. Muhammad b. Murtaḍā al-Fayḍ al-Kāshānī, Kitāb al-Ṣāfi fi tafsīr al-Qur’ān, ed. M. al-Husaynī al-Amīnī (Tehran: Dār al-Kutub al-Islāmiyya, 1998), 2:175-76.

101. In fact, the biblical garden narrative is even more clearly present in a Persian commentary on Q 4:1, in which Mullā Fatḥ Allāh Kāshānī (d. 988/1580) explains that "When God Most High created Adam and brought him to Paradise, he did not have, in the midst of emptiness, anyone of the same species with whom to socialize, although there were houris and servant boys of clean disposition in Paradise. He asked God Most High for someone of the same species. God put him into a deep sleep and commanded Gabriel to take out a bone from his left side. And He created Eve out of this bone." Fath Allāh Kāshānī, Manhaj al-șādiqīn fi ilzām al-mukhālifin (Tehran: Čāpkhāna-yi Muhammad Ḥasan 'Ilmī, 1917), 2:416; translation by Ilkka Lindstedt. Adam’s loneliness and his apparent need for a woman-as well as the process of her making-are here depicted in a way that resembles the biblical creation narrative (Genesis 2:18-22). However, here Gabriel acts as a mediator of the "bone," which Kāshānī identifies as a rib earlier in his explication, and in this account there were other humanlike creatures with Adam before the creation of woman.

102. Muḥsin al-Fayḍ, al-Ṣāfî, 2:176; cf. al-Ḥuwayzī, Nūr, 1:430-31. 
slightly from that in al-Huwayzì's, both convey the idea that the woman is inferior to the man because of her derivative creation.

However, Mullā Muhsin also provides his own opinions and editorial comments on the traditions he cites. He quotes the abovementioned tradition according to which Eve was created from Adam's insides on the left side and from the clay that was left over from the creation of his left-hand rib. Interestingly, he concludes that this explains why men have one rib fewer than women do. ${ }^{103}$ As is nowadays known, this claim is in fact false, but its inclusion in the commentary demonstrates Bauer's point that exegeses are firmly dependent on the knowledge of their time. ${ }^{104}$ Furthermore, in order to harmonize the somewhat contradictory views regarding the origin of the first woman and the substance of her creation, Muhsin al-Fayd finally-and uniquely-gives his own opinion on the matter:

I say: What has been reported to us-that she was created from his left-hand rib-is an indication that the bodily, animalistic tendency (al-jiha al-jusmāniyya al-ḥayawāniyya) is stronger in women than it is in men, and the spiritual, angelic tendency (al-jiha al-rūhāniyya al-malakiyya) is contrary to it. This is because "the right" alludes to the spiritual, heavenly world, and "the left" alludes to the bodily realm. The "clay" is an expression of the corporeal substance, and "the right" is an expression of the spiritual substance, and there is no corporeal world (mulk) without a spiritual world (malaküt). This is the meaning of his [the imam's] saying "Both of His hands are right [hands]." So the left-hand rib missing from Adam is a metaphor for some of the desires that grow from bodily dominance, which is [typically] from the physical world (khalq), and they are the leftover clay extracted from his [Adam's] interior, which became the substance of Eve's creation. It is pointed out in the tradition that in men the side of spirituality and command is stronger than the side of corporeality and physicality, unlike in women. So what is apparent is a sign of what is hidden, and this is the secret of the deficiency in male bodies in relation to women. God's secrets are not achieved except by the people of the secret [i.e., the enlightened], so disbelief in the words of the infallible [imams]peace be upon them-is due to the understanding of the Sunnis (al-'āmma), which is based on the apparent [meaning] and disregards the origin of the tradition. ${ }^{105}$

Muhsin al-Fayd may be acknowledged for his effort to reconcile the somewhat contradictory claims regarding the substance from which the first woman was created. ${ }^{106}$ However, his

103. Muhsin al-Fayḍ, al-Ṣāfi, 2:177-78. There is also another tradition in the Imāmī hadith corpus that suggests that men have fewer ribs than women do; see Inloes, Women in Shi'ism, 129-30.

104. Bauer, "Room for Interpretation," 52; eadem, Gender Hierarchy in the Qur'ān, 127.

105. Muhsin al-Fayḍ, al-Ṣāfi, 2:178. Cf. Bauer's translation of the same passage in Gender Hierarchy in the Qur'ān, 128-29. Similarly, in Fāțimid Ismā'īlī interpretations, the creation of Adam and Eve is understood metaphorically, as described by Bauer, "Spiritual Hierarchy."

106. Another kind of harmonizing effort is evident in al-Majlisī's collection of traditions (Bihāa al-anwār, 11:116), which suggests that Imāmī scholars endorsed the idea that woman was created from a rib only as an expression of taqiyya, precautionary dissimulation permitted to evade persecution. In fact, al-Majlisī identifies the rib narrative as a Sunni tradition, though he notes that it is also present in "our tradition" (Biḥār al-anwār, 11:222). Al-Majlisī may have played a direct role in the trend toward greater gender segregation in the late 
elucidation serves to confirm the presumptions of the time: men are strong, whereas women are weak; men are spiritual, whereas women are profane, even mundane. Other potential views on the matter are presented in sectarian terms. Besides emphasizing sectarian distinctions, Mullā Muhsin's explanation of Q 4:1 thus also provides evidence in support of gender segregation-women are simply the other, fundamentally different from men. This perspective is very much in line with societal developments at the time, as the visibility of women in society clearly shrank. As Osman points out, it is nearly preposterous that the same tale that the imams had strongly rejected could suddenly be seen as a calculated metaphor, ${ }^{107}$ but apparently it served well the interests of the author-or those of the elite around him.

\subsection{Hāshim b. Sulaymān al-Baḥrānī (d.1107/1696)}

Hāshim al-Baḥrānī is known as an Akhbārī-affiliated commentator. In his al-Burhān fi tafsīr al-Qur'ān, completed in 1094/1683 and closely based on traditions, he repeats many of the narrations already provided in 'Abd 'Alī al-Huwayzī's Nūr al-thaqalayn and Muhsin al-Fayḍ's al-Șāfi, though he generally cites them without further discussion. ${ }^{108}$ This is also the approach he adopts in connection with the passage of interest in this study. For example, al-Bahrānī presents traditions according to which the name of Eve and the word for "woman" are derivative of man, in one way or another. ${ }^{109} \mathrm{He}$ also reproduces the already mentioned traditions about women's intrinsic lust for men, which justifies women's seclusion, and the contriving of a female creature for Adam in the hole between his hips, which established the woman as subordinate to the man. ${ }^{110}$ Nevertheless, as with all exegetes, the personal selection of the traditions to include constitutes a form of interpretation and an editorial statement.

\subsection{Nūr al-Dīn Muhammad b. Murtaḍā al-Kāshānī (d. 1115/1703)}

Nūr al-Dīn Muhammad al-Kāshānī was a pupil of Muḥsin al-Fayḍ. ${ }^{111}$ However, his Akhbārī-style Tafsīr al-mu īn discusses the passage in question only briefly. Like many other commentaries, it affirms that khalaqakum min nafs wāhida means Adam, and khalaqa minhā zawjahā means Eve. However, unlike some others, Nūr al-Dīn's commentary does not present any alternative interpretations of the substance of Eve's creation: he states that Eve was created from the leftover clay of Adam and that she is consequently dependent on him. ${ }^{112}$

\footnotetext{
Safavid period, as noted by Matthee, "From the Battlefield to the Harem," 98, citing earlier literature.

107. Osman, Female Personalities, 27.

108. Gleave, Scripturalist Islam, 226; Lawson, “Akhbārī Shi'ī Approaches to Tafsīr," 187-88.

109. Hāshim b. Sulaymān al-Bahrānī, al-Burhān fị tafsīr al-Qur’ān (Beirut: Mu’assasat al-A'lamī, 2006), 3:153.

110. Al-Baḥrānī, al-Burhān, 3:154-56.

111. Gleave, Scripturalist Islam, 170.

112. Nūr al-Dīn Muhammad al-Kāshānī, Tafsīr al-mu īn, ed. Ḥ. Dargāhī (Qum: Maktabat Āyat Allāh al-'Uẓmā al-Mar'ashī, n.d.), 1:204.
} 


\subsection{Muḥammad b. Muhammad Rị̣̂ā al-Qummī al-Mashhadī (d. 1125/1713)}

Mīrzā Muḥammad al-Mashhadī's Quranic commentary Kanz al-daqā’iq wa-baḥr al-gharā'ib was possibly completed in the middle of the eleventh/seventeenth century. He was a student of Mullā Muhsin al-Fayḍ, which explains why most of the traditions he includes come from the latter's al-Șāfi. However, not much is known about Mīrzā Muhammad himself. ${ }^{113}$ His discussion of $\mathrm{Q}$ 4:1 begins by identifying the subject of khalaqakum min nafs wāhida as Adam. He then gives two possible explanations for wa-khalaqa minhā zawjahā: either God created humanity from a single person (min shakhș wāhid) and Eve from the leftover clay of the soul, or she was created from the single soul from which God created its mate. Both the terminology and the idea seem similar to those of al-Ṭabrisì half a millennium earlier. ${ }^{114}$ However, the expression "from a single person" is unique. It may reflect the author's understanding of the first person, Adam, as being the soul and simultaneously serving as the origin of human creation. Mīrzā Muhammad further cites several other traditions quoted by the Imāmī exegetes discussed above. ${ }^{115}$ In fact, certain narrations are repeated by almost all the exegetes of this discursive stage, and they seem to constitute the main innovation in their commentaries. Mīrzā Muhammad is not an exception. He mainly lists earlier narrations on the topic without providing his own interpretation.

The third discursive stage is characterized by numerous elaborations on the lore concerning Eve's creation, emphasizing the otherness of women and the need for their seclusion, in particular. This tendency is likely to represent societal developments in the Safavid period, which saw women's visibility diminish and restrictions on their freedom expand. In addition to invoking the gendered characteristics and duties of women, the commentaries frequently bring up sectarian elements, thus reflecting the political environment of their authors.

\section{Conclusion}

This study has examined the evolution of the Twelver Shici interpretive tradition, which largely relies on the lore ascribed to the infallible imams. Its focus was the Quranic verse almost invariably understood as describing the creation of the primordial couple, Adam and Eve. I analyzed the diachronic development of the Imāmī exegetic discourse within the theoretical framework of feminist discourse analysis, which is aimed at uncovering power structures, especially gender hierarchies. My gender-sensitive analysis highlighted several misogynous elements and identified the patriarchal ethos apparent at every stage of the interpretive trajectory, in the course of which the creation of woman was first conceptualized as occurring after and from the man, later also for the man. Importantly, I showed that the construction of gender ideology in the interpretive tradition can be explicated through a genealogical methodology that traces the beginning, developments,

113. Bauer, "Room for Interpretation," 209.

114. Muhammad b. Muḥammad Rị̣ā al-Qummī al-Mashhadī, Tafsīr kanz al-daqāì wa-baḥr al-gharā’ib, ed. Ḥ. Dargāhī (Tehran: Shams al-Ḍuhāā, 1968), 3:315; cf. al-Ṭabrisī, Jawāmi` al-jāmi``, 1:368.

115. Mìrzā Muhammad, Kanz al-daqāìq, 3:316-18. 
and shifts of the discourse, hence giving us a more systematic perspective on Imāmī exegesis. Interestingly, the discursive stages identified in this study are not directly dependent on the religious tradition, sect, or Quranic verse, ${ }^{116}$ although the features of Imāmi exegeses within each stage seem to reflect the political and sectarian circumstances of the exegetes as well as their doctrinal beliefs.

The first discursive stage in the development of Imāmī exegetic discourse on the creation of woman took shape in the formative period of Shici tafsir during the third-fourth/ninthtenth centuries and reflected the formation of a distinct Imāmi identity in this period. This stage was defined by the establishment of the corpus of traditions on the matter. Eve's creation was defined in dismissive terms: she was born of either Adam's smallest and lowest rib or leftover clay from his creation. Because of her derivative creation, these traditions argued, the woman is so promiscuous that she has to be kept indoors. The second discursive stage coincided with the classical period of Imāmi exegesis between the fifth/ eleventh and seventh/thirteenth centuries-that is, during and shortly after the Shici golden age, when scholars were free to express Imāmì doctrines. In this stage, the standard views on Eve were consolidated, and the prominence of the claimed substance of her creation, Adam's rib, was further minimized. In addition, the already insignificant rib was described as crooked, implying the obliquity of women themselves. This dismissive view of Eve's creation was expanded on during the third discursive stage of Imāmi exegetic discourse in the tenth/sixteenth to eleventh/seventeenth centuries under the flourishing Safavid dynasty. This broader political context may explain the fact that the exegetes of this stage often highlight sectarian elements in their interpretations. Speculation over the pejorative attributes of the rib or over Eve's possible alternative (though still derivative) origins was widespread, and the woman was depicted as weak, inclined toward the material and the corporal, and made for the man, to serve him in various ways. The circumstances of her creation were used to justify gender hierarchy, even the seclusion of women, a practice that seems to have grown in popularity in late Safavid society.

The content of Imāmī exegesis regarding the creation of woman diverges from the Sunni interpretive tradition to some extent, ${ }^{117}$ although the commentaries offer evidence of the wide circulation of scholarly writings: Twelver Shici commentators frequently refer to Sunni traditions and conceptions or at least to a putative transsectarian consensus. Many of the Imāmī exegetes claim that most scholars-by which they probably mean also Sunni onesopt for Adam's rib as the substance from which the first woman was created; most of these Imāmì exegetes even seem to consider this primarily Sunni tradition correct. The rib theory may have been so dominant in the intellectual context of these scholars that it simply could not be ignored, and it is likely that contextual phenomena sometimes forced the exegetes to take Sunni views into account more centrally than they might have otherwise done. Almost all of the commentators discussed here also bring up an alternative tradition attributed to the fifth imam, Abū Ja'far al-Bāqir, according to which the material of Eve's

116. Cf. von Schöneman, "Evolution of Rabbinic Discourse”; eadem, “"Confine Your Women!”; and AbouBakr, "Interpretive Legacy of Qiwamah," respectively.

117. Cf. von Schöneman, “"Confine Your Women!”” 
creation was not a rib but clay left over from Adam's creation, an explanation that seems to be particular to the Shici interpretive tradition. From a gender-sensitive perspective, however, the difference between the two theories is limited: in both, the woman is a by-product of the man. Furthermore, a narration from the sixth imam, Abū 'Abd Allāh al-Ṣādiq, reduces the material even further, specifying that Eve was made of a leftover portion from the creation of Adam's rib. Thus, regardless of the details, the implications of the various accounts for the status of women are remarkably similar: women are derivative, dependent, subordinate, and comprehensively problematic. Moreover, the diachronic development of this discourse points to a corresponding genealogical trajectory: the core of the traditions on the matter of woman's creation was defined, then sustained and strengthened, and finally embroidered with novel, imaginative elements. Whether this process mainly reflects contextual factors or is characteristic of religious interpretive traditions in general remains to be determined. 


\section{Bibliography}

Abou-Bakr, O. "The Interpretive Legacy of Qiwamah as Exegetical Construct." In Men in Charge? Rethinking Authority in Muslim Legal Tradition, edited by M. Al-Sharmani et al., 44-64. Oxford: OneWorld, 2015.

Abugideiri, H. "Allegorical Gender: The Figure of Eve Revisited." American Journal of Islamic Social Sciences 13 (1996): 518-36.

Abū Ḥayyān al-Andalusī. Tafsīr al-baḥr al-muhịț. Edited by A. 'Abd al-Mawjūd et al. Beirut: Dār al-Kutub al-'Ilmiyya, 2001.

Abū al-Layth al-Samarqandī. Baḥr al-'ulüm. Edited by 'A. M. Mu'awwad et al. Beirut: Dār al-Kutub al-`Ilmiyya, 1993.

Amir-Moezzi, M. The Divine Guide in Early Shi'ism: The Sources of Esotericism in Islam. Albany: State University of New York Press, 1994.

- - . "Furāt b. Furāt al-Kūfi." In Encyclopaedia of Islam, 3rd ed., edited by K. Fleet et al. Leiden: Brill Online.

-_-. “Al-Ṭ̂̄īì, Muḥammad b. al-Hasan.” In Encyclopaedia of Islam, 2nd ed., edited by P. J. Bearman et al., 10:745-46. Leiden: Brill, 1954-2009.

Anaïs, S. "Genealogy and Critical Discourse Analysis in Conversation: Texts, Discourse, Critique." Critical Discourse Studies 10 (2013): 123-35.

Arpaguş, H. “The Position of Woman in the Creation: A Qur'anic Perspective.” In Muslima Theology: The Voices of Muslim Women Theologians, edited by E. Aslan et al., 115-32. Frankfurt am Main: Peter Lang, 2013.

Ayoub, M. "The Speaking Qur'ān and the Silent Qur'ān: A Study of the Principles and Development of Imāmī Tafsīr." In Approaches to the History of the Interpretation of the Qur'an, edited by A. Rippin, 177-98. Piscataway, NJ: Gorgias Press, 2013.

al-`Ayyāshī, Muhammad b. Mas'c̄ud. Tafsīr al-`Ayyāshī. Edited by H. Rasūlī Maḥallātī. Beirut: Mu'assasat al-A'lamī, 1991.

al-Baḥrānī, Hāshim b. Sulaymān. Al-Burhān fì tafsīr al-Qur’ān. Beirut: Mu’assasat al-A`lamī, 2006.

Baker, C. Medieval Islamic Sectarianism. Amsterdam: Arc Humanities Press, 2019.

Bar-Asher, M. Scripture and Exegesis in Early Imami-Shiism. Boston: Brill, 1999.

Bauer, K. Gender Hierarchy in the Qur'ān: Medieval Interpretations, Modern Responses. Cambridge: Cambridge University Press, 2015. 
-_-. "Room for Interpretation: Qur'anic Exegesis and Gender." PhD dissertation, Princeton University, 2008.

-_-. "Spiritual Hierarchy and Gender Hierarchy in Fāțimid Ismā̄î̀ī Interpretations of the Qur'an.” Journal of Qur'anic Studies 14 (2012): 29-46.

Bazargani, D. "A Comparative Study on Two Translations of the Holy Qur'an: A Critical Discourse Analysis Approach.” Translation Studies 12 (2015): 49-64.

Bronson, C. "Eve in the Formative Period of Islamic Exegesis: Intertextual Boundaries and Hermeneutic Demarcation." In Tafsīr and Islamic Intellectual History: Exploring the Boundaries of a Genre, edited by A. Görke and J. Pink, 27-61. Oxford: Oxford University Press, 2014.

--_. "Imagining the Primal Woman: Islamic Selves of Eve." PhD dissertation, University of Chicago, 2012.

Burr, V. Social Constructionism. 3rd ed. London: Routledge, 2015.

Butler, J. Bodies That Matter: On the Discursive Limits of "Sex." Abingdon: Routledge, 1993.

Chittick, W. C. "Muḥsin-i Fayḍ-i Kāshānī." In Encyclopaedia of Islam, 2nd ed., edited by P. J. Bearman et al., 7:475-76. Leiden: Brill, 1954-2009.

Dargāhī, Ḥ. Introduction to Muḥammad b. al-Ḥasan al-Shaybānī, Nahj al-bayān 'an kashf ma‘ānī al-Qur’ān, edited by Ḥ. Dargāhī. Qum: Nashr al-Hādī, 1958-99.

Dhala, M. "Five Foundational Women in the Qur'an: Reading their Stories from a Shia Female Perspective." Berkeley Journal of Religion and Theology 5 (2019): 3-26.

Fairclough, N. Analysing Discourse: Textual Analysis for Social Research. London: Taylor and Francis, 2004.

-_- Critical Discourse Analysis: The Critical Study of Language. London: Longman, 1995.

-_- Discourse and Social Change. Cambridge: Polity Press, 1992.

Fudge, B. Qur'anic Hermeneutics: Al-Tabrisi and the Craft of Commentary. London: Routledge, 2012.

Geissinger, A. Gender and Muslim Construction of Exegetical Authority: A Rereading of the Classical Genre of Qur'an Commentary. Leiden: Brill, 2015.

Gleave, R. "Between Hadīth and Fiqh: The 'Canonical' Imāmì Collections of Akhbār." Islamic Law and Society 8 (2001): 350-82.

Gleave, R. Scripturalist Islam: The History and Doctrines of the Akhbārī Shīì School. Leiden: Brill, 2007.

Gutting, G. Foucault: A Very Short Introduction. Oxford: Oxford University Press, 2005. 
Hadromi-Allouche, Z. "Creating Eve: Feminine Fertility in Medieval Islamic Narratives of Eve and Adam." In In the Arms of Biblical Women, edited by J. Greene and M. Caspi, 27-64. Piscataway, NJ: Gorgias Press, 2013.

Hassan, R. "The Issue of Woman-Man Equality in the Islamic Tradition." In Women's and Men's Liberation, edited by L. Grob et al., 65-82. New York: Greenwood Press, 1991. Available online at http://riffathassan.info/wp-content/uploads/2014/03/The_Issue_ of_Woman-Man_Equality_in_the_Islamic_Tradition1.pdf.

-_-. "Made from Adam's Rib? The Woman's Creation Question." Al-Mushir 27 (1985):124-55.

Hasyim, S. Understanding Women in Islam: An Indonesian Perspective. Jakarta: Solstice, 2006.

Hjelm, T. "Discourse Analysis." In The Routledge Handbook of Research Methods in the Study of Religion, edited by S. Engler and M. Stausberg, 134-50. Abingdon: Routledge, 2011.

al-Ḥuwayzī, 'Abd 'Alī. Tafsīr nūr al-thaqalayn. Edited by H. al-Rasūlī al-Mahallātī. Qum: Mațba'at al-'Ilmiyya, 1980.

Ibn Abī Ḥātim, 'Abd al-Raḥmān al-Rāzī. Tafsīr al-Qur’ān al-'azịm. Edited by A. M. al-Ṭayyib. Mecca: Maktabat Nizār Mușțafā al-Bāz, 1999.

Ibn Kathīr, 'Imād al-Dīn Ismā'îl. Tafsīr al-Qur’ān al-'aẓim. Edited by M. S. Muhammad et al. Cairo: Mu'assasat Qurțuba, 2000.

Inloes, A. Women in Shi'ism: Ancient Stories, Modern Ideologies. Piscataway, NJ: Gorgias Press, 2020.

Jawad, F., and N. Othman. "A Critical Discourse Analysis of Risalat al-Huquq of Imam Ali al-Sajjad." Majallat al-`ulūm al-insāniyya 24 (2017): 50-69.

Jeenah, N. "Towards an Islamic Feminist Hermeneutic." Journal for Islamic Studies 21 (2008): 36-70.

Kāshānī, Fatḥ Allāh.Manhajal-ṣādiqīn fị ilzām al-mukhālifinn. Tehran: Čāpkhāna-yi Muḥammad Hasan 'Ilmī, 1917.

al-Kāshānī, Muḥammad b. Murtaḍā al-Fayḍ. Kitāb al-Șāfi fị tafsīr al-Qur’ān. Edited by M. al-Ḥusaynī al-Amīnī. Tehran: Dār al-Kutub al-Islāmiyya, 1998.

al-Kāshānī, Nūr al-Dīn Muhammad. Tafsīr al-muīin. Edited by Ḥ. Dargāhī. Qum: Maktabat Āyat Allāh al-'Użmā al-Mar'ashī, n.d.

Kister, M. “Adam: A Study of Some Legends in 'Tafsir' and 'Hadit' Literature.” Israel Oriental Studies 13 (1993): 113-74.

. "Legends in Tafsīr and Hadith Literature: The Creation of Ādam and Related Stories." In Approaches to the History of the Interpretation of the Qur'ān, edited by A. Rippin, 82-114. Piscataway, NJ: Gorgias Press, 2013. 
Kohlberg, E. “Al-Ṭabrisī (Ṭabarsī), Amīn al-Dīn.” Encyclopaedia of Islam, 2nd ed., edited by P. J. Bearman et al., 10:40-41. Leiden: Brill, 1954-2009.

Kueny, K. “Reproducing Power: Qur'ānic Anthropogonies in Comparison." In The Lineaments of Islam:Studies in Honor of Fred McGraw Donner, edited by P. M. Cobb, 235-60. Leiden: Brill, 2012.

al-Kūfí, Furāt. Tafsīr Furāt al-Kūfí. Edited by M. al-Kāẓim. Beirut: Mu’assasat al-Tārīkh al-`Arabī, 2011.

Kulaynī, Muḥammad b. Yađqūb. Al-Kāfi. Tehran: Dār al-Kutub al-Islāmiyya, 1947.

Lawson, T. “Akhbārī Shi'ī Approaches to Tafsīr." In Approaches to the Qur'ān, edited by G. R. Hawting and A. Shareef, 173-210. London: Routledge, 1993.

Lazar, M. "Feminist Critical Discourse Analysis: Articulating a Feminist Discourse Praxis 1." Critical Discourse Studies 4 (2007): 141-64.

al-Majlisī, Muḥammad Bāqir. Bịhār al-anwār: al-Jāmi`a li-durar akhbār al-a'imma al-aṭhār. Beirut: Dār Iṇyā’ al-Turāth al-`Arabī, 1983.

al-Mashhadī, Muḥammad b. Muḥammad Rị̣ā al-Qummī. Tafsīr kanz al-daqāì wa-baḥr al-gharāỉb. Edited by Ḥ. Dargāhī. Tehran: Shams al-Ḍuhā, 1968.

Matthee, R. "From the Battlefield to the Harem: Did Women's Seclusion Increase from Early to Late Safavid Times?" In New Perspectives on Safavid Iran:Empire and Society, edited by C. P. Mitchell, 99-120. London: Routledge, 2010.

McAuliffe, J. "Quranic Hermeneutics: The Views of al-Ṭabarī and Ibn Kathīr.” In Approaches to the History of the Interpretation of the Qur'an, edited by A. Rippin, 46-62. Piscataway, NJ: Gorgias Press, 2013.

Morgan, S. "Feminist Approaches." In Approaches to the Study of Religion, edited by P. Connolly, 42-72. London: Continuum, 1999.

Mulder, S. The Shrines of the 'Alids in Medieval Syria. Edinburgh: Edinburgh University Press, 2014.

al-Nākūrī, Abū al-Fayḍ al-Fayḍī. Sawātị cal-ilhām fì tafsīr kalām al-malik al-`allām. Edited by M. al-Shīrāzī. Iran: n.p., 1996.

Newman, A. Safavid Iran: Rebirth of a Persian Empire. London: I. B. Tauris, 2006.

Nordin, M. “IIm al-Tafsir and Critical Discourse Analysis: A Methodological Comparison.” Journal of Language Studies 15 (2015): 129-42.

Osman, R. Female Personalities in the Qur'an and Sunna: Examining the Major Sources of Imami Shi'i Islam. New York: Routledge, 2015. 
Pregill, M. "Exegesis." In Routledge Handbook on Early Islam, edited by H. Berg, 98-125. Abingdon: Routledge, 2018.

al-Qummī, 'Alī b. Ibrāhīm. Tafsīr al-Qummī. Edited by Ț. al-Mūsawī al-Jazā'rī. Najaf: Mațba'at al-Najaf, 1966.

al-Qummī, Muḥammad b. 'Alī b. al-Ḥusayn b. Bābāwayh. Man lā yaḥưruhu al-faqīh. Qum: Jamā'at al-Mudarrisīn fì al-Ḥawza al-'Ilmiyya, 1885.

The Qur'ān with a Phrase-by-Phrase English Translation by 'Ali Qulī Qarā̄̄ì. London: Islamic College for Advanced Studies Press, 2004.

al-Qurțubī, Muḥammad b. Aḥmad. Al-Jāmic li-aḥkām al-Qur’ān. Beirut: al-Risāla, 2000.

al-Rāzī, Fakhr al-Dīn. Al-Tafsīr al-kabīr wa-mafātīh al-ghayb. Beirut: Dār al-Fikr, 1981.

Rizvi, S. "Twelver Shī̄ī Exegesis." In The Oxford Handbook of Qur'anic Studies, edited by M. A. Abdel Haleem and M. A. A. Shah, 708-20. Oxford: Oxford University Press, 2020.

Rizwan, S. "Religion, Ideology and Discourse: A Critical Discourse Analysis of Majlis-e-Hussain." Journal of Islamic and Middle Eastern Multidisciplinary Studies 1 (2011): 1-35.

Ruffle, K. "An Even Better Creation: The Role of Adam and Eve in Shici Narratives about Fatimah al-Zahra." Journal of the American Academy of Religion 81 (2013): 791-819.

Saar, M. “Genealogy and Subjectivity." European Journal of Philosophy 10 (2002): 231-45.

Saleh, W. The Formation of the Classical Tafsīr Tradition: The Qurān Commentary of al-Tha'labì. Boston: Brill, 2004.

von Schöneman, K. “'Confine Your Women!': Diachronic Development of Islamic Interpretive Discourse on the Creation of Woman." Hawwa (published online ahead of print, October 2020, https://doi.org/10.1163/15692086-BJA10010): 1-45.

--C. "Evolution of Rabbinic Discourse on the Creation of Woman in Late Antiquity." MA thesis, University of Helsinki, 2019. Available online at https://helda.helsinki.fi/ handle/10138/306271.

Shaikh, S. "Knowledge, Women and Gender in the Hadith: A Feminist Interpretation." Islam and Christian-Muslim Relations 15 (2004): 99-108.

al-Shaybānī, Muḥammad b. al-Ḥasan. Nahj al-bayān 'an kashf ma'ānī al-Qur’ān. Edited by Ḥ. Dargāhī. Qum: Nashr al-Hādī, 1958-99.

al-Shīrāzī, M. Introduction to Abū al-Fayḍ al-Nākūrī, Sawāțí al-ilhām fì tafsīr kalām al-malik al-'allām, edited by M. al-Shīrāzī. Iran: n.p., 1996. 
Sideeg, A. "Traces of Ideology in Translating the Qurān into English: A Critical Discourse Analysis of Six Cases across Twenty Versions." International Journal of Applied Linguistics and English Literature 4 (2015): 214-26.

Sinai, N. “The Qur'anic Commentary of Muqātil b. Sulaymān and the Evolution of Early Tafsīr Literature." In Tafsir and Islamic Intellectual History: Exploring the Boundaries of a Genre, edited by A. Görke and J. Pink, 113-43. Oxford: Oxford University Press, 2014.

Smith, J., and Y. Haddad. "Eve: Islamic Image of Woman." Women's Studies International Forum 5 (1992): 135-44.

Steigerwald, D. “Twelver Shī'ī Ta'wīl.” In The Blackwell Companion to the Qur’ān, edited by A. Rippin, 373-85. Hoboken, NJ: Wiley, 2006.

Stowasser, B. Women in the Quran:Traditions and Interpretation. New York: Oxford University Press, 1996.

Sunderland, J. Gendered Discourses. Basingstoke: Palgrave Macmillan, 2004.

al-Suyūṭī, Jalāl al-Dīn. Al-Durr al-manthūr fì tafsīr al-ma’thūr. Edited by 'A. M. al-Turkī. Cairo: Markaz al-Hajr, 2003.

al-Ṭabarī, Abū Ja'far Muḥammad. Jāmi` al-bayān 'an ta’wīl āy al-Qur’ān. Cairo: Dār Hijr, 2001.

al-Ṭabrisī, Faụl b. al-Ḥasan. Jawāmi` al-jāmi` fị tafsīr al-Qur’ān al-majīd. Qum: Mu’assasat al-Nashr al-Islāmì, 2003.

-—-. Majma` al-bayān fì tafsīir al-Qur’ān. Beirut: Dār al-Murtaḍā, 2006.

Tottoli, R. “The Corpora of Isrā̄iliyyāt.” In The Oxford Handbook of Qur'anic Studies, edited by M. A. Abdel Haleem and M. A. A. Shah, 682-92. Oxford: Oxford University Press, 2020.

al-Ṭūsī, Abū Ja'far Muḥammad. Al-Tibyān fị tafsīr al-Qur’ān. Edited by A. Sh. al-Amīn and Ax. Ḥ. Qașīr. Najaf: Maktabat al-Amin, 1989.

Wadud, A. Qur'an and Woman: Rereading the Sacred Text from a Woman's Perspective. New York: Oxford University Press, 1999.

al-Wāḥidī, Abū al-Ḥasan `Alī b. Aḥmad. Tafsīr al-basịt. Riyadh: Wizārat al-Ta'līm al-'Ālī, 2010.

Warhol, T. "Gender Constructions and Biblical Exegesis: Lessons from a Divinity School Seminar." In Language and Religious Identity: Women in Discourse, edited by A. Jule, 50-72. Basingstoke: Palgrave Macmillan, 2007.

Wodak, R. Gender and Discourse. London: Sage, 1997.

-- - "What CDA Is About: A Summary of Its History, Important Concepts and Its Developments." In Methods of Critical Discourse Analysis, edited by R. Wodak and M. Meyer, 1-13. London: Sage, 2001. 


\title{
The Life of Christopher
}

\author{
Joshua Mugler \\ Hill Museum and Manuscript Library
}

(jmugler001@hmml.org)

\begin{abstract}
Christopher, a native of Baghdad who became patriarch of Antioch in about 349/960, was assassinated by Muslim rebels in 356/967 because of his loyalty to their Muslim ruler. When the Byzantines conquered Antioch two years later, his story was told in a variety of ways by those with different and competing interests. Christopher was mentioned in Byzantine histories and in Antiochian liturgies. However, by far the most extensive and detailed version of the story comes to us in the Life of Christopher, written by Ibrāhìm b. Yühannā, a Byzantine bureaucrat and translator who grew up in Antioch and knew Christopher when he, Ibrāhìm, was a young boy. The hagiography was originally composed in Greek and translated by its author into Arabic, but only the Arabic survives. Here I provide, for the first time, both a critical edition of the two known Arabic manuscripts and a full English translation. This text is a valuable testimony to Christian life in Antioch under both the Hamdānids and the Byzantines, and to the difficulties of life along the constantly shifting frontier of medieval northern Syria.
\end{abstract}

long with the history of Yahyā b. Sa ${ }^{\mathrm{i}} \overline{\mathrm{d}}$ al-Anțākī, with which it has a close and
complex relationship, the Life of Christopher is one of our most important testimo-
nies to Christian life in Hamdānid Syria. ${ }^{1}$ The Chalcedonian patriarch Christopher (d. 356/967), whose birth name was 'İsā, was born and raised in Baghdad, the Life tells us. He then moved to Syria and entered the Hamdānid bureaucracy, where he became a favorite of the emir Sayf al-Dawla (r. 333-56/944-67). In about 349/960, he became the patriarch of Antioch, the last to serve in that position before the Byzantine conquest of the city in 358/969. The Life was written by the Byzantine official Ibrāhīm b. Yūhannā. Ibrāhīm knew Christopher when the former was a young boy, but he did not write the Life until

1. Much of the information in this introduction, along with an earlier version of this translation, can also be found in my dissertation: Joshua Mugler, “A Martyr with Too Many Causes: Christopher of Antioch (d. 967) and Local Collective Memory” (PhD diss., Georgetown University, 2019).

(c) 2021 Joshua Mugler. This is an open access article distributed under the terms of the Creative Commons Attribution-NonCommercial-NoDerivatives License, which allows users to copy and distribute the material in any medium or format in unadapted form only, for noncommercial purposes only, and only so long as attribution is given to the original authors and source. 
his old age, around the late 410s/1020s. According to the heading of the text, he originally wrote it in Greek and then translated his own text into Arabic. Nevertheless, only the Arabic survives-and that only in two or possibly three manuscripts, one of which is currently unaccounted for.

The Hamdānids were one of many provincial dynasties that came to power as the central authority of the 'Abbāsid caliphate found itself stretched thin. ${ }^{2}$ They were members of the Arab tribe of Taghlib and originated from northern Mesopotamia. Nominally subordinate to the government in Baghdad, different branches of the family ruled Mosul and Aleppo from the early fourth/tenth century to the early fifth/eleventh. It seems that they had Shī'i sympathies, but they were not aggressively sectarian, and their allegiances sometimes shifted with the tides of political opportunism. ${ }^{3}$

Most of Christopher's adult life took place under the rule of the first Hamdānid emir of Aleppo, Sayf al-Dawla. Sayf al-Dawla made himself famous by patronizing some of the most prominent writers of the time, most notably the poets al-Mutanabbi (d. 354/965) and Abū Firās al-Ḥamdānī (320-57/932-68), a cousin of the emir. ${ }^{4}$ Other scholars criticized Sayf al-Dawla's harsh policies, but in the Life of Christopher we can see the protagonist receiving some of the same generous patronage that prompted so many celebrated poems. ${ }^{5}$

Unfortunately for Sayf al-Dawla, his rise to power in northern Syria coincided with a great expansion in Byzantine power, and during the reigns of Sayf al-Dawla and his descendants, the Byzantine Empire began to regain territory in this region for the first time since the first-/seventh-century Muslim conquests. Most of the Life's action takes place within this context, as Byzantine advances led to panic and rebellion in cities such as Antioch that grew ever nearer to the border. A major rebellion broke out in Antioch in 354/965, and this forms the pivot point of Christopher's patriarchate in the Life. ${ }^{6}$ Although Sayf al-Dawla was able to suppress the uprising, he had already begun to suffer from hemiplegia and was largely confined to his bed until his death in Șafar 356/February 967, at which point the brief power vacuum prompted further chaos in Hamdānid territory.

As the Hamdānids struggled with both internal and external pressures, the armies of Emperor Nikephoros II (r. 352-59/963-69) conquered Antioch in Dhū al-Hijja 358/October 969. Although Nikephoros was soon assassinated, his successor, John I (r. 359-65/969-76), thrilled to have regained control of the city that was once the great metropolis of Syria, quickly sought to reintegrate Antioch into the empire. As Gilbert Dagron puts it, "without Antioch, the 'reconquest' would win no more for Byzantium than some lands and cities;

2. Hugh Kennedy, The Prophet and the Age of the Caliphates: The Islamic Near East from the Sixth to the Eleventh Century (London: Routledge, 2016), 229-43; Clifford Edmund Bosworth, The Islamic Dynasties: A Chronological and Genealogical Handbook (Edinburgh: University Press, 1967), 49-50; Marius Canard, Histoire de la dynastie des H'amdanides de Jazîra et de Syrie (Paris: Presses universitaires de France, 1953).

3. Kennedy, Prophet, 231.

4. For selections from these poets and other authors that discuss Sayf al-Dawla and the events that took place under his rule, see Marius Canard, Sayf al Daula (Algiers: Editions Jules Carbonel, 1934).

5. Hugh Kennedy mentions the geographer Ibn Hawqal, who painted "a grim picture of overtaxation and exploitation"; see Kennedy, Prophet, 229.

6. Ibid., 241. 
with Antioch, it created a second pole, the virtual capital of a Roman Orient." John sent secular and ecclesiastical administrators from Constantinople and other parts of the empire to make Antioch Roman again. These administrators included the new patriarch, Theodore II, who is mentioned briefly in the Life. ${ }^{8}$ The empire undertook the translation of the liturgy of Constantinople into Syriac for use in the Church of Antioch, replacing local practices with those of the capital..$^{9}$ The Life also mentions several stages of imperial commemoration of Christopher, showing the new administration's determination to incorporate this local martyr into the new ecclesiastical order.

The Life was written after about fifty years of these imperial efforts and reflects some degree of local discontent with Roman control. The preceding rule of Sayf al-Dawla is presented in glowing terms, emphasizing the nuances and positive aspects of life with Muslims at a time when the empire viewed them primarily as foreign enemies. The text celebrates the autonomy and influence of the Antiochian Church under Muslim rule, in stark contrast to the situation of the church within the Byzantine Empire. Around the time that the Life was composed, in the late 410s/1020s, the empire's fortunes in the region began to turn again, and after decades of stagnation and lost ground, Antioch fell to the Seljuk Turks in 477/1084.

We know fairly little about the life of Ibrāhīm b. Yūhannā, author of the Life of Christopher, but we can make a general sketch. ${ }^{10}$ He was born in the early 340s/950s in Antioch to a prominent family with close connections to the church, and he was educated there under Patriarch Christopher. He spent his career within the Byzantine bureaucracy and attained the rank of prōtospatharios, along the way producing Arabic translations of some of the Greek works that had recently become available in Antioch thanks to the Byzantine reconquest of that city. These included works attributed to some of the greatest fourth-century CE Christian theologians, such as Pseudo-Dionysius the Areopagite and Ibrāhīm's older contemporary Symeon Metaphrastēs. It is very likely that he was also closely involved with the imperial project of translating the Constantinopolitan liturgy into Syriac. Late in life, Ibrāhīm finally found the time to compose a hagiography of Christopher in Greek and Arabic-likely in conjunction with the celebration of Christopher's life under Patriarch Nicholas II in the 410s/1020s-as he had long intended to do. He must have died around $421 / 1030$ or shortly thereafter. Although he is not as famous as some other translators from middle Byzantine Antioch, most notably 'Abd Allāh b. al-Fạ̣l (d. ca. 444/1052), his life

7. Gilbert Dagron, "Minorités ethniques et religieuses dans l'Orient byzantin a la fin du Xe et au XI ${ }^{\mathrm{e}}$ siècle: L'immigration syrienne," Travaux et mémoires 6 (1976): 177-216, at 205.

8. Theodore is mentioned in $\S 18$ of the Life. For examples of Byzantines sent to administer the frontier cities, see Jean Darrouzès, ed., Épistoliers byzantins du Xe siècle (Paris: Institut français d'études byzantines, 1960).

9. Joseph Nasrallah, "La liturgie des patriarcats melchites de 969 à 1300," Oriens christianus 71 (1987): 156-81, at 156-59; Sebastian Brock, "Syriac Manuscripts Copied on the Black Mountain, near Antioch," in Lingua restituta orientalis, ed. Regine Schulz and Manfred Görg, 59-67 (Wiesbaden: Otto Harrassowitz, 1990), 66-67.

10. For more details on Ibrāhīm, see Joshua Mugler, "Ibrāhīm ibn Yūhannā and the Translation Projects of Byzantine Antioch," in Patristic Literature in Arabic Translations, ed. Barbara Roggema and Alexander Treiger, 180-97 (Leiden: Brill, 2020). 
offers an important window into the transition from Hamdānid Muslim rule to Byzantine Christian rule in Antioch, which he describes in the Life. ${ }^{11}$

Other testimonies to Christopher's story are far more limited in detail. They include Byzantine histories in Greek and entries in Antiochian liturgical calendars, both Syriac and Arabic. The history of Leo the Deacon, for example, claims that Antioch's "former Hagarene ruler killed the patriarch Christopher, an apostolic and divinely inspired man, by driving a javelin through his chest, bringing against the man the charge of reverence for Christ the Savior." ${ }^{12}$ This brief statement strips the story of any complexity and lends itself well to a polemic against the tyranny endured by Christians under Muslim rule. By contrast, the Life provides a much more nuanced picture of the situation.

The earliest and most reliable manuscript of the Life is Sinai Arabic 405 (S), which consists of the May-June volume of a full-year Menologion, a compilation of saints' lives according to the ecclesiastical calendar. ${ }^{13}$ The manuscript was copied at Mount Sinai in Kānūn al-Awwal 6843 Anno mundi, or Rabī' al-Thānī 735/December 1334. It was microfilmed by the Library of Congress in 1950, and the microfilm has now been made digitally available on the library's website. More recently, the manuscript has been digitized in color and made available through the website of UCLA's Sinai Manuscripts Digital Library project. ${ }^{14}$

The second manuscript (Z) was copied by Būlus b. al-Za'īm (d. 1079/1669), also known as Paul of Aleppo, son of Patriarch Makarios III (d. 1083/1672). It is a compilation of stories and other texts relevant to the history of Antioch. This manuscript was published with a French translation by Habib Zayat in 1952, but Zayat did not have access to the Sinai manuscript. Zayat says that Būlus's manuscript "is found in our possession" (se trouve en notre possession) but does not clarify this statement or explain where the manuscript is located. ${ }^{15}$ After his death in 1954, the matter became even more obscure, and there is now

11. For more on 'Abd Allāh, see Alexandre M. Roberts, Reason and Revelation in Byzantine Antioch: The Christian Translation Program of Abdallah ibn al-Fadl (Oakland: University of California Press, 2020).

12. Leo the Deacon, The "History" of Leo the Deacon: Byzantine Military Expansion in the Tenth Century, trans. Alice-Mary Talbot and Denis F. Sullivan (Washington, DC: Dumbarton Oaks Research Library and Collection, 2005), VI.6.

13. On the Antiochian Menologion, the large, full-year compilation of hagiographies that includes this manuscript, see Alexander Treiger, "Sinaitica (1): The Antiochian Menologion, Compiled by Hieromonk Yūhannā 'Abd al-Masī (First Half of the 13th Century)," Khristīanskĭ Vostok" 8 (2017): 215-52; Habib Ibrahim, "Liste des vies de saints et des homélies conservées dans les Ms. Sinaï Arabe 395-403, 405-407, 409 et 423," Chronos 28 (2018): 47-114. Treiger has recently redated the life of Yūhannā 'Abd al-Masīh, and thus the compilation of the Antiochian Menologion, to the early fifth/eleventh century. A note in the Menologion indicates that Yūhannā was a contemporary and acquaintance of Ibrāhīm, and in fact it is now clear that he must have been one of Christopher's disciples, mentioned at the end of his Life as "Anbā Yūhannā the Marvelous." See Alexander Treiger, "The Beginnings of the Graeco-Syro-Arabic Melkite Translation Movement in Antioch," Scrinium 16 (2020): 306-32, at 327-32. Habib Ibrahim has also edited an abridged version of the Menologion, published as Yūḥannā 'Abd al-Masīḥ al-Anțākī, Ma (īn al-ḥayāt:al-Markab al-sā'ir fị mīnā' al-najāt, al-ma rūf bi-Kitāb al-dūlāb, ed. Ḥabīb Ibrāhīm, 2 vols. (Beirut: Markaz al-Turāth al-`'Arabī al-Masīhī, 2020-21).

14. https://sinaimanuscripts.library.ucla.edu/ (accessed July 12, 2021). The Library of Congress microfilm is available at https://www.loc.gov/item/00279389955-ms/.

15. Habib Zayat, "Vie du patriarche melkite d'Antioche Christophore († 967) par le protospathaire Ibrahîm b. Yuhanna: Document inédit du X $\mathrm{X}^{\mathrm{e}}$ siècle," Proche-Orient chrétien 2 (1952): 11-38, 333-66, at 13. 
no way to determine where this copy can be found. Fortunately Zayat's edition is available until Būlus's manuscript is uncovered again.

Alexander Treiger has recently discovered an additional copy of the Antiochian Menologion, presumably including the Life of Christopher, located in St. Petersburg: National Library of Russia, Arab. N.S. 92. ${ }^{16}$ This eight-volume set was copied in Damascus in 1261/1845 by Hannā b. Jirjis Șarrūf al-Dimashqī. Treiger believes that it was copied from a manuscript in the collection of the Greek Orthodox patriarchate in Damascus and that the antigraph was subsequently destroyed in the sectarian conflicts of 1276/1860, while Arab. N.S. 92 was brought to Russia by Porfirĭ Uspenskĭ. It will hopefully be available for study soon, but I have not been able to consult it in the process of preparing this edition.

An edition of the text was published by Ignatius Dick in 1997, but even though it uses both the Sinai manuscript and Zayat's text, it is not a critical edition. ${ }^{17}$ It lacks a thorough presentation of the variants between the manuscripts and instead presents a seamless text that leans heavily on the Sinai manuscript, bringing in occasional corrections from Zayat. Furthermore, it is extremely difficult to obtain a copy of this book outside the Middle East. Finally, Sofia Moiseeva published a Russian translation of Zayat's text in 2013, incorporating only those Sinai variants that were found in a short excerpt published in a 1979 article by Joseph Nasrallah. ${ }^{18}$

Zayat explains that his copy of the text was damaged and that Būlus himself was copying from a badly damaged copy. Būlus writes:

Be aware, my brother, that at the beginning of the patriarchate of my father, I found this marvelous and unique account at the end of a very old book, badly written, deprived of diacritical points, nearly illegible, and gnawed by mites; numerous passages had also disappeared. But in all the Arab countries with their monasteries and churches, I have not been able to find a second copy of it. I believed it necessary to reproduce it here, because it is so precious. ${ }^{19}$

Thus Zayat's text, although extremely valuable as a second witness alongside Sinai Ar. 405, has suffered greatly from the ravages of time.

The historical sections of the Life bear an obvious resemblance to those found in Yahyā b. Sa'īd al-Anțākī's history, known as the Dhayl. Scholars have typically explained the similarity by claiming that the Life is "the source" of these elements of the Dhayl. ${ }^{20}$ In most cases, these scholars worked only with Zayat's published text, in which the verbatim

16. Treiger, "Beginnings," 332.

17. Ighnāṭiyūs Dīk, Sīrat al-bațiyark Kharīsțūfūrus al-Anțākī șadīq Sayf al-Dawla (Aleppo: n.p., 1997).

18. Ibrāhīm b. Yūḥannā, "Zhitie antiokhiı̌skogo patriarkha Khristofora," trans. S. A. Moiseeva, in ArabyKhristiane v istorii i literature Blizhnego Vostoka, ed. N. G. Golovnina, 28-61 (Moscow: PSTGU, 2013); Joseph Nasrallah, "Deux auteurs melchites inconnus du Xe siècle," Oriens christianus 63 (1979): 75-86, at 79-82. The translation is reprinted in Moiseeva's 2015 monograph; see Sofia A. Moiseeva, Arabskaia mel'kitskaia agiografiia IX-XI vekov (Moscow: PSTGU, 2015), 142-75.

19. Zayat, "Vie," 15.

20. Ibid., 15; John Harper Forsyth, "The Byzantine-Arab Chronicle (938-1034) of Yahyā b. Sacīd al-Anțākī” (PhD diss., University of Michigan, 1977), 182-86. 
borrowing from one text to the other is extensive. However, when examining the $\mathrm{S}$ version of the Life, the relationship between the two works becomes far murkier: there is greater divergence between the two extant manuscripts in the historical sections than there is in other sections, and the most significant differences concern the summaries and verbatim equivalents of al-Anțākī's account, which are consistently found in $\mathrm{Z}$ but have no parallelor are phrased very differently-in $\mathrm{S}^{21}$

The $\mathrm{Z}$ variants contain nothing that is not found in al-Anțākīs text, but $\mathrm{S}$ does contain information not found elsewhere. For example, when Christopher is assassinated, Z states that the murderers threw his head into a public bath furnace-as described in al-Anțākìs Dhayl-whereas S claims instead that his body was dragged around the city on a ladder, a detail found in no other source. ${ }^{22}$ This makes it highly unlikely that the recension contained in $\mathrm{S}$ was produced by editing an original text closer to Z. Instead, it seems likely that the redactor of Z's version edited an earlier text while copying and summarizing material from the Dhayl. The fact that $\mathrm{S}$ is an earlier manuscript witness than $\mathrm{Z}$ is circumstantial evidence for this position. The editing may have been carried out by Būlus b. al-Za'īm or by one of his predecessors. Perhaps it was done to make the text more historically rich and-occasionally-more straightforwardly comprehensible, as the literary style of $\mathrm{S}$ is sometimes rather difficult to follow. ${ }^{23}$ Counterintuitively, therefore, much of the material shared between the two texts was actually added from al-Anțākīs text to Ibrāhīm's by a later editor, not borrowed from Ibrāhīm's work by al-Anțākī himself.

Other, less substantial variants between $\mathrm{S}$ and $\mathrm{Z}$ involve the replacement of archaic or obscure words in $\mathrm{S}$ with their more current equivalents in $\mathrm{Z}$ or simply glossing obscure terms, as $\mathrm{Z}$ does with the term bāqūlā. ${ }^{24}$ With all this in mind, it seems nearly certain that $\mathrm{S}$ is closer to the original text of the Life than $\mathrm{Z}$ is, especially in the historical sections in which $\mathrm{Z}$ relies heavily on borrowing from al-Anțākì's work. As a result, my approach in the edition has been to prefer the reading of $S$ in most cases. This approach yields a more

21. The one exception to this rule occurs in $\$ 17$ of the Life, where S recounts in detail that Peter the Stratopedarkhēs was attacking Aleppo while the Syrian gang was trying to return the captive Ibn Mānik to him. Here S follows closely the description of events in al-Anțākī's Dhayl, whereas Z simply states that the Syrians "brought him [Ibn Mānik] to the stratopedarkhēs" and ignores the attack on Aleppo altogether. Compare Yahyā b. Sa'īd al-Anțākī, "Histoire de Yahya-Ibn-Sa“ïd d'Antioche, continuateur de Sa“ïd-Ibn-Bitriq," ed. and trans. I. Kratchkovsky and A. Vasiliev, Patrologia orientalis 18, no. 5 (1924): 699-833, at 823-24.

22. Ibrāhīm, Life, §15; al-Anțākī, "Histoire," 809.

23. For example, $\mathrm{S}$ has a tendency to describe major characters and refer to them by epithets without revealing their names until the end of their part in the story, if at all. $\mathrm{Z}$ rearranges the text to introduce characters by name, generally when they are first mentioned. This difference helps explain some of the quirks noted by Moiseeva. For example, Moiseeva notes an instance in which an entire set of sentences is repeated; it now seems clear that the first occurrence of these sentences is borrowed from al-Anțāki and placed earlier in Z, whereas the second occurrence, found later in both manuscripts, reflects Ibrāhīm's original composition. The borrowing from al-Anțākī thus explains the repetition. See Sofia A. Moiseeva, "The Early Melkite Arabic Hagiography (IXth-XIth Centuries): Evolution of the Literary Style," Parole de l'Orient 39 (2014): 33-56, at 51; Ibrāhīm, Life, §17; al-Anțākī, "Histoire," 814.

24. Ibrāhīm, Life, §17. 
accurate picture of the text composed by Ibrāhīm b. Yūhannā in the fifth/eleventh century while still giving access to the redactor's later work in the apparatus.

Beyond variants, $\mathrm{S}$ fills most of the gaps present in the damaged text of $\mathrm{Z}$. More noteworthy than any of these variants and lacunae, however, is the presence in $S$ of a two-page ethical preface that has been completely excised from Z. In this introductory section, Ibrāhīm lays out a vision of human nature and divine justice that should shape the way we read the text as a whole. He emphasizes the human capacity to improve and to turn away from a past life of sin-or even just a past life of ethical mediocrity-and argues that we, like God, "should view all those whom we see according to the way they look at the end of their days, whether they have been good and righteous or have returned to goodness and righteousness after straying far away." 25 This is the context in which Ibrāhìm introduces his protagonist, Christopher, whose early life in the luxurious context of government employment was suspect in ethical terms, but who turned from that life to one of asceticism and generosity when he became the patriarch of Antioch. The inclusion of this preface and the benefits to be gained from critically comparing the two manuscripts will greatly improve our understanding of this valuable text.

In this edition and translation, I have largely kept to the standard spelling of modern Arabic with respect to issues such as the presence or absence of dots on the letters $\checkmark$ and $\mathrm{s}$ and the letters $\bullet$ and $\mathrm{o}$. However, I have preserved the forms of $\mathrm{S}$ that do not indicate the hamza, or glottal stop. I have also standardized proper names, which often differ slightly between the two manuscripts and from one occurrence to the next within a single manuscript, and I have not indicated their numerous small variants. Otherwise, all variants have been noted in the apparatus to the edition; in the translation, I have mentioned only those variants that seem especially noteworthy or entail significant changes in meaning. The notes to the translation also clarify historical and narrative details that are relevant for understanding the text. I use w (in the edition) and S (in the translation) to refer to Sinai Arabic 405, and $j$ and $Z$ to refer to the lost manuscript edited by Zayat in 1952. Folio numbers in both edition and translation refer to the folios of $S$, from fol. $111 \mathrm{v}$ to fol. $131 \mathrm{r}$.

25. Ibrāhīm, Life, preface. 


\section{Arabic Edition}

\section{ب11v بسم الاب والابن والروح القدس الالاه الواحد}

اليوم الثالث و العشرون من ايار

قصة سيرة البطريرك على انطاكية الثهيد خريسطوفورس وشهادته بها الفها ابر اهيم بن يحنا الابروطسباثار الملكي بها يونانيا ثم نقلها ايضا عربيا نفعنا الله بها امين

ان الطبيعـة و الجـري على الصـورة الالاهيـة فعـل مـن افعـال الله تبـارك ذكـره. فامـا الخطيـة و التعريـج عـن الرسـوم الموجودة في الصورة فذللك فعل من افعال الثرير.

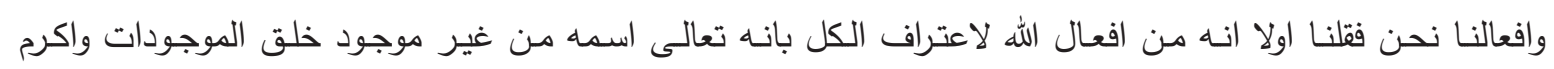

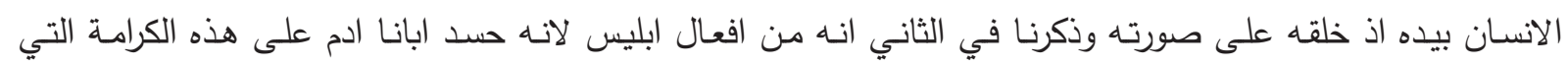

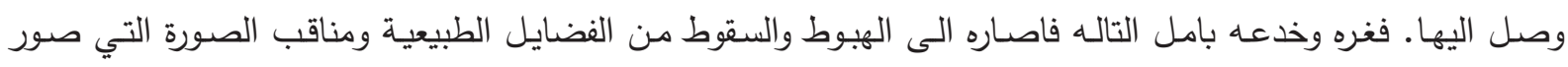

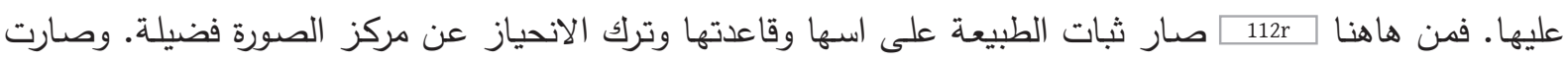

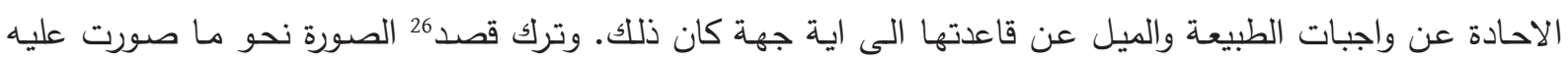
وتوجهها الى ضد ذلك نقيصة 27 ورذيلة.

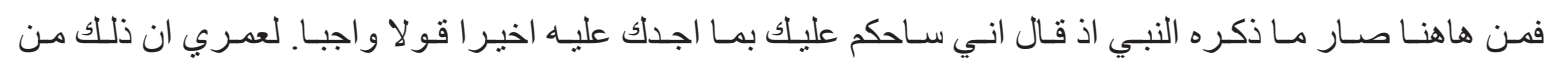

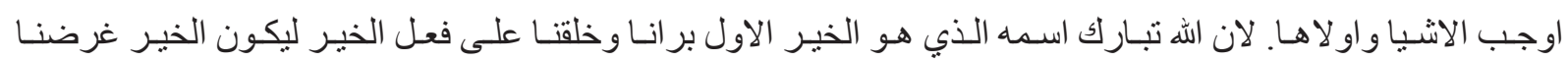

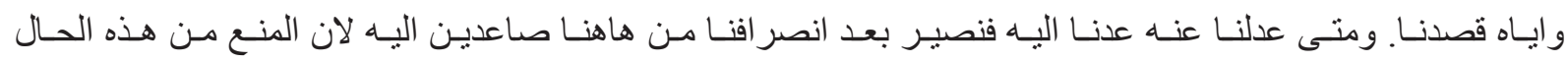

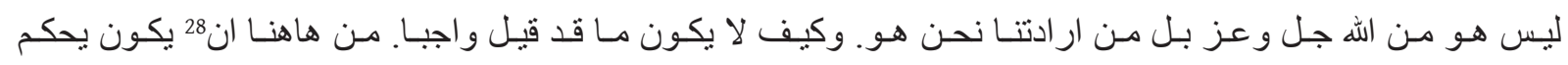

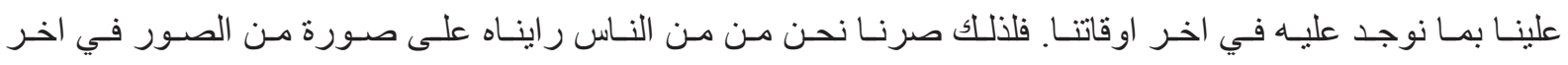

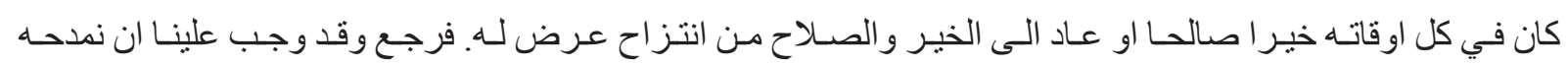

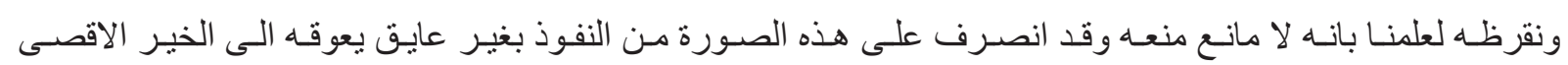
والماثور الابعد.

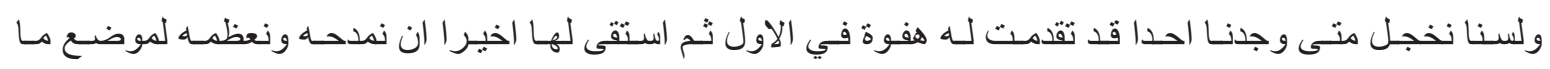

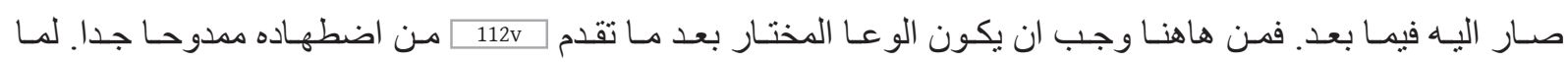

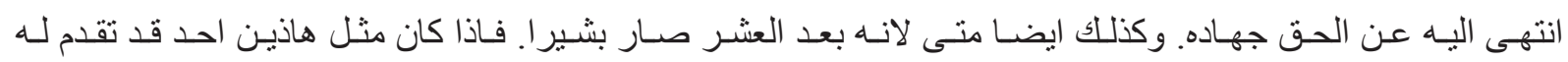

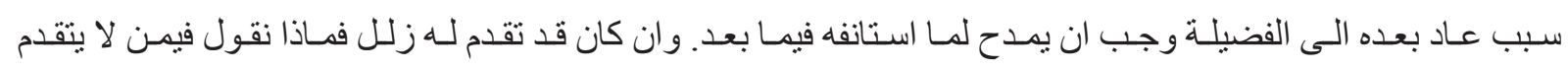

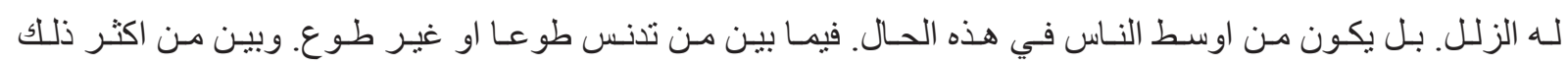

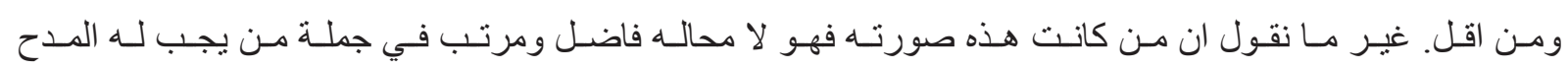
الجزيل.

\footnotetext{
26. قصد: صححته؛ قصر : س

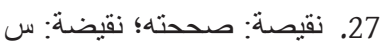

28. ان: صححته؛ ان يكون ما قد قيل واجبا من هاهنا ان: س في س 
[1] و الذذي نعرفـه بهذه الصـورة فهو خريسطوفورس البطريـرك العظيـم و الثـهيد الكريـم فيمـا تقدم لـه مـن عطايـاه

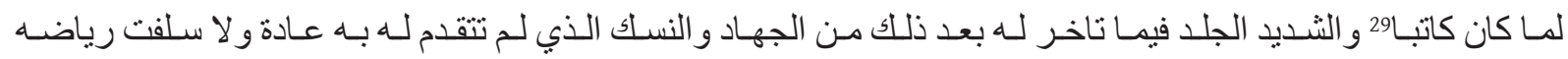

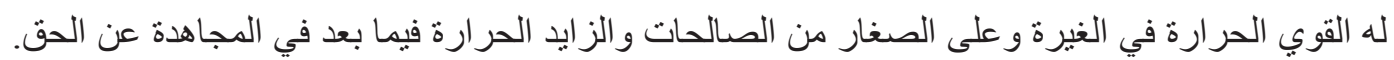

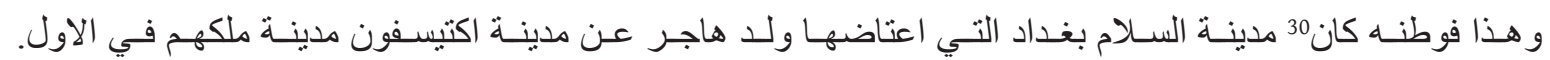

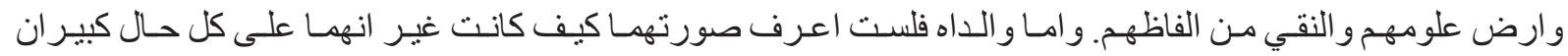

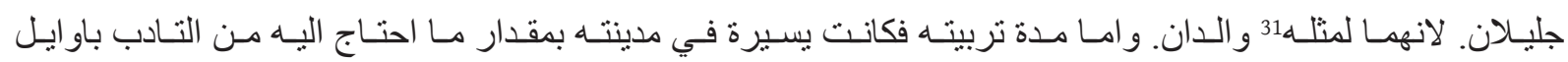

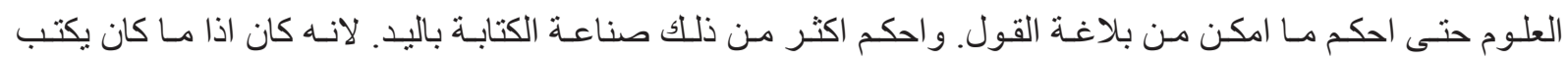

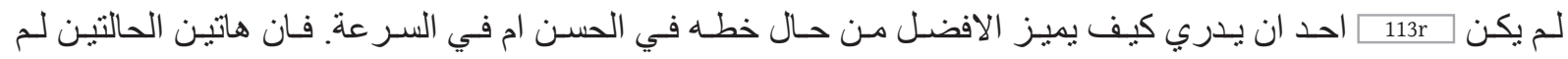

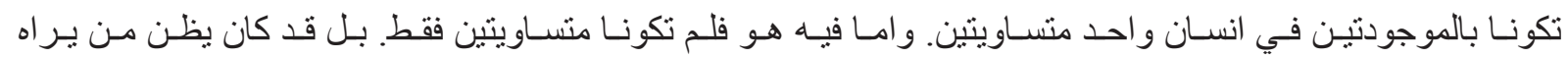

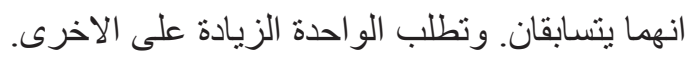

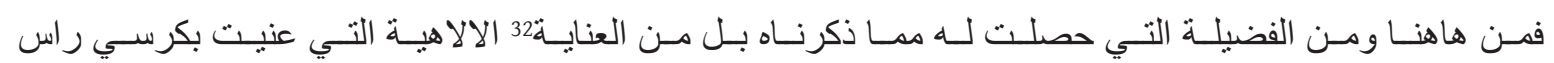

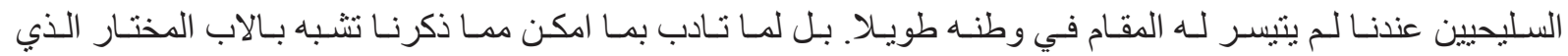

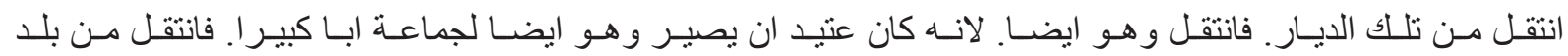

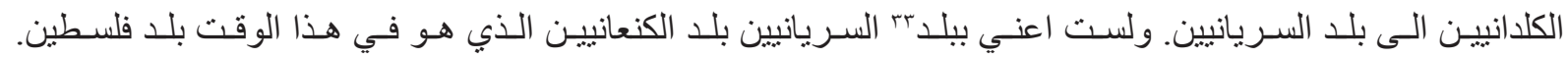

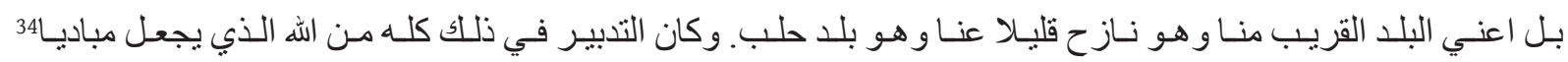

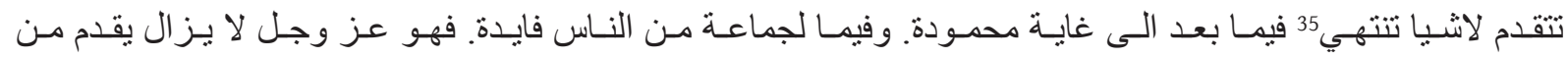
الصغار مقدمات لكبار لا تخطر فيما قبل بو هم.

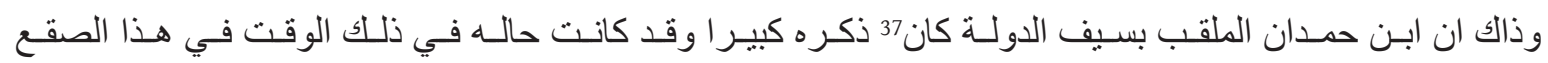

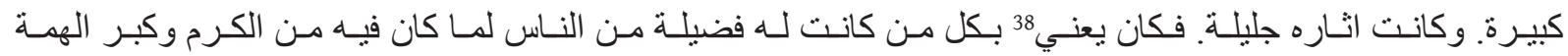

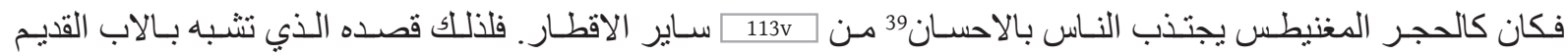

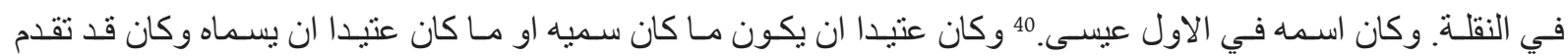

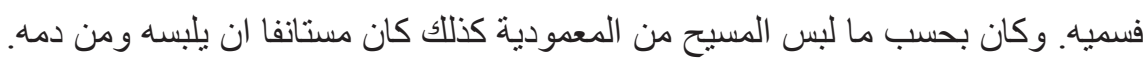

$$
\begin{aligned}
& \text { 29. بسم الاب . . . كان كاتبا: س؛ هذا المغبوط السعيد و البطريرك المعظم و المكرم الثهيد: ز }
\end{aligned}
$$

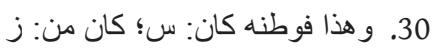

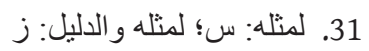

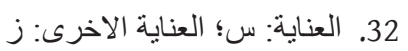

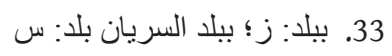

$$
\begin{aligned}
& \text { 34. مباديا: س؛ مناديا: ز ز }
\end{aligned}
$$

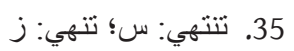

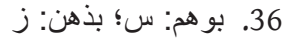

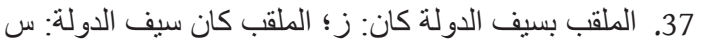

$$
\begin{aligned}
& \text { 38. 38 بعني: س؛ يعين: ز }
\end{aligned}
$$

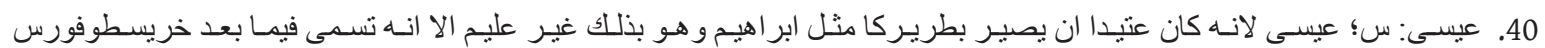




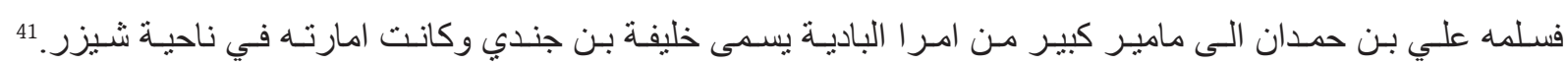

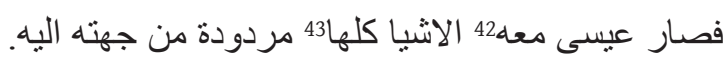

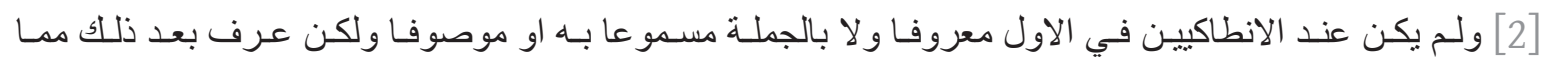

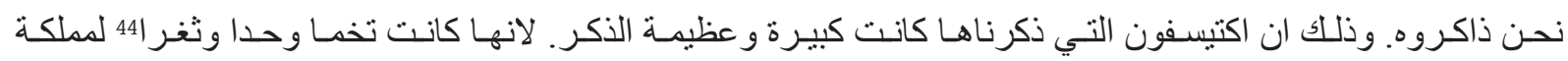

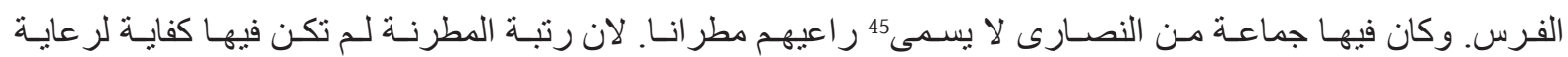

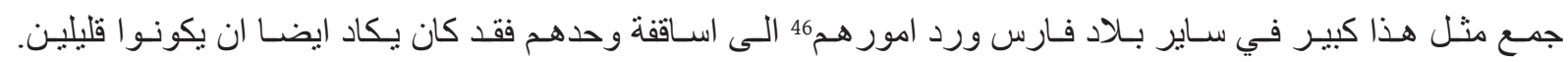

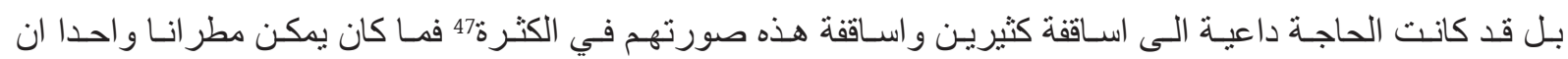

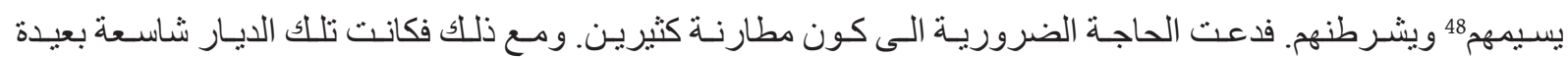

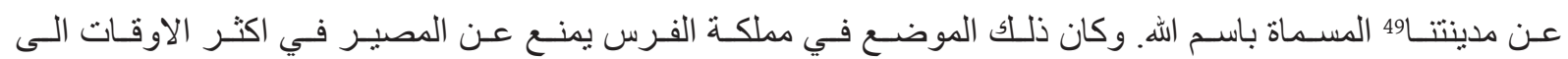

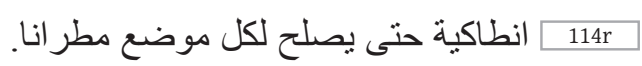

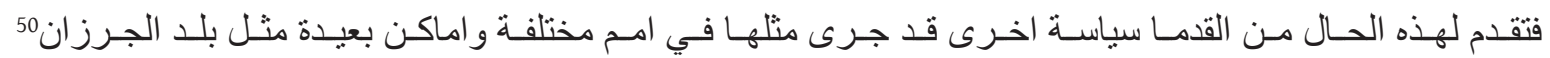

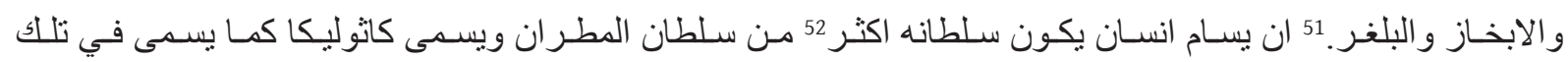

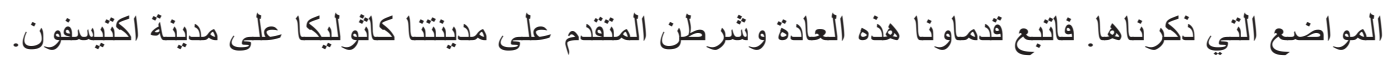

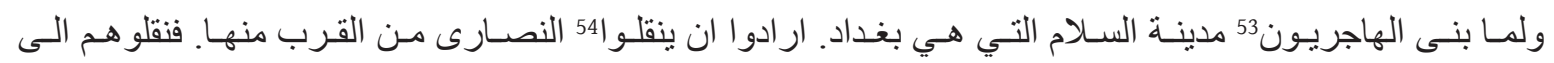

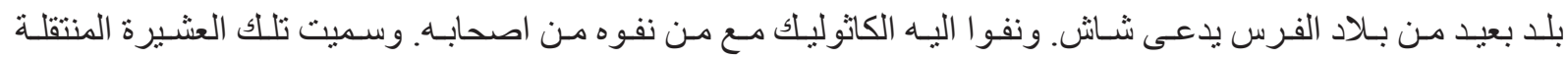
جماعة الروم. فوجب ان يكون اسم جمعهم هذا الاسم.

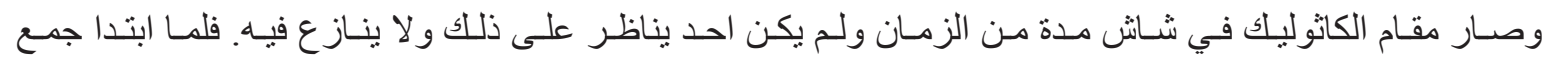

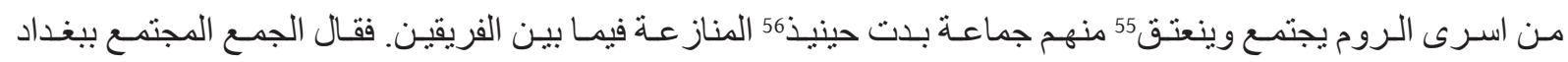

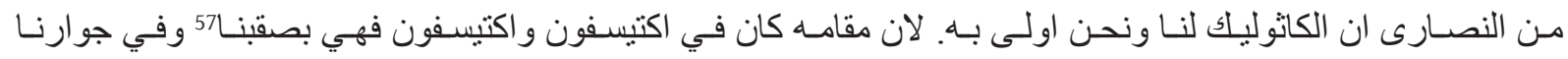

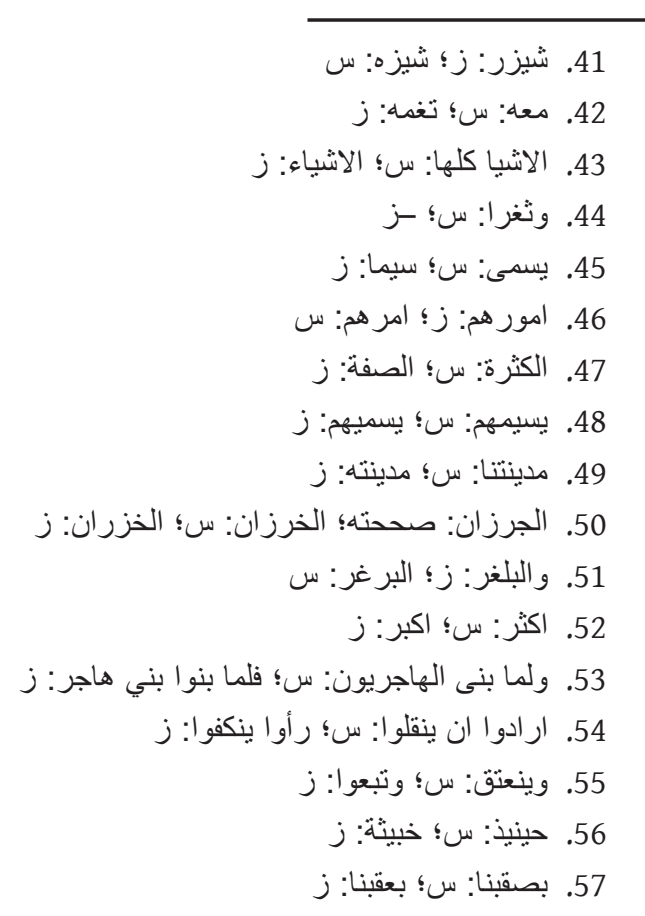

Al- 'Ușūr al-Wusțā 29 (2021) 


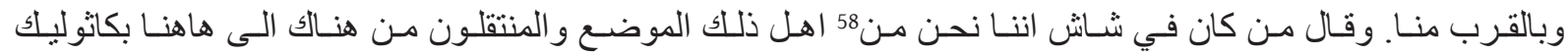

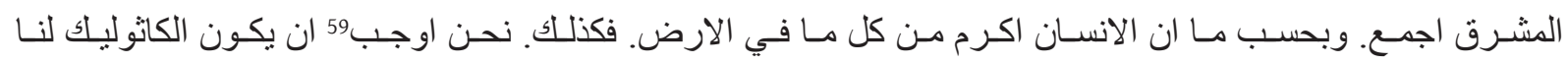

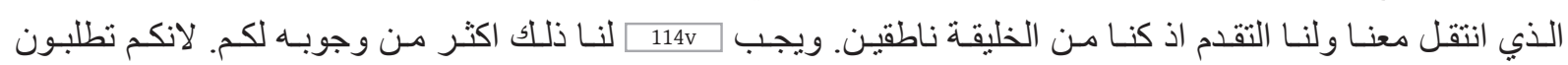
ان يكون لكم التقدم من الحجارة و التزاب.

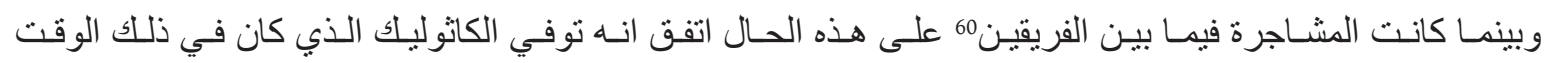

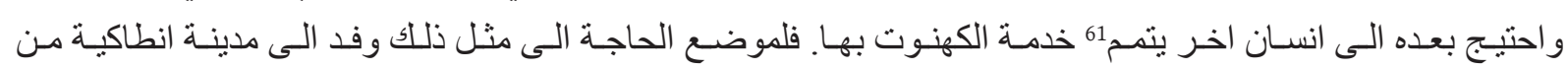

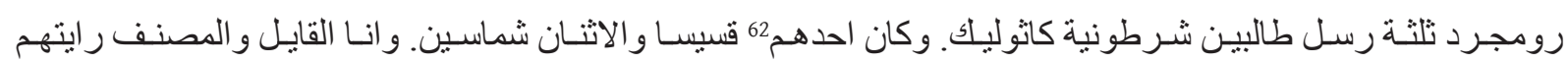

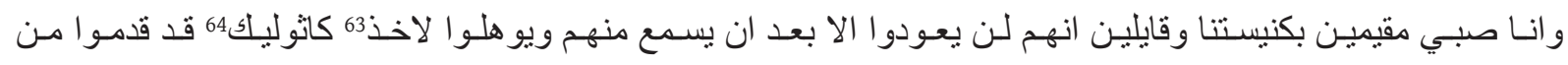

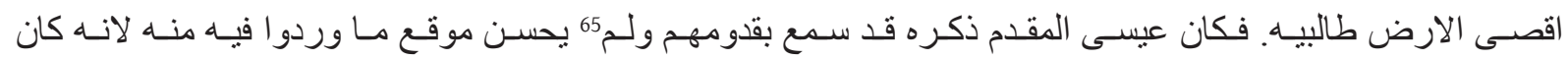

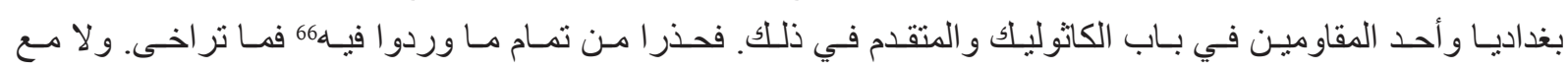

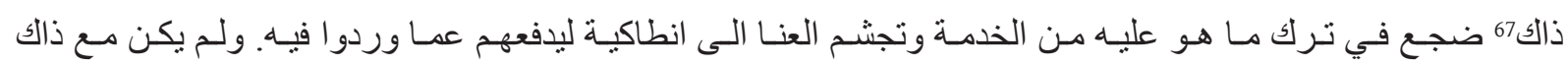

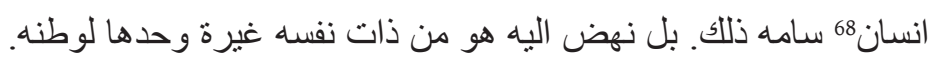

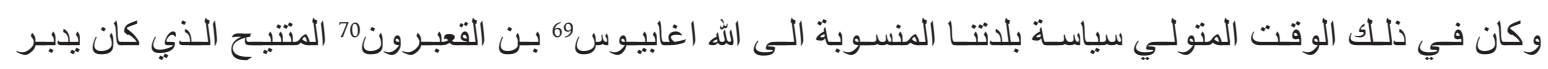

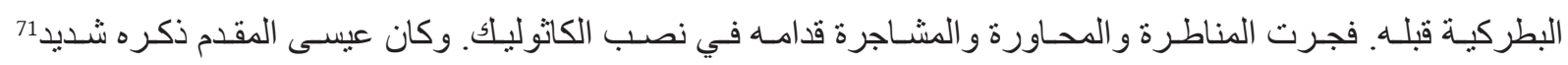

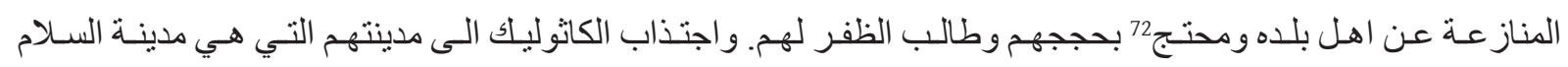

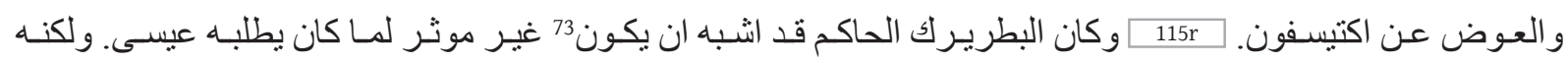

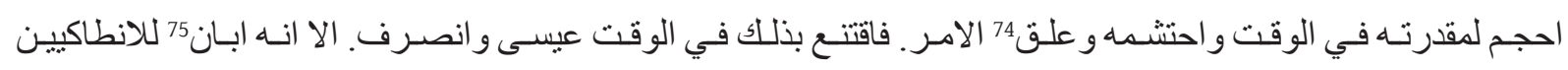
منه انه رجل كبير جلد وان له غيرة شديدة في امور الكنيسة.

$$
\begin{aligned}
& \text { 58. 5ن: ز؛ هم: س } \\
& \text { 59. 58. اوجب: س؛ و واجب: زئ ز } \\
& \text { 60. الفريقين: س؛ الفئتين: ز ز }
\end{aligned}
$$

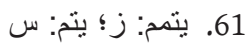

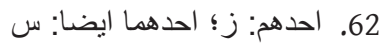

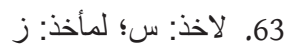

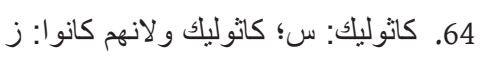

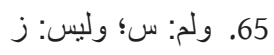

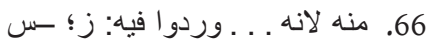

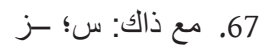

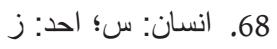

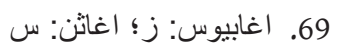

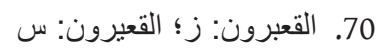

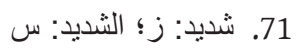

$$
\begin{aligned}
& \text { 72. }
\end{aligned}
$$

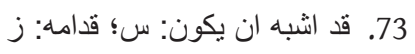

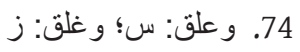

$$
\begin{aligned}
& \text { 75. ابان: س؛ بان: ز ز }
\end{aligned}
$$


[3] فلم يكن الا هنيهـة مـن الزمسان حتـى76 توفي البطريـرك. وصـار اهتمـام الانطاكيين في اختيـار بطريـرك وراع

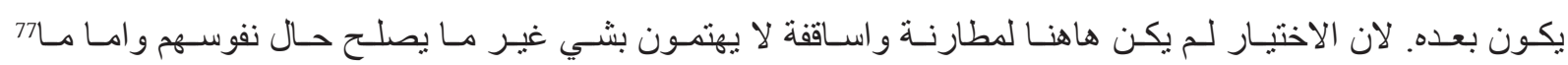

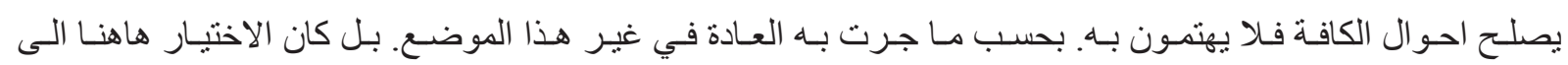

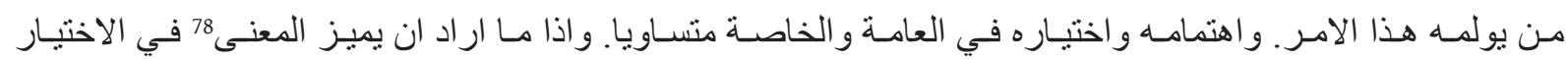

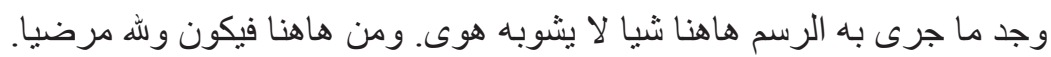

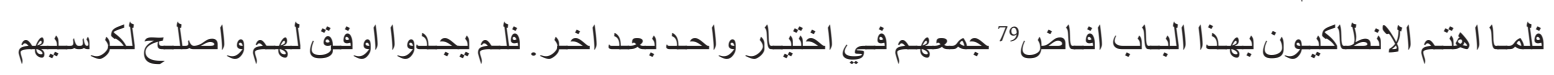

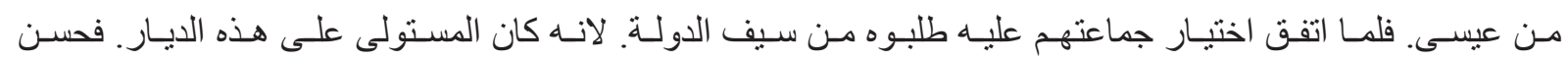

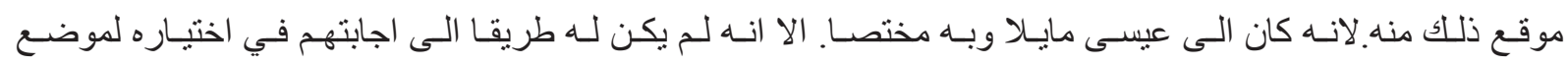

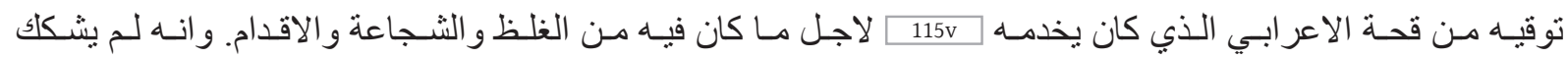

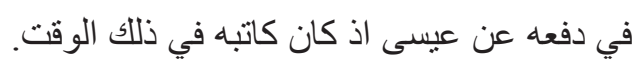

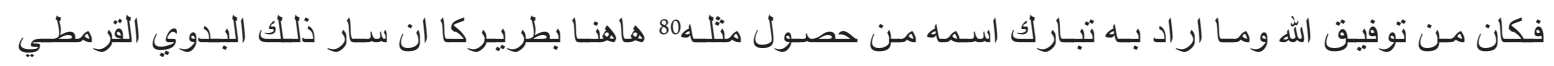

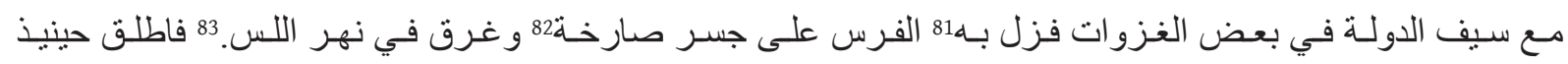

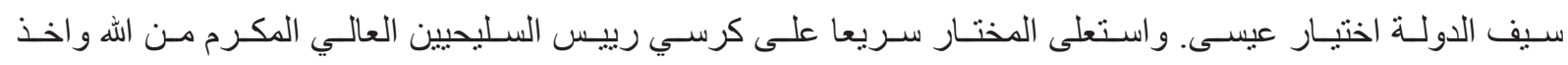

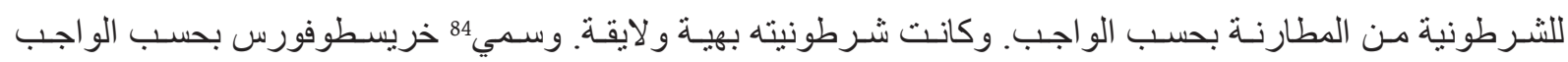

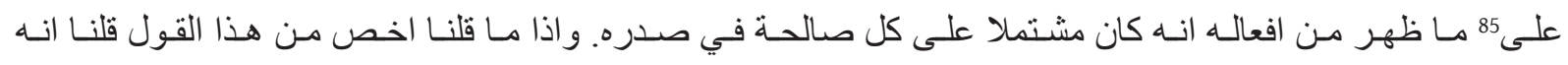
كان قد ضم المسيح في قلبه.

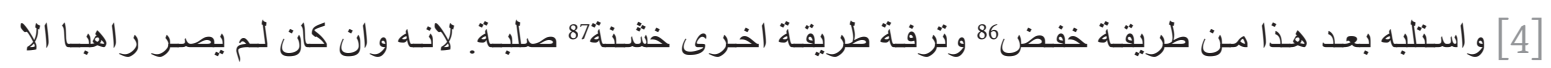

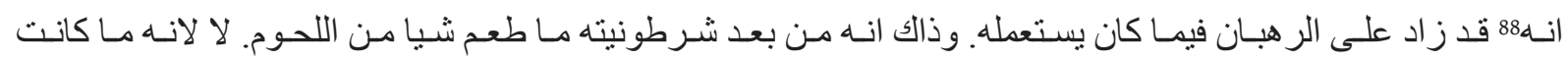

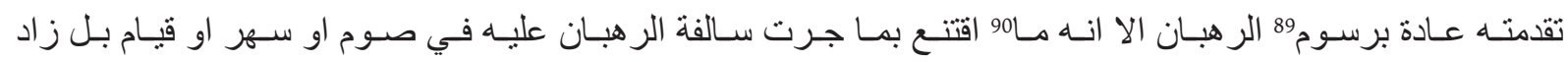

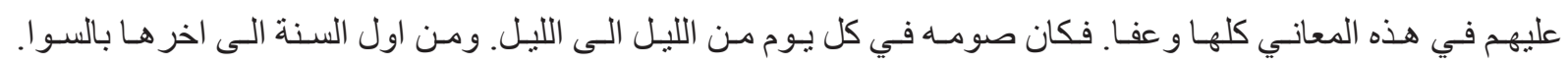

\author{
76. حتى: س؛ -ـز

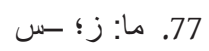

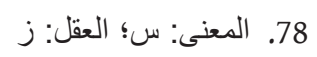 \\ 79. افاض: ز؛ حاض: سئ سل سل

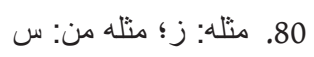

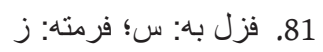

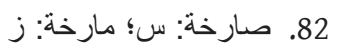

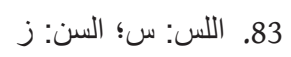 \\ 84. وسمي: س؛ وتسمى: زل زل \\ 85. الواجب على: س؛ - -ز

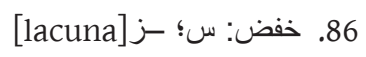

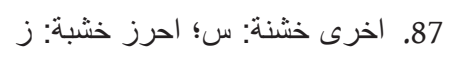

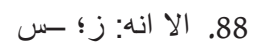

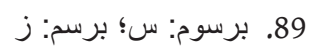 \\ 90. الا انه ما: ز؛ سـ برس
}

Al-`Ușūr al-Wusțā 29 (2021) 


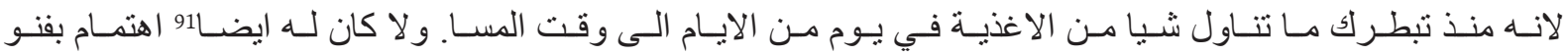

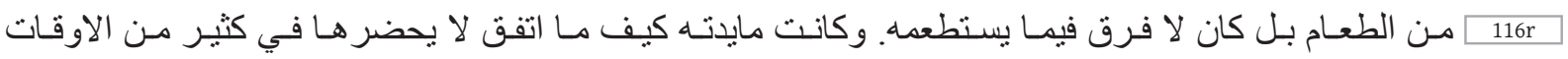

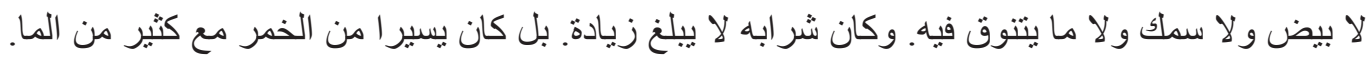

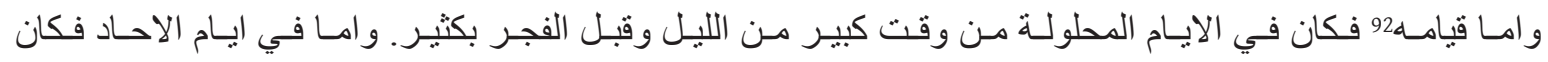

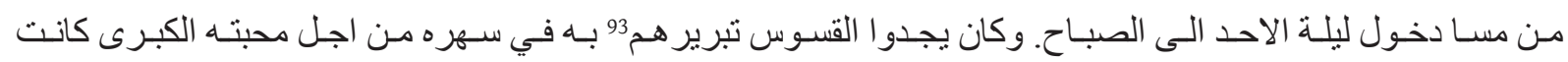

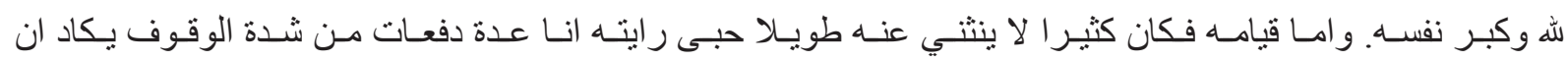

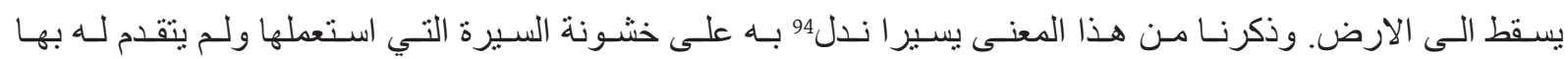

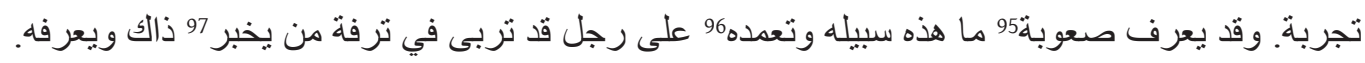

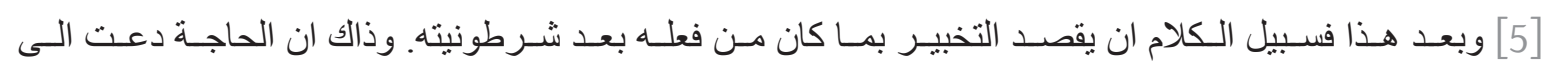

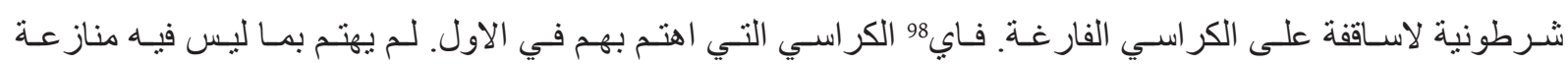

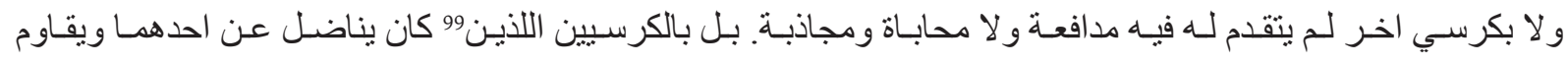

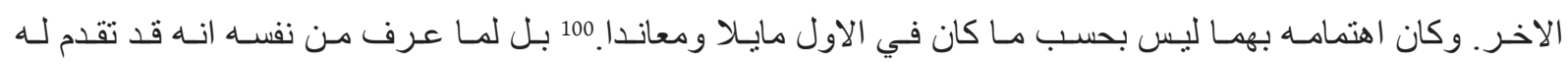

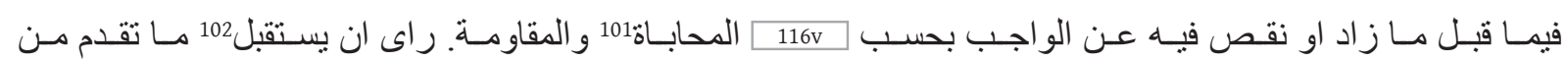

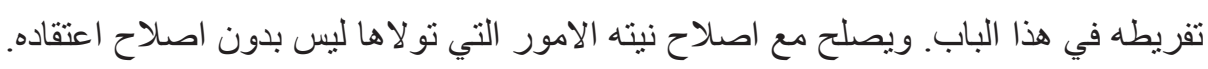

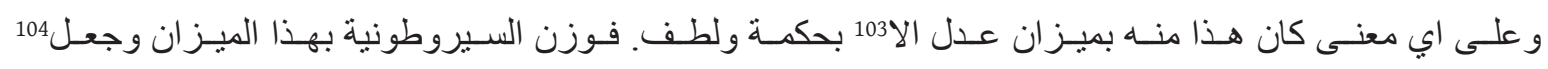

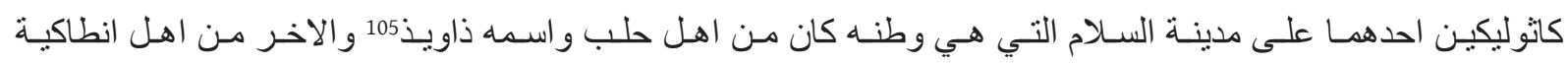

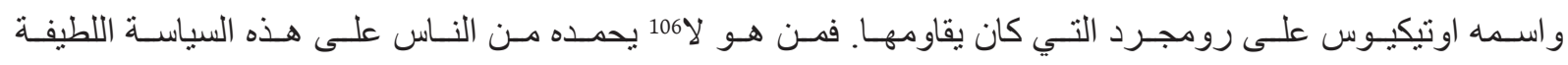

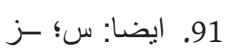

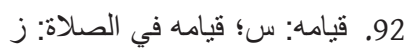

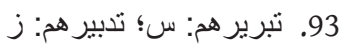

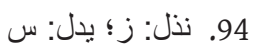

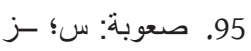

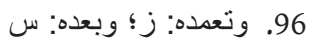

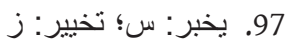

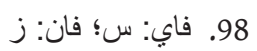

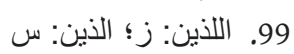

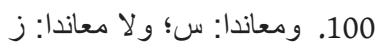

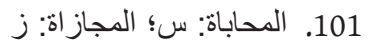

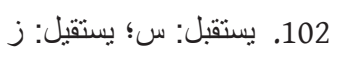

$$
\begin{aligned}
& \text { 103. بميزان عدل الا: س؛ يميز سئ ان عمل الامر: ز }
\end{aligned}
$$

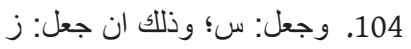

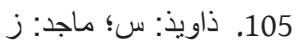

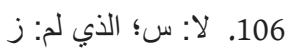

Al- 'Ușūr al-Wusțā 29 (2021) 


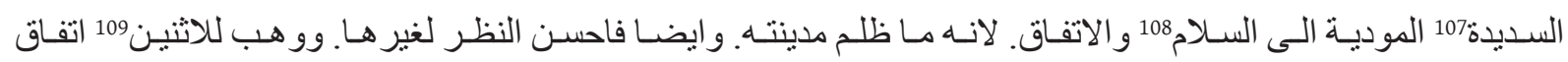
النفوس و البعد من الخصايم و المناز عات.

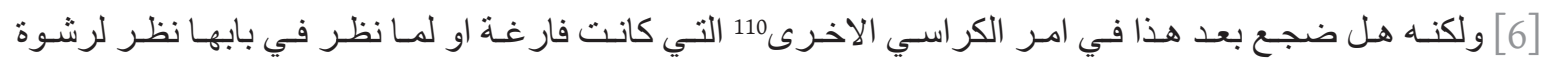

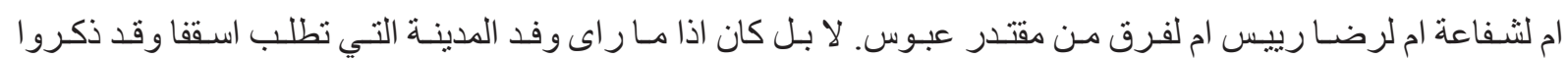

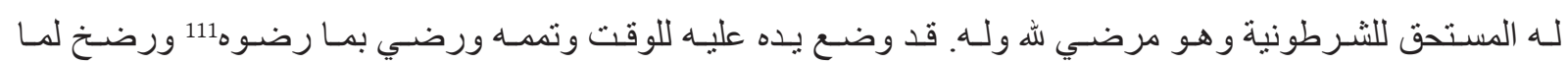

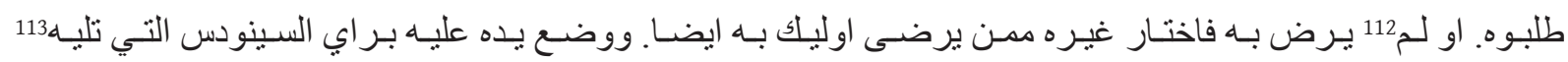

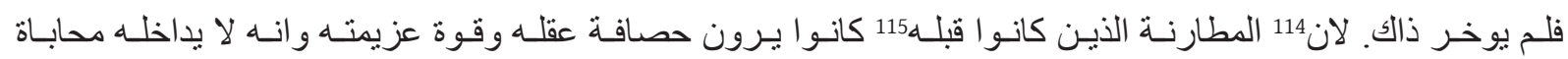
ولا ير غب في عطا ولا رشوة. فكيف كان يمكنهم ان يخالفوه في شي مما يو مي 116 اليه. 117

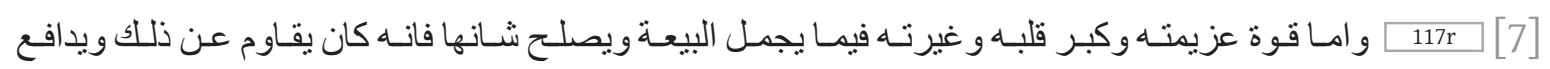

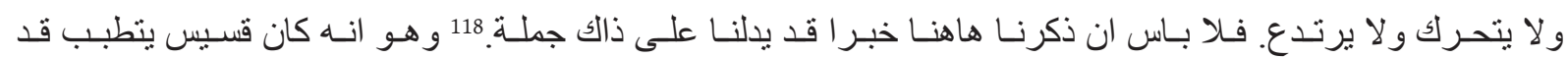

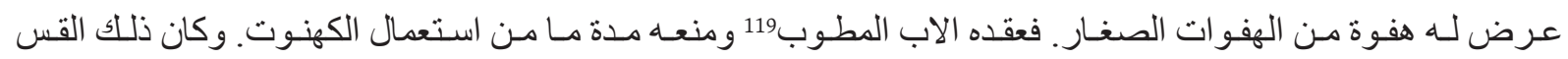

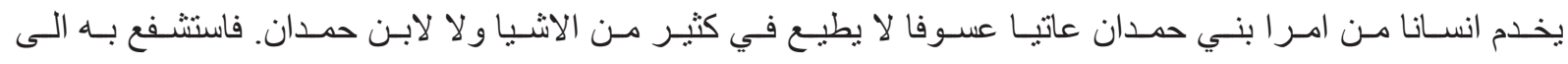

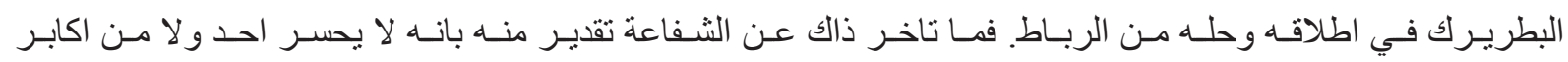

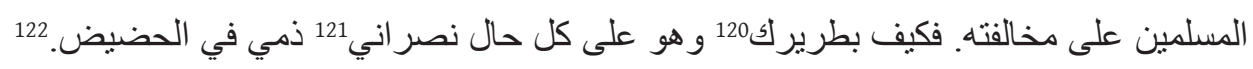

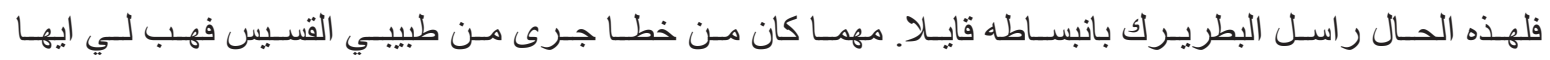

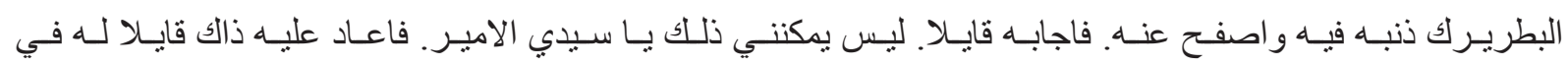

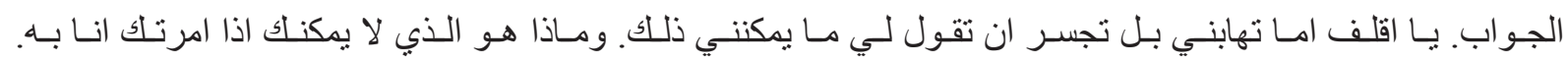

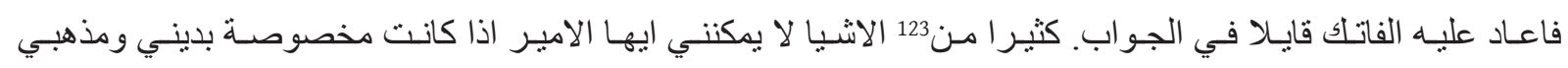

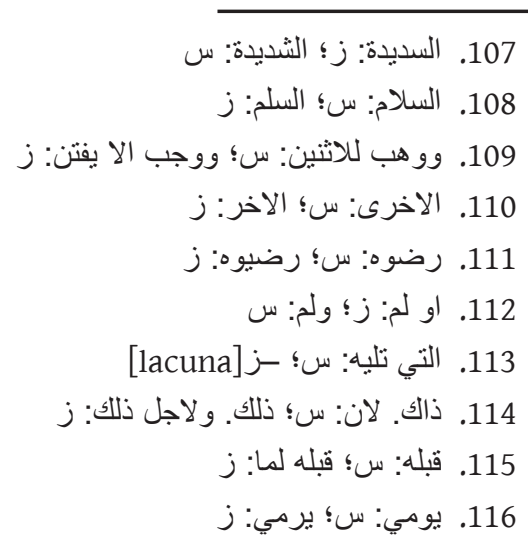

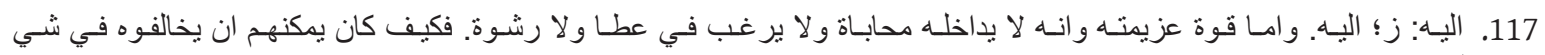
مما يومي اليه: س البه:

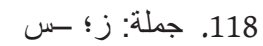

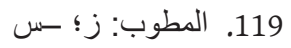

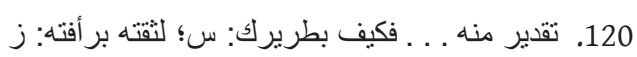

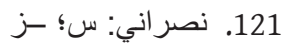

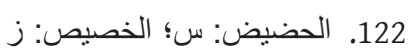

123. الفاتك قايلا . . . كثبر ا من: س؛ القائل قائلا: الحو ادث كثيرة من هذه: ز 


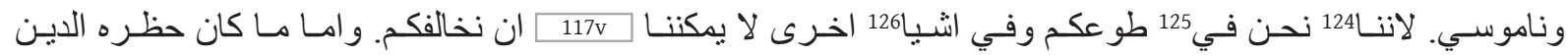

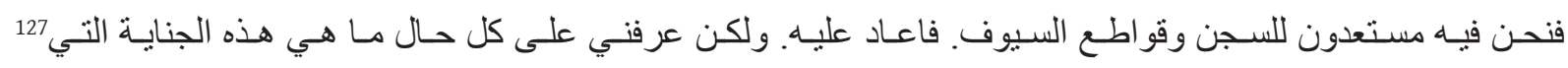

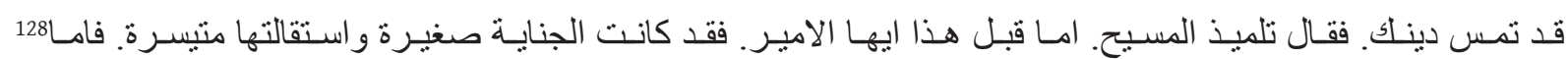

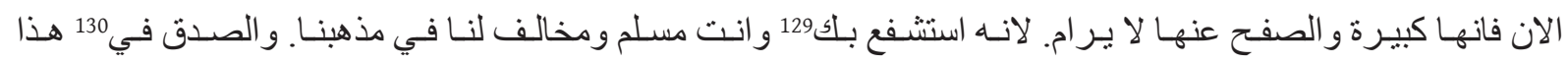

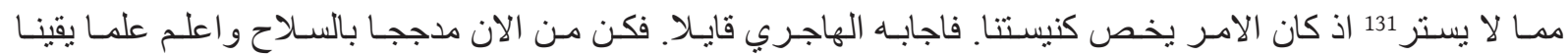
انك ستموت. وذاك اني اخذ راسك ولو كان في حضن الامير الاكبر.

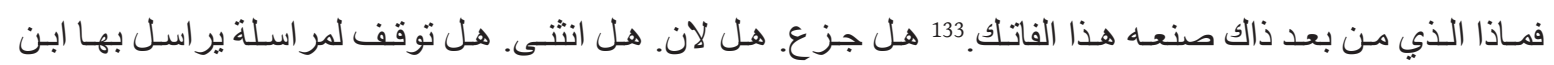

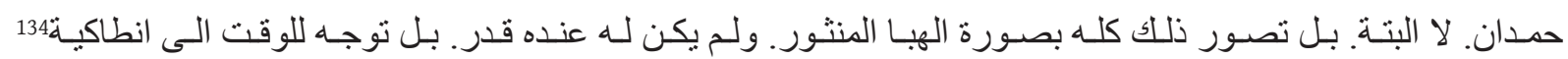

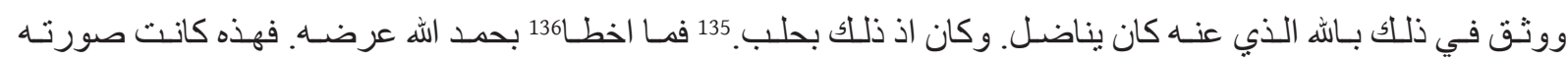

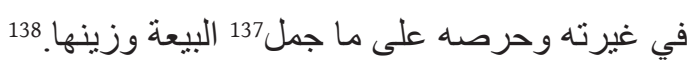

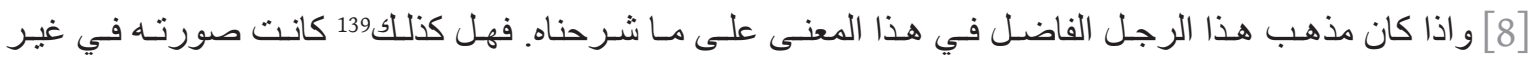

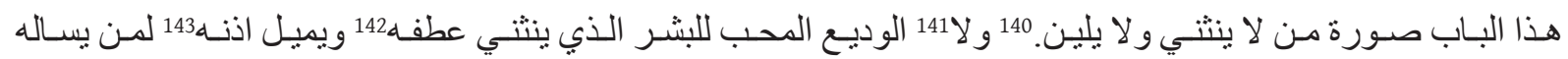

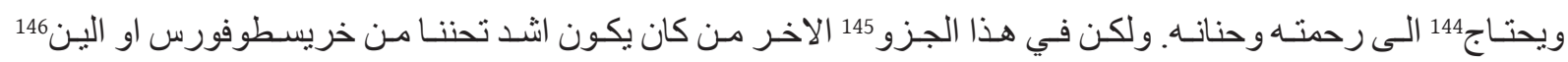

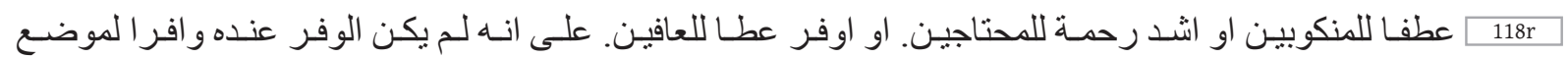

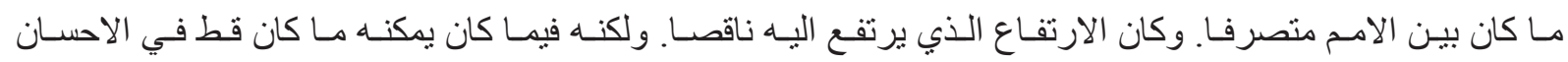

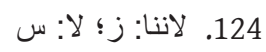

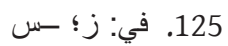

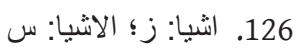

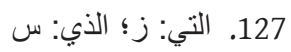

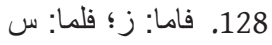

$$
\begin{aligned}
& \text { 129. لانه استشفع بك: س؛ سك لاني استشنع به: ز ز } \\
& \text { 130. في: س؛ - سز }
\end{aligned}
$$

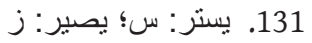

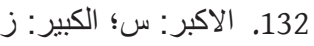

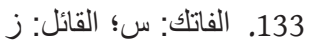

$$
\begin{aligned}
& \text { 134. انطاكية: س؛ انطاكية وكان اذ ذلك بحلب: ز زل زل }
\end{aligned}
$$

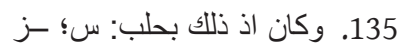

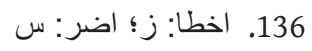

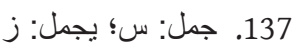

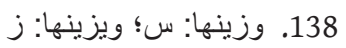

$$
\begin{aligned}
& \text { 139. فهل كذلك: س؛ فئ فينلك: ز ز ز }
\end{aligned}
$$

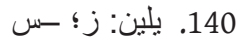

$$
\begin{aligned}
& \text { 141. و لا: س؛ ولا وكيف كان يليق انه من اعماله تلميذ المسيح: ز }
\end{aligned}
$$

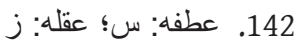

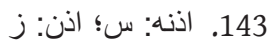

$$
\begin{aligned}
& \text { 144. ويحتاج: س؛ ما يحتاج: ز }
\end{aligned}
$$

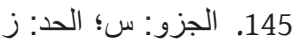

$$
\begin{aligned}
& \text { 146. او الين: ز؛ و اللين: س }
\end{aligned}
$$


مقصـر ا و الارفـاد و العنايــة والبـذل ليـس دفعـة واحـدة وغيـر دفعـات و لا متفو اتـا وغير منصـل اذ كان يتسـع الامـكان ويساعد اليسر 147 ولا يقاوم العشر.

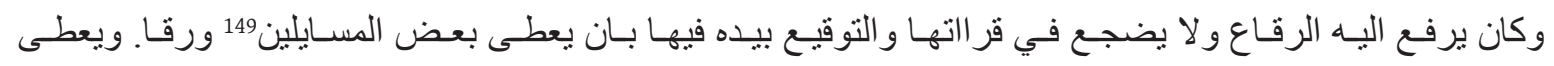

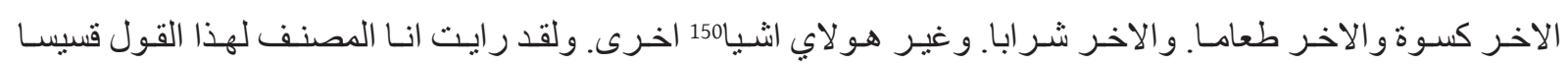

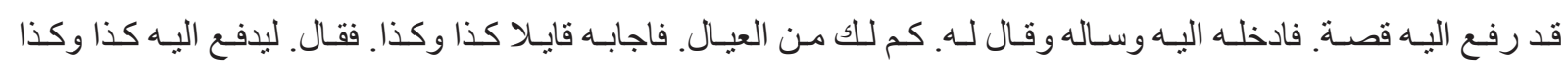

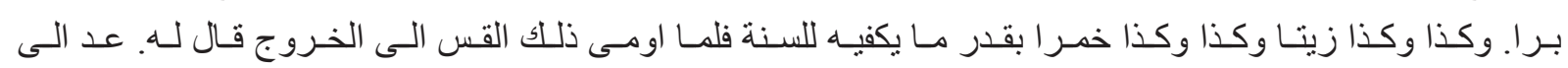

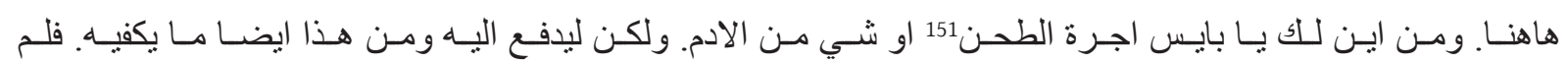
يتركه152 القديس ينصرف ومن اينى قام له بجميع ما يقنعه لسنته كلها.

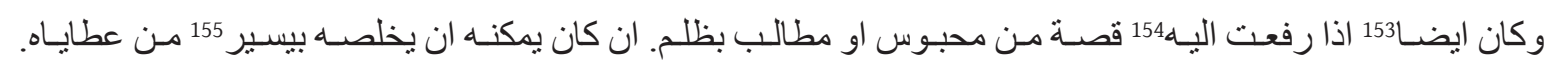

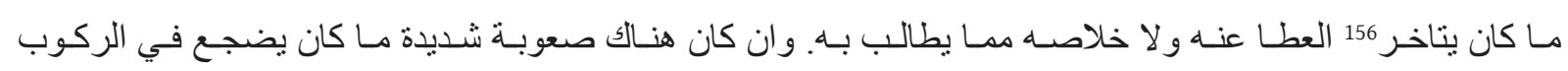

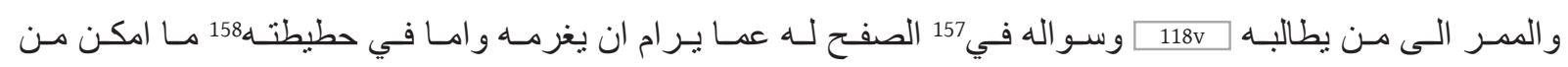

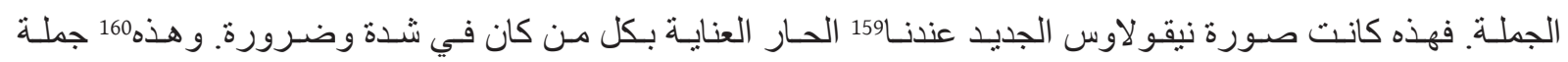
مما يستدل161 به على ما كان يفعله بنفسه وييذل معروفه.

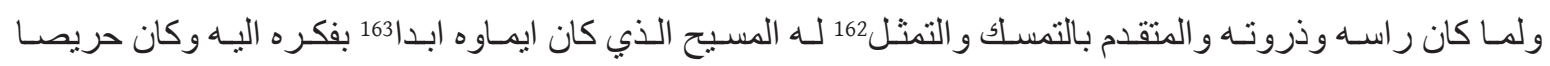

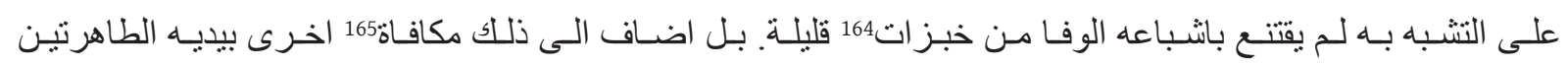

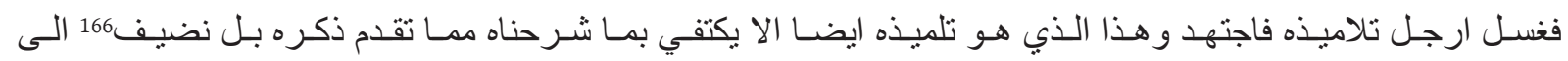

$$
\begin{aligned}
& \text { 147. اليسر: س؛ البشر: ز }
\end{aligned}
$$

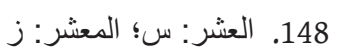

$$
\begin{aligned}
& \text { 149. المسايلين: س؛ المساكين: ز ز ز }
\end{aligned}
$$

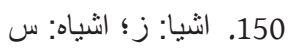

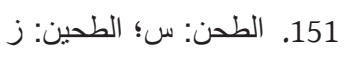

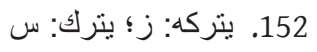

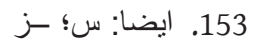

$$
\begin{aligned}
& \text { 154. اليه: س؛ اليه ايضا: زئ ز }
\end{aligned}
$$

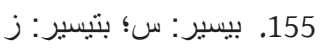

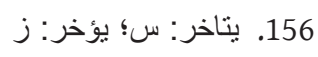

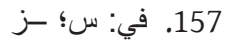

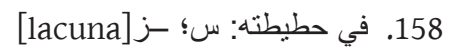

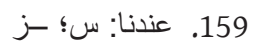

$$
\begin{aligned}
& \text { 160. و هذه: س؛ و هدم: ز ز } \\
& \text { 161. يستدل: س؛ بستبدل: ز ز ز } \\
& \text { 162. بالتمسك والتمثل: س؛ بـ بالتمثل: ز ز } \\
& \text { 163. ايماوه ابدا: س؛ دايما مؤيدا: زئ زئل }
\end{aligned}
$$

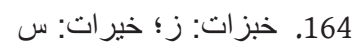

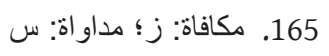

$$
\begin{aligned}
& \text { 166. نضيف: س؛ يضيف: ز ز }
\end{aligned}
$$




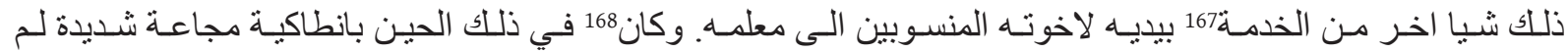

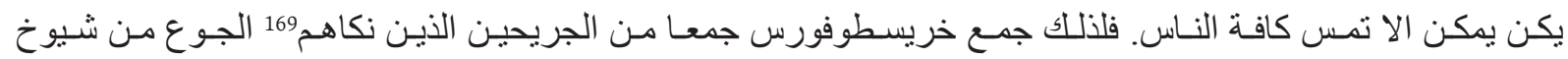

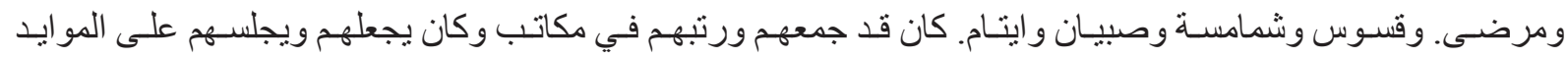

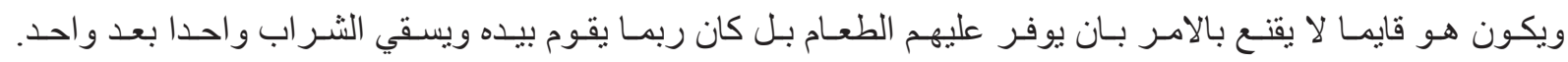

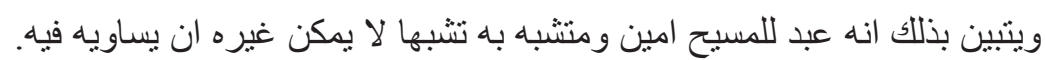

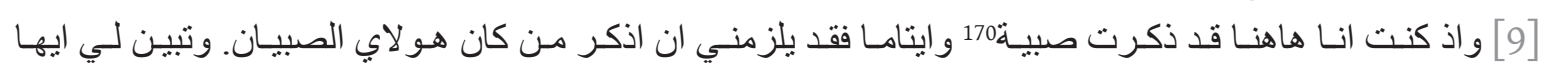

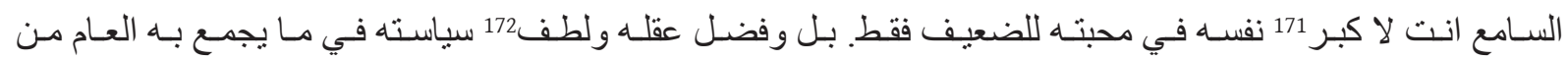

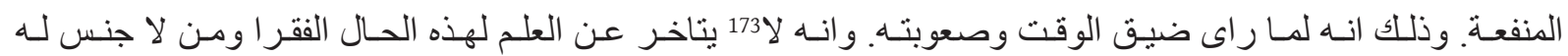

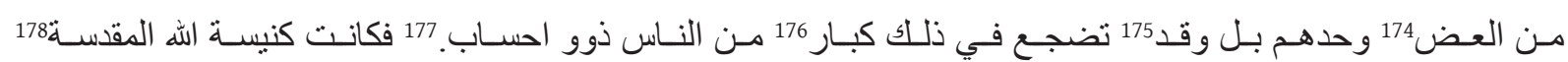

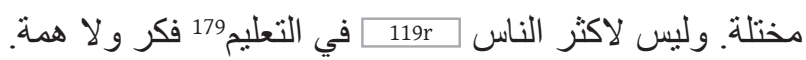

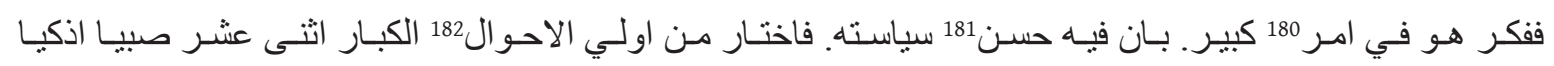

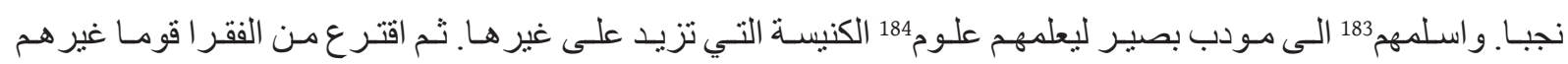

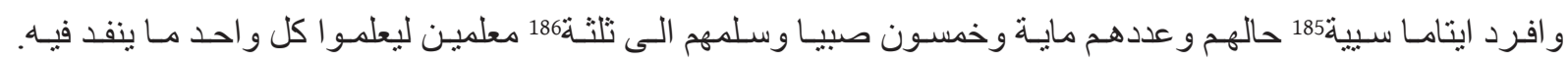

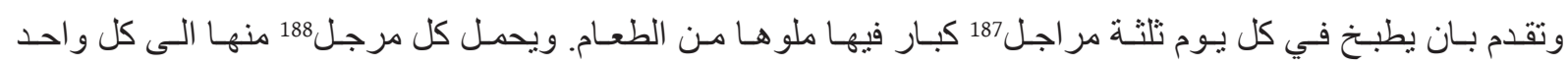

$$
\begin{aligned}
& \text { 167. الخدمة: س؛ المدنية: ز }
\end{aligned}
$$

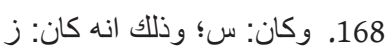

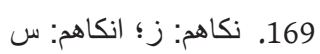

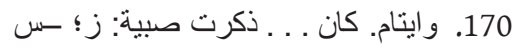

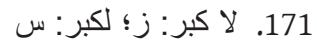

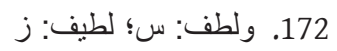

$$
\begin{aligned}
& \text { 173. لا: س؛ لا يتيه ولا: زل زل زل }
\end{aligned}
$$

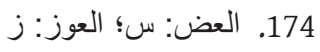

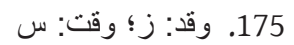

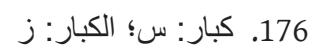

$$
\begin{aligned}
& \text { 177. احساب: س؛ الاحساب: ز ز }
\end{aligned}
$$

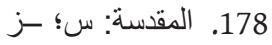

$$
\begin{aligned}
& \text { 179. التعليم: س؛ العلم: ز ز }
\end{aligned}
$$

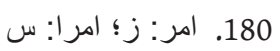

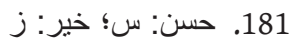

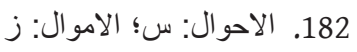

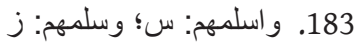

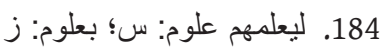

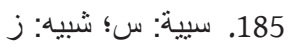

$$
\begin{aligned}
& \text { 186. تلثة: س؟ - سز }
\end{aligned}
$$

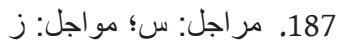

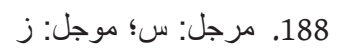

Al- 'Ușūr al-Wusțā 29 (2021) 


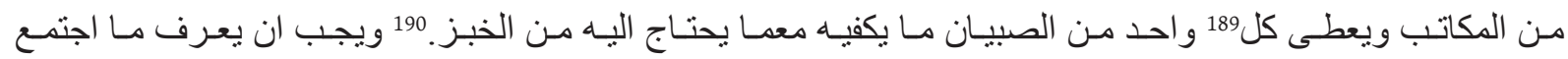

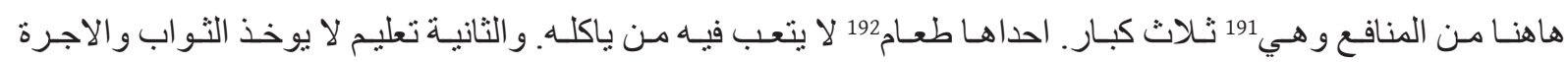

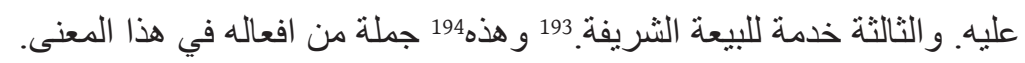

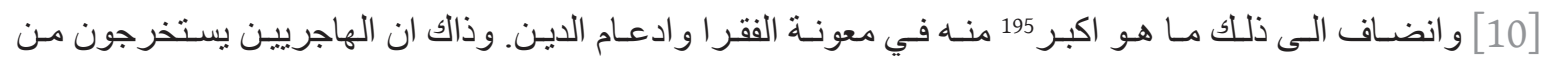

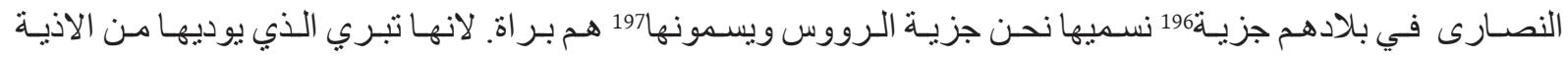

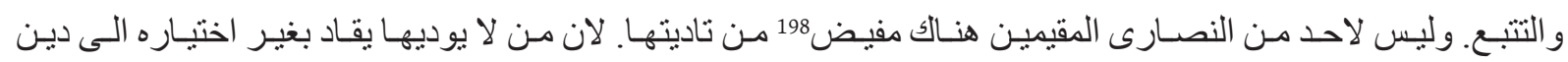

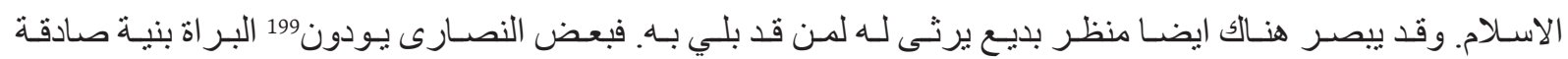

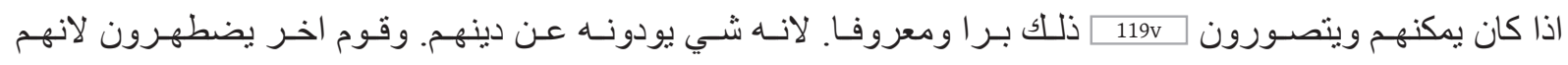

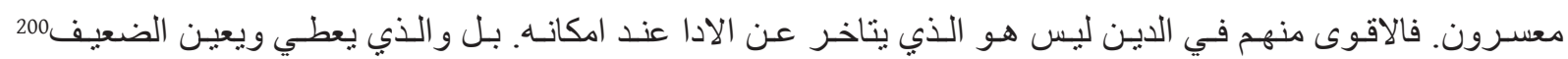
فيما يستادى منه.

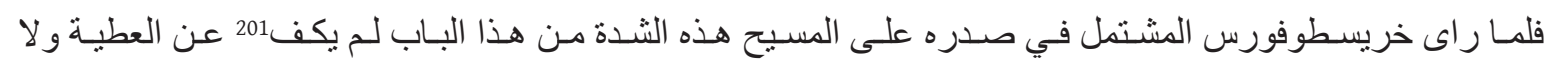

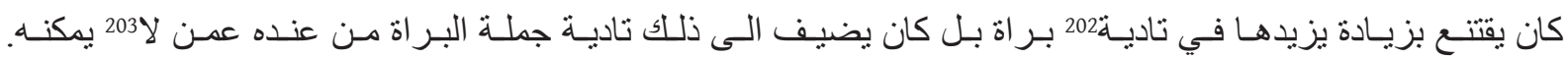

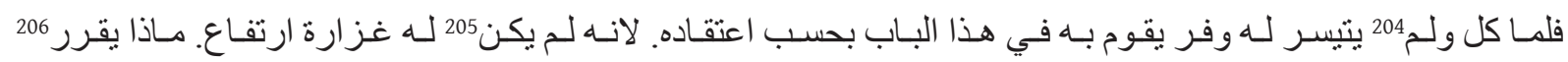

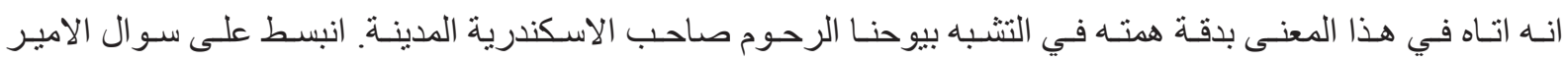

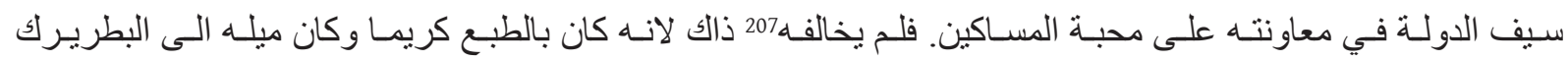

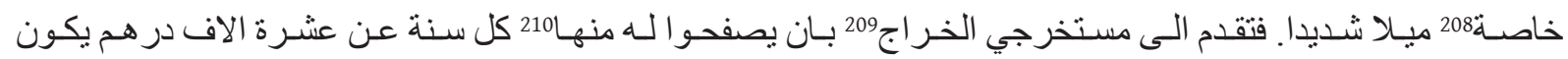

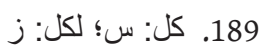

$$
\begin{aligned}
& \text { 190. الخبز: ز؛ الخير: سل سل }
\end{aligned}
$$

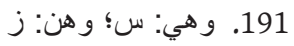

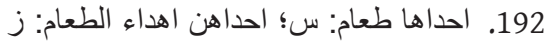

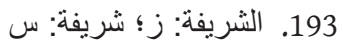

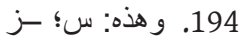

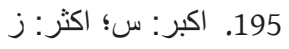

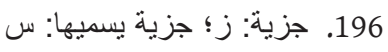

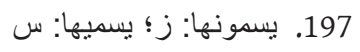

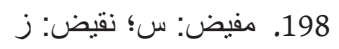

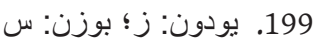

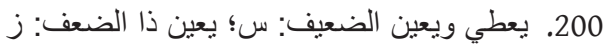

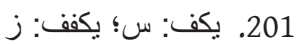

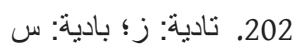

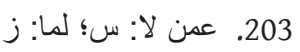

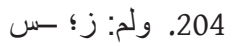

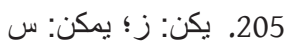

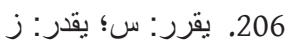

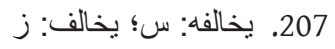

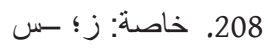

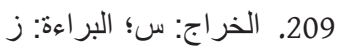

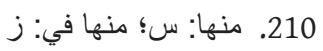




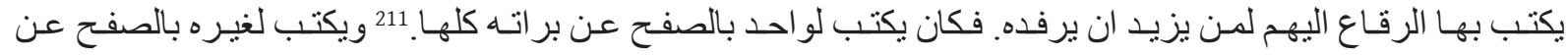

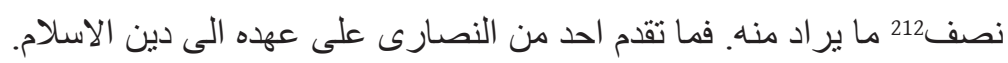

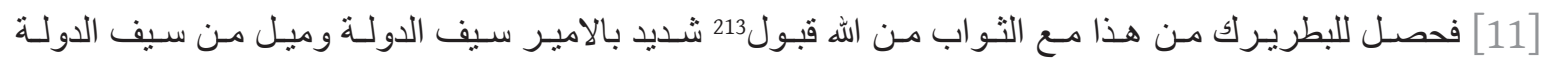

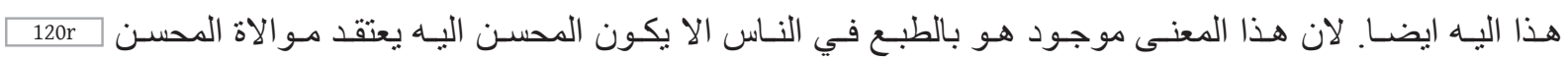

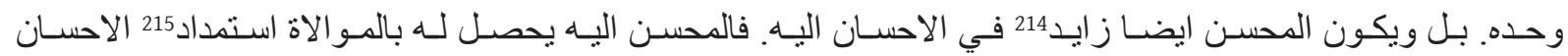

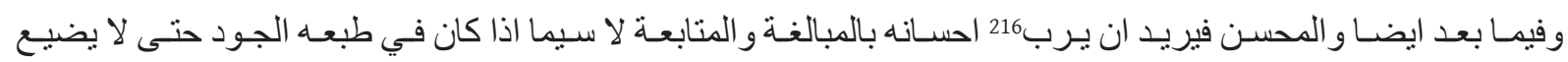
ما تقدم من احسانه بالامساك.

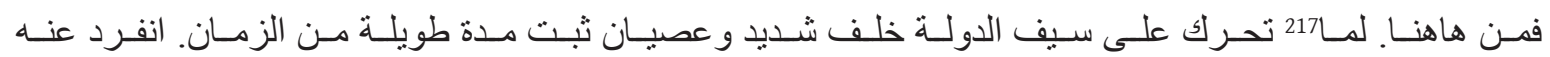

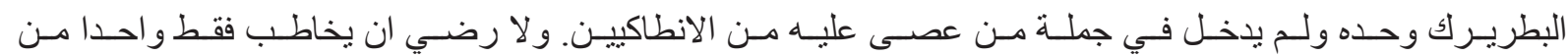
المتمردين.

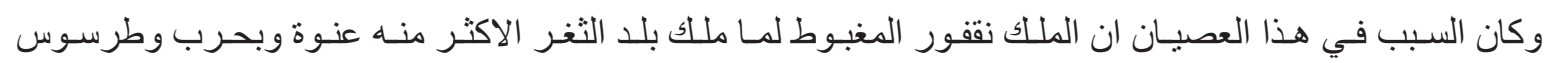

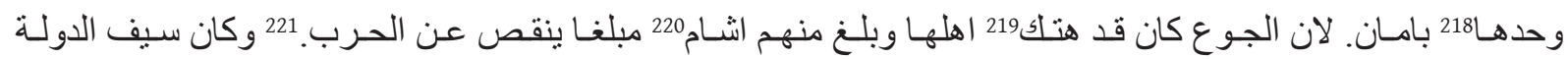

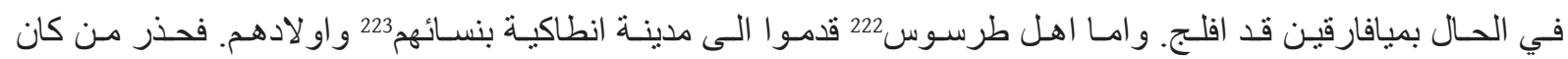

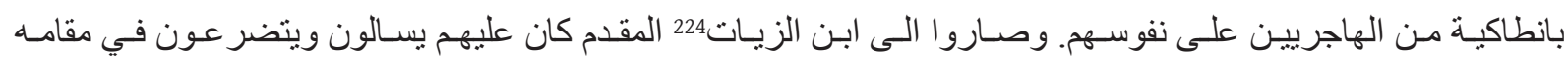

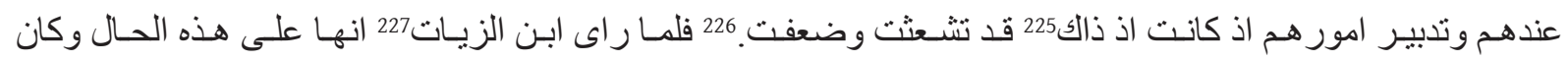
جز عهد28 من نققور الملك يكره. 229 امتنع من المقام بالكلية.

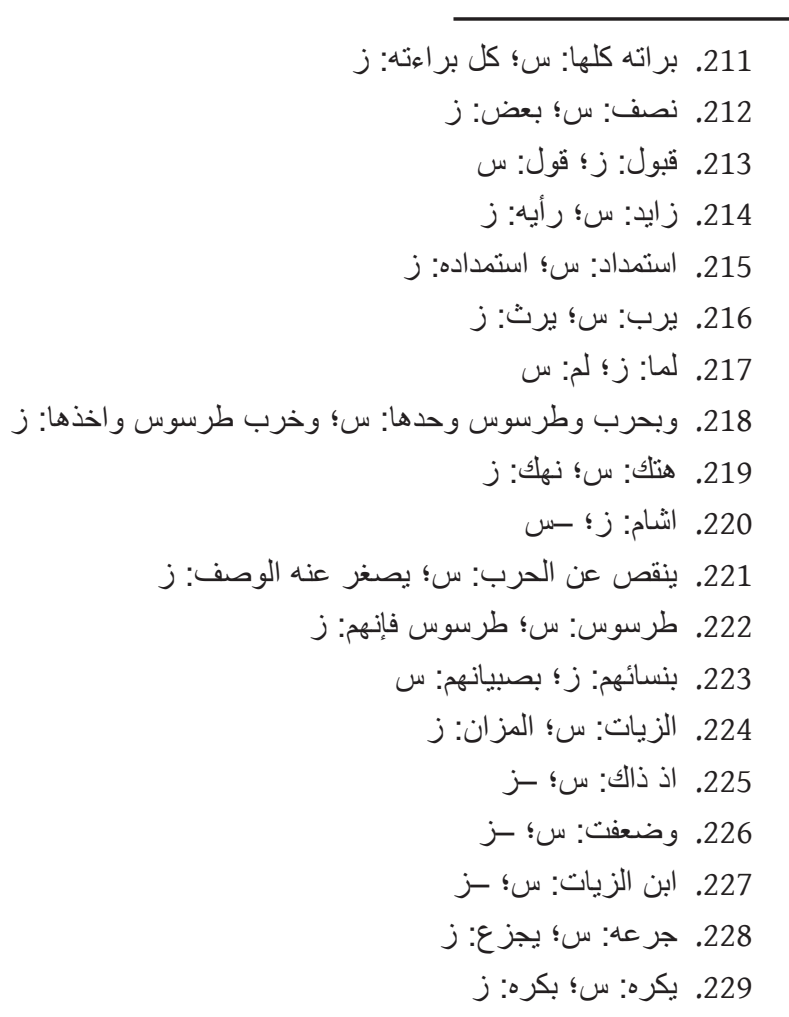

Al- 'Ușūr al-Wusțā 29 (2021) 


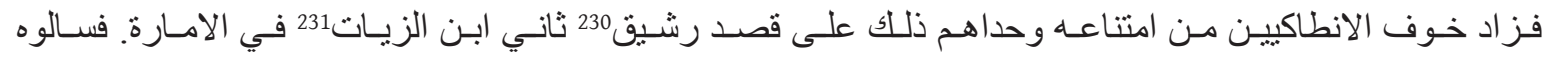

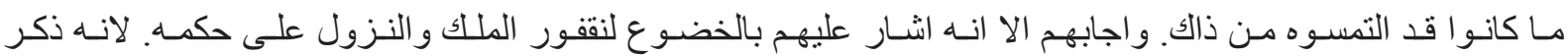

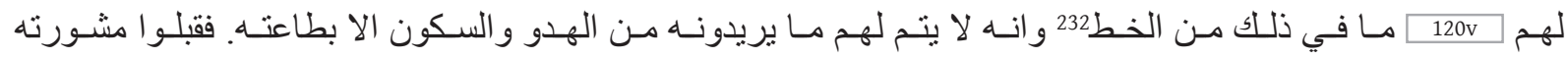

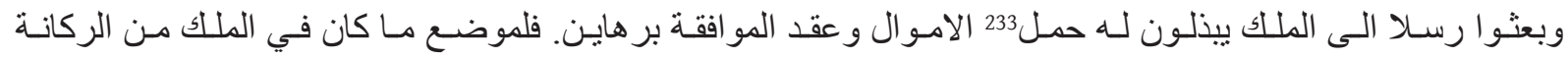

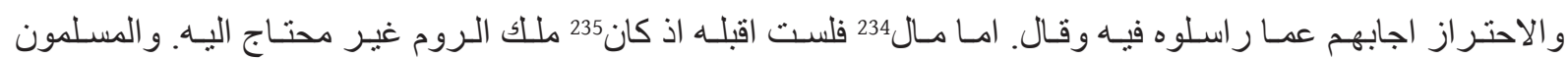

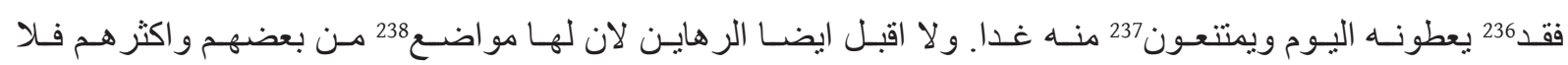

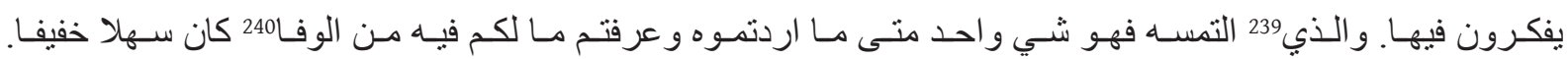

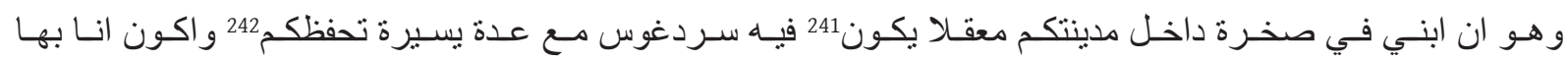

\section{مستظهر ا.}

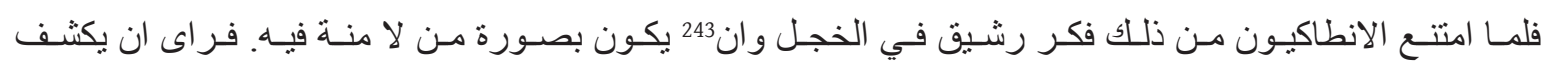

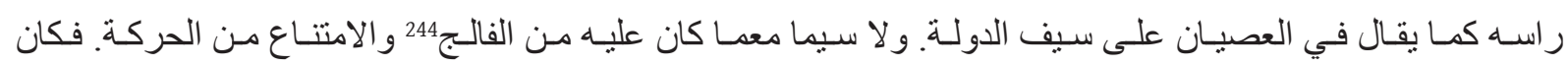

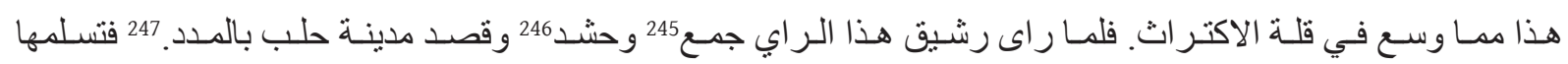

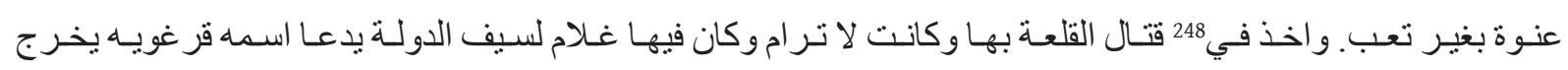

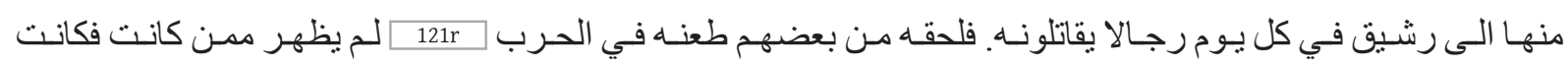

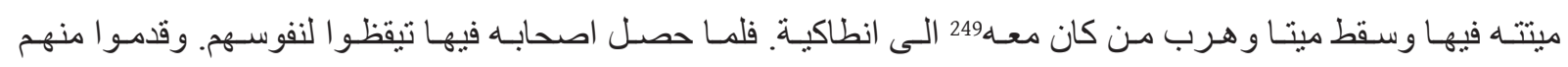

$$
\begin{aligned}
& \text { 230. رشيق: س؛ رشيق النسيمي الوارد من طرسوس وكان: ز }
\end{aligned}
$$

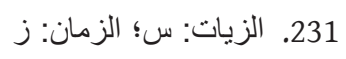

$$
\begin{aligned}
& \text { 232. الخط: س؛ الخطأ: ز ز }
\end{aligned}
$$

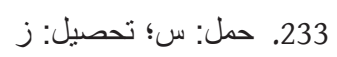

$$
\begin{aligned}
& \text { 234. مال: س؛ المال: ز ز }
\end{aligned}
$$

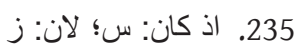

$$
\begin{aligned}
& \text { 236. فقد: ز؛ فقد فقد: سل سل سن }
\end{aligned}
$$

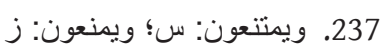

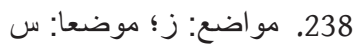

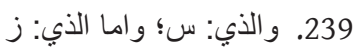

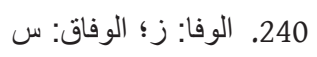

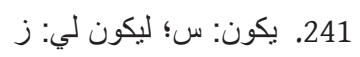

$$
\begin{aligned}
& \text { 242. تحفظك: س؛ تحفظهم: ز ز } \\
& \text { 243. وان: س؛ و وانه: ز ز }
\end{aligned}
$$

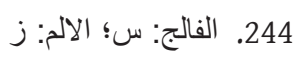

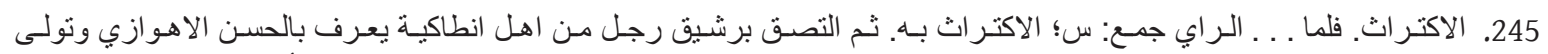

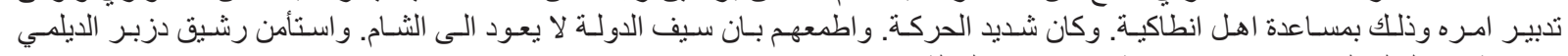

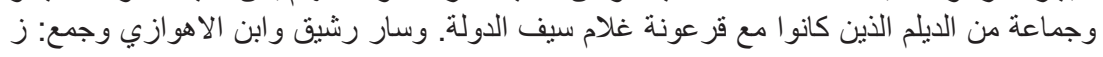

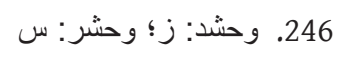

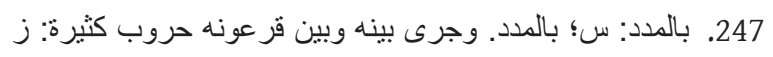

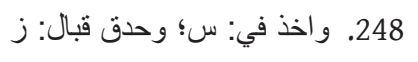

249. وكانت ل ا . . كان معه: س؛ ثلثة اشهر وعشرة ايام. فقتل رشيق بعد ذلك بطعنة اصابته وانهزم اصحابه: ز 


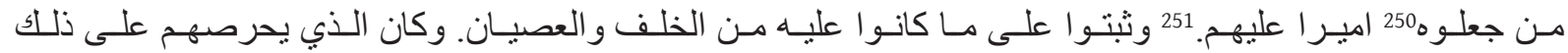

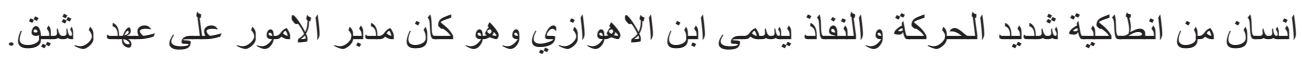

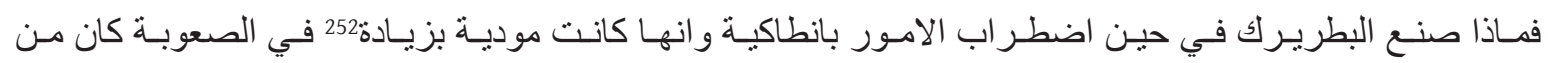

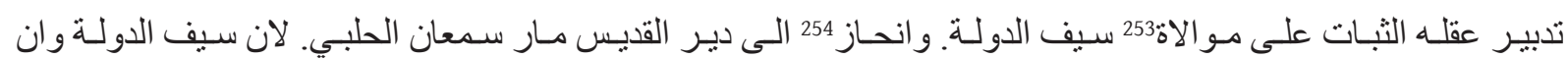

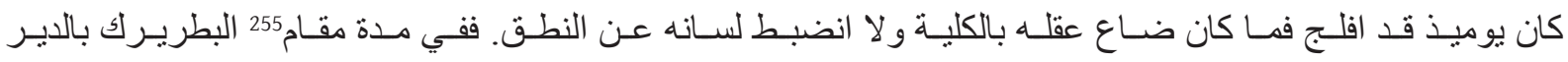

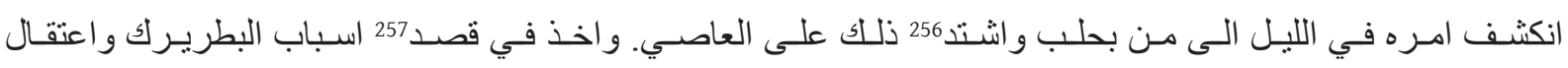

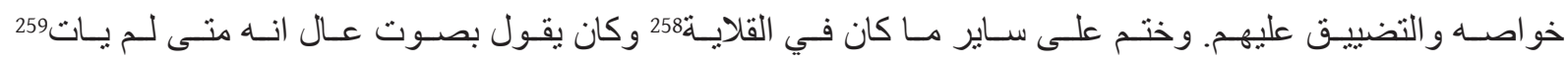

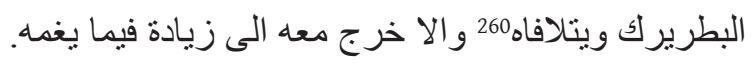

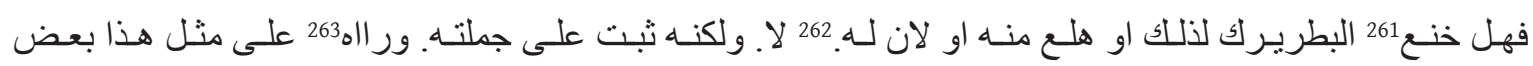

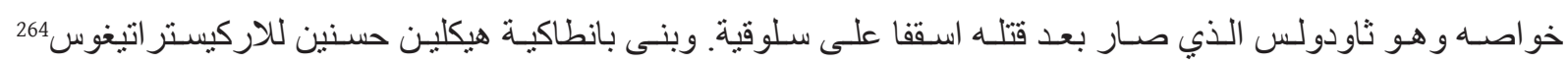

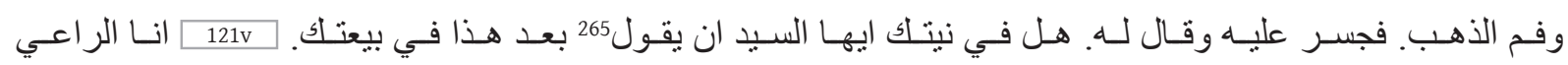

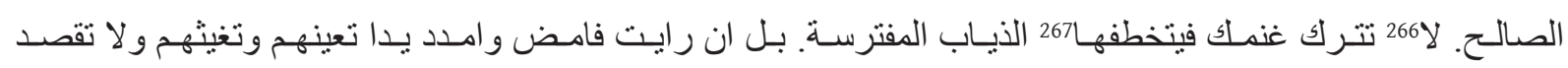

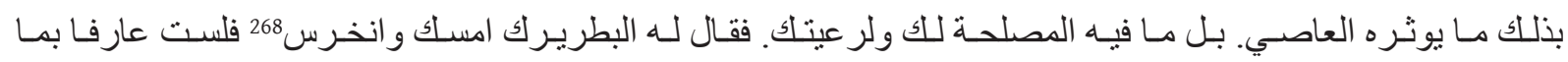
تقوله. فلزمه الامساك.

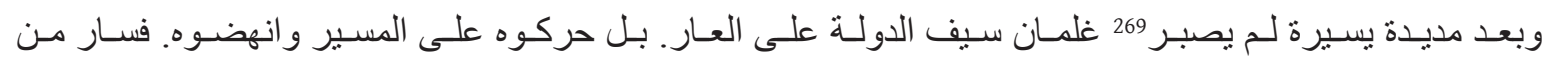

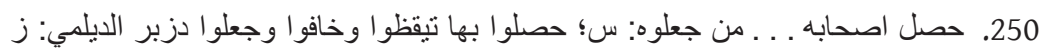
251. عليهم: س؛ عليهم وابن الاهوازي المدبر له: ز ز

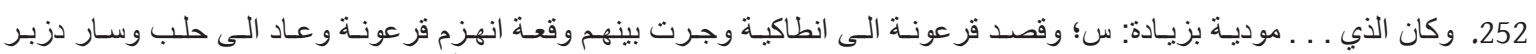

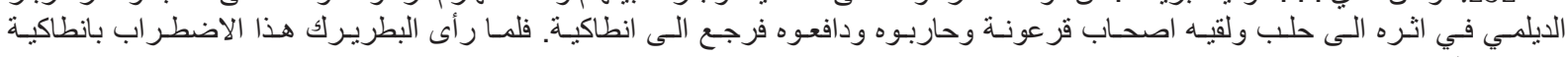

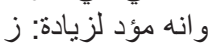

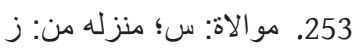

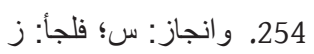

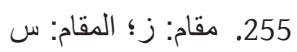

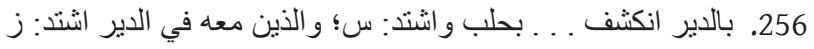

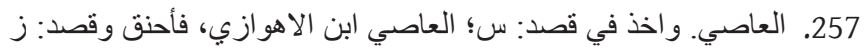

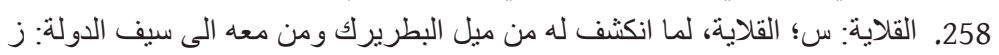

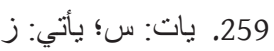

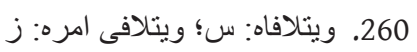

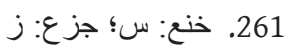

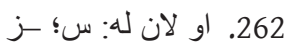

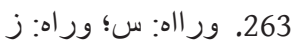

264. للاركيستر اتيغوس: صححته؛ للاكسير اتيقوس: س؛ الازكسعوطس: ز

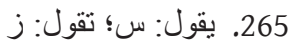

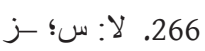

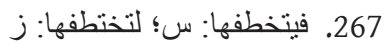

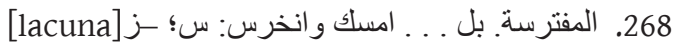

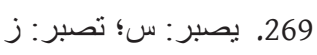

Al- 'Ușūr al-Wusțā 29 (2021) 
ميافارقيـن الـى نواحسي معـرة مصريـن. و انتشـبت الحـرب فيمـا بيـن الفيتيـن. وكان الظفر لسـيف الدولـة. واسـر روســا عسكر الخوارج وحصلهم 270 في القيود و السلاسل.

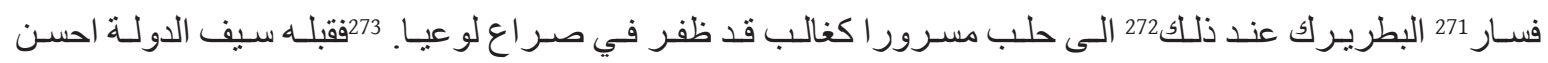

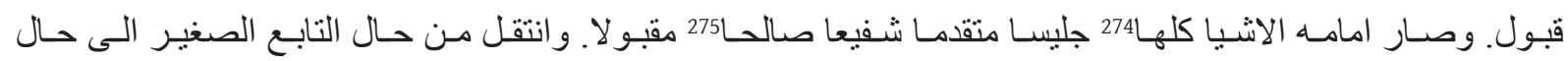

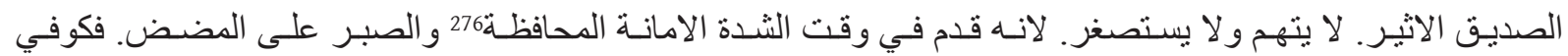

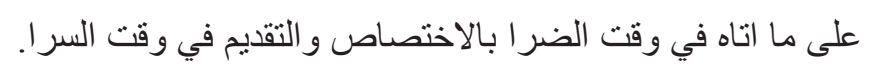

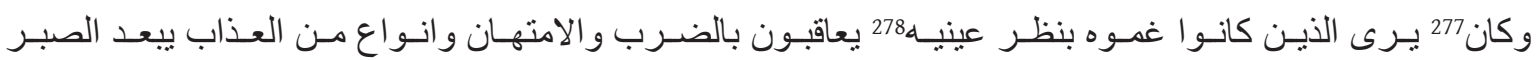

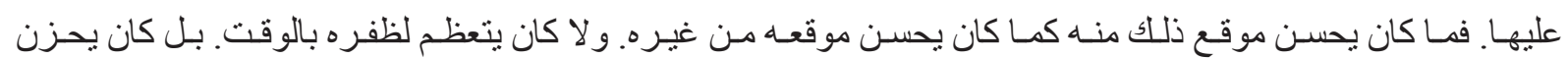

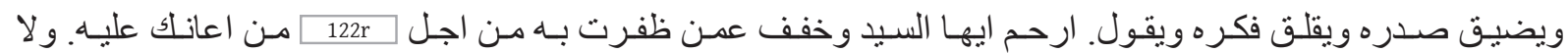

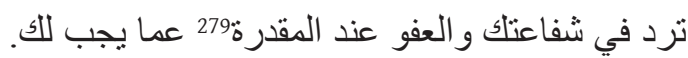

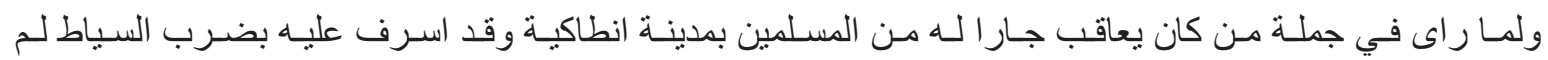

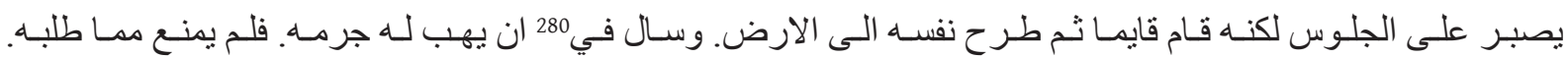

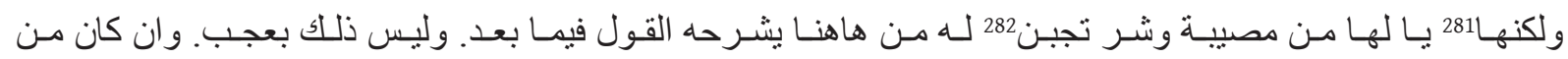

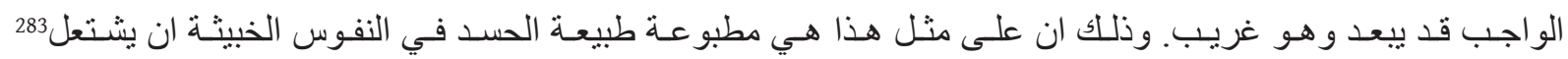

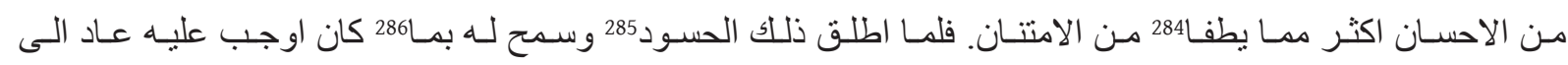
انطاكية بريا من التبعة. 287 وليت ذلك لم يكن. 288

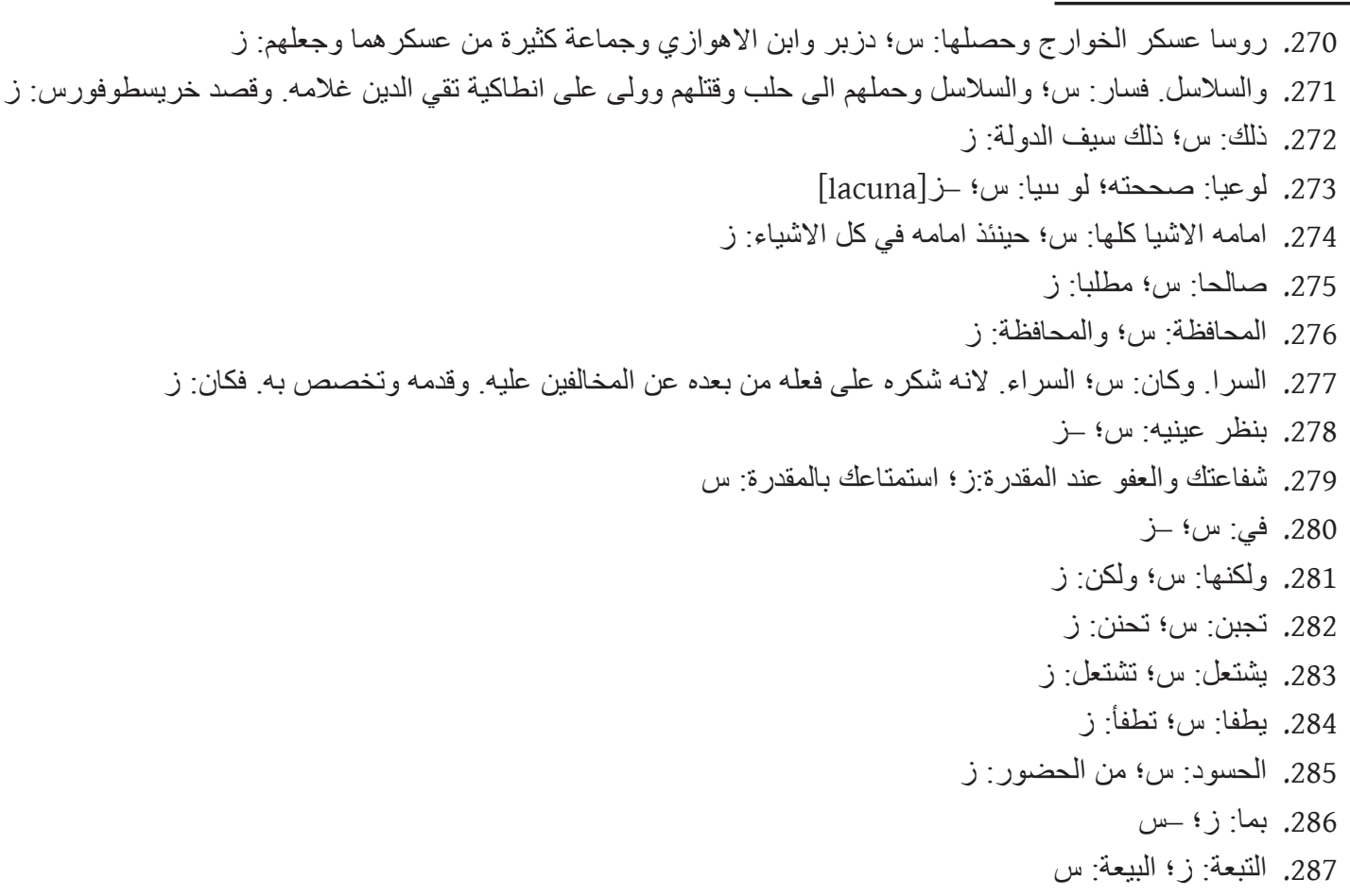

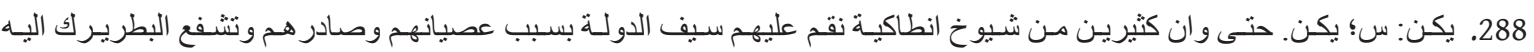

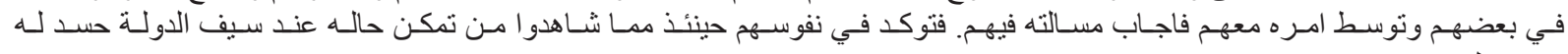
وحقد عليه: ز فيمتر 


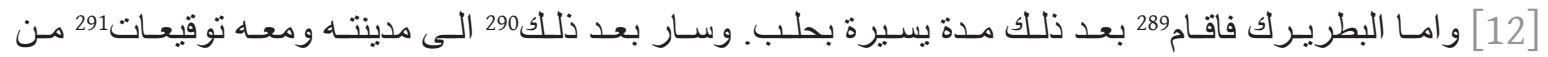

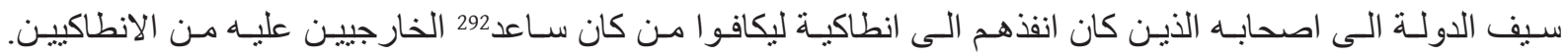

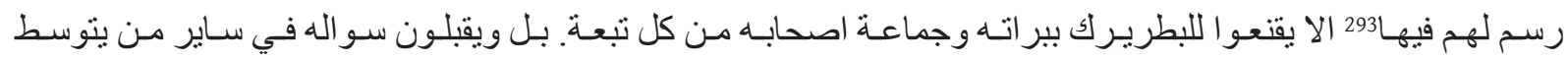
امره بمقدار ما يمكن القبول منه. لان مثل هذا كان غرض

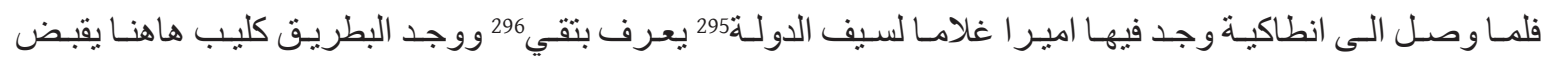

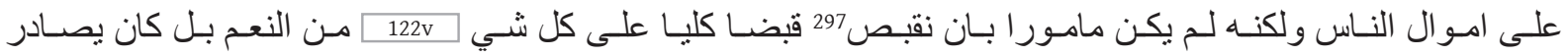

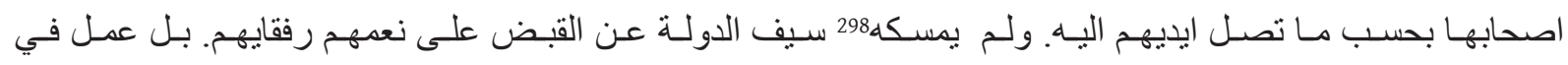

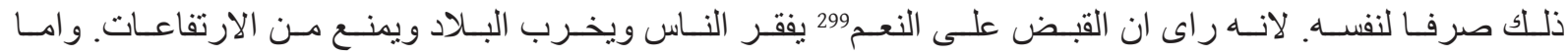

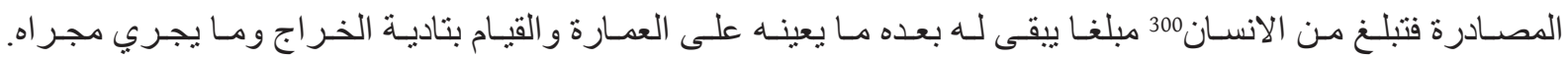

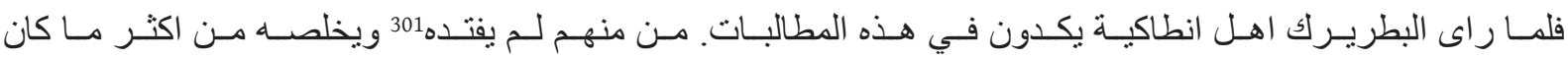

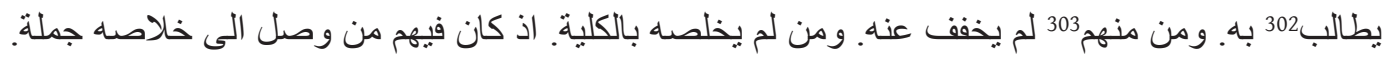

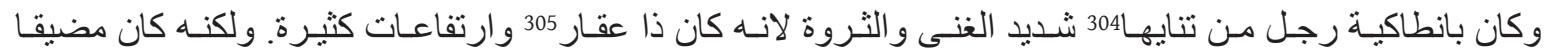

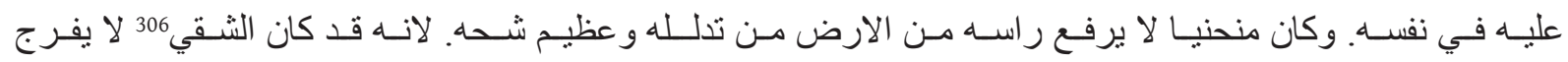

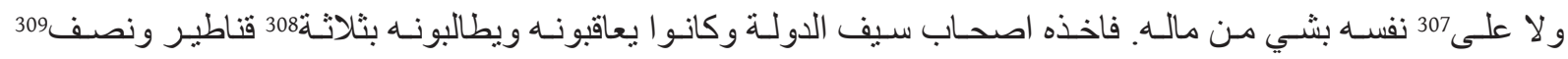

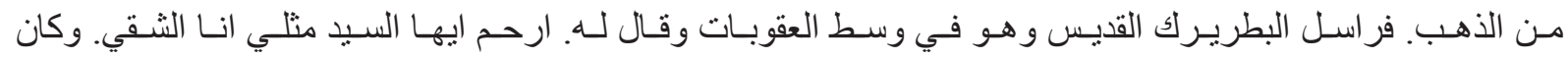

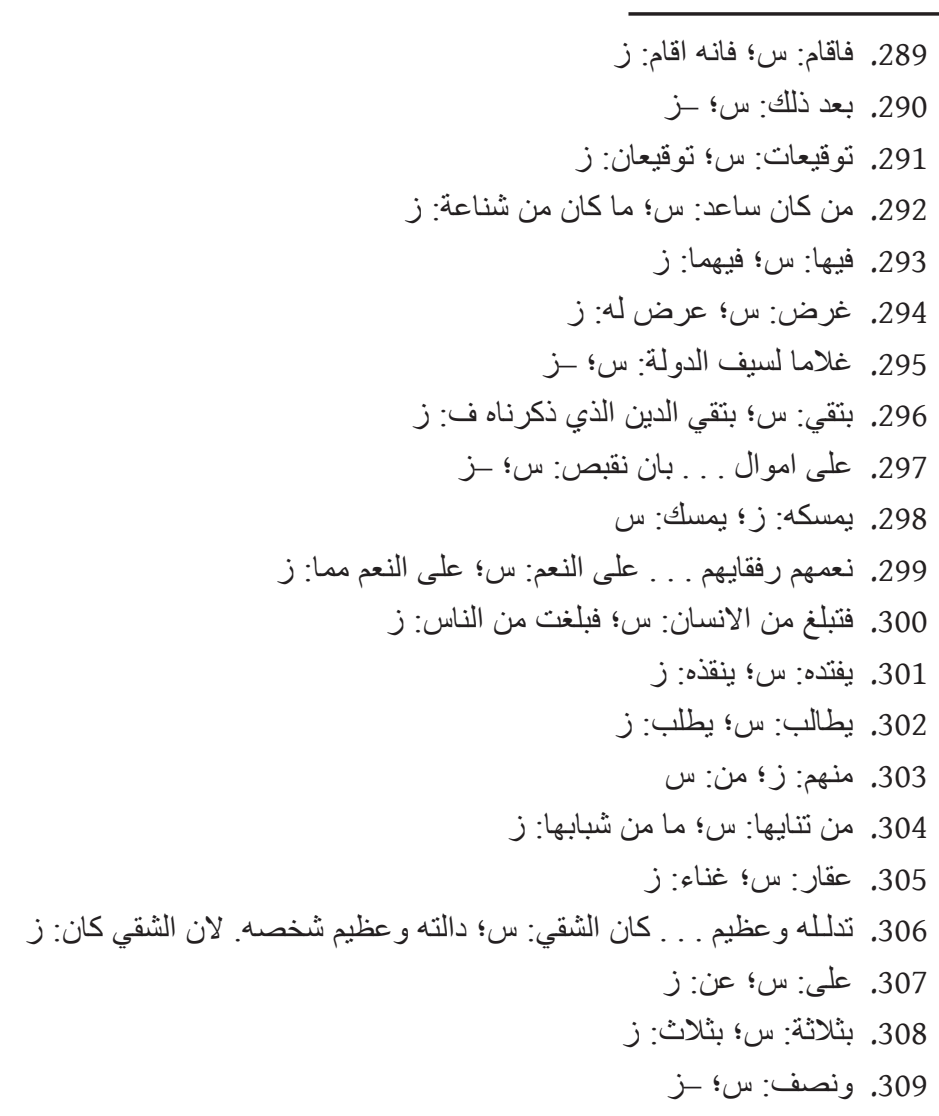

Al- 'Ușūr al-Wusțā 29 (2021) 


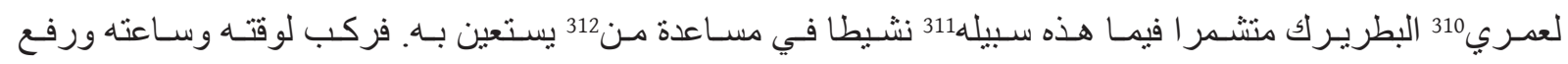

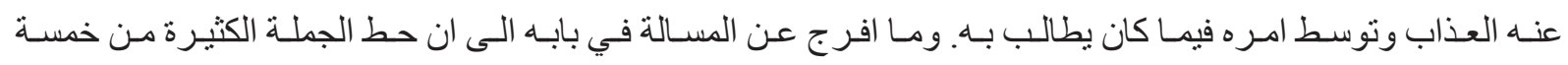

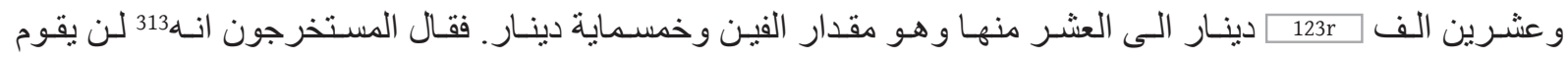

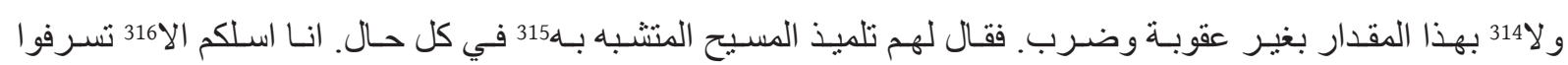

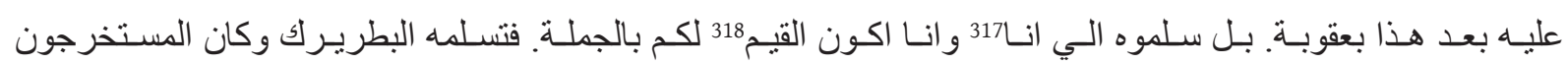

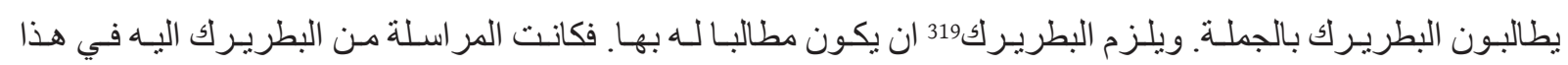

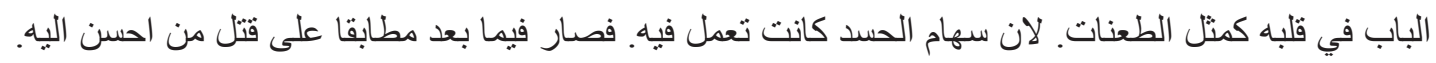

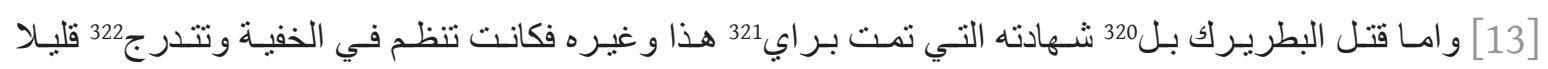

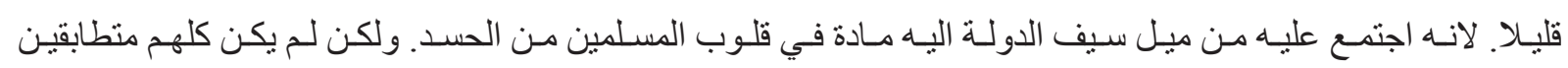

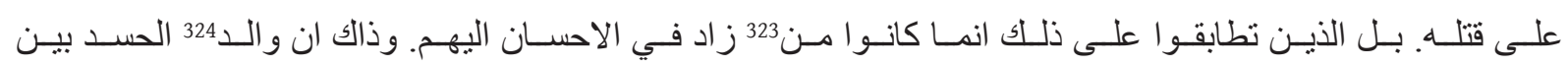
فيهم فعله. 325

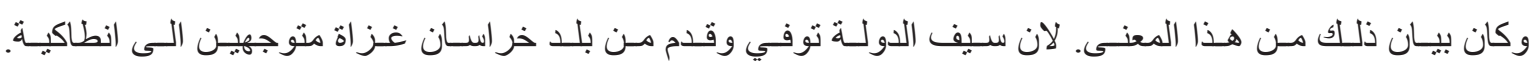

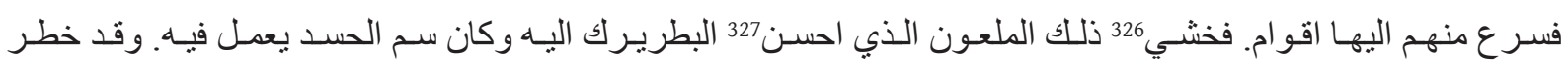

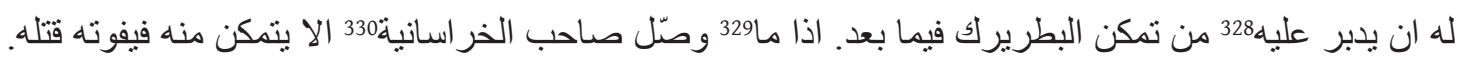

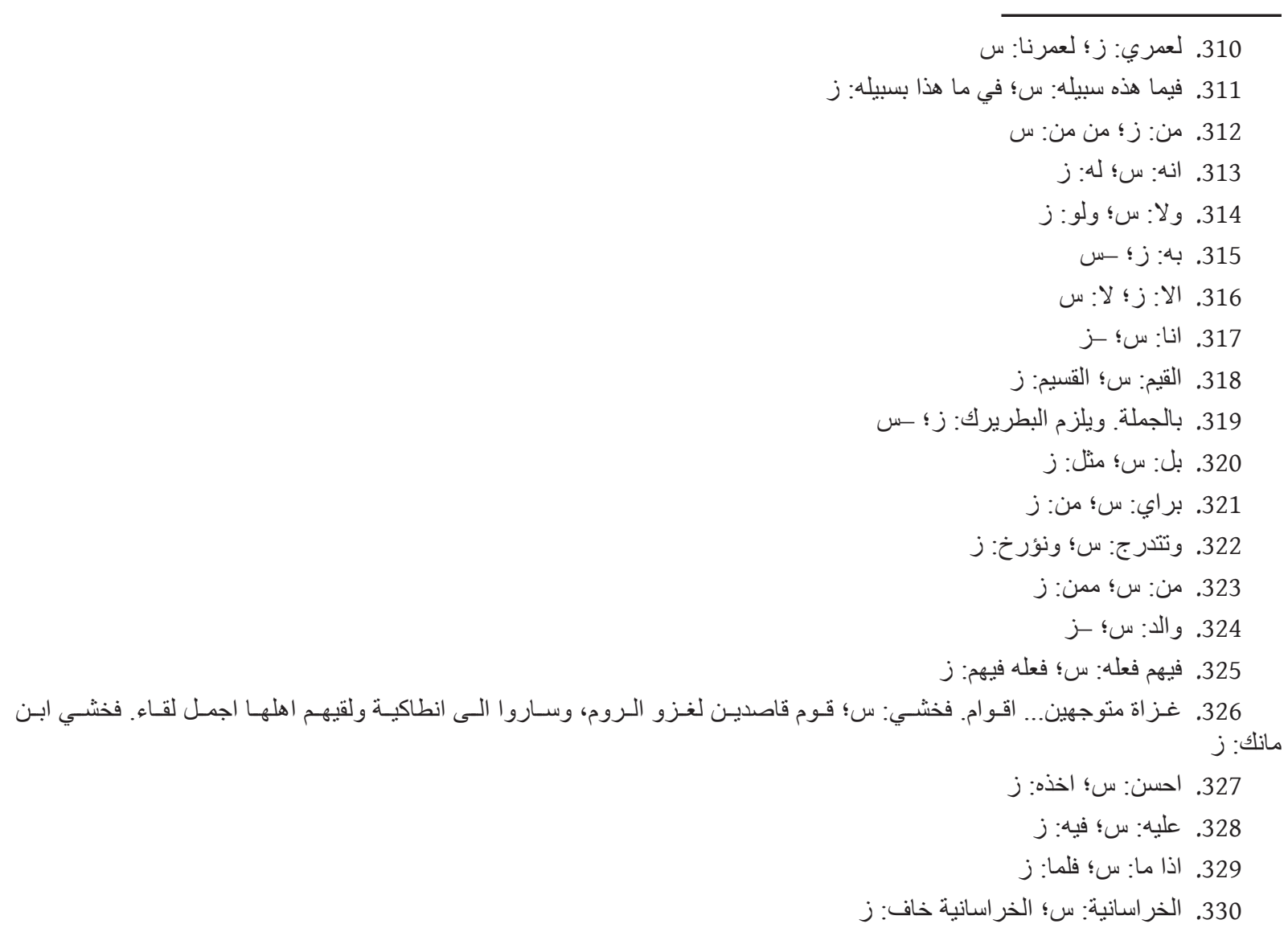

Al-`Ușūr al-Wusțā 29 (2021) 


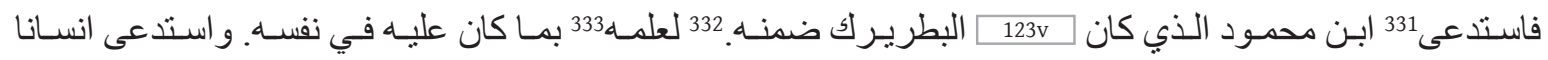

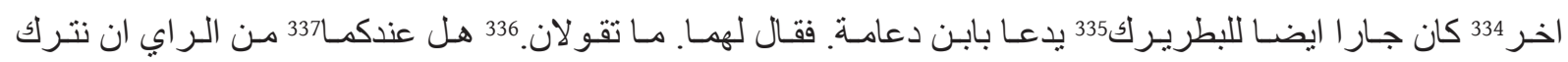

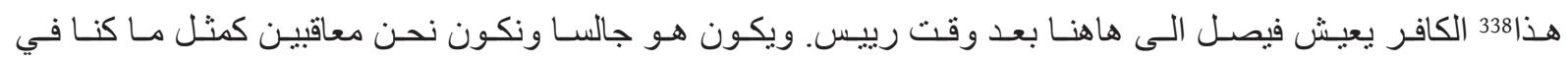

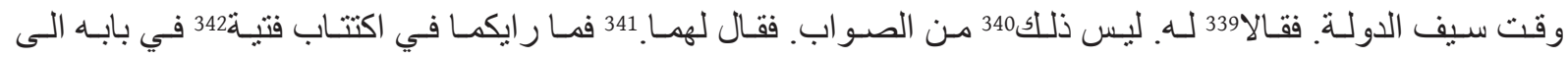

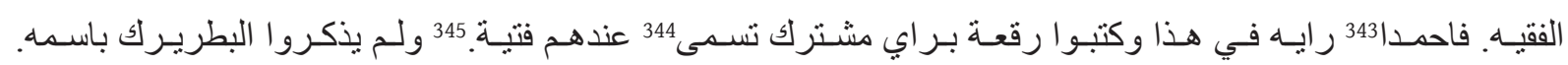

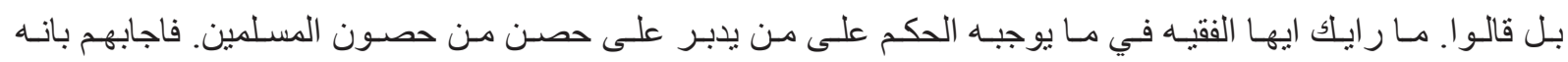
يجب عليه القتل.

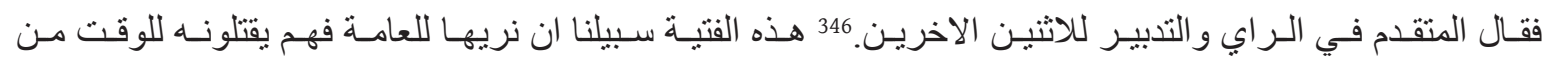

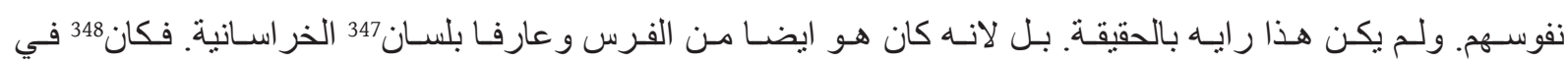

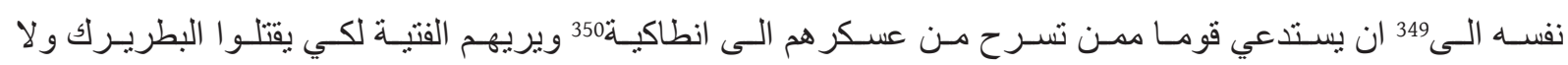

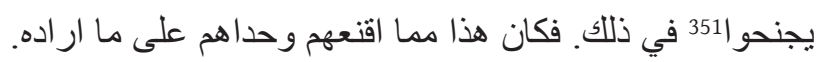

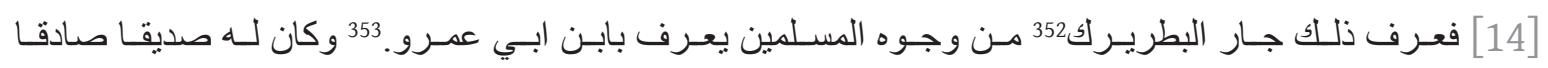

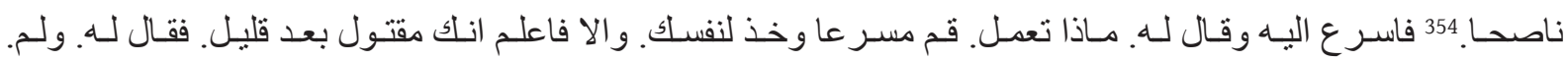

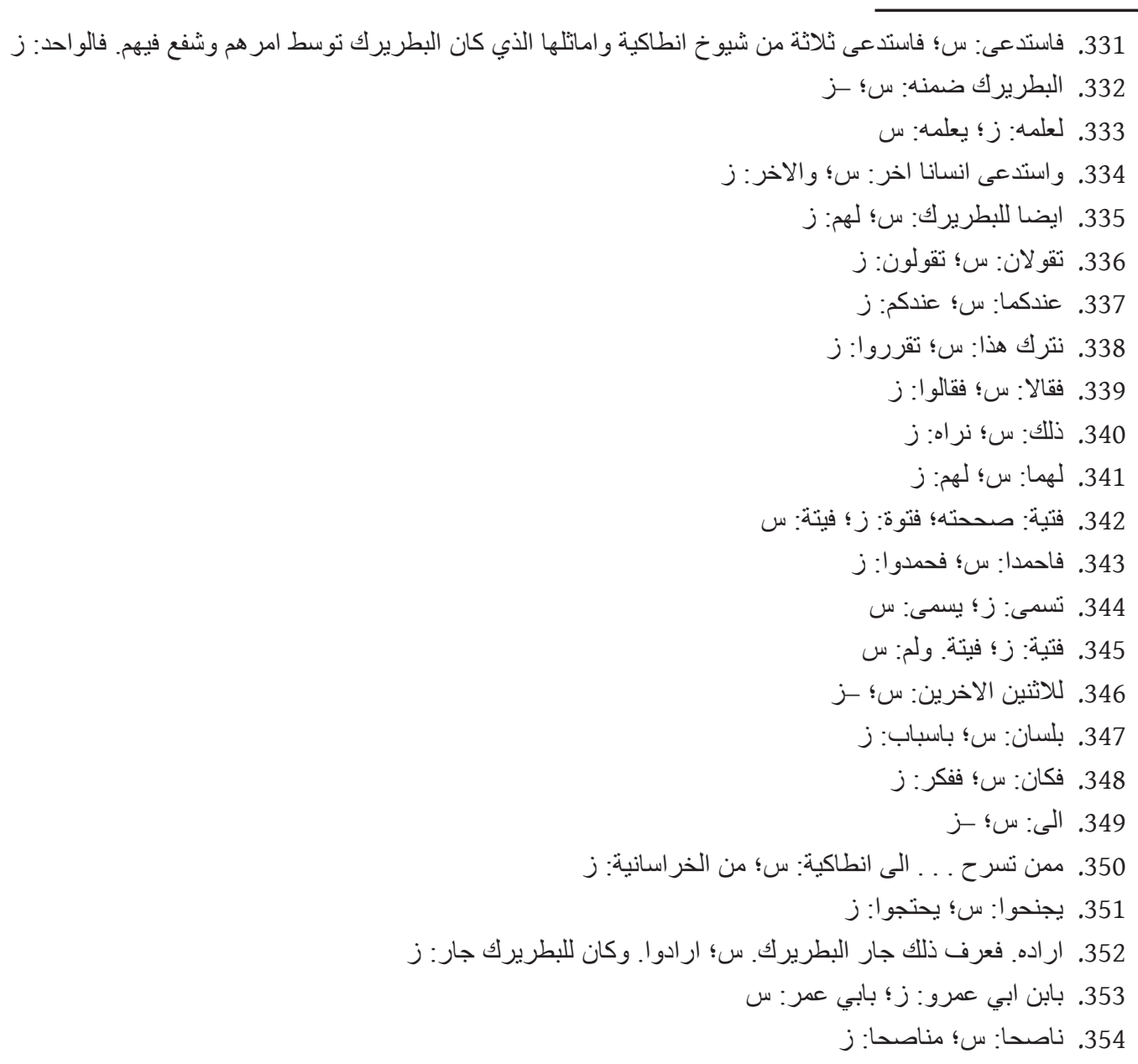

Al-'Ușūr al-Wusțā 29 (2021) 


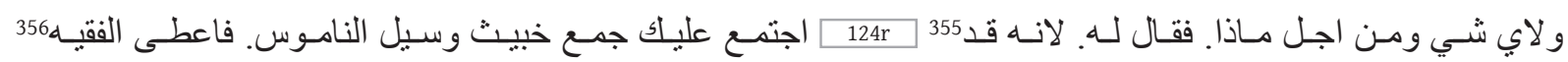

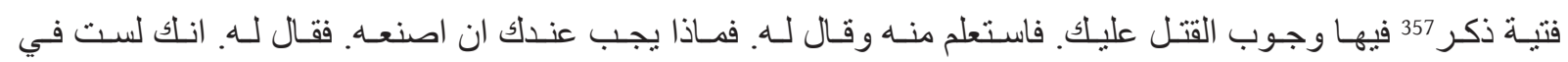

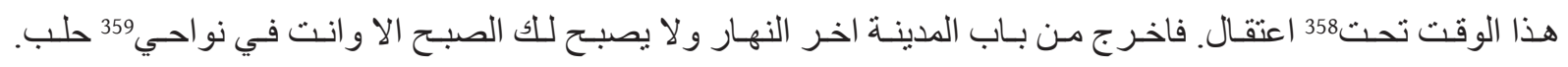

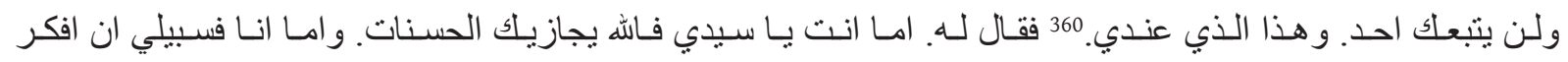
فيما اعمله.

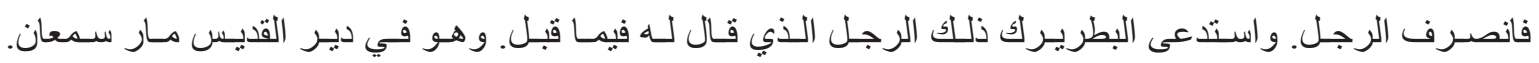

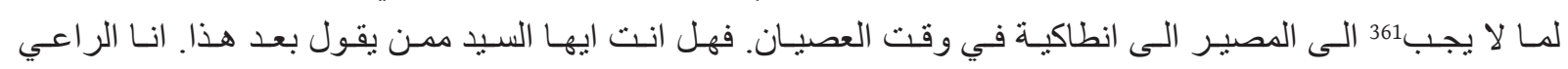

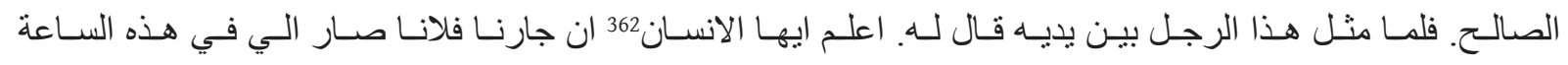

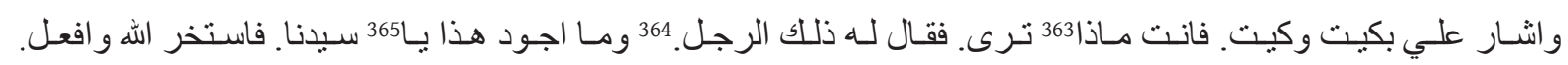

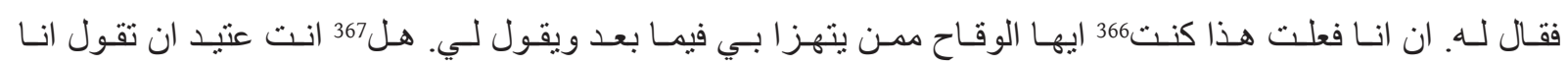

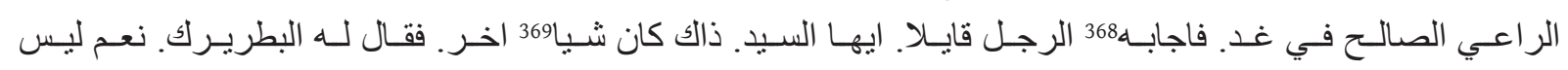

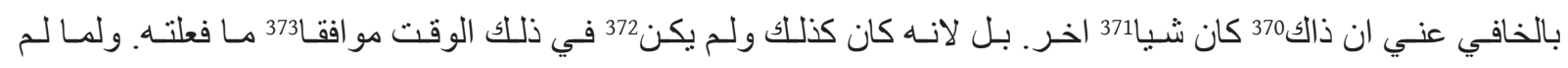

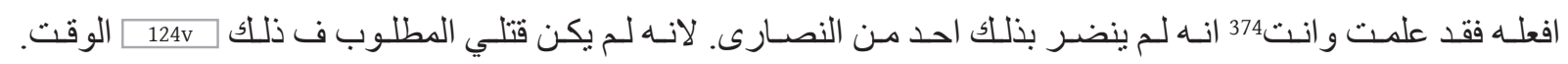

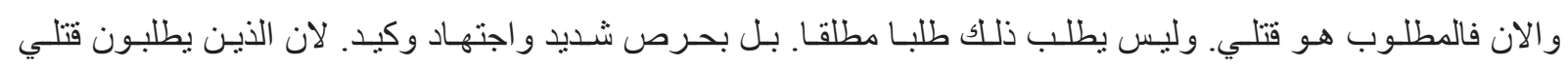

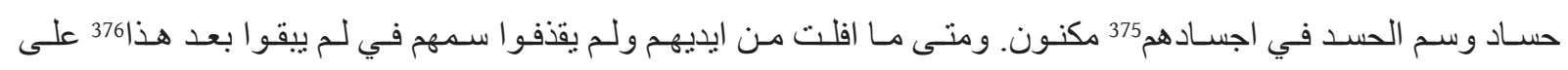

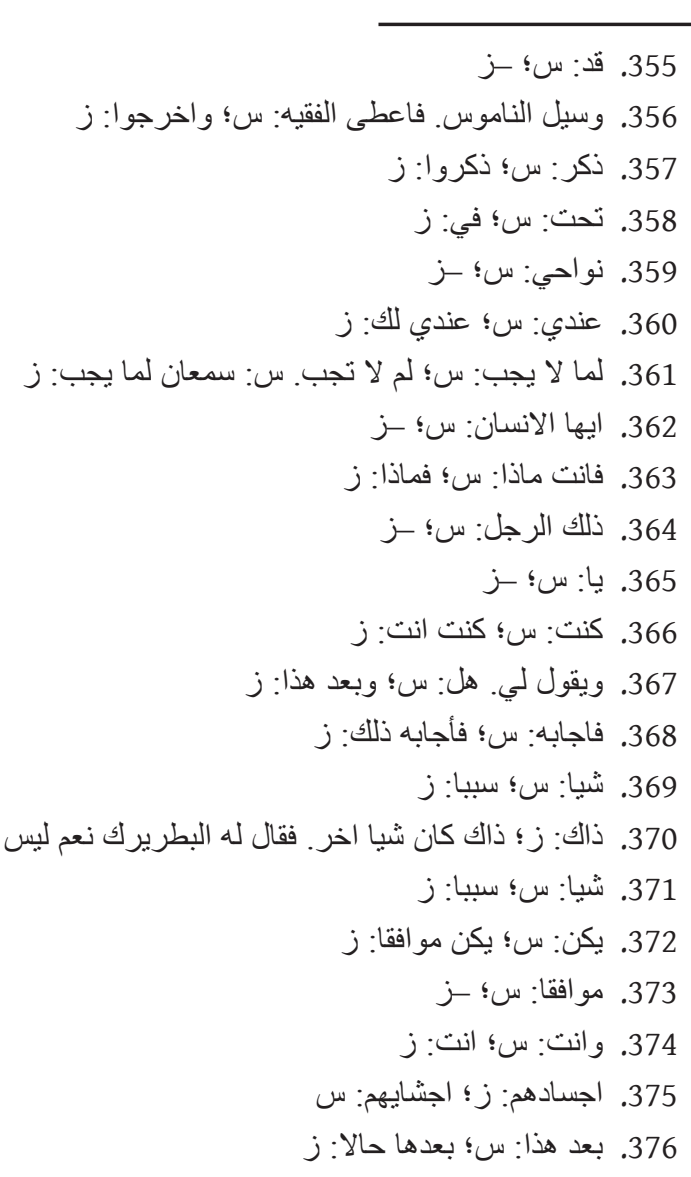

Al-`Ușūr al-Wusțā 29 (2021) 
نصر انـي و لا على كنيسـة. ولكن هذا الوقت377 الذي يجب 378 لـي379 ان اقول380 يـا هذا. ليس انـا الر اعي الصلالـح فقط.

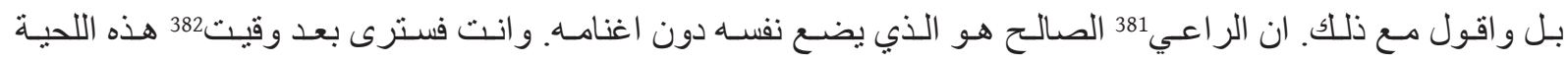

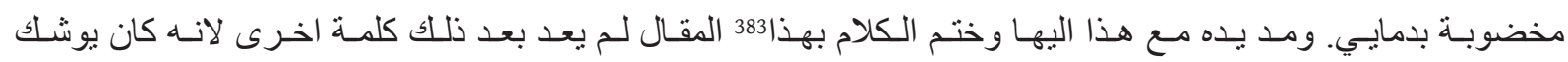
انه قد تشور 384 من الفكر.

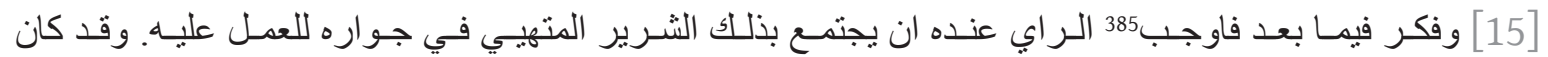

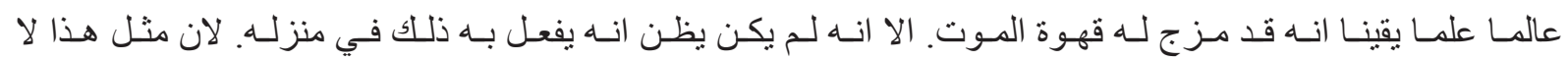

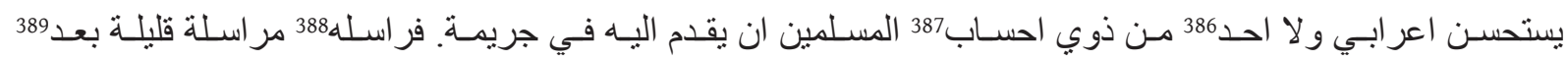

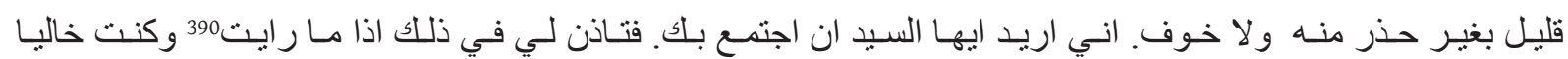

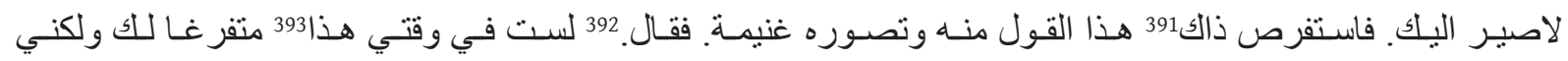

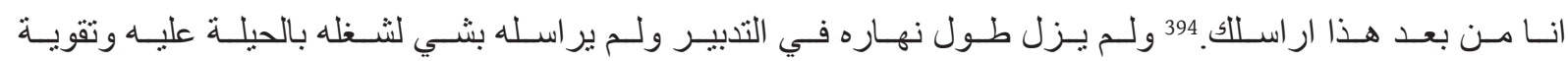
ما يطبخه له.

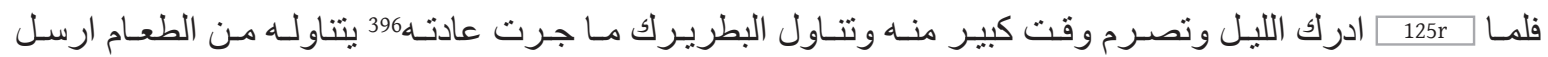

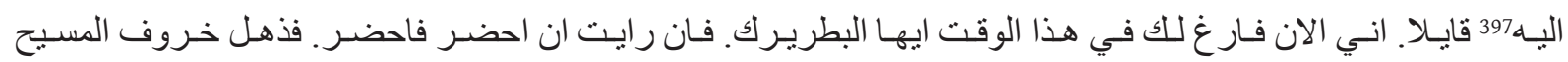

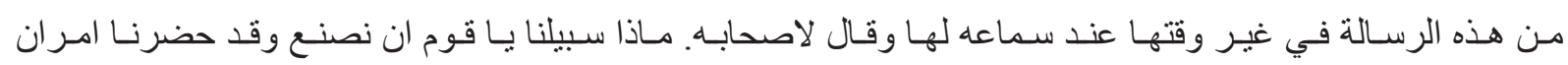

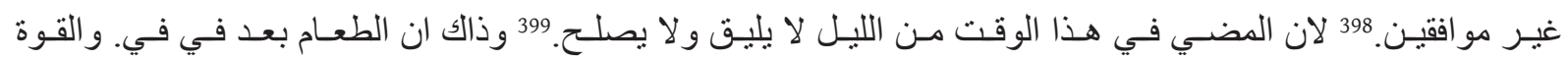

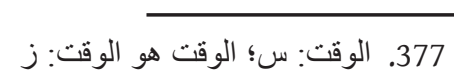

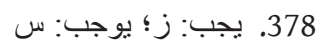

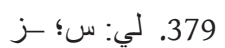

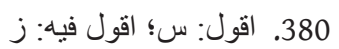

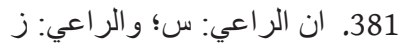

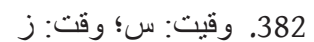

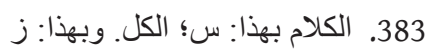

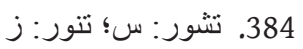

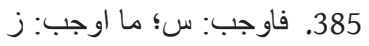

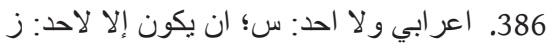

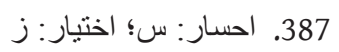

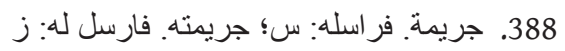

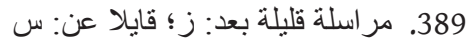

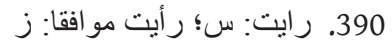

$$
\begin{aligned}
& \text { 391. فاستفرص ذالك: س؛ فلما سمع ابن مانك ذلك استفرص: ز ز }
\end{aligned}
$$

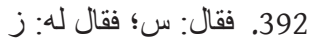

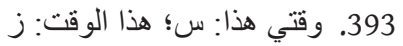

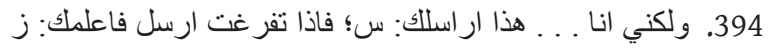

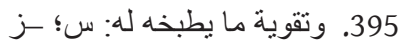

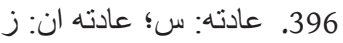

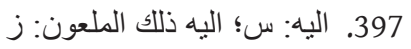

$$
\begin{aligned}
& \text { 398. مو افقين: س؛ سي سو افقان: ز زل } \\
& \text { 399. يصلح: س؛ يصلح اذ كان: ز ز زلقان }
\end{aligned}
$$

Al-'Ușūr al-Wusțā 29 (2021) 


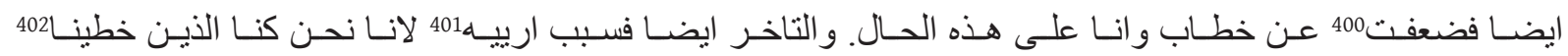

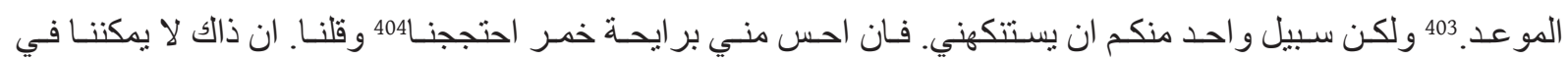

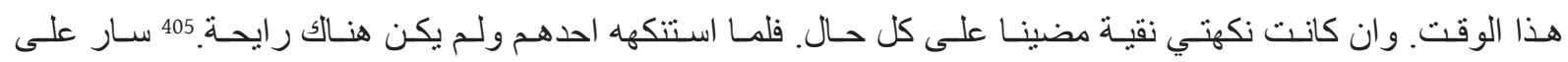
قدميه كمثل حمل 406 باختياره الى الذبح.

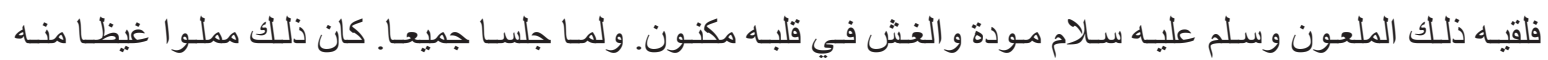

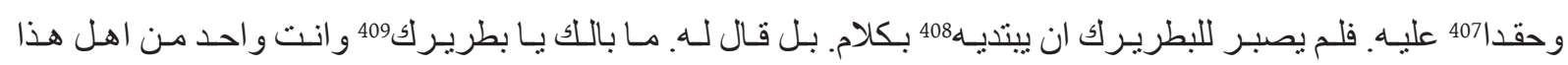

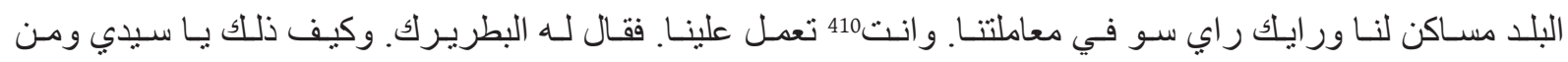

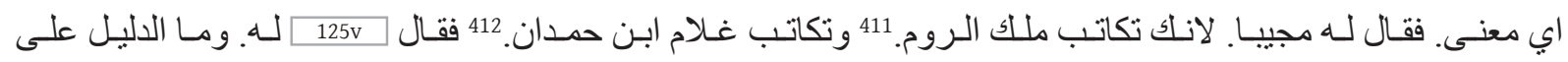

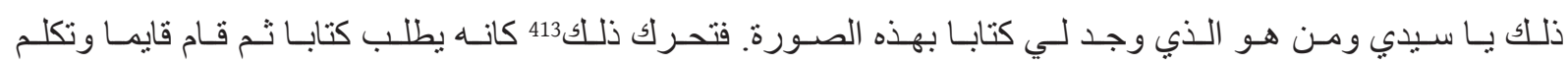
بالفارسية و استدعى لمن كان قـ414 اعدهم 415 للقتل من الخر استانية.

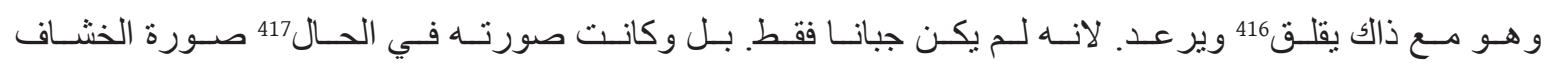

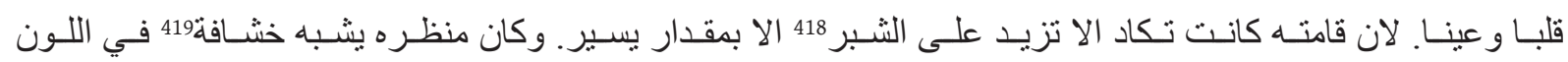

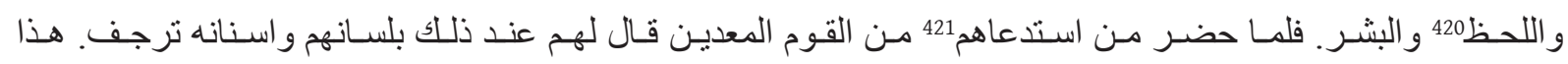
هو المطلوب. هذا هو الذي يريد ان يسلم هذه المدينة. هذا هو عدو المسلمين. فدونكن واياه بضعوه بغير اشفاق.

$$
\begin{aligned}
& \text { 400. خطينا: ز؛ فتضعف: س ول } \\
& \text { 401. و التاخر ايضا فسبب اريبه: س؛؛ والتأخير ايضا بسبب بلية: ز }
\end{aligned}
$$

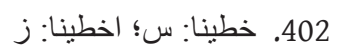

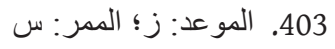

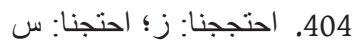

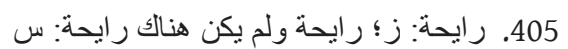

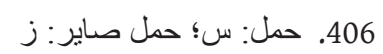

$$
\begin{aligned}
& \text { 407. غيظا منه وحقدا: س؛ عظامه حقدا و غيظا: ز ز }
\end{aligned}
$$

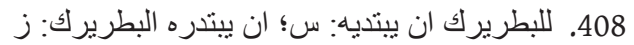

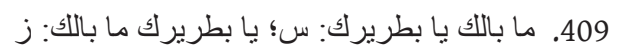

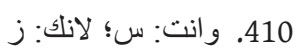

$$
\begin{aligned}
& \text { 411. الروم: س؛ الروم وتستهذهم الى قصدنا وتطمعهم فينا: ز }
\end{aligned}
$$

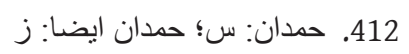

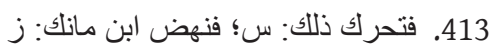

$$
\begin{aligned}
& \text { 414. قد: س؛ - نز }
\end{aligned}
$$

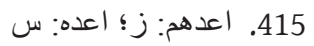

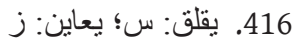

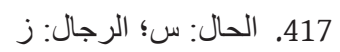

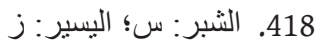

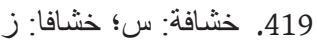

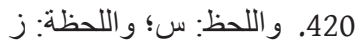

$$
\begin{aligned}
& \text { 421. استد عاهم: ز؛ استدعاه: س سل }
\end{aligned}
$$

Al- 'Ușūr al-Wusțā 29 (2021) 


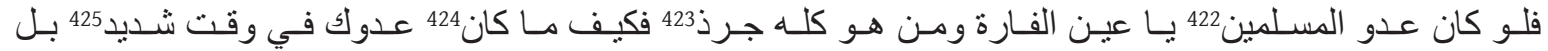

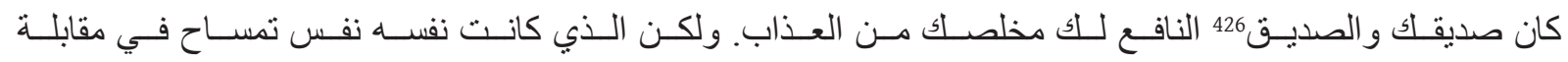
الخير بشر. 427 لما امر في بابه428 بما امر مد ذبح 429 المسيح عنقه وهو جالس بغير انزعاج منتظر ا اخذ راسه.

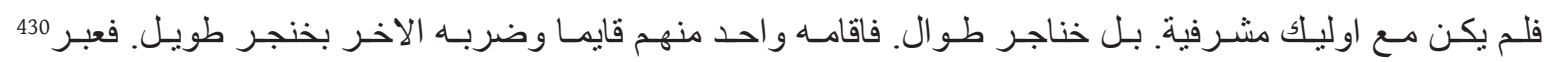

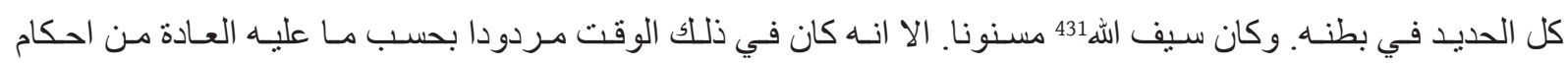

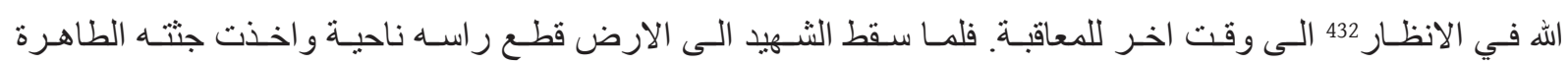

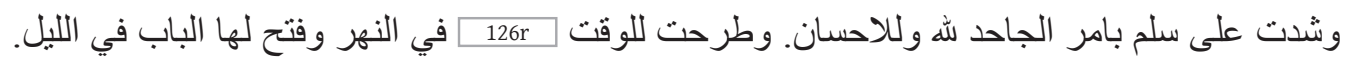

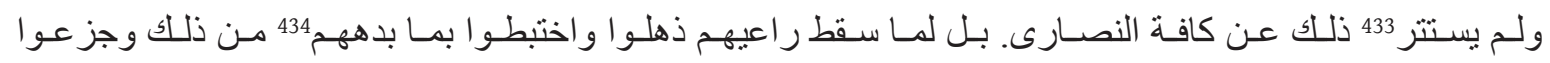

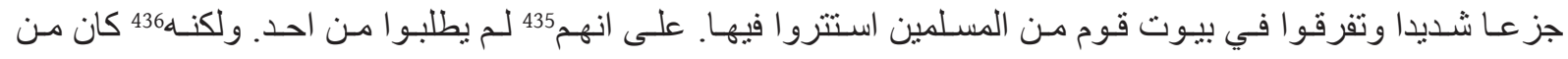

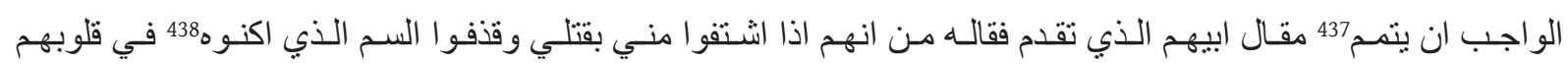
علي فلن بطلبو اسواي.

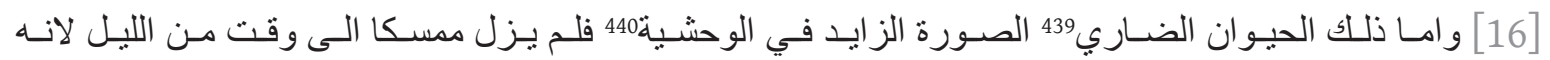

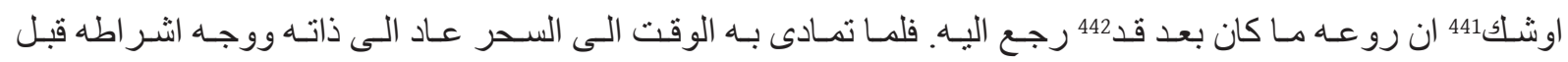

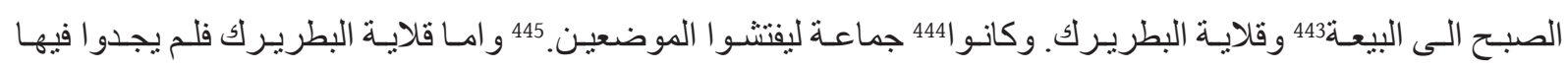

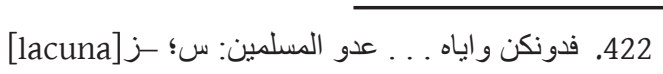

$$
\begin{aligned}
& \text { 423. جرذ: س؛ جود: سون ز } \\
& \text { 424. ما كان: س؛ مارى: زد: ز }
\end{aligned}
$$

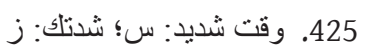

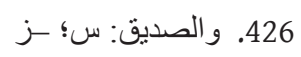

$$
\begin{aligned}
& \text { 427. بشر: س؛ بالشر: ز ز }
\end{aligned}
$$

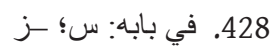

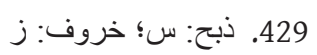

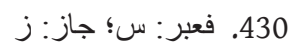

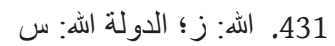

$$
\begin{aligned}
& \text { 432. الانظار: س؛ الانتظار: ز ز }
\end{aligned}
$$

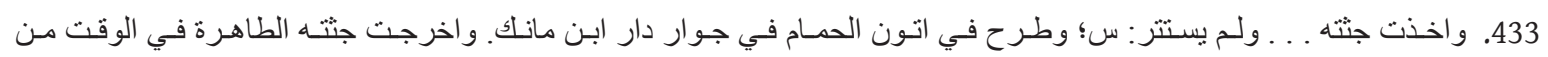

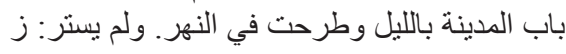

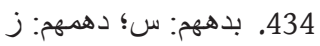

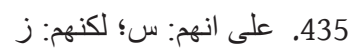

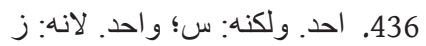

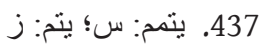

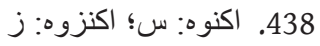

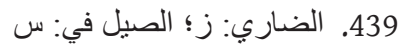

440. الوحشية: س؛ الوحشة: ز ز

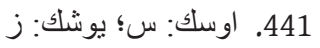

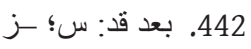

443. البيعة: س؛ البيعة التي هي كنيسة القسيان: ز

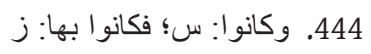

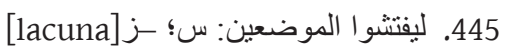




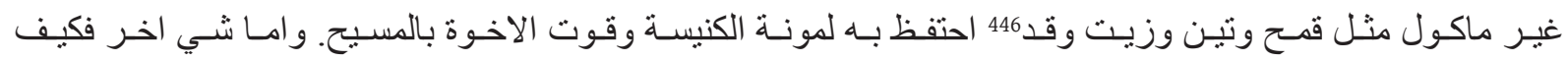

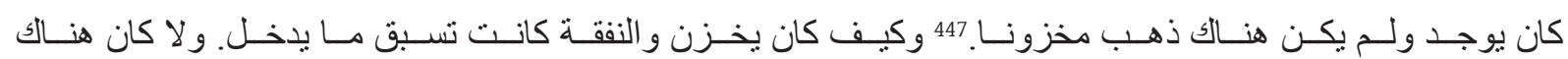

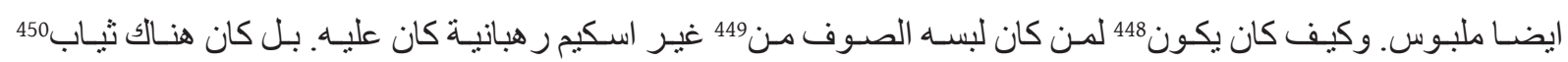

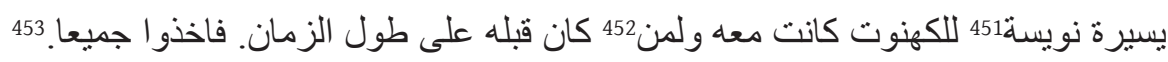

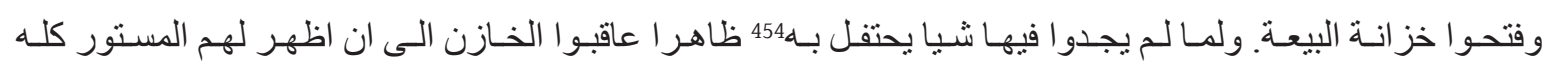

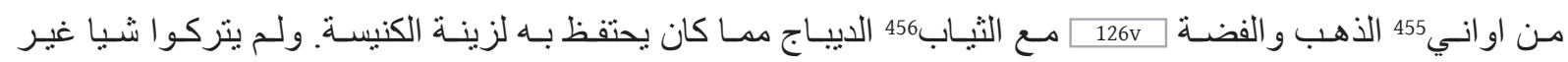

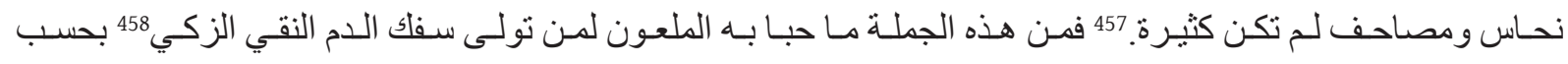

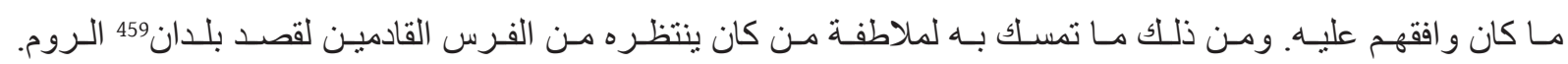

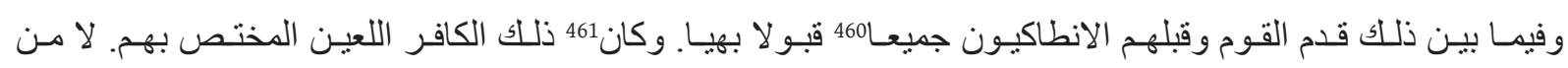

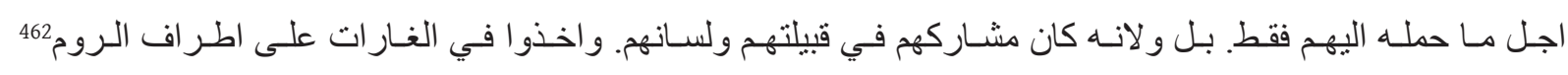

واجتياحها.

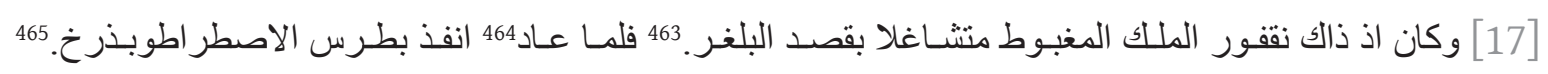

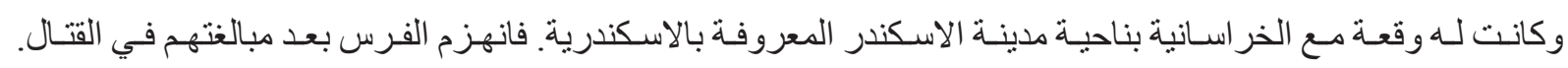

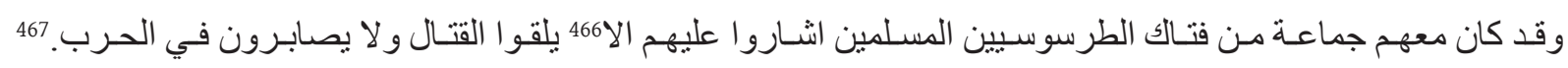

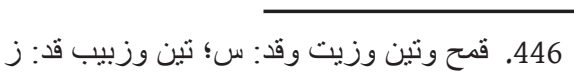

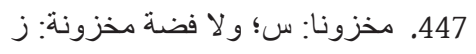

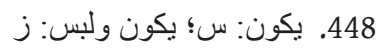

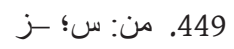

$$
\begin{aligned}
& \text { 450. ثياب: س؛ اشياء: ز ز نز }
\end{aligned}
$$

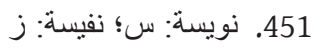

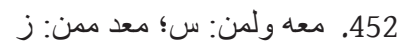

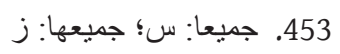

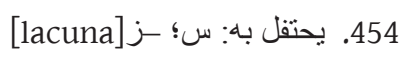

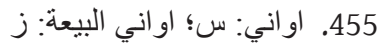

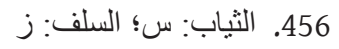

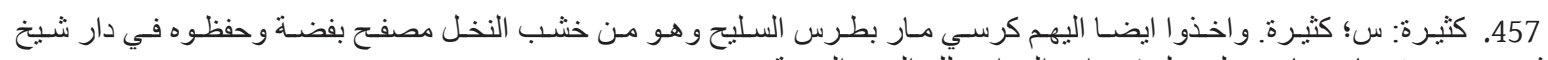

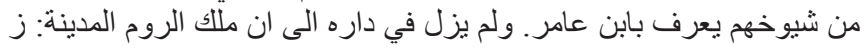

$$
\begin{aligned}
& \text { 458. الزكي: س؛ الذكي جنسه: ز ز }
\end{aligned}
$$

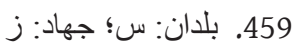

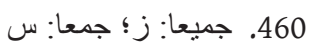

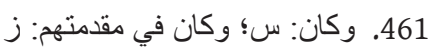

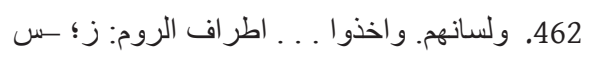

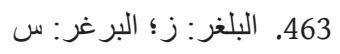

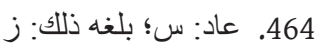

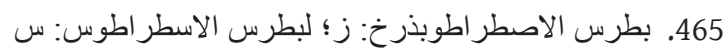

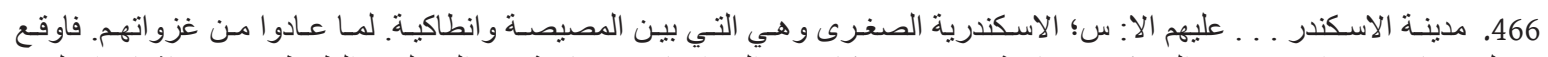

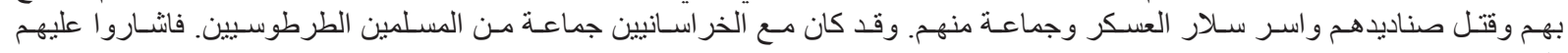


اذ قالـوا. ان هذا الجيش الذني يقاتلكم عسكر ملكي وليسـت468 لكم بهم طاقـة. فلم يقبـل منهم الفـرس. بـل صابروا الصى

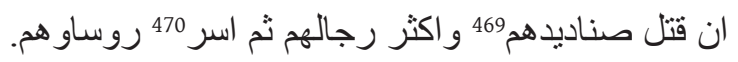

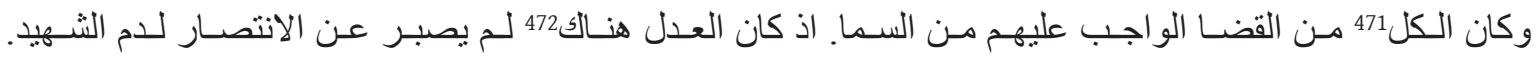

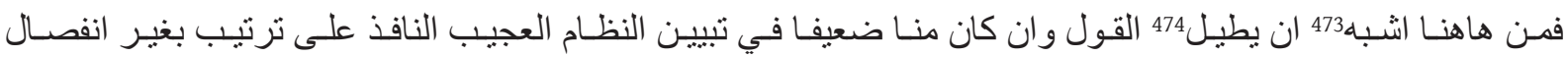

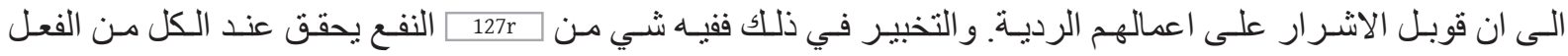

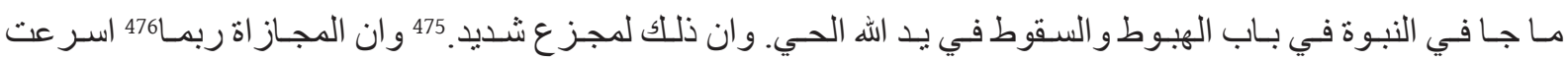

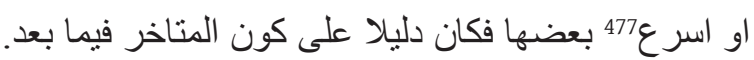

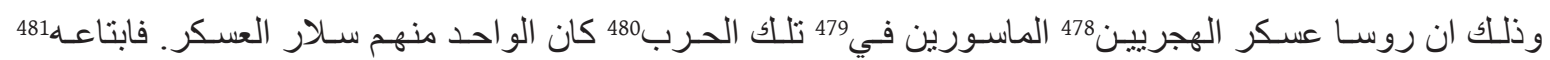

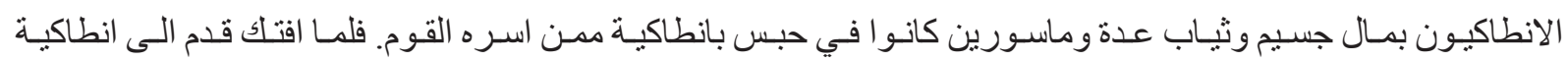

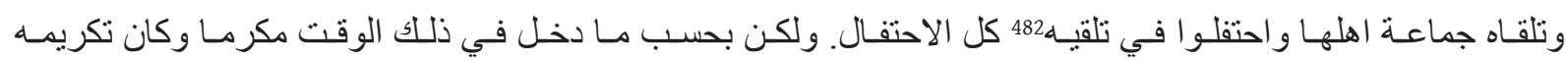

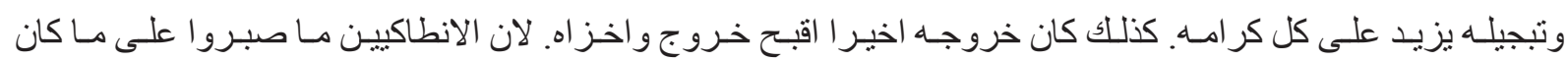

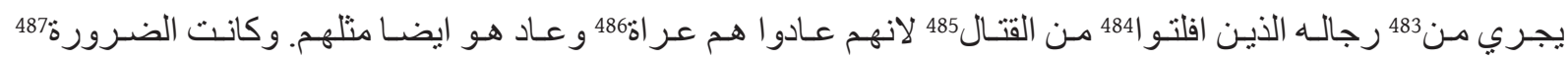

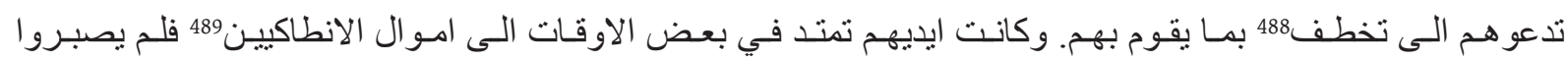

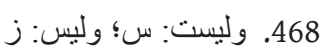

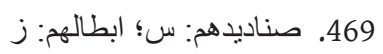

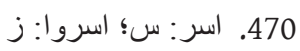

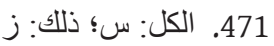

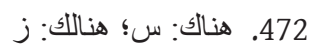

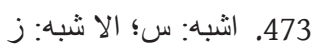

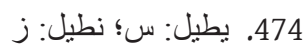

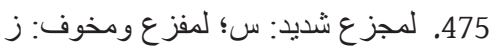

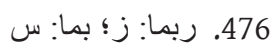

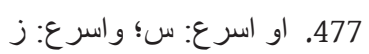

$$
\begin{aligned}
& \text { 478. روسا عسكر الهجريين: س؛ رؤس رؤساء الخراسانيين: ز }
\end{aligned}
$$

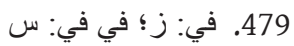

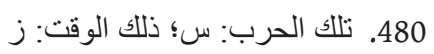

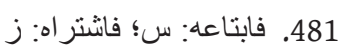

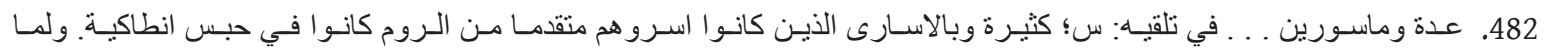

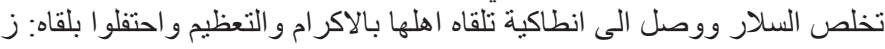

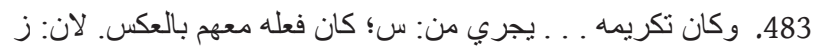

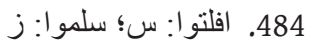

485. 285 القتال: س؛ القتل: ز ز

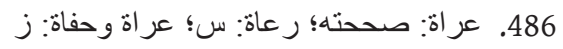

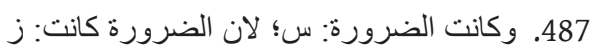

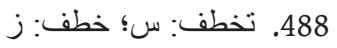

489. وكانت ايديهم . . . امو ال الانطاكيين: س؛ فتسلطو ا على الانطاكيين وصاروا يتخطفو ا امو الهم ورحالاتهم: ز 
لهم 490 على ذللك. بل دافعو هم وانتشبت491 الحرب فيما بينهم واخرجهم اهل 492 المدينة عراة.

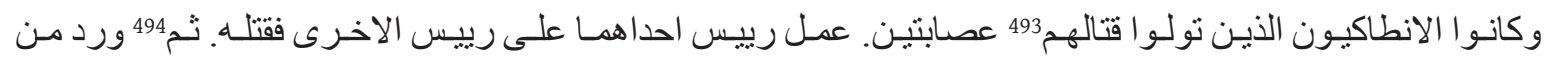

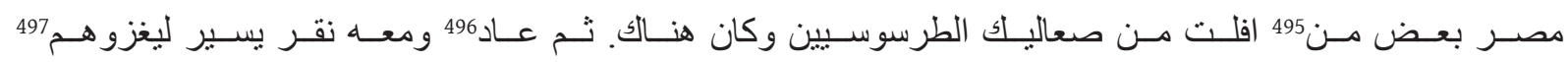

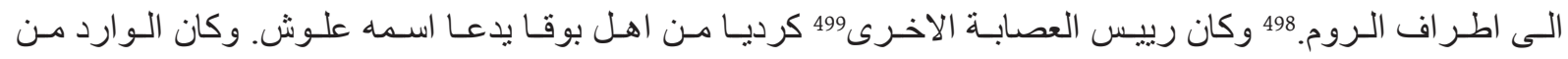

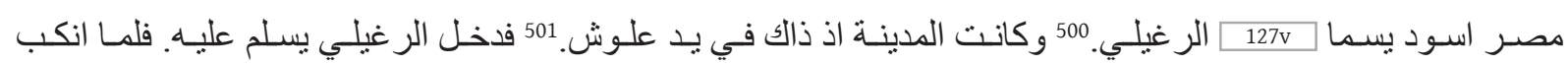

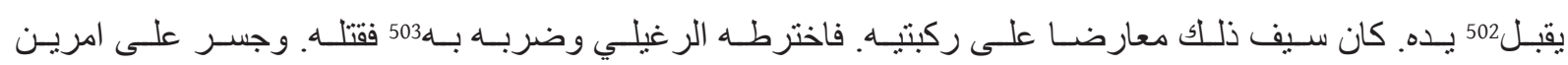

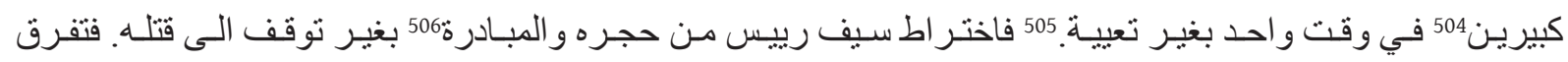

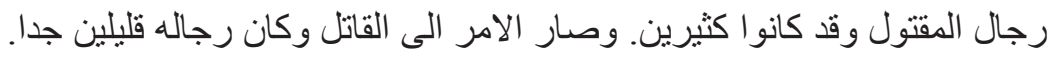

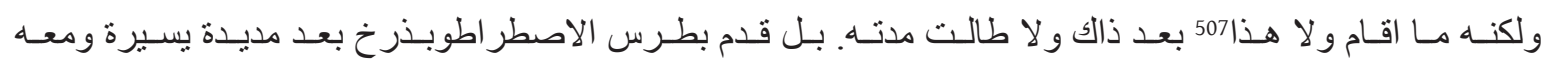

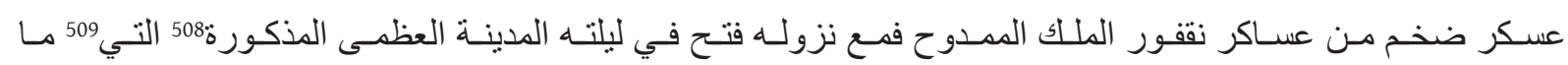

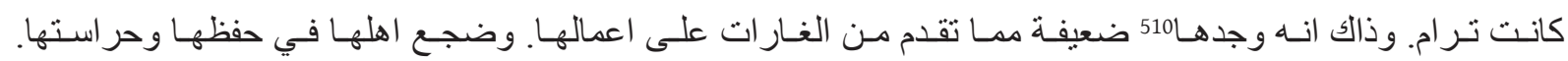

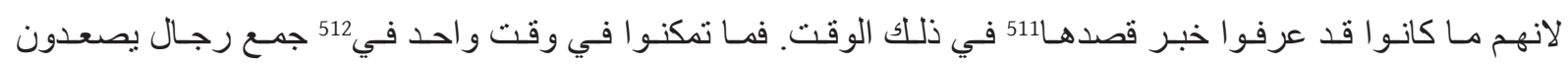

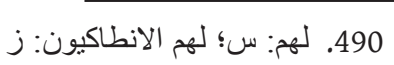

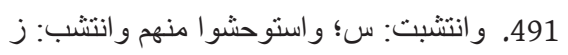

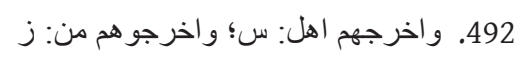

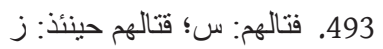

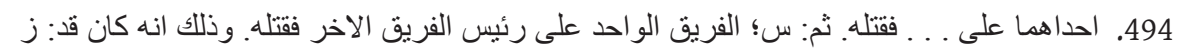

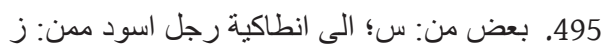

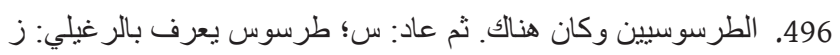

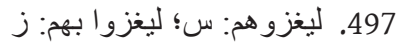

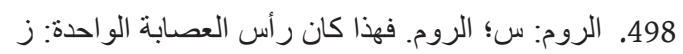

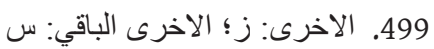

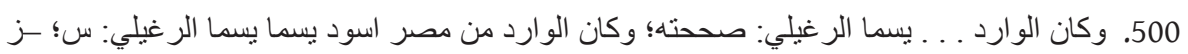

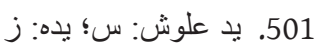

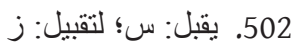

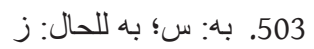

504. 504. امرين كبيرين: صححته؛ امرين كثيرين: س؛ امر ان كبيران: ز ز

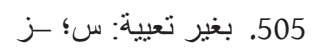

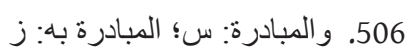

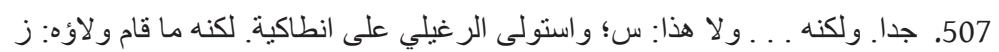

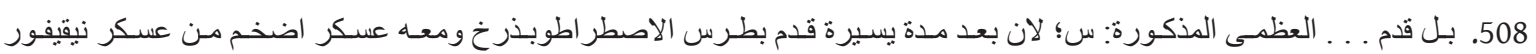

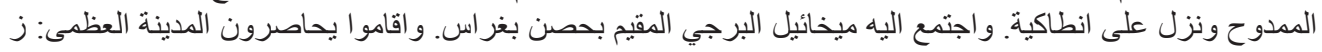

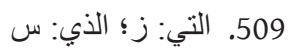

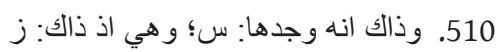

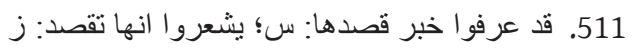

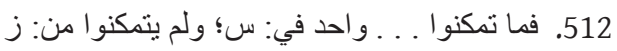

Al- 'Ușūr al-Wusțā 29 (2021) 


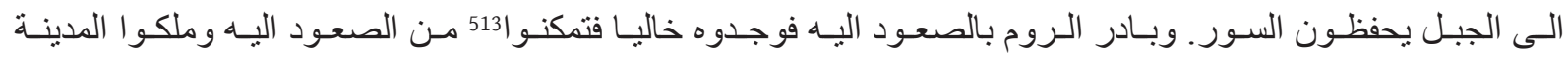

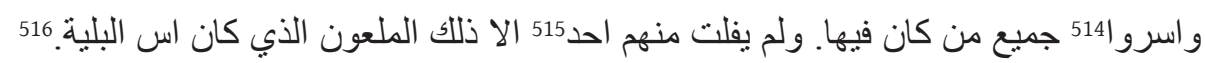

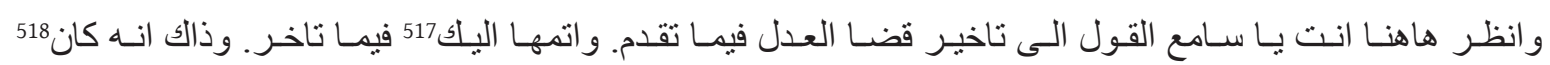

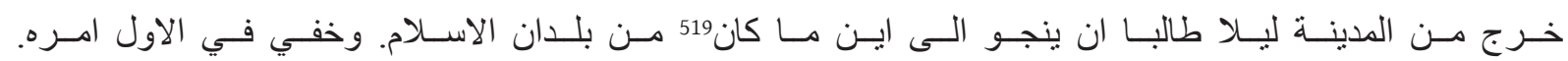

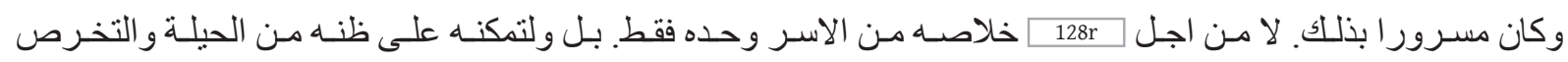

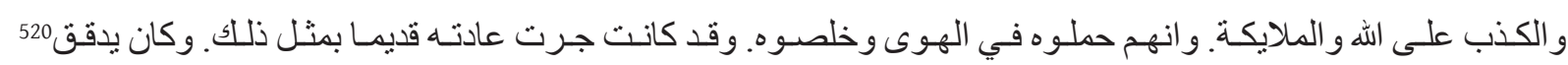

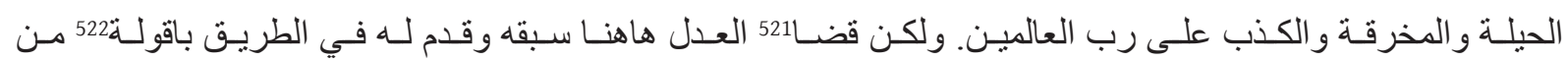

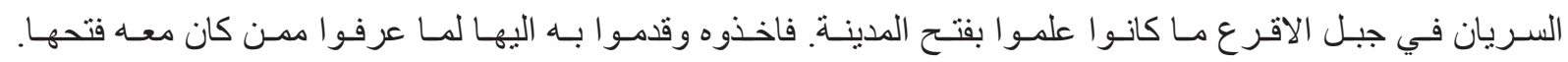

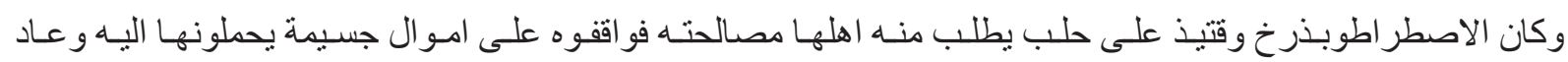

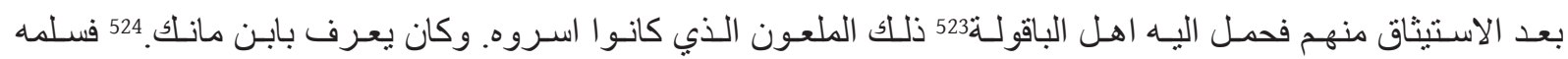

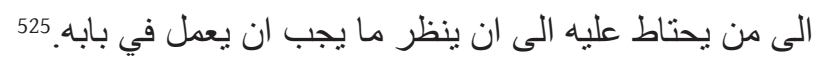

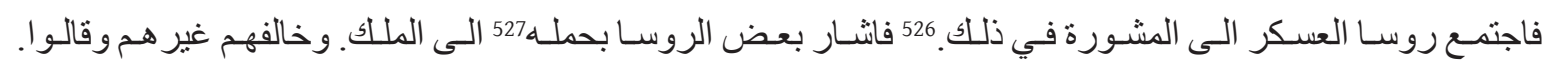

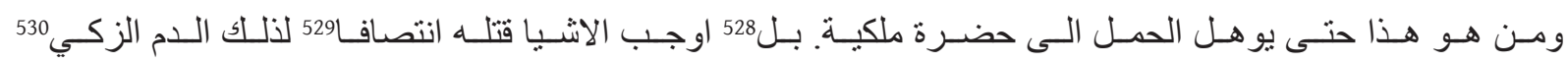

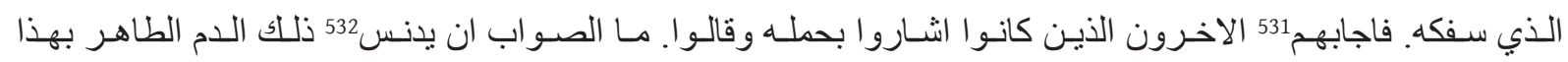

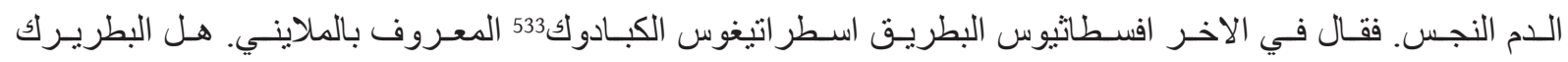

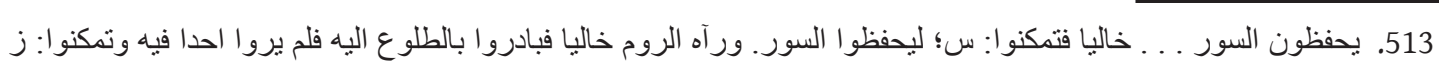

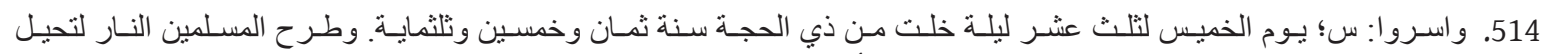

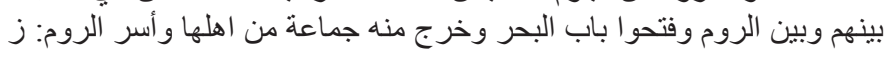

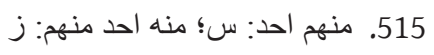

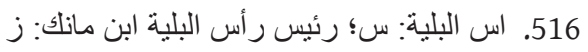

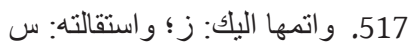

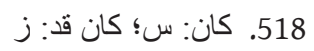

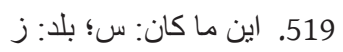

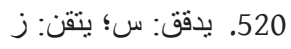

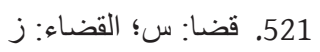

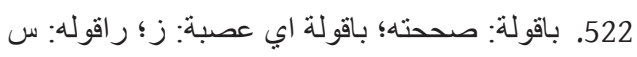

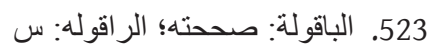

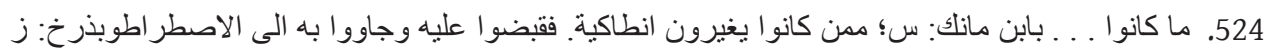

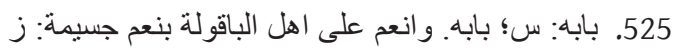

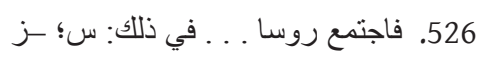

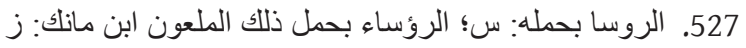

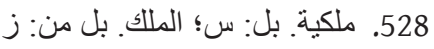

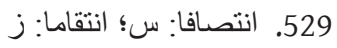

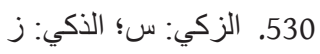

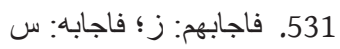

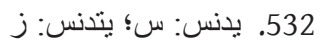

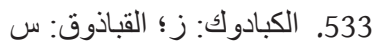




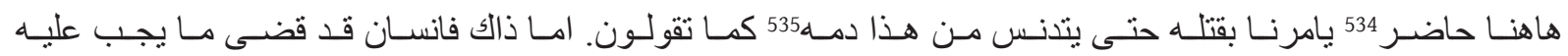

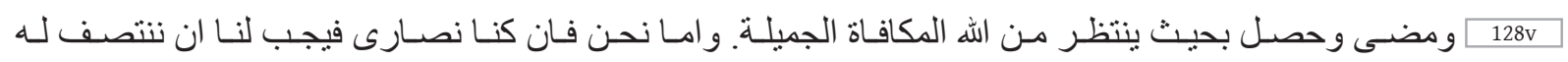
من الظلم الجاري عليه.

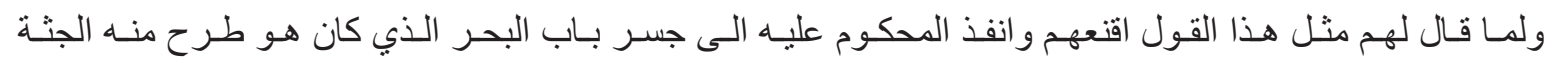

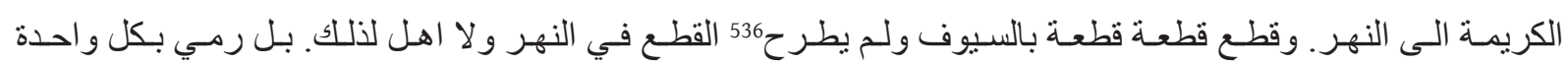

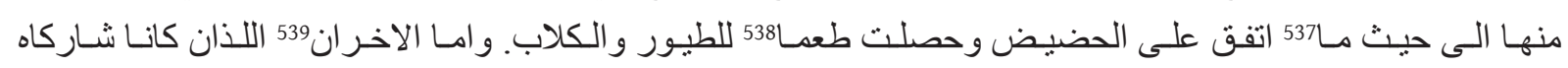

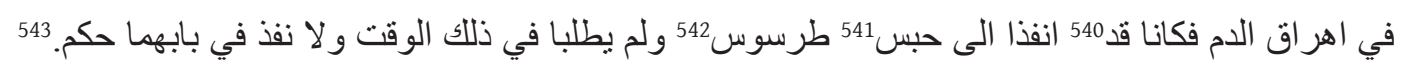

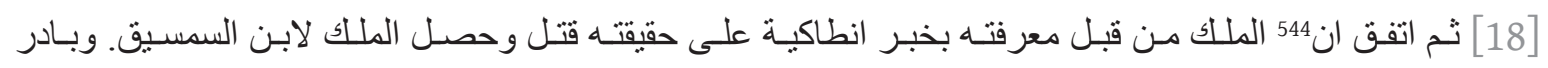

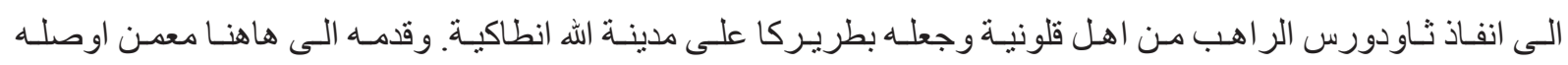

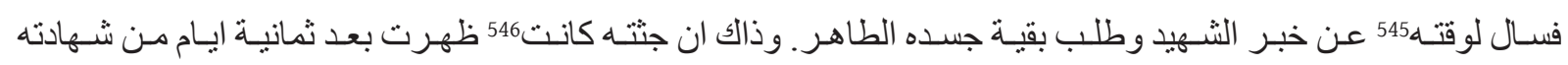

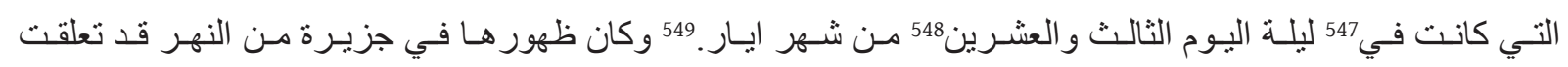

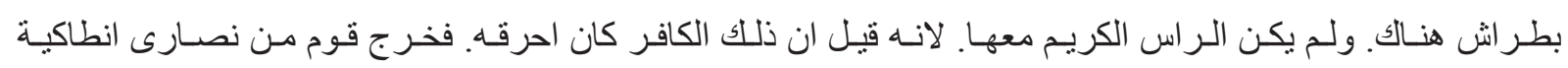

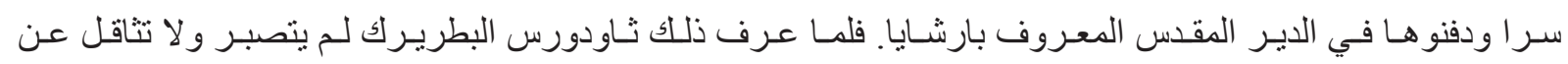

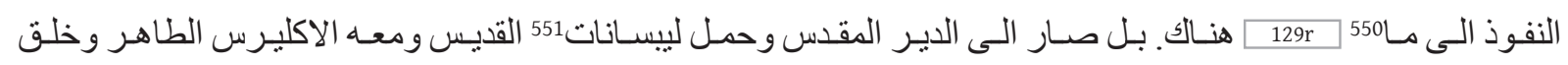

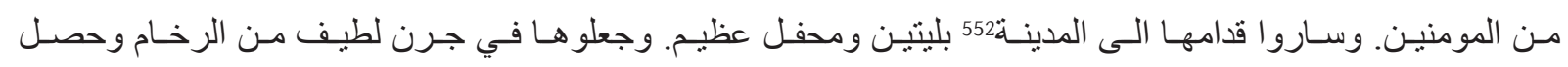
على مايدة503 رخام في مغارب الكنيسة الكبرى.

534. حاضر : ز؛ حاضر ا: س

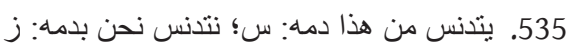

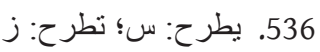

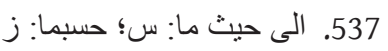

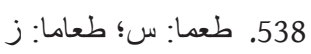

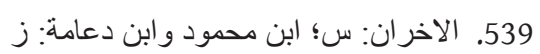

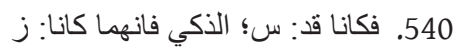

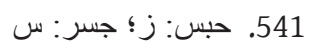

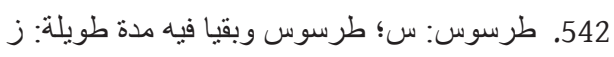

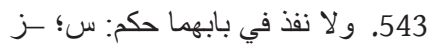

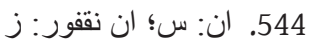

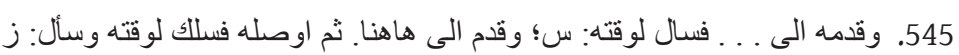

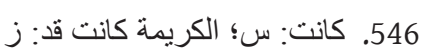

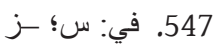

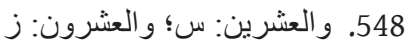

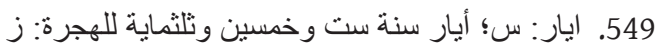

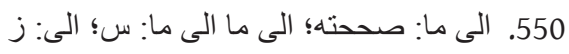

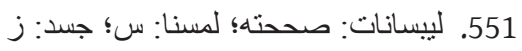

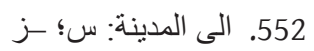

553. وحصل على مايدة: س؛ وروضعوه سل على مائدة من: ز

Al- 'Ușūr al-Wusțā 29 (2021) 
الا ان انبـا54 نقو لا البطريـرك مـن بعد برهـة مـن السـنين نقله مـن هنـالك باكر ام ايضـا. وحصلــ555 في جـوف بيت

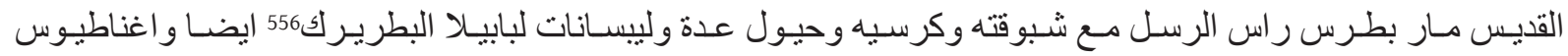

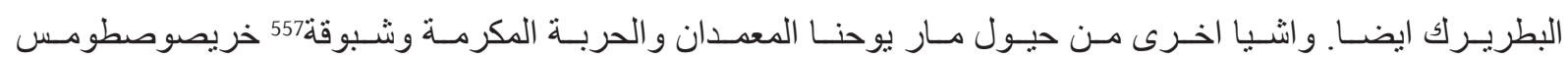
ومنطقة مار سمعان الحلبي العمودي. و غير ذللك مما هو كله في خزانة القديس مار بطرس الى غايتنا هذه.

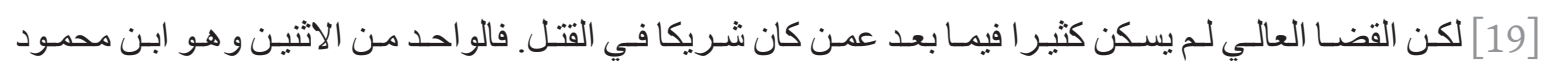

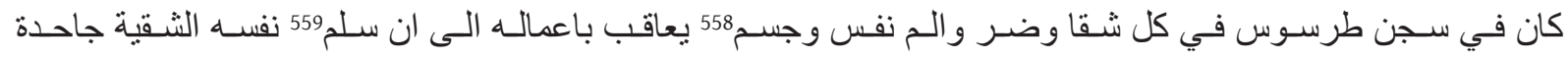

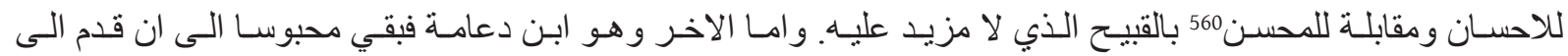

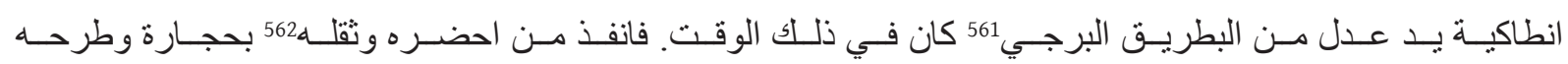

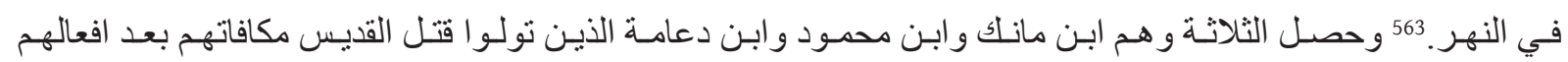
وفي 564 الاخرة ينتظرون العقوبة الدايمة.

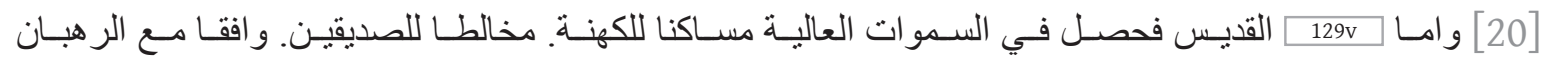

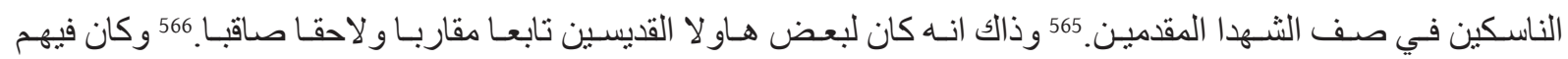

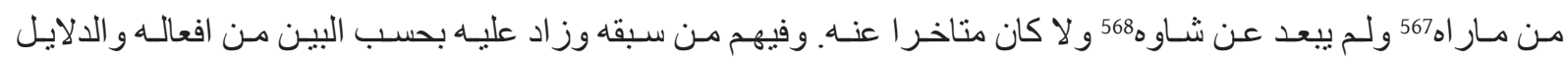
المعروفة من اعماله.

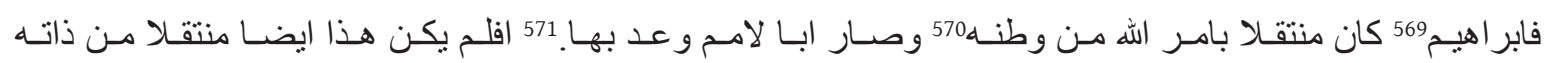

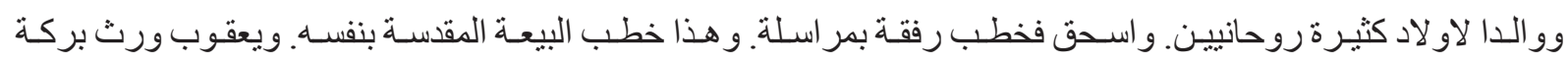

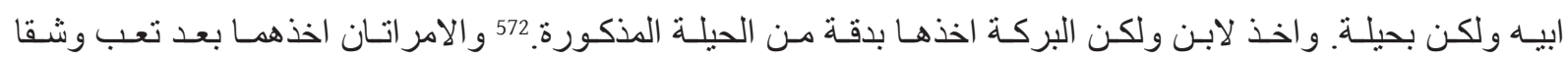

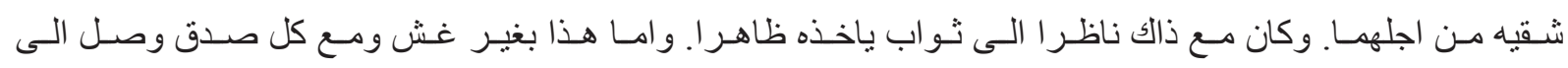

$$
\begin{aligned}
& \text { 554. - 5 انبا: س؛ القديس: ز ز }
\end{aligned}
$$

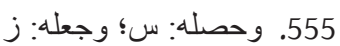

$$
\begin{aligned}
& \text { 556. ولييسانات لبابيلا البطريرك: س؛ ولبك: ولباسات للآباء البطاركة: ز }
\end{aligned}
$$

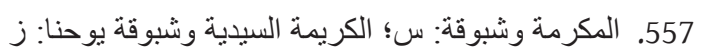

$$
\begin{aligned}
& \text { 558. نفس وجسم: س؛ يقين وجسيم: ز }
\end{aligned}
$$

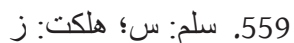

$$
\begin{aligned}
& \text { 560. جاحدة للاحسان ومقابلة للمحسن: س؛ سل المقابلة للحسن: ز } \\
& \text { 561. 560. يد عدل من البطريق البرجي: س؛ ميخائيل البرجي البطريق: ز لز }
\end{aligned}
$$

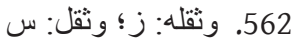

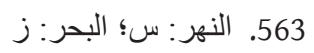

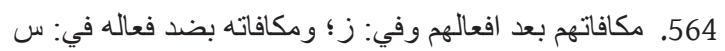

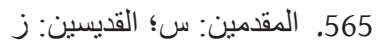

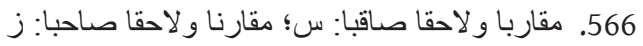

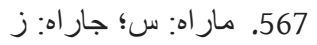

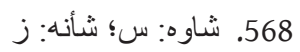

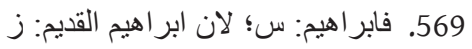

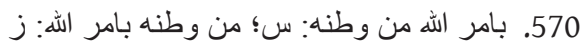

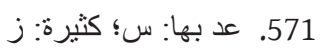

$$
\begin{aligned}
& \text { 572. و واخذ لابن . . . الحيلة المذكورة: سك؛ -ـز }
\end{aligned}
$$




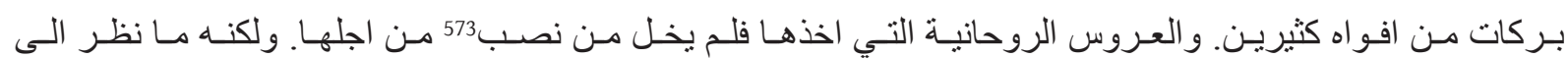

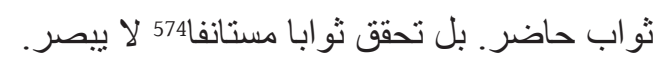

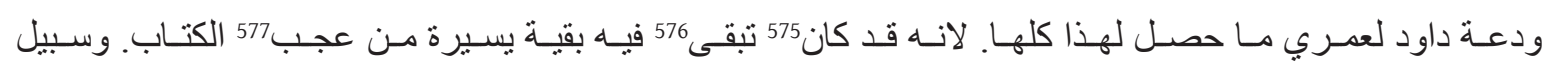

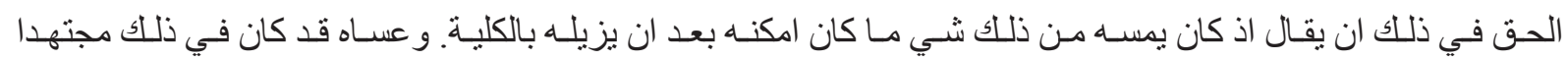

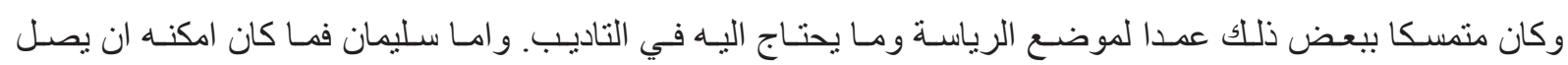

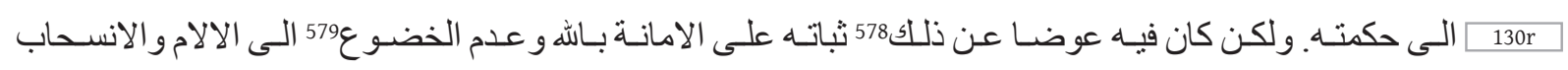
الى الخنى. و هذا580 فهو اشرف من حكمة الدنبا واثر عند فئه الله.

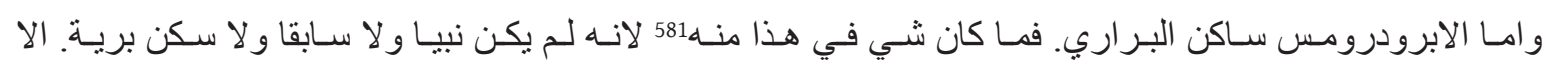

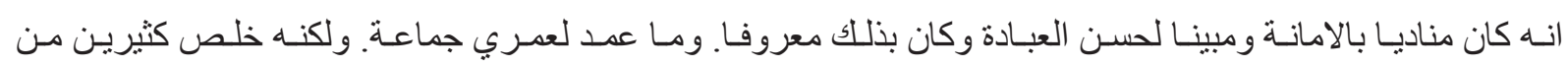

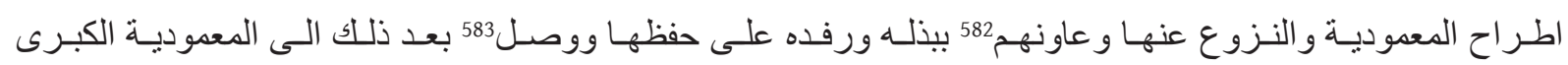

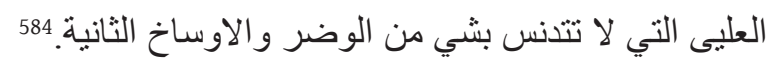

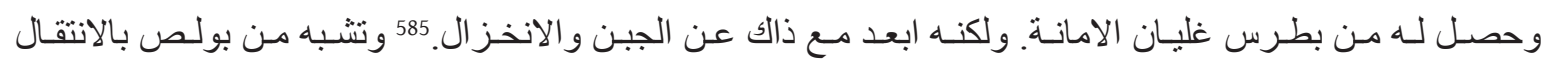

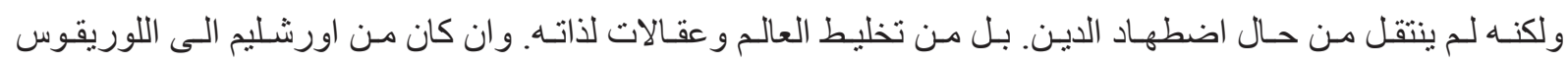

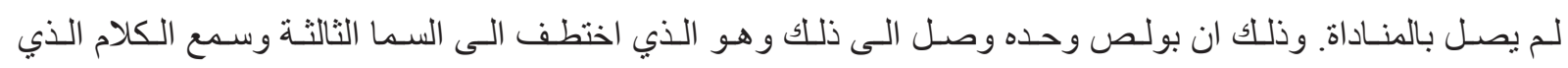

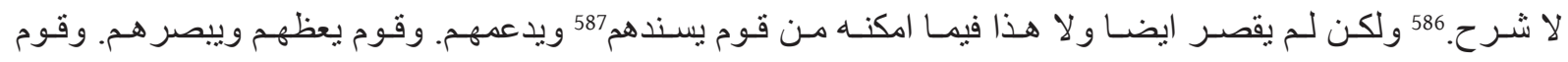

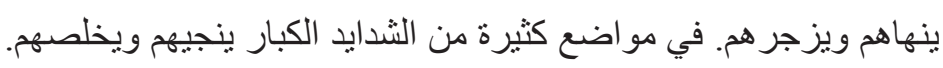

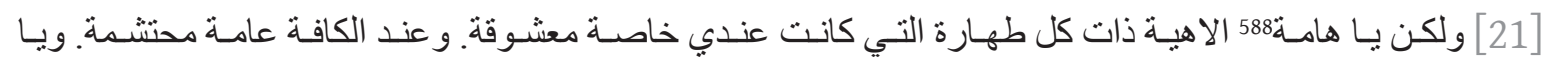

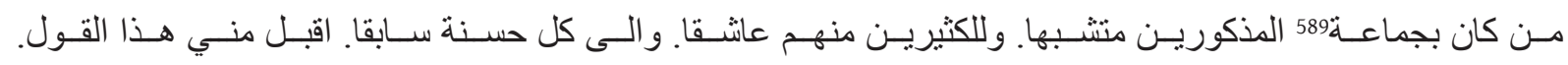

$$
\begin{aligned}
& \text { 573. نصب: س؛ تعب: ز }
\end{aligned}
$$

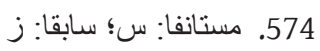

$$
\begin{aligned}
& \text { 575. قد كان: س؛ كان قد: سكا: ز ز } \\
& \text { 576. تنقى: ز؛ يبقا: سي؛ كان }
\end{aligned}
$$

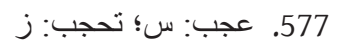

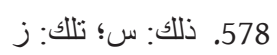

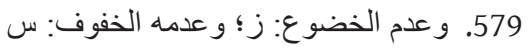

$$
\begin{aligned}
& \text { 580. الخنى. و هذا: س؛ الحياة. و هذا لعمري: ز ز }
\end{aligned}
$$

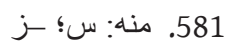

$$
\begin{aligned}
& \text { 582. و النزوع عنها و عاونهم: س؛ و الترو غ عنها و عادتهم: ز }
\end{aligned}
$$

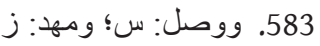

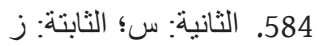

$$
\begin{aligned}
& \text { 585. ذاك عن الجبن و الانخز ال: س؛ ذلك الك الجبن و والانحر اك: ز ز }
\end{aligned}
$$

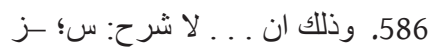

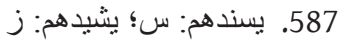

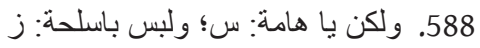

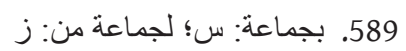




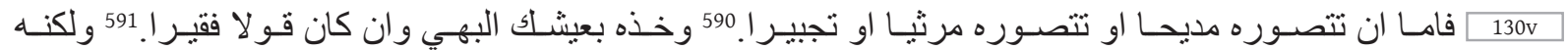

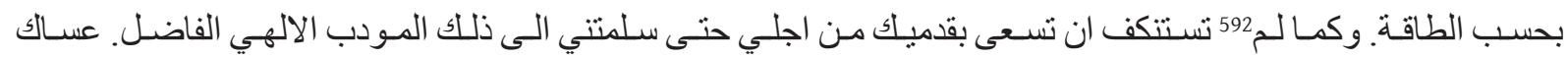

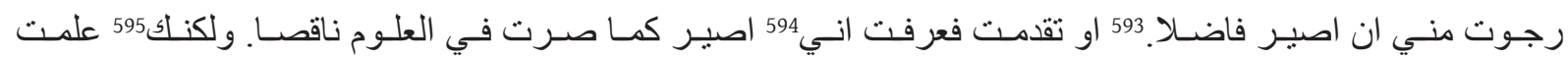

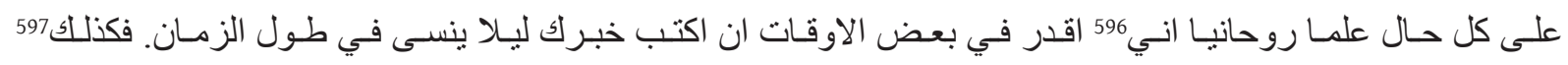

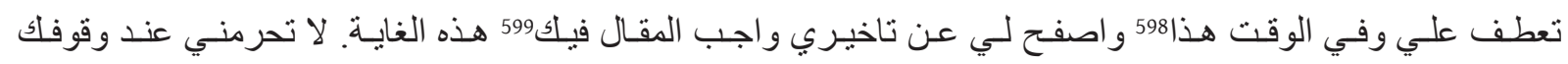

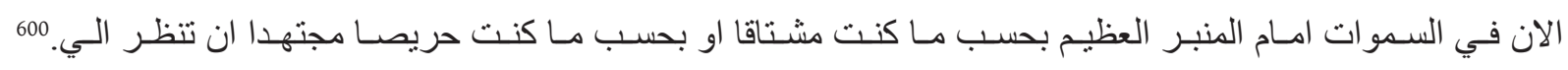

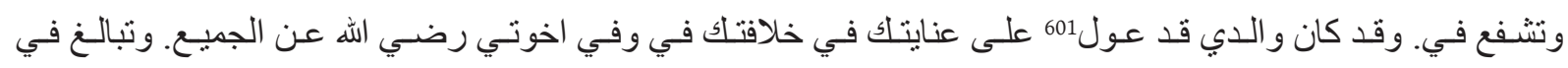

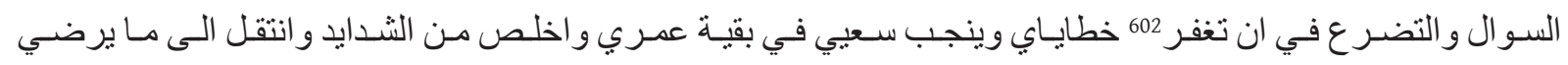
الله ويزلف لديه.

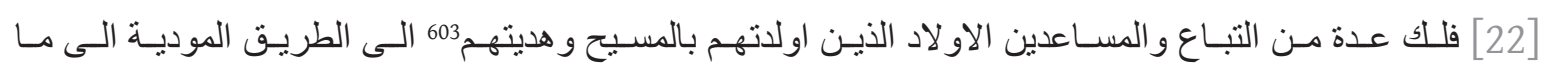

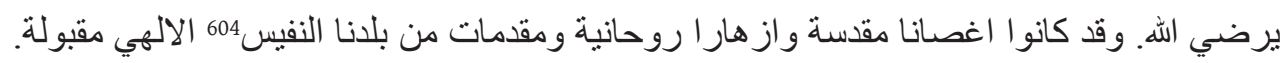

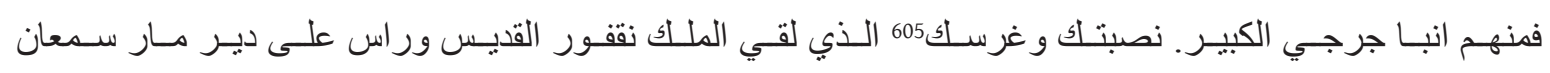
العمودي الحلبي الجبلي.

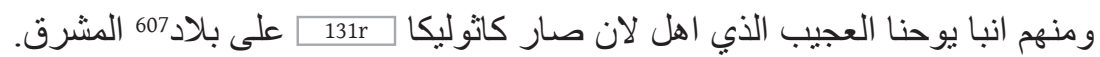

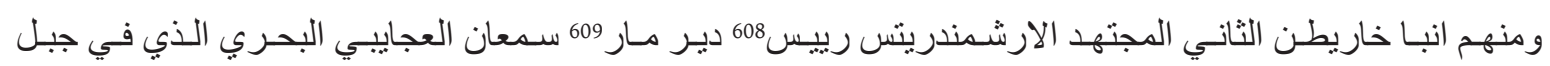

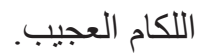

$$
\begin{aligned}
& \text { 590. مديحا او . . . او تجبيرا: س؛ موفقا او تتصوره مرتبا او تخبيرا: ز }
\end{aligned}
$$

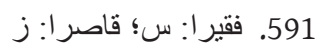

$$
\begin{aligned}
& \text { 592 5. لم: ز؛ لا: سي سل } \\
& \text { 593. اصير فاضلا: س؛ اصف لإن واصبر قليلا: ز }
\end{aligned}
$$

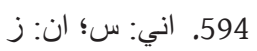

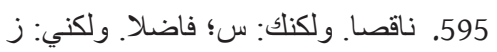

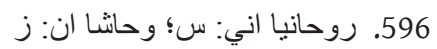

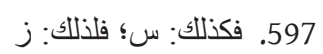

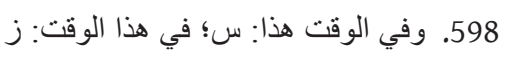

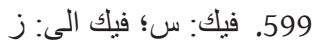

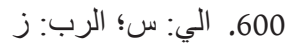

$$
\begin{aligned}
& \text { 601. كان و الدي قد عول: س؛ كانوا الذين عولو ا: ز }
\end{aligned}
$$

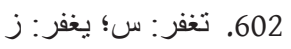

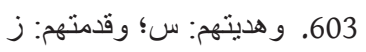

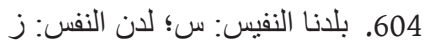

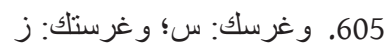

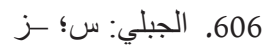

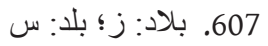

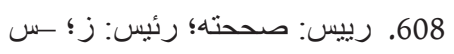

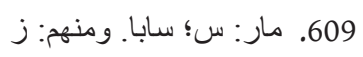


ومنهم انبا يعيش الحبيس610 الذي جاهد في 611 انواع من عمد الحبس وصنع القوات العجيبة.

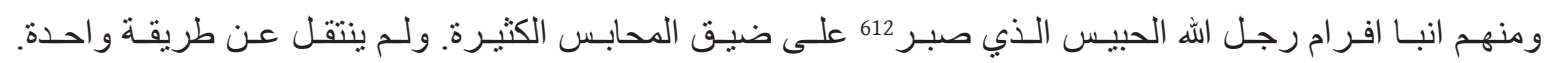
وكان حبيسا بنا مخصوصاف613 بل بالمسيح في دير القديس غريغوريوس الثاولو غس.

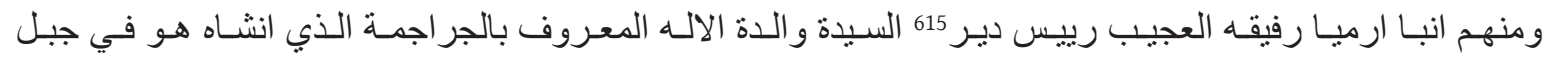
اللكام المقدس. ومنهم الاب المغبوط افتيكيوس ابن فرخوس.616

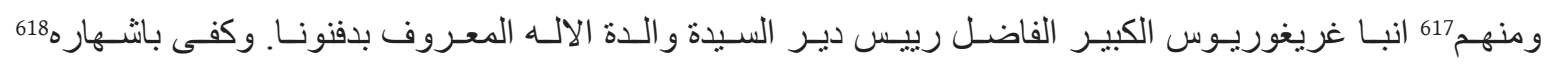
في الفضايل. وكذلاك فقد ذكرت لكل منهم خبر ا مفردا على حده619 كمـا استاهلو ا ان يكونـو ا مذكوريـن. وان كنت اختصـرت فيهـ

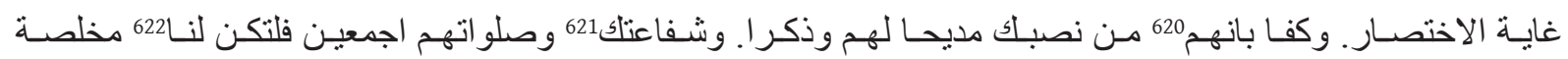
وحافظة الان ودايما و الى اقصى الدهور كلها. 623 امين. >وليقل كافة الشعب الهين.

$$
\begin{aligned}
& \text { 610. الحبيس: س؛ الحلبي: ز }
\end{aligned}
$$

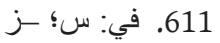

$$
\begin{aligned}
& \text { 612. الحبس وصنع . . . الذي صبر : س؛ الحبيس وصبر : ز } \\
& \text { 613. حبيسا بنا مخصوصا: س؛ سبع حبيبا بنا: ز }
\end{aligned}
$$

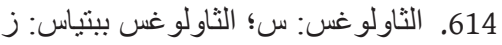

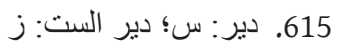

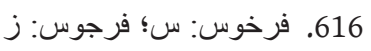

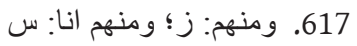

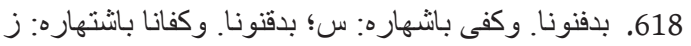

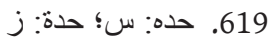

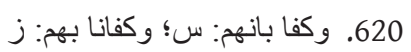

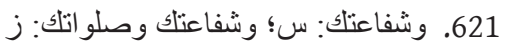

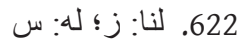

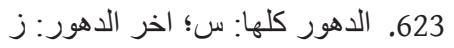

$$
\begin{aligned}
& \text { 624. وليقل كافة الثعب امين: س؟ - -ز }
\end{aligned}
$$




\section{Translation}

$111 \mathrm{v}$ In the name of the Father and the Son and the Holy Spirit, one God.

The twenty-third day of May.

The story of the life of the patriarch of Antioch,

the martyr Christopher, and his martyrdom there.

Ibrāhīm b. Yūhannā, the imperial ${ }^{625}$ prōtospatharios there, composed it in Greek, then also translated it into Arabic. May God benefit us by it, amen.

Nature and actions in accordance with the divine image ${ }^{626}$ are among the deeds of God (blessed be every mention of him). As for sin and all things that diverge from the outlines of that image, they are among the deeds of the Evil One.

And as for our own deeds, we say first that they are among the deeds of God, because everything recognizes that he (exalted be his name) created all things that exist out of nothing and ennobled humans by his own hand when he created them in his image. But we mention secondly that they are among the deeds of Iblīs, because he envied our father Adam for the nobility that he had attained, so he deceived and misled him with the hope of divinization, making him sink and fall away from the natural virtues and outstanding traits of the image upon which he was formed. Thus $112 \mathrm{r}$ it has become a virtue to establish our nature upon its original foundation and basis and to put an end to our separation from the core of the image, and it has become a shortcoming and a vice to remove ourselves from the duties of our nature, to turn away from its original basis in any direction, to abandon the image's journey toward that upon which it was formed, and to turn our faces toward its opposite.

Thus the prophet's saying "I will judge you according to the state in which I find you at the end" ${ }^{627}$ became necessary. By my life, this is one of the most necessary and important things! For God (blessed be his name), who is the first good, made us and created us to do good, so that good might be our goal and intention. After we have deviated from it, we return to it, so that we might begin to ascend toward it after turning away, because the only thing that prevents us from doing so is not God (powerful and great), but our own will. How, then, could this saying not be necessary? From this it follows that he will judge us according to the state in which we are found at the end of our days. So we have come to this point: Whomever we see in a given form at the end, whether they have been good and

625. "Imperial" (malakī) could also be translated "Melkite" in a reference to Ibrāhīm's Christological affiliation. However, compare MS British Library Or. 8607, fol. 28b, where an Abraham (possibly this author) is described as "the emperor's scribe," kātbā d-malkā. See Brock, "Syriac Manuscripts," 62, 66-67. For more on this translation choice, see Mugler, "Ibrāhīm ibn Yūhannā," 192-93; Samuel Noble, "A Byzantine Bureaucrat and Arabic Philosopher: Ibrāhīm ibn Yūhannā al-Anțākī and His Translation of On the Divine Names 4.18-35," in Caught in Translation: Studies on Versions of Late Antique Christian Literature, ed. Madalina Toca and Dan Batovici, 276-312 (Leiden: Brill, 2020), 268-69.

626. The preface uses the roots $s-W-r$ and $s-y-r$ ("image," "become," etc.) as a running motif.

627. Ezekiel 7:3? 
righteous all of their days or have returned to goodness and righteousness after straying far away-they have returned, and we must praise and commend them, because we know that nothing prevented them and they have turned toward this form of power without anything to hinder them, unto the ultimate blessing and the furthest remembrance.

When we find someone who first made a mistake and then apologized for it in the end, it is no embarrassment to praise and exalt them on account of what they became afterward. So the "chosen vessel," ${ }^{28}$ despite his previous $112 \mathrm{v}$ acts of persecution, must be highly praised, since his struggle ${ }^{629}$ ended on the side of truth. The same applies to Matthew, because he became an evangelist after collecting taxes. ${ }^{630}$ So if anyone is like these two, who first went one way but afterward returned to virtue, they must be praised for what they began to do afterward. And if this is true of those who were in error before, what can we say about one who was not in error before, but was rather in the middle ranks of people, among those who were polluted voluntarily or involuntarily, between the highest and the lowest? The person who fits this description must certainly be considered virtuous and counted among those who should be greatly praised.

\section{[1. The Early Years]}

One person we know who fits this description is Christopher, ${ }^{631}$ the great patriarch and the noble martyr, because of the payments he received before, when he was a secretary, ${ }^{632}$ and because he endured his later struggle and devotion, though he did not have an earlier custom or precedent of religious exercise. He had a powerful passion and zeal for even the smallest good works and later had an even greater passion for struggling on behalf of the truth.

His homeland was the City of Peace, Baghdad, which the early children of Hagar substituted for the city of Ctesiphon as their capital city, the land of their sciences and their pure language. As for his parents, I do not know what they were like, but they must have been prominent and important to become the parents of someone like him. The period of his education in his own city was brief, consisting only of what he needed to become well educated in the elementary sciences, then to master rhetoric as well as he could, and beyond that to master the skill of handwriting. For when he wrote, no $113 \mathrm{r}$ one could decide which was more perfect in his calligraphy: its beauty or its speed. For these two qualities had never been equally present in a single person. In him, not only were they equal, but everyone who saw him thought that they were competing with each other and striving for precedence.

628. Saul/Paul; Acts 9:15.

629. Jihād.

630. Cf. Matthew 9:9.

631. The text of $\mathrm{Z}$ begins here and reads "Christopher, the blessed, fortunate one."

632. Z omits: "because of ... a secretary." 
For this reason, and due to his aforementioned virtue-or rather, due to the concern of divine providence for the see of the Head of the Apostles ${ }^{633}$ that is here-it was not possible for him to dwell in his homeland for long. Once he had become as well educated as he could be, as we have mentioned, he imitated the chosen father ${ }^{634}$ who had migrated from those regions; he, too, migrated, because he, too, was going to become the great father of a multitude. He migrated from the land of the Chaldeans to the land of the Syrians. And by "the land of the Syrians," I do not mean "the land of the Canaanites," which is now the land of Palestine, but I mean the town near us, not far away, the town of Aleppo. The management of all of this was with God, who lays the foundations of things in advance, so that at last they come to a praiseworthy end beneficial to all. He (great and powerful) continuously makes small things the prologue to great things that do not even occur to the imagination beforehand.

In this case, Ibn Hamdān, whose surname was Sayf al-Dawla and whose renown was great, was important and had a powerful influence in this region. He showed concern for every virtuous person who had nobility and high ambition, so he was like a magnetic stone whose goodness attracted ${ }^{635}$ people from $113 \mathrm{v}$ all other countries. Therefore, the one who had imitated the ancient father in his migration headed in his direction. His name was originally 'I $\bar{s} \bar{a},{ }^{636}$ and he was going to become what he was going to be named-or rather, what he was going to be named came first, so he took that name. ${ }^{637}$ And just as he had put on Christ in baptism, ${ }^{638}$ so he would also put him on in his blood.

'Alī b. Hamdān handed him over to one of the great emirs of the wilderness, named Khalīfa b. Jundī, whose emirate was in the area of Shayzar. So 'Īsā was with him, and all of his affairs were handed over to him.

\section{[2. The Christians of Iraq and Central Asia]}

He was not known among the Antiochians at first; no one had heard of him or knew anything about him, but afterward he became known because of the coming story. Ctesiphon, which we have mentioned, was large and greatly renowned, because it was the limit, frontier, and boundary of the kingdom of the Persians. And there was a community

633. Ra's al-salīhiyyīn, that is, Peter, whose first see was in Antioch.

634. Abram/Abraham, whose two names mean "great (or high) father" and "father of a multitude," respectively; cf. Genesis 11:31-12:9, 17:5.

635. Lacuna in Z omits: "like a ... goodness attracted."

636. The typically Muslim name for Jesus (the typically Christian name is Yasūc). Z adds: "because he was going to become a patriarch like Abraham, though he did not know it. But he was later named Christopher."

637. This sentence is confusing, and quite different in the two manuscripts. It seems, however, that the idea is that Christopher was going to live up to his name by becoming a bearer of Christ. The second part of the sentence suggests a correction to the first: he was already a bearer of Christ, and that was why he chose the name Christopher when he became patriarch. This assumes the audience's knowledge that the Greek name Christopher means "bearer of Christ," which would have been obvious in the original Greek.

638. Cf. Galatians 3:27. 
of Christians there whose pastor was not called a metropolitan, because the rank of metropolitan was not sufficient to shepherd such a large group throughout all the countries of Persia and to hand over their affairs to bishops alone. For they were also rather few, and the situation called for numerous bishops, so many that it was not possible for one metropolitan to name and ordain them all, so there was a need for numerous metropolitans. Moreover, those regions were distant, far from our city called by the name of God, ${ }^{639}$ and they were in the kingdom of the Persians, which often prevented travel to $114 \mathrm{r}$ Antioch for the appointment of a metropolitan for every place.

There was already another policy among the ancients for this situation, the likes of which had been used for different nations and distant places, such as the Georgians, ${ }^{640}$ the Abkhaz, and the Bulgars: a person was ordained whose authority was greater than the authority of a metropolitan, and he was called a catholicos, as they were called in those places that we mentioned. Our predecessors followed this custom, and the leader of our city ordained a catholicos for the city of Ctesiphon.

When the Hagarenes ${ }^{641}$ built the City of Peace, which is Baghdad, they wanted to move the Christians away from its vicinity, so they moved them to a distant city in the Persian lands, called Shash, ${ }^{642}$ and sent the catholicos into exile there with his exiled companions. That relocated tribe was called "the community of the Romans," and naturally their group was called by this name. ${ }^{643}$

So the residence of the catholicos was in Shash for some time, and no one challenged or disputed it. But when a group of Roman prisoners began to accumulate and some of them obtained their freedom, a dispute began between the two sides. The group of Christians gathered in Baghdad said, "The catholicos belongs to us, and we are more deserving of him, because his residence was in Ctesiphon, and Ctesiphon is near us." And the people in Shash said, "We are the people of that place, who were moved from there to here with the catholicos of all the East, and as a person is nobler than any piece of land, it is necessary for us to have the catholicos, who moved here with us. We have precedence, as we are rational creatures, and it is more proper $114 \mathrm{v}$ for us than for you. You ask that you should have precedence on account of nothing but stones and dust!"

While the quarrel between the two sides was ongoing, the current catholicos died, and there was need for another person after him to carry out the ministry of the priesthood there. Therefore, three emissaries came to Antioch from Romagird requesting the ordination

639. A reference to Antioch's Greek title of Theou Polis, or "City of God."

640. For "Georgians," Z reads: al-Khazarān. There is no known catholicate among the Khazars, and Marius Canard suggests that Ibrāhīm intended Jurzān, the Georgians. This seems to be the reading in S, though it could also be read as Khurzān. See Marius Canard, "Une vie du patriarche melkite d'Antioche, Christophore († 967)," Byzantion 23 (1953): 561-69, at 562.

641. For "Hagarenes," Z reads: "children of Hagar."

642. Now part of Tashkent, Uzbekistan.

643. Apparently a reference to Rōmagird (Persian)/Rhōmagyris (Greek), the name of this Christian colony in Central Asia. The etymology of the name is disputed and difficult to reconcile with Ibrāhīm's jamā'at al-Rūm; see Néophyte Edelby, "Note sur la catholicosat de Romagyris," Proche-Orient chrétien 2 (1952): 39-46, at 40; Canard, "Vie," 563. 
of a catholicos. One was a priest and the other two were deacons. I, the speaker and writer, saw them-while I was still a boy-remaining in our church and saying that they would not return until they were given an audience and allowed to take the catholicos whom they had come from the end of the earth to request. And the aforementioned 'İsā heard they had come, and he was not pleased with their plan, because he was a Baghdadi and one of their opponents on the topic of the catholicos-in fact, the leader of that side. Working to put an end to their plan, ${ }^{644}$ he did not delay or rest, but left his work behind and took up the pain of the journey to Antioch to drive them away. There was no one who appointed him to do this; he took up the cause of his own accord, simply out of zeal for his homeland.

At that time, the one entrusted with the administration of our town named for God was the late Agapios ${ }^{645}$ b. Qa'barūn, who held the patriarchate before him. So the dispute, discussion, and quarrel over the installation of the catholicos took place in his presence, and the aforementioned 'İsā fiercely contended for the people of his country, presenting their arguments and seeking victory for them-to bring the catholicos to their city, which is the City of Peace and the replacement for Ctesiphon. $115 \mathrm{r}$ As the patriarch judged, he seemed not to be swayed by what 'Īsā was requesting, but he recoiled from his skill and was ashamed to face him, so he left the matter hanging. ${ }^{646}$ 'İsā was satisfied and departed, but he had shown the Antiochians that he was a man of great endurance and that he had a fierce zeal for the affairs of the church.

\section{[3. His Election to the Patriarchate]}

It was only a little later that the patriarch died, and it became the concern of the Antiochians to choose a patriarch and pastor to succeed him. For here, the choice did not belong to metropolitans and bishops-who care about nothing except what will improve their own situation, and do not care what will improve the situation of the masses-as is the custom in other places. Here, the choice was available to everyone affected; both commoners and elites cared about it and had a choice in it. Anyone who precisely considers the concept of choice will find that the system used here is unspoiled by personal desires, and therefore also pleasing to God.

When the Antiochians set about doing this, a group of them debated at length whether to choose one person or another. But they did not find anyone more agreeable to them or more suitable for their see than 'İsā. So when their community agreed to choose him, they brought their request to Sayf al-Dawla, because he was in command of the region. He was pleased with their position, because he was partial and favorable toward 'İsā. But he had no way to approve their choice, because he was wary of the impudence of the desert Arab whom he was serving, $115 \mathrm{v}$ a man of great ruggedness, boldness, and audacity. He had no doubt that the man would fight to keep 'Īsā, his secretary.

644. S omits: "because he ... their plan."

645. For "Agapios," S reads: "Agathon." This is Agapios I (bishop 341-48/953-59).

646. For "he left the matter hanging," $\mathrm{Z}$ reads: "he closed the matter." 
It was good fortune from God, who (blessed be his name) willed for such a man to become patriarch here, that that Qarmatị Bedouin ${ }^{647}$ went with Sayf al-Dawla on one of his raids. ${ }^{648}$ His horse slipped on Șārikha ${ }^{649}$ Bridge and he drowned in the Halys ${ }^{650}$ River. Then Sayf al-Dawla gave permission for the selection of 'İsā, and the chosen one was quickly elevated to the exalted and God-honored see of the Head of the Apostles. He received ordination from the metropolitans, as is required. The ordination was splendid and dignified, and he naturally took the name Christopher, for it was obvious from his actions that he bore all goodness within his breast-more precisely, we could say that he bore Christ within his heart.

\section{[4. His Asceticism and Piety]}

From this point on he ${ }^{651}$ led him away from the path of ease and luxury onto another path, rough and difficult. For although he had not become a monk, he exceeded all monks in his practices: after his ordination, he tasted nothing of meat. Because he had no previous custom of following the monastic lifestyle, he was not satisfied with the things that his monastic predecessors had done, whether in fasting or vigils or rising for prayer. Rather, he exceeded and surpassed them in everything. He fasted every day from nighttime to nighttime, from the beginning of the year to the end, for from the time when he became patriarch, there was not a single day when he ate a bite of food before evening. Nor was he concerned about different types $116 \mathrm{r}$ of food; he made no distinctions among the things he ate, and his table was spread in whatever way, often without eggs or fish or any other fine thing. His drinking was not excessive, but it included a little wine and plenty of water.

On ordinary days he was awake for a large portion of the night, long before dawn. ${ }^{652}$ On Sundays, he was awake from the evening before Sunday until the morning. The priests took his vigils as a model because of the great love that he had for God and the greatness of his soul. And often he would not go back to bed for a long time, so that I even saw him nearly fall to the ground on numerous occasions because of the intensity of the practice.

647. Badawī. The Qarmațīs were an apocalyptic, revolutionary branch of Ismācīlì Shīcî Islam (at some points also closely associated with Zoroastrianism) that gained numerous adherents in Syria, among other regions, in the early fourth/tenth century. The movement lost much of its appeal, however, after the infamous, bloody Qarmați raid on Mecca during the hajj season of 317/930. At this point, numerous Qarmatịs entered the service of Sunnī rulers, including the Hamdānids. See Canard, Histoire, 1:315-18, 602-6, 632-34.

648. Ghazawāt.

649. For "Ṣārikha," Z reads: "Mārikha."

650. For "Halys," Z reads: "al-Sinn." As Canard notes, this is a slightly garbled reference to the Halys (Arabic "Alis"), now the Kizllırmak in northern Turkey. Șārikha appears in Byzantine and Muslim sources as well, and Canard writes that this text allows us to place it precisely on the Halys, "without doubt upstream from Sivas." Zayat, on the other hand, takes "al-Sinn" as the correct term and places it on the Tigris. The connection to Șārikha (as it appears in S, though it is misspelled in Z) makes Canard's reading more likely. See Canard, "Vie," 567; Zayat, "Vie," 26.

651. That is, Christ.

652. Fajr. 
We have mentioned a few things on this topic to show the difficulty of the life that he led, in which he had no prior experience. Anyone who has experienced this or has heard about it will surely know how difficult this path and practice were for a man who was raised in luxury.

\section{[5. The Catholicos Issue]}

It is now time to discuss what he did after his ordination. It was necessary to ordain bishops for the sees that were vacant. Which sees did he turn to first? He did not turn somewhere uncontested, nor to a see in which he had no history of opposition or favoritism or contention, but to the two sees that he had defended and opposed. His concern for them was not the same as it had been earlier, partial and headstrong. When he realized within himself that he had not acted in an appropriate way, as a result of $116 \mathrm{v}$ his favoritism and opposition, he decided to confront the aspects of the situation that he had previously ignored and to reform both his own intention and the things that were now under his control, even reforming his own beliefs.

Thus he approached the situation with a just balance, but also with wisdom and kindness. So he weighed the ordination on this balance and created two catholicoi: one for the City of Peace, his homeland, who was a man of Aleppo named David, ${ }^{653}$ and the other for Romagird (which he had opposed), a man of Antioch named Eutykhios. Who will not praise him for this kind and correct policy that led to peace and harmony? For he did not wrong his own city, but he also looked well upon the other, and he gave them harmony of souls and removed their discord and contention.

\section{[6. Other Vacant Sees]}

But did he then lie down on the issue of the other vacant sees? When he looked into the issue, did he consider bribes or intercessions, or a ruler's pleasure, or the terror of a powerful person's frown? No! On the contrary, when he saw that the delegation from a city requesting a bishop had mentioned someone worthy of ordination, and that person was pleasing to God and to him, he would lay his hands upon him immediately and confirm him, being pleased with what pleased them and yielding to their request. Or if he was not pleased with that person, he would choose someone else with whom they were also pleased, and would lay his hands upon him with the consent of the following ${ }^{654}$ synod. There was no delay, because the metropolitans who were before him could see that his mind was judicious, his determination was strong, no favoritism affected him, and he did not desire gifts or bribes. So how could they contradict him in anything he decided?655

653. For "David," Z reads: "Mājid." Tūmā Bītāar suggests that Mājid (if this is the correct reading) might be the author of a fourth-/tenth-century Arabic commentary on the Nicene Creed, though the evidence is limited, and the variant reading of S makes the identification even less likely. See Tūmā Bìțār, al-Qiddīsūn al-mansiyyūn fi al-turāth al-Anțākī (Duma, Lebanon: 'A'̉ilat al-Thālūth al-Quddūs, 1995), 385-86.

654. Lacuna in Z omits: "following."

655. S repeats: "his determination ... he decided." 


\section{[7. Church Administration]}

$117 \mathrm{r}$ He had a strong determination, a great heart, and a zeal to beautify and reform the church. He fought for it and defended it, never being moved or turned back. It should not be a problem for us to mention a story as proof. There was a priest, a physician, who committed a small fault, so the blessed father restrained him and suspended him from exercising the priesthood for some time. This priest was serving one of the Hamdānid emirs-a fierce tyrant obedient to no one, not even Ibn Hamdān. He asked him to intercede with the patriarch to secure his release and cancel his suspension. His intercession came without delay, because he believed that no one-not even one of the most powerful Muslims-would dare to disobey him. So how could the patriarch, a lowly Christian dhimmi? ${ }^{656}$

Therefore he addressed the patriarch gladly, saying, "Whatever sin was committed by my physician, the priest, transfer his offense to me, O patriarch, and forgive him." He answered him, saying, "That is not possible for me, O my lord the emir." He responded to him, saying, "O uncircumcised man, don't you fear me? Yet you dare to tell me 'That is not possible for me'? What could be impossible for you if I have commanded it?" The bold man responded to him, saying "Many things are impossible for me, $\mathrm{O}$ emir, if they relate to my religion, my doctrine, and my law. ${ }^{657}$ For we are in obedience to ${ }^{658}$ you, ${ }^{659}$ and in other things it is not possible for us $117 \mathrm{v}$ to disobey you. But as for what religion has forbidden, when it comes to these things we are prepared to face prison and the blades of swords." So he responded to him: "At least let me know what is this grave offense that has violated your religion." The disciple of Christ said, "Before this, O emir, the crime was only a little one, and it would be easy to make satisfaction for it. But now it is great, and it is undesirable to forgive it, because he asked you to intercede ${ }^{660}-$ you, a Muslim, who disagrees with us in doctrine! ${ }^{661}$-and the truth of this case is no secret, since the matter concerns only our church." The Hagarene answered him, saying, "From now on, be armed to the teeth, and know beyond a shadow of a doubt that you are going to die. I would take your head even if it were on the breast of the Great Emir."

What did this bold man do after that? Was he anxious? Did he relent? Did he bend the knee? Did he stop to send a message about it to Ibn Hamdān? Absolutely not! Rather, he considered all of that to be nothing more than scattered dust of no importance. He set out at once for Antioch and entrusted it to God, his defender. At that time he was in Aleppo. ${ }^{662}$ Praise God, his aim was not off the mark. And this was his zeal and ambition for all that would beautify and adorn the church.

656. For "because he .. Christian dhimmī," Z reads: "trusting in his kindliness, especially as he was a dhimmī."

657. Dīnī wa-madhhabī wa-nāmūsī.

658. For "are in obedience to," S reads: "do not obey."

659. Plural.

660. For "he asked you to intercede," Z reads: "I find it horrible."

661. Madhhab.

662. Z places "At that ... in Aleppo" after the word "Antioch" in the previous sentence. 


\section{[8. Care for the Poor]}

If the way of this virtuous man in these things was as we have described, did he behave the same way in other things-as one who does not bend over or yield, and not ${ }^{663}$ as the meek lover of humanity who lends his sympathy and inclines his ear to anyone who asks, anyone who needs his mercy and compassion? In other areas, who was stronger in compassion than Christopher, or more tender $118 \mathrm{r}$ in sympathy for the afflicted, or stronger in mercy for those in need, or more generous in giving to the pure? His wealth was not abundant, because he was working among the Gentiles, so his revenues were diminished. Nevertheless, as far as it was possible for him, he never cut short his generosity, support, care, and giving-not only once, but many times, and not only occasionally, but continuously-if it was possible, conditions were easy, and he did not face difficult obstacles.

He received messages, and he never failed to read them and to record with his own hand that one of the petitioners ${ }^{664}$ should be given documents, ${ }^{665}$ another clothing, another food, another drink, and still others similar things. I myself, the composer of this text, saw a priest who had told him a story, so he brought him into his presence and asked him about it, saying, "How many dependents do you have?" He answered him, saying such and such, so he said, "Let him be paid this much wheat, this much oil, and this much wine," enough to last him a year. When the priest was beginning to leave, he said to him, "Come back here. Where, $\mathrm{O}$ unfortunate one, will you get the price of milling ${ }^{666}$ or any seasoning? No; pay him this, too, whatever is enough for him." The saint did not let him leave until he had given him enough to satisfy him for the whole year.

Furthermore, whenever the story of an imprisoned or unjustly extorted person came to him, if it was possible to redeem them with small gifts, he did not hesitate to give and to redeem them from whatever was demanded of them. But if there was an intense difficulty, he never failed to ride over to the one making the demands, $118 \mathrm{v}$ asking them to forgive whatever they wanted the person to pay and to make any possible reduction to the sum. This was the image of a new Nicholas ${ }^{667}$ among us, passionate in concern for all who were in hardship and need. All of this is evidence of the things he would do of his own accord and of his generous kindness.

His head, his zenith, the prototype to which he adhered and whose likeness he boreChrist, the imitation of whom was always in his thoughts and whom he desperately wished to emulate-was not content to fill the bellies of thousands with a few pieces of bread, but added another satisfying gift with his two pure hands: he washed the feet of his disciples. ${ }^{668}$

663. Z adds: "How would he then have shown by his actions that he was a worthy disciple of Christ?"

664. For "petitioners," Z reads: "poor."

665. Waraq. Potentially paper money.

666. For "milling," Z reads: "flour."

667. A fourth-century CE bishop of Myra, famed for his generous gifts; inspiration for the modern Santa Claus and his counterparts. Nicholas was extremely popular in this period. See Roberts, Reason, 68-72, 105-8, 111.

668. Cf. John 13:1-20. 
So this disciple of his also strove ${ }^{669}$ not to be satisfied with what we have described and added another service with his two hands for those who were his brothers in their connection to his teacher. In Antioch there was an intense famine that naturally affected all the people. Therefore, Christopher gathered a group of those most severely injured by hunger-the elderly, the sick, priests, deacons, young people, and orphans. He gathered them, organized them into schools, and had them sit at tables while he stood, not satisfied just because they had abundant food, but sometimes taking the task into his own hands and serving them drinks, one by one. It is thus clear that he was a faithful slave of Christ, imitating him in a way that no other could match.

\section{[9. Educational Works]}

Since I have now mentioned young people and orphans, ${ }^{670}$ I must explain who these young people were. It is clear, O listener, that he extended his soul not only in love for the weak but also in excellence of mind and in the benevolent administration of everything for the greater good. He saw how tight and difficult things were and that for this reason people were falling behind in their learning-and that not only the poor and powerless but even the notables, the people of esteem, were failing in it. The holy Church of God was lacking, and most of the people had no $119 \mathrm{r}$ thought or care for learning.

So he thought of a major program that would show his good administration: he chose from among the powerful ${ }^{671}$ twelve young people, intelligent and distinguished, and handed them over to an insightful teacher, who would teach them the ecclesiastical sciences that surpass all others. Then he cast lots to choose other people from among the poor, especially orphans in bad situations-150 young people-and handed them over to three teachers who would teach each one whatever they could do skillfully. He ordered that three large kettles full of food should be cooked every day, each one taken to one of the schools, and that every young person should be given whatever was enough for them, along with whatever bread they needed. We must recognize how many benefits he provided here-namely, three major ones: first, food that the eater did not have to labor for; second, education without price or payment; third, noble service to the church ${ }^{672}$ These are all among his great deeds in this area.

\section{[10. Defending the Faith]}

He added to this an even greater help for the poor and support for the faith. The Hagarenes extract from all Christians in their countries a $\operatorname{tax}^{673}$ that we call the "head

669. Ijtahada.

670. S omits: "He gathered ... and orphans." This lengthy variant is likely an accidental omission in S due to the repetition of "young people and orphans."

671. For "powerful," Z reads: "wealthy."

672. Bī`a.

673. Jizya. 
tax" 674 but they call the "acquittal," 675 because it acquits those who pay it of any damages or prosecution. None of the Christians who live there can escape from paying it, because whoever does not pay is led without a choice into the religion of Islam. An amazing and lamentable spectacle can be seen there among the afflicted. Some Christians pay the acquittal with righteous intentions, if they can, and consider $119 \mathrm{v}$ it a charitable gift and a good deed, because it is something they pay on account of their religion. But other people are oppressed by it because they are impoverished. Thus the strongest $\mathrm{n}$ religion is not the one who hesitates to pay what they can, but rather the one who gives to assist the weaker person with whatever is demanded of them.

When Christopher, who held Christ within his breast, saw the harshness of these things, giving was not enough for him, and he was not satisfied with making additions to people's acquittal payments; rather, he went beyond that and paid from his own wealth the entire acquittal for people who could not pay. However, his wealth was wearing out, and it was not easy for him to do these things in the way that he believed he should, because he did not have abundant revenues. So how do you think he approached this issue? In precise imitation of John the Merciful, ${ }^{676}$ master of Alexandria. He happily asked the emir, Sayf al-Dawla, to help him in his love for the poor, and he did not reject him, because he was generous in nature and intensely favorable to the patriarch. He ordered the tax ${ }^{677}$ collectors to forgive 10,000 dirhams for him every year, and he ${ }^{678}$ would write messages to them on behalf of whomever he wished to help. So he might write to forgive the entire acquittal for one person and write for another forgiving half of the amount. Thus not a single Christian went over to the religion of Islam during his time.

\section{[11. Loyalty to Sayf al-Dawla]}

So the patriarch received-along with rewards from God-a strong welcome from Sayf al-Dawla the emir, and favor from the same Sayf al-Dawla. For this is part of human nature: not only does the one for whom good is done trust in the patronage of their benefactor, $120 \mathrm{r}$ but the benefactor also adds to the benefits given to them. The beneficiary derives benefits from the patronage, but then the benefactor wishes to give them still more benefits, going to great lengths in both quantity and duration-especially if they have goodness in their nature-so that their previous benefaction will not be made futile by their miserliness.

Thus when intense opposition and rebellion broke out against Sayf al-Dawla and persisted for a long time, the patriarch alone kept his distance from it and did not join the group of Antiochians who were rebelling against him. He did not even wish to speak to the insurgents.

674. Jizyat al-ru'ūs.

675. Barā’a.

676. John V, Chalcedonian patriarch of Alexandria 606-16 CE, known for his almsgiving.

677. S calls this tax kharāj; Z calls it barāà.

678. That is, Christopher. 
Now, the reason for this rebellion was that the blessed Emperor Nikephoros ${ }^{679}$ was taking possession of the border country ${ }^{680}$ most of it by violence and war. Tarsus alone ${ }^{681}$ he took by a treaty of safe conduct, ${ }^{62}$ for hunger had ravished its people, and they had reached a disastrous state, inadequate for war. At the time, Sayf al-Dawla was suffering from paralysis ${ }^{683}$ in Mayyafariqin. ${ }^{684}$ As for the people of Tarsus, they came to the city of Antioch with their wives ${ }^{685}$ and children. The Hagarenes of Antioch were also concerned for themselves, so they went to Ibn al-Zayyāt, ${ }^{686}$ their governor, ${ }^{687}$ asking and begging him to stay with them and manage their affairs, since things were falling apart and becoming fragile. When Ibn al-Zayyāt saw that things were in such a state, he began to worry about Emperor Nikephoros. He loathed the idea and absolutely refused to stay.

The fear of the Antiochians increased at his refusal, which drove them to seek out Rashīq, ${ }^{688}$ Ibn al-Zayyāt's second-in-command. They asked him the same thing they had requested of the other, and he responded positively but indicated that they should submit to Emperor Nikephoros and yield to his rule. He reminded them $120 \mathrm{v}$ that this was the way of prosperity and that they would never attain the calm and tranquility that they desired if they did not obey him. They accepted his advice and sent messengers to the emperor, offering to bring money and to secure their agreement with pledges. Because the emperor was unyielding and was wary of them, he responded to the message they had sent, saying, "I do not accept money, because the emperor of the Romans has no need of it, and because the Muslims might give it today and refuse it tomorrow. Nor do I accept pledges, because while they have meaning for some people, most think nothing of them. I request only one thing, whenever you are ready and realize that it is an easy and insignificant thing for you to do: I wish to build on a rock formation within your city a fortress, in which I will have a stratēgos and a small number of others to defend you, and through them I will conquer."

When the Antiochians refused that, Raship felt ashamed and thought that he had become completely useless, so he decided to "uncover his head"-as the saying goes-in rebellion

679. Nikephoros II (r. 352-59/963-69).

680. Balad al-thaghr. Zayat translates this phrase as des villes du littoral ("the towns of the coast"), another potential (especially modern) meaning of thaghr, but it seems more likely that this is a reference to the Islamic geographical concept of al-thughūr, the border fortresses on the frontiers of Muslim-ruled territory, especially on the Byzantine border.

681. For "took Tarsus alone," $\mathrm{Z}$ reads: "destroyed Tarsus and took it."

682. Amān.

683. Aflaja. The primary meaning of this word is "to be victorious," but the context (along with other historical sources) makes it clear that Sayf al-Dawla was suffering from paralysis, or fālij; see 'Izz al-Dīn b. al-Athīr, al-Kāmil fi al-tārīkh, ed. Muhammad Yūsuf al-Daqqāq (Beirut: Dār al-Kutub al-'Ilmiyya, 1987), 7:279.

684. Modern Silvan, Turkey.

685. For "wives," S reads: "young people."

686. For "Ibn al-Zayyāt," Z reads: "Ibn al-Zamān.” This variant continues throughout the text.

687. That is, the newly arrived governor of Tarsus; see Canard, Histoire, 648-49.

688. For "Rashīq," Z reads: "Rashīq al-Nasīmī, who had come from Tarsus." This is the first of the edits that have been made to $\mathrm{Z}$ in order to bring it in line with the Dhayl of Yahyā b. Sa ${ }^{\mathrm{i}} \mathrm{d}$ al-Anțākī; see al-Anțākī, "Histoire," 797. 
against Sayf al-Dawla, especially because of his paralysis and inability to move, which made people think little of him. Once Rashīq had made this decision, ${ }^{689}$ he gathered his supporters together and headed for the city of Aleppo. ${ }^{690} \mathrm{He}$ took it by force without much effort and began to lay siege to the citadel, but it would not budge. A servant of Sayf al-Dawla named Qarghuwayh ${ }^{691}$ was there, and he would send out men every day to fight Rashīq. One of them-it was not clear who-struck him with a spear thrust during the battle, $121 \mathrm{r}$ so he died there, and when he fell dead, ${ }^{692}$ the others fled to Antioch. When they arrived, they were concerned for themselves, and they set a member of their group at their head as their emir. ${ }^{693}$ They remained firmly committed to their opposition and rebellion. The one who encouraged them in this was a person of Antioch named Ibn al-Ahwāzì, an intense and dynamic person who had been the manager of their affairs in the time of Rashìq. ${ }^{694}$

What did the patriarch do during this time of chaos in Antioch, which was only growing more and more difficult? His well-managed mind encouraged him to remain firm in the patronage of Sayf al-Dawla, so he withdrew to the monastery of St. Symeon of Aleppo. For even if Sayf al-Dawla was paralyzed at the time, his mind had not completely faded, and his tongue had not lost the power of speech. So while the patriarch ${ }^{695}$ was staying in the monastery, his situation was revealed by night to those in Aleppo, ${ }^{696}$ and it was unbearable for the rebel. He began to investigate the patriarch's connections and to arrest and harass his closest companions. He sealed up everything in the patriarchal cells ${ }^{697}$ and said aloud that if the patriarch did not come and take care of it, he would cause him even more grief.

Did the patriarch surrender to him, or get worried, or yield? No! He remained completely firm. One of his closest companions-Theodoulos, who became bishop of Seleucia after he

689. For "Once Rashīq . . . this decision," Z reads: "Then a man of Antioch known as al-Hasan al-Ahwāzī attached himself to Rashī and took over the management of his affairs with the help of the people of Antioch. He was intense and dynamic, and he gave them hope that Sayf al-Dawla would never return to Syria (al-Shām). Dizbar al-Daylamī and a group of Daylamites who were with Qarghuwayh, the servant of Sayf al-Dawla, sought the protection of Rashīq. Rashīq and Ibn al-Ahwāzī set out." See al-Anțākī, "Histoire," 797-98.

690. Z adds: "Many battles took place between him and Qarghuwayh." See ibid., 798.

691. The spelling of this name is very uncertain. Zayat transliterates it as Qarghoyah and Canard (Histoire, 649-51) as Qargawaih.

692. For "lay siege ... fell dead," Z reads: "lay siege to the citadel for three months and ten days. Afterward Rashīq was killed by a spear thrust that hit him." Al-Anțākī includes the "three months and ten days" detail but not the detail about the spear thrust, which is probably a summarized form of S; see al-Anțākī, "Histoire," 798.

693. For "they were . . . their emir," Z reads: "they were concerned and afraid, and they made Dizbar al-Daylamī their emir and Ibn al-Ahwāzī his manager." See ibid.

694. For "The one ... of Rashīq," Z reads: "Qarghuwayh headed for Antioch and a battle took place between them, but Qarghuwayh fled and returned to Aleppo. Dizbar al-Daylamī went to Aleppo after him, but the companions of Qarghuwayh met him, fought him, and repulsed him, so he returned to Antioch." See ibid.

695. $\mathrm{Z}$ adds: "and those with him."

696. Z omits: "his situation ... in Aleppo."

697. $Z$ adds: "because of the inclination of the patriarch and those with him toward Sayf al-Dawla, which had been revealed to him." See al-Anțākī, "Histoire," 798. 
was killed and who built two beautiful churches ${ }^{698}$ in Antioch, for the Arkhistratēgos ${ }^{699}$ and for Chrysostom-observed him acting in this way. He grew bold and said to him, "Sir, when this is all over, do you intend to tell your church, ${ }^{700} \square 121 \mathrm{v}$ 'I am the good shepherd'? ${ }^{701}$ Do not leave your sheep for the ravishing wolves to snatch up! Consider the matter, then go and extend a hand to help them, and do not think about what the rebel wants, but about what is best for you and your flock." The patriarch said, "Hold your tongue and be silent, ${ }^{702}$ because you do not know what you are saying." So he had to hold his tongue.

After a little while, the servants of Sayf al-Dawla could no longer bear their shame quietly. They got him started on his journey and helped him get up, so he journeyed from Mayyafariqin to the area of Ma'arrat Mișrin, and war broke out between the two sides. The victory went to Sayf al-Dawla, and the chief officers of the rebels ${ }^{703}$ were taken prisoner. He put them in shackles and chains. ${ }^{704}$

Then the patriarch made his way to Aleppo, as happy as one who had triumphed in an agonizing ${ }^{705}$ struggle. Sayf al-Dawla gave him the warmest welcome and he became his close companion in all things, a helpful and beloved intercessor. He went from the status of an insignificant follower to that of an influential friend, not to be accused or belittled, because in the time of hardship he had been faithful, constant, and patient in spite of his affliction. What he had given in the time of distress was repaid in the time of happiness with special treatment and preference. ${ }^{706}$

He saw those who had grieved him punished before his very eyes with beatings, abuse, and other types of torment that are impossible to bear, but he was not pleased as others were. He did not grow arrogant on account of his victory; rather, he mourned, he felt a tightness in his chest, his thoughts were troubled, and he said, "Have mercy, sir, and go easy

698. Haykalayn.

699. For "the Arkhistratēgos," S reads: al-aksīrātīqūs; Z reads: al-azkis 'üțus. I take this to be the Greek arkhistratēgos, "supreme commander" (a common epithet of Michael, the "supreme commander" of the heavenly forces), as suggested to me by Dmitry Morozov. Dick's edition has al-iksābtirīghūs, Greek hexapterygos, meaning "six-winged" (seraph). This must be Dick's guess at the original word, because it is not supported by either manuscript. The meaning is almost right, however, even if the word is not. See Dik, Sira, 15, 46.

700. $B \bar{i}^{c} a$.

701. John 10:11, 14

702. Lacuna in $\mathrm{Z}$ omits: "Consider the ... be silent."

703. For "the chief . . . the rebels," Z reads: "Dizbar and Ibn al-Ahwāzī and a large group of their soldiers." See al-Anțākī, "Histoire," 805. The term "rebels" translates khawārij (sg. khārijī), an allusion to the khārijī rebel group of the early Islamic period, but Ibrāhīm uses the term here in a general sense.

704. Z adds: "and brought them to Aleppo, and killed them, and he made his servant Taqi governor of Antioch." See ibid.

705. This word is omitted in Z and not fully legible in S. Dick's edition (Dīk, Sīra, 47) reads it as lūyā, but in S there seems to be at least one letter between the wāw and the yā'. I have read it here as law'iyyan, although the meaning of “agonizing" works for Dick's reading as well. It could perhaps be emended to lūdīyā and read as a reference (via Greek and/or Syriac) to the gladiator games, Latin ludi.

706. $\mathrm{Z}$ adds: "because he was grateful to him for his act of distancing himself from those who rebelled against him, and so he preferred him and gave him special treatment." See al-Anțākī, "Histoire," 806. 
on those you have defeated, for the sake of $122 \mathrm{r}$ the one who helped you stand against them! Do not refuse intercession and forgiveness as much as your duty allows."

When he saw one of his neighbors, one of the Muslims of the city of Antioch, ${ }^{707}$ being punished and struck with far too many lashes, he did not sit patiently. He stood up, threw himself on the ground, and asked that the man's crime be given to him, and his request was not rejected. But what misfortune and evil grew out of this for him, I will explain in what follows. And that should not be surprising, even if it is improbable and strange. For so the nature of envy is imprinted on malicious souls, that their fire is ignited by goodness more than it is extinguished by kindness. When that envious one was set free and released from everything that had been imposed on him, he returned to Antioch without any consequences. If only it had not been so! ${ }^{708}$

\section{[12. Return to Antioch]}

After that, the patriarch stayed for a little while in Aleppo and then went to his city, bringing signed notes from Sayf al-Dawla to those whom he had dispatched to Antioch in an effort to get even with everyone who had helped the Antiochian rebels ${ }^{709}$ against him. He ordered them not only to absolve the patriarch and his companions of any responsibility but also to approve his requests-as often as possible-when he interceded on behalf of others, for the patriarch had taken up many such cases.

When he arrived in Antioch, he found a governor there, a servant of Sayf al-Dawla ${ }^{710}$ known as Taqi. ${ }^{711} \mathrm{He}$ also found the patrikios Kulayb ${ }^{712}$ seizing the wealth of the people, though he had not been commanded to take ${ }^{713}$ so much, $122 \mathrm{v}$ and confiscating all of their possessions. Sayf al-Dawla did not show them the kindness of restraining him from seizing their goods but acted out of pure self-interest, for he could see that these seizures were $e^{714}$ impoverishing the people, ruining the country, and eliminating any revenue. The fines had

707. It is not entirely clear, but it seems from the description in $§ 13$ that this may be Ibn Mānik, the future leader of the assassination plot (not actually named in S until §17).

708. Z adds: "Even so, there were many other elders of Antioch with whom Sayf al-Dawla was angry on account of their rebellion and whom he had arrested. The patriarch interceded with him for some of them and acted as his mediator with them, and he granted his request regarding them. So at that time, because they witnessed his powerful position with Sayf al-Dawla, their souls became set in envy and resentment of him." See al-Anțākī, "Histoire," 806-7.

709. Khārijiyyinn, another allusion to the early Islamic khawārij; see note 104 above.

710. Z omits: "a servant of Sayf al-Dawla."

711. For “Taqī,” Z reads: “Taqī al-Dīn, whom we have mentioned." See al-Anțākī, "Histoire,” 805.

712. Kulayb, likely a Syriac Orthodox Christian, later became basilikos of Antioch and eventually of Melitene under Byzantine rule; see ibid., 2:369, 373-74, 420. Al-Anțākī simply calls him a "Christian” (nașrānī), but Michael the Syrian mentions that he sponsored construction work at a Syriac Orthodox monastery in Melitene; see Michael the Syrian, Chronique, ed. and trans. J.-B. Chabot (Brussels: Culture et Civilisation, 1963), 3:126, 4:553; Catherine Holmes, "'How the East Was Won' in the Reign of Basil II," in Eastern Approaches to Byzantium, ed. Antony Eastmond, 41-56 (Aldershot: Ashgate, 2001), 49.

713. Z omits: "the wealth ... to take."

714. Z omits: "but acted... seizures were." 
brought people to such a state that they barely had enough to pay for housing, taxes, and other such things. When the patriarch saw the people of Antioch struggling under these demands, whom did he not deliver and redeem from the bulk of their fines? Whose burden did he not lighten? Whom did he not redeem entirely, if he could?

Now, there was a resident ${ }^{715}$ of Antioch who was very wealthy because he owned extensive real estate and had many sources of income but who thought of nothing but himself. He would hunch over as he walked, never raising his head from the ground, because he was such an arrogant miser. The wretch had never used a bit of his money to help anyone, not even himself. So the companions of Sayf al-Dawla seized him and began to punish him, demanding three and a half qințārs ${ }^{716}$ of gold. He sent to the holy patriarch in the midst of his punishment and said to him, "Have mercy, sir, on a wretch like me." By my life, the patriarch got to work quickly, as usual, eager to help anyone who asked for his aid. He rode over at that very moment, relieved him of his torment, and mediated for him regarding the amount that was demanded. He did not stop making requests on his behalf until he had reduced the massive sum from 25,000 $123 \mathrm{r}$ dinars to a tenth of that, that is, 2,500 dinars. The tax collectors said, "He will not pay even this amount without being punished and beaten." So the disciple of Christ, who resembled him in every way, said, "I am asking you not to go overboard by punishing him any more, but to hand him over to me, and I will be responsible for the whole sum." He was handed over to the patriarch, and the tax collectors would later demand from the patriarch the entire sum, and then the patriarch would have to ${ }^{717}$ demand it from him. Whenever the patriarch would write to him about this, it was like his heart was being pierced, as the arrows of envy worked within him. Thus he later consented to kill the one who had been his benefactor.

\section{[13. The Assassination Plot]}

Now the killing of the patriarch-or rather, his martyrdom-was carried out by the decision of this man and others. It was organized in secret and proceeded little by little. For because Sayf al-Dawla was inclined toward him, ${ }^{718}$ the raw material of envy had accumulated in the hearts of the Muslims. However, they were not all agreed on killing him. On the other hand, those who did agree were among those whom he had most generously benefited, for the father of envy was at work within them.

The proof was as follows: after Sayf al-Dawla died, ${ }^{719}$ people came from the land of Khorasan, warriors hurrying on their way to Antioch. ${ }^{720}$ That cursed one, whose benefactor

715. It is not entirely clear, but it seems from his description in $\S 13$ that this may be Ibn Mahmūd.

716. From Latin centenarius/Greek kentēnarion, the qințār is a variable weight equivalent to 100 arțāl and sometimes used to refer to an indeterminate (large) amount. Based on the typical Syrian qințār of $256 \mathrm{~kg}$, the amount demanded from this miser was likely almost $900 \mathrm{~kg}$ (nearly one ton) of gold.

717. S omits: "the entire ... have to."

718. That is, Christopher.

719. 25 Șafar 356/9 February 967.

720. For "from the ... to Antioch," $\mathrm{Z}$ reads: "from the land of Khorasan, intending to raid the Romans, so they traveled to Antioch, and its people gave them the most beautiful welcome." See al-Anțākī, "Histoire," 807. 
the patriarch had been, ${ }^{721}$ in whom the venom of envy was at work, and who had thought to plot against the patriarch because of his empowerment, was afraid. If he did not communicate with the leader of the Khorasanis, ${ }^{722}$ he would miss the chance of killing him.

So he summoned ${ }^{723}$ Ibn Mahmūd, for whom $123 \mathrm{v}$ the patriarch had vouched, ${ }^{724}$ who had made known to him what he had against him in his soul; and he summoned another person, a neighbor of the patriarch called Ibn Di'āma. He said to them, "What do you say? Do you think we should leave this infidel alive until a governor arrives, so that he will be sitting in court while we are punished, as we were in the time of Sayf al-Dawla?" They said, "That is not right." So he said, "Then what do you think about requesting a written fatwa $\bar{a}^{725}$ about him from the jurist?" They praised this idea and with one mind, they all wrote a note called a fatwa. ${ }^{726}$ They did not mention the patriarch by name but said, "What is your opinion, 0 jurist, on the just response to someone who plots against a Muslim fortress?" He answered that the person must be killed.

The leader of the plot said to the other two, "This fatwā is the way: if we show it to the masses, they will kill him immediately." This was not actually his opinion; rather, because he was also a Persian and knew the language of the Khorasanis, he was secretly planning to call a group of the soldiers who had been sent to Antioch and show them the fatwa so that they would kill the patriarch without hesitation. This helped to convince them and to spur them toward what he wanted.

\section{[14. The Patriarch's Decision]}

One of the patriarch's neighbors, a prominent Muslim named Ibn Abī 'Amr who was a true friend and adviser to him, found out about this. So he rushed over and said to him, "What are you doing? Get up quickly and look out for yourself! Otherwise, you should be aware that you are going to be killed soon." He said, "Why? For what reason?" He said, "Because $124 \mathrm{r}$ a malicious group gathered against you and consulted the law, and the jurist gave a fatwā that says you must be killed." He asked for more information and said, "What do you think I should do?" He said, "At the moment you are not under arrest, so leave through the city gate at the end of the day, and when morning breaks, you will be

These soldiers were likely coming to reinforce the frontier defenses and preserve Muslim control of Antioch as word spread of Byzantine advances in the region; see Kennedy, Prophet, 238, 240.

721. For "whose benefactor ... had been," Z reads: "whom the patriarch had taken under his wing." This is Ibn Mānik, likely the man whose punishment he alleviated at the end of §11 above.

722. This leader is not named here, but al-Anțākì ("Histoire," 807) claims that his name was Muhammad b. 'Īsā.

723. $\mathrm{Z}$ adds: "three of the elders and model citizens of Antioch for whom the patriarch had mediated and interceded." See ibid.

724. Z omits: "for whom ... had vouched."

725. Throughout this passage, both $\mathrm{S}$ and $\mathrm{Z}$ use a variety of spellings for this word, including fatwa (in Z), fita (in S), and futya (in both).

726. Normally, fatwā would refer more specifically to the jurist's response to their question, but Ibrāhīm apparently uses it to mean both the question and the answer. 
near Aleppo, and no one will follow you. That is what I think." He said, "Sir, may God reward you with good things. As for me, I must think about what I will do."

The man departed, and the patriarch summoned that man who had said to him when he was at the monastery of St. Symeon, "Why do you not go to Antioch in the time of rebellion? Are you, sir, the sort of person who can say after this, 'I am the good shepherd'?"727 When he arrived, he ${ }^{728}$ said to him, "You should know, O man, that our neighbor so-and-so came to me this very hour and told me such-and-such. What do you think?" The man said to him, "What could be better than this, sir? Ask God's blessing and do it!" He said, "If I do this, $\mathrm{O}$ insolent one, you will be among those who mock me afterward, saying, "Can you say tomorrow, "I am the good shepherd"?" The man answered, saying, "Sir, that was different." So the patriarch said to him, "Yes, it is not hidden from me that it was different. ${ }^{729}$ That is why, because I did not agree with you then, I did not do it. And when I did not do it, even you knew that none of the Christians would be harmed as a result, because no one was demanding my murder at that $124 \mathrm{v}$ time. But now, my murder is demanded, and not simply demanded, but demanded with intense desire and effort. For those who demand my murder are envious, and the venom of envy is concealed within their bodies. So if I slip out of their hands and they cannot inject their venom into me, they will not leave behind a single Christian or a single church. This is the time, O man, when I must say not only 'I am the good shepherd' but also that 'the good shepherd lays down his life for his sheep.730 Soon you will see this beard dyed with my blood." With that, he moved his hand toward it. His speech ended with this saying, and after that he said not another word; he was almost ashamed at the thought.

\section{[15. The Assassination]}

Afterward, he gave it some thought and decided to meet with that evil man who was preparing to act against him. He knew beyond a shadow of a doubt that he had mixed for him the brew ${ }^{731}$ of death. However, he did not think that he would do this in his home, for no desert Arab, ${ }^{732}$ nor any esteemed person among the Muslims, would consider this a good way to commit a crime. So after a little while, he sent him a note, showing neither wariness nor fear: "Sir, I would like to meet with you. Please tell me what you think and I will be available to come to you." ${ }^{733}$ He saw this message as an opportunity and as potential spoils,

727. See §11. The man’s name is Theodoulos.

728. Christopher.

729. S repeats: "So the ... was different."

730. John 10:11.

731. Qahwa. This Arabic word became the word "coffee," and it is the ultimate source of the beverage's name in all languages, including English. However, coffee was (most likely) discovered several centuries after the composition of this text. At this time, according to Lisān al-'Arab, qahwa referred to a type of wine. In any case, the metaphorical meaning of the phrase is clear.

732. A'rābì.

733. Z adds: "When Ibn Mānik heard this." See al-Anțākī, "Histoire," 808. 
and he said, "I am not available at the moment, but later I will send for you." Then he spent his entire day on the plot and did not send him anything because he was busy deceiving him and strengthening what he had cooking for him.

When $125 \mathrm{r}$ much of the night had come and gone, and the patriarch had eaten his customary food, he ${ }^{734}$ sent to him, saying, "I am now available, O patriarch, so if you want to come, then come." When the lamb of Christ heard this message, at such an unusual time, he was stunned and said to his companions, "What is the right thing to do, O people, when we are facing two irreconcilable options? Going at this time of night is neither proper nor appropriate, because the food is already in my mouth, and my strength-I am too weak to speak at this point. But postponing would also lead to trouble, because then we would be the ones who missed the appointment. But there is a way: can one of you check my breath? If you smell wine on me, we will use that as an excuse and say that it is not possible at this time. But if my breath is clean, we will go anyway." When one of them checked his breath and there was no odor, ${ }^{735}$ he went on his own two feet, like a lamb going to the slaughter ${ }^{736}$ of its own free will.

That cursed one welcomed him and greeted him with affection, even as deceit was concealed within his heart. When they sat together, he was full of wrath and hatred against him, so he could not wait for the patriarch to begin speaking, but said to him, "What are you thinking, O patriarch? You are one of the people of this town, dwelling among us, yet you think badly of our interactions and act against us." The patriarch said, "And how is that, sir? What do you mean?" He said in response, "Because you correspond with the emperor of the Romans, ${ }^{737}$ and you correspond with the servant of Ibn Hamdān." So he said, ${ }_{125 \mathrm{v}}$ "And what is the evidence for that, sir? Who has found such a letter from me?" $\mathrm{He}^{738}$ got up as if he were searching for a letter, then suddenly stood and spoke in Persian, summoning the Khorasanis whom he had prepared for the murder.

Still, he was worried and trembling. Not only was he a coward, but to both heart and eye, he looked like a bat. For he was hardly taller than a span, ${ }^{739}$ only by a little. He looked like a bat in color, facial expressions, and complexion. When those whom he had prepared and summoned arrived, he said to them in their language, his teeth chattering, "This is the one you are looking for! This is the man who wants to hand over this city! This is the enemy of the Muslims! Here you are, and here he is! Cut him to pieces without pity!"

If he were the enemy of the Muslims, ${ }^{740}$ you mouse's eye, you complete rat, then why was he not your enemy in the time of difficulty? Rather, he was your friend, the friend who

734. Ibn Mānik. Z calls him "that cursed one."

735. S repeats: "and there was no odor."

736. Cf. Isaiah 53:7; Jeremiah 11:19; Acts 8:32.

737. $\mathrm{Z}$ adds: "and incite them to come toward us, and encourage them against us." See al-Anțākī, "Histoire," 809.

738. For "He," Z reads: "Ibn Mānik." See ibid.

739. A span (Arabic shibr) is the distance from the end of the thumb to the end of the little finger, roughly $23 \mathrm{~cm}$-obviously hyperbole in this case.

740. Lacuna in Z omits: "Here you ... the Muslims." 
was helpful to you and delivered you from torment! But when this one whose soul was like that of a crocodile, requiting goodness with evil, gave the command regarding him, the sacrificial lamb of Christ stretched out his neck without any alarm, waiting for his head to be taken.

Those people had not swords, but long daggers. One of them made him stand up while the other struck him with a long dagger, and all of the iron passed through his belly. The sword of $\mathrm{God}^{741}$ was sharpened, but at that time it was held back, as God's judgments often are, awaiting punishment at another time. When the martyr fell to the ground, his head was first cut off, then his pure body was dragged around on a ladder by the command of the one who had rejected both God and goodness. It was immediately thrown $126 \mathrm{r}$ into the river after the gate was opened for it at night. ${ }^{742}$

But this could not be hidden from the Christian populace, and when their shepherd fell, they were stunned, struck by what had happened so suddenly, and intensely anxious. They scattered into the houses of some of the Muslims, where they hid. However, no one sought them out, for it was necessary that the earlier saying of their father should be fulfilled: "If they satisfy their thirst for revenge by killing me, and inject into me the venom concealed within their hearts, they will not pursue anyone but me."

\section{[16. Plundering the Church]}

As for that animal with the ferocious appearance, ever increasing in beastliness, he kept quiet for most of the night, because he was on the edge of losing his mind for good. But when dawn had come, he returned to himself and directed his guards toward the church $^{743}$ and the patriarchal cells. There was a group to search each of the two places. ${ }^{744}$ In the patriarchal cells, they found nothing but some foodstuffs, such as wheat, figs, and oil, preserved as provisions for the church and nourishment for the brothers in Christ. How could they find anything else when there was no gold ${ }^{745}$ hoarded there? How could he hoard when his expenses exceeded what he took in? Nor was there any clothing. How could any belong to someone whose clothing was only wool ${ }^{746}$ without even a monastic habit? ${ }^{747}$ But there were a few priestly funeral garments there that belonged to his predecessors throughout time, and they took all of them.

And they opened the treasury of the church, and when they did not see anything there, they punished the treasurer until he showed them the hidden gold and silver utensils of the

741. Sayf Allāh. In S, the scribe mistakenly wrote Sayf al-Dawla before crossing out al-Dawla and writing Allāh.

742. For "then his ... at night," Z reads: "and thrown into the furnace of the bath in the neighborhood of Ibn Mānik's house. Then his pure body was immediately brought out of the city gate by night and thrown into the river." See al-Anțākī, "Histoire," 809.

743. Bīca. Z adds: "the Church of Cassian" (Kanīsat Qusyān). See ibid., 809-10.

744. Lacuna in Z omits: "to search ... two places."

745. Z adds: "or silver."

746. Șüf.

747. Askìm rahbāniyya. Askīm is from the Greek skhēma. 
church, $126 \mathrm{v}$ along with the silk garments that were kept to decorate the church. They left nothing but a few copper things and manuscripts. ${ }^{78}$ Out of all this, the cursed one did not give those who had shed the pure and innocent blood ${ }^{749}$ everything that they had agreed. He kept back some of it in order to give it as a gift to the Persians whom he was expecting to come on their way to the land of the Romans. In the midst of all this, they arrived, and the Antiochians welcomed them magnificently. That cursed infidel was especially important for them, not only because of what he brought them, but also because he shared their tribe and language. And they began to raid the Roman border regions $\mathrm{s}^{750}$ and to devastate them.

\section{[17. Divine Retribution]}

Now the blessed Emperor Nikephoros was busy with the Bulgars. When he returned, he sent Peter the Stratopedarkhēs, ${ }^{751}$ who had a battle with the Khorasanis near the city of Alexander known as Alexandria, ${ }^{752}$ and the Persians were put to flight after extensive fighting. ${ }^{753}$ With them was a group of Muslim assassins of Tarsus ${ }^{754}$ who had advised them not to fight, nor to keep making war, for they said, "The army that is fighting you is an imperial army, and you have no power against them." The Persians did not accept this but persisted until their bravest men and most of the others were killed, and their chiefs were taken captive.

All of this was a necessary judgment from Heaven, for justice could not delay in avenging the blood of the martyr. Here it seems that we may go on for too long-even if it would be insufficient, coming from us-in clarifying the marvelous and efficient system, working according to an uninterrupted arrangement, by which the wicked received an evil repayment for their deeds. But telling the story contains some $127 \mathrm{r}$ benefit, for from these facts everyone can verify what prophecy tells us about falling into the hands of the living God: both that it is terrifying, and that repayment might come quickly, or else only a part of it might come quickly, in which case it is evidence that the remainder will later come to pass.

748. $\mathrm{Z}$ adds: "And they also took the chair of St. Peter the Apostle, which was made of palm wood overlaid with silver. They kept it in the house of one of their elders, known as Ibn 'Āmir, and it remained in his house until the Romans took possession of the city." See al-Anțākī, "Histoire," 810.

749. Z adds: "those of his nation."

750. S omits: "and language ... border regions."

751. An army commander. S: al-isțirātūus.

752. This is Alexandretta, now known as İskenderun.

753. For "and the ... extensive fighting," Z reads: "which is between Mopsuestia and Antioch, as they were returning from their raids. He attacked them, killed their bravest men, and took the sālār of the army and others as captives." See al-Anțākī, "Histoire," 814.

754. For “Tarsus," Z reads: "Ṭarțūs." 
One of the chiefs of the Hagarenes ${ }^{755}$ imprisoned in that war was the sālār ${ }^{756}$ of the army. The Antiochians purchased him for a massive amount of money, garments, and prisoners ${ }^{757}$ who were in Antioch and whom the people had taken captive. ${ }^{758}$ When it was done, ${ }^{759}$ he came to Antioch, and some of its people welcomed him and celebrated his arrival. However, as much as he entered in honor, and they honored and exalted him beyond any legitimate level, in the end he had the most shameful and disgraceful exit. For the Antiochians could not endure what they were undergoing at the hands of his men who had escaped the fighting. They had returned naked, and he like them. Thus necessity forced them to seize whatever would preserve them, and their hands stretched toward the wealth of the Antiochians. ${ }^{760}$ They did not endure that from them, but resisted them, war broke out between them, and the people of the city drove them out naked.

The Antiochians who fought them were in two bands, and the chief of one turned against the chief of the other and killed him. For someone had come from Egypt, ${ }^{761}$ one of the brigands ${ }^{762}$ of Tarsus ${ }^{763}$ who had fled. He returned with a small band to raid the Roman border region. ${ }^{764}$ The chief of the other band was a Kurd from Būqa ${ }^{765}$ called 'Allūsh, and the one who came from Egypt was a Black man named al-Rughayli. ${ }^{766} 127 \mathrm{v}$ At that point the city was in the hand of 'Allūsh. ${ }^{767}$ Al-Rughayli entered and greeted him, and when he bent over to take his hand, his sword was sideways on his knees. So al-Rughayli drew it, struck him with it, and killed him. Thus he dared to do two impressive things at one time and openly: drawing a chief's sword from his lap, and quickly killing him without a pause. So the followers of the one who was killed were scattered, even though they were many, and command passed to the killer, even though his men were very few. ${ }^{768}$

However, his rule did not endure and his time was not long, for Peter the Stratopedarkhēs came shortly with a huge contingent from the army of the praiseworthy Emperor

755. Z reads: "Khorasanis." See al-Anțākī, "Histoire," 814.

756. A Persian word for a chieftain or leader.

757. $\mathrm{Z}$ adds: "whom they had previously taken captive from the Romans." See al-Anțākī "Histoire," 814.

758. Z omits: "whom the ... taken captive."

759. For "When it was done," Z reads: "When the salār was set free." See al-Anțākī, "Histoire," 814.

760. For "and their ... the Antiochians," Z reads: "so they overpowered the Antiochians and began to seize their wealth and their goods." See ibid.

761. For "For someone . . from Egypt," Z reads: "A Black man had come from Egypt to Antioch.” See ibid., 822.

762. "Brigands" translates șa ălīk. My impression is that this man had escaped from Tarsus during the Byzantine conquest.

763. Z adds: "known as al-Rughaylī." See al-Anțākī, "Histoire," 822.

764. $\mathrm{Z}$ adds: "This was the chief of the first band."

765. Often spelled Būqa, a fortress and village near Antioch, somewhat important in the early centuries of Islam but eventually lost.

766. Z omits: "and the ... al-Rughayli." As with many of the names in this text, the correct spelling of the name "al-Rughaylī" is uncertain (in Arabic as well as in English).

767. For "in the hand of 'Allūsh," Z reads: "in his hand."

768. Z adds: "and al-Rughaylī took control of Antioch." See al-Anțākī, "Histoire," 822. 
Nikephoros. When he came, he conquered the great city that very night, ${ }^{769}$ although he had not even been seeking it. He found it weak because of the previous raids on its territories, and he found its people neglecting to preserve and protect it, because they had not heard the news that someone was coming for it. They could not in one moment gather enough men to climb the mountain and defend the wall, ${ }^{770}$ so the Romans quickly climbed it. They found it empty, so they were able to climb it. They took possession of the city ${ }^{771}$ and took everyone in it captive, and no one escaped except that cursed one who was the foundation of the whole catastrophe. ${ }^{772}$

Now see here, $\mathrm{O}$ listener, how the just judgment for earlier actions is delayed but comes to you more perfectly later on. For he had gone out of the city at night, seeking to find safety in some place within the lands of Islam, and at first the affair remained hidden. He was happy, not only because $128 \mathrm{r}$ he alone was saved from captivity, but also because he was able-as he thought-to trick, deceive, and lie to God and the angels, so that they had carried him through the air and saved him. This had long been his habit, and he had achieved precision in the art of tricking, swindling, and lying to the Lord of the Worlds. ${ }^{773}$ However, just judgment got ahead of him, and on the road, a bāqūlā ${ }^{774}$ of Syrians met him on Jabal al-Aqrac ${ }^{775}$ They did not know that the city had been conquered. ${ }^{776}$ They seized him and brought him there once they found out about the conquest from the people who were with him. At that time the stratopedarkhēs was in Aleppo, and its people were seeking

769. For "he conquered . . very night," Z reads: "Michael Bourtzēs, who was in charge of the fortress of Baghrās, joined him, and they continuously besieged the great city." See ibid.

770. Antioch lies at the base of Mount Silpius, and its historic city walls climb up and enclose a portion of the mountain to provide additional protection from higher ground.

771. Z adds: "on Thursday, when thirteen nights had passed from Dhū al-Hijja, in the year 358 [28 October 969]. The Muslims threw fire to turn the Romans away from them and opened the Sea Gate, and some people left through it." See al-Anțākī, "Histoire," 822-23.

772. Z adds: "Ibn Mānik." See ibid., 823.

773. Rabb al- '`̄lamīn.

774. S reads: rāqūla, here and below. Z adds: "that is, a gang" ('așaba). This seems to be an obscure Syriac word, mentioned only in Thomas Audo's dictionary: the agent-noun form of the equally obscure verb bqal, usually used for plants, meaning "to sprout, blossom, shoot up." The literal translation would thus be "one who shoots up" or "springs up," perhaps indicating that these Syrians were a band of outlaws "springing up" in rebellion against the various rulers of Aleppo, Antioch, and beyond. Such outlaws would no doubt find the mountains a congenial site for their operations. Another possibility is that this is the Greek word bakyla, meaning "sticks" or even "fasces," or the Syriac būqālā (cowherd). Could there be a connection to the Qarmați rebels known as Baqliyya, the "green vegetable people," thanks to their ascetic vegetarian diet? This is not impossible, especially given the presence of Qarmatîs in other parts of the Life, but mentions of the Baqliyya are mostly confined to the Sawād region of southern Iraq, and it would be strange to hear of Qarmațis who are also Suryān (and thus likely Christian). Canard ("Vie," 565) even suggests that this may be the name of a tribe. If $r \bar{q} q \bar{u} l a$ is the correct form, the Arabic word rāqūl, referring to a type of rope, is a possible origin, along with the Syriac rakālā (peddler, merchant). The derivation of the present meaning is unclear in any case, and it is no surprise that the scribe of $Z$-or one of his predecessors-felt the need to insert a less obscure Arabic gloss.

775. Also known as Mount Kasios, now on the border between Turkey and Syria, just south of Antioch. Z adds: "They used to raid Antioch." See al-Anțākī, "Histoire," 823.

776. Z omits: "They did ... been conquered." 
a peace settlement with him. They agreed on a massive amount of money and brought it to him, and after he had checked the amount, he returned. So the people of the bāqūla brought him that cursed one, whom they had taken captive; he was known as Ibn Mānik. ${ }^{777}$ He handed him over to someone who would guard him until he could determine what he needed to do with him. ${ }^{778}$

The chiefs of the army gathered to deliberate on the issue, ${ }^{779}$ and some of the chiefs advised that he should be brought to the emperor. But others disagreed and said, "Who is this man that he is worthy to be brought into the imperial presence? The most appropriate thing is to kill him, in order to avenge the innocent blood that he shed." But the others, who were advising that he be brought there, answered them and said, "It is not right to pollute that pure blood with this impure blood." At last the patrikios Eustathios, strategos of Cappadocia, known as Maleinos, said, "Is the patriarch here ordering us to kill him, so that his blood can be 'polluted,' as you say? He completed what was necessary for him to do, $128 \mathrm{v}$ then departed and arrived at a place where he awaits a beautiful reward from God. But as for us, if we are Christians, then we must avenge the injustice that was done to him."

When he said something like this, it convinced them, and they sent the one who had been judged to the bridge at the Sea Gate, from which he himself had thrown the noble body into the river. He was cut apart with swords, piece by piece, but the pieces were not thrown into the river, for he was not worthy of that. Rather, each one was thrown at random onto the ground, and they became food for the birds and the dogs. As for the other two ${ }^{780}$ who had shared with him in spilling the blood, they were sent to the prison of Tarsus. ${ }^{781}$ They were not sought at that time, and no judgment was carried out in their cases. ${ }^{782}$

\section{[18. The Remains of the Saint]}

Now as it happened, the emperor ${ }^{783}$ was killed before learning the news from Antioch, and the empire passed to the son of Tzimiskēs. ${ }^{784}$ He quickly sent Theodore, ${ }^{785}$ a monk from Koloneia, and made him patriarch of the City of God, Antioch. He arrived here with those who brought him and immediately began to inquire about the story of the martyr and to seek out the remains of his pure body. For his body had appeared eight days after his martyrdom, which was on the night of the twenty-third day of May. ${ }^{786}$ It appeared on an

\footnotetext{
777. For "They seized .. . Ibn Mānik," Z reads: "They seized him and brought him to the stratopedarkhēs."

778. $\mathrm{Z}$ adds: "And he bestowed massive favors on the people of the bāqūiā."

779. Z omits: "The chiefs ... the issue."

780. For "the other two," Z reads: "Ibn Maḥmūd and Ibn Dicāma."

781. $\mathrm{Z}$ adds: "and remained there a long time." See al-Anțākī, "Histoire," 825.

782. Z omits: "and no ... their cases."

783. Z adds: "Nikephoros."

784. John I (r. 359-65/969-76).

785. Theodore II (bishop 359-65/970-76).

786. Z adds: "in the year 356 of the hijra." This year corresponds to 967 CE. See al-Anțākī, “Histoire,” 809.
} 
island in the river, where it was caught on an oak tree. ${ }^{787}$ The noble head was not with it, and it was said that the infidel had burned it. Some Christians of Antioch went out secretly and buried it in the holy monastery known as Arshāyā. ${ }^{788}$ When Patriarch Theodore learned this, he did not delay in sending for what was $129 \mathrm{r}$ there but went to the holy monastery and took up the relics ${ }^{789}$ of the saint with the pure clergy and a crowd of believers. They went before them to the city with a procession ${ }^{790}$ and a great assembly and put them in a fine marble sarcophagus, which they placed on a marble table in the western part of the Great Church. ${ }^{791}$

After a few years, $\mathrm{Abba}^{792}$ Nicholas the patriarch ${ }^{793}$ again moved him with honor and put him inside the house of St. Peter the Head of the Apostles, with his staff, ${ }^{794}$ his chair, numerous balms, ${ }^{795}$ the relics ${ }^{796}$ of Patriarch Babylas and Patriarch Ignatius, and other things: the balms of St. John the Baptist, the honorable lance, the staff of Chrysostom, the belt of St. Symeon the Stylite of Aleppo, and so on. All of them are in the treasury of St. Peter to this day.

\section{[19. More Divine Retribution]}

However, the highest judgment of those who shared in the killing did not delay long after that. One of the two, Ibn Mahmūd, was in the prison of Tarsus in total misery, distress, and pain of soul and body. He was punished for his deeds until he handed over his miserable soul, which had rejected goodness and repaid its benefactor with a vileness that cannot be surpassed. The other, Ibn Dicāma, remained in prison until the just hand of the patrikios ${ }^{797}$ Bourtzēs came to Antioch. He sent people to take him, weigh him down with a stone, and throw him into the river. So the three-Ibn Mānik, Ibn Maḥmūd, and Ibn Di āma, who had taken upon themselves the murder of the saint-received the recompense for their actions, and in the afterlife they await eternal punishment.

787. Tarrāsh, from Syriac țarāshā.

788. Located just outside Antioch. See Nasrallah, “Auteurs," 85; Claude Cahen, La Syrie du Nord à l'époque des Croisades et le principauté franque d'Antioche (Paris: P. Geuthner, 1940), 324.

789. For "relics," Z reads: "body." S has limsanā, which I take to be a garbled version of the Greek leipsana, "relics."

790. Lìtīn. Zayat and Dick both interpret this word as a transliteration of the Greek litēn (Zayat simply writes it in his French translation as $\left.\lambda_{\imath \imath \eta}\right)$, meaning "procession." I see no preferable alternative translation for this enigmatic word, though as Canard notes ("Vie," 569), "one would like to find there a note and other examples."

791. This seems to be the Church of Cassian mentioned earlier.

792. For "Abba," Z reads: "Saint."

793. Nicholas II (bishop 415-21/1025-30).

794. Shabūqa, from the Syriac shabūqtā.

795. Huyūl. As Canard notes ("Vie," 568), this is a technical term for a "miraculous liquid that oozes from certain icons," as described by Zayat in his history of Șaydnāyā; see Habib Zayat, Khabāyā al-zawāyā fi tārīkh Șaydnāyā (Harissa, Lebanon: Imprimerie de Saint Paul, 1932), 144-51.

796. Libsānāt, from Greek leipsana. Z reads: "clothing” (libāsāt).

797. Z adds: "Michael." See al-Anțākī, “Histoire," 825. 


\section{[20. Comparison with Other Saints]}

As for $129 \mathrm{v}$ the saint, he has reached the dwellings of the priests in the highest heavens, mingling with the righteous, standing with the ascetic monks in the ranks of the earlier martyrs. For he closely followed and tightly adhered to one of the saints; another he contended with-neither far from the target nor far behind-and another he left behind and surpassed, as is obvious from his actions and the well-known evidence of his deeds.

For ${ }^{798}$ Abraham left his homeland by the command of God and became the father of the nations he was promised. Did this man not also set out of his own accord and give birth to many spiritual children? And Isaac became engaged to Rebekah by correspondence, ${ }^{799}$ but this man became engaged to the holy church directly. And Jacob inherited the blessing of his father, but by a trick-he inherited it as a son, but to be precise, he took the blessing itself by a trick. ${ }^{800}$ And as for his two wives, he took them only after labor and misery on their account, all the while looking toward an outward reward that he would receive. ${ }^{801}$ But this man, without fraud and in complete truthfulness, received blessings from the mouths of many, and while he was not lacking in labor for the sake of his spiritual bride, ${ }^{802}$ he was not looking toward a present reward but was ensuring that he would receive the unseen, anticipated reward.

As for the gentleness of David, by my life, he did not possess it completely, for a small remnant of the vanity of the secretaries remained within him. The right way to approach this topic is to say that even if a bit of that still touched him, and he was never able to eliminate it completely, perhaps he struggled with it and even held onto some of it intentionally because of his leadership position and the strictness that goes along with it. As for Solomon, he was not able to attain $130 \mathrm{r}$ his wisdom, but as a substitute, he had a firm faith in God and submitted neither to passions nor to the temptation of obscene things. This is nobler than the wisdom of the world and preferable in the sight of God.

As for the Prodromos, ${ }^{803}$ who dwelled in deserts, this man was nothing like him, for he was neither a prophet nor a forerunner and he did not dwell in the desert. However, he did call to faith and display the beauty of worship, and he was well known for this. By my life, he did not baptize a multitude, but he saved many from casting aside and losing baptism, helping them to preserve it by his expenditures and gifts. And afterward, he arrived at the greater, higher baptism, which is not polluted by any dirt or subsequent filth.

From Peter he received a fervent sort of faith, but he nevertheless avoided his cowardice and his denial. ${ }^{804}$ And he resembled Paul in his transformation, though he did not turn from

798. $\mathrm{Z}$ adds: "the ancient."

799. Cf. Genesis 24 .

800. Z omits: "he inherited ... a trick." Cf. Genesis 27.

801. Cf. Genesis 29:15-30.

802. I take this as a reference to the church, specifically the Church of Antioch, thus establishing (as elsewhere in the text) a parallel between Christopher and Christ; cf. Ephesians 5:22-33.

803. A Greek word meaning "forerunner," a title of John the Baptist.

804. Cf. Matthew 26:69-75; Mark 14:66-72; Luke 22:54-62; John 18:15-18, 25-27. 
persecuting religion ${ }^{805}$ but from the confusion of the world and the bondage of the self. And even if he did not make it from Jerusalem to Illyricum to preach ${ }^{806}$-for only Paul made it that far, and he is the one who was snatched up to the third heaven and heard the speech that cannot be expressed ${ }^{807}$-he certainly did not fall short in what he was able to do. There were people whom he supported and strengthened, those he warned and informed, and those he restrained, rebuked, and often rescued and delivered from great difficulties.

\section{[21. Address to the Patriarch]}

But $O$ divine crown, possessor of all purity, especially loved by me and generally venerated by the masses, $O$ you who resembled all of those mentioned here, who loved so many of them and was first to every good deed, receive this discourse from me. $130 \mathrm{v}$ Imagine it as an encomium, or imagine it as an elegy or a consolation, and receive it in your blessed life, even if it is a poor speech, for it is done according to my ability. You did not disdain to run the race for my sake until you could hand me over to that learned divine educator-perhaps you hoped that I would become highly learned, or perhaps you knew beforehand that I, like you, would be lacking ${ }^{808}$ in the sciences. In any case you knew by spiritual knowledge that I was planning to write down your story at some time, so that it might not be forgotten in the course of time. Therefore have compassion on me even now, and pardon me for delaying so long the duty of speaking about you. Do not reject me, now that you are standing in the heavens before the great dais, since I longed-or since I eagerly strove-for you to look upon me and intercede for me. My father relied on you when he made me and my brothers-may God be pleased with all of them ${ }^{809}$-your disciples. And you go to great lengths, asking and begging that my sins be forgiven, that my actions be noble for the remainder of my life, and that I be saved from difficulties and seek whatever will please God and bring me nearer to him.

\section{[22. His Disciples]}

You had numerous followers and helpers, the children whom you fathered in Christ and guided in the way that pleases God. ${ }^{810}$ They were holy branches, spiritual flowers, and pleasing first fruits from our precious, divine town.

Among them was Abba George the Elder, your plant and seedling, who met the holy Emperor Nikephoros and was head of the monastery of St. Symeon the Stylite of Aleppo, the one on the mountain. ${ }^{811}$

\footnotetext{
805. Cf. Acts 9:1-19.
}

806. Cf. Romans 15:19.

807. Z omits: "for only ... be expressed." Cf. 2 Corinthians 12:1-4.

808. For "lacking," Z reads: "excellent."

809. Radilya Allāh 'an al-jamī c.

810. Several of the disciples listed here, along with Ibrāhīm (the author of this text), became translators in Antioch after the Byzantine conquest; see Treiger, "Beginnings," 314-32.

811. Z omits: "the one on the mountain." 
Abba John the Marvelous was worthy of becoming catholicos $131 \mathrm{r}$ over the lands of the East.

Abba Chariton II was the diligent archimandrite of the monastery of St. Symeon the Marvelous, ${ }^{812}$ the one by the sea on the Marvelous Mountain of Lukkām. ${ }^{813}$

Abba Ya'ish the Hermit ${ }^{814}$ struggled upon various pillars of seclusion and performed marvelous feats.

Abba Ephrem, the man of God, ${ }^{815}$ was a hermit who patiently bore the confinement of many cells and did not turn away from his solitary path. He was mainly confined with usor rather, with Christ-in the monastery of St. Gregory the Theologian..$^{816}$

Abba Jeremiah, ${ }^{817}$ his marvelous companion, was head of the monastery of Our Lady the Mother of God al-Jarājima, ${ }^{818}$ which he himself founded on the holy mountain of Lukkām.

The blessed Father Eutykhios, son of Farkhos.

The virtuous Abba Gregory the Elder was head of the monastery of Our Lady the Mother of God Dafnūnā, ${ }^{819}$ and it suffices to mention how famous his virtues were.

I have devoted to each of them an individual account, as they deserve to be remembered, even though I have been far too brief. The simple fact that they were planted by you suffices as a eulogy and commemoration for them. May your intercession and the prayers of all of them save and preserve us, now and ever and until the utmost of all the ages. Amen. May all the people say amen. ${ }^{820}$

812. Z writes that Chariton was the archimandrite of the monastery of St. Saba and lists Symeon the Marvelous as if he were another disciple of Christopher, but Symeon-also known as St. Symeon the Stylite the Younger or as St. Symeon of the Marvelous/Admirable Mountain-lived in the sixth century CE. Alexander Treiger suggests that the text originally listed two Charitons, one abbot of Arshāyā and the other abbot of St. Symeon's monastery; see Treiger, "Beginnings," 323-24.

813. That is, the Black Mountain ("Lukkām" is from the Syriac ūkāmā, meaning "black"), the ancient Amanos, just northwest of Antioch. This monastery is southwest of Antioch, where the southern end of the Lukkām range overlooks the Orontes near its mouth.

814. For "Ya'īsh the Hermit," Z reads: "Ya'īsh of Aleppo." Ya'īsh, along with Jeremiah, is mentioned as a contemporary of St. Timon in several synaxarion entries for March 25; see Joseph-Marie Sauget, Premières recherches sur l'origine et les caractéristiques des synaxaires melkites (XI'-XVII siècles) (Brussels: Société des Bollandistes, 1969), 367-69.

815. Z omits: "of seclusion ... of God." It therefore combines Ya'īsh and Ephrem into one person.

816. Z adds "in Bityas." Bityas, also within the Lukkām mountain range, is now called Batıayaz and lies west of Antioch.

817. Jeremiah is mentioned alongside $\mathrm{Ya}^{\mathrm{C}} \mathrm{i}$ sh as a contemporary of St. Timon in several synaxarion entries for March 25; see Sauget, Recherches, 367-69.

818. The Jarājima, known to the Byzantines as Mardaites, were a Christian group living in the mountains near Antioch, often serving as mercenaries for the Byzantines or their enemies; see Nasrallah, "Auteurs," 81-82.

819. Dafnūnā is a reference to Daphnē (modern Harbiye), a suburb south of Antioch with an important history as a pre-Christian religious center; see ibid., 83.

820. Z omits: "May all ... say amen." 


\section{Bibliography}

al-Anțākī, Yahyā b. Sa'īd. "Histoire de Yahya-Ibn-Sa 'ïd d'Antioche, continuateur de Sa ïd-IbnBitriq." Edited and translated by I. Kratchkovsky and A. Vasiliev. Patrologia orientalis 18, no. 5 (1924): 699-833.

al-Anțākī, Yūḥannā 'Abd al-Masīḥ. Maīn al-ḥayāt: al-Markab al-sā'ir fi mīnā' al-najāt, al-ma'rūf bi-Kitāb al-dūlāb. Edited by Habīb Ibrāhīm. 2 vols. Beirut: Markaz al-Turāth al-`Arabī al-Masīhịi, 2020-21.

Bịtāar, Tūmā. Al-Qiddīsūn al-mansiyyūn fi al-turāth al-Anțākī. Duma, Lebanon: 'Ā'ilat al-Thālūth al-Quddūs, 1995.

Bosworth, Clifford Edmund. The Islamic Dynasties: A Chronological and Genealogical Handbook. Edinburgh: University Press, 1967.

Brock, Sebastian. "Syriac Manuscripts Copied on the Black Mountain, near Antioch." In Lingua restituta orientalis, edited by Regine Schulz and Manfred Görg, 59-67. Wiesbaden: Otto Harrassowitz, 1990.

Cahen, Claude. La Syrie du Nord à l'époque des Croisades et le principauté franque d'Antioche. Paris: P. Geuthner, 1940.

Canard, Marius. Histoire de la dynastie des H'amdanides de Jazira et de Syrie. Paris: Presses universitaires de France, 1953.

-—-. Sayf al Daula. Algiers: Editions Jules Carbonel, 1934.

-_- "Une vie du patriarche melkite d'Antioche, Christophore († 967)." Byzantion 23 (1953): 561-69.

Dagron, Gilbert. "Minorités ethniques et religieuses dans l'Orient byzantin a la fin du Xe et au XI ${ }^{\mathrm{e}}$ siècle: L’immigration syrienne.” Travaux et mémoires 6 (1976): 177-216.

Darrouzès, Jean, ed. Épistoliers byzantins $d u X^{e}$ siècle. Paris: Institut français d'études byzantines, 1960 .

Dīk, Ighnāțiyūs. Sīrat al-bațriyark Kharīsțūfürus al-Anțākī șadīq Sayf al-Dawla. Aleppo: n.p., 1997.

Edelby, Néophyte. "Note sur la catholicosat de Romagyris." Proche-Orient chrétien 2 (1952): 39-46.

Forsyth, John Harper. "The Byzantine-Arab Chronicle (938-1034) of Yahyā b. Sa'īd al-Anțākī.” PhD dissertation, University of Michigan, 1977.

Holmes, Catherine. “'How the East Was Won' in the Reign of Basil II.” In Eastern Approaches to Byzantium, edited by Antony Eastmond, 41-56. Aldershot: Ashgate, 2001. 
Ibn al-Athīr, 'Izz al-Dīn. Al-Kāmil fỉ al-tārīkh. Edited by Muhammad Yūsuf al-Daqqāq. Beirut: Dār al-Kutub al-'Ilmiyya, 1987.

Ibrahim, Habib. "Liste des vies de saints et des homélies conservées dans les Ms. Sinaï Arabe 395-403, 405-407, 409 et 423." Chronos 28 (2018): 47-114.

Ibrāhīm b. Yūḥannā. "Zhitie antiokhiĭskogo patriarkha Khristofora." Translated by S. A. Moiseeva. In Araby-Khristiane v istorii i literature Blizhnego Vostoka, edited by N. G. Golovnina, 28-61. Moscow: PSTGU, 2013.

Kennedy, Hugh. The Prophet and the Age of the Caliphates: The Islamic Near East from the Sixth to the Eleventh Century. London: Routledge, 2016.

Leo the Deacon. The "History" of Leo the Deacon: Byzantine Military Expansion in the Tenth Century. Translated by Alice-Mary Talbot and Denis F. Sullivan. Washington, DC: Dumbarton Oaks Research Library and Collection, 2005.

Michael the Syrian. Chronique. Edited and translated by J.-B. Chabot. 4 vols. Brussels: Culture et Civilisation, 1963.

Moiseeva, Sofia A. Arabskaia mel'kitskaia agiografiia IX-XI vekov. Moscow: PSTGU, 2015.

---. "The Early Melkite Arabic Hagiography (IXth-XIth Centuries): Evolution of the Literary Style." Parole de l'Orient 39 (2014): 33-56.

Mugler, Joshua. "Ibrāhīm ibn Yūḥannā and the Translation Projects of Byzantine Antioch." In Patristic Literature in Arabic Translations, edited by Barbara Roggema and Alexander Treiger, 180-97. Leiden: Brill, 2020.

-C-. "A Martyr with Too Many Causes: Christopher of Antioch (d. 967) and Local Collective Memory.” PhD dissertation, Georgetown University, 2019.

Nasrallah, Joseph. "Deux auteurs melchites inconnus du $\mathrm{X}^{\mathrm{e}}$ siècle." Oriens christianus 63 (1979): 75-86.

-_-. "La liturgie des patriarcats melchites de 969 à 1300." Oriens christianus 71 (1987): 156-81.

Noble, Samuel. "A Byzantine Bureaucrat and Arabic Philosopher: Ibrāhīm ibn Yūḥannā al-Anțākī and His Translation of On the Di vine Names 4.18-35." In Caught in Translation: Studies on Versions of Late Antique Christian Literature, edited by Madalina Toca and Dan Batovici, 276-312. Leiden: Brill, 2020.

Roberts, Alexandre M. Reason and Revelation in Byzantine Antioch: The Christian Translation Program of Abdallah ibn al-Fadl. Oakland: University of California Press, 2020.

Sauget, Joseph-Marie.Premières recherches sur l'origine et les caractéristiques des synaxaires melkites (XI - XVII siècles). Brussels: Société des Bollandistes, 1969. 
Treiger, Alexander. "The Beginnings of the Graeco-Syro-Arabic Melkite Translation Movement in Antioch." Scrinium 16 (2020): 306-32.

-_-. "Sinaitica (1): The Antiochian Menologion, Compiled by Hieromonk Yūhannā 'Abd al-Masịh (First Half of the 13th Century)." Khristianskïr Vostok" 8 (2017): 215-52.

Zayat, Habib. Khabāyā al-zawāyā fĩ tārīkh Șaydnāyā. Harissa, Lebanon: Imprimerie de Saint Paul, 1932.

- - "Vie du patriarche melkite d'Antioche Christophore († 967) par le protospathaire Ibrahîm b. Yuhanna: Document inédit du X $\mathrm{X}^{\mathrm{e}}$ siècle." Proche-Orient chrétien 2 (1952): 11-38, 333-66. 


\title{
The Ribāṭ of Gurjī Khātūn ("the Georgian Lady"): New Data about Women Patrons, Chancery Practices, and Foundation Inscriptions in Seventh/Thirteenth- Century Saljuq Anatolia*
}

\author{
DAVID DURAND-GuÉDY \\ Independent Scholar
}

(david_durandguedy@yahoo.com)

\begin{abstract}
The Mar'ashī Library of Qum owns an unstudied manuscript containing official documents from the Rum Saljuq dynasty. The manuscript includes an Arabic text for the foundation of a ribāt. Its patron was unmistakably the Georgian wife of Ghiyāth al-Dīn Kay-Khusraw II (d. 644/1246), the unfortunate sultan beaten by the Mongols at Kösedăg. The building was a caravanserai, most probably located at the stage of Düden, immediately northeast of Antalya. Its construction can be dated to around 636/1238. It was part of a cluster of buildings erected with sultanic patronage on the road from Antalya to Konya. Gurjī Khātūn's aim in founding the ribāt was to establish her son, 'Alä' al-Dīn Kay-Qubād II, as indisputable heir apparent over the other (and older) offspring of the sultan. Beyond the light it casts on her long-term strategy to become wālida (Tk.valide, queen mother), the text allows us to refine our knowledge of women patrons, a subject that had been tackled so far mostly through the case of Māhparī Khātūn. Finally, the source in which this text was found proves that inscriptions (at least this one) were authored by personnel of the chancery, as supposed by van Berchem and by Redford after him.
\end{abstract}

I $\mathrm{n}$ the first part of the seventh/thirteenth century, most of Anatolia fell under the rule of the Saljuq state. ${ }^{1}$ The sultans of Konya conquered a large part of the Mediterranean coast and the Black Sea coast and made decisive territorial gains in the east and the southeast (Fig. 1). Three Christian polities continued to exist (the empires of Nicea and Trabzon and the Armenian kingdom of Cilicia), but the Saljuqs were hegemonic. In this move toward political unification, marriage was a powerful tool alongside military conquests.

1. An epistolary exchange with Andrew Peacock about MS Mar'ashī 11136 spurred me to write a short note on this inscription, which eventually took me much further than anticipated. I am grateful to Scott Redford for reading a previous version of this article and for sharing with me his comments and expertise on Saljuq caravanserais. I am also thankful to Emad al-Din Sheykh al-Hokamaee for clearing some reading issues. In addition, I have benefited from the useful remarks and suggestions made by the peer reviewers.

(c) 2021 David Durand-Guédy. This is an open access article distributed under the terms of the Creative Commons Attribution-NonCommercial-NoDerivatives License, which allows users to copy and distribute the material in any medium or format in unadapted form only, for noncommercial purposes only, and only so long as attribution is given to the original authors and source. 
Figure 1: The Saljuq Sultanate and the Neighboring Powers before Kösedağ (641/1243) (Date of Capture inside Frame)

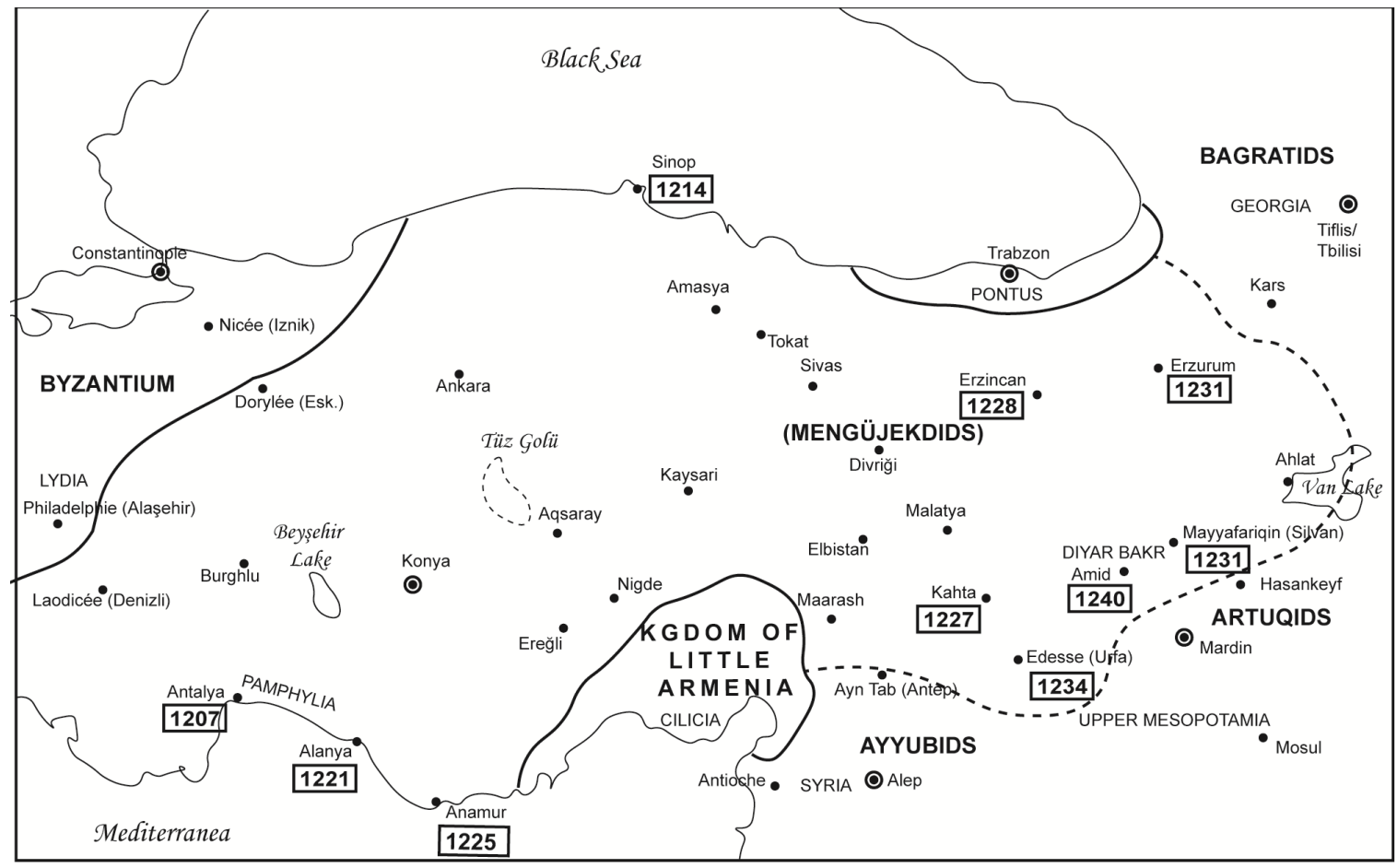

Many khātūns, as the female sultans were known, were of foreign origin. Their political role behind the curtains has been mentioned, most often to be deplored, in the chronicles. ${ }^{2}$ Recent scholarship has focused on their role as "patrons of architecture," to quote Bates's pioneering article on the subject. ${ }^{3}$ Indeed, a significant number of buildings from this period in Anatolia can be traced to female patrons. ${ }^{4}$ The daughters of the Ayyubid wife of sultan 'Alā' al-Dīn Kay-Qubād I (d. 1237), built for her a well-known mausoleum in Kayseri

2. On the political role of the khātūns, see the state of the art in B. De Nicola, Women in Mongol Iran: The Khatuns, 1206-1335 (Edinburgh: Edinburgh University Press, 2017), 5-9.

3. Ü. Bates, "Women as Patrons of Architecture in Turkey," in Women in the Muslim World, ed. L. Beck and N. Keddie, 245-60 (Cambridge, MA: Harvard University Press, 1978). Since Bates's article, which dealt mostly with the Ottomans, several important articles have been published, in particular in D. Fairchild Ruggles, ed., Women, Patronage, and Self-Representation in Islamic Societies (Albany: State University of New York Press, 2000). See also H. Z. Watenpaugh, "Art and Architecture," in Encyclopedia of Women \& Islamic Cultures, ed. S. Joseph, online ed. (Leiden: Brill, 2014). The last book of D. Fairchild Ruggles, The Extraordinary Architectural Patronage of the 13th-Century Egyptian Slave-Queen Shajar al-Durr (Oxford: Oxford University Press, 2020), deals with a female sultan on the other side of the Mediterranean Sea who was an exact contemporary of the subject of the present article.

4. In his landmark survey of Saljuq architectural patronage in the seventh/thirteenth century, Crane mentioned several women patrons but did not focus on them. See H. Crane, "Notes on Saldjūq Architectural Patronage in Thirteenth Century Anatolia," Journal of the Economic and Social History of the Orient 36 (1993): $1-57$. 
after her death (Fig. 2). Māhparī Khātūn, a Greek or Armenian noble whose marriage with the same 'Alā' al-Dīn sealed the conquest of Alanya, built a famous complex in Kayseri that has recently been the subject of in-depth publications by Eastmond, Blessing, and Yalman. ${ }^{5}$ Another wife of the same sultan, 'Ișmat Khātūn, the sister of the deposed ruler of Erzurum, also engaged in building, as Redford has shown. ${ }^{6}$ These construction activities took place from the Pamphylian coast to the Yeşilirmak River.

Figure 2: Genealogical Tree of the Rum Saljuqs in the Seventh/Thirteenth Century (Spouses Noted in Italics)

\footnotetext{
Generation of

Rum Saljuq Sultan
}

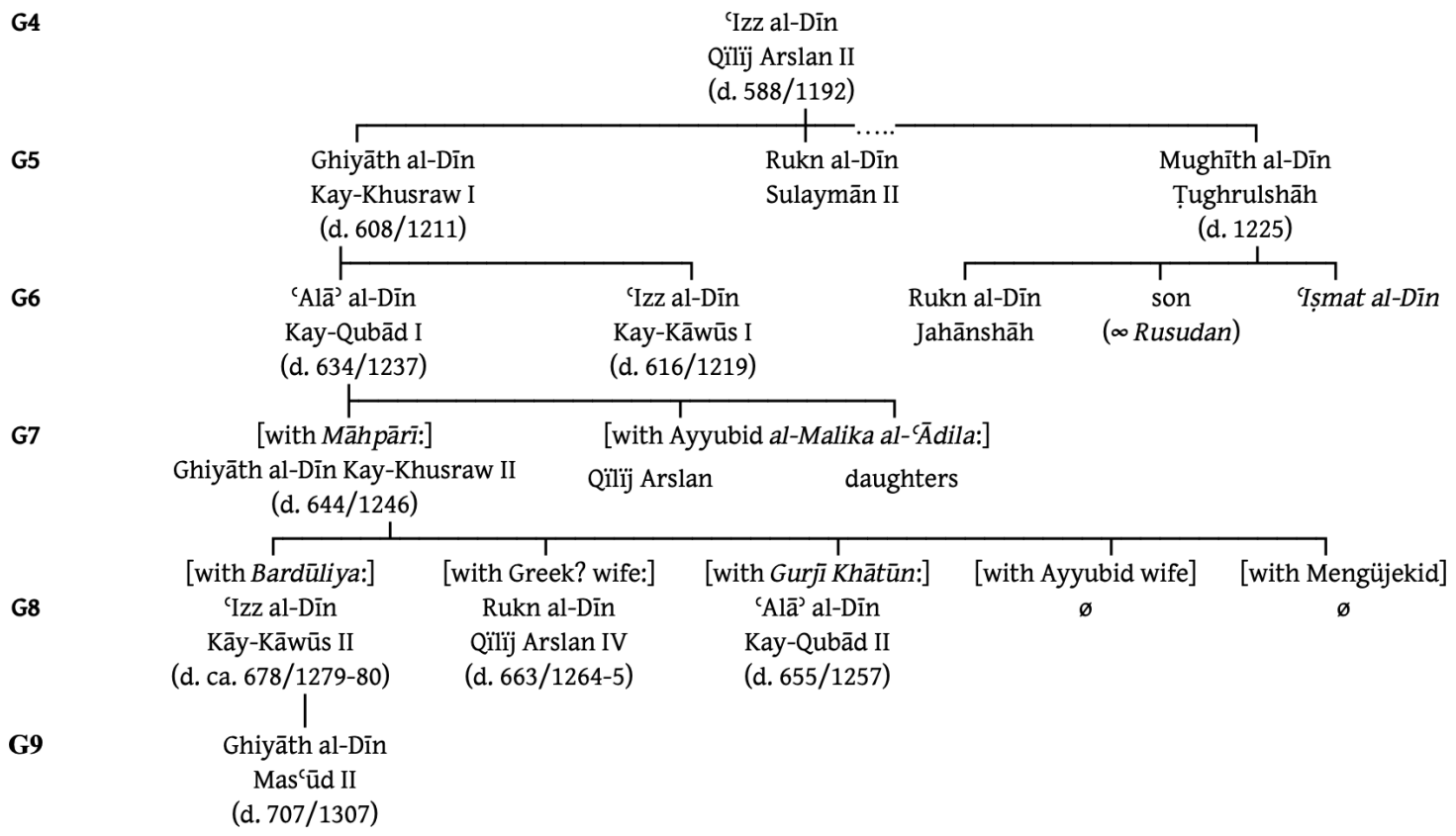

The present article aims to contribute to this active scholarly field, but through a different kind of source: an inscription copied in MS Mar'ashī 11136. The manuscript, long held in private hands in Iran and now kept at the Mar'ashī Library in Qum, is a munsha'àt, that is,

5. A. Eastmond, "Gender and Patronage between Christianity and Islam in the Thirteenth Century," in Change in the Byzantine World in the Twelfth and Thirteenth Centuries, ed. A. Ödekan, E. Akyürek, and N. Necipoğlu, 78-88 (Istanbul: Vehbi Koç Vakfi, 2010); P. Blessing, "Women Patrons in Medieval Anatolia and a Discussion of Māhbarī Khātūn's Mosque Complex in Kayseri," Belleten 78 (2014): 475-526; S. Yalman, “The 'Dual Identity' of Mahperi Khatun: Piety, Patronage and Marriage across Frontiers in Seljuk Anatolia," in Architecture and Landscape in Medieval Anatolia, 1100-1500, ed. P. Blessing and R. Goshgarian, 224-52 (Edinburgh: Edinburgh University Press, 2017).

6. S. Redford, "Paper, Stone, Scissors: 'Ismat al-Dunya wa'l-Din, 'Ala' al-Din Kayqubadh, and the Writing of Seljuk History," in The Seljuks of Anatolia: Court and Society in the Medieval Middle East, ed. A. C. S. Peacock and S. N. Yildiz, 151-70 (London: I. B. Tauris, 2012). 
a compilation of official and private writing, primarily designed to serve as a letter-writing handbook for secretaries. This manuscript has a complex history, and it was produced by several hands over a period of several decades in seventh/thirteenth- and early eighth/ fourteenth-century Anatolia. ${ }^{7}$ The document that sparked this article is copied in a section on the correct use of honorific titles (alqāb, sg. laqab). Laqabs were used since the beginning of Islam, initially for the caliphs, but in the Saljuq period their use ballooned seemingly out of control (the inflation was already deplored by the great Saljuq vizier Nizāam al-Mulk, d.485/1092). Although never-ending laqabs can be disconcerting to modern historians, the phenomenon can tell us a lot about the state and the society in which it took place. ${ }^{8}$

The inscription under study here is preceded by the following introductory words: "Honorific titles (alqāb) of the King of the world and the Queen of the world that are [inscribed] above the doorway of the caravanserai of Dūd.n" (alqāb-i khudāygān-i 'ālam wa malika-yi jahān kī bar dar-i kārawānsarāy-i dūd.n ast). This text is exceptional on several grounds. First, it is far longer than the lengthiest building inscription of a Saljuq caravanserai known so far. ${ }^{9}$ Second, the patron is none other than the Georgian wife of the last independent Saljuq ruler of Rum. Her eventful life is documented in a vast array of written sources, first collected by Vryonis. She is famous for having erected, much later, the mausoleum of the mystic Jalāl al-Dīn Rūmī (d. 672/1273) in Konya, but nothing was hitherto known of her building activities during the reign of her husband. ${ }^{10}$ Third, the text seems also to be the only surviving example of a foundation inscription copied in a munsha'at, and as such it can inform us about the relationship between "paper, stone, and scissors," to use Redford's words. ${ }^{11}$

7. The manuscript was in a private collection in Tabriz before entering the Mar'ashī Najafi Library of Qum at the end of the twentieth century. It has never previously been exploited by scholars working on medieval Anatolia. For an introduction to its contents and its complex history, see D. Durand-Guédy, "Manba'ī-yi muhim dar bāra-yi Saljūqiyān-i Rūm wa dabīr-khāna-yi fārsī-yi ān-hā: Nuskha-yi khaț̣ī-yi Kitābkhāna-yi Āyat Allāh Mar'ashī, shumāra 11136," Mīrāth-i Shahāb 100 (tābistān 1399sh. [2020]): 63-84; D. Durand-Guédy, "A New Source on the Saljuqs of Rum and Their Persian Chancery: Manuscript 11136 of the Mar'ashī Library (Qum)," Der Islam, forthcoming in 2022.

8. Research on titulature does not belong only to diplomatics. It has also been explored successfully by several historians, such as C. E. Bosworth, "The Titulature of the Early Ghaznavids," Oriens 15, no. 1 (1962): $210-33$ (with reference to previous essential scholarship in French); L. Richter-Bernburg, "Amīr-Malik-Shāhānshāh: 'Aḍud ad-Daula's Titulature Reexamined," Iran 18 (1980): 83-102; and, with reference to the "jihad titulature" of the Mamluks, C. Hillenbrand, The Crusades: Islamic Perspectives (New York: Routledge, 2000).

9. According to Redford, the lengthiest inscription known to date is Kirkgöz Han's, near Antalya. See S. Redford, "The Inscription of the Kırkgöz Hanı and the Problem of Textual Transmission in Seljuk Anatolia," Adalya 12 (2009): 347-59, at 347. The inscription under study here is $40 \%$ longer.

10. On Rūmī's mausoleum, see Crane, "Notes," 46 (no. 71); Eastmond, "Gender and Patronage," 85; Blessing, "Women Patrons," 480.

11. Redford, "Paper, Stone, Scissors." I could have started my article with the exact words chosen by Redford (ibid., 151): "This chapter addresses three main issues relating to writing a history of the Seljuks. The first is the accordance, or lack thereof, between two different historical sources: chronicles and inscriptions (the 'paper' and 'stone' in the title). The second concerns sultans' wives and their place in the Seljuk social order, and the third is legitimacy." 
I will start by giving a transcription of the Arabic text, followed by a translation and analysis of its content. Beyond the obvious issues of identification (identity of the patron, location of the caravanserai), I will highlight the new insights the text provides about the period in which it was produced. I will also put it in perspective with what we know of the history of the manuscript in which it is included. At the end of the article, I will argue that this document proves the role of the dīwān al-inshā' (official chancery) in the composition of foundation inscriptions.

\section{The Text of the Inscription and Its Translation}

The text of the inscription appears on fol. 29v of MS Mar'ashi 11136. The author of the manuscript included it in a series of nine documents about the honorific titles suitable for members of the royal family-especially the sultan, but also his appointed heir. In this part of the manuscript the script is handsome and can be deciphered without a problem (Fig. 3).

Figure 3: Text of the inscription in MS Mar'ashī 11136
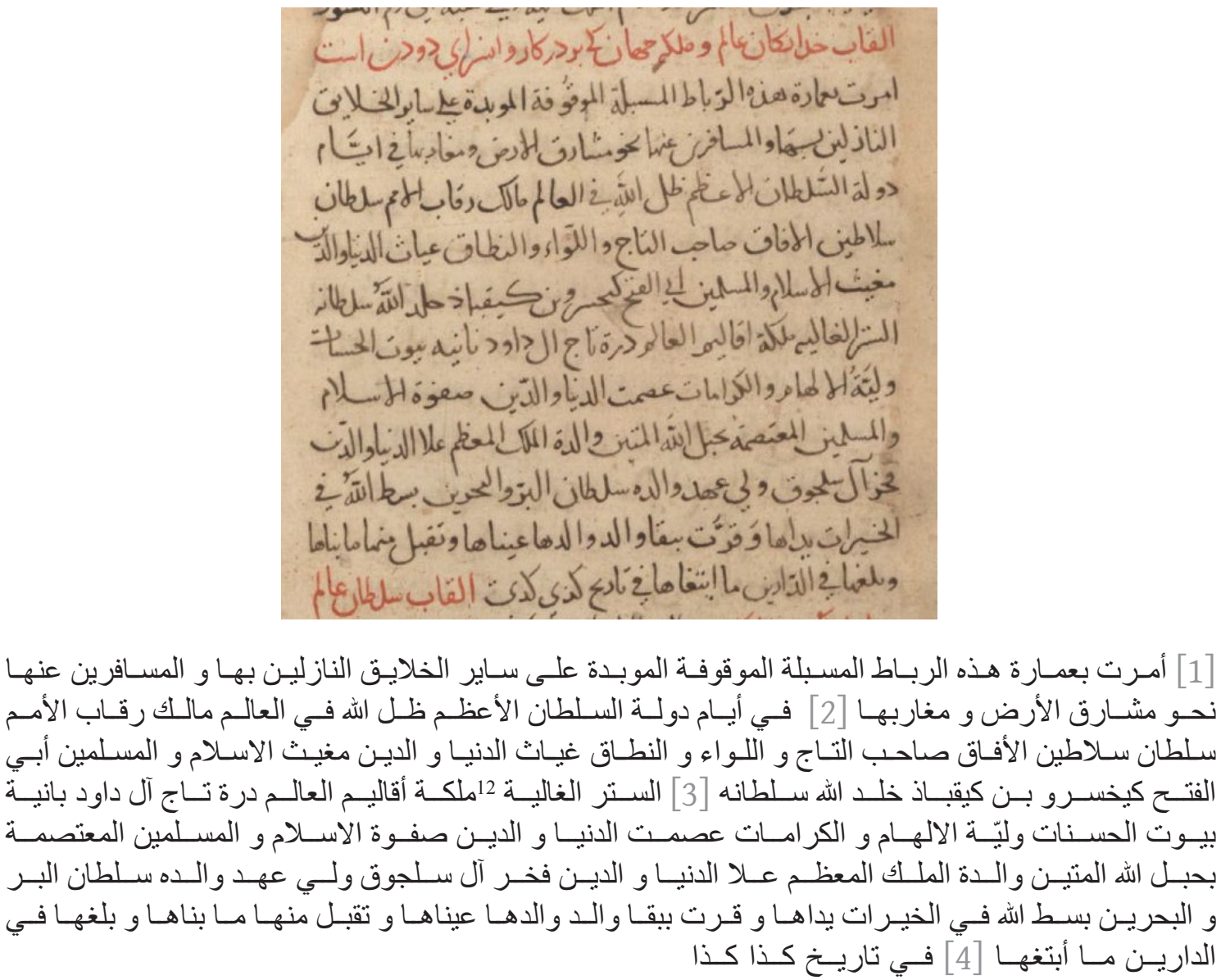

12. Recte العاليـة الستـر. Al-sitr al-Calliyya (“the elevated veil”) is more probable than al-sitr al-ghâliyya ("the expansive veil") for a metaphoric address to a high-ranking lady. 
[1] Amarat bi-'imārat hādhihi al-ribāt al-musbala al-mawqūfa al-mu'abbada 'alā sāiir al-khalā’iq al-nāzilīn bihā wa-l-musāfirīn 'anhā naḥw mashāriq al-arụ wa-maghāribihā,

[2] fî ayyām dawlat sulțān al-a`ẓam, zill Allāh fị al-`ālam, mālik riqāb al-umam, sulțān salāțīn al-āfāq, șāhịib al-tāj wa-1-liwā’ wa-1-nițāq, Ghiyāth al-dunyā wa-l-dīn, Mughīth al-islām wa-l-muslimīn, Abī al-Fatḥ Kay-Khusraw b. Kay-Qubādh-khallada Allāhu sulțānahu,

[3] al-sitr al-cāliyya, malikat aqālīm al-cālam, durrat tāj āl Dā’ūd, bāniyya buyūt al-ḥasanāt, waliyyat al-ilhām wa-1-karāmāt, 'Ișmat al-dunyā wa-1-dīn, Șafwat al-islām wa-l-muslimīn, al-mu'tașima bi-ḥabl Allāh al-matīn, wālidat al-malik al-mu'aẓz̧am 'Alā' al-dunyā wa-l-dīn, fakhr āl Saljūq, walī 'ahd wālidihi, sulțān al-barr wa-l-baḥraynbassața Allāhu fi al-khayrāt yādahā wa-qarrat bi-baqā' wālid wālidihā 'aynāhā wa-taqabbala minhā mā banāhā wa-ballaghāhā fi al-dārīn mā ibtaghāhā

[4] fì ta'rīkh kadhā wa-kadhā.

The text follows the classical structure of foundation inscriptions. ${ }^{13}$ It starts (\$1) with a statement of foundation containing a verb ("order") and an object (here: the construction of a ribāt). ${ }^{14}$ These are followed by (\$2) an adverbial phrase of time (here: during the reign of Ghiyāth al-Dīn Kay-Khusraw II"), (\$3) the subject of the action (here: 'Ișmat al-Dīn), and finally (\$4) the date. The only originality in this text, to which we will come back later, lies in the qualification of the building (its charitable purpose).

The inscription can be translated as follows:

[1] She has ordered the construction of this ribăt, dedicated to a charitable purpose, endowed, eternal for all the creatures setting foot in it and [all] the travelers arriving to it and leaving it for the east or the west of the world, ${ }^{15}$

[2] in the days of the greatest sultan, God's shadow on earth, the master of the necks of the nations, sultan of all the sultans under the sky, possessor of the crown, the flag, and the belt, Ghiyāth al-dunyā wa-l-dīn , Mughïth al-islām wa-l-muslimīn Abū al-Fatḥ Kay-Khusraw b. Kay-Qubād-may God make his rule eternal,

[3] the high lady, queen of the climes of the world, pearl of the crown of the family of David, builder of pious foundations [maybe: mosques], the inspiring woman through whom God works miracles, 'Ișmat al-dunyā wa-l-dīn, Șafwat

13. J. M. Rogers, "Waqf and Patronage in Seljuk Anatolia: The Epigraphic Evidence," Anatolian Studies 26 (1976): 69-103, at 72 .

14. The verb is distinctly in the feminine third person (amarat), instead of the usual "amara bi- 'imāra" (sometimes read in the passive voice, umira, or even the passive of the intensive form, ummira) seen in foundation inscriptions for both male and female patrons (see Rogers, "Waqf and Patronage," 73).

15. The same expression is in the inscription of Kırkgöz Han1. Contrary to Redford ("Kırkgöz Hanı," 353, line 2), I understand al-nāzilūn bihā and al-musāfirūn 'anhā not as people "residing in the caravenserai and travellers", but as "arriving and departing travellers". 
al-islām wa-l-muslimin, holding firm to God's rope [cf. Quran 3:103], mother of the powerful prince 'Alä' al-Dunyā wa-l-Dīn, glory of the Saljuq family, appointed heir by his father, sultan of the land and the two seas-may God make

her hand extend her good deeds, and may she be happy with the father of her father, ${ }^{16}$ may what she has built receive a good reception, and may she obtain in the two worlds [this one and the next] what she desires

[4] on the date of so and so.

\section{Identification}

\section{Gurjī Khātūn}

There is no doubt whatsoever about the identity of the patron. First, the inscription is dated to the reign of Ghiyāth al-Dinn Kay-Khusraw b. Kay-Qubād, that is, Kay-Khusraw II (r. 634-44/1237-46). Mentioning the name of the reigning sultan was expected when the building was not erected by the sultan himself. Second, the patron is introduced as the "mother of the powerful prince 'Alā' al-Dunyā wa-l-Dīn." This can be none other than the mother of 'Alā') al-Dīn Kay-Qubād II (d. 655/1257) (Fig. 2). ${ }^{17}$

She bore the name of her grandmother, Tamar, the mighty queen of Georgia at the end of the twelfth century (Fig. 4). Her mother, Rusudan, was also a formidable queen of Georgia, who acceded to the throne at the age of twenty-nine and picked the son of the Saljuq ruler of Erzurum as her husband. Their daughter Tamar was given in marriage to seal the alliance between the Rum Saljuqs and the Bagratid Georgians after the two dynasties became neighbors. Specifically, after his tremendous victory over the Khwārazmians at Yāsī Chaman in 627/1230, 'Alā' al-Dīn Kay-Qubād I of Konya took Erzurum, abolished the independent principality of his cousin Jahān-Shāh, married his sister, and pushed his advantage by sending his army into Georgian territory, where Jahān-Shāh had withdrawn. After the loss of several fortresses, in the troubled context created by the Mongol conquests, Queen Rusudan of Georgia proposed to Kay-Qubād I a marriage between her daughter and his son, the appointed heir Ghiyāth al-Dīn Kay-Khusraw II. ${ }^{18}$

16. The manuscript has wālid wālidihā, "father of her father", but this is obviously a mistake, as Gurjī Khātūn's grand-father, Mughīth al-Dīn Ṭughrulshāh, was then long dead (Fig. 2). Maybe the copyist meant wālid waladihā, "the father of her son", i.e. the reigning sultan.

17. Ibn Bībī says explicitly that 'Alā' al-Dīn was "born of the princess of Georgia" (az malaka-yi Gurj). See his al-Awāmir al-'Alā’iyya fí al-umūr al-'alā’iyya, ed. Zh. Mutaḥịīn (Tehran: Pazhūhishgāh-i 'Ulūm-i Insānī wa Muțāli āt-i Farhangī, 1390sh.), 420. Cf. al-Mukhtașar Saljūq-nāma-yi Ibn Bībīi, ed. M. T. Houtsma in Recueil de textes relatifs à l'histoire des Seldjoucides, vol. 3: Histoire des Seldjoucides d'Asie mineure, d'après Ibn Bîbî (Leiden: Brill, 1902), 212.

18. Rusudan was enjoying a moment of respite after the demise of the Khwārazm-Shāh, who had occupied Georgia since 622/1225. The Mongols would not invade Georgia until 633/1236. See C. E. Bosworth, "Al-Kabk," in Encyclopaedia of Islam, 2nd ed., 4:341-50 (Leiden: Brill, 1978). 


\section{Figure 4: The Bagratids of Georgia in the Thirteenth Century}

\begin{tabular}{|c|c|c|c|}
\hline \multicolumn{4}{|c|}{$\begin{array}{c}\text { Tamar } \\
\text { (r. 1184-1212) }\end{array}$} \\
\hline & \multicolumn{3}{|c|}{$-(\infty 1189$ David Soslan $)\rceil$} \\
\hline $\begin{array}{l}\text { Giorgi IV Lasha } \\
\text { (r. 1213-23) }\end{array}$ & \multicolumn{2}{|c|}{$\begin{array}{l}\text { Rusudan } \\
\text { (r. 1223-45) }\end{array}$} & Giorgi I \\
\hline | & \multicolumn{2}{|c|}{ (o son of Saljuq ruler of Erzurum, Mughith al-Dīn Ṭughrulshāh) } & | \\
\hline \multirow[t]{3}{*}{$\begin{array}{l}\text { David VI Ulu } \\
(\text { r. 1224-69) }\end{array}$} & $\begin{array}{l}\text { David V Narin } \\
(\text { r. 1225?-93) }\end{array}$ & $\begin{array}{l}\text { Tamar/Gurjī } \\
\text { Khātūn }\end{array}$ & $\begin{array}{l}\text { Demetre II the Self-Sacrificer } \\
\text { (d. 1288) }\end{array}$ \\
\hline & \multicolumn{3}{|c|}{ 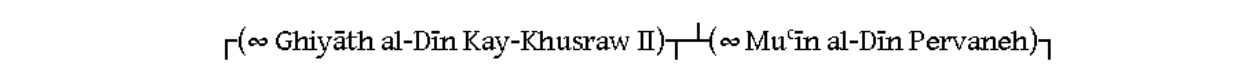 } \\
\hline & $\begin{array}{l}{ }^{\mathrm{C}} \mathrm{A} 1 \overline{\mathrm{a}} \\
\mathrm{Kay}- \\
\text { (d. } 6\end{array}$ & Ọ`Ayn al-Ḥayāt & $\begin{array}{c}0^{7} \\
(\infty \text { king of Armenian Cilicia's } \\
\text { daughter) }\end{array}$ \\
\hline
\end{tabular}

The marriage was eventually concluded in 635/1237, after the prince ascended the throne (634/1237). ${ }^{19}$ At the Saljuq court, Tamar was known as Gurjī Khātūn, as evidenced by Georgian and Persian sources. ${ }^{20}$

Despite Brosset's commented translation of the Georgian Chronicle, Tamar/Gurjī Khātūn has long been overlooked. Canard did not deal with her in his article dedicated to the (often very negative) image of Georgian queens in Muslim sources. ${ }^{21}$ Vryonis totally ignored her in his 1971 monograph on Saljuq Anatolia. However, he made up for the oversight in a later article. Commenting on the painted figure of a woman called "Kira Thamàris" in a church in Cappadocia, Vryonis argued that this "Lady Tamar" is no other than Gurji Khātūn, of whom he offered a detailed biography. ${ }^{22}$ To this end, he analyzed all the available

19. The most detailed account of Ghiyāth al-Dīn Kay-Khusraw II's reign is that of N. Kaymaz, Anadolu Selçuklu Sultanlarından II. Giyâsu'd-dân Keyhusrev ve Devri (Ankara: Türk Tarih Kurumu Basımevi, 1958); see 37-39, 80-82. Cf. G. Leiser, "Observations on the 'Lion and Sun' Coinage of Ghiyath al-Din Kai-Khusraw II," Mesogeios 2 (1998): 96-114, at 103.

20. Georgian Chronicle = Kartlis Tskhovreba (K'art'lis C'xovreba), trans. M. F. Brosset, Histoire de la Géorgie depuis l'antiquité jusqu'au XIXe siècle, part 1: Histoire ancienne, jusqu'en 1469 de J.-C. (Saint Petersburg: Imprimerie de l'académie impériale des sciences, 1849), 502 n. 2, 508: “Tamar, fille de Rusudan, que le sultan nommait Gurji Khātūn" (all of these events are dealt with in the "Hundred Years' Chronicle" book of the Georgian Chronicle). Āqsarāyī says that the mother of 'Alā' al-Dīn Kay-Qubād was "Gurjī Khātūn, the queen of the Georgians (malaka-yi Abkhāz).” Āqsarā̄ī, Tārīkh-i Salājaqa yā Musāmirat al-akhbār, ed. O. Turan as Müsâmeret ül-ahbâr, Mogollar zamininda Türkiye Selçukluları Tarihi (Ankara: Türk Tarih Kurumu Basımevi, 1944 ), 47. The benevolent figure of Gurjī Khātūn appears sixteen times in Aflākī's hagiography of Jalāl al-Dīn Rūmī, the great mystic of Konya who died in 672/1273. See Aflākī 'Ārifí, Manāqib al-'ārifin, ed. T. Yazici, corrections and additions by T. Subḥānī (Tehran: Dūstān, 1396sh.), index.

21. Georgian Chronicle, 502; M. Canard, "Les reines de Géorgie dans l'histoire et la légende musulmane," Revue des études islamiques 37 (1969): 3-20 (Gurjī Khātūn is mentioned in passing at 12).

22. S. Vryonis Jr., The Decline of Medieval Hellenism in Asia Minor and the Process of Islamization from the Eleventh through the Fifteenth Century (Berkeley: University of California Press, 1971); idem, "Another Note 
sources in Georgian (the Royal Chronicle), Syriac (Bar Hebraeus), and Persian (mainly Āqsarāyī's chronicle of the Saljuqs and Aflākī's hagiography of Jalāl al-Dīn Rūmī). In 1998, Leiser discussed Gurjī Khātūn in an article about the famous Rum Saljuq gold dinar showing a sun and a lion (a passage from Bar Hebraeus had led to the surmise that Kay-Khusraw II had represented himself as a lion and his beloved Georgian queen as the sun). ${ }^{23}$ Two other scholars dealt with Gurjī Khātūn from different perspectives. In 2006, Peacock published an important article in which he interpreted the marriage as "a response to the Mongol threat, even if the Georgian-Seljuk alliance proved to be of little concrete use in practice." 24 And in 2007, Eastmond studied Gurjī Khātūn as a symbol of the "cultural syncretism" visible in the artistic production of seventh/thirteenth-century Anatolia. ${ }^{25}$

\section{Düden}

The author of the munsha'àt indicates that the inscription was located "above the doorway of the caravanserai" (bar dar-i kārawānsarā), which was the usual location of such inscriptions. ${ }^{26}$ At the similar caravanserai of Kırkgöz Han, the inscription is "carved on a single block of limestone and inserted over the entrance into the building." 27 Understandably, the geographical location of the building did not need to be mentioned in the inscription. The toponym "Dūd.n" given by the author of the munsha'ät in the "title"

on the Inscription of the Church of St. George of Belisırma," Byzantina 9 (1977): 9-22. The church is located 25 km south of Aksaray. Vryonis believed that "Mas'ūd," the male figure represented next to Kira Thamàris, was the puppet Saljuq sultan Mas'ūd II (d. 707/1307). In the image, the woman called Kira Thamàris is about threequarters the latter's size and appears as the donor of the portrait. This identification of the principal donor has been questioned, see bibliographical references in T. Uyar, "Thirteenth-century 'Byzantine' art in Cappadocia and the question of the Greek painters at the Seljuq Court," in Islam and Christianity in Medieval Anatolia, ed. A.C.S. Peacock, B. De Nicola and S. Nur Yildiz, 215-231 (Burlington, VT; Surrey, UK: Ashgate, 2015), at note 12.

23. Leiser, "Observations."

24. A. C. S. Peacock, "Georgia and the Anatolian Turks in the 12th and 13th Centuries," Anatolian Studies 56 (2006): 127-46, at 143.

25. A. Eastmond, "Art and Frontiers between Byzantium and the Caucasus," in Byzantium: Faith and Power (1261-1557); Perspectives on Late Byzantine Art and Culture, ed. S. T. Brooks, 154-69 (New York: Metropolitan Museum of Art, 2007). Gurjī Khātūn is mentioned in passing in the standard syntheses of Cahen and Turan. See C. Cahen, La Turquie pré-ottomane (Istanbul: Institut français d'études anatoliennes, 1988), 92 and 164; O. Turan, Selçuklular Zamanında Türkiye:Siyasi Tarih Alp Arslan'dan Osman Gazi'ye (1071-1328), 6th ed. (Istanbul: Ötüken, 2004), 474, 477, 492, 563. For further details, see Kaymaz, Keyhusrev, 80-82. See also O. Turan, "Les souverains seldjoukides et leurs sujets non-musulmans," Studia Islamica 1 (1953): 65-100, at 81; O. Turan, "Keyhusrev II.," in İslam Ansiklopedisi, 6:620-29, trans. G. Leiser as "Kaykhusraw II Ghiyath al-Din," Journal of the Pakistan Historical Society 33 (1985): 81-107, at 103; Eastmond, "Gender and Patronage," 84-85; Blessing, "Women Patrons," 480-81; R. Shukhurov, "Harem Christianity: The Byzantine Identity of Seljuk Princes," in Peacock and Yildiz, Seljuks of Anatolia, 115-50, at 122. For the image of Gurjī Khātūn in Jalāl al-Dīn Rūmī’s hagiography, see also B. De Nicola, "The Ladies of Rūm: A Hagiographic View of Women in Thirteenth- and Fourteenth-Century Anatolia," Journal of Sufi Studies 3, no. 2 (2014): 132-56.

26. S. Redford, "Rum Seljuq Caravanserais: Urbs in Rure," in The Seljuqs and Their Successors: Art, Culture and History, ed. S. Canby, D. Beyazit, and M. Rugiadi, 35-50 (Edinburgh: Edinburgh University Press, 2020 ), 39.

27. Redford, "Kırkgöz Hanı," 347. Marble was a more frequent alternative to limestone. 
of the document is unfamiliar to me. However, Ibn Bībī speaks of a "manzil-i Dūdān." It appears in the chapter on the conquest of Antalya, which reports that after the conquest, Ghiyāth al-Dīn Kay-Khusraw I (d. 608/1211), the namesake grandfather of Gurjī Khātūn's husband, wanted to go back to his capital, Konya. According to Ibn Bībì, "as they were one stage (manzil) from the coast, the delegates of the sultan's divan gave the order to settle at manzil-i Düdān and to gather the sheep of the sultan." 28 This reference to the flocks belonging to the sultan (akhmās-i khāșș) is interesting, as they are seldom mentioned in the chronicles on the Saljuqs.

Dūdān is the persianized form of Diadion, which fell to the Saljuqs one generation before the capture of Antalya. ${ }^{29}$ The Düden River now flows from the mountains north of Antalya into the sea east of the city. The Düdan caravanserai was probably located upstream, east or northeast of the city (Fig. 5). ${ }^{30}$ Its site is now occupied by the current urban agglomerationof 2.5 million inhabitants. The only evidence we have of Seljuk construction on the Düden River proper is what seems to be a rebuilding of part of a Roman aqueduct as a bridge (see the Soğukasku bridge in Fig. 5). ${ }^{31}$

\section{Figure 5: Antalya and its Hinterland (Base Map: Google Earth)}

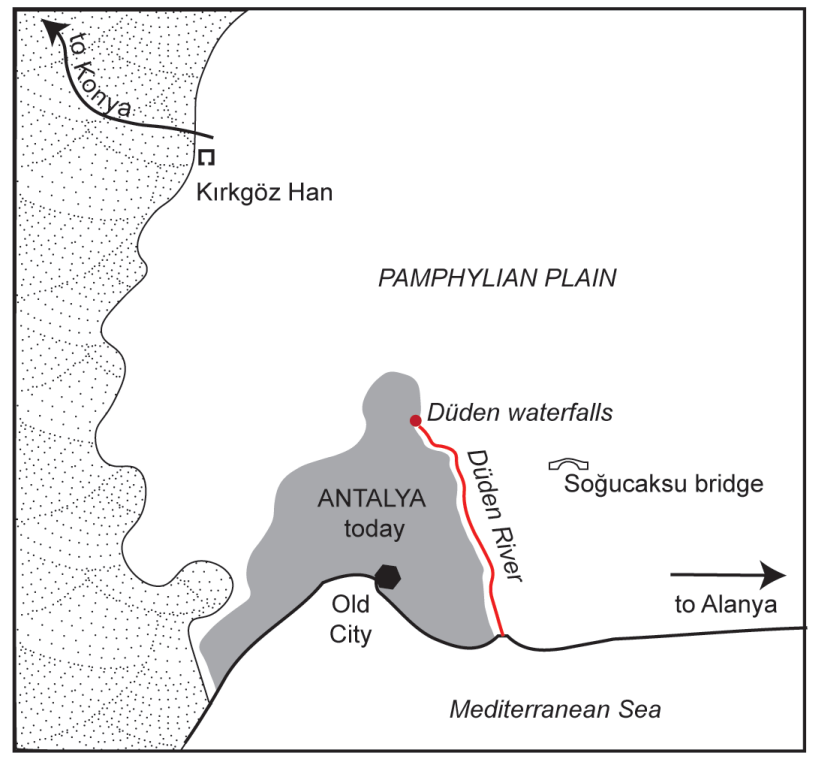

The toponym itself may be one of the rare survivals from Hittite, as the Hittite düden refers to a stream or river that disappears only to reappear. The Düden Çayı that flows into the Mediterranean east of Antalya is such a stream: it originates in a series of springs at the

28. Ibn Bībī, Awāmir, 99. Cf. Mukhtașar, 35, lines 11-12.

29. According to the Christian historians quoted by Cahen, Turquie, 48, Diadion was captured by 'Izz al-Dīn Qiliij Arslan II (d. 588/1192).

30. The Greek name for the river, katarraktes, refers to its waterfalls. The Upper Düden Waterfalls, about eight kilometers from the Hadrian Gate, are today a well-known recreation spot for the inhabitants of Antalya.

31. I am indebted to Scott Redford for this information. 
base of the foothills of the Taurus mountains (the K1rkgözler springs) and then disappears in the limestone formations (karst) of the region, only to reappear after several kilometers. ${ }^{32}$ There are several other locations called "Düden" in Anatolia (around Niksar, southeast of Malatya, and east of Denizli, respectively), but they are less likely to be the site of our caravanserai. None of them is mentioned in the pre-Ottoman sources, and they are all way out of the center of Saljuq power in that period. The Düden Lake north of Tuz Gölü occupies a more strategic position, and it would have been meaningful to build a caravanserai at the intersection of two key trade roads: the Tarsus-Ankara road (via Niğde and Aksaray) and the Antalya-Ankara road (via Konya). However, I am not aware of any construction in this bare landscape.

Conversely, a caravanserai near Antalya would fit perfectly what we know of the region (Pamphylia) in that period. Redford remarked that "Seljuk sub-sultanic patronage often clustered in certain regions of Anatolia." ${ }^{33}$ During Ghiyāth al-Dīn Kay-Khusraw II's reign, Pamphylia was such a cluster. The conquest of the southern littoral had been the great project of the Saljuqs before they looked eastward. 'Izz al-Dīn Qiliij Arslan II prepared the ground; his son Ghiyāth al-Din Kay-Khusraw I carried out the conquest of Antalya; and the latter's son 'Alā' al-Dīn Kay-Qubād I conquered Kalonoros (renamed Alanya). He also launched several building projects to tie the region to the Saljuq Kernland: a road from Alanya to Konya and a caravanserai at Alara (Fig. 6).

Figure 6: Women's Patronage in Rum Anatolia (1232-45) (Free Vector Form from Vecteezy.com)

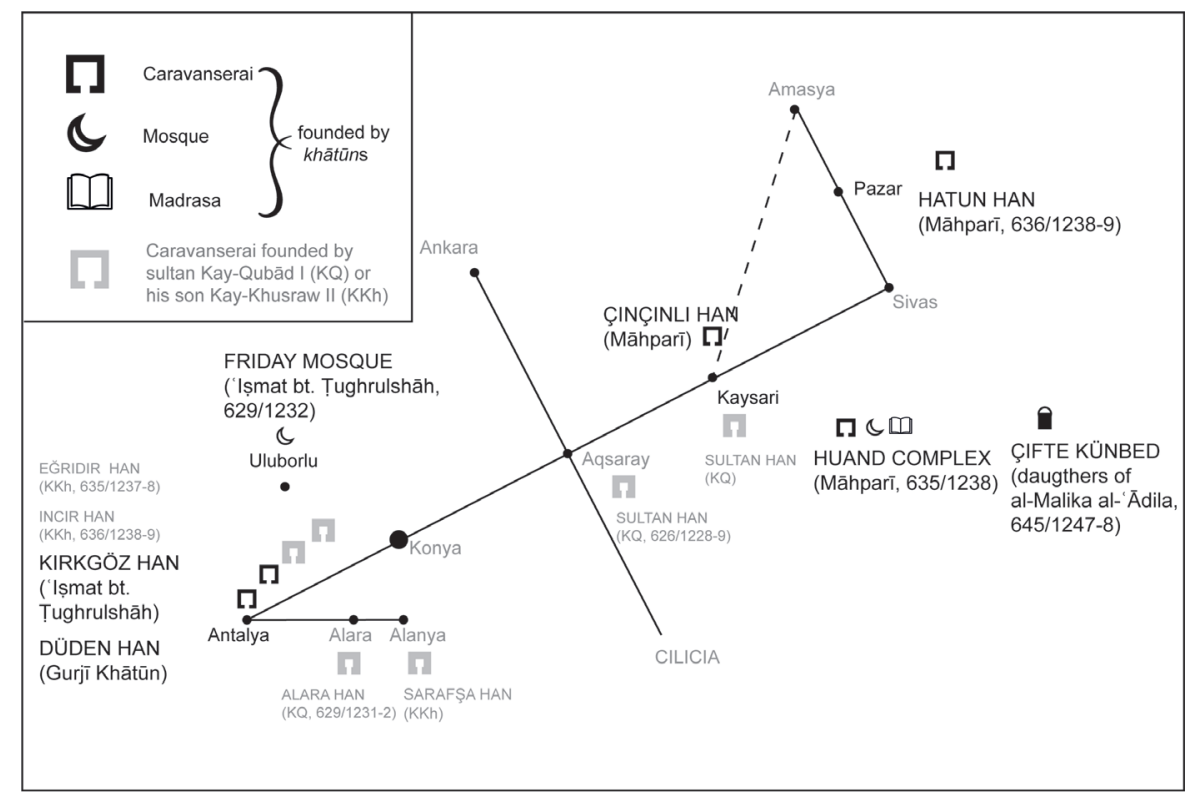

32. A presentation of the Düden water basin can be found in T. Baran, Y. Dalkiliç, and Ü. Öziş, "AntalyaDüden Havzasi Su Kaynaklarinin Geliştirilmesi," in Antalya Yöresinin Inşaat Mühendisliği Sorunları Kongresi, 2:52-60 (Antalya: İnşaat Mühendisleri Odası Antalya Şubesi, 2005).

33. Redford, “Kırkgöz Hanı,” 350. 
His son, Gurjīi Khātūn's husband, was even more dedicated to Antalya: while Kay-Qubād I also built caravanserais in central Anatolia (at Aksaray and Kayseri), Kay-Khusraw II built exclusively on the Mediterranean coast (Sarafşa Han) and in its near hinterland (Kirkgöz Han, İncir Han). ${ }^{34}$ The aim was to turn the Pamphylian coast into a commercial hub between the Southwest Asian trade, the eastern Mediterranean (more specifically Cyprus), and even Armenian Cilician territories. ${ }^{35}$

The exact location of the caravanserai is a matter of conjecture. Kırkgöz, where the sources that feed the Düden River emerge, is a possible location. But that would mean that Kirkgöz Han and the caravanserai of Gurjī Khātūn are one and the same building, which would require us to hypothesize a complex building history with a change of patron. The most likely location, however, is somewhere near the Düden River east of Antalya. Its proximity to the city would easily explain the lack of remains. The well-known example of Eğirdir Han reminds us that cut stones were sought-after commodities: built near Lake Eğirdir (110 km north of Antalya), this caravanserai’s monumental portal has been entirely removed and reassembled in the nearby town as the portal for a madrasa. ${ }^{36}$

The author of the munsha'at replaced the date of the original inscription with "so-andso," following common practice. ${ }^{37}$ We know that the reign of Ghiyāth al-Dīn Kay-Khusraw II lasted eight solar years, from 634/1237 to 643/1245. ${ }^{38}$ If 'Alä' al-Dìn was seven years old at the death of his father, it means he was born within the first year of his parents' marriage, ${ }^{39} 636 / 1238$ is a plausible guess. ${ }^{40}$ It corresponds to the dates of construction of the caravanserais built by the sultan in the Antalya region. The two that are dated (Eğirdir Han in $635 \mathrm{AH}$ and İncir Han in $636 \mathrm{AH}$ ) happen to be on the road linking Antalya to Konya via the lakes of Eğirdir and Beyşehir (site of the palace of Qubād-ābād). So is also Kırkgöz Han, built by Ghiyāth al-Dīn Kay-Khusraw II's mother-in-law.

It is tempting to surmise that Gurjī Khātūn, who appears to have been very close to the sultan, launched the Düden building project as soon as her son 'Alā' al-Dīn was born. But a later date cannot be excluded. Although the defeat at Kösedağ $(641 / 1243)$ had immediate

34. Ghiyāth al-Dīn Kay-Khusraw II also finished Eğridir Han, located further from the coast and started by his father. See Redford, "Urbs in Rure," 42-43.

35. Cahen, Turquie, 122, 124.

36. Redford, "Urbs in Rure," 43. As a consequence, the inscription of Eğirdir Han is still visible, but not at its original site.

37. The place and date mentioned in the colophons of the letters copied in munsha'àt are systematically left out. Redford ("Kırkgöz Han1," 349) believes that on the inscription of Kırkgöz Han, the scribe left out the date because of a lack of space.

38. The date of his death is not recorded in the sources. For long, it was dated to 644/1246, as in C. E. Bosworth, The New Islamic Dynasties: A Chronological and Genealogical Manual (Edinburgh: Edinburgh University Press, 1996), 213. But Kaymaz, followed by Turan, opted for 643/1245, see Leiser, “Observations," 114 n. 56. Cahen mentions only the CE year (Turquie, 230: "end 1245 or 1246 ").

39. The age of 'Alā' al-Dīn at the death of his father is given by Simon de Saint-Quentin in Histoire des Tartares, ed. J. Richard (Paris: Geuthner, 1965), 82 ("Raconadius erat .XI. annorum, Azardinus .IX., Aladinus vero .vII, et iste quidem natu minimus regine filius quoad ipsos paterne hereditatis heres erat legitimus"). See also Cahen, Turquie, 230 n. 8.

40. This is the date assumed by Turan, Selçuklular Zamanında Türkiye, 477. 
financial repercussions for the Saljuq state, the region of Antalya had not lost its appeal for the sultan, and actually it is the only region in which Saljuq patronage is attested after 641/1243. This is irrefutable for military architecture (the walls of Antalya), but very probably true for commercial buildings, too. ${ }^{41}$ The reason is obvious: it was the city furthest from the Mongol ordu, with an easy escape route by boat if necessary.

\section{Remarks about the Text of the Inscription}

To enable a more thorough analysis, I have prepared several tables listing the denominations found in foundation inscriptions. Table 1 references all the foundations by woman patrons in Rum, Table 2 the foundations by male patrons during the reign of Ghiyāth al-Dīn Kay-Khusraw II, and Table 3 the foundations of that particular sultan.

The patron of the Düden caravanserai is referred only by her honorific titles (laqabs), without mention of her name (ism) or genealogy (nasab). This is not unusual. The most frequent form of denomination in Table 1 (accounting for seven out of thirteen inscriptions) combines a laqab with an ism, but the dominance of this form is largely due to the many foundations of Māhparī Khātūn, 'Alā' al-Dīn Kay-Qubād I's wife. ${ }^{42}$ Another of 'Alā' al-Dīn's wives, Țughrulshāh's daughter, is referred to only by her laqab, never her ism (Table 1: items 4 and 11). In fact, in the official documents (sulțāniyyāt) copied into the munsha'att, laqab is the denomination by default, and the ism may or may not be given.

In the Düden inscription, ${ }^{43}$ two of these laqabs are standard for Saljuq queens: "Ișmat al-dunyā wa-l-dīn" (literally, "the virtue of the world and the faith") and "Șafwat al-islām wa-1-muslimīn" (literally, "The quintessence of Islam and the Muslims"). Two other "Ișma are known in the Saljuq family: the daughter of Țughrulshāh (himself a Saljuq) who married sultan 'Alā' al-Dīn Kay-Qubād (Fig. 2) ${ }^{44}$ and, in the previous generation, a sister of Ghiyāth al-Dīn Kay-Khusraw I. ${ }^{45}$ According to Uzunçarş1l1, followed by Blessing, the title "Ṣafwa" was given to queens of non-royal origin, whereas "Ișma" seems to have been reserved for women born as princesses (indeed, Māhparī, the daughter of the Christian commander of Kalonoros, is never given the laqab 'Ișmat al-Dīn). ${ }^{46}$ However, the titles were not exclusive.

41. Blessing ("Women Patrons," 480) writes that "after 641/1243 Seljuks rulers are no longer recorded as patrons of architecture," but several royal inscriptions on the walls of Antalya postdate Kösedağ. For Redford ("Kırkgöz Hanı," 350), the "plainer caravansarays" of Pamphylia without decoration (like Şarapsa and Karg1) "were built in the last years of the sultan's reign [...] a time when he had diminished resources, but spent most of his time in these parts".

42. Five of the six inscriptions for Māhparī contain a laqab and an ism.

43. I speak hereafter of the "Düden inscription" to refer to the text under study, although the text presently exists only in a manuscript. At the end of this article I address the relationship between the stone and the paper.

44. Redford, "Paper, Stone, Scissors," 155. For the title Șafwat [al-Dīn], see also İ. H. Uzunçarsıll, Osmanlı Devleti Teşkilâtına Medhal (Istanbul: Maarif Matbaası, 1941), 66; E.S. Wolper, "Princess Safwat al-Dunyā wa al-Dīn and the Production of Sufi Buildings and Hagiographies in Pre-Ottoman Anatolia," in D. Fairchild Ruggles, Women, Patronage, 35-52, at 42-43

45. 'Ișmat al-Dunyā wa-l-Dīn Gawhar Nasība; see Crane, "Notes," 41; Blessing, "Women Patrons," 479 n. 12.

46. Blessing, "Women Patrons," 492, 510. 
Table 1: Denominations in Foundation Inscriptions by Women Patrons

\begin{tabular}{|c|c|c|c|c|c|c|}
\hline \multirow[t]{2}{*}{ Item } & \multirow{2}{*}{$\begin{array}{l}\text { Foundation } \\
\text { (AH date) }\end{array}$} & \multirow{2}{*}{$\begin{array}{l}\text { Patron } \\
\text { (ism when } \\
\text { known) }\end{array}$} & \multirow{2}{*}{$\begin{array}{c}\text { Denomination } \\
\text { of the sultan } \\
\text { (see Appendix) }\end{array}$} & \multicolumn{2}{|c|}{ Denomination of the patron } & \multirow[t]{2}{*}{ RCEA no. } \\
\hline & & & & $\begin{array}{c}\text { laqab (first word or } \\
\text { in full) }\end{array}$ & other & \\
\hline 1. & $\begin{array}{l}\text { Çifte Medrese } \\
\text { in Kayseri } \\
(602)\end{array}$ & Gawhar & $\begin{array}{l}\text { var. 1 + GhD } \\
\text { KKh b. QA }\end{array}$ & 'Ișma & $\begin{array}{l}\text { Gawhar Nașība } \\
\text { b. QA }\end{array}$ & \\
\hline 2. & $\begin{array}{l}\text { Külük Mosque } \\
\text { in Kayseri } \\
(607)\end{array}$ & Atsüz Altï & $\begin{array}{l}\text { var. } 1+{ }^{C} \mathrm{IzD} \text { AbF } \\
\text { KK b. KKh + } 21\end{array}$ & - & $\begin{array}{l}\text { Atsïz Altï Khātūn } \\
\text { b. Maḥ. b. } \\
\text { Yāghībașān }\end{array}$ & 3665 \\
\hline 3. & $\begin{array}{l}\text { Hospital of } \\
\text { Divriği (626) }\end{array}$ & Tūrān Malik & - & - & $\begin{array}{l}\text { Tūrān Malik bt. } \\
\text { FD Bahrāmshāh }\end{array}$ & \\
\hline 4. & $\begin{array}{l}\text { Uluborlu } \\
\text { Friday Mosque } \\
(629)\end{array}$ & $\begin{array}{l}\text { Țughrulshāh's } \\
\text { daughter }\end{array}$ & $\begin{array}{l}\text { 1-2, 22, var. } 24, \\
\text { 'AD AbF KQ b. } \\
\text { KKh }\end{array}$ & 'Ișma, Șafwa & $\begin{array}{l}\text { bt. Țughrulshāh } \\
\text { bt. QA }\end{array}$ & 4044 \\
\hline 5. & \multirow{2}{*}{$\begin{array}{l}\text { Huand Hatun } \\
\text { complex in } \\
\text { Kayseri (635) }\end{array}$} & \multirow[t]{2}{*}{ Māhparī } & $\begin{array}{l}1+\mathrm{GhD} A b F \\
\mathrm{KKh} \text { b. KQ }\end{array}$ & $\begin{array}{l}\text { Șafwa, Fātiḥat al- } \\
\text { khayrāt }\end{array}$ & - & 4146 \\
\hline 6. & & & $\begin{array}{l}1+\mathrm{GhD} A b F \\
\text { KKh b. KQ }\end{array}$ & Șafwa & Māhparī Khātūn & 4147 \\
\hline 7. & \multirow[t]{2}{*}{$\begin{array}{l}\text { Hatun Han in } \\
\text { Pazar (636) }\end{array}$} & \multirow[t]{2}{*}{ Māhparī } & $\begin{array}{l}\text { 1, var. } 2,22+ \\
\text { GhD AbF KKh b. } \\
K Q+21\end{array}$ & Șafwa, Wālida & Māhparī Khātūn & 4157 \\
\hline 8. & & & $\begin{array}{l}1, \text { var. } 2,22+ \\
\text { GhD AbF KKh b. } \\
K Q+21\end{array}$ & $\begin{array}{l}\text { Șafwa,Wālida, } \\
\text { Malika }\end{array}$ & Māhparī Khātūn & $\begin{array}{l}4158 \\
\text { (Erdmann } \\
\text { no. 36) }\end{array}$ \\
\hline 9. & $\begin{array}{l}\text { Çinçili Han } \\
(637)\end{array}$ & Māhparī & var. 9 & $\begin{array}{l}\text { Malika, Șafwa, } \\
\text { Wālida }\end{array}$ & Māhparī Khātūn & $\begin{array}{l}\text { (Erdmann } \\
\text { no. 37) }\end{array}$ \\
\hline 10. & $\begin{array}{l}\text { [Düden Ribāt } \\
\text { (n.d.)] }\end{array}$ & $\begin{array}{l}\text { Tamar/Gurjī } \\
\text { Khātūn }\end{array}$ & $\begin{array}{l}\text { 1, 22, var. 23, } 25 \\
+ \text { GhD MghI AbF } \\
\text { KKh b. KQ } \\
\text { [mother of } \\
\text { malik mu'azzam } \\
\text { 'AD, Fkhr, wali } \\
\text { 'ahd, 5] }\end{array}$ & $\begin{array}{l}\text { Sitr, Malika, Durra, } \\
\text { Waliyya, 'Ișma, } \\
\text { Șafwa, Wālida }\end{array}$ & & - \\
\hline 11. & Kırkgöz Han & $\begin{array}{l}\text { Țughrulshāh's } \\
\text { daugther }\end{array}$ & $\begin{array}{l}\text { 1, 22, var. 23, } \\
25, \mathrm{GhD} A b \mathrm{~F} \\
\text { KKh b. KQ }\end{array}$ & $\begin{array}{l}\text { 'Ișma, Durrat Tāj } \\
\text { al-Duwal }\end{array}$ & & $\begin{array}{l}4263 \\
\text { (Erdmann } \\
\text { no. 56) }\end{array}$ \\
\hline 12. & $\begin{array}{l}\text { Māhparī’s } \\
\text { cenotaph in } \\
\text { Kayseri (645) }\end{array}$ & Māhparī & $\begin{array}{l}\text { [mother of GhD } \\
\text { KKh b. KQ] }\end{array}$ & $\begin{array}{l}\text { Malika, Maryam, } \\
\text { Khadīja, Șafwa, } \\
\text { Wālida }\end{array}$ & Māhparī Khātūn & 4259 \\
\hline 13. & $\begin{array}{l}\text { Çifte Künbed } \\
\text { in Kayseri } \\
(645)\end{array}$ & $\begin{array}{l}\text { al-Malika } \\
\text { al-'Ādila's } \\
\text { daughters (not } \\
\text { named in the } \\
\text { inscription) }\end{array}$ & - & $\begin{array}{l}\text { dedicatee: 'Ișma, } \\
\text { Șafwa, Sayyida, } \\
\text { Zubayda, Șāhibat } \\
\text { al-Khișāl, Khātūn } \\
\text { al-Dunyā, Malika, } \\
\text { Manshā' al-Yumn }\end{array}$ & - & 4273 \\
\hline
\end{tabular}


Table 2: Denominations in Foundation Inscriptions by Male Patrons during the Sultanate of Ghiyāth al-Dīn Kay-Khusraw II

\begin{tabular}{|c|c|c|c|c|c|c|}
\hline \multirow[t]{2}{*}{ Item } & \multirow{2}{*}{$\begin{array}{l}\text { Foundation } \\
\text { (AH order) }\end{array}$} & \multirow{2}{*}{$\begin{array}{c}\text { Patron } \\
\text { (ism when } \\
\text { known) }\end{array}$} & \multirow{2}{*}{$\begin{array}{l}\text { Denomination of the } \\
\text { sultan (see Appendix) }\end{array}$} & \multicolumn{2}{|c|}{ Denomination of the patron } & \multirow[t]{2}{*}{ RCEA no. } \\
\hline & & & & laqab & other & \\
\hline 1. & $\begin{array}{l}\text { Kutahya Mosque } \\
(634)\end{array}$ & $\begin{array}{l}\text { 'Imād al-Dīn } \\
\text { Hizār Dīnārī }\end{array}$ & $\begin{array}{l}1,22+\mathrm{GhD} A b F \mathrm{KKh} \\
\text { b. KQ }\end{array}$ & 'ImādD & Hizār Dīnārī & 4134 \\
\hline 2. & $\begin{array}{l}\text { Madrasat Sirāj al-Dīn } \\
\text { in Kayseri (636) }\end{array}$ & $\begin{array}{l}\text { Sirāj al-Dīn } \\
\text { Badr }\end{array}$ & $\begin{array}{l}1+\mathrm{GhD} \text { AbF KKh b. KQ } \\
+22\end{array}$ & SirājD & Badr & 4156 \\
\hline 3. & $\begin{array}{l}\text { 'Alä' al-Dīn Mosque in } \\
\text { Antalya (637) }\end{array}$ & $\begin{array}{l}\text { atabeg } \\
\text { Armaghān }\end{array}$ & $\begin{array}{l}1,22+\mathrm{GhD} A b F \mathrm{KKh} b \\
\mathrm{KQ}+21\end{array}$ & & $\begin{array}{l}\text { Atabak } \\
\text { Armaghān }\end{array}$ & 4179 \\
\hline 4. & Qarāțāy Han (638) & Qarāțāy & $\begin{array}{l}1-2,22+\mathrm{GhD} A b F \mathrm{KKh} \\
\text { b. KQ + } 21\end{array}$ & \multicolumn{2}{|l|}{ missing } & $\begin{array}{l}4190 \\
\text { (Erdmann } \\
\text { no. 32) }\end{array}$ \\
\hline 5. & $\begin{array}{l}\text { Elbistan's Friday } \\
\text { mosque (639) }\end{array}$ & Chawlii & $\begin{array}{l}\text { var. } 1+\mathrm{GhD} \text { AbF KKh b. } \\
\mathrm{KQ}+21\end{array}$ & MubārizD & $\begin{array}{l}\text { Abū al-'Izz, } \\
\text { Chawlī al- } \\
\text { Dhawwāq } \\
\text { al-sulțānī }\end{array}$ & 4199 \\
\hline 6. & $\begin{array}{l}\text { Sirchālī Mosque in } \\
\text { Konya }\end{array}$ & $\begin{array}{l}\text { Badr al-Dīn b. } \\
\text { Muṣlih }\end{array}$ & $\begin{array}{l}1,22+\mathrm{GhD} A b F \mathrm{KKh} b \\
\mathrm{KQ}+21\end{array}$ & BadrD & b. Muṣliḥ & 4211 \\
\hline 7. & Hidirlik Mosque & $\begin{array}{l}\text { 'Imād al-Dīn } \\
\text { Hizār Dīnārī }\end{array}$ & $\begin{array}{l}\text { 1, } 22+\mathrm{GhD} A b F \mathrm{KKh} \\
\text { b. KQ }\end{array}$ & 'ImādD & Hizār Dīnārī & 4228 \\
\hline 8. & $\begin{array}{l}\text { Tower in the walls of } \\
\text { Antalya (642) }\end{array}$ & $\begin{array}{l}\text { Abū Bakr b. } \\
\text { Sacīd }\end{array}$ & $\begin{array}{l}1-3, \text { var. } 4+\mathrm{GhD} A b F \\
\text { KKh b. KQ + } 21\end{array}$ & & $\begin{array}{l}\text { Abū Bakr b. } \\
\text { Sa'īd }\end{array}$ & 4239 \\
\hline 9. & $\begin{array}{l}\text { Burmali Minaret in } \\
\text { Amasya (645) }\end{array}$ & $\begin{array}{l}\text { brothers } \\
\text { Farrukh \& } \\
\text { Yusūf al- } \\
\text { Khāzin }\end{array}$ & $\begin{array}{l}1+\mathrm{GhD} A b F \mathrm{KKh} \text { b. KQ } \\
\text { b. KKh }+21\end{array}$ & & $\begin{array}{l}\text { Farrukh \& } \\
\text { Yusūf al- } \\
\text { Khāzin }\end{array}$ & 4261 \\
\hline
\end{tabular}

Table 3: Denominations of Ghiyāth al-Dīn Kay-Khusraw II in Buildings $\mathrm{He}$ Commissioned

\begin{tabular}{|c|l|l|l|}
\hline Item & Foundation (AH date) & Denomination of the sultan (see Appendix) & $R C E A$ no. \\
\hline 1. & Eğirdir Han (635) & $1-20+$ GhD AbF KKh b. KQ b. QA b. Mas b. QA + 21 (total: 22) & $\begin{array}{l}4148 \\
(\text { Erdmann } \\
\text { no. 33) }\end{array}$ \\
\hline 2. & Walls of Antalya (636) & $1,22$, var. $4+$ GhD AbF KKh b. KQ + 21 (total: 5$)$ & 4159 \\
\hline 3. & Incir Han (636) & $1-6,8,20+$ GhD AbF KKh b. KQ b. KKh + 21 (total: 10) & $\begin{array}{l}4162 \\
(\text { Erdmann } \\
\text { no. 29) }\end{array}$ \\
\hline 4. & Walls of Antalya (642) & $1-3,9$, var. $4,23+$ GhD + 24, var. 22 + AbF KKh b. KQ + 21 (total: 10) & 4238 \\
\hline
\end{tabular}


Kay-Qubād I's two royal spouses (Bint Ṭughrulshāh and al-Malika al-'Ādila) are both called "Ișma" and "Șafwa" (see Table 1: items 4 and 13). Yalman noted that the inscription for al-Malika al-'Ādila does not fit Uzunçarşıll's theory, but she tried to normalize the exception by arguing that "the Ayyubid princess seemed to be implying descent from the Rum Seljuk dynasty." 47 Since the princess and her son were slaughtered by her Saljuq "parents," this assumption is difficult to accept (the daughters of al-Malika al- 'A $\bar{A}$ dila took the extraordinary initiative of declining to mention the reigning Saljuq sultan in the inscription on the monument they built for their mother in Kayseri to show their aversion to the dynasty).

Gurjī Khātūn's rank was even higher than those of Ṭughrulshāh's daughter and al-Malika al-'ÂAila. Her mother ruled Georgia, and her father was a Saljuq prince (Fig. 4). The Düden inscription shows that "Ișma" and "Șafwa" were usual titles for Rum Saljuq khātūns. This is confirmed by a model of a letter for a khātūn in the manuscript from which our text is drawn. ${ }^{48}$ The same was true in Mongol Iran, as evidenced by Muhammad b. Nakhjawānī's Dastūr al-kātib, a chancery manual completed in Tabriz in 767/1365-66. ${ }^{49}$

The second laqab given to Gurjī Khātūn, "pearl of the crown of the family of David," signals her origin. The "family of David" is the usual expression used to refer to the Bagratid dynasty, which can be traced back to the start of the ninth century CE and which ruled Georgia and the western Caucasus since the days of David IV the Builder (d. $1125 \mathrm{CE}$ ). David had been the emblematic royal first name since Bagratid propagandists advanced the claim of biblical descent. ${ }^{50}$ Ibn Bỉbi uses it in the message Queen Rusudan allegedly sent to 'Alā' al-Dīn Kay-Qubād I to offer peace:

It has come to our mind that now our countries are neighbors. My pure and secluded child, who is descended from the loins of the Saljuqs and the race of David (az sulb-i Saljūq u nizhād-i Dāwūd), [should] go to the nuptial room of the prince of Islam, Ghiyāth al-Dīn Kay-Khusraw. ${ }^{51}$

The son Gurjī Khātūn had with the sultan had the same dual background. ${ }^{52}$ Let us note

47. Yalman, “'Dual Identity,"” 235.

48. MS Mar`ashī 11136, fol. 10r.

49. We can note that the Dastūr al-kātib gives six possible series of laqabs for khātūns: 'Ișma appears in two of them and Șafwa in three (Nușra, a title not recorded for Rum Saljuq khātūns, is also mentioned). See Muhammad Munshī Nakhjawānī, Dastūr al-kātib fị ta'yīn al-marātib, ed. 'A. A. Aḥmadī Dārānī, 2 vols. (Tehran: Mīrāth-i Maktūb, 1395sh.), 1:63-64.

50. David was the name of Queen Rusudan's father, father-in-law, son, nephew, and great-nephew. The claim of Davidic descent is detailed by Sumbat in his chronicle of the Bagratids. See S. Rapp Jr., "Sumbat Davitcis-dze and the Vocabulary of Political Authority in the Era of Georgian Unification," Journal of the American Oriental Society 120, no. 4 (2000): 570-76. But it is also mentioned even earlier, in mid-tenth-century Byzantium; see Constantine Porphyrogenitus, De Administrando Imperio, ed. G. Moravcsik, trans. R. J. H. Jenkins (Washington, DC: Dumbarton Oaks Center for Byzantine Studies, 1949; reprint, 2008), 204-7 (§45).

51. Ibn Bībī, Awāmir, 378. Cf. Mukhtașar, 184, lines 16-20; Peacock, “Georgia,” 138.

52. The links between the Saljuqs and the Bagratids were not exclusive, and Gurjī Khātūn had on her side a formidable range of connections that stretched over the whole of Asia Minor (see Eastmond, "Art and Frontiers"). Contrary to Yalman ("Dual Identity"), I prefer to speak of "background" rather than "identity," as the latter notion is now being used so extensively and in such a way that its very meaning has become blurred 
that in the Sünbül Zaviye of Tokat (691 AH), the dual descent of Mu'inn al-Dinn Pervaneh's daughter is also exalted. The patron, Sünbül, praises her former master as al-malika ... al-mukarrama ilā al-țarafayn al-nasībat al-abuwayn ("the queen ... venerated on both sides for the genealogy of her two parents"). ${ }^{53}$

Do the honorific titles of Gurjī Khātūn tell us something about her faith? The question deserves to be asked because according to the Georgian chronicle, she had been allowed to remain a Christian and to practice her religion openly. ${ }^{54}$ The same source details the events that led to her conversion during the reign of Ghiyāth al-Dīn Kay-Khusraw II, but it is not dated. ${ }^{55}$ Many of the titles mentioned in the Düden inscription carry no religious connotations, but "Șafwat al-islām wa-1-musliminn" followed by a reference to "holding firm to God's rope" implies that she was a Muslim. ${ }^{56}$ In sum, the Düden inscription portrays Gurjī Khātūn as a woman of royal blood and as a staunch Muslim, but also as the wife of the sultan and the mother of the appointed heir. It gives her seven laqabs altogether.

The reigning sultan is mentioned in the inscription, as was customary. The sultan's main title, "Ghiyāth al-dunyā wa-l-dīn", had been borne already by his homonymous grandfather, the conqueror of Antalya, Kay-Khusraw I. ${ }^{57}$ The other sultanic titles used in the Düden inscription are also found elsewhere. As can be seen in Tables 2, 3, and in the appendix, al-sultān al-a'zam appears every time the name of the sultan is mentioned. ${ }^{58}$ "Shadow of God on earth" also appears recurrently, though not on Eğirdir Han or İncir Han, which were built by the sultan at the beginning of his reign. However, the evidence is not sufficient to conclude that the Düden caravanserai was built after Kösedağ, as this title appears on the walls of Antalya both before and after 641/1243, and also on all the caravanserais built by female patrons at Kayseri, Pazar, Çinçili, and Kırkgöz (see Tables 2-3).

(obviously, this already lengthy article is not the place to engage with this issue).

53. Répertoire chronologique d'épigraphie arabe, ed. E. Combe, J. Sauvaget, and G. Wiet, 18 vols (Cairo: IFAO, 1931-91) [henceforth RCEA], inscription no. 4959. This Sufi lodge is discussed by Wolper, "Princess Safwat al-Dunyā," 41-43.

54. Georgian Chronicle, 1:502 and 524 ("en effet elle avait un prêtre, des images et des croix, non secrètement mais tout à fait à découvert”). See Turan, "Souverains seldjoukides," 81; Eastmond, “Art and Frontiers," $163-64$.

55. According to the Georgian Chronicle, Gurjī Khātūn's conversion was the unforeseen consequence of her mother Rusudan's schemes to get rid of her nephew David (future David VI Ulu; see Fig. 4), who also stayed at the court of Konya. At some point, Rusudan told the sultan that her daughter Gurjī Khātūn and her nephew David had maintained illicit relations. The sultan beat her, and "the unfortunate woman, tired of suffering, renounced the true faith she had been keeping until then" (Georgian Chronicle, 1:524; Peacock, "Georgia," 142). Vryonis ("Another Note") put forward the influence of Jalāl al-Dīn Rūmī as a decisive factor in Gurjī Khātūn's conversion. Since Rūmī's father settled in Konya in 626/1228, this is not impossible.

56. Wa-'tașimū bi-ḥabl Allāhi jamī'an wa-lā tafarraqū is one of the most famous verses of the Quran. "God's rope" has usually been interpreted as a metaphor for the Quran. The sincerity of Gurjī Khātūn's conversion has been questioned by Vryonis ("Another Note," 20), but it is not the issue here.

57. Ghiyāth and Mughīth (both meaning "succorer") are built on the same root, ghātha, meaning "to water (with rain)," hence "to help."

58. In some inscriptions, al-sulțān al-a 'zam is followed by shāhanshāh al-mu'azzam, but the latter epithet is not as powerful a title as the superlative $a^{\prime}$ zam. 
The title "possessor of the crown, the flag, and the belt" is much rarer. It appears only once elsewhere: in the nearby Kırkgöz Han, built by Ṭughrulshāh's daughter (Table 1: item 11). The two inscriptions are remarkably similar as far as the denominations for the sultan are concerned. ${ }^{59}$ Since the text is in Arabic, the word liwä (flag) has been preferred over sanjaq, the emblematic Turkish word used in Persian chronicles but not in Arabic ones. ${ }^{60}$ Redford noted that the belt (nițāq) is a new and unexpected element of Saljuq regalia, but he meant in an inscriptional sense. ${ }^{61}$ In fact it was used in qașidas in honor of great Saljuq sultans. For example, Amīr Mu'izzī, the malik al-shu'arā of sultan Malik-Shāh b. Alp Arslan (d. 485/1092), declaimed:

$$
\text { داد جوانى و بيروزى و دولت و سياه وكمر ناج و تخت و شمشير و افسر و نكين }
$$

The ring, the "hat," the sword, the throne, the crown, and the belt;

they conferred [on this sultan] an army and a state, as well as victory and youth. ${ }^{62}$

The belt is a symbol of determination (the Persian kamar bastan is the exact equivalent of the English "to gird one's loins"), and the image is often used by the same panegyrist. ${ }^{63}$ Redford, who surmises that Kırkgöz Han was built after Kösedağ, suggests that "the enumeration of regalia could be read as an insistence on his legitimacy: the sultan actually had these items in his possession, and with them retained the right to rule, despite his defeat at Kösedağ." ${ }^{4}$

The last person mentioned in the Düden inscription is Gurjī Khātūn's son with the sultan, 'Alā' al-Dīn Kay-Qubād II. Like all Saljuq princes, he is al-malik al-mu'azzam. ${ }^{65}$ His title "sultan of the land and the two seas" refers to the Saljuq control over the ports on the Black Sea and the Mediterranean achieved during the reigns of Kay-Khusraw II's father (Sinop, 1214) and grandfather (Antalya, 1207). ${ }^{66}$ Ghiyāth al-Dīn Kay-Khusraw II himself bore this title at the beginning of his reign, as evidenced by inscriptions dated 635 and $636 \mathrm{AH}$ in the

59. Nițāq (pl. nuțuq) is also mentioned as Saljuq regalia elsewhere in MS Mar'ashī 11136: we read "dhū al-tāj wa-l-nițāq wa-l-liwā’ wa-l-'alam" on fol. 28v (quoted below). In the Kirkgöz Han inscription, however, Redford ("Kırkgöz Hanı," 353, line 4, and 355) reads națaq. The word was left blank in the RCEA (no. 4263). Fikri Erten (quoted by Redford, "Kırkgöz Hanı,” 348, line 4) suggested awțān.

60. See S. Redford, "Flags of the Seljuk Sultanate of Anatolia: Visual and Textual Evidence," in The Hidden Life of Textiles in the Medieval and Early Modern Mediterranean:Contexts and Cross-Cultural Encounters in the Islamic, Latinate and Eastern Christian Worlds, ed. N. Vryzidis, 67-82 (Turnhout: Brepols, 2020).

61. Redford, "Kırkgöz Hanı," 355 n. 14.

62. Amīr Mưizzī, Dīwān, ed. 'A. Iquāl (Tehran: Kitābfurūshī-yi Islāmiyya, 1318sh.), 147, v. 3380.

63. E.g. Amīr Mu'izzī, Dīwān, 145, v. 3328: bast dar shāhī kamar tā lājaram 'alam gushād: "in kingship, he put on his belt so that necessarily he will conquer the world." There are many similar verses in the Dīwān.

64. Redford, "Kırkgöz Hanı," 357.

65. In Saljuq Iran, the head of the family was al-sultān al-a'zam, while the princes with an appanage (such as Sanjar b. Malik-Shāh and his nephews in western Iran) were only al-malik al-mu'azzam.

66. 'Izz al-Dīn Kay-Kāwūs I is called "sultan of the land and the sea" on the walls of Sinop (RCEA, inscription no. 3761). Antalya is reconquered afterward, and only then do we see the use of the dual "the two seas." See G. Leiser and S. Redford, Victory Inscribed: The Seljuk Fetihname on the Citadel Walls of Antalya, Turkey (Istanbul: AKMED, 2008), 101. 
region of Antalya (see Table 3: items 1-3 and Table 2: item 8). However, it is not included among the titles inscribed on the walls of Antalya in $642 \mathrm{AH}$ (Table 3: item 4), maybe because it had been granted to 'Alā' al-Dīn in the meantime, possibly when the latter was appointed "heir of his father" (wali 'ahd wālidihi).

Let us now turn to the functions of Gurjī Khātūn's foundation.

\section{Functions of the Foundation}

The inscription speaks of a ribāt. This is a loaded word. Long thought to denote a kind of "Muslim military monastery" or "fortified convent," its meaning has been entirely reassessed after Chabbi's seminal article in the Encyclopaedia of Islam (2nd ed.). ${ }^{67}$ The tribal sense had to do with horses, or rather, the action of keeping horses. The term came to be used for buildings after a complex evolution. In fourth/tenth-century geography (first and foremost in the writings of Ibn Hawqal and al-Muqaddasī), ribāt has a military, religious (synonymous with khānaqāh), or commercial function. ${ }^{68}$ In other words, a ribāt could mean a caravanserai (that is, a staging post and lodging built on a trade road). Al-Ișțakhri (fl. fourth/tenth century) may be the earliest source on "the evolution from the military ribāt to the manzil, i.e. staging post along itineraries." 69

In Anatolia, caravanserais were usually called khān..$^{70}$ The word was first used in Ayyubid territories at the beginning of the seventh/thirteenth century. ${ }^{71}$ It also appears in the inscriptions of Eğirdir Han and İncir Han, both built by Ghiyāth al-Dīn Kay-Khusraw II. Ribāt is found in older inscriptions, such as that at Dokuzun Han built north of Konya by Kay-Khusraw II's grandfather. ${ }^{72}$ But it would be wrong to think that the term khān merely

67. J. Chabbi, "Ribāț. 1. History and Development of the Institution," in Encyclopaedia of Islam, 2nd ed., 8:493-506 (Leiden: Brill, 1995). See also C. Picard and A. Borrut, "Râbata, ribât, râbita: Une institution à reconsidérer," in Chrétiens et musulmans en Méditerranée médiévale (VIII ${ }^{e}-X I I I^{e}$ s.): Échanges et contacts, ed. P. Sénac and N. Prouteau, 33-65 (Poitiers: Centre d'études supérieures de civilisation médiévale, 2003); E. de La Vaissière, "Le Ribāt d'Asie centrale," in Islamisation de l'Asie centrale: Processus locaux d'acculturation du VII au XI siècle, ed. E. de La Vaissière, 71-94 (Paris: Association pour l'avancement des études iraniennes, 2008).

68. A. Miquel, La géographie humaine du monde musulman (jusqu'au milieu du 11 e siècle), vol. 4: Les travaux et les jours (Paris: EHESS, 1988), 54-56 ("Les ribāț-s: De la piété militaire à la piété tout court")

69. Picard and Borrut, "Râbata," 48.

70. The standard reference works on caravanserais in Turkey are those of Erdmann, Rogers and Yavuz: K. Erdmann (with H. Erdmann for vols. 2-3), Das anatolische Karavansaray des 13. Jahrhunderts, 3 vols (Berlin: Gebrüder Mann, 1961-76); J.M. Rogers, "Royal Caravansarays and Royal Inscriptions in Seljuk Anatolia," Atatürk Üniversitesi Edebiyat Fakültesi Araştırma Dergisi - In Memoriam Prof. Albert Louis Gabriel 9 (1978): 397-431; A. T. Yavuz, “The Concepts that Shape Anatolian Seljuq Caravanserais," Muqarnas 14 (1997): 80-95 (with reference to her publications in Turkish). The chapter on caravanserais in Hillenbrand's summa is very useful for putting the pre-Ottoman Anatolian buildings in a wider perspective: R. Hillenbrand, Islamic Architecture: Form, Function, Meaning (Edinburgh: Edinburgh University Press, 1994), 346-50. A good introduction on the subject of Saljuq caravanserais is now Redford, "Urbs in Rure."

71. See the inscription at Aqaba in RCEA, inscription no. 3720. See also N. Elisséeff, "Khān," in Encyclopaedia of Islam, 2nd ed., 4:1010-17 (Leiden: Brill, 1978), 1011.

72. $R C E A$, inscription no. 3668. See also the inscription for Karaçaviran (dated 607/1210) in RCEA, inscription no. 3669 . 
replaced ribāt, as the latter still appears in Kırkgöz Han and Derebucak Han, two foundations very close in space and time to the Düden caravanserai. ${ }^{73}$

The Kırkgöz and Düden (and Derebucak) inscriptions also share mention of the function of the building: it was for the benefit of "all the creatures living in it and [all] the travelers leaving it for the east or the west of the world." 74 The reference to arriving and departing travelers (al-nāzilūn bihā wa-l-musāfirūn 'anhā) is enough to conclude it was a caravanserai. That being said, caravanserais were more than instruments of trade, and recent scholarship tends to view them as multifunction institutions that also played a role in tax collection, monitoring rural neighborhoods, royal residence (more on this below), and possibly even defense (the original meaning of ribāt).

Several types of caravanserai buildings could be found in Anatolia. We lack sufficient information to decide whether Gurjī Khātūn built a caravanserai with a monumental entrance giving access to a central rectangular courtyard surrounded by rooms, like Kırkgöz Han, or whether her ribāt was of a mixed type, like Dokuzun Han (Fig. 7). I would guess the former because of the building's geographical location (close to Kırkgöz Han), but this is speculative.

By erecting a caravanserai, Gurjī Khātūn was following the example set by her motherin-law, Māhparī, who had been very active in construction at the beginning of the reign of her son Ghiyāth al-Dīn Kay-Khusraw II. Not only did Māhparì finish a vast complex at the gate of Kayseri (a mosque and a madrasa with a mausoleum and a bathhouse); she also built at least two caravanserais in Central Anatolia (five more are attributed to her by tradition) (Fig. 6). ${ }^{75}$

Building caravanserais was a typical charity work in the Saljuq lands, and women were among the most prolific patrons, both because they could possess fortunes and because these constructions were "a public demonstration of the ruling family's piety and generosity." 76 But beyond the desire to accommodate travelers and to sustain long-distance trade, Gurji Khātūn was pursuing more personal goals: strengthening her son's chances of becoming the next sultan and therefore her own of becoming "mother of the reigning sultan"

73. The eight words remaining from the foundation inscription of Derebucak Han (south of Beyşehir Lake) are quoted in Redford, "Kırkgöz Hanı," 349.

74. The same formula is also found on what remains of the Derebucak Han and hence is not as unusual as Redford thought (ibid., with reference to Rogers, "Waqf and Patronage," 72).

75. See Eastmond, "Gender and Patronage," 81. Eastmond attributes to Māhparī a further caravenserai, known only through the report of a seventeenth-century French traveler (ibid., n. 27). Interestingly, this traveler speaks of "Aladin, Roy des Selgioukes," which is likely to refer to an inscription in the name of 'Alā' al-Dīn Kay-Qubād I, Māhparī's husband. However, the possibility that it refers to 'Alā' al-Dīn Kay-Qubād II is not to be totally excluded. Besides, Konyalı tentatively attributes the foundation of Kadın Han (620/1223-24), halfway between Konya and Akşehir, to one of the wives of Ghiyāth al-Dīn Kay-Khusraw II. See İ. H. Konyall, Âbideleri ve Kitabeleri ile Konya Tarihi (Konya: Yeni Kitap Basımevi, 1964), 382-86, quoted by Crane, "Notes," 48-49 and Blessing, "Women Patrons," 502 and 522 (see RCEA, inscription no. 3896).

76. D. Fairchild Ruggles, "Women, Patrons," in Medieval Islamic Civilization, ed. J. Meri (New York: Routledge, 2006), 863-5, at 864. On the economic function of the caravanserai, "pious foundations, offering food and lodging free to all comers, or else commercial enterprises," see Rogers, "Royal caravansarays," 410. 
Figure 7: Two Thirteenth-Century Caravanserais
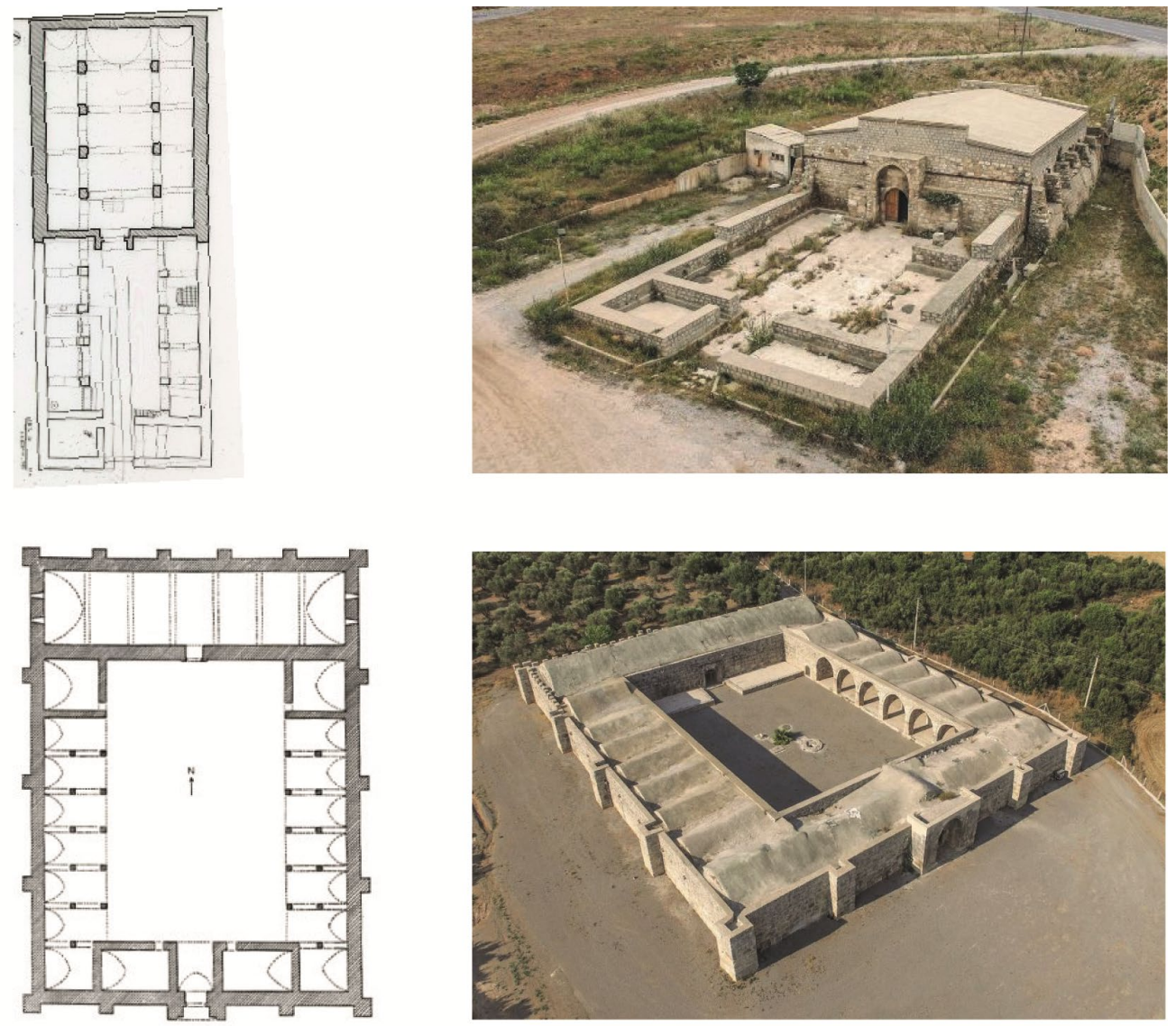

Top: Dokuzun Han (10 km North of Konya); Bottom: Kırkgöz Han (30 km North of Antalya) (Source: Erdmann, Karavansaray, 1, Taffel I, Fig. 4 and Taffel XXX;

Photos from Turkishhan.org)

(wālida, Tk. valide). She knew she was not the sultan's only wife. And she was not even the only khātūn of royal blood: like his father, Ghiyāth al-Dīn Kay-Khusraw II had sought a matrimonial alliance with the Ayyubids, and in 635/1238, the same year he married Tamar alias Gurjī Khātūn, he also married the sister of the ruler of Aleppo. ${ }^{77}$ The marriage would remain childless, but Gurjī Khātūn did not know that. The sultan also married the daughter of one Muẓaffar al-Dīn Muhammad, the ruler of eastern Karahisar. More critically, he had fathered two sons by Greek wives: 'Izz al-Dīn Kay-Kāwūs and Rukn al-Dīn Qiliij Arslan (Fig. 2). According to Āqsarāyī and Simon de Saint-Quentin, both were older than Gurjī Khātūn's son. ${ }^{78}$

77. The marriage is described by the Aleppine Ibn al-'Adìm, who was sent as an envoy to Konya. In exchange, al-Malik al-Nāșir included the name of the Saljuq sultan on his coins and in the sermon of the Friday prayer. Ibn al-'Adīm, Zubdat al-țalab fi ta'rīkh al-Halab, ed. Kh. al-Manșūr (Beirut: Dār al-Kutub al-'Ilmiyya, 1996), 495. See A.-M. Eddé, La principauté ayyoubide d'Alep (579/1183-658/1260) (Stuttgart: Franz Steiner, 1999), 115.

78. Āqsarāyī, Tārīkh, 47; Simon de Saint-Quentin quoted by Cahen, Turquie, 230 n. 8. 
Bar Hebraeus affirms that the sultan was deeply in love with Gurjī Khātūn, to the extent that he neglected the affairs of the state. ${ }^{79}$ A qsarāyi insists, however, that her royal lineage was the decisive factor:

[Ghiyāth al-Dīn Kay-Khusraw] made ['Alā') al-Dīn Kay-Qubād II] his appointed heir (walī 'ahd), because his mother was Gurjī Khātūn, the queen of the Georgians (malaka-yi $A b k h \bar{a} z$ ). It is by virtue of the lineage of her mother that he succeeded over his brothers; moreover, his father loved him more than he did his other children. ${ }^{80}$

The death of the sultan's father had shown that succession was unforeseeable and could quickly become bloody. On that occasion, Ghiyāth al-Dīn Kay-Khusraw II had seized the chance to ascend the throne in Kayseri and immediately got rid of his half-brothers, the

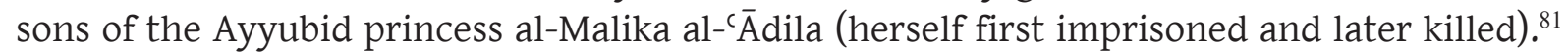
Redford surmises he may have benefited from the help of 'Ișmat al-Dīn bt. Tughrulshāh, the unhappy wife of Kay-Qubād I. In any case, the sultan's accession showed that double royal descent did not guarantee the throne, and this was not good news for Gurjī Khātūn. If even Saladin's niece could be ousted this way, she herself must take better precautions.

By having her son mentioned explicitly as wali-' $a$ hd in her inscription, already with the royal title "sultan of the land and the two seas" and associated with Saljuq regalia (the crown, the flag, and the belt), Gurjī Khātūn aimed to carve in stone the succession to her husband..$^{82}$ The inscription was visible at the beginning of the royal road linking the Mediterranean coast with the capital Konya and, beyond it, with Kayseri and eastern Anatolia. That caravanserais could also serve as royal residences gave further support to her goals, as the inscription would lie in plain view of all the court..$^{83}$ If the sultan of Rum traveled like the sultans in Iran did, his departure from his Antalya would have happened in two stages: first the caravan would have been prepared a few kilometers away from the city, and then it would leave for good. The Düden caravanserai would have been ideally located to serve as the first staging post. That it did so is even more plausible since we have seen that Ibn Bỉbī said that the Saljuq court spent time in the area.

What happened next? If Ibn Bībī is correct (and he was a direct witness to the events), after Ghiyāth al-Dīn Kay-Khusraw II's death, the great amir Jalāl al-Dīn Qarāțāy and the vizier

79. Bar Hebraeus says that "he loved her dearly"; Maktbānūț zabnēe, ed. and trans. E. A. Budge, The Chronography of Gregory Abû'l-Faraj, 2 vols. (London: Oxford University Press, 1932), 2:403. As mentioned in note 55, the Georgian Chronicle reports that the sultan got mad at his wife and forced her to embrace Islam after Rusudan led him to believe she had been unfaithful. Whether this burst of rage should be interpreted as proof of jealous love is debatable. The whole anecdote rather reads like a tale inspired by Ways-u-Rāmin.

80. Āqsarāyī, Tārīkh, 47.

81. Ibn Bībī, Awāmir, 419-20. Cf. Mukhtașar, 212.

82. Rogers ("Royal Caravansarays," 414) discusses insightfully whether the inscriptions of sultanic titles and motto could have "Chancery force".

83. Rogers ("Royal Caravansarays," 406, 411) speaks of caravanserais as "Royal staging places," "Royal lodgings," or "palaces of winterquarters;" Eastmond ("Gender and Patronage," 82) as "royal houses." See also A. Yavuz, "Anatolian Seljuk Caravanserais and their Use as State Houses," 10th International Congress of Turkish Art, 17-23 September 1995, Geneva, ed. F. Déroche et al. 757-65 (Geneve: Fondation Max van Berchem, 1999). 
Shams al-Dīn Ișfahānī agreed to put another son of the late sultan, 'Izz al-Dīn Kay-Kāwūs II, on the throne. He was of Greek ancestry, like Qarāțāy, and his background may have played in his favor in the new strategic configuration (Byzantium was very weak but still existed, while Georgia had been occupied by the Mongols). This must have been a disappointment for the partisans of 'Alä') al-Dīn and his mother. However, the succession was not as bloody as the previous one. The young Prince 'Alā al-Dīn even became associated with the crown, at first in a subaltern position and then as an equal in the unusual "indivis sultanate" that Jalāl al-Dīn Qarātāy imposed in the name of the three brothers. Unfortunately for Gurjī Khātūn, her son died a few years later, during a diplomatic mission to Mongolia. ${ }^{84}$

\section{Function of the Text within the Manuscript}

Finally, we need to consider the function of this text within the munsha'àt. I have described elsewhere the complex assemblage making up MS Mar'ashī $11136 .{ }^{85}$ The only colophon found in the manuscript is dated $716 \mathrm{AH}$, but the first ninety-two folios were written seven decades or so earlier. On the basis of the incipit and the contents of the documents, I hypothesized that the first author/compiler/copyist (I called him "Author A") worked in the chancery of Ghiyāth al-Dīn Kay-Khusraw II, and that he started his work shortly before Kösedağ and resumed it afterward.

The manuscript opens with eleven folios filled with alqāb/khițāb, that is, the various formulas and honorific titles to be used depending on the rank of the addressee. This is a logical start for letter-writing guidelines. This section contains forty-one documents dealing first with officials of the Saljuq state (including the khätūns) and then with a few non-Muslim correspondents the Saljuqs had on their eastern frontier (Mongols, Georgians, Armenians) ${ }^{86}$ Interestingly, addressing the sultan is not discussed. This is understandable if the author, as I surmise, was at the service of the sultan. The following section (fols. 11r-28r) contains thirty-two documents organized thematically (letters of felicitation, condolences, etc.). Then, quite unexpectedly, the author adds nine sample documents-including the Düden inscription-on honorific titles suitable for the sultan (alqāb-i salātīn; fols. 28r-31r). Except for the Düden inscription, these texts are quoted from official correspondence. The reason these documents are not part of the first section on honorifics is not immediately clear, but a closer examination reveals that six out of the nine deal not with the sultan, Ghiyāth al-Dīn Kay-Khusraw II, but with his son, Prince 'Alā' al-Dīn Kay-Qubād II. Hence, it appears that this section was written by someone who was close to the circles favorable to Gurjī Khātūn and keen to portray her son as the future head of the Saljuq dynasty. 'Alä'

84. Gurjī Khātūn managed to keep her position in Konya by marrying Mu'īn al-Dīn Pervaneh (and incidentally by helping Jalāl al-Dīn Rūmī), but this part of her career lies outside the scope of this article (the relevant sources have been translated to French by Brosset and Huart and used by Vryonis and Eastmond in their studies of Gurjī Khātūn). See also the standard study of N. Kaymaz, Pervane Mu'inü'd-din Süleyman, index (Ankara: Ankara Üniversitesi Basımevi, 1970).

85. See Durand-Guédy, "Manba'ī," 80-81; see also idem, "New Source."

86. I expect to publish this alqāb/khițāb section in a future article. The documents dealing with khātūns may have been written for Gurjī Khātūn, but there is nothing to prove it. 
al-Dīn is called the appointed heir (wali 'ahd) in the Düden foundation inscription but also in four other documents in this series.$^{87}$ As a comparandum with the Düden inscription, here is the text of the first document:

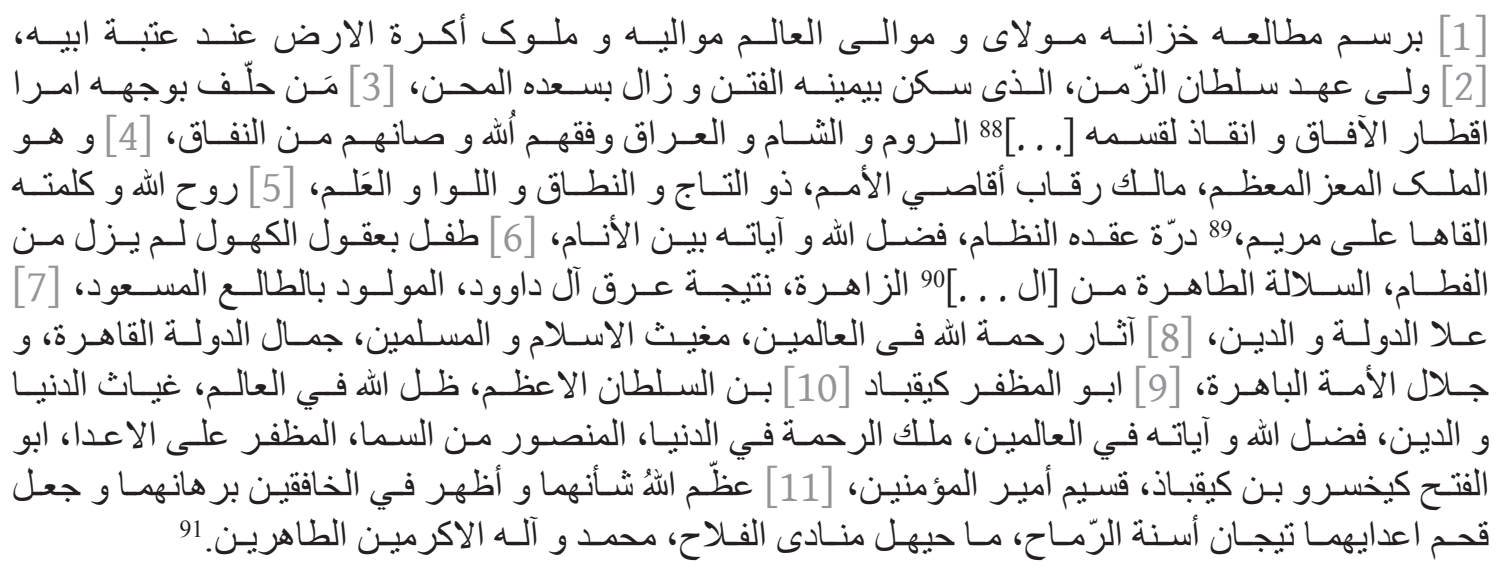

For the transliteration and translation, I have divided the text into eleven units:

[1] According to the study of the archives of my lord-the masters of the world are his slaves (bi-rasm-i muțāli a-yi khazāna-yi mawlāy mawālì al-'ālam mawālīhi); the kings of the ploughmen of the earth are present on the threshold of his father (mulük akarat al-ard 'inda 'atabat abīhi) -

[2] the appointed heir of the sultan of the age, by whose oath conflicts are appeased and by whose fortune hardships disappear (walī-'ahd sulțān al-zaman al-ladhī sukina bi-yaminihi al-fitan wa-zāla bi-sa'dihi al-miḥan),

[3] the one by whose face the amirs of the outlying regions have sworn oaths (man hallafa bi-wajhihi umarā' aqțār al-āfāq), and whom the [lands?] of Rum, Syria, and Iraq, which God gave to him and preserved from costly expenditure, have sworn to obey (wa anqādha li-qasamihi [. . .] al-Rūm al-Shām wa-l-Irāq waffaqahu Allāh wa-șānahum min al-nifāq);

[4] he is the glorious and magnificent prince (wa-huwa al-malik al-mucizz al-mu'az̧am), the master of the necks of the most distant nations (mālik riqāb aqāṣi al-umām), the possessor of the crown, the belt, the flag, and the standard (dhü al-tāj wa-1-nițāq wa-lliwā’ wa-l-'alam).

[5] He is the "spirit from God and His Word cast on Maryam" (rūḥ Allāh wa-kalimatihi

87. 'Alā') al-Dīn Kay-Qubād II is also mentioned as walī 'ahd in other documents included in the manuscript, such as two letters sent from Konya on fols. $37 \mathrm{v}-38 \mathrm{v}$.

88. One word starting with $k \bar{f} f$ has been erased.

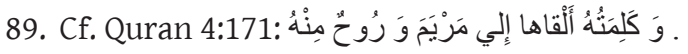

90. One word is not legible.

91. MS Mar'ashī 11136, fol. 28r-v. 
alqāhā 'alā Maryam), ${ }^{92}$ the pearl of His necklace (durrat 'iqdihi al-nizāam), the gift of God and a proof of [God] among all the creatures (faḍl Allāh wa āyātihi bayn al-anām).

[6] He is a child with the understanding of mature men, even though he has not been weaned yet (țifl bi-'uqūl al-kuhūl lam yazal min al-fițām), a pure scion of the shining [missing word] (al-sulāla al-țāhira min al-[. . . al-zāhira), a product of the lineage of the family of David (natījat 'irq âl Dā'ūd), born on an auspicious day (al-mawlüd bi-l-țālic al-mas $\left.{ }^{(} \bar{u} d\right)$,

[7] 'Alā' al-Dawla wa-1-Dīn;

[8] a mark of God's compassion in all worlds (āthār raḥmat Allāh fị al-'ālamīn), succorer of Islam and the Muslims (mughith al-islām wa-1-musliminn), the beauty of the victorious state (jamāl al-dawla al-qāhira), the glory of the shining umma (jalāl al-umma al-bāhira),

[9] Abū al-Muẓaffar Kay-Qubād;

[10] son of the greatest sultan (al-sulțān al-a'zam), the shadow of God on earth (zill Allāh fi al-'ālam), Ghiyāth al-Dunyā wa-l-Dīn, the gift of God and a proof of [God] among all the creatures (faḍl Allāh wa-āyātihi bayn al-anām), the dispenser of mercy in this low world (malik al-raḥma fi al-dunyā), the victorious thanks to heaven (al-manșūr min al-samā'), victorious over the enemies (al-muzaffar 'alā' al-a'dā'), Abū al-Fath Kay-Khusraw b. Kay-Qubād, the partner of the commander of the faithful (qasìm amìr al-mu'minin).

[11] May God enhance the greatness of both of them ('azzama Allāh sha'nahumā); may He make their proofs more visible (azhara fi al-khāfiqayn burhānahumā); may He transform the dangers posed by their enemies into a crown made of spearheads (wa-ja'ala quḥam a'dāyihumā tījān asinnat al-rammaḥ), until the herald says, "Hasten to salvation" (mā ḥayyahal munādī al-falāḥ). ${ }^{93}$

This text exhibits many similarities with, but also notable differences from, the Düden inscription. Right away, 'Alā') al-Dīn Kay-Qubād II is designated as the "appointed heir" (\$2). Multiple references are made to the "oaths" (yamin, qasam, hallafa bi-) binding the great amirs of the sultanate to him $(\S \S 2,3)$. We know that oaths were an essential instrument of what Mottahedeh called the "acquired loyalties" that structured Islamic polities. ${ }^{94}$ It is perhaps because of these oaths that 'Alä' al-Dīn, still a prince (malik), is adorned with title ("master of the necks of the most distant nations") and regalia (crown, belt, flag, standard) given to the sultan in the Düden inscription (\$4).

92. In the Quranic verse 4:171, the preposition following alqā is 'alā, replaced here by ilā. Arberry's translation of this verse reads: "[The Messiah, Jesus son of Mary, was only the Messenger of God], and His Word that he committed to Mary, and a Spirit from Him."

93. This refers to the muezzin's call to prayer (adhān): ḥayya 'alā al-ṣalā wa-ḥayya 'alā al-falāh .

94. R. Mottahedeh, Loyalty and Leadership in an Early Islamic Society, 2nd rev. ed. (New York: I. B. Tauris, 2001), 40-60. 
The following section emphasizes the divine favor enjoyed by the prince. He is not only a "sign of God"; 95 he is the "Spirit of God" (rüh Allāh) and the "Word of God," two expressions from a Quranic verse about Jesus (\$5). This may or may not be a reference to the prince's Christian mother. (The reference to Maryam should not be interpreted as a marker of Christianity, as she is the most venerated female figure in the Quran.) The next sentences provide additional credentials: he may be a child, but he has "the understanding of mature men"; and thanks to his mother, the royal blood of David's house ('irq âl Dầu $\bar{d}$ ) flows through his veins (\$6).

His main laqab, 'Alā̄' al-Dīn (§7), is followed by four others (§8), then a generic kunyā, his ism (\$9), and finally his nasab (son of al-sulțān al-a 'zam Ghiyāth al-Dīn Kay-Khusraw, whose list of titles ends with the usual "partner of the commander of the faithful," §10). We can note that two of the sultan's titles emphasize his victories; ${ }^{96}$ two others (fadll Allāh wa-āyātihi bayn al-anām and malik al-raḥma fi al-dunyā) do not appear in any of the foundation inscriptions (see Tables $1-3)$. The concluding sentences are prayers $(d u(\bar{a})$, one of them explicitly referring to the "dangers" awaiting the Saljuqs (quham, sg. quhma).

No date is given, but since 'Alā') al-Dīn Kay-Qubād II is described as a child not yet weaned (\$6), the text was probably composed around 636/1238-39. But the message is clear: the text describes the prince as the rightful heir, appointed by his father, product of the union of two dynasties, recognized by all the amirs, already invested with Saljuq regalia, and intellectually competent to assume royal power. It is this kind of text that led me to surmise that Author A worked in the chancery of Konya, in the circles advocating the rights of Gurji Khātūn's son. The formula chosen for the Düden caravanserai, though shorter, is perfectly in line with this program.

There are other instances of a "Georgian connection" in this part of the munsha'at. For example, the malik Abkhāz (meaning the Georgian king) is one of the few non-Muslim rulers to be dealt with in the alqāb/khitāa section. Author A also included an interesting oath (sawgand-nāma) sent by Saladin to the king of Georgia. The document, in Persian, is attributed to the famous kātib 'Imād al-Dīn al-Ișfahānī and begins with the words "In the name of the father, the son, and the holy spirit, of God the Unique ..." (fols. 27v-28r). Further on, the same Author A has copied three answers to the King Dā' $\bar{u} d$ of Georgia, obviously David V Narin, who happened to be Gurjī Khātūn's brother. By contrast, the manuscript contains no correspondence from Konya toward Byzantium or the Ayyubid states.

The Düden inscription tells us something more. In Victory Inscribed, their detailed study of the long Saljuq inscriptions on the walls of Antalya, Leiser and Redford address the issue of authorship. Following the hypothesis of van Berchem, they argue that the

95. With about four hundred occurrences, āya (pl. āyāt) is one the most ubiquitous terms in the Quran; see Encyclopaedia of the Qur’ān, 5:2.

96. The title "beauty of the victorious state" would have rung hollow after the devastating defeat at Kösedağ, but it might have been an instance of wishful thinking. And Ibn Bỉbi recalls that the vizier sent to negotiate with the Mongols told their general that the bulk of the Saljuq army was still ready to fight. 
inscriptions had been written by members of the Saljuq chancery ${ }^{97}$ The argument is logical: only the secretaries (kātibs) of the chancery (diwān al-inshā') would have had not only the necessary linguistic skills but also the expertise to choose the right honorific titles and the right words. A qādī would have known the former, but not the latter. In his later article on Kırkgöz Han, Redford takes up the same argument: "We can hypothesize that the texts of lapidary inscriptions derived indirectly from the Seljuk chancery, through the mediation of the Persianate administrative class of the Anatolian Seljuks, specifically those attached to the retinues of the patrons of those buildings." 98

With the evidence available to him, Redford could make only a strong case for his "chancery hypothesis." MS Mar'ashī 11136, with the Düden inscription, provides what we might call the "smoking gun." The inclusion of a foundation inscription within a munsha'att seems less incongruous if we surmise that the inscription had been drafted by the author of the munsha'àt himself. Of course, in the absence of epigraphic remains, we cannot say whether the text found in the manuscript had really been carved in full on the caravanserai's portal (it is unusually long). In 1976, Rogers argued that since the Saljuq chancery operated in Persian, it could have only "indirect" control over foundation inscriptions, which were invariably in Arabic. ${ }^{99}$ However, this argument is not tenable, as we know that the Anatolian chancery was in fact multilingual, issuing documents in Arabic, Persian, Greek, and possibly Armenian. Indeed, the Antalya inscription published by Redford in Legends of Authority is clearly an Arabic product of the Saljuq chancery. ${ }^{100}$ Besides, seventh/thirteenth-century Persian prose was phagocytized by Arabic words and expressions (the chronicles of 'Atâa' Malik Juwaynī and Ibn Bībī, two Khurasanians working in the Ilkhanid administration, are emblematic of this evolution). The recourse to formulaic sentences and the concision of the text meant that the kātib, whoever he was, had an easy job. ${ }^{101}$

The high likelihood of the "chancery hypothesis" is even more obvious when we compare the Düden inscription with those of the nearby and contemporary Kirkgöz Han (and Derebucak Han). The similarities in the sentences they have in common are striking. The only differences concern one title (durrat tāj al-duwal), the date, and a handful of variants. On that account, the readings of some words in the Kırkgöz Han inscription might

97. Leiser and Redford, Victory Inscribed, 116-17. See M. Van Berchem, Matériaux pour un Corpus Inscriptionum Arabicarum. Première partie - Égypte, tome premier, Paris: Ernest Leroux, 1893-1903, 553 (quoted by Rogers, "Waqf and Patronage," 71). The article of Rogers, "Royal caransarays", also investigates "some parallelism in Saljuq epigraphy between certain inscriptions and chancery formula", but he emphasizes the role of the qadi (p. 431).

98. Redford, “Kırkgöz Hanı," 352.

99. Rogers, "Waqf and Patronage," 71.

100. S. Redford, Legends of Authority: The 1215 Seljuk Inscriptions of Sinop Citadel, Turkey (Istanbul: Koç University Press, 2014).

101. I do not imply that chancery staff were involved in all the inscriptions found in Anatolia; the case of waqf inscriptions, recently surveyed by Peacock, is of course different, as they often constitute abstracts of legalized paper waqfiyyas written by the qāḍi, occasionally even complete with witnessed signatures. See A. C. S. Peacock, "Waqf Inscriptions from Medieval Anatolia," in Philanthropy in Anatolia through the Ages, ed. O. Tekin, C. Roosevelt, and E. Akyürek, 183-93 (Istanbul: Koç University Press, 2020). 
be emended. I have already mentioned națaq (recte nițāq?), but the same may also apply to other words (certainly to mus'ala/musbala, and probably to mu'ayyada/mu'abbada). ${ }^{102}$ The wordings of the two inscriptions are so close they can be published as two versions of the same text. If the Kırkgöz Han inscription is chosen as the master copy, it would look as follows (the $40 \%$ of text added in Düden appears between brackets):

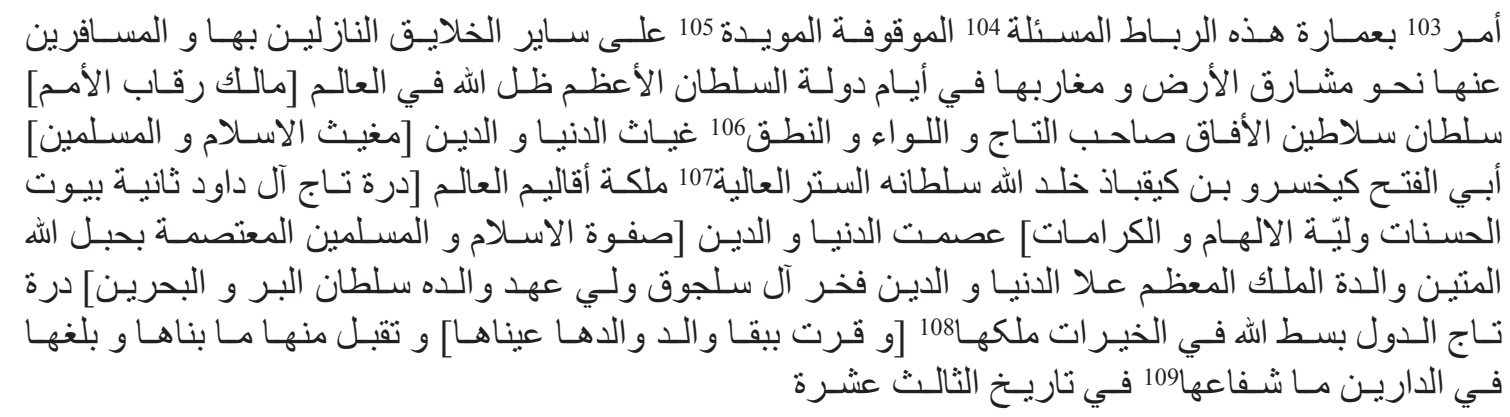

If Kırkgöz Han was built after Kösedağ, as Redford is inclined to think on the basis of its plain decoration, its inscription could therefore have been copied (with minor modifications) from Düden Han's.

How can we be sure that the caravanserai of Gurjī Khātūn was indeed built? The question needs to be asked because the only evidence we have of its existence is an inscription in a munsha'āt. Redford notes that caravanserais "were larger and more impressive than any Seljuq palace that we know, and most mosques as well," and I am not aware of the remains of a caravanserai on the Düden River. ${ }^{110}$ Besides, we know that some munsha'at with didactic ambitions included mock documents composed by the authors themselves. However, I believe it is highly likely that the caravanserai existed. Our inscription does not belong to the category of mock documents: not only can the various protagonists be easily identified, but the inscription was copied in the 1240s into a work almost certainly dedicated to Ghiyāth al-Dīn Kay-Khusraw II. Referring explicitly to the caravanserai of Düden if there was in fact no caravanserai there would have made no sense. And it would have defeated the purpose, since the goal of this text, was to enhance the legitimacy of 'Alä' al-Dīn Kay-Qubād II.

102. Musbala is clearly readable in the manuscript. Redford (Legends of Authority, 352), who suggested mus'ala, admitted he does not know of other parallels for that word in Anatolian Saljuq epigraphy.

103. Düden: أمرت.

104. Recte المسبلة: الدرنة; cf. Düden.

105. Düden: الموبدة.

106. Recte النطاق; cf. Düden.

107. Düden: الغالية.

108. Var. Düden: يداها.

109. Var. Düden: أبتغها.

110. Redford, "Urbs in Rure," 48. 


\section{Conclusion}

The manuscript Mar'ashī 11136 reveals a hitherto unknown caravanserai built in Anatolia during the Saljuq period. There were perhaps hundreds of them. ${ }^{111}$ New vestiges continue to be discovered. ${ }^{112}$ But few are documented by foundation inscriptions, and none of the known inscriptions are as long as this one. The text informs us of the ambitions of the patron, the Georgian wife of Ghiyāth al-Dīn Kay-Khusraw II. It proves that she was indeed active as a patron of architecture during the lifetime of the sultan. It confirms the existence of a cluster of "Saljuq sub-sultanic patronage" (in Redford's phrase) in the region of Antalya during the reign of this sultan. Incidentally, it allows us to reassess some of the previous readings of inscriptions in the same region. And it confirms the account of the late chronicler Āqsarāyī according to which the son of Gurjī Khātūn was appointed walī 'ahd. Ibn Bỉbī, who was a direct witness to the events, says nothing about her and not much about her son, probably on purpose, since Gurjī Khātūn's grand plan was foiled at the death of the sultan and she never became an omnipotent queen mother (although she kept her influence through other means). ${ }^{113}$ Finally, this source gives a fascinating insight into a subject long of interest to historians of Islam and art historians: the relationships among inscriptions, those who compose them, and those who chisel them onto stone tablets and fit them into architectural spaces. It proves that some foundation inscriptions were drafted by personnel of the dīwān al-inshā'. These are remarkable results for a few lines that had long waited to be read in a library in Qum.

111. According to Yavuz, up to two hundred caravanserais were built in Anatolia during the Saljuq period. But Erdmann (quoted by Elisséeff, "Khān," 1011) speaks of 119 khans built in the seventh/thirteenth century in southwest Asia. He himself cataloged ninety-eight such buildings West of Sivas.

112. A Saljuq caravanserai has been recently identified at Seyitgazi, south of Eskişehir; see Redford, "Urbs in Rure," 49 n. 12.

113. Redford ("Paper, Stone, Scissors," 165) commented in detail on the treatment of 'Ișmat Khātūn, the wife of 'Alā' al-Dīn Kay-Qubād I, by Ibn Bībī and speculated that he refrained deliberately from mentioning her. 


\section{Appendix: Honorific Titles Given to Ghiyāth al-Dīn Kay-Khusraw II in Inscriptions}

\begin{tabular}{|c|c|c|}
\hline Item & Title & Translation \\
\hline 1. & al-sulțān al-a'zāàm & the greatest sultan \\
\hline 2. & shāhanshāh al-mu'aẓ̌am & the magnificent king of kings \\
\hline 3. & mālik riqāb al-umām & the master of the necks of the nations \\
\hline 4. & sayyid salātīin al-'arab wa-1-'`ajam & lord of the sultans of the Arabs and the Persians \\
\hline 5. & sulțān al-barr wa-1-bahrayn & sultan of the land and the two seas \\
\hline 6. & dhū al-qarnayn al-zamān & the Dhū al-Qarnayn of the age \\
\hline 7. & șāḥib Khusraw al-cādil & the just lord Khusraw \\
\hline 8. & Iskandar al-thānī & the second Alexander \\
\hline 9. & sulțān al-salātịn al-cālam & sultan of the sultans of the world \\
\hline 10. & al-mu’ayyad min al-samā' & the one assisted by heaven \\
\hline 11. & al-muẓaffar 'alā [al-a'dā'] & the victorious over [the enemies] \\
\hline 12. & qāhir al-kafara wa-1-mushrikīn & the conqueror of the infidels and the polytheists \\
\hline 13. & qāmi` al-zanādiqa wa-1-mutammaridīn & the suppressor of the atheists and the rebels \\
\hline 14. & qātti`al-khawārij wa-l-bāghiyyin & $\begin{array}{l}\text { the crusher of whose who revolt and transgress } \\
\text { against the law }\end{array}$ \\
\hline 15. & 'umdat al-haqq & the upholder of the truth \\
\hline 16. & 'uddat al-khalq & the viaticum of mankind \\
\hline 17. & muTin khalīfat Allāh & the aide of the caliph of God \\
\hline 18. & mughīth khalīfat Allāh & the helper of the caliph of God \\
\hline 19. & $\begin{array}{l}\text { sulțān bilād al-Rūm wa-l-Armān wa-1- } \\
\text { Shām wa-Diyār Bakr wa-l-Ifranj }\end{array}$ & $\begin{array}{l}\text { sultan of the lands of Rum, Armenia, Syria, Diyār Bakr, } \\
\text { and the Franks }\end{array}$ \\
\hline 20. & tāj āl-i Saljūq & the crown of the Saljuq family \\
\hline 21. & qasìm amïr al-mu'minīn & the partner of the commander of the faithful \\
\hline 22. & zill Allāh fi al-cālam & shadow of God on earth \\
\hline 23. & marzbān al-āfāq & margrave of the horizons \\
\hline 24. & 'alā' al-islām wa-l-muslimīn & the elevation of Islam and the Muslims \\
\hline 25. & șāhib al-tāj wa-l-li wā’ wa-1-nițāq & possessor of the crown and the banner and the belt \\
\hline
\end{tabular}

The numeration of these 25 items is used in Tables 1, 2, 3 for the denomination of the sultan. The other abbreviations used in the Tables are:
AbF: Abū al-Fațh
KQ: Kay-Qubād
GhD: Ghiyāth al-Dīn
KKh: Kay-Khusraw
'IzD: 'Izz al-Dīn
Mas: $\operatorname{Mas}^{\top} \bar{u} d$
KK: Kay-Kāwūs
QA: Qïzil Arslan 


\section{List of Figures}

Fig. 1. The Saljuq Sultanate and the Neighboring Powers before Kösedağ (641/1243) (Date of Capture inside Frame)

Fig. 2. Genealogical Tree of the Rum Saljuqs in the Seventh/Thirteenth Century (Spouses Noted in Italics)

Fig. 3. Text of the Inscription in MS Mar'ashī 11136

Fig. 4. The Bagratids of Georgia in the Thirteenth Century

Fig. 5. Antalya and Its Hinterland (Base Map: Google Earth)

Fig. 6. Women's Patronage in Rum Anatolia (1232-45) (Free Vector Form from Vecteezy.com)

Fig. 7. Two Thirteenth-Century Caravanserais. (Maps from Erdmann, Karavansaray, 1, Taffel I, Fig. 4 and Taffel xxx; photos from Turkishhan.org).

\section{List of Tables}

Table 1. Denominations in Foundation Inscriptions by Women Patrons

Table 2. Denominations in Foundation Inscriptions by Male Patrons during the Sultanate of Ghiyāth al-Dīn Kay-Khusraw II

Table 3. Denominations of Ghiyāth al-Dīn Kay-Khusraw II in Buildings He Commissioned 


\section{Bibliography}

Aflākī ‘Ārifî. Manāqib al-`ārifin. Edited by T. Yazici. Corrections and additions by T. Subhān̄ī. Tehran: Dūstān, 1396sh. [2017]. Translated by C. Huart as Les saints des derviches tourneurs. 2 vols. Paris: Ernest Leroux, 1918-22.

Amīr Mu'izzì. Dīwān. Edited by `A. Iqbāl. Tehran: Kitābfurūshī-yi Islāmiyya, 1318sh.

Āqsarā̄ì, Maḥmūd b. Muḥammad. Tārīkh-i Salājaqa yā Musāmirat al-akhbār. Edited by O. Turan as Müsâmeret ül-ahbâr, Mogollar zamininda Türkiye Selçukluları Tarihi. Ankara: Türk Tarih Kurumu Basımevi, 1944.

Bar Hebraeus. Maktbānūt zabnē. Edited and translated by E. A. Budge as The Chronography of Gregory Abû'l-Faraj. 2 vols. London: Oxford University Press, 1932.

Baran, T., Y. Dalkiliç, and Ü. Öziş. "Antalya-Düden Havzasi Su Kaynaklarinin Geliştirilmesi.” In Antalya Yöresinin Inşaat Mühendisliği Sorunları Kongresi, 2:52-60. Antalya: İnşaat Mühendisleri Odası Antalya Şubesi, 2005.

Bates, Ü. U. "Women as Patrons of Architecture in Turkey." In Women in the Muslim World, edited by L. Beck and N. Keddie, 245-60. Cambridge, MA: Harvard University Press, 1978.

Blessing, P. "Women Patrons in Medieval Anatolia and a Discussion of Māhbarī Khātūn's Mosque Complex in Kayseri." Belleten 78 (2014): 475-526.

Bosworth, C. E. "Al-Kabạ, 1.-3.” In Encyclopaedia of Islam, 2nd ed., 4: 341-50. Leiden: Brill, 1978.

-_-. "The Titulature of the Early Ghaznavids." Oriens 15, no. 1 (1962): 210-33.

-- - The New Islamic Dynasties: A Chronological and Genealogical Manual. Edinburgh: Edinburgh University Press, 1996.

Cahen, C. La Turquie pré-ottomane. Istanbul: Institut français d'études anatoliennes, 1988.

Canard, M. “Les reines de Géorgie dans l'histoire et la légende musulmane." Revue des études islamiques 37 (1969): 3-20.

Chabbi, J. "Ribāț. 1. History and Development of the Institution." In Encyclopaedia of Islam, 2nd ed., 8:493-506. Leiden: Brill, 1995.

Constantine Porphyrogenitus. De Administrando Imperio. Edited by G. Moravcsik. Translated by R. J. H. Jenkins. Washington, DC: Dumbarton Oaks Center for Byzantine Studies, 1949. Reprint, 2008.

Crane, H. "Notes on Saldjūq Architectural Patronage in Thirteenth Century Anatolia." Journal of the Economic and Social History of the Orient 36 (1993): 1-57. 
De Nicola, B. "The Ladies of Rūm: A Hagiographic View of Women in Thirteenth- and Fourteenth-Century Anatolia." Journal of Sufi Studies 3, no. 2 (2014): 132-56.

-- . Women in Mongol Iran: The Khatuns, 1206-1335. Edinburgh: Edinburgh_University Press, 2017.

Durand-Guédy, D. "Manba'ī-yi muhim dar bāra-yi Saljūqiyān-i Rūm wa dabīr-khāna-yi fārsī-yi ān-hā: Nuskha-yi khatțī-yi Kitābkhāna-yi Āyat Allāh Mar'ashī, shumāra 11136." Mìrāth-i Shahāb 100 (tābistān 1399 sh. [2020]): 63-84.

--C. "A New Source on the Saljuqs of Rum and Their Persian Chancery: Manuscript 11136 of the Mar'ashī Library (Qum).” Der Islam (forthcoming, 2022).

Eastmond, A. "Art and Frontiers between Byzantium and the Caucasus." In Byzantium: Faith and Power (1261-1557); Perspectives on Late Byzantine Art and Culture, edited by S. T. Brooks, 154-69. New York: Metropolitan Museum of Art, 2007.

---. "Gender and Patronage between Christianity and Islam in the Thirteenth Century." In Change in the Byzantine World in the Twelfth and Thirteenth Centuries, edited by A. Ödekan, E. Akyürek and N. Necipoğlu, 78-88. Istanbul: Vehbi Koç Vakfi, 2010.

Eddé, A.-M. La principauté ayyoubide d'Alep (579/1183-658/1260). Stuttgart: Franz Steiner, 1999.

Elisséeff, N. “Khān.” In Encyclopaedia of Islam, 2nd ed., 4:1010-17. Leiden: Brill, 1978.

Erdmann, K. Das anatolische Karavansaray des 13. Jahrhunderts. Vol. 1. Berlin: Gebrüder Mann, 1961.

- - - and H. Erdmann. Das anatolische Karavansaray des 13. Jahrhunderts. Vols. 2 and 3. Berlin: Gebrüder Mann, 1976.

Fairchild Ruggles, D, ed. Women, Patronage, and Self-Representation in Islamic Societies. Albany: State University of New York Press, 2000.

-_-. "Women, Patrons." In Medieval Islamic Civilization, ed. J. Meri, 863-865. New York: Routledge, 2006.

-- - The Extraordinary Architectural Patronage of the 13th-Century Egyptian Slave-Queen Shajar al-Durr. Oxford: Oxford University Press, 2020.

Georgian Chronicle $=$ Kartlis Tskhovreba (K'art'lis C'Xovreba). Translated by M. F. Brosset as Histoire de la Géorgie depuis l'antiquité jusqu'au XIX siècle, part 1: Histoire ancienne, jusqu'en 1469 de J.-C. Saint Petersburg: Imprimerie de l'académie impériale des sciences, 1849.

Hillenbrand, C. The Crusades: Islamic Perspectives. New York: Routledge, 2000. 
Hillenbrand, R. Islamic Architecture: Form, Function, Meaning. Edinburgh: Edinburgh University Press, 1994.

Ibn al-'Adīm. Zubdat al-țalab fi ta'rīkh al-Halab. Edited by Kh. al-Manșūr. Beirut: Dār al-Kutub al-'Ilmiyya, 1996.

Ibn Bībī. Al-Awāmir al-'Alā'iyya fì al-umūr al-'alā'iyya. Edited by Zh. Mutaḥịidīn. Tehran: Pazhūhishgāh-i 'Ulūm-i Insānī wa Muṭāli'āt-i Farhangī, 1390sh. [2011].

--C. Al-mukhtașar Saljūq-nāma-yi Ibn Bībī [abridgment]. Edited by M. T. Houtsma in Recueil de textes relatifs à l'histoire des Seldjoucides, vol. 3: Histoire des Seldjoucides d'Asie mineure, d'après Ibn Bîbî. Leiden: Brill, 1902.

Kaymaz, N. Anadolu Selçuklu Sultanlarından II. Giyâsu'd-dân Keyhusrev ve Devri. Ankara: Türk Tarih Kurumu Basımevi, 1958.

-_-. Pervane Mu'inü'd-din Süleyman. Ankara: Ankara Üniversitesi Basımevi, 1970.

Konyalı, İ. H. Âbideleri ve Kitabeleri ile Konya Tarihi. Konya: Yeni Kitap Basımevi, 1964.

La Vaissière, E. de. "Le Ribāt d'Asie centrale." In Islamisation de l'Asie centrale: Processus locaux d'acculturation du VII e au XI siècle, edited by E. de La Vaissière, 71-94. Paris: Association pour l'avancement des études iraniennes, 2008.

Leiser, G. "Observations on the 'Lion and Sun' Coinage of Ghiyath al-Din Kai-Khusraw II." Mesogeios 2 (1998): 96-114.

-- - and S. Redford. Victory Inscribed:The Seljuk Fetihname on the Citadel Walls of Antalya, Turkey. Istanbul: AKMED, 2008.

Miquel, A. La géographie humaine du monde musulman (jusqu'au milieu du $11^{e}$ siècle), vol. 4: Les travaux et les jours. Paris: EHESS, 1988.

Mottahedeh, R. Loyalty and Leadership in an Early Islamic Society. 2nd rev. ed. New York: I. B. Tauris, 2001.

Muḥammad Munshī Nakhjawānī. Dastūr al-kātib fị ta'yīn al-marātib. Edited by 'A. A. Ahmmadī Dārānī. 2 vols. Tehran: Mīrāth-i Maktūb, 1395sh. [2016].

Peacock, A. C. S. "Georgia and the Anatolian Turks in the 12th and 13th Centuries." Anatolian Studies 56 (2006): 127-46.

-- . "Waqf Inscriptions from Medieval Anatolia." In Philanthropy in Anatolia through the Ages, edited by O. Tekin, C. Roosevelt, and E. Akyürek, 183-93. Istanbul: Koç University Press, 2020.

Picard, C. and Borrut, A. "Râbata, ribât, râbita: Une institution à reconsidérer." In Chrétiens et musulmans en Méditerranée médiévale (VIII ${ }^{e}-X I I I^{e}$ s.): Échanges et contacts, edited 
by P. Sénac and N. Prouteau, 33-65. Poitiers: Centre d'études supérieures de civilisation médiévale, 2003.

Rapp, S., Jr. "Sumbat Davit'is-dze and the Vocabulary of Political Authority in the Era of Georgian Unification.” Journal of the American Oriental Society 120, no. 4 (2000): 570-76.

$R C E A=$ Répertoire chronologique d'épigraphie arabe. Edited by E. Combe, J. Sauvaget, and G. Wiet. 18 vols. Cairo: IFAO, 1931-91.

Redford, S. "The Inscription of the Kırkgöz Hanı and the Problem of Textual Transmission in Seljuk Anatolia." Adalya 12 (2009): 347-59.

--C. "Paper, Stone, Scissors: 'Ismat al-Dunya wa'l-Din, 'Ala' al-Din Kayqubadh, and the Writing of Seljuk History." In The Seljuks of Anatolia: Court and Society in the Medieval Middle East, edited by A. C. S. Peacock and S. N. Yildiz, 151-70. London: I. B. Tauris, 2012.

-- . Legends of Authority: The 1215 Seljuk Inscriptions of Sinop Citadel, Turkey. Istanbul: Koç University Press, 2014.

. "Flags of the Seljuk Sultanate of Anatolia: Visual and Textual Evidence." In The Hidden Life of Textiles in the Medieval and Early Modern Mediterranean: Contexts and CrossCultural Encounters in the Islamic, Latinate and Eastern Christian Worlds, edited by N. Vryzidis, 67-82. Turnhout: Brepols, 2020.

-_-. "Rum Seljuq Caravanserais: Urbs in Rure." In The Seljuqs and Their Successors: Art, Culture and History, edited by S. Canby, D. Beyazit, and M. Rugiadi, 35-50. Edinburgh: Edinburgh University Press, 2020.

Richter-Bernburg, L. "Amīr-Malik-Shāhānshāh: 'Aḍud ad-Daula's Titulature Reexamined." Iran 18 (1980): 83-102.

Rogers, J. M. "Waqf and Patronage in Seljuk Anatolia: The Epigraphic Evidence." Anatolian Studies 26 (1976): 69-103.

-_-. "Royal Caravansarays and Royal Inscriptions in Seljuk Anatolia." Atatürk Üniversitesi Edebiyat Fakültesi Araştırma Dergisi - In Memoriam Prof. Albert Louis Gabriel 9 (1978): 397-431.

Shukurov, R. "Harem Christianity: The Byzantine Identity of Seljuk Princes." In The Seljuks of Anatolia: Court and Society in the Medieval Middle East, edited by A. C. S. Peacock and S. N. Yildiz, 115-50. London: I. B. Tauris, 2012.

Simon de Saint-Quentin. Histoire des Tartares. Edited by J. Richard. Paris: Geuthner, 1965.

Turan, O. "Les souverains seldjoukides et leurs sujets non-musulmans." Studia Islamica, 1 (1953): 65-100. 
-_- Selçuklular Zamanında Türkiye: Siyasi Tarih Alp Arslan'dan Osman Gazi'ye (10711328). 6th ed. Istanbul: Ötüken, 2004 (1st ed. 1971).

-_-. "Keyhusrev II." In Íslam Ansiklopedisi, 6:620-29. Translated by G. Leiser as “Kaykhusraw II Ghiyath al-Din." Journal of the Pakistan Historical Society 33 (1985): 81-107.

Uyar, T. "Thirteenth-century 'Byzantine' art in Cappadocia and the question of the Greek painters at the Seljuq Court." In Islam and Christianity in Medieval Anatolia, edited by A.C.S. Peacock, B. De Nicola and S. Nur Yildiz, 215-231. Burlington, VT; Surrey, UK: Ashgate, 2015.

Uzunçarsılı, İ. H. Osmanlı Devleti Teşkilâtına Medhal. Istanbul: Maarif Matbaası, 1941.

Van Berchem, M. Matériaux pour un Corpus Inscriptionum Arabicarum. Première partie Égypte, tome premier. Paris: Ernest Leroux, 1893-1903.

Vryonis, S., Jr. "Another Note on the Inscription of the Church of St. George of Belisirma." Byzantina 9 (1977): 9-22.

-- - The Decline of Medieval Hellenism in Asia Minor and the Process of Islamization from the Eleventh through the Fifteenth Century. Berkeley: University of California Press, 1971.

Watenpaugh, H. Z. "Art and Architecture." In Encyclopedia of Women \& Islamic Cultures, edited by S. Joseph. Online ed. Leiden: Brill, 2014. http://dx.doi.org/10.1163/1872-5309_ ewic_COM_00004 (accessed April 4, 2021).

Wolper, E.S. "Princess Safwat al-Dunyā wa al-Dīn and the Production of Sufi Buildings and Hagiographies in Pre-Ottoman Anatolia." In Women, Patronage, and Self-Representation in Islamic Societies, edited by D. Fairchild Ruggles. 35-52. Albany, NY: State University of New York Press.

Yalman, S. "The 'Dual Identity' of Mahperi Khatun: Piety, Patronage and Marriage across Frontiers in Seljuk Anatolia." In Architecture and Landscape in Medieval Anatolia, 1100-1500, edited by P. Blessing and R. Goshgarian, 224-52. Edinburgh: Edinburgh University Press, 2017.

Yavuz, A. T. "The Concepts that Shape Anatolian Seljuq Caravanserais.” Muqarnas 14 (1997): 80-95.

- "Anatolian Seljuk Caravanserais and their Use as State Houses." In 10th International Congress of Turkish Art, 17-23 September 1995, Geneva, edited by in F. Déroche, C. Geneguard, G. Renda and J.M. Rogers, 757-65. Geneve: Fondation Max van Berchem, 1999. 


\title{
Mariun: An Exiled Queen's Pilgrimage and Death in Jerusalem*
}

\author{
GOHAR GRIGORYAN SAVARY \\ University of Fribourg (Switzerland)
}

(gohar.grigoryan@unifr.ch)

\begin{abstract}
Upon the Mamluk takeover of Sis in 1375 CE, the former Queen Mariun of the Armenian state of Cilicia was taken into captivity and held first in Aleppo and then in Cairo. From there she traveled to Jerusalem, where she lived until her death. Her tomb at the Sts. James Monastery in Jerusalem is often mentioned in medieval and postmedieval texts, but the information in later historiography concerning Mariun and some of her contemporaries who survived the fall of the Armenian kingdom and lived through the fourteenth century has been subject to inaccuracies. This article considers some of these accretions and misrepresentations using textual and archaeological documentation, and reconstructs several key episodes in the life and afterlife of Mariun. The story of this remarkable noblewoman crosses the political realms of at least three Mediterranean communities-Armenian, Mamluk, and Latin-and reflects the scope of the ever-changing geopolitical complexities that continued to mark the eastern Mediterranean under Mamluk domination. Spending the final stages of her life in exile and on pilgrimage, the former queen of Armenia appeared in the Holy City at a time when female spirituality was flourishing within self-organized monastic institutions.
\end{abstract}

$\mathrm{T}$

he Empress Helena's journey to the Holy Land and her vast constructions in fourth-century Jerusalem gave rise to her archetypal image as a royal pilgrim and formed the tradition of Christian aristocratic pilgrimage, which inspired noblewomen in particular. ${ }^{1}$ The Crusades to the Holy Land seem to have given birth to various devotional

* Research for this article was carried out in the framework of the project "Royal Epiphanies: The King's Body as Image and Its Mise-en-scène in the Medieval Mediterranean (12th-14th Centuries)," funded by the Swiss National Science Foundation (project no. 173045, University of Fribourg, Switzerland). I thank the Armenian Patriarchate of Jerusalem and the Mekhitarist Congregation of Venice for providing me with access to their manuscript collections. Throughout this essay, Armenian letters are transliterated according to the Hübschmann-Meillet-Benveniste system. To indicate the collections of Armenian manuscripts, I follow Bernard Coulie's system of acronyms in his Répertoire des manuscrits arméniens / Liste des sigles utilisés pour désigner

(c) 2021 Gohar Grigoryan Savary. This is an open access article distributed under the terms of the Creative Commons Attribution-NonCommercialNoDerivatives License, which allows users to copy and distribute the material in any medium or format in unadapted form only, for noncommercial purposes only, and only so long as attribution is given to the original authors and source. 
and ascetic exercises among women, and these resulted in a significant number of female pilgrims. In the thirteenth and fourteenth centuries, Jerusalem saw the establishment of religious organizations and special hospices designated for female pilgrims and travelers; secular women, for example, who stayed at the so-called saeculum, had now more freedom to exercise their spirituality in these self-organized institutions. ${ }^{2}$ The continuous wave of late medieval pilgrims included several European queens and noblewomen, who showed a particular devotion to the Virgin Mary and Mary Magdalene. ${ }^{3}$ Two well-documented pilgrimages, by (Saint) Bridget of Sweden (1372/73) and Margery Kempe from England (1413), have enjoyed a great deal of attention in Western scholarship. ${ }^{4}$ Shortly before these

les manuscripts (Association internationale des études arméniennes): $\mathrm{M}=$ Yerevan, Matenadaran Institute of Ancient Manuscripts; J = Jerusalem, Armenian Patriarchate; V = Venice, Library of the Mekhitarists; W = Vienna, Library of the Mekhitarists; and LOB = London, British Library. Additionally, in order to facilitate the readers' use of the present article, two different numbers are mentioned for Venice manuscripts. In V1318/923, for example, the first number (1318) indicates the manuscript's inventory number, while the second one is the manuscript's consecutive number (923) in the published catalogue.

1. K. G. Holum, "Hadrian and St. Helena: Imperial Travel and the Origins of Christian Holy Land Pilgrimage," in The Blessings of Pilgrimage, ed. R. Ousterhout, 66-81 (Urbana: University of Illinois Press, 1990). Holum argues also that the concept of Christian pilgrimage in general came into being with Empress Helena. On this, see also Holum's abstract "Imperial Travelers and the Origins of Christian Pilgrimage," in Tenth Annual Byzantine Studies Conference, November 1-4, 1984, Cincinnati: Abstracts of Papers, 1-2 (Washington: Dumbarton Oaks, 1984).

2. S. Schein, "Bridget of Sweden, Margery Kempe and Women's Jerusalem Pilgrimage in the Middle Ages," Mediterranean Historical Review 14 (1999): 44-58, at 45-49, esp. 49. See also S. Schein, "Latin Hospices in Jerusalem in the Late Middle Ages," Zeitschrift des deutschen Palästina-Vereins 101, no. 1 (1985): 82-92, esp. 91.

3. Schein, "Bridget of Sweden," 53-54; O. Limor, "Jerusalem," in Europe: A Literary History 1348-1418, ed. D. Wallace, 2:217-43 (Oxford: Oxford University Press, 2016), 231-32. On the phenomenon of pilgrimage to Marian shrines from an anthropological point of view, see V. Turner and E. Turner, Image and Pilgrimage in Christian Culture: Anthropological Perspectives (New York: Columbia University Press, 1978), esp. ch. 5 ("Locality and Universality in Medieval Pilgrimages") and ch. 1 ("Introduction: Pilgrimage as a Liminoid Phenomenon") for a discussion of pilgrimage as an institutional form regarded within the concept of liminality. It is noteworthy that during the twelfth and fourteenth centuries, when the cult of Mary Magdalene reached its peak, canticles dedicated to this female saint became commonplace in Cilician Armenia. See A. Arevchatian, "Les cantiques consacrés à Marie-Madeleine dans la pratique musicale des églises arménienne et catholique," Revue des études arméniennes 35 (2013): 79-88, at 81.

4. Both women related their pilgrimages to the desire to see the places associated with the Birth and Passion of Jesus Christ. See Schein, "Bridget of Sweden," esp. 54; Limor, "Jerusalem," 231-33 (with previous bibliography). A similar phenomenon is also discernible in late medieval Armenian art and devotion, and the artistic evidence related to Queen Mariun offers a good example. Relevant to Mariun's Holy Land pilgrimage (whose historical circumstances are detailed in this article) may be the three images of her that appear in the Gospel of Queen Mariun dating from 1346 (J1973). These images show Mariun as one of the participants in three important Christological scenes- the Nativity, Entry into Jerusalem, and Descent of Christ from the cross (Figs. 4-6)- thus allowing the Armenian queen to virtually experience and visually imitate the pilgrimage to the holy sites that she would undertake in reality twenty-nine years later. It is not impossible that Mariun made more than one pilgrimage, but there is no evidence to support this possibility. The virtual pilgrimage suggested by the festive cycle of this and other manuscripts and by some Mediterranean analogues of this kind are discussed in G. Grigoryan, "Royal Images of the Armenian Kingdom of Cilicia (1198-1375) in the Context of Mediterranean Intercultural Exchange” (PhD diss., University of Fribourg, Switzerland, 2017), 260-66. For the Gospel of Queen Mariun, see also below (\$3). 
two pilgrimages, in 1372, a journey to the Holy City was undertaken by Isabelle Lusignan, the daughter of the Armenian King Guy Lusignan (r. 1342-44) and the spouse of Manuel Kantakouzenos (despot of Morea). ${ }^{5}$ However, the most important Armenian dignitary to appear in this vibrant milieu was Queen Mariun, the protagonist of this article.

A systematic history of Armenian female pilgrimage to medieval Jerusalem is yet to be written, but the material discussed in this article may offer some preliminary observations. The story of Mariun crosses the political realms of at least three Mediterranean communities- Armenian, Mamluk, and Latin-and reflects the scope of the ever-changing geopolitical complexities that continued to mark the eastern Mediterranean under Mamluk domination. Without undermining Mariun's pious aspirations, it should be noted that her final pilgrimage and settlement in Jerusalem was an immediate consequence of the Mamluk takeover of the Armenian capital Sis (present-day Kozan, Turkey), which marked the end of the Cilician state. In the present article, this royal pilgrimage is examined through the lens of the specific political circumstances and ambiguous realities of the time but also through devotional manuscripts and objects that accompanied Mariun and eventually kept her memory alive in the centuries that followed.

Upon the Mamluk takeover of Sis in April 1375, Lewon V Lusignan (r. 1374-1375), the last king of the Armenian state of Cilicia, and the rest of the royal court were taken into captivity in Egypt. With the exception of Lewon's subsequent activities, which are well documented and studied, little is known about what happened to the rest of the Armenian nobility after April 1375. We know that when the Catholicos Kostandin was freed in Cairo in the same year and was allowed to return to Cilicia, some Armenian lords accompanied him. ${ }^{6}$ Others continued their activities in Europe, as can be seen in various episodes narrated by Jean Dardel in his Chronique d'Arménie, our main source for these years. ${ }^{7}$ Another destination for the stateless Armenian aristocrats was Mamluk Jerusalem, where also

5. She is known as Margaret or Mary Lusignan in Cypriot sources, from where her name penetrated Western scholarship in these forms. She is often misrepresented as the sister of the Armenian King Guy Lusignan (as, for example, in the important articles of Schein, "Bridget of Sweden," 50, and Limor, "Jerusalem," 231), but in fact she was his daughter. See W. H. Rüdt-Collenberg, The Rupenides, Hethumides and Lusignans: The Structure of the Armeno-Cilician Dynasties (Paris: A. Pigné, 1963), III (H2), no. 193. For these clarifications and certain circumstances related to Isabelle Lusignan's visit to Jerusalem, see C. Mutafian, L'Arménie du Levant (XI $-X I V^{e}$ siècle), vol. 1 (Paris: Les belles lettres, 2012), 392-93.

6. Chronique d'Arménie par Jean Dardel, in Recueil des historiens des croisades: Documents arméniens, 2:1-109 (Paris: Imprimerie nationale, 1906), 87; Yovhannu Dardeli Žamanakagrut'iwn Hayoc' [Chronicle of Armenia by Yovhan Dardel], trans. K. Ezeanc', Society for the Armenian Book Publication of Tbilisi no. 28 (Saint Petersburg: Skōrōxōdov, 1891), 154. See also the brief excerpt preserved in the manuscript J1255, reproduced in N. Połarean, Mayr c'uc'ak jeragrac' Srboc' Yakobeanc' [Grand catalog of Sts. James manuscripts], vol. 4 (Jerusalem: Press of Sts. James, 1969), 424, and G. Grigoryan, “Armenian Colophons on the Takeover of Sis (1375)," Revue des études arméniennes 40 (2021): forthcoming (text accompanied with English translation).

7. Dardel's Chronicle has been published twice, in the original French (1906) and in an Armenian translation prepared by Karapet Ezeanc' (1891). Both the edition and the Armenian translation are based on the same manuscript dating from the early fifteenth century, preserved in the Bibliothèque municipale de Dole. Both publications are cited in the present article. 
the former queen Mariun ${ }^{8}$ settled and lived until her death. The life of this remarkable noblewoman coincided with the reigns of the last five kings of Cilician Armenia, a period full of vicissitudes that led to the fall of the Armenian state and to Mariun's own exile from the capital Sis. The first, introductory part of this article narrates Mariun's queenship and provides an overview of the situation at the Armenian court in 1374-75, when the court split into two dissident groups, each struggling to preserve the Armenian state in its own way. Though Mariun belonged to the group that supported King Lewon V against the group that contained, among others, the catholicos, she became a beloved personage for later Armenian historiographers, most of whom were followers of the Armenian Apostolic creed. ${ }^{9}$ The second and third parts of the article focus on the reasons for this interest. I hypothesize that her popularity is due not only to Mariun's efforts for the preservation of the Cilician state (which, however, proved ineffective) but also to her relevance to the Armenian Holy Land tradition. Her tomb at the Sts. James Monastery in Jerusalem is often mentioned in medieval and postmedieval texts. However, the information found in later historiography concerning Mariun and some of her contemporaries who survived the fall of the kingdom and lived through the fourteenth century has been subject to inaccuracies, which this article seeks to correct on the basis of textual and archaeological documentation.

\section{Queen Mariun and the Takeover of Sis (1375)}

Mariun was born of the marriage of the pali (bailiff) Awšin, the powerful lord of Korikos (also Corycus, present-day Kizkalesi, Turkey), and Joan of Anjou, the widow of King Awšin (r. 1308-1320) and former queen of Armenia. ${ }^{10}$ Mariun's queenship started when her husband Kostandin of Nłir acceded to the royal throne to reign as King Kostandin I (r. 1344-62/63). However, her queenship turned to be not just a symbolic one, for she actually governed the kingdom for a few years. Thus, a fourteenth-century chronicle records that after the death of Kostandin I, Mariun occupied the Armenian throne for one year (1363-64). ${ }^{11}$ We learn from the same source that Mariun succeeded also the next King

8. Also spelled Mariwn, Marun, Mariawn/Marion, Marian, Mariam, Mary, and Maria.

9. I avoid labeling the two rival groups "Latinophile" and "non-Latinophile," because although they are generally known as such, I do not think that the disagreements among the members of the royal court were primarily based on their religious-cultural orientations. This question requires a deeper analysis, but the episodes discussed under $\S 1$ (especially in relation to Mathieu Cappe) demonstrate the advisability of adopting a more cautious approach to the straightforward characterization of "Latinophile" versus "non-Latinophile." In addition, Queen Mariun, who supported King Lewon V on various occasions and might therefore be taken as a "Latinophile" (also because of her Angevin mother and her close relationship with the West and the papacy), was a follower of the Armenian Church (not to mention her final installment in the Sts. James Monastery, which functioned then as it does now as the seat of the Armenian Patriarchate of Jerusalem).

10. For Mariun's origins, see the principal colophon of the Gospel of Queen Mariun (J1973), the relevant parts of which are transcribed and translated below (\$3). For other sources, see Chronique d'Arménie, 19; Yovhannu Dardeli Žamanakagrut'iwn, 28; Samuēl Anec'i ew šarunakołner: Žamanakagrut'iwn Adamic' minč'ew 1776 t’. [Samuēl Anec'i and continuators, Chronicle from Adam to 1776], critical text, study, and commentary by K. Matevosyan (Yerevan: Nairi, 2014), 274.

11. A. Mat'evosyan, "Het'um Axtuc' tiroǰ ew Vasil Maraǰaxti žamanakagrut'iwnnerə" [The chronicles of Het'um, Lord of Axtuc', and of Vasil Maraǰaxt], Patma-banasirakan handes 4 (1963): 183-202, at 198; L. 
Kostandin II (r. 1365-73) and governed the state for a second time in 1373-74, until the reign of Lewon V, the last king-to-be. ${ }^{12}$ This information is confirmed by Jean Dardel, Lewon's future confessor-companion, who calls Mariun "the old queen of Armenia." ${ }^{13}$ This second period of Mariun's rule is especially interesting from the point of view of her legitimacy, since as seen below, the widow of Kostandin II, likewise called Mary, was alive and could have laid a more rightful claim to the throne of her late husband than could Mariun, who was the widow of the previous king. During the reign of Kostandin II and especially in the early 1370s, we see Mariun actively engaged in negotiations with the papacy and the West with the aim of gaining support for and preserving the Armenian state. In view of these initiatives undertaken by the former queen, questions have been raised about the surprising silence in these negotiations of King Kostandin II, who was the acting king and alive until $1373 .{ }^{14}$ Mariun's efforts were important also in 1374, when, after some diplomatic arrangements, Lewon was finally able to arrive in Sis and take up his royal responsibilities. ${ }^{15}$

Ter-Petrosyan, Ananun žamanakagrakan grairumner, XIV d. [Anonymous chronicles, fourteenth century], appendix 3 in L. Ter-Petrosyan, Xač́akirnerə ew hayero [The Crusaders and the Armenians], vol. 2: HistoricoPolitical Study (Yerevan: Print-Info, 2007), 555. This and several other excerpts from anonymous chronicles, as well as three larger chronicles attributed to Smbat Sparapet, Het'um Nłirc'i, and Marajaxt Vasil, are preserved in a manuscript dating from 1382-1404: MS London, British Museum, Or. 5458, now in the British Library. For the manuscript's description, see Frederick C. Conybeare, A Catalogue of the Armenian Manuscripts in the British Museum (Oxford: Oxford University Press, 1913), 290-92. This seems to be the very manuscript on the basis of which the first publication of Smbat's History was prepared by Oskan Gēorgean Yovhanniseanc' (Moscow 1856), although, for the sake of accuracy, a comparative textual analysis is desirable. The two less-known chronicles, preserved in the same manuscript and attributed by Artašes Mat'evosyan to Het'um Nłirc'i and to Marajaxt Vasil, were published in 1963. In the same publication, Mat'evosyan also included four important excerpts from anonymous chronicles that occupy various folios of LOB Or. 5458. The reason these texts have been preserved in a fragmentary and mixed state is that the manuscript has missing folios, and the current binding of the folios was done in an incorrect order. Unaware of this edition, in 2007, Levon Ter-Petrosyan prepared a new publication of some chronicles found in LOB Or. 5458, reproducing the text of the Chronicle of Het'um Nłirc'i and five excerpts from anonymous chronicles. The two publications organize and number the excerpts differently, because Mat'evosyan arranged them with an eye to paleographical and scribal peculiarities, whereas Ter-Petrosyan placed the excerpts in the chronological order of the narrated events. Thus, the fourteenthcentury chronicle in which Mariun's double rulership is mentioned appears in Mat'evosyan's edition as excerpt 6 (Mat'evosyan, "Het'um Axtuc' tiroǰ," 198) and, in Ter-Petrosyan's edition as excerpt 2 (Ter-Petrosyan, Ananun žamanakagrakan graíumner, 555).

12. Mat'evosyan, "Het'um Axtuc' tiroȳ," 198; Ter-Petrosyan, Ananun žamanakagrakan grarumner, 555.

13. Chronique d'Arménie, 41-42: “. . . les Armins s'apperçeürent et pour ce le [King Kostandin II] tuerent ou moys d'avril l'an mil CCCLXXIII, et donnerent par commun assentement le gouvernement du royaume à la vielle royne d'Armenye [Queen Mariun], qui femme avoit esté du premier roy tirant [King Kostandin I], jusques à la venue du dit messire Lyon [future King Lewon V Lusignan], leur droit seigneur naturel." See also Yovhannu Dardeli Žamanakagrut'iwn, 68.

14. H. Kühl, Leon V. von Kleinarmenien: Ein Leben zwischen Orient und Okzident im Zeichen der Kreuzzugsbewegung Ende des 14. Jahrhunderts (Frankfurt am Main: Peter Lang Europäischer Verlag der Wissenschaften, 2000), 34-36, 74, 118-19 (mentioned as Kostandin III); M.-A. Chevalier, Les ordres religieuxmilitaires en Arménie cilicienne: Templiers, hospitaliers, teutoniques \& arméniens à l'époque des croisades (Paris: Geuthner, 2009), 661-62, 666 (mentioned as Kostandin III).

15. C. Mutafian, "Léon V Lusignan: Un preux chevalier et/ou un piètre monarque," in Actes du colloque "Les Lusignans et l'Outre mer," Poitiers, 20-24 octobre 1993, 201-10 (Poitiers: Sipap, 1995), 204-205; Kühl, Leon V. 
When the Armenian capital was taken by the Mamluks in April 1375, the current queen of Armenia was Margaret of Soissons, who had been coronated in the cathedral of Saint Sophia of Sis a year earlier, on September 14,1374 , together with her spouse Lewon V. ${ }^{16}$ At the time of the kingdom's fall, two other former queens in addition to Margaret were also present in the royal fortress of Sis: Mariun, the widow of Kostandin I, and Mary, the widow of Kostandin II. These two homonymous noblewomen were widows of two consecutive kings, both called Kostandin. Furthermore, the former queens were daughters of two namesake lords, both named Awšin: Mariun's father, as already noted, was Awšin of Korikos, whereas Mary was the daughter of Awšin Ołruy (and the granddaughter of Awšin of Korikos through the maternal line, which means that Mariun was her aunt). In the genealogical tables of Rüdt-Collenbert and Toumanoff, Mariun is referred to as "the old queen," apparently following Dardel's above-quoted designation, while Mary of Ołruy is called "the young queen." ${ }^{17}$ Between 1374 and 1375, the latter also seems to have been active at the court of the declining state, as shown in the passage summarized below.

On the day of his coronation, Lewon $\mathrm{V}$ had given the title of knight to two noblemen, Sohier Doulcart (also known as Soher de Sart) and Mathieu Cappe, who were at the same time also proclaimed marajaxt (marshal) of the state and the king's chancellor, respectively. On the same day, the newly minted knights further married two widowed noblewomen. Sohier Doulcart, the new marshal, married the widow of Prince Bohemond of Korikos, ${ }^{18}$ Lady Ephemie (also spelled Femye, Femi, and Fimi), whose name appears in Dardel's Chronicle as Remye. ${ }^{19}$ Mathieu Cappe, the new chancellor, married the "young queen" Mary, the widow of King Kostandin II. ${ }^{20}$ In the case of Cappe, however, Lewon's generosity was not rewarded with faithfulness. According to Dardel, it was Cappe who, supported by his new spouse Mary, Catholicos Kostandin, and Paron Vasil, ${ }^{21}$ initiated an assassination attempt against King Lewon on March 24, 1375. ${ }^{22}$ Lewon managed to evade the assassination, and Cappe

von Kleinarmenien, 119-25; L. Ter-Petrosyan, Xač akirnerə ew hayerə [The Crusaders and the Armenians], vol. 2: Historico-Political Study (Yerevan: Print-Info, 2007), 456; Mutafian, L’Arménie du Levant, 220-21.

16. Chronique d'Arménie, 66; Yovhannu Dardeli Žamanakagrut'iwn, 114.

17. Rüdt-Collenberg, Rupenides, Hethumides and Lusignans, III (H2), no. 165/175 (for Mariun) and no. 169/192 (for Mary of Ołruy); C. Toumanoff, Les dynasties de la Caucasie chrétienne de l'Antiquité jusqu'au XIXe siècle: Tables généalogiques et chronologiques (Rome, 1990), 291 (table 61).

18. Bohemond of Korikos was Lewon V's uncle, who was assassinated together with King Guy Lusignan.

19. Chronique d'Arménie, 66; see also ibid., n. 5 for the identification of Lady Remye with Ephemie; Yovhannu Dardeli Žamanakagrut'iwn, 114-15.

20. Chronique d'Arménie, 75; Yovhannu Dardeli Žamanakagrut'iwn, 130.

21. Vasil was a son of Constable T'oros and the brother of Liparit, the well-known hero of Yovhannēs T'lkuranc'i's poem about the defense of Sis in 1369. See Mutafian, L'Arménie du Levant, 219-20. For literary interpretations of this event and previous studies, see T. M. van Lint, "Sis. The Armenian Kingdom of Cilicia," in Europe: A Literary History 1348-1418, ed. D. Wallace, 2:259-81 (Oxford: Oxford University Press, 2016), at 268-70.

22. Chronique d'Arménie, 75-76; Yovhannu Dardeli Žamanakagrut'iwn, 130-32. The failed assassination attempt was followed by another one, organized by Vasil. See Chronique d'Arménie, 77-78; Yovhannu Dardeli Žamanakagrut'iwn, 135-36. 
himself was killed by falling down from the castle tower. ${ }^{23}$ We are not told what happened to the twice-widowed Mary. Unlike Mariun and Margaret of Soissons, she is not listed among the prisoners who accompanied Lewon during his exile from Sis (though she may have been among the twenty exiled aristocrats whom Dardel mentions but does not name ${ }^{24}$ ).

After this episode, Lewon, along with a small group of guardians, moved to the residence of Mariun, situated in the so-called Second Castle, where he was "accepted very honorably." Soon, Sohier Doulcart and some groups of people and soldiers joined Lewon in Mariun's castle. The tower castle, which was the king's official residence, was occupied by the initiators of the coup, who-according to Dardel-did not want to hand it back to Lewon despite the latter's initially peaceful (and later military) efforts to regain control of it. ${ }^{25}$ On the feast of the Annunciation, Lewon could finally enter the royal castle, and his banner was raised atop the tower, as our chronicler proudly describes. But his opponents were there, too, and Dardel accuses the catholicos and Paron Vasil of handing Lewon over to the Mamluks. ${ }^{26}$ According to a contemporary manuscript colophon, the royal castle surrendered on Friday, April 16, after several months of blockade. ${ }^{27}$

\section{Queen Mariun after the Fall of Sis}

According to Jean Dardel, the victorious Mamluk commander ordered one of his officials to replace him in Sis, while he accompanied Lewon's retinue to Aleppo. The commander was 'Ashiq Tamur ('Ashaqtamur), the emir of Aleppo. On the day of Easter (April 22, 1375), the group of royal prisoners, comprising "the king and the queen [Lewon V and Margaret of Soissons], their children, the former queen of Armenia [Mariun], who was the spouse of the tyrant king Kostandin I, and Sir Sohier Doulcart and his countess [Lady Remye], as well as Armenian barons and great men from the city of Sis, altogether twenty persons," left Sis. ${ }^{28}$ At the end of April, the travelers approached Aleppo but did not enter the city immediately, because the emir wanted it to be splendidly decorated before his solemn entry, which Dardel explains by the emir's desire to highlight the significance of his recent victory and to exhibit his glory and magnificence to Lewon. ${ }^{29}$ After spending the entire month of May in Aleppo, on the first day of June the prisoners were sent to Cairo at the command of Sultan

23. Chronique d'Arménie, 75-76; Yovhannu Dardeli Žamanakagrut'iwn, 130-32.

24. See below, $\$ 2$ (n. 28).

25. After his messengers were rejected, Lewon initiated a military attack in order to take back the tower castle. Four attacks were launched in one night, but none of them was successful, because, as described by Dardel, the tower castle was "very strong, and its entrance was so thin that the soldiers could enter only one by one." Because of this, many of the attackers were wounded. See Chronique d'Arménie, 76-77; Yovhannu Dardeli Žamanakagrut'iwn, 132-34.

26. Chronique d'Arménie, 78-80; Yovhannu Dardeli Žamanakagrut'iwn, 137-41.

27. However, in another Armenian source dating from the fourteenth century, the date of the final surrender of the royal castle is given as April 12. Both texts are reproduced and translated in Grigoryan, "Armenian Colophons."

28. Chronique d'Arménie, 84; Yovhannu Dardeli Žamanakagrut'iwn, 148.

29. Chronique d'Arménie, 84-85; Yovhannu Dardeli Žamanakagrut'iwn, 149. 
al-Ashraf Sha'bān. They arrived there on Wednesday, July 9, and were given appropriate accommodation, though the sultan did not receive them immediately but only several days later. ${ }^{30}$ Dardel writes that it was decided that Lewon would stay in Cairo with a daily subsidy of sixty silver drams, whereas the former queen Mariun, together with Sohier Doulcart and Lady Remye, would head for Jerusalem upon their own request. According to a permission letter issued by al-Ashraf Sha'bān in April 1375, the sultan guaranteed the safety of Lewon, his queen, and his children. ${ }^{31}$ The security of the other members of Lewon's retinue was guaranteed as well, but they were given a modest subsidy to cover the costs of their trip to Jerusalem. ${ }^{32}$ Mamluk Jerusalem seems to have been the best destination for these stateless aristocrats, for it boasted an active Armenian community and patriarchate and had become the focus of renewed interest of Western aristocratic pilgrimage. As for the rest of the captured Armenian aristocracy, they soon managed to repatriate to Sis, led by Catholicos Kostandin..$^{33}$

In autumn 1377, a knight called Manuēl, who had in the early 1370s engaged in diplomatic affairs initiated by Queen Mariun, appears to have conducted negotiations with Peter III of Catalonia (known also as Peter IV of Aragon or Peter the Ceremonious) for Mariun's liberation. For this purpose, on November 25 the king signed several letters addressed to recipients whose names are not known but who were to write to the Mamluk sultan to advocate for Mariun's freedom. ${ }^{34}$ Madalena Sáez Pommés has observed that Manuēl's negotiations may have been a pretext for him to stay on at the Catalan court for a while. ${ }^{35}$ After the fall of Sis, Manuēl himself was held as a prisoner in Aleppo, where, according to Dardel, he became a "sarrasin." ${ }^{36}$ Through the intercession of Lewon V, Manuēl managed to gain his liberty and move to Europe. His efforts to liberate Mariun in 1377 are indeed a little surprising. Although Jerusalem was under Mamluk control, the aged queen seems to have lived there not as a prisoner in urgent need of liberation. According to certain manuscript colophons, reproduced and discussed below, Mariun lived a "merciful and charitable" life in the Holy City, which suggests a monastic lifestyle. Indeed, when she died she was buried at the Sts. James Monastery. The events preceding Manuēl's initiative in October-November of 1377 further highlight its apparent lack of purpose. First, in 1375, before the imminent end of his reign, Sultan al-Ashraf Sha'bān had already granted Mariun a sort of freedom by allowing her to leave Cairo and to move to Jerusalem upon her own wishes. Second,

30. Chronique d'Arménie, 85-86; Yovhannu Dardeli Žamanakagrut'iwn, 151; see also the brief excerpt preserved in the manuscript J1255, reproduced in Połarean, Mayr c'uc'ak, 4:424, and Grigoryan, "Armenian Colophons" (for the English translation). See also Kühl, Leon V. von Kleinarmenien, 140-41.

31. The text of the sultan's guarantee letter is reproduced in chapter 104 of Dardel's chronicle. See Chronique d'Arménie, 80-81; Yovhannu Dardeli Žamanakagrut'iwn, 141-42.

32. Chronique d'Arménie, 87; Yovhannu Dardeli Žamanakagrut'iwn, 153-54.

33. For sources, see above, n. 6.

34. M. Sáez Pomés, "La ayuda de Valencia a León V de Armenia, I de Madrid," Estudios de edad media de la Corona de Aragón 3 (1947-48): 386-419, at 400. I thank Sofía Fernández Pozzo for her help with translating this article.

35. Ibid., 400.

36. Chronique d'Arménie, 85, 99; Yovhannu Dardeli Žamanakagrut'iwn, 150, 177. 
a fourteenth-century manuscript colophon and several later Armenian texts mention that Mariun died in July 1377 (see below, \$2.1), which does not fit chronologically with Manuēl's undertaking of efforts to liberate her in autumn 1377. He was either unaware of Mariun's death months earlier or had other intentions, such as to stay at the Catalan court, as suggested by Saez Pommés, or to obtain financial support for himself, as Dardel suggests on one occasion. ${ }^{37}$

\subsection{Evidence from Manuscript Colophons and Minor Texts}

The final account on Queen Mariun in Dardel's chronicle says that she and her two companions, Sohier Doulcart and his wife, were paid poorly for their trip to Jerusalem. ${ }^{38}$ In the Holy City, a certain Vahram acquired from Mariun a now-lost gospel book, which had originally belonged to King Kostandin I, Mariun's late husband. ${ }^{39}$ This parchment manuscript had been created in 1290 for the priest Kostandin in the Monastery of Armēn (situated on the eponymous mountain, east of the fortress of Lambron), and according to the colophon's text, it had been richly illustrated in 1345 at the command of King Kostandin I. When Mariun was expelled from Sis, she apparently took her husband's gospel along and carried it with her all the way to Jerusalem. Curiously enough, sometime before the seventeenth century (or perhaps in the seventeenth century) the manuscript was moved back to Sis, the seat of the catholicosate of Cilicia, as two Cilician catholicoi-Yovhannēs Ant'ēpc' $i$ (1601-21) and Kirakos Aǰapahean (1797-1822)-are mentioned as having repaired it. ${ }^{40}$ By 1851, the gospel of King Kostandin was still in Sis, for in that year Łewond Pirłalemean documented the manuscript and reproduced its colophon from $1345 .{ }^{41}$ Soon thereafter, in 1852, the manuscript-described as having a silver binding-was also mentioned by Victor Langlois, who saw it in the treasury of the Chapel of Surb Grigor (St. Gregory) in Sis.

37. Chronique d’Arménie, 99-100; Yovhannu Dardeli Žamanakagrut'iwn, 177-79. Manuēl's European activities in the post-kingdom period feature several contradictory episodes. On one occasion, he represented himself falsely as King Lewon's messenger (Chronique d'Arménie, 99-100; Yovhannu Dardeli Žamanakagrut'iwn, 177-79; see also Kühl, Leon V. von Kleinarmenien, 153-54). In another episode, the re-Christianized Manuēl asked for financial support from the royal treasury of the Aragonese court in order to undertake a pilgrimage to Santiago de Compostela. On his activities in Europe, see Mutafian, "Léon V Lusignan," 205; V. Matiossian, “An Overview of Armenian-Spanish Relations during the Cilician Period," Handēs Amsoreay 1-12 (1996): 321-25; V. Matiossian, "Sant'iakō tē Gomp'ostela ew hayero" [Santiago de Compostela and the Armenians], Bazmavēp 1-4 (2005): 219-23; R. Gulbenkian, "Les relations entre l’Arménie et le Portugal du Moyen-Âge au XVI siècle," Revue des études arméniennes 14 (1980): 199-200.

38. Chronique d'Arménie, 87; Yovhannu Dardeli Žamanakagrut'iwn, 153-54.

39. A detailed description of this gospel manuscript is to be found in a handwritten notebook compiled in Adana between the years 1919 and 1921 by the later Catholicos Sahak Xapayean. His notebook is preserved as J3602/24. The whereabouts of the gospel belonging to King Kostandin I (and then to Queen Mariun) remain unknown to me. Xapayean's description of the manuscript is reproduced in N. Połarean, Mayr c'uc'ak jeragrac' Srboc' Yakobeanc' [Grand catalog of Sts. James manuscripts], vol. 11 (Jerusalem: Press of Sts. James, 1991), 15-18.

40. Colophons about the later restorations are reproduced in Połarean, Mayr c'uc'ak, 11:17-8.

41. Pirłalemean's transcription is reproduced in L. Xač 'ikyan, ŽD. dari hayeren jeragreri hišatakaranner [Colophons of Armenian manuscripts of the fourteenth century] (Yerevan: Press of the Academy of Sciences, 1950), 343. 
Langlois documented it in his travelogue study, providing a French translation of the same colophon. ${ }^{42}$

But before the manuscript was repatriated to Cilicia in the postmedieval period, sometime in the last decades of the fourteenth century, the aforesaid Vahram composed a colophon that includes a brief eyewitness account of the queen's sojourn in Jerusalem. Of the known sources, this is one of the closest to Queen Mariun, from whom Vahram acquired the manuscript, apparently shortly before her death: ${ }^{43}$

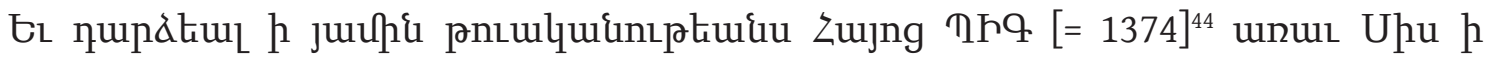

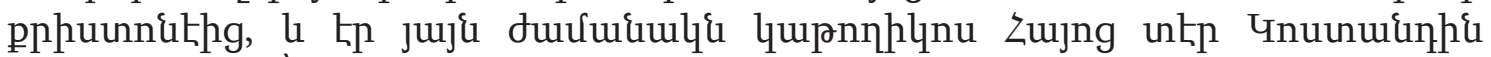

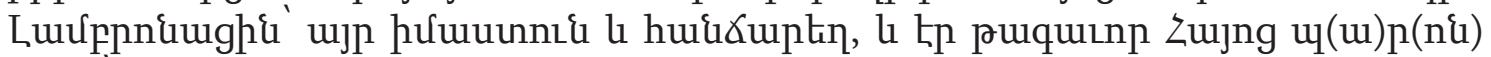

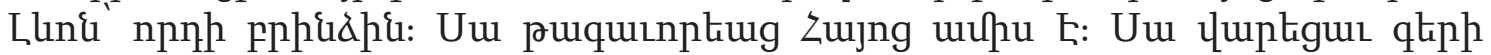

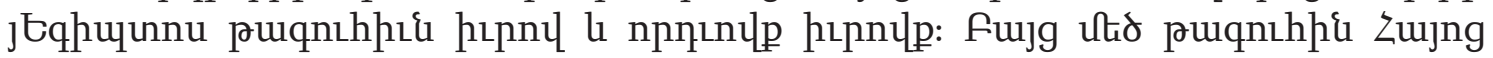
Uuphs\{ jEpntum

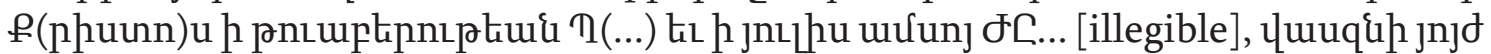

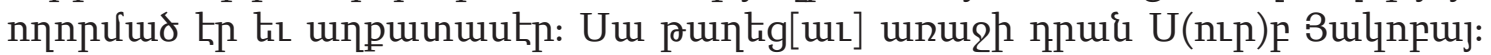

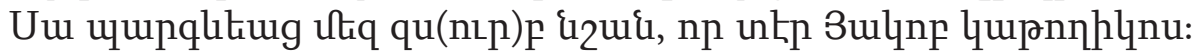

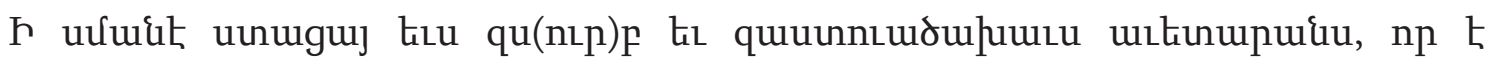

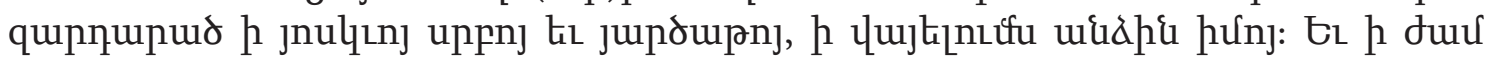

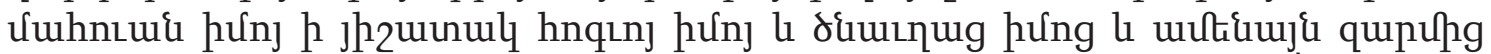

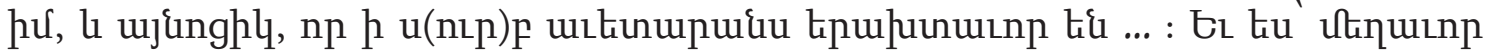

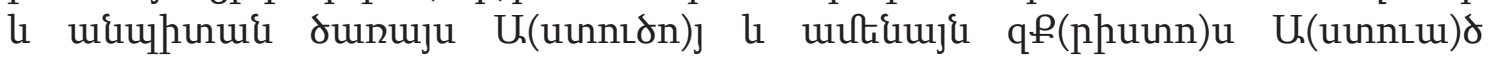

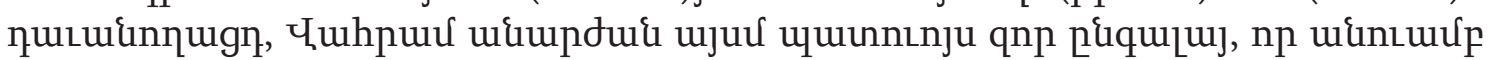

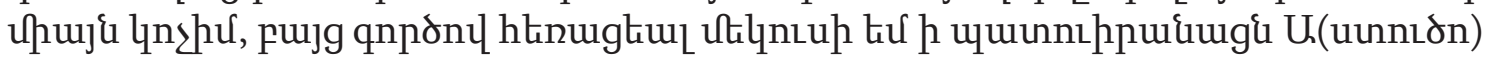

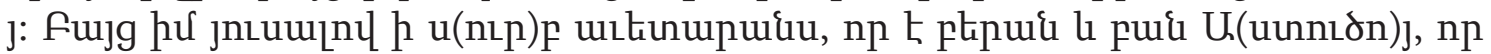

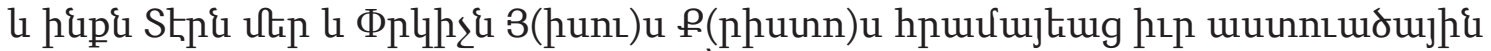

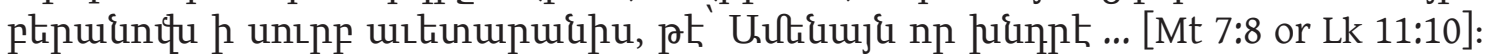

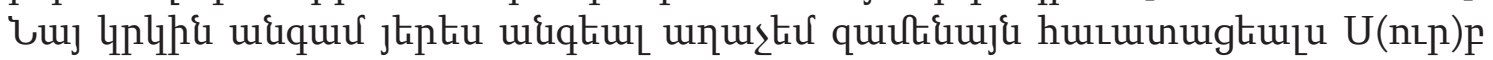

42. V. Langlois, Voyage dans la Cilicie et dans les montagnes du Taurus exécuté pendant les années 1852-1853 (Paris: Benjamin Duprat, 1861), 403.

43. Sahak Xapayean's handwritten transcription of this colophon appeared in Połarean, Mayr c'uc'ak, 11:17, and it served as the basis of my reproduction and English translation, expanding only the abbreviations. It is also reproduced in Covakan, Hay gričner, $T^{\prime}-\check{Z} \bar{E}$ dar [Armenian scribes, tenth-seventeenth centuries] (Jerusalem: Press of Sts. James, 1992), 144-46, and Covakan, Vanatur: Banasirakan yōduacneru žołovacoy [Vanatur: Collection of philological essays] (Jerusalem: Press of Sts. James, 1993), 275 (in part). Previously, an abbreviated version of the colophon was published by Bishop Mkrtič Aławnuni in his Miabank' ew ayc'eluk' hay Erusałēmi [Cenobites and visitors to Armenian Jerusalem] (Jerusalem: Press of Sts. James, 1929), 170-71); Aławnuni had likewise used Xapayean's transcription, available at that time in Xapayean's handwritten catalog of Sts. James manuscripts. This catalog was never published and in fact is now obsolete due to the eleven-volume series of catalogs published successively by Połarean until 1991.

44. The date of the takeover of Sis is given erroneously as Thq $(823=1374 \mathrm{CE})$ instead of $T h \uparrow(824=1375$ $\mathrm{CE}$ ). The error may have been caused by the false reading of the letter/number ₹, whose form resembles that of the letter 9. Because the original manuscript is missing, it is impossible to verify the colophon's text, which was transcribed by Xapayean and recopied by several scholars (see the previous note). 


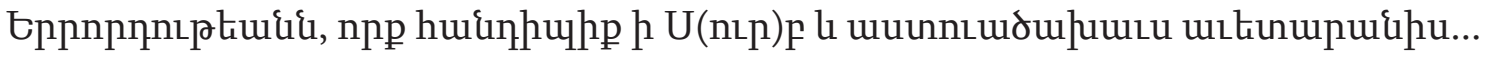

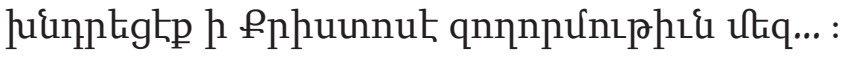

Translation:

And again, in the Armenian year $823[=1374], 45$ Sis was taken from the Christians; and this happened when tēr Kostandin of Lambron, a wise and ingenious man, was catholicos of the Armenians, and when Paron Lewon, son of the prince, was king of the Armenians. He reigned over the Armenians for seven months. He was taken captive into Egypt together with his queen and children. But the great queen of Armenia, Mariwn, [dwelt] in Jerusalem for three years with truly great virtue and fell asleep in Christ on July 18 in the [Armenian] year eight hundred... [illegible], for she was very merciful and charitable [lit. lover of the poor]. She was buried in front of the door of Saint James. She offered us the holy sign which [had belonged to] Catholicos Yakob.

From her I also acquired for my own enjoyment this holy and God-spoken gospel, which is adorned with pure [lit. holy] gold and silver. And when I pass away, [may this be] a memory of my soul, of my parents, of my relatives, and of all those who are beneficiaries of this holy gospel. ...And I, Vahram, sinful and useless servant of God and of all you who confess Christ [as] God, accepted this honor undeservedly, for I have the name only, but with my deeds I have turned away and isolated myself from God's commandments. But my hope is in this holy gospel, which is God's mouth and word, as He Himself, our Lord and Savior Jesus Christ, commanded with His divine mouth in the holy gospel: "Everyone who asks [receives]..." [Mt 7:8 or Lk 11:10]. Yet again, falling on my face, I beseech all believers of the Holy Trinity who will come upon this holy and God-spoken gospel... ask Christ to have mercy on us....

The fact that Vahram acquired the now-lost gospel of King Kostandin I in Jerusalem and directly from Queen Mariun shows that she took it with her when leaving Sis, along with a certain "holy sign" (i.e., a cross) that had belonged to Catholicos Yakob. Apart from these two objects, another gospel manuscript, known as the Gospel of Queen Mariun and now preserved as J1973, may well have been among the sacred objects that the queen brought with her to the Holy City. ${ }^{46}$ These were, moreover, neither the sole manuscripts associated with the former queen nor the only royal codices to have appeared in Jerusalem after the final takeover of Sis. The ritual manuscript J2027, copied in 1266 by the scribe Awetik' and illustrated by T'oros Roslin, contains a later colophon that was added in the last decades of the fourteenth century, most likely in Jerusalem (where, incidentally, the best collection of Cilician royal manuscripts is currently preserved). This colophon, ${ }^{47}$ written on folio $275 \mathrm{v}$ in

45. About the erroneous date of the takeover of Sis, see above, n. 44.

46. For the Gospel of Queen Mariun and its relevance to the queen's Jerusalem pilgrimage elsewhere, see Grigoryan, "Royal Images," 260-66.

47. In his monumental manuscript catalog, Połarean did not include this colophon in the description of manuscript J2027; see N. Połarean, Mayr c'uc'ak jeragrac' Srboc' Yakobeanc' [Grand catalog of Sts. James manuscripts], vol. 7 (Jerusalem: Press of Sts. James, 1974), 59-66. It is, however, reproduced in one of his later essays; see Covakan, Vanatur, 276. 
a somewhat careless way, is clearly dependent on the above-quoted colophon of Vahram, likely being its revised abbreviation:

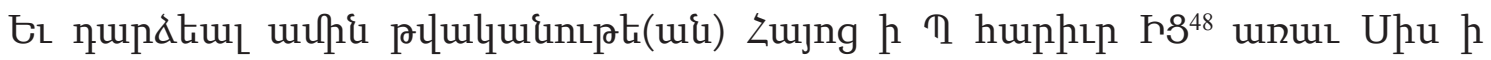

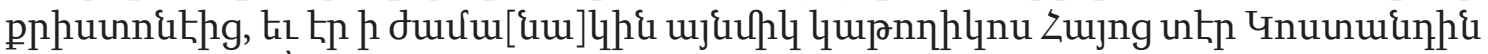

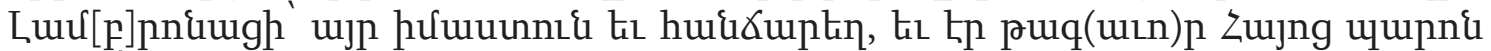

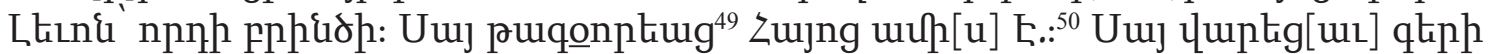

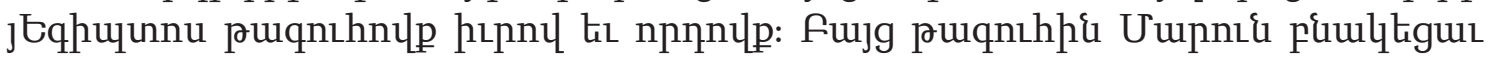

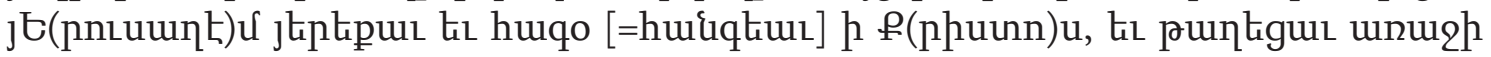
прưqu U(nıp)p Bulpnp[u]]:

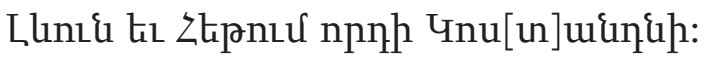

Translation:

And again, in the Armenian year $82(4),{ }^{51}$ Sis was taken from the Christians; and this happened when tēr Kostandin of Lambron, a wise and ingenious man, was catholicos of the Armenians, and when Paron Lewon, son of the prince, was king of the Armenians. He reigned over the Armenians for seven months. ${ }^{52}$ He was taken captive into Egypt together with his queens and children. But Queen Marun dwelt in Jerusalem for three [years], after which she fell asleep in Christ and was buried in front of the door of Saint James.

Lewun and Het'um, son[s] of Kostandin.

The information on Mariun's death and on her burial in front of the door of St. James that is found in these two manuscripts can also be found in the Chronological History of Armenian Cilicia, authored by Yakob erēc' Ssec'i and preserved in the seventeenth-century manuscript V1318/923. ${ }^{53}$ The events between the years 1375 and 1377

48. Here, too, the date of the takeover of Sis is copied erroneously: instead of T huphtp $\mathrm{H}$ ( $(824=1375 \mathrm{CE})$ we read $T$ huphıp $\mathrm{h}$, which does not make sense and confirms the questionable writing of the letter/number $\mathrm{\imath}$ in the original manuscript (see above, n. 44). Połarean transcribed the date as $\uparrow$ huphıp hq? $(823=1374$ $\mathrm{CE}$ ), following the unpublished catalog of Sahak Xapayean. However, he added a question mark to indicate the questionable writing of the date. See Covakan, Vanatur, 276. See also Aławnuni, Miabank' ew ayc'eluk', 170-71 (who similarly used Xapayean's handwritten catalog of manuscripts).

49. Probably because of the pronunciation, the scribe has written "o" instead of "uu." However, "uul" is pronounced "o" when it is followed by a consonant letter. In this case, the correct writing would therefore be puiquinptiug.

50. Uuj puuqonpliug Zuung uu[[u] F. ("He reigned over the Armenians for seven months") is missing from Połarean's transcription (Covakan, Vanatur, 276).

51. For the writing of the date, see above, n. 48.

52. See above, n. 50.

53. The identification of the chronicler was made by Gēorg Tēr-Vardanean, who has also prepared the text of the Chronological History to be published soon (private communication with Gēorg Tēr-Vardanean, who also

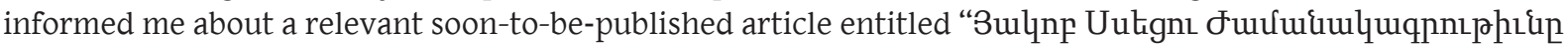

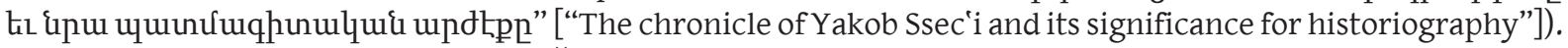
For the description of V1318/923, see S. Čemčemean, Mayr c'uc'ak hayerēn jeragrac' matenadaranin Mxit'areanc' 
are narrated twice on folios 249 and 250, apparently having been copied from two different sources. To my knowledge, the excerpts from V1318/923 transcribed below have never before been published. Correspondences to other sources and some clarifications about the abovementioned events and persons are given in the notes that accompany the English translation.

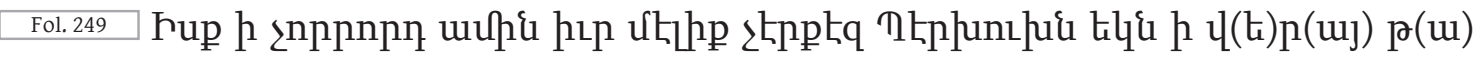

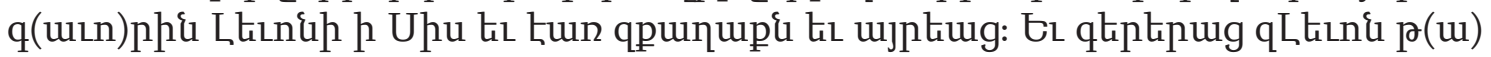

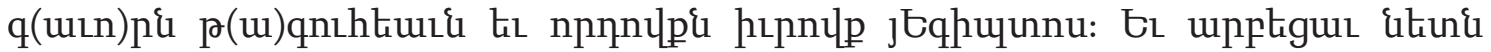

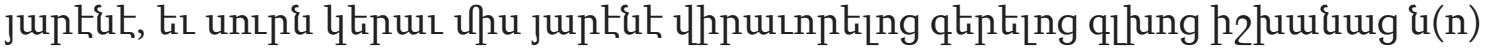

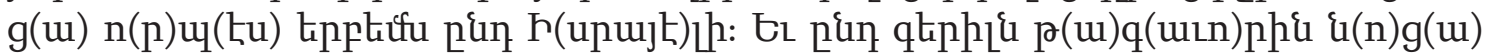

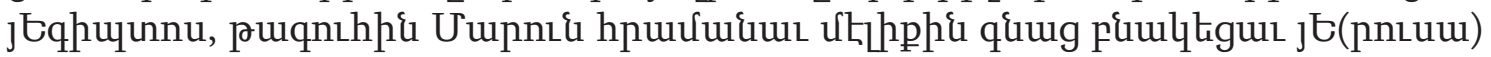

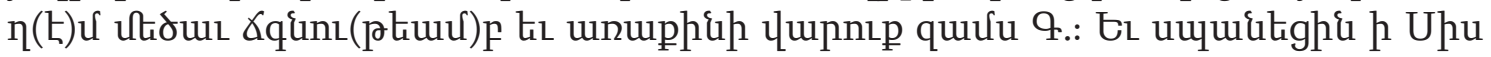

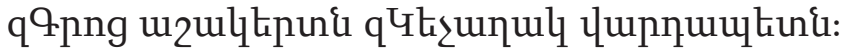

...

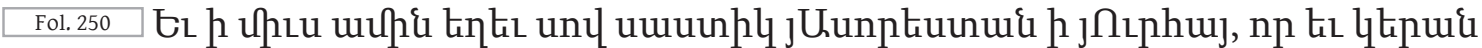

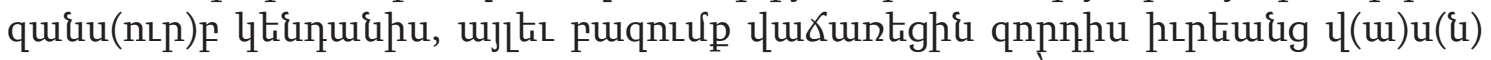

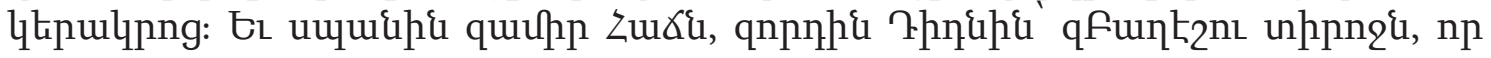

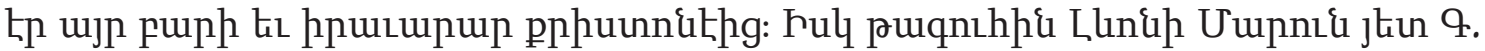

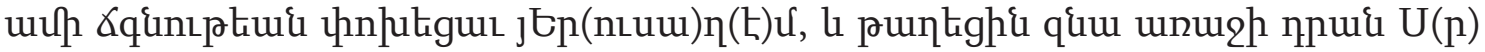

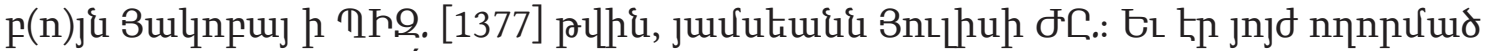

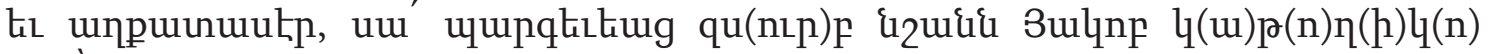

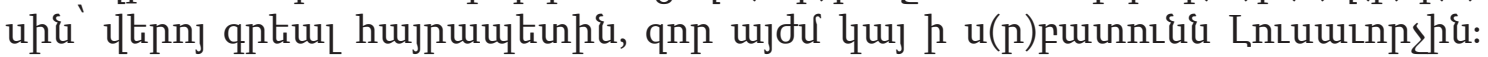

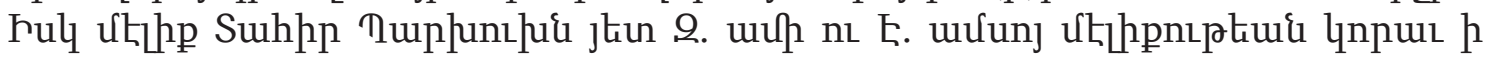

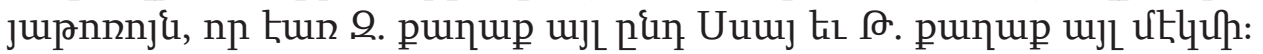

\section{Translation:}

Fol. 249 And in the fourth year of his reign, the Circassian mēlik' Pērxux ${ }^{54}$ came against King Lewon in Sis, took the city, and burned it down. And he took King Lewon captive to Egypt, together with the queen and their children. And the arrow became drunk with blood, and the sword ate the flesh of the heads of the wounded, captured princes, as had happened long ago to Israel. And when their king was taken into captivity in Egypt, Queen Marun, by the order of mēlik', went to dwell in Jerusalem for three years, leading an ascetic life, full of virtuous deeds. And in Sis they murdered vardapet Kečałak, who was a student of the Scriptures. ${ }^{55}$

i Venetik [General catalog of Armenian manuscripts of the Mekhitarist library in Venice], vol. 6 (Venice: San Lazzaro, 1996), 221-26.

54. This is al-Zāhir Barqūq, the first sultan of the so-called Circassian dynasty, who seized power and reigned 1382-89 and 1390-99. The chronicler is clearly confusing the events related to the takeover of Sis, which happened during the reign and by the order of a previous Mamluk sultan, al-Ashraf Sha'bān (1363-77).

55. This episode of a certain vardapet Keç'ałak's being killed in Sis during its takeover is also narrated in the continuation of Samuēl Anec'i's History, from where the cited part of the present excerpt is likely taken.

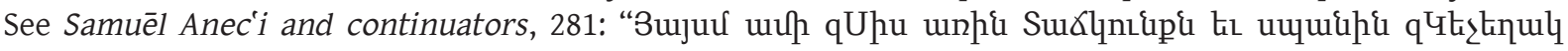


...

Fol. 250 And in the following year there was such a severe famine in Urhay [i.e., Edessa], Assyria, that [people] ate impure animals, and many were compelled to sell their own children for the sake of food. And emir Hačn, son of Di(a)din, lord of Bałēš, who was a kind and righteous man toward the Christians, was killed. ${ }^{56}$ And Marun, Queen of Lewon, ${ }^{57}$ after three years of ascetic life, passed away in Jerusalem and was buried in front of the door of Saint James in the year 1377, on July 18. She was very merciful and charitable [lit. lover of the poor]. She bequeathed the holy sign of the abovementioned Catholicos Yakob, which is now kept in the sacristy of [Grigor] the Enlightener. And Parxux, mēlik' [of] Tahir, who had taken six cities, including Sis, ${ }^{58}$ and nine other cities one by one, disappeared from the mēlik's' throne after six years and seven months of reign.

The account referring to Queen Mariun's death and to the cross of Catholicos Yakob that she gave away is apparently taken from the now-lost gospel of King Kostandin I, discussed above. Yakob Ssec'i, when preparing his Chronological History, made a precious addition, writing that "the holy sign" of Catholicos Yakob "is now kept in the sacristy of [Grigor] the Enlightener." He seems to have used the very manuscript of King Kostandin, which, according to Langlois's nineteenth-century description, was kept in the church of Surb Grigor (St. Gregory the Enlightener) of Sis. ${ }^{59}$ As for Mariun's stay in Jerusalem, Ssec'i confirms the previously cited accounts of her dwelling in the Holy City for three years, during which she led an ascetic, merciful, and charitable life, performing "virtuous deeds."

In these sources, Mariun's passing away is dated to 1377, and the initial location of her tomb is mentioned as being in front of the St. James cathedral. This information can also be found in an anonymous continuation of a chronicle attributed to King Het'um II: ${ }^{60}$

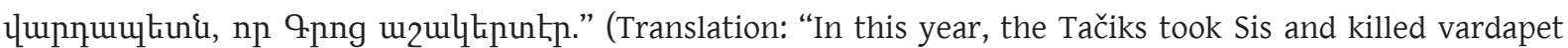
Kečałak, who was a student of the Scriptures.")

56. A similar narrative of these events is to be found in the continuation of Samuēl Anec' 'i. See Samuēel Anec'i

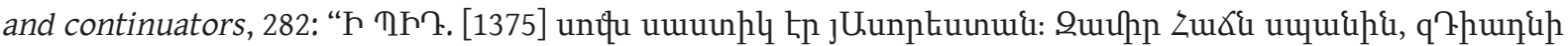

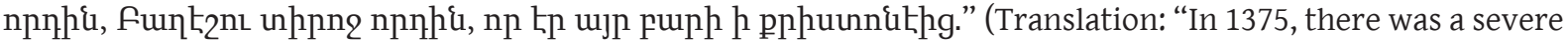
famine in Assyria. Emir Hačn- son of the lord of Bałēš, Diadin- who was a kind man toward the Christians was killed.")

57. Similar misrepresentations of Mariun's relationship with King Lewon $V$ can also be found in the other texts discussed below.

58. Here, too, the author confuses the events related to the takeover of Sis. See above, n. 54.

59. Langlois, Voyage dans la Cilicie, 403.

60. Reproduced in Het'um B-i Taregrut'yuny, XIII d. [Chronicle of Het'um II, thirteenth century], in Manr žamanakagrut' yunner, XIII-XVIII dd. [Brief chronicles, thirteenth-eighteenth centuries], ed. V. Hakobyan, vol. 1 (Yerevan: Press of the Academy of Sciences, 1951), 89, n. 10 (version Г, based on the text available in manuscript M3079); S. Čemčemean, Mayr c'uc'ak hayerēn jeŕagrac' matenadaranin Mxit'areanc' $i$ Venetik [General catalog of Armenian manuscripts of the Mekhitarist library in Venice], vol. 8 (Venice: San Lazzaro, 1998), 365 (based on manuscript V1412/1588, fol. 401, in which the chronicle is attributed to Het'um the Historian and not to King Het'um II; Vazgen Hakobyan's clarifications in the cited volume seem to have resolved this issue). 


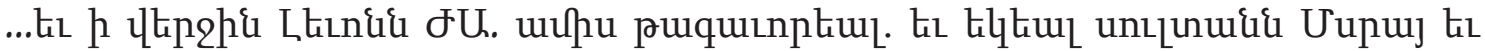

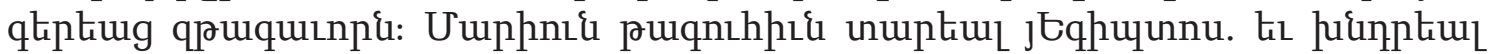
puqnıhh\{ $\mathrm{h}$ unı

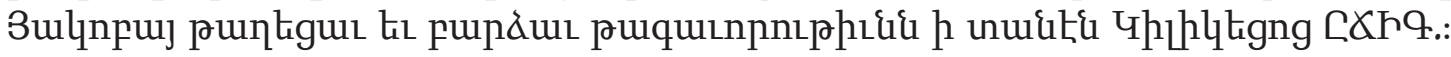

Translation:

And the last [King] Lewon reigned for eleven months, until the sultan of Msr [i.e., Egypt] came and captured the king. Queen Mariun was taken to Egypt, [where] she requested of the sultan [to go to Jerusalem]; and she went to Jerusalem and died there in 754 [1305?] and was buried at the door of Saint Yakob [i.e., James]. And in 823 [1374?] the kingdom of the house of the Cilicians fell.

Another later narrative referring to the events in question is given by Martiros Erimec'i (1620-83) in his rhythmic narrative Yupq tis phl puquinnuug hujng (Karg ew t'iw $t^{\prime}$ agaworac' hayoc", "Order and list of Armenian kings"). Łrimec'i, who was the patriarch of Jerusalem, provides the following retelling of the events of interest to this study: ${ }^{61}$

Finally, after Konstandin, ${ }^{62}$

the miserable King Lewon [came and]

reigned for eleven months,

[but] lost the crown and the throne,

because the sultan of Egypt

came and captured everyone,

including the baron

together with his [family],

also the queen, their stepmother.

The tyrant pitied the queen

and [with these words] let her free:

"Go wherever you wish!"

And she headed for Palestine.

Her life ended in the Holy City of Jerusalem,

and she was buried under a pillar in the holy cathedral

of the Holy See of the Armenian nation ${ }^{63}$

in the Armenian year 823 [1374?].

Although both the continuator of Het'um's chronicle and Erimec'i commit several errors-notably, in the dates of Lewon V's reign, the alleged participation of the sultan in

61. For the original version in Armenian, see A. Tēr-Yovhannēseanc', Žamanakagrakan patmut'iwn S. Erusałēmi [Chronological history of Holy Jerusalem], vol. 1 (Jerusalem: Press of Sts. James, 1890), 214; Aławnuni, Miabank' ew ayc'eluk', 171. Cf. the brief compilation of chronicles preserved in J995, fols. 468-70: N. Połarean, Mayr c'uc'ak jeragrac' Srboc' Yakobeanc' [Grand catalog of Sts. James manuscripts], vol. 3 (Jerusalem: Press of Sts. James, 1968), 597.

62. King Kostandin II.

63. Here meaning Sts. James Cathedral in Jerusalem. 
the capture of Sis, and the year of the queen's death-these texts are apparently accretions of earlier accounts, for their vision of the events essentially corresponds to that of the manuscript colophons reproduced above. Another Armenian patriarch of Jerusalem, Minas Hamt'ec'i (1697-1704), also included information on the takeover of Sis and the capture of the last king, "together with Queen Mariun," in his Genealogy of Armenian kings. ${ }^{64}$ Remarkably, in these late narratives Mariun continues to be called queen, whereas no specific reference can be found to Margaret of Soissons, who was the actual queen at the time of the kingdom's fall. From the time of Martiros Łrimec'i (probably even before), there has been persistent confusion about the identities of the noblewomen who accompanied Lewon $\mathrm{V}$ during his exile from Sis. Later traditions and stories woven around the last queens of Cilicia resulted in mistaken identifications regarding various episodes of their lives. A point that further deepened this confusion is the mention of a royal heir, traditionally represented in scholarship as Mariun's daughter. As will be seen below, this claim does not in fact accord with contemporary or near-contemporary sources, some of which are explicit in representing the complex genealogy of the royal family and of the court members. These questions are discussed below, taking into consideration-among other evidencerecords of several nonsystematic excavations that have taken place at the Sts. James Cathedral since the nineteenth century.

\subsection{Archaeological Information}

In November 1897, during excavations prompted by renovation works, two skeletons were found in front of the chapel of the Martyrdom of St. James the Great, also known as the chapel of Glxadir, the most popular pilgrimage destination in the Cathedral of Sts. James. Małak'ia Ormanean suggested that these were the remains of Queen Mariun and Lady Remye, ${ }^{65}$ apparently on the basis of Dardel's account, according to which Remye and her husband accompanied Mariun on her trip to Jerusalem (see above). Tigran Sawalaneanc', followed by Kevork Hintlian and Parsegh Kalemderian, attributed the remains to Mariun and "her daughter." ${ }^{66}$ Another attribution for the two skeletons found in 1897 was made by Mkrtič Aławnuni, who ascribed them to Mariun and her young relative P'enna. ${ }^{67} \mathrm{P}^{\prime}$ enna has also been

64. Minas Hamt'ec'i, Azgabanut'iwn t'agaworac' hayoc' [Genealogy of Armenian kings] (Constantinople, 1735), 57-58.

65. M. Archbishop Ormanean,Haykakan Yerusałēm:NkaragirAt'óroySrboc' Yakobeanc'[ArmenianJerusalem: A description of the See of Sts. James] (Jerusalem: Press of Sts. James, 1931), 14-15. See also M. Archbishop Ormanean, Azgapatum [History of the nation], vol. 2 (Constantinople: Press of V. and H. Tēr-Nersēsean, 1914), $\$ 1346$.

66. T. Sawalaneanc', Patmut'iwn Erusałèmi [History of Jerusalem], vol. 1 (Jerusalem: Press of Sts. James, 1931), 526, n. 1; K. Hintlian, History of the Armenians in the Holy Land, 2nd ed. (Jerusalem: Press of Sts. James, 1989), 53; P. Kalemderian, The Armenian Sts. James Cathedral of Jerusalem (Jerusalem: Press of Sts. James, 2007), 12 (Armenian) and 9 (English).

67. M. Bishop Aławnuni, Haykakan hin vank'er ew ekełec'iner Surb Erkrin mēǰ [old Armenian monasteries and churches in the Holy Land] (Jerusalem: Press of Sts. James, 1931), 257-58. 
represented as Mariun's daughter ${ }^{68}$ (or as her granddaughter ${ }^{69}$ )-a widespread opinion that is not, however, attested in fourteenth-century sources. A further opinion about the two deceased noblewomen, who were said to have spent the last years of their lives in Jerusalem before being buried in the Monastery of Sts. James, was expressed by Yarut'iwn Tēr Łazarean, who identified them as Queen Mariun and Countess Fimi. ${ }^{70}$

In November 1957, the newly elected Bishop Šnorhk' Galustean undertook renovation work inside the Sts. James Cathedral with the aim of replacing its old pavement, which has since been covered with marble. ${ }^{71}$ Coming across a skeleton, Bishop Šnorhk' initiated spontaneous excavations, which turned up about a dozen more skeletons and many human bones in the main nave of the cathedral, in the chapel of St. Minas (Menas) and in the Church of Holy Ëymiacin..$^{72}$ Modern visitors to the Sts. James Cathedral are told that the massive column standing near the Glxadir shrine marks the burial place of Queen Mariun (Fig. 1), a claim that echoes Martiros Erimec'i's seventeenth-century narrative.

Within the monastic complex there are, however, two other locations that have been associated with Mariun's tombstone. In his voluminous Chronological History of Jerusalem (1890), Bishop Tēr-Yovhannēseanc' writes that although the tombs of Queen Mariun and of "her daughter P'enna" have since been covered, they were buried in the gavit' of the Sts. James Cathedral, near a column. ${ }^{73}$

68. See, e.g., M. Č'amč'eanc', Patmut'iwn hayoc' [History of Armenia], vol. 3 (Venice: Press of Yovhan P'iac'eanc', 1786), 364; X. Vanec'i Mxit'arean, Hamarōt patmut'iwn Erusałēmi ew storagrut'iwn srbazan teleac' [A brief history of Jerusalem and description of the holy sites] (Jerusalem: Press of Sts. James, 1867), 185; Tēr-Yovhannēseanc', Žamanakagrakan patmut'iwn, 213; R. Ervine, "Women Who Left the World: The Armenian Nuns of Jerusalem," in Patterns of the Past, Prospects for the Future: the Christian Heritage in the Holy Land, ed. T. Hummel, K. Hintlian, and U. Carmesund, 124-34 (London: Melisende, 1999), 127, n. 14; Kalemderian, Armenian Sts. James Cathedral, 12 (Armenian) and 9 (English).

69. R. Ervine, "The Brotherhood of the Sts. James Monastery and the Symbolism of Armenian Jerusalem," in Monastic Life in the Armenian Church: Glorious Past-Ecumenical Reconsiderations, ed. J. Dum-Tragut and D.W. Winkler, 81-104 (Zürich: LIT Verlag, 2018), 89, n. 35.

70. Y. Tēr Łazarean, Haykakan Kilikia: Tełagrut'iwn [Armenian Cilicia: Topography] (Antelias: Armenian Catholicosate of Cilicia, 1966), 294-95.

71. Š. Galustean, "Salarkum S. Yakobay tačarin ew patahakan pełumner ayd artt'iw" [Pavement works at St. James Cathedral and accidental excavations on that occasion], Sion 9-10 (1958): 232-38, at 234.

72. Š. Galustean, “Salarkum S. Yakobay tačarin,” Sion 7-8 (1958): 194-97, and Sion 9-10 (1958): 232-38; Bishop Š. (Galustean), "Norogut'iwnner S. Minasi matran mēj” [Renovations in the Chapel of St. Minas], Sion 11-12 (1958): 289-93. The bulk of the 1958 report of Bishop Šnorhk' was recently translated into English by Yana Tchekhanovets and Fr. Pakrad Berjekian. See Y. Tchekhanovets and P. Berjekian, "Excavating the Armenian Cathedral of St. James in Jerusalem: The Unknown Report from the 1950s," Journal of the Society for Armenian Studies 26 (2017): 119-34; Y. Tchekhanovets, The Caucasian Archaeology of the Holy Land: Armenian, Georgian and Albanian Communities between the Fourth and Eleventh Centuries CE (Leiden: Brill, 2018), 98-106.

73. Tēr-Yovhannēseanc', Žamanakagrakan patmut'iwn, 213. It is not clear which part of the Sts. James Cathedral he means with gavit'. There are two possibilities: the modern gavit' is where the principal entrance is currently situated (i.e., in the western part of the cathedral), whereas the gavit' of the original medieval structure was situated where the chapel-church of Holy Ējmiacin is now (i.e., in the southern part of the cathedral). The chapel was constructed in the seventeenth century by walling up the gavit and thus closing the main entrance of the original structure. For the cathedral's plan and architectural history, see D. Pringle, The Churches of the Crusader Kingdom of Jerusalem: A Corpus, vol. 3: The City of Jerusalem (Cambridge: Cambridge University 


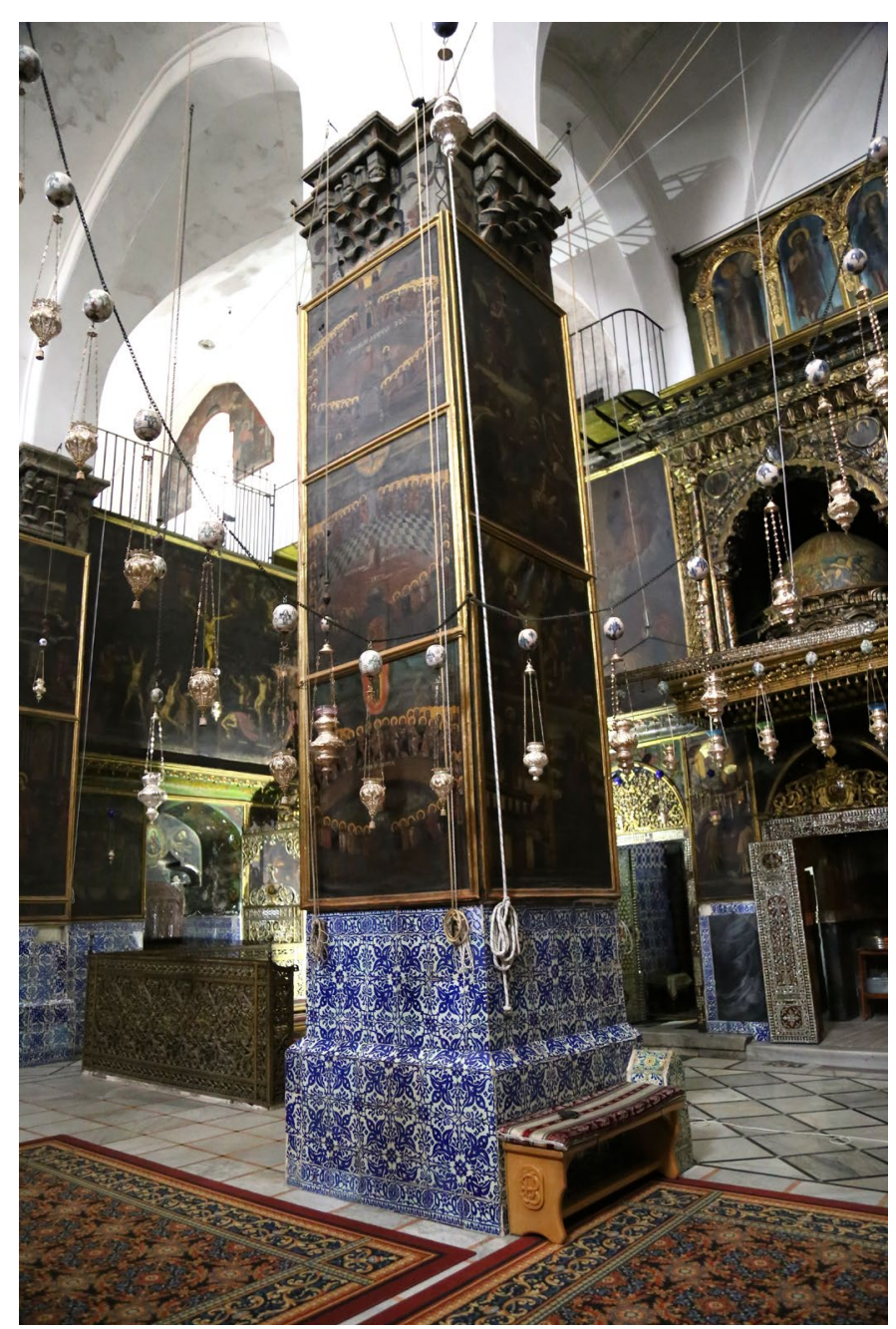

Figure 1: The massive column facing the Chapel of the Martyrdom of St. James the Great, northwestern view, Sts. James Cathedral, Jerusalem.

(Photo: Gohar Grigoryan Savary, December 2018)

He also reports that sometime in the nineteenth century the galiacik' (i.e., the Franks/ French) made an inquiry about the grave of P'enna. ${ }^{74}$ Tēr-Yovhannēseanc"s identification of "Mariun and her daughter P'enna" and his locating their graves within the cathedral's gavit" coincide with the mid-nineteenth-century records of Xorēn Mxit'arean, who describes the western gavit' as containing the graves of these two women, as well as of three Armenian patriarchs of Jerusalem-Abraham, Yovhannēs, and Dawit' (see below). ${ }^{75}$

Press, 2007), 168-82, esp. 172-78. See also A. Kazaryan, "The Armenian Cathedral of Saints James in Jerusalem: Melisende and the Question of Exchange between East and West," in Romanesque Patrons and Processes:Design and Instrumentality in the Art and Architecture of Romanesque Europe, ed. J. Camps, M. Castiñeiras, J. McNeill, and R. Plant, 83-92 (London: Routledge, 2018).

74. Tēr-Yovhannēseanc', Žamanakagrakan patmut'iwn, 213.

75. Mxit'arean, Hamarōt patmut'iwn Erusałēmi, 185. 
Another location for Mariun's gravestone has been indicated by Abraham Terian, who specifies that "an ancient tombstone inscription marks her [Mariun's] grave in the southwestern corner of the courtyard of the Saint James monastery." 76 Currently, that corner of the courtyard is occupied by the tombstone of Patriarch Abraham of Jerusalem, with an inscription mentioning the Armenian year 641, or 1192 CE (see Fig. 2). ${ }^{77}$ During my several visits to the Sts. James Monastery, I was unable to discern the supposed gravestone of Queen Mariun in that courtyard. ${ }^{78}$

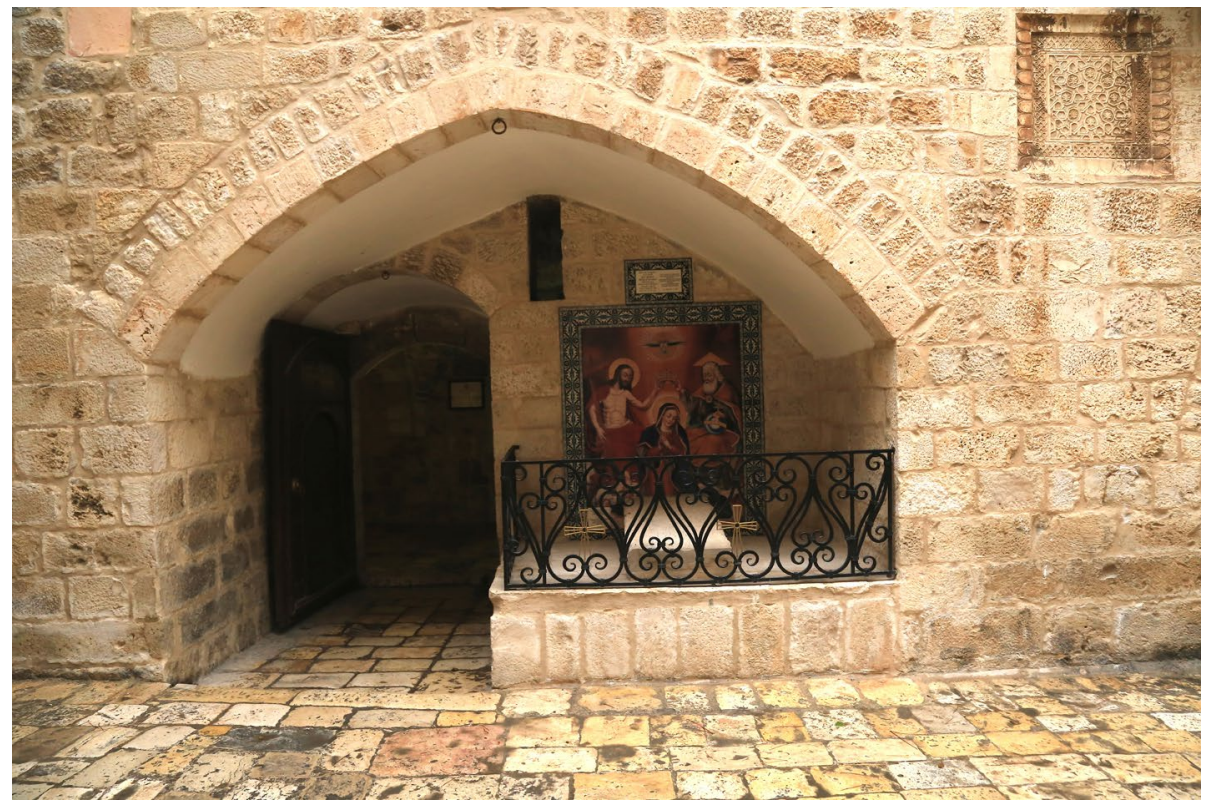

Figure 2: Armenian Patriarchate of Jerusalem, entrance to the courtyard and the tombstone of Patriarch Abraham, facing the modern principal entrance of the Sts. James Cathedral.

(Photo: Gohar Grigoryan Savary, December 2018)

Interestingly, however, in 1867, when the abovementioned restorations of the Sts. James Cathedral had not yet taken place, the gavit', where the tombstone of Patriarch Abraham was initially located, is described as follows (translation from Armenian): ${ }^{79}$

76. A. Terian, "Armenian Writers in Medieval Jerusalem," in Patterns of the Past, Prospects for the Future: The Christian Heritage in the Holy Land, ed. T. Hummel, K. Hintlian and U. Carmesund, 135-56 (London: Melisende, 1999), 145, n. 35.

77. The inscription text is reproduced in Aławnuni, Miabank' ew ayc'eluk', 5-6.

78. The information about Mariun's gravestone being located in the southwestern corner of the courtyard was communicated to Abraham Terian by the late Archbishop Norayr Połarean some six decades ago. The tombstone that the savant archbishop identified as the gravestone of Queen Mariun was a poorly inscribed stone, half the size of the tombstone of Patriarch Abraham, which currently occupies the space under the baldachin-like structure (private communication with Abraham Terian, October 5, 2018).

79. Mxit'arean, Hamarōt patmut'iwn Erusałēmi, 185. 
First, if you enter the gavit' of the holy church of this glorious monastery, you will see the image of the Awesome Judgment, which is situated above the main door of the church. And on each side of this door there is a liturgical table in the form of a built-in closet; one of them is named after Saint Gēorg and the other one after Nikołayos Skančelagorc [Nicholas the Wonderworker], and on each of these mass is served on the corresponding feast days. And in this gavit' are buried Mariam, the queen of King Lewon, and her daughter Benna, also the patriarchs Abraham, Yovhannēs, and David. And the walls of the gavit' are decorated with many wonderful images.

This pre-restoration description of the main entrance by Xorēn Mxit'arean, a scholar of the Sts. James congregation, appears to correspond entirely with the modern appearance of the cathedral's main entrance, with its depiction of the Last Judgment in the upper part and with the two closet-like altars dedicated to St. George and St. Nicholas, respectively (Fig. 3). These closet-altars are still in use for occasional ceremonies. As for the tombstones mentioned by Mxit'arean, apparently they were later moved out of the gavit' or around it, as was the case with Patriarch Abraham's tombstone (Fig. 2). Although several written and oral traditions-some of which date back centuries-regarding Queen Mariun's final resting place seem to corroborate each other, only serious archaeological research will help us achieve any level of certainty on this and many other issues related to the multilayered history of the Sts. James Cathedral.

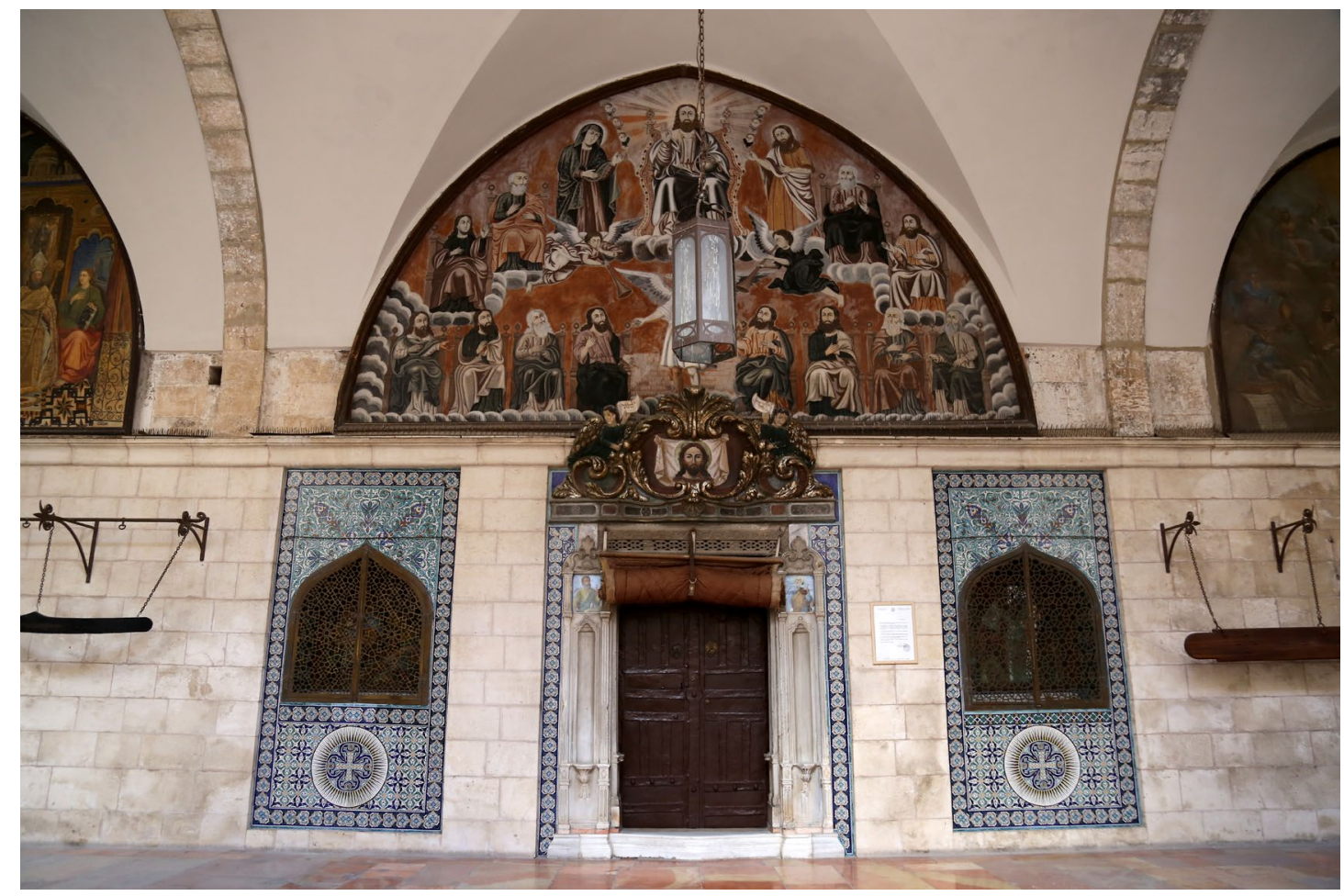

Figure 3: The modern principal entrance of Sts. James Cathedral, flanked on both sides by closet-like altars dedicated to St. George and to St. Nicholas the Wonderworker. (Photo: Gohar Grigoryan Savary, December 2017) 


\section{Did Queen Mariun Have a Daughter?}

As seen above, various narratives and studies mention Mariun's having a daughter who presumably accompanied her to Jerusalem and was even buried in the Sts. James Cathedral together with her mother. The name of this daughter differs from one study to another: she appears as P'enna (Benna), as Fimi (or Euphemie), or simply as "Mariun's daughter." However, neither in the minor texts cited above nor in the extensive chronicle of Jean Dardel can we find anything about a daughter of Mariun. When describing the exile of Lewon's retinue from Sis, Dardel lists the following aristocrats: "the king and the queen [Lewon V and Margaret of Soissons], their children, the former queen of Armenia [Mariun], who was the spouse of the tyrant King Kostandin I, and Sir Sohier Doulcart and his countess [Lady Remye], as well as Armenian barons and great men from the city of Sis." In this account, the former queen Mariun is not said to be accompanied by any child, male or female. If she had been, the child or children would have been mentioned right after her name, like the children of the king and the queen (that is, of Lewon and Margaret) were. Queen Margaret died in Mamluk captivity sometime in the early 1380s: in 1384, two Franciscan pilgrims are said to have visited the graves of Margaret and her daughter Maria in Cairo ${ }^{80}$ The absence of Margaret of Soissons in Armenian historiography and the misrepresentation of Mariun as the spouse of Lewon V may have reinforced later associations connecting the last king's children to Mariun. Let us now consider Mariun's heirs and whether she ever had a daughter, as is often presumed.

A significant primary source for clarifying the genealogy of the royal family is the principal colophon of the Gospel of Queen Mariun. This richly illustrated manuscript was produced in 1346 at the Surb Nšan (Holy Sign/Cross) Monastery of Sis and is currently kept at the Armenian Patriarchate of Jerusalem (J1973). I have dealt with this royal manuscript elsewhere, providing also transcriptions and translations of its colophons. Here I will make use of the principal colophon insofar as it pertains to the question of Mariun's "daughter." Another peculiarity of the Gospel of Queen Mariun is its remarkable miniature painting, whose interpretations have further confused the issue of Mariun's supposed daughter. Thus, among the illustrations created by the famous Sargis Picak there is an inscribed image of Queen Mariun (fol. 258v; Fig. 6) and two further images of a stemma-bearing female figure (fols. 8v, 114r; Figs. 4-5).

80. For this account and references to sources, see G. Golubovich, Biblioteca bio-bibliografica della Terra Santa e dell' Oriente Francescano, vol. 5: dal 1346 al 1400 (Florence: Collegio di S. Bonaventura, 1927), 230-31; Kühl, Leon V. von Kleinarmenien, 145-46; C. Mutafian, "Prélats et souverains arméniens à Jérusalem à l'époque des croisades: Légendes et certitudes (XII $-X I V$ e siècle)," Studia Orientalia Christiana-Collectanea 37 (2004): 109-51, at 149; C. Mutafian, "Les arméniens et Jérusalem au Moyen Âge (IV e-XIV siècle)," Revue arménienne des questions contemporaines 4 (January 2006): 9-18, at 16. With this account, another widespread error, referring to Margaret of Soissons's and her daughter's deaths in Jerusalem and their burial at Sts. James Cathedral, can be refuted. 


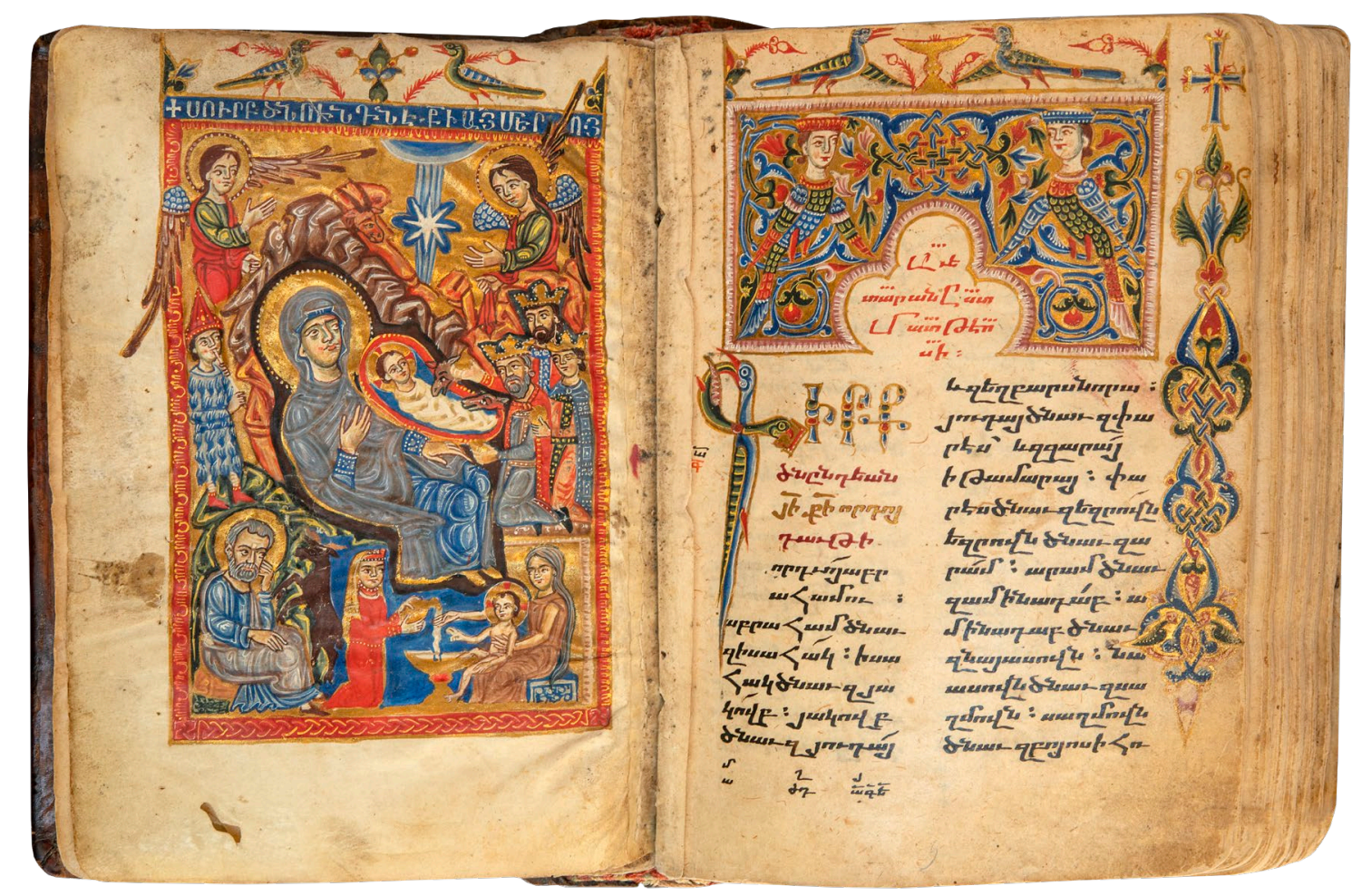

Figure 4: Gospel of Queen Mariun (1346 CE),

Armenian Patriarchate of Jerusalem, manuscript J1973, fols. 8v-9r. (Photo: Hrair Hawk Khatcherian, July 2014)

Several art-historical studies have identified these images as representing Mariun's daughter "Princess Fimi." It turns out, however, that this identification is based on a false reading of the colophon of the Gospel of Queen Mariun, which requires closer consideration. Before we turn to the relevant passages of that colophon, some remarks must be made to clarify the reason for the abovementioned confusion.

81. S. Der Nersessian, Miniature Painting in the Armenian Kingdom of Cilicia from the Twelfth to the Fourteenth Century, vol. 1 (Washington: Dumbarton Oaks Research Library and Collection, 1993), 146, 160, also 142; I. Rapti, "Le mécénat des princesses arméniennes," in Impératrices, princesses, aristocrats et saintes souveraines de l'Orient chrétien et musulman au Moyen Âge et au début des Temps modernes, ed. É. Malamut and A. Nicolaïdès (Aix-en-Provence: Presses universitaires de Provence, 2014), 265 (based on Der Nersessian); I. Christoforaki, "An Unusual Representation of the Incredulity from Lusignan Cyprus," Cahiers archeologiques 48 (2000): 71-87, at 83 (based on Der Nersessian). Another view, however, which was expressed by Sirarpie Der Nersessian before her monumental study on Cilician miniature painting and which was followed by more scholars, interprets both stemma-bearing images as depicting Queen Mariun, which seems to me the most plausible identification. See S. Der Nersessian, Aght amar: Church of the Holy Cross (Cambridge, MA: Harvard University Press, 1965), 44-45; S. Der Nersessian, Armenian Art (Paris: Arts et métiers graphiques, 1978), 162; N. Bishop Covakan, "Yišatakaran Nersēs episkoposi" [Colophon of Bishop Nersēs], Sion 3-4 (1967): 125-29, at 125; Covakan, Hay gričner, 137 (considers both identifications- Mariun or her daughter- possible); B. Narkiss, ed., with M. E. Stone, Armenian Art Treasures of Jerusalem, historical survey by A. K. Sanjian (Jerusalem: Massada Press, 1979), 87; L. Zakarian, "Les arts," in Le royaume arménien de Cilicie (XII $-X I V^{e}$ siècle), ed. C. Mutafian, 127-39 (Paris: CNRS, 1993), 136; Terian, “Armenian Writers,” 145, n. 35. 


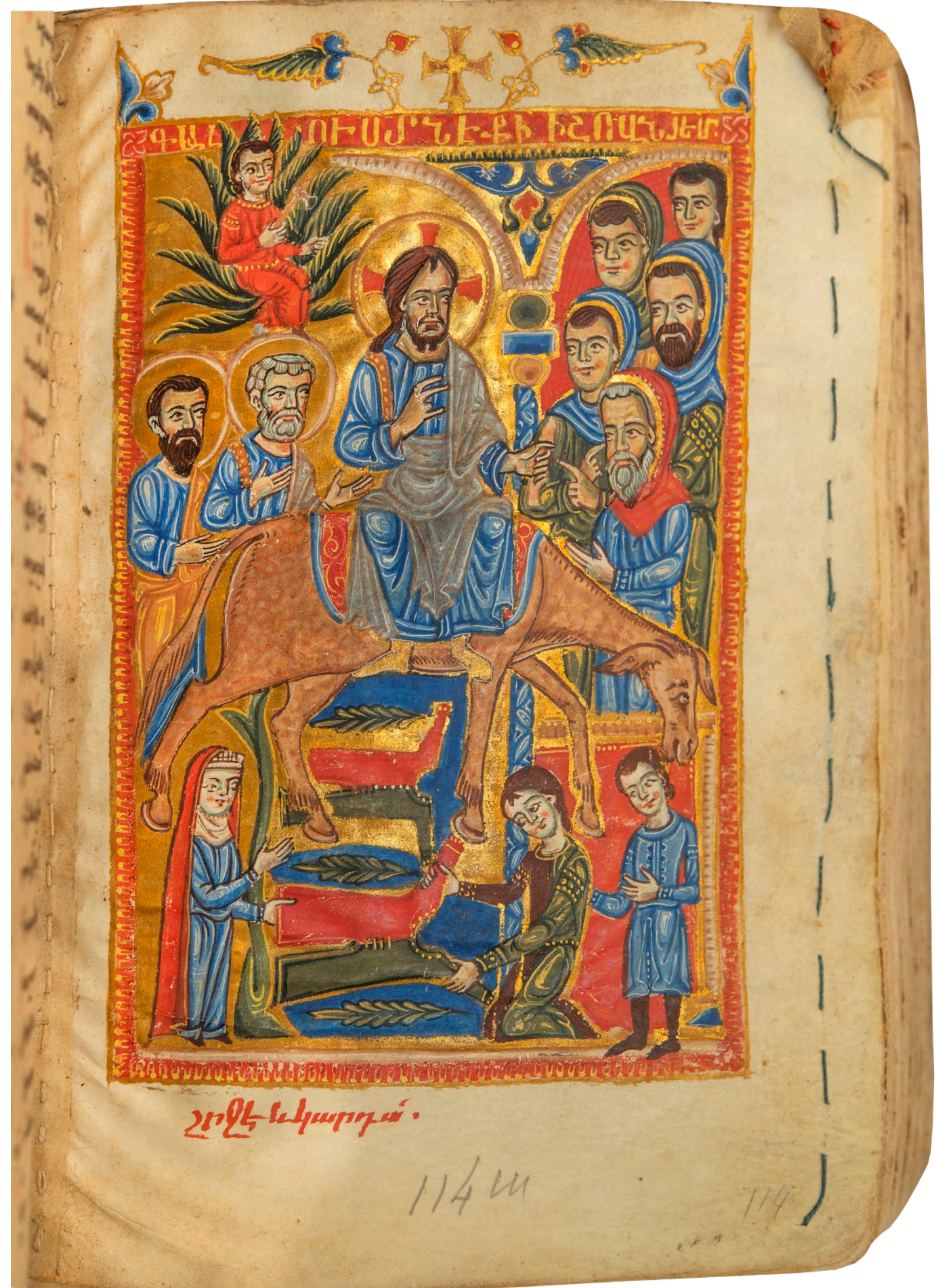

Figure 5: Gospel of Queen Mariun (1346 CE), Armenian Patriarchate of Jerusalem, manuscript J1973, fol. 114r. (Photo: Hrair Hawk Khatcherian, July 2014) 


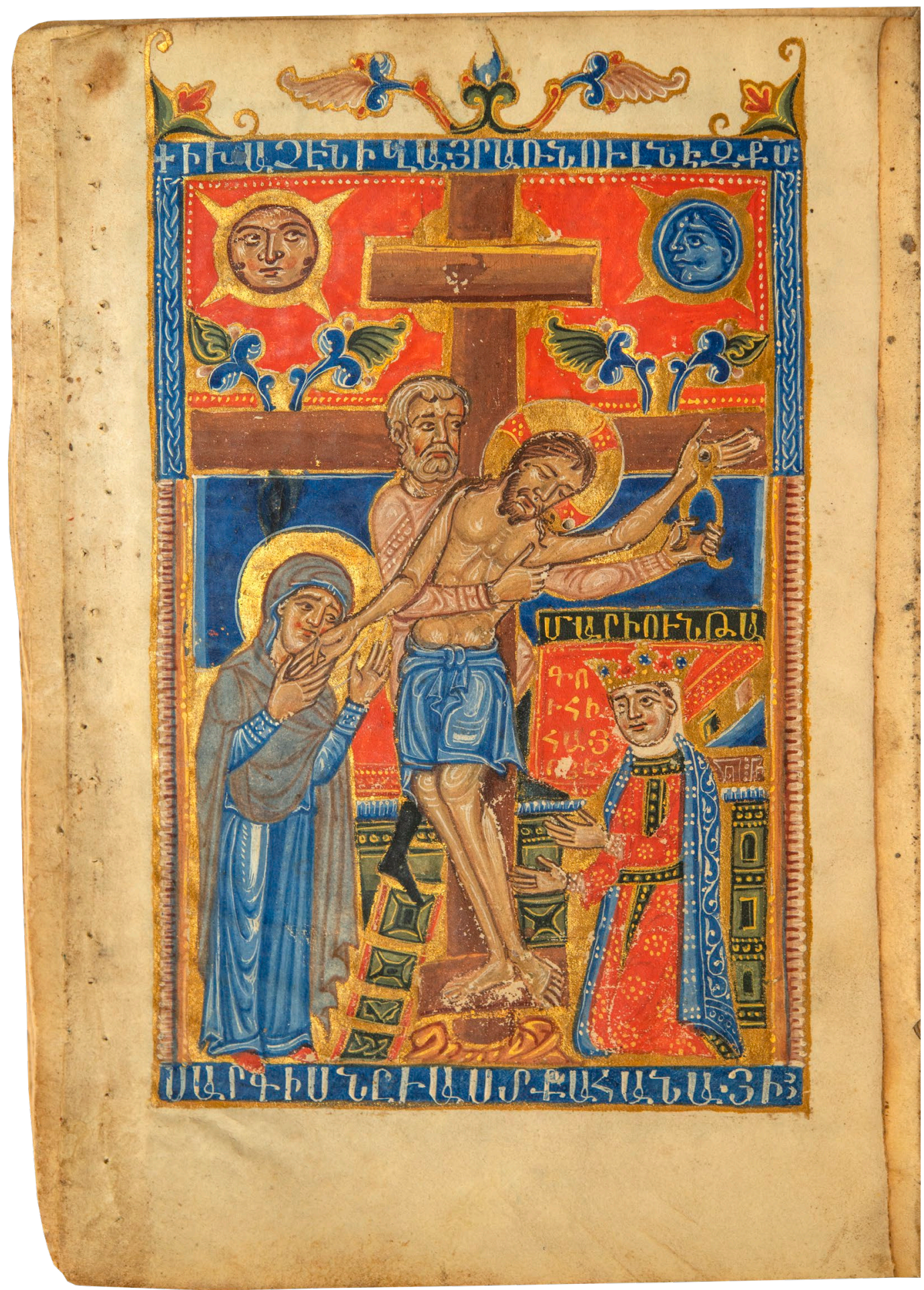

Figure 6: Gospel of Queen Mariun (1346 CE), Armenian Patriarchate of Jerusalem, manuscript J1973, fol. 258v.

(Photo: Hrair Hawk Khatcherian, July 2014) 
The scribe Nersēs composed the principal colophon of J1973 using, first, the genealogy of Queen Mariun (the manuscript's intended owner) and, second, the genealogy of her spouse, King Kostandin I. Reading the colophon in this light, it becomes easier to identify the aristocrats mentioned therein-altogether seventeen persons, whose relationships are visualized in the genealogical chart included in this article (Fig. 7).

\section{Figure 7: Royal family members mentioned in the colophon of the Gospel of Queen Mariun (J1973), 1346 CE.}

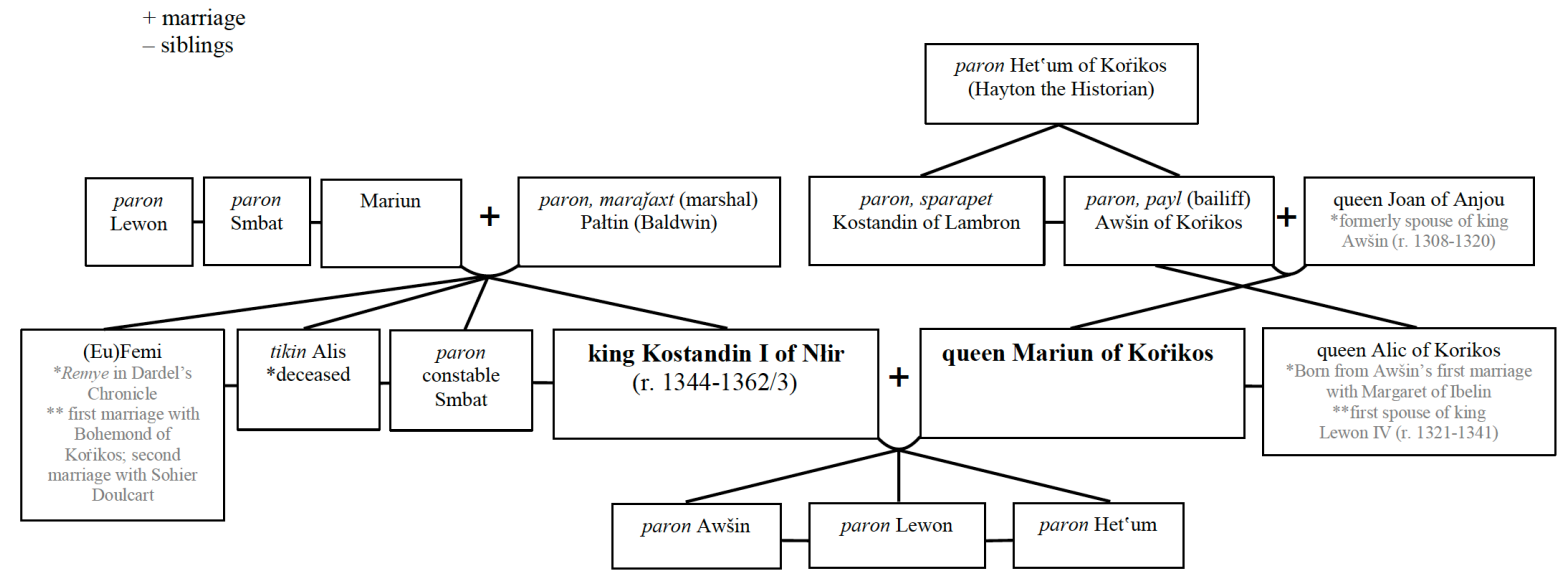

Unsurprisingly, some of these ruling aristocrats have the same first names, popular at that time within the royal court. Thus, the same pedigree colophon mentions not only Queen Mariun (as Mariawn) but also another noblewoman of the same name, Lady Mariawn, and her daughter Femi. The identities of the two homonymous women mentioned in the same colophon were conflated, and the expression "her daughter Femi" was mistakenly connected to Queen Mariun. Lady Mariun was the spouse of Marshal Pattin (Baldwin) and the mother of King Kostandin I-that is, Queen Mariun's mother-in-law. Consequently, Femi (elsewhere Ephemie) is the daughter of Lady Mariun (not of Queen Mariun) and of Marshal Pałtin and a sister of King Kostandin I; ${ }^{82}$ she later appears as Countess Femi (Ephemie/Fimi/Remye) in collaboration with Lewon V and Queen Mariun. ${ }^{83}$ Although the colophon translated below has thus been the cause of the misidentification of Queen Mariun with Lady Mariun, it is in fact a precise and invaluable source for reconstructing the relationship between these two noblewomen. ${ }^{84}$ The bold part of the text refers to Lady Mariun and her daughter Femi.

82. See Rüdt-Collenberg, Rupenides, Hethumides and Lusignans, III (H2), no. 167 (mentioned as Euphemie).

83. Chronique d'Arménie, 47, also 61; Yovhannu Dardeli Žamanakagrut'iwn, 78-79, also 105. See also Kühl, Leon V. von Kleinarmenien, 123.

84. Already in 1937, when referring briefly to J1973, Archbishop Garegin Yovsēp'eanc' noticed that both the spouse and the mother of King Kostandin were called Mariawn. See G. Yovsēp'eanc', Hawuc' T'ari Amenap'rkič'o ew noynanun yušarjanner hay aruesti mě̌: Patma-hnagitakan usumnasirut'iun [The All Savior of Hawuc' T'ar and homonymous monuments in Armenian art: A historical-archaeological survey] (Jerusalem: Press of Sts. James, 1937), 83, n. 1. 
The paragraph division is mine, aimed at facilitating the reading of the colophon as conceived by the scribe Nersēs.

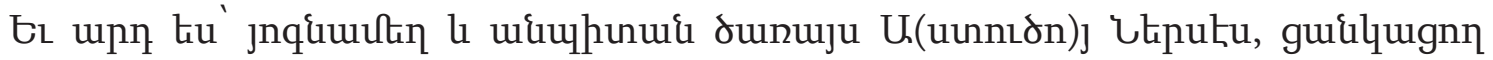

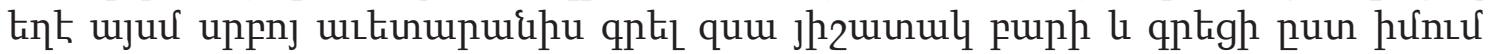

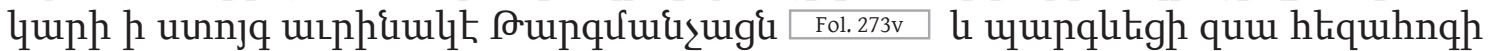

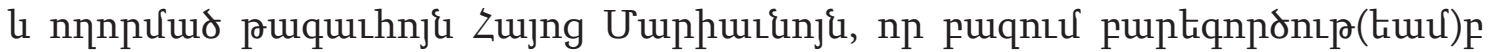

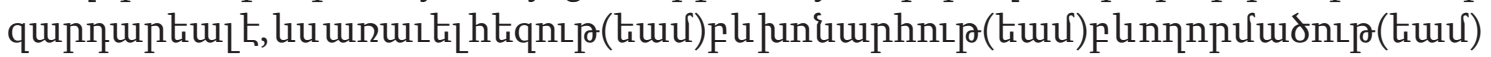

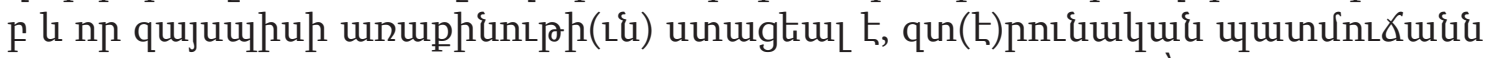

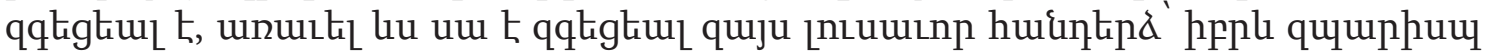

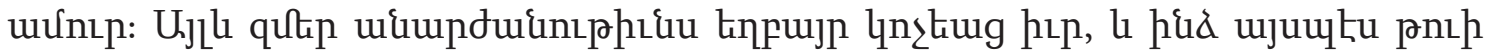

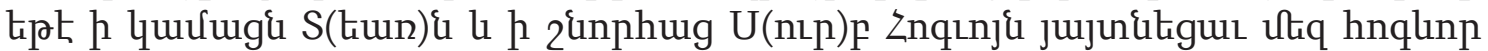

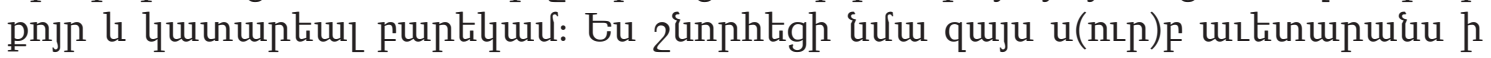

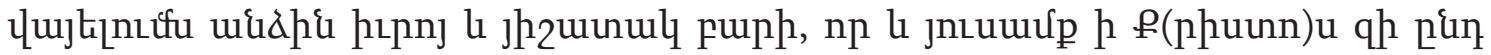

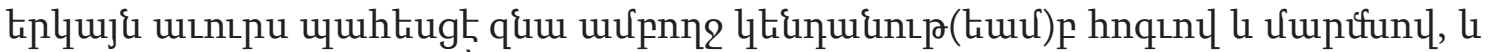

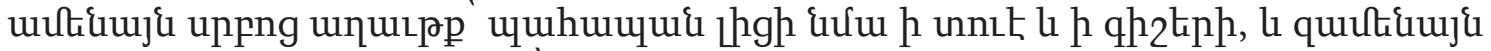

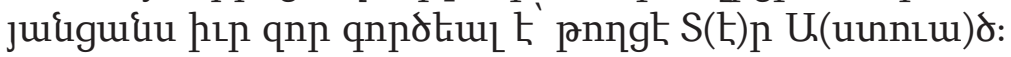

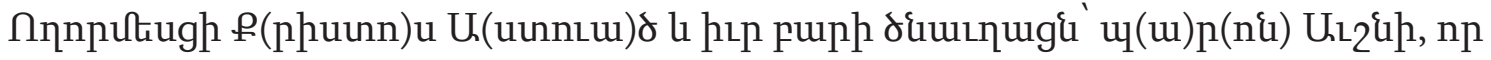

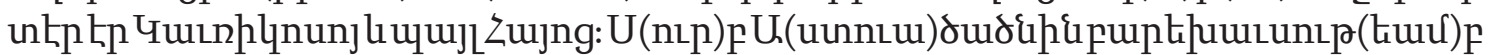

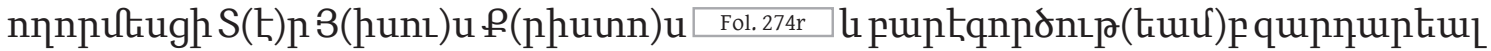

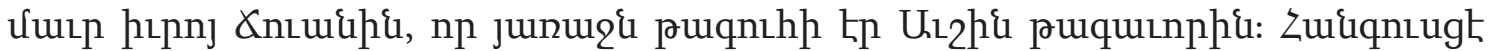
S(t)p 3(huns)u qhnqhu \&npu juppujnıpti(wi)\& tplquhg: @nnputiugh e(phuunn)

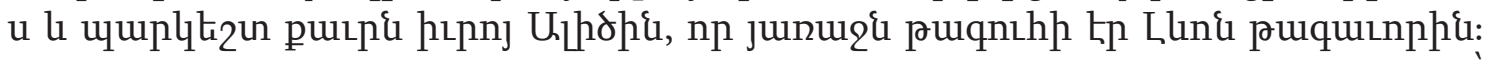

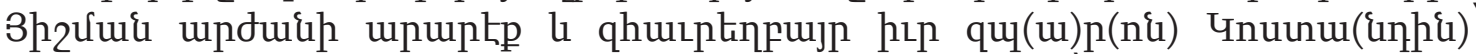

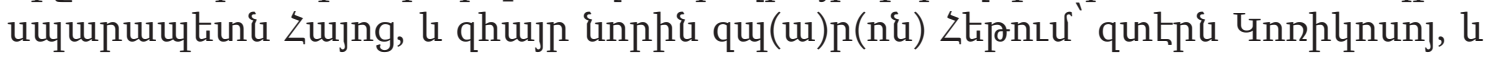
huiqqnuugk qhnqhu angu:

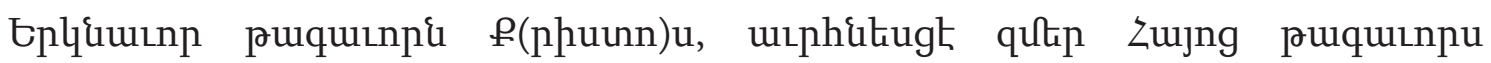

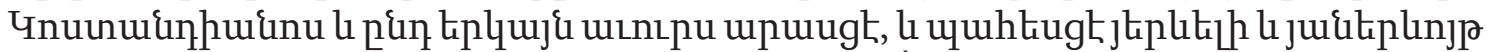

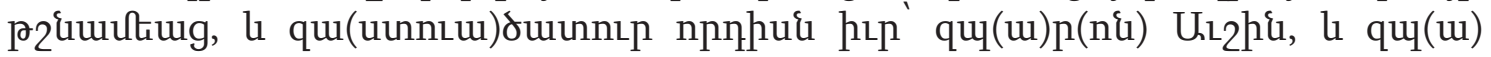

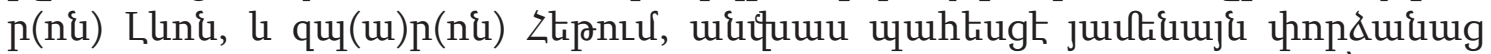

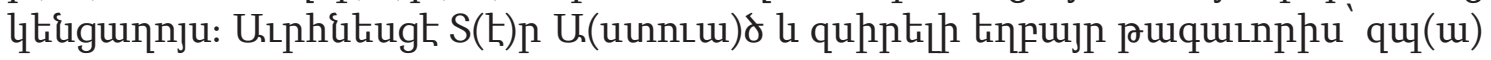

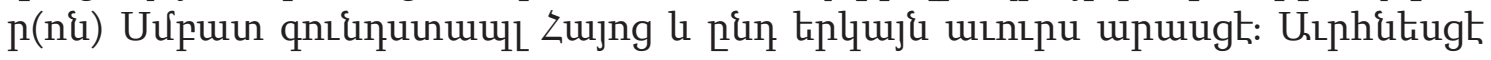

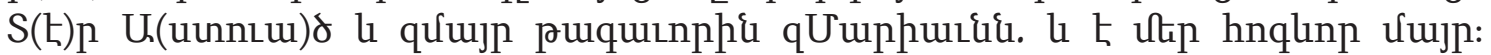

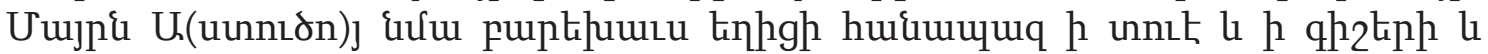

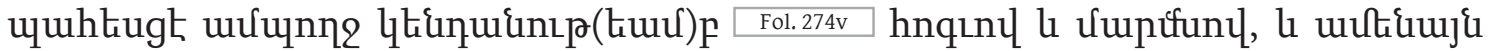

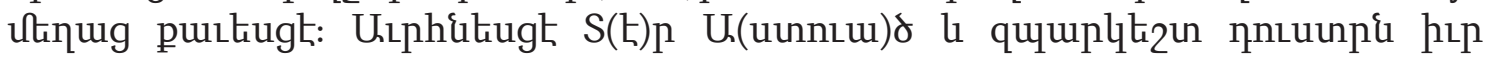

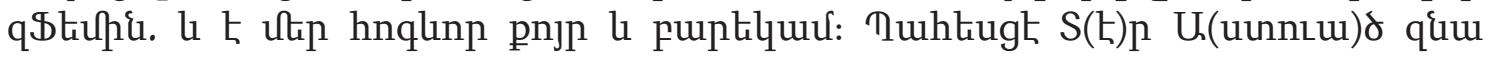

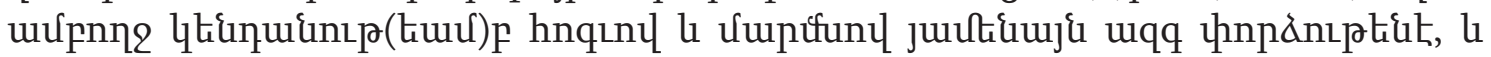

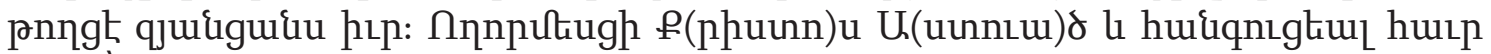

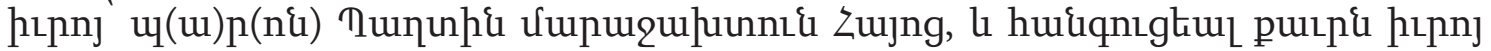

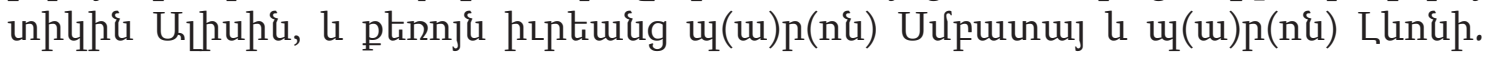




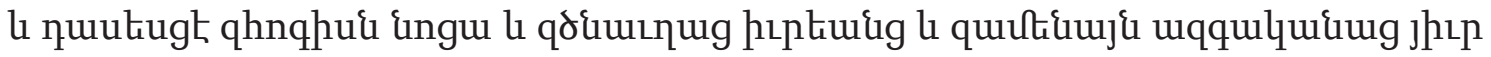
u(nıp)p uppujnıphtuq:

Translation:

Fol. 273r ...And I, Nersēs, sinful and useless servant of God, desired to copy this holy gospel as a good remembrance, and I copied it according to my abilities from an authentic example by the Translators Fol. 274v and offered it as a gift to the meek [lit. meek of soul] and merciful queen of the Armenians, Mariawn, who is adorned with numerous good deeds and with utmost mildness, humbleness, and charity, and who has acquired so much virtue and is clothed with the Lordly garment; and yet further, she is clothed with this luminous cloak as a strong rampart. Despite our unworthiness, she called us her brother, and it seems to me that it was by the Lord's will and by the grace of the Holy Spirit that she appeared to us as spiritual sister and perfect friend. I offered her this holy gospel for her own enjoyment and as a good remembrance, hoping that Christ will keep her safe with full vitality of spirit and body for long days. And may the prayers of all the saints be a guardian for her by day and by night; and may the Lord God pardon all the transgressions that she has committed.

May Christ God also have mercy on her [Queen Mariun's] good parents, Paron Awšin, who was the lord of Kawrikos and payl [i.e., bailiff] of Armenia. ${ }^{85}$ Through the intercession of the Holy Astuacacin [i.e., Theotokos] may the Lord Jesus Christ have mercy Fol. 274r also on her mother, Čuan, who is adorned with good works and who formerly was the queen of King Awšin. ${ }^{86}$ May the Lord Jesus grant her soul rest in the Kingdom of Heaven. May Christ also have mercy on her [Queen Mariun's] modest sister Alic, who formerly was the queen of King Lewon. ${ }^{87}$ Make also her uncle, Paron Kostandin, the sparapet [i.e., constable] of Armenia, ${ }^{88}$ and his father, Paron Het ${ }^{\prime} u m$, the lord of Korikos, worthy of remembrance. ${ }^{89}$ May their souls rest in peace.

May Christ, the heavenly king, bless Kostandianos, ${ }^{90}$ our king of Armenia, and grant him length of days, and protect him from enemies visible and invisible. May also his God-given sons, Paron Awšin, Paron Lewon, and Paron Het'um, ${ }^{91}$ be kept unharmed from all the temptations of this life. May the Lord God bless also Paron Smbat, the

85. Awšin, lord of Korikos, father of Queen Mariun. See Rüdt-Collenberg, Rupenides, Hethumides and Lusignans, III (H2), no. 143.

86. This is Joan of Anjou, mother of Queen Mariun. After the death of King Awšin, Joan married payl Awšin, Mariun's father. See ibid., III (H2), no. 143/2. See also above, n. 10.

87. Alic of Korikos, sister of Queen Mariun and the first spouse of King Lewon IV (r. 1321-1341). See ibid., III (H2), no. 173.

88. Constable Kostandin, lord of Lambron and uncle of Queen Mariun. See ibid., III (H2), no. 142.

89. Het'um (Hayton) the Historian, lord of Korikos and father of Constable Kostandin. See ibid., III (H2), no. 117.

90. King Kostandin I, spouse of Queen Mariun. See ibid., III (H2), no. 165 (mentioned as Constantine III).

91. Three sons of King Kostandin I- Awšin, Lewon, and Het'um. The latter's name is unknown to RüdtCollenberg (ibid., III (H2), nos. 188-190). See also Covakan, “Yišatakaran Nersēs episkoposi,” 127, nn. 10-12; Covakan, Vanatur, 273, 276. 
beloved brother of the king and the constable of Armenia, ${ }^{92}$ and grant him length of days. May the Lord God bless also the mother of the king, Mariawn, who is our spiritual mother. ${ }^{93}$ May the Mother of God intercede for her day and night and may She preserve her with full vitality Fol. 274r of spirit and body, and may she be cleansed of all her sins. May the Lord God bless also her [Lady Mariawn's] modest daughter Femi, who is our spiritual sister and friend..$^{94}$ May the Lord God preserve her with full vitality of spirit and body from every kind of temptation, and may He forgive her transgressions. May Christ God also have mercy on his [King Kostandin I's] deceased father, Paron Pałtin, the marajaxt [marshal] of Armenia, ${ }^{95}$ and his deceased sister, Lady Alis, ${ }^{96}$ and their uncle, Paron Smbat, ${ }^{97}$ as well as Paron Lewon..$^{98}$ And may He enroll their souls and the souls of their parents and of all of their kinsmen in the Holy Kingdom.

Although the Femi mentioned in this colophon was clearly not Queen Mariun's daughter, the question remains whether Queen Mariun ever had a daughter. The names of her and Kostandin's sons-Awšin, Lewon, and Het'um, all bearing the title "baron" (paron)are attested in the colophon. Lewon and Het'um are also mentioned in a later colophon preserved in the manuscript J2027 and reproduced above. Apparently, none of these sons survived the fall of the state: Dardel reports that Kostandin I had many children but they all died at an early age "by the will of God, who did not want these children to reign after King Kostandin, for he had no royal blood." ${ }^{99}$ In addition, Yakob Ssec'i, the author of

92. Constable Smbat, brother of King Kostandin I. See Rüdt-Collenberg, Rupenides, Hethumides and Lusignans, III (H2), no. 166.

93. Lady Mariawn, the spouse of Marshal Pałtin and the mother of King Kostandin I- i.e., the mother-in-law of Queen Mariun. For both Queen Mariun and Lady Mariun, their relationship, and their family members, see also Rüdt-Collenberg, Rupenides, Hethumides and Lusignans, genealogical table III (H2), nos. 174 (Queen Mariun), 147/136 (Lady Mariawn), 167 (Femi/Euphemie, daughter of Lady Mariawn and Marshal Pałtin). On Marshal Pałtin and Lady Mariun, see also the extensive colophon of the lectionary preserved as MS Vatican, Borg.arm. 61, fol. 437v, reproduced in E. Tisserant, Codices armeni Bybliothecae Vaticanae Borgiani, Vaticani, Barberiniani, Chisiani (Rome: Typis polyglottis Vaticanis, 1927), 99; Hayeren jeragreri hišatakaranner, ŽD dar [Colophons of Armenian manuscripts, fourteenth century], part 1: 1301-1325, comp. L. Khachikyan, A. Matevosyan, and A. Ghazarosyan (Yerevan: Nairi, 2018), 389.

94. Femi, the daughter of Lady Mariun and Marshal Pałtin; see the previous note.

95. Marshal Pałtin, spouse of Lady Mariun and father of Femi and King Kostandin I. See Rüdt-Collenberg, Rupenides, Hethumides and Lusignans, III (H2), no. 136. On Marshal Pałtin and Lady Mariun, see above, n. 93. See also Mutafian, L'Arménie du Levant, 355-56.

96. Alis, sister of King Kostandin I (deceased by 1346). See Rüdt-Collenberg, Rupenides, Hethumides and Lusignans, III (H2), no. 164.

97. Smbat, brother of Lady Mariawn and uncle of King Kostandin I. See ibid., III (H2), no. 146.

98. Połarean identifies both Smbat and Lewon as brothers of Lady Mariawn (Covakan, "Yišatakaran Nersēs episkoposi,” 127, n. 19). Cf. Rüdt-Collenberg, Rupenides, Hethumides and Lusignans, III (H2), nos. 146-47a (Lewon's name is missing here).

99. Chronique d'Arménie, 35-36; Yovhannu Dardeli Žamanakagrut'iwn, 58-59. Though Kostandin may have had distant blood relations with the royal family or may have been connected to them through earlier intermarriages (on which see Ter-Petrosyan, Xačakirnerə ew hayerə, 428-34), his ascension to the Armenian throne through election was indeed unprecedented in the history of the Cilician state. Two nephews of the 
the seventeenth-century Chronological History of Armenian Cilicia, mentions that King Kostandin and his sons died of the plague in 1356 in Sis. ${ }^{100}$

Given that the colophon of the Gospel of Queen Mariun names six different female members of the royal court (both living and deceased), the simplest explanation for the absence of a royal princess among them is her nonexistence. In the part referring to the family members of Queen Mariun, the colophon mentions the queen, her mother Joan, and her sister Alic, whereas in the second part, referring to the family of King Kostandin, only his mother Mariun, and his sisters Alis (deceased) and Femi are named. None of the sources known to me or to previous writers on this subject mention Queen Mariun's having a daughter. Had she had a daughter, that information would have been reflected in some sources or at least in those manuscript colophons that refer to royal children. As the material treated in this article demonstrates, the erroneous identification of a daughter of Mariun entered modern scholarship from later narratives and from the misreading of the colophon of the Gospel of Queen Mariun and was then reinforced by its circulation from one study to another. Further, the nineteenth-century theory that the two skeletons found in the Sts. James Cathedral belonged to Queen Mariun and "her daughter" can now be dismissed, especially in light of the subsequent discovery of numerous additional skeletons in the cathedral.

\section{Conclusion}

The available evidence about Queen Mariun's last years allows the following conclusions to be drawn. According to the fourteenth-century sources treated in this article-namely, Jean Dardel's Histoire d'Arménie and several manuscript colophons-after the fall of the Armenian kingdom the queen journeyed to Aleppo, Cairo, and then Jerusalem, where she passed away and was buried in the Cathedral of Sts. James. The source closest to her in time is the account of Vahram, the next owner of the now-lost gospel book, since he acquired the manuscript directly from the queen before her death. It is Vahram ${ }^{101}$

previous King Guy Lusignan- Bohemond and Lewon (the sons of the former pali Jean Lusignan)- were alive and could have a stronger claim to the royal throne than any other nobleman did, since their grandmother, Princess Zapēl, was the daughter of King Lewon II Rubenid-Het'umid. It appears that this delicate matter did not escape the attention of the newly elected king: shortly after coming to the throne, Kostandin I tried to assassinate the Lusignan brothers and their mother, Lady Sult'an, who left the Armenian kingdom and fled to Cyprus, taking shelter in the hospice of St. Simeon (see Chronique d'Arménie, 32-34; Yovhannu Dardeli Žamanakagrut'iwn, 53-57). King Kostandin's hostile attitude toward the Lusignan heirs is probably one of the reasons Dardel assesses his reign quite negatively, often juxtaposing him with the "brave and courageous" Lusignan kings.

100. See V1318/923, fols. 240-41. Although the chronicler mistakenly dates the death of King Kostandin as 1356, we know that he died in the early 1360s. Whatever the exact date of the king's death, his sons had already passed away by the time of their own succession to the throne and certainly by the fall of Sis in 1375- an event that finds a modified echo in this later Chronological History preserved in V1318/923. For clarifications of some relevant errors in the Chronological History, see Ter-Petrosyan, Xač akirnerə ew hayerə, 441, n. 18.

101. It is noteworthy that shortly after the fall of the kingdom, a certain Fimi, who identified herself as the "spouse of Vahram," acquired a gospel manuscript in Ayas (present-day Yumurtalık, Turkey). This manuscript (now V1635/125) is a remarkable specimen of the Skewray school of miniature painting. It was commissioned in 1193 by Nersēs Lambronac' $i$ and his brother Het'um. According to the later colophon written by Fimi, the 
who tells us about Mariun's pious way of life in Jerusalem, such as helping the poor (he calls her ałk'atasēr, "charitable," lit. lover of the poor). This portrayal became increasingly popular over time, giving rise to the now widespread view that Mariun became a nun in the Sts. James Monastery. ${ }^{102}$ Although Vahram does not specifically mention her becoming a nun, the monastic lifestyle adopted by Mariun in the last years of her life appears to support this possibility and reflects similar practices of female spirituality in late medieval Jerusalem. When heading for Jerusalem to lead "an ascetic life, full of virtuous deeds," Mariun carried along from Cilicia several objects, such as two gospel manuscripts and a holy cross, which must have also accompanied her during her final settlement in the Holy City. Crosses and sacred manuscripts are the two most often used objects in the liturgical and devotional practices of the Armenians, but they are also two symbols through which the iconography of monasticism was expressed: thus, in one of the miniatures depicting "Saint Grigor the Hermit" (Unıppq qphqnp Kquuınp, as the accompanying inscription reads), the renowned saint of Narekavank" is shown holding a golden cross and a richly adorned book in his hands (Fig. 8). Although the current state of this miniature portrait suggests a later provenance than the twelfth-century manuscript in which it is found, it nevertheless bears traces of the Armenian reception of medieval monasticism. ${ }^{103}$

manuscript came to Ayas from the captured Lambron castle. One might speculate that Fimi's spouse Vahram is the same person who had acquired from Queen Mariun the now-lost gospel of King Kostandin I. What is certain, however, is that both Fimi and Vahram were of a high social standing and could afford to buy royal manuscripts that had once belonged to the rich library of Sis or that of the powerful Lambron castle. From a contemporary manuscript colophon we learn that after the fall of Sis many churches and scriptures "had fallen into captivity"

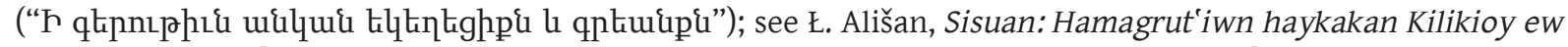
Lewon Mecagorc [Sisuan: A documentary study of Armenian Cilicia and Lewon the Great] (Venice: San Lazzaro, 1885), 228, and Grigoryan, "Armenian Colophons." Another interesting, though not uncommon, feature of the colophon is that Fimi describes the act of buying the gospel manuscript as rescuing it from captivity, hoping, in exchange, that she ("her soul") and her parents will be remembered (V1635/125, fol. 322v): "2ultinghi

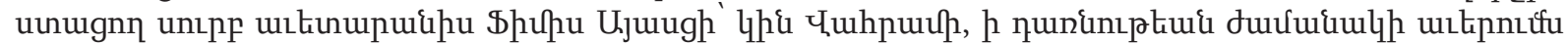

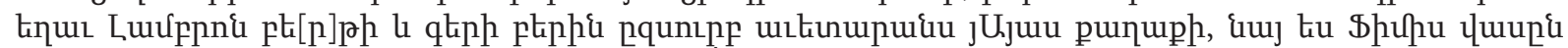

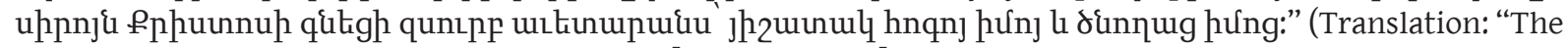
last acquirer of this holy Gospel, I, Fimi Ayasc'i [i.e., from Ayas], spouse of Vahram. In this bitter time, when the castle of Lambron was plundered, this holy gospel was brought to the city of Ayas as a captive, and for the sake of Christ's love, I, Fimi, bought this holy gospel in memory of my soul and of my parents.") The original text in Armenian is reproduced in B. Sargisean, Mayr c'uc'ak hayerēn jeragrac' matenadaranin Mxit'areanc' $i$ Venetik [General catalog of Armenian manuscripts of the Mekhitarist library in Venice], vol. 1 (Venice: San Lazzaro, 1914), 559-60; Xač 'ikyan, ŽD. dari hayeren jeragreri hišatakaranner, 521. Both scholars consider the possibility that Fimi's colophon might have been written during or shortly after the fall of Sis in 1375.

102. Ervine, "Women Who Left the World," 127; Pringle, Churches of the Crusader Kingdom, 170 (although here, too, Queen Mariun is misrepresented as the spouse of Lewon V). See also Ervine, "Brotherhood of the Sts. James Monastery," 89.

103. The image of Grigor of Narek representing him as a hermit is found in M1568, which is the oldest surviving copy of the Book of Lamentations, created in 1173 for Nersēs of Lambron. The same manuscript contains three other images of Grigor, representing him (according to the accompanying inscriptions) as "Grigor the Philosopher" (fol. 7v) and "Grigor the Watchful/Vigilant" (fol. 55v) and as kneeling before Christ (fol. 178v). Unlike these three representations, which are contemporary to the manuscript, the one showing Grigor as a hermit seems to be a result of a later repainting. For the miniature paintings of M1568, see S. Der Nersessian, Miniature Painting, 12-13. 


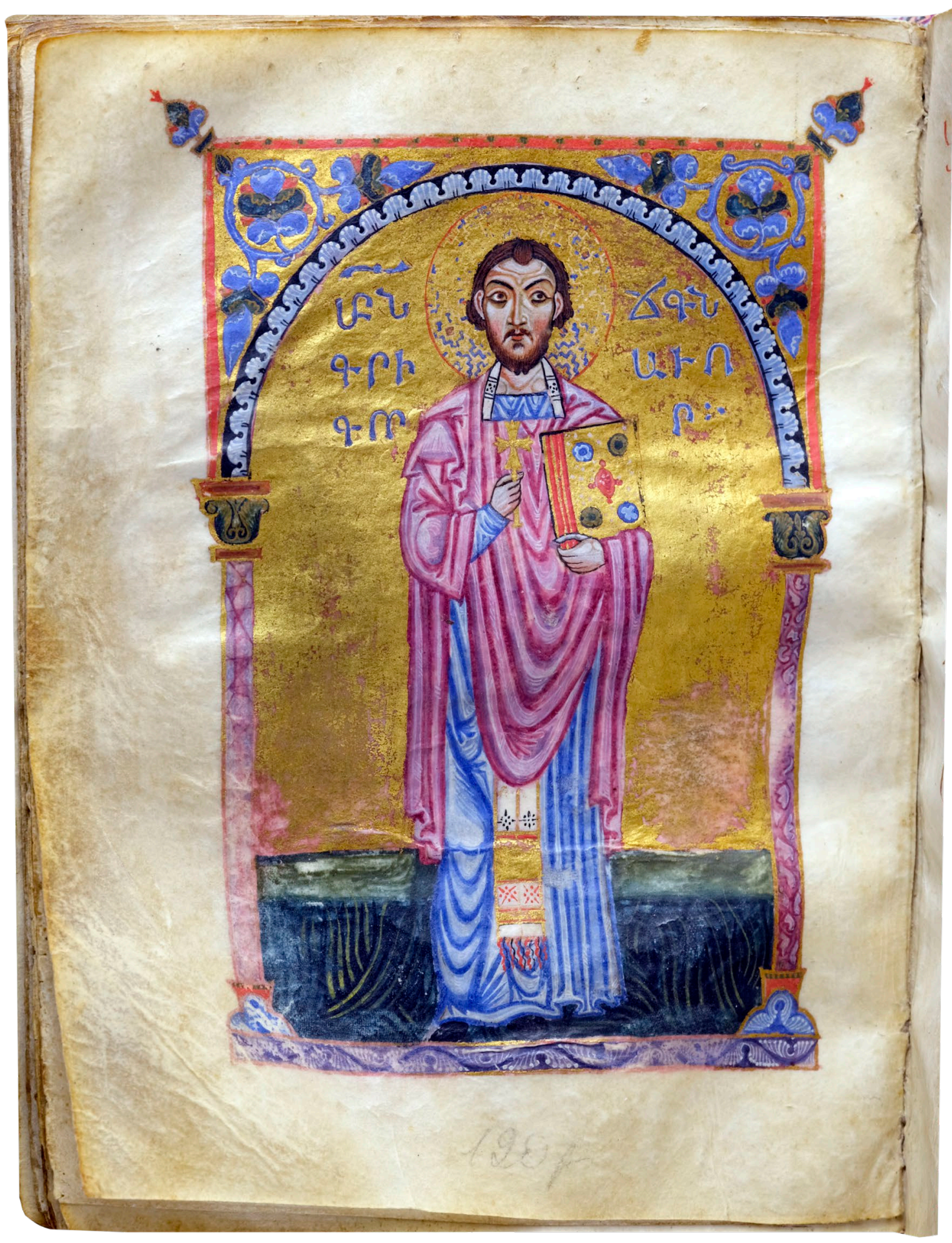

Figure 8: "Saint Grigor the Hermit" in Grigor Narekac'i's Book of Lamentations, manuscript M1568, fol. 120v. (Source: Yerevan, Matenadaran Institute of Ancient Manuscripts.) 
Although the current state of this miniature portrait suggests a later provenance than the twelfth-century manuscript in which it is found, it nevertheless

While a magnifying glass is needed to find any information in the textual sources about Armenian female monasticism in the Holy Land, the archaeological data provide some episodic but valuable details for reconstructing the history of the subject. An example is a tomb inscription in Greek found in 1870 just above the Garden of Gethsemane that mentions a certain "Charate, hegumeness of the chaste monastery of the Armenian women."104 The existence of the Armenian patriarchate in Jerusalem and of numerous hospices belonging to the Armenian Church-many of which are still available for modern pilgrims ${ }^{105}$-made Jerusalem the preferred abode for the aged queen Mariun, who undertook her Holy Land pilgrimage in the unique circumstances of exile after her former kingdom had ceased to exist. In Jerusalem, as in her native Cilicia, the "merciful" queen was still able to perform one of the most emblematic royal duties, almsgiving, continuing in this way the wellestablished tradition of her institutional predecessors. In Mariun's new dwelling at the Sts. James Monastery, the Armenian clergy were managing "a large hospital for bringing the poor of their nation," as evidenced by the twelfth-century eyewitness description of John of Würzburg. ${ }^{106}$

A further issue that the present article clarifies is the widespread misidentification of Queen Mariun with other contemporary noblewomen, as well as the misrepresentation of several young ladies as Mariun's daughters. Although it is not impossible that Mariun had a daughter, the current state of research offers little support for such a claim. On the basis of the colophon of the Gospel of Queen Mariun, we can affirm with some certainty that by 1346 Mariun had no daughter, only three sons (see the genealogical chart, Fig. 7). This also means that the two portraits of a stemma-bearing female person depicted on folios $8 \mathrm{v}$ and $114 \mathrm{r}$ (Figs. 4-5) of that manuscript cannot be associated with Mariun's daughter, as has been proposed, but instead most likely represent Queen Mariun herself, the manuscript's intended owner, whose inscribed portrait appears on folio 258v (Fig. 6). Other fourteenth-

104. See Tchekhanovets, Caucasian Archaeology, 107-8, fig. 72.

105. For pilgrim guesthouses belonging to the Armenian convent of Sts. James, see, e.g., Mxit'arean, Hamarōot patmut'iwn Erusałēmi, 184; Uxtawor, Alēluia yErusałēm [Hallelujah in Jerusalem] (Constantinople: Matt'ēosean, 1903), 53; J. Prawer, "The Armenians in Jerusalem under the Crusaders," in Armenian and Biblical Studies, ed. M. E. Stone, 222-36 (Jerusalem: Press of Sts. James, 1976), 230; Terian, “Armenian Writers,” 145-46; Kazaryan, "Armenian Cathedral," 83. The recent archaeological evidence affirms an Armenian presence also in the earliest xenodochia (pilgrims' hospices) found in Jerusalem, particularly in the Musrara area, on Mount Scopus, and probably also in Mamilla (see Tchekhanovets, Caucasian Archaeology, 213-14, fig. 45, and table 2). This information matches textual and epigraphic sources that provide explicit testimonies of the tradition of Armenian pilgrimage to late antique Jerusalem, which continued to flourish in the following centuries. See M. Stone, "Holy Land Pilgrimage of Armenians before the Arab Conquest," Revue biblique 93, no. 1 (1986): 93-110; E. Bonfiglio, J. Preiser-Kapeller, "From Ararat to Mount Zion: Armenian Pilgrimage and Presence in the Holy Land, Fourth to Seventh Century," in Pilgrimage to Jerusalem: Journeys, Destinations, Experiences across Times and Cultures, ed. F. Daim, J. Pahlitzsch, J. Patrich, C. Rapp, J. Seligman, 75-85 (Mainz: Verlag des RömischGermanischen Zentralmuseums, 2020).

106. ". . . and beyond another street is a large church built in honor of St. James the Great, where Armenian monks live and also have there a large hospital for bringing together the poor of their nation." See Pringle, Churches of the Crusader Kingdom, 169. 
century sources, notably those created after the fall of Sis, are also silent about the existence of a daughter of the queen. It is only in the postmedieval narratives and especially in modern scholarship that we read about women described as Mariun's daughters, but these narratives cite no corroborating primary or near-contemporary sources. The most reliable source on the queen's genealogy is the principal colophon of the Gospel of Queen Mariun, and much of the confusion regarding Mariun's supposed daughter can be traced to a misreading of this text. The available archaeological material, though poorly studied, provides no support to the widespread narrative of "Mariun's daughter": the traditional attribution of the two skeletons found at the end of the nineteenth century in the Sts. James Cathedral to Mariun and her daughter can now be rejected, especially since the accidental excavations of 1957 brought to light even more skeletons and human bones. On the basis of the textual sources, we can be certain only about Mariun's being buried at the Sts. James Cathedral. Inside the cathedral, near the massive column facing the Chapel of the Martyrdom of St. James the Great (Fig. 1), Armenian pilgrims continue to pay tribute to Queen Mariun, believing that her grave is somewhere under the pavement, even though the actual location of her tomb is currently unknown. It is to be hoped that it will not remain so forever. 


\section{Bibliography}

Aławnuni, Bishop M. Haykakan hin vank'er ew ekełec'iner Surb Erkrin mēǰ [Old Armenian monasteries and churches in the Holy Land]. Jerusalem: Press of Sts. James, 1931.

-_-. Miabank' ew ayc'eluk' hay Erusałēmi [Cenobites and visitors to Armenian Jerusalem]. Jerusalem: Press of Sts. James, 1929.

Ališan, Ł. Sisuan:Hamagrut'iwn haykakan Kilikioyew Lewon Mecagorc[Sisuan: A documentary study of Armenian Cilicia and Lewon the Great]. Venice: San Lazzaro, 1885.

Arevchatian, A. "Les cantiques consacrés à Marie-Madeleine dans la pratique musicale des églises arménienne et catholique." Revue des études arméniennes 35 (2013): 79-88.

Bonfiglio, E., and Preiser-Kapeller, J. "From Ararat to Mount Zion: Armenian Pilgrimage and Presence in the Holy Land, Fourth to Seventh Century." In Pilgrimage to Jerusalem: Journeys, Destinations, Experiences across Times and Cultures, edited by F. Daim, J. Pahlitzsch, J. Patrich, C. Rapp, J. Seligman, 75-85. Mainz: Verlag des RömischGermanischen Zentralmuseums, 2020.

Čamčeanc', M. Patmut'iwn hayoc' [History of Armenia]. Vol. 3. Venice: Press of Yovhan P'iac'eanc', 1786.

Čemčemean, S. Mayr c'uc'ak hayerēn jerragrac' matenadaranin Mxit'areanc'i Venetik [General catalog of Armenian manuscripts of the Mekhitarist library in Venice]. Vol. 6. Venice: San Lazzaro, 1996.

-_-. Mayr c'uc'ak hayerēn jeragrac' matenadaranin Mxit'areanc' i Venetik [General catalog of Armenian manuscripts of the Mekhitarist library in Venice]. Vol. 8. Venice: San Lazzaro, 1998.

Chevalier, M.-A.Les ordres religieux-militaires en Arménie cilicienne:Templiers, hospitaliers, teutoniques \& arméniens à l'époque des croisades. Paris: Geuthner, 2009.

Christoforaki, I. "An Unusual Representation of the Incredulity from Lusignan Cyprus." Cahiers archeologiques 48 (2000): 71-87.

Chronique d'Arménie par Jean Dardel. In Recueil des historiens des croisades: Documents arméniens, vol. 2: 1-109. Paris: Imprimerie nationale, 1906.

Covakan [=N. Archbishop Połarean]. Hay gričnner, $T^{t}-Z ̌ \bar{E}$ dar [Armenian scribes, tenthseventeenth centuries]. Jerusalem: Press of Sts. James, 1992.

-_- Vanatur: Banasirakan yōduacneru žołovacoy [Vanatur: Collection of philological essays]. Jerusalem: Press of Sts. James, 1993.

-—-. "Yišatakaran Nersēs episkoposi" [Colophon of Bishop Nersēs]. Sion 3-4 (1967): 125-29. 
Der Nersessian, S. Aght'amar: Church of the Holy Cross. Cambridge, MA: Harvard University Press, 1965.

-—-. Armenian Art. Paris: Arts et métiers graphiques, 1978.

--- Miniature Painting in the Armenian Kingdom of Cilicia from the Twelfth to the Fourteenth Century. Vol. 1. Washington: Dumbarton Oaks Research Library and Collection, 1993.

Ervine, R. "The Brotherhood of the Sts. James Monastery and the Symbolism of Armenian Jerusalem." In Monastic Life in the Armenian Church: Glorious Past- Ecumenical Reconsiderations, edited by J. Dum-Tragut and D.W. Winkler, 81-104. Zürich: LIT Verlag, 2018.

--- "Women Who Left the World: The Armenian Nuns of Jerusalem." In Patterns of the Past, Prospects for the Future: The Christian Heritage in the Holy Land, edited by T. Hummel, K. Hintlian, and U. Carmesund, 124-34. London: Melisende, 1999.

Galustean, Bishop Š. "Norogut'iwnner S. Minasi matran mēě” [Renovations in the Chapel of St. Minas]. Sion 11-12 (1958): 289-93.

-_-. "Salarkum S. Yakobay tačarin ew patahakan pełumner ayd artt'iw" [Pavement works at St. James Cathedral and accidental excavations on that occasion]. Sion 7-8 (1958): 194-97, and Sion 9-10 (1958): 232-38.

Golubovich, G. Biblioteca bio-bibliografica della Terra Santa e dell' Oriente Francescano. Vol. 5: Dal 1346 al 1400. Florence: Collegio di S. Bonaventura, 1927.

Grigoryan, G. "Royal Images of the Armenian Kingdom of Cilicia (1198-1375) in the Context of Mediterranean Intercultural Exchange." PhD dissertation, University of Fribourg, Switzerland, 2017.

-_- "Armenian Colophons on the Takeover of Sis (1375)." Revue des études arméniennes 40 (2021) (forthcoming).

Gulbenkian, R. "Les relations entre l'Arménie et le Portugal du Moyen-Âge au XVI siècle." Revue des études arméniennes 14 (1980): 171-213.

Hayeren jeragreri hišatakaranner, ŽD dar [Colophons of Armenian manuscripts, fourteenth century]. Part 1: 1301-1325. Compiled by L. Khachikyan, A. Matevosyan, and A. Ghazarosyan. Yerevan: Nairi, 2018.

Het'um B-i Taregrut'yuny, XIII d. [Chronicle of Het'um II, thirteenth century]. In Manr žamanakagrut'yunner, XIII-XVIII dd. [Brief chronicles, thirteenth-eighteenth centuries], vol. 1, edited by Vazgen Hakobyan. Yerevan: Press of the Academy of Sciences, 1951. 
Hintlian, K. History of the Armenians in the Holy Land. 2nd ed. Jerusalem: Press of Sts. James, 1989.

Holum, K. G. "Hadrian and St. Helena: Imperial Travel and the Origins of Christian Holy Land Pilgrimage." In The Blessings of Pilgrimage, edited by R. Ousterhout, 66-81. Urbana: University of Illinois Press, 1990.

-_- "Imperial Travelers and the Origins of Christian Pilgrimage." In Tenth Annual Byzantine Studies Conference, November 1-4, 1984, Cincinnati: Abstracts of Papers, 1-2. Washington: Dumbarton Oaks, 1984.

Kalemderian, P. The Armenian Sts. James Cathedral of Jerusalem. Jerusalem: Press of Sts. James, 2007.

Kazaryan, A. "The Armenian Cathedral of Saints James in Jerusalem: Melisende and the Question of Exchange between East and West." In Romanesque Patrons and Processes: Design and Instrumentality in the Art and Architecture of Romanesque Europe, edited by J. Camps, M. Castiñeiras, J. McNeill, and R. Plant, 83-92. London: Routledge, 2018.

Kühl, H. Leon V. von Kleinarmenien: Ein Leben zwischen Orient und Okzident im Zeichen der Kreuzzugsbewegung Ende des 14. Jahrhunderts. Frankfurt am Main: Peter Lang Europäischer Verlag der Wissenschaften, 2000.

Langlois, V. Voyage dans la Cilicie et dans les montagnes du Taurus exécuté pendant les années 1852-1853. Paris: Benjamin Duprat, 1861.

Limor, O. "Jerusalem." In Europe: A Literary History 1348-1418, edited by D. Wallace, 2: 217-43. Oxford: Oxford University Press, 2016.

Mat'evosyan, A. "Het'um Axtuc' tiroǰ ew Vasil Maraǰaxti žamanakagrut'iwnnerə" [The chronicles of Het'um, Lord of Axtuc', and of Vasil Maraǰaxt]. Patma-banasirakan handes 4 (1963): 183-202.

Matiossian, V. "An Overview of Armenian-Spanish Relations during the Cilician Period." Handēs Amsoreay 1-12 (1996): 296-335.

- - "Sant'iakō tē Gomp'ostela ew hayerə" [Santiago de Compostela and the Armenians]. Bazmavēp 1-4 (2005): 194-226.

Minas Hamt'ec'i. Azgabanut'iwn t'agaworac' hayoc' [Genealogy of Armenian kings]. Constantinople, 1735.

Mutafian, C. L'Arménie du Levant (XI $-X I V^{e}$ siècle). Vol. 1. Paris: Les belles lettres, 2012.

-—-. "Les arméniens et Jérusalem au Moyen Âge (IV ${ }^{\mathrm{e}}-\mathrm{XIV}^{\mathrm{e}}$ siècle)." Revue arménienne des questions contemporaines 4 (January 2006): 9-18. 
_-_. "Léon V Lusignan: Un preux chevalier et/ou un piètre monarque." In Actes du colloque "Les Lusignans et l'Outre mer," Poitiers, 20-24 octobre 1993, 201-10. Poitiers: Sipap, 1995.

-_-. "Prélats et souverains arméniens à Jérusalem à l'époque des croisades: Légendes et certitudes (XII ${ }^{e}-\mathrm{XIV}{ }^{\mathrm{e}}$ siècle).” Studia Orientalia Christiana-Collectanea 37 (2004):109-51.

Mxit'arean, Vanec'i, X. Hamarōt patmut'iwn Erusałēmi ew storagrut'iwn srbazan teleac' [A brief history of Jerusalem and description of the holy sites]. Jerusalem: Press of Sts. James, 1867.

Narkiss, B., ed. with M. E. Stone. Armenian Art Treasures of Jerusalem. Historical survey by A. K. Sanjian. Jerusalem: Massada Press, 1979.

Ormanean, Archbishop M. Azgapatum [History of the nation]. Vol. 2. Constantinople: Press of V. and H. Tēr-Nersēsean, 1914.

--- Haykakan Yerusałēm. Nkaragir At'oroy Srboc' Yakobeanc' [Armenian Jerusalem: A description of the See of Sts. James]. Jerusalem: Press of Sts. James, 1931.

Połarean, N.Mayrc'uc'akjeragrac' Srboc' Yakobeanc' [Grand catalog of Sts. James manuscripts]. Vol. 3. Jerusalem: Press of Sts. James, 1968.

--_. Mayr c'uc'ak jeragrac' Srboc' Yakobeanc' [Grand catalog of Sts. James manuscripts]. Vol. 4. Jerusalem: Press of Sts. James, 1969.

--_. Mayr c'uc'ak jeragrac' Srboc' Yakobeanc' [Grand catalog of Sts. James manuscripts]. Vol. 7. Jerusalem: Press of Sts. James, 1974.

---. Mayr c'uc'ak jeragrac' Srboc' Yakobeanc' [Grand catalog of Sts. James manuscripts]. Vol. 11. Jerusalem: Press of Sts. James, 1991.

Prawer, J. "The Armenians in Jerusalem under the Crusaders." In Armenian and Biblical Studies, edited by M. E. Stone, 222-36. Jerusalem: Press of Sts. James, 1976.

Pringle, D. The Churches of the Crusader Kingdom of Jerusalem: A Corpus. Vol. 3: The City of Jerusalem. Cambridge: Cambridge University Press, 2007.

Rapti, I. "Le mécénat des princesses arméniennes." In Impératrices, princesses, aristocrats et saintes souveraines de l'Orient chrétien et musulman au Moyen Âge et au début des Temps modernes, edited by É. Malamut and A. Nicolaïdès, 249-72. Aix-en-Provence: Presses universitaires de Provence, 2014.

Rüdt-Collenberg, W. H. The Rupenides, Hethumides and Lusignans: The Structure of the Armeno-Cilician Dynasties. Paris: A. Pigné, 1963.

Sáez Pomés, M. "La ayuda de Valencia a León V de Armenia, I de Madrid." Estudios de edad media de la Corona de Aragón 3 (1947-1948): 386-419. 
Samuēl Anec'i ew šarunakołner: Žamanakagrut'iwn Adamic' minčew $1776 t^{\prime}$. [Samuēl Anec'i and continuators: Chronicle from Adam to 1776]. Critical text, study, and commentary by K. Matevosyan. Yerevan: Nairi, 2014.

Sargisean, B. Mayr c'uc'ak hayerēn jeragrac' matenadaranin Mxit'areanc' i Venetik [General catalog of Armenian manuscripts of the Mekhitarist library in Venice]. Vol. 1. Venice: San Lazzaro, 1914.

Sawalaneanc', T. Patmut'iwn Erusałēmi [History of Jerusalem]. Vol. 1. Jerusalem: Press of Sts. James, 1931.

Schein, S. “Bridget of Sweden, Margery Kempe and Women's Jerusalem Pilgrimage in the Middle Ages." Mediterranean Historical Review 14 (1999): 44-58.

-- . "Latin Hospices in Jerusalem in the Late Middle Ages." Zeitschrift des deutschen Palästina-Vereins 101, no. 1 (1985): 82-92.

Stone, M. "Holy Land Pilgrimage of Armenians before the Arab Conquest." Revue biblique 93, no. 1 (1986): 93-110.

Tchekhanovets, Y. The Caucasian Archaeology of the Holy Land: Armenian, Georgian and Albanian Communities between the Fourth and Eleventh Centuries CE. Leiden: Brill, 2018.

--- and P. Berjekian. "Excavating the Armenian Cathedral of St. James in Jerusalem: The Unknown Report from the 1950s." Journal of the Society for Armenian Studies 26 (2017): 119-34.

Tēr Łazarean, Y. Haykakan Kilikia: Tełagrut'iwn [Armenian Cilicia: Topography]. Antelias: Armenian Catholicosate of Cilicia, 1966.

Ter-Petrosyan, L. Ananun žamanakagrakan grarumner, XIV d. [Anonymous chronicles, fourteenth century]. Appendix 3 in L. Ter-Petrosyan, Xačakirnerə ew hayerə [The Crusaders and the Armenians]. Vol. 2: Historico-Political Study, 554-58. Yerevan: PrintInfo, 2007.

-- . Xač akirnerə ew hayerə [The Crusaders and the Armenians]. Vol. 2: Historico-Political Study. Yerevan: Print-Info, 2007.

Tēr-Yovhannēseanc', A. Žamanakagrakan patmut'iwn S. Erusałēmi [Chronological history of Holy Jerusalem]. Vol. 1. Jerusalem: Press of Sts. James, 1890.

Terian, A. "Armenian Writers in Medieval Jerusalem." In Patterns of the Past, Prospects for the Future: The Christian Heritage in the Holy Land, edited by T. Hummel, K. Hintlian, and U. Carmesund, 135-56. London: Melisende, 1999.

Tisserant, E. Codices armeni Bybliothecae Vaticanae Borgiani, Vaticani, Barberiniani, Chisiani. Rome: Typis polyglottis Vaticanis, 1927. 
Toumanoff, C. Les dynasties de la Caucasie chrétienne de l'Antiquité jusqu'au XIXe siècle: Tables généalogiques et chronologiques. Rome, 1990.

Turner, V., and E. Turner. Image and Pilgrimage in Christian Culture: Anthropological Perspectives. New York: Columbia University Press, 1978.

Uxtawor [=Yarut'iwn Mrmrean]. Alēluia yErusałēm [Hallelujah in Jerusalem]. Constantinople: Matt'ēosean, 1903.

Van Lint, T. M. "Sis. The Armenian Kingdom of Cilicia." In Europe: A Literary History 13481418, edited by D. Wallace, 2:259-81. Oxford: Oxford University Press, 2016.

Xač ikyan, L. ŽD. dari hayeren jeragreri hišatakaranner [Colophons of Armenian manuscripts of the fourteenth century]. Yerevan: Press of the Academy of Sciences, 1950.

Yovhannu Dardeli Žamanakagrut'iwn Hayoc' [Chronicle of Armenia by Yovhan Dardel]. Translated by K. Ezeanc'. Society for the Armenian Book Publication of Tbilisi no. 28. Saint Petersburg: Skōrōxōdov, 1891.

Yovsēp'eanc', Archbishop G. Hawuc' T'ari Amenap'rkič́s ew noynanun yušarjanner hay aruesti meǰ: patma-hnagitakan usumnasirut'iun [The All Savior of Hawuc' T'ar and homonymous monuments in Armenian art: A historical-archaeological survey]. Jerusalem: Press of Sts. James, 1937.

Zakarian, L. "Les arts." In Le royaume arménien de Cilicie (XII ${ }^{e}-X I V^{e}$ siècle), edited by C. Mutafian, 127-39. Paris: CNRS Éditions, 1993. 


\title{
Review Essay
}

\section{Blurred Boundaries and Novel Normativities: The Jews of Arabia, the Quranic Milieu, and the "Islamic Judaism" of the Middle Ages*}

\author{
Aaron W. Hughes. Shared Identities: Medieval and Modern \\ Imaginings of Judeo-Islam (Oxford: Oxford University Press, \\ 2017), 240 pp. ISBN 978-01-906-8446-4. Price: $\$ 105.00$ (cloth).
}

Aaron W. Hughes. Muslim and Jew: Origins, Growth, Resentment (London: Routledge, 2019), 106 pp. ISBN 978-11385-9944-4. Price: $\$ 60.00$ (cloth).

\author{
Michael E. Pregill \\ Lecturer, Chapman University and Postdoctoral Researcher, \\ ERC Synergy Project “The European Qur'an"
}

(michael.pregill@gmail.com)

\begin{abstract}
This article discusses critical issues surrounding the Jewish-Muslim encounter, framed as an evaluation of the approach and conclusions of two recent publications by Aaron W. Hughes: Shared Identities: Medieval and Modern Imaginings of Judeo-Islam (2017) and Muslim and Jew (2019). Hughes's works present a critique of the established historiography on Jewish-Muslim relations and exchanges, examining such subjects as the Jews of late antique Arabia, the Jewish matrix of the Quran and formative Islam, and the Judeo-Islamic synthesis of subsequent centuries. I interrogate Hughes's use of sources, treatment of previous scholarship, and privileging of the specific lens of the "religionist" in approaching the historical evidence. Both of the works under consideration here exhibit numerous problems of conception and argumentation that undermine their value for broadening current horizons of research or refining prevailing pedagogies. Ultimately, although they provoke numerous important questions and deftly expose the conceptual and ideological underpinnings of older scholarship, the books fail to offer a constructive path forward for specialists or stimulate a meaningful paradigm shift in the field.
\end{abstract}

\footnotetext{
* Feedback from numerous readers improved this essay tremendously. I am exceedingly grateful for the productive comments I received from Phil Lieberman, Brian Pennington, and Stephen Shoemaker, as well as from the anonymous reviewers of the article. Luke Yarbrough provided numerous invaluable suggestions at multiple junctures. I also thank Cate Bonesho for her kind help with a bibliographic matter. Naturally, errors and failures of judgment remain my responsibility alone.

(c) 2021 Michael E. Pregill. This is an open access article distributed under the terms of the Creative Commons Attribution-NonCommercial-NoDerivatives License, which allows users to copy and distribute the material in any medium or format in unadapted form only, for noncommercial purposes only, and only so long as attribution is given to the original authors and source.
} 
$\mathrm{D}$ espite the long flourishing of scholarship on the topic, the Muslim-Jewish encounter remains for the most part an undertheorized and less than cogent field of research. ${ }^{1}$ This is perhaps not surprising, because the scholarly work relevant to it, though considerable, is distributed among a number of areas that are notionally interconnected but have little to do with one another in practice. Thus, someone broadly interested in Jewish-Muslim relations and exchanges might take note of the significant research done in recent years on the Quran's representations of Jews and relationship to traditions of late antique Judaism, or of the perennial effort to uncover the social and religious history of the Jews of Arabia in the time of Muhammad. Regarding the later period, the massive advances in Geniza studies over the last couple of decades, illuminating numerous aspects of the florescence of an Islamicate Judeo-Arabic culture in the high Middle Ages, are surely no less relevant for the subject. One might also consider the ongoing revision of our understanding of that titan of medieval Jewish intellectual and religious life, Maimonides, whose profound engagement with not only Arab but also Islamic thought has been at the forefront of recent endeavors to reorient the prevailing image of his significance. We could readily adduce other topics that demonstrate the persistent importance of the Muslim-Jewish encounter for our understanding of the history and development of both traditions. Given the complexity of the evidence, the lack of cross-pollination between fields, and the sheer magnitude of research production in Europe, the Americas, Israel, and parts of the Islamic world, a competent synthesis integrating these disparate areas of inquiry into a theoretically coherent whole is likely beyond the ability of any single scholar.

The perceptive reader will notice that I have already invoked a couple of slippery descriptors for the religious, cultural, social, and historical relationships between Jews and Muslims. Although terms such as "encounter," "exchange," and "engagement" seem innocuous enough, upon reflection they are far from transparent, and each carries a significant amount of cultural and ideological baggage. Other terms have often been deployed in describing those relationships, and many of them are even more self-evidently problematic: "influence," "dependence," "borrowing," "symbiosis," "coevolution." This lexicon features prominently in the most important works on the subject by some of the greatest scholars of Jewish and Islamic studies stretching back two hundred years to the

1. There is no equivalent in the field of premodern Jewish-Muslim relations to Gil Anidjar's provocative and complex The Jew, the Arab: A History of the Enemy (Stanford, CA: Stanford University Press, 2003), which focuses on modernity. Anidjar prefers the ethnonym "Arab" as the antipode to "Jew" and generally eschews a specific focus on religious identity. However, despite this, many of Anidjar's observations apply equally well to Muslims as an ideological construct in European thought as to Arabs, reflecting the fact that "Muslim" and "Arab" are often used interchangeably in the heavily racialized discourses of historical and contemporary Islamophobia in the Anglo-European world. Conversely, despite the broader remit implied by Hughes's focus on Muslims and Islam, he is overwhelmingly concerned with the Arabophone world in both of the books under consideration here. Another important theoretical precursor to Hughes's endeavor in Shared Identities is Rina Drory's functionalist-structuralist approach to Islamicate Jewish literature in Models and Contacts: Arabic Literature and Its Impact on Medieval Jewish Culture (Leiden: Brill, 2000). Though her critique of shopworn conceptions of "influence" is relevant to Hughes's project, he cites Drory only in passing in Shared Identities, making one brief reference to her article on the proliferation of established Arab-Muslim genres in Karaite literature. 
early nineteenth century. Despite those aspects of their work that now seem objectionable or outmoded, the impact of figures such as Abraham Geiger, Ignác Goldziher, S. D. Goitein, Bernard Lewis, and Norman Stillman still resonates today, and their vision and ideas haunt much contemporary scholarship.

The legacy previous generations of scholars have bequeathed to us, particularly the terminology and frameworks we use to conceive of and describe the dynamic of JewishMuslim relations, is the subject of two recent books by Aaron Hughes. The first, Shared Identities: Medieval and Modern Imaginings of Judeo-Islam, is an extended reflection on the historiography of the Jewish-Muslim encounter from the early Islamic period to the Middle Ages. Here Hughes focuses on the methodologies and underlying ideologies that guided past scholarship in an attempt to come to a more theoretically sophisticated understanding of that encounter. The second, Muslim and Jew, is a streamlined survey, presumably intended for classroom use, that is much broader in scope than Shared Identities. ${ }^{2}$ Here Hughes offers a suite of three concise chapters centering on major themes in Jewish-Muslim relations"Origins," "Growth," and "Resentment"-from the foundational period to the modern era. Hughes avers that this new survey offers a fresh perspective that builds upon the theoretical insights he developed in Shared Identities, setting it apart from the classic works in the genre by Goitein, Stillman, Lewis, and others that are still often used as introductory textbooks today. ${ }^{3}$ Shared Identities and Muslim and Jew perhaps represent the most significant, and certainly most ambitious, attempts at reevaluation and synthesis of the Judeo-Islamic encounter in recent years; given that such attempts are relatively rare, appearing only once every couple of decades at most, Hughes's works warrant close and critical scrutiny. ${ }^{4}$

Hughes contends that much historical scholarship on the subject of Jewish-Muslim relations has been driven by questionable ideological commitments, and that these commitments merit careful examination and interrogation. This is especially so, he argues, because contemporary scholarship, though usually less transparently ideological, barely improves upon older research insofar as it tends to be theoretically anemic and so fails to come to a more refined understanding of how Jewish-Muslim relations should be

2. With a list price of 60 USD for a short hardcover, Muslim and Jew is perhaps not practical for classroom use, though in the post-COVID era the e-book version of the volume, priced under $\$ 20$, may present a reasonable alternative.

3. Hughes explicitly notes at the beginning of Muslim and Jew (p. xi) that in this book he operationalizes the "post-symbiotic" perspective developed in Shared Identities, where he claims to have articulated the critical vocabulary that enables the reassessment he offers in his brief survey. The most important precursors to Muslim and Jew in English are S. D. Goitein, Jews and Arabs, first published in 1955 and subsequently revised (3rd rev. ed., New York: Schocken, 1974); Norman Stillman, The Jews of Arab Lands: A History and Sourcebook (New York: Jewish Publication Society of America, 1979); and Bernard Lewis, The Jews of Islam (Princeton, NJ: Princeton University Press, 1984).

4. The only other synthetic work of this sort to appear in the twenty-first century, at least in English, is Jacob Lassner's Jews, Christians, and the Abode of Islam: Modern Scholarship, Medieval Realities (Chicago: University of Chicago Press, 2012), a work that is now almost a decade old. Notably, Hughes has a third volume on the Jewish-Muslim encounter forthcoming: Somewhere between Islam and Judaism: Critical Reflections (Sheffield: Equinox, 2021). 
conceptualized and described. The main questions I will pursue here are whether Hughes succeeds in his task of theoretical reevaluation in the first book, and whether the second consequently represents a significant improvement over currently available surveys. I suggest that although Hughes's critical intervention is timely and necessary, his efforts in both volumes are impaired by various conceptual roadblocks that he fails to surmount. In the case of Shared Identities, despite the work's many virtues, pervasive problems in both conception and the handling of evidence undermines the work's value for its intended audience of scholarly specialists who work in this field. These problems recur in Muslim and Jew, where they are considerably exacerbated by still other problems, and these flaws obscure many of the issues that would be critical for the book's intended audience of nonspecialists and students to apprehend clearly.

\section{A "Post-symbiotic" Perspective on the Jewish-Muslim Encounter}

In Shared Identities, Hughes investigates the critical period from the seventh through the eleventh century CE, during which time both Judaism and Islam gradually acquired their mature forms through complex dialogical processes of mutual enrichment and codevelopment. Judaism contributed to major aspects of Islam during the latter's formation, and Islam subsequently came to "return the favor" by contributing to the reformulation and reshaping of Judaism during the high Middle Ages. ${ }^{5}$ This is why the history of JudeoIslamic (or Islamo-Judaic) engagements should be characterized as a dynamic of reciprocity, in contrast to the emphasis among previous generations of scholars on Judaism's antiquity and thus originality and priority as the donor tradition, with Islam as the latecomer and so the passive recipient of that donor's largesse. ${ }^{6}$ As noted above, Hughes is particularly interested in dissecting and exposing "the cognitive problems associated with framing metaphors" and so seeks to rectify or discard conceptual and descriptive frameworks such as "influence," "exchange," and "symbiosis" that so frequently predominate in the literature on these processes. ${ }^{7}$

\section{Shared Identities, ix.}

6. Hughes presents normative Judaism and normative Islam as both only gradually crystallizing out of a complex and fluid milieu in the early centuries after the Arab conquests; this is his main justification for considering mature Judaism and Islam as the products of mutually fruitful processes of coevolution. This statement regarding messianism as a discourse transcending the boundaries between groups is typical of his approach: "[A]n unstable Islam created further instability in various Jewish and Judaizing groups by providing vocabularies and tropes, many of which had been adopted and adapted, reused and recycled, from earlier Jewish messianic circles" (Shared Identities, 64). Bulliet makes a similar observation about Christianity and Islam, which can be imagined as two halves of a single civilizational complex that emerged at roughly the same time and followed parallel trajectories for centuries. This argument is predicated on the idea that after the Arab conquests Christian culture was essentially "rebooted" (my term), with Islam gradually becoming demographically dominant in what became the Muslim Middle East and Christianity eventually dominant in Europe. See Richard Bulliet, The Case for Islamo-Christian Civilization (New York: Columbia University Press, 2004), ch. 1.

7. Shared Identities, 29. One does occasionally find slippages in the book, as when Hughes refers to forms of Judaism "beholden" (p. 70) or "indebted" (p. 80) to Islam. I am fully sympathetic to the difficulty he faces in critiquing problematic terminology while attempting to redescribe the phenomena to which it is 
These frameworks have often been predicated on the notion that Judaism and Islam were largely well-defined and stable entities already at the time of their earliest encounters, and especially that Judaism was a fully formed and largely monolithic tradition when Islam emerged. Further, many scholars of the past proceeded from the assumption that the relationships between Jewish and Muslim communities were superficial and transactive rather than impactful and transformative. However fruitful their reciprocal engagements may have been-so the conventional narrative goes-the two communities remained separate and discrete throughout their long shared history, distinct and immutable in their spiritual and doctrinal essences. ${ }^{8}$ In particular, despite the considerable impact of Islamic "host cultures" upon Arab, Persian, Central Asian, and Andalusian Jews in the Middle Ages, their Judaism at its core remained a pure, unadulterated Judaism, the essential, unchanging faith of their forefathers. As Samuel Bäck put it in his 1878 History of the Jewish People, despite the massive achievements of the Jews of medieval Spain under Muslim rule and their profound embeddedness in a culture dominated by Islam, they "maintained a steadfast fidelity to their religion ... [they] never forgot that they were Jews."

To Hughes, the premises that inform such an approach simply do not and cannot withstand critical scrutiny. Throughout Shared Identities, he repeatedly emphasizes that in fact the opposite situation must have prevailed: during the initial centuries of their interactions and engagements, not only were Judaism and Islam both quite malleable and pluriform, but at various junctures, groups of Jews and Muslims may have been largely indistinguishable from one another. Approaches that assume otherwise vastly overstate the degree to which the traditions had cohered on the practical level, let alone been codified on the doctrinal level; scholars of the past (and many today as well) err in assuming that religious communities are always and everywhere characterized by stable essences. In asserting that the porous boundaries between the traditions were populated by "Jewmuslims" or "Muslimjews" who drove the encounters that shaped both traditions over the centuries during which the classical forms of their doctrines, practices, and textual

conventionally applied, since I have myself written a number of studies critiquing the concept of "influence" and likewise struggled, perhaps even less successfully, to formulate and implement meaningful conceptual and terminological alternatives.

8. This model typically centers language as the primary index of identity, with Arabic supposedly being the medium of "secular" culture and commerce among diglossic or polyglot Jews but Hebrew maintaining its time-honored status as the preferred language of religious expression and creativity (and so being privileged as the primary and indispensable marker of personal and communal identity). With the much-discussed Greek/ Hebrew divide in antiquity, "Hellenism" has traditionally been downplayed as only minimally manifest in, and so irrelevant to, "Hebraic" (that is, quintessentially Jewish) cultural forms; similarly, many scholars have tended to assume that the ongoing use of Hebrew in religious and some cultural contexts indexes an absence of significant Arabization or Islamization, at least as determining individual or communal identity. Recent research has shown, however, that Hellenism or Romanization may be reflected in and expressed through literary production in Hebrew. This is only one of the ways in which the dubious dichotomy between Hellenistic and "original" Hebraic Judaism has been challenged in contemporary scholarship.

9. Hughes's translation of the German of Bäck's Die Geschichte des jüdischen Volkes (Shared Identities, 23). A similar emphasis on the normative, mature, and clearly bounded form of Judaism that impacted the rise of Islam is found in the works of Geiger and Graetz; see, e.g., Shared Identities, 24-25 and 50-51. 
traditions coalesced, Hughes sets his sights on no less grand a goal than the formulation of "a new paradigm . . . that acknowledges and taxonomizes the fluidity of religious and ethnic identity." ${ }^{10}$ However, it is unclear whether he really achieves this goal by the book's conclusion.

In seeking to articulate a new paradigm-explicitly described in both Shared Identities and Muslim and Jew as a "post-symbiotic" perspective ${ }^{11}$-Hughes sets the stage by examining the previously (and currently) dominant outlook governing the study of Jewish-Muslim relations during this germinal period. Thus, in the introduction and chapter 1 of Shared Identities, he discusses the regnant categories invoked in scholarship and the various figures of the nineteenth and twentieth century-Heinrich Graetz, Bäck, Goitein, and others-whose work established much of the terminology, framing, and conceptual baggage that we still bring to the subject today and that continues to influence research agendas in ways both subtle and overt. Subsequent chapters of the book focus on specific subtopics that traverse the historical period under consideration here: the emergence of Islam and the problem of Muhammad's relationship to the Jews of his milieu (and supposed "debt" to Jewish informants); the heterodox fringe of early Jewish (or Judeo-Islamic) messianism after the Arab conquests; kalām as a shared rationalist discourse that bridged and shaped both Jewish and Muslim intellectual developments and ultimately contributed to the doctrinal (and thus notional) distinction of the traditions; the vaunted "Golden Age" of convivencia that produced Maimonides and other magisterial Jewish thinkers and litterateurs of the Judeo-Arabic tradition; and finally Jewish Sufism as a case study demonstrating the ongoing porousness of boundaries between Jew and Muslim after the maturation of both traditions and the general hardening of social and religious distinctions between groups.

Specialists who work in fields touching upon Muslim-Jewish relations will likely recognize the necessity, even urgency, of Hughes's attempt to interrogate and refine the categories and language we use in seeking to describe those relations. In both books, but especially Muslim and Jew, Hughes explicitly acknowledges the larger political implications of this work in our contemporary context. Although he expresses some caution regarding the politicization of scholarly priorities, he himself sets an overtly political agenda for his project in Muslim and Jew. ${ }^{12}$

10. Shared Identities, 63. In his treatment of the early Islamic period here, Hughes repeatedly refers to the work of Peter Webb on Arab ethnogenesis (Imagining the Arabs: Arab Identity and the Rise of Islam [Edinburgh: Edinburgh University Press, 2016]), which has received a fair amount of criticism for exaggerating the degree to which Arab identity was an invention of the caliphal era, a point that seems germane to Hughes's approach to the sources as well (see, e.g., the review of Youssef M. Choueiri, Journal of Near Eastern Studies 76 [2017]: 377-79).

11. The term "post-symbiotic" recurs a number of times in Shared Identities, though only once in Muslim and Jew (p. xi), which is, as already noted, presented as a "post-symbiotic" survey.

12. Thus, in Shared Identities Hughes critiques the concept of convivencia as problematically inflected by contemporary concerns, particularly a quest to anchor the modern value of tolerance in the past (pp. 29-30). However, he explicitly presents his own work as intended to address contemporary political problems, for example in both the introduction and chapter 3 of Muslim and Jew, as well as in the conclusion of Shared Identities itself (pp. 145-49). 
Hughes's reevaluation is particularly indebted to the pioneering and massively influential work of Daniel Boyarin, whose approach to the early Jewish-Christian relationship Hughes seeks to apply to the comparatively underexplored Jewish-Muslim dynamic. ${ }^{13}$ Shared Identities in particular also conspicuously rehearses the arguments of Steven Wasserstrom's 1995 monograph Between Muslim and Jew: The Problem of Symbiosis Under Early Islam, a groundbreaking study that likewise aimed at a serious theoretical reevaluation of the early Muslim-Jewish encounter. ${ }^{14}$ Hughes's book retreads much of the territory covered in Between Muslim and Jew, pursuing fundamentally similar goals and touching upon many of the same subjects. However, in what feels like an odd manifestation of the anxiety of influence-ironic given the topic at hand-Hughes downplays the importance of Wasserstrom's precedent and cites his work explicitly only a handful of times in Shared Identities. ${ }^{15}$

In Between Muslim and Jew, Wasserstrom drew attention to the years after the Arab conquest of the Middle East as a notoriously obscure period in Jewish history. ${ }^{16} \mathrm{He}$ engaged Goitein's work specifically for its foregrounding of the complex and admittedly problematic concept of symbiosis (thus the subtitle of the book) and argued that in the early period, Islam and Judaism were so closely intertwined socially and religiously that at least some communities at the margins of the traditions were practically indistinguishable or even identical. This early proximity was largely ignored by later Jewish spokesmen, while Muslim commentators effaced most traces of it, relegating groups such as the Isawiyya, whose "syncretistic" (Wasserstrom's term, p. 86) prophetological and messianic doctrines may be seen as vestigial traces of that proximity, to the category of "heresy." Modern scholars have long been similarly perplexed by such seemingly hybrid groups, which explains the inability of the analytical language we have inherited to describe such phenomena in a sophisticated way, as well as why attempts to do so typically come up short. ${ }^{17}$ In subsequent chapters of Between Muslim and Jew, Wasserstrom showed that later developmentskalām, heresiography, isrā'̄iliyyāt, Judeo-Arabic philosophy-similarly preserve traces of the early intimacy (or even identity) of the traditions, as well as demonstrating the efforts

13. Daniel Boyarin, Border Lines: The Partition of Judaeo-Christianity (Philadelphia: University of Pennsylvania Press, 2004). The recent work of Michael Penn, Envisioning Islam: Syriac Christians and the Early Muslim World (Philadelphia: University of Pennsylvania Press, 2015), explicitly seeks to apply Boyarin's approach to the Muslim-Christian encounter under Islamic dominion in the early centuries AH.

14. Steven M. Wasserstrom, Between Muslim and Jew: The Problem of Symbiosis Under Early Islam (Princeton, NJ: Princeton University Press, 1995).

15. Hughes graciously acknowledges Wasserstrom as a conversation partner at the beginning of Shared Identities (p. xiii), but the paucity of explicit citations of Between Muslim and Jew in both of his books seems to me to conceal a much more broad-ranging engagement with Wasserstrom's work than is readily apparent.

16. Steven Wasserstrom, Between Muslim and Jew, 17-18, citing, among others, Salo W. Baron, Goitein, and Leon Nemoy; cf. Shared Identities, 83-84, focusing on Goitein's view of the "blackout period" in particular.

17. See Between Muslim and Jew, ch. 2. It is tempting to invoke the term "hybrid" in response to communal formations that seem to combine elements from others, especially larger or more dominant groups. However, the term is misleading because it implies the combination of traits from two established species, whereas both Wasserstrom and Hughes would emphasize that the existence of the "hybrid" form actually demonstrates the instability of the original entities. 
of later spokesmen to separate the two traditions and marginalize, quarantine, or eliminate ambiguous or boundary-challenging phenomena.

Hughes retreads much of the same territory that Wasserstrom explored almost thirty years ago, although the former's work is rather more focused. Insofar as Hughes does acknowledge his precedent, he avers that Wasserstrom's approach is marred by an uncritical reliance on the concept of symbiosis. To be fair, however, I read Wasserstrom as rather persistently interrogating and problematizing this notion, which we mainly inherit from Goitein, throughout Between Muslim and Jew. Questioning the utility of symbiosis as a concept while exploring some of its lesser-known implications seems to me to be the whole point of Wasserstrom's book, and so Hughes's critique strikes me as misplaced. ${ }^{18}$

Despite its significant impact on specialists working in this field of study (or perhaps because of it), it is certainly true that Wasserstrom's book is ripe to be revisited and updated; moreover, many of his most important insights are often couched in language that is overly dense, opaque, or recherché. ${ }^{19}$ One of the great virtues of Hughes's work is its clarity and accessibility: his prose is direct and elegant, and he excels at analyzing and summarizing complex historiographic problems, so that his exposition of the underlying ideology and implications of historical scholarship on Jewish-Muslim encounters is deft, vigorous, and lucid. While Wasserstrom's book still strikes me as endlessly rich, provocative, and exciting, he often operates in what we might recognize as a mode of scholarly discourse characteristic of the history of religions approach pioneered in Islamic studies by Marshall Hodgson (whose inspiration Wasserstrom openly acknowledged). Like many provocative works, Wasserstrom's book can be forbidding to the uninitiated; thus, we can welcome Shared Identities as a productive revisiting and reformulation of Wasserstrom's attempt at a more theoretically self-conscious exploration of the Muslim-Jewish encounter that might be more comprehensible and appealing to nonspecialists. ${ }^{20}$

18. While acknowledging the value of Wasserstrom's work, Hughes claims that "the term nevertheless remains his default model, and it is ultimately left intact at the end of his analysis" (Shared Identities, 4). As proof he cites the concluding remarks of Between Muslim and Jew (p. 224), where Wasserstrom summarizes the ways in which he has sought to expand and reinterpret the concept of symbiosis. It is not clear to me how Hughes improves upon this by rejecting this term (among others) outright without replacing it with any practically deployable alternative.

19. In the recent tribute volume All Religion Is Inter-Religion:Engaging the Work of Steven M. Wasserstrom, ed. Kambiz GhaneaBassiri and Paul Robertson (London: Bloomsbury Academic, 2019), only a couple of the contributions refer to Wasserstrom's theoretical insights in Between Muslim and Jew, and none engage its main subject matter directly. This suggests that it is Wasserstrom's broader work on methodology in religious studies, particularly his monograph on the Eranos School, Religion After Religion: Gershom Scholem, Mircea Eliade, and Henry Corbin at Eranos (Princeton, NJ: Princeton University Press, 1999), that has had the widest impact on the field. However, this author can attest (admittedly only on the basis of anecdotal evidence) that numerous other scholars who now work in the field of Judeoislamica/Islamojudaica were significantly impacted by Between Muslim and Jew in choosing to explore this area of research. A brisk, unsystematic survey of citations of Between Muslim and Jew via Google search demonstrates that the book has been cited in at least a dozen monographs of significance, as well as numerous peer-reviewed journal articles and reference works.

20. Hodgson's works on both historiography and esoteric Shiism are cited in Between Muslim and Jew. Moreover, an early paper of Wasserstrom's dealing with both of these topics was awarded the 1984 Marshall G. S. Hodgson Memorial Prize at the University of Chicago and subsequently published as "The Moving Finger 
However, specialists may find Hughes's work frustrating, for it is not clear that it represents a significant conceptual and methodological advance over Wasserstrom's achievement. For one thing, Hughes's attempt to apply Boyarin's approach to the formative Jewish-Christian encounter in Border Lines to its later Jewish-Muslim counterpart is obviously laudable, but the study of the former at the time Boyarin undertook this endeavor was light-years ahead of where the study of the latter is right now, despite the significant progress made in various fields of inquiry relevant to the topic over the last couple of decades. Moreover, Boyarin's insights in Border Lines built upon his formidable command of the sources and extensive research in the years leading up to it; his theoretical intervention was grounded in his previous work on rabbinic literature and his demonstrable philological mastery of the relevant literature. Likewise, Wasserstrom's approach was informed by his deep engagement with classical Islamic sources, particularly the work of the twelfth-century heresiologist Shahrastānī, whose survey of Jewish sects was central to Wasserstrom's (still unpublished!) doctoral dissertation at the University of Toronto. ${ }^{21}$

In contrast, Hughes is a specialist in medieval philosophy; thus, unsurprisingly, his chapter in Shared Identities on the historiography of the Spanish Golden Age is the most robust and provocative section of the book. ${ }^{22}$ He has also published numerous works of methodological reflection on the discipline of religious studies, and one can see a direct continuity between the discourse analysis of contemporary academic approaches to the study of Islam he executes in those books and the analytical lens he trains on various influential figures in the study of the Muslim-Jewish encounter among previous generations of Anglo-European scholars in Shared Identities. ${ }^{23}$ However, Hughes's approach to Islamic origins and the Jews of early Islam-subjects located in a period well outside of his area of main expertise-sometimes reflects a problematic handling of the sources and a neglect of

Writes: Mughìra b. Sa'īd's Islamic Gnosis and the Myths of Its Rejection," History of Religions 25 (1985): 1-29. A mentor of mine who will remain anonymous here once remarked that Hodgson is the scholar most likely to induce fits of aggravation in undergraduates; my personal experience indicates that Wasserstrom is also a strong contender for this honor.

21. Steven M. Wasserstrom, "Species of Misbelief: A History of Muslim Heresiography of the Jews" (PhD diss., University of Toronto, 1987).

22. Hughes, Shared Identities, ch. 5.

23. Hughes's criticisms of the contemporary field of Islamic studies have often devolved into ad hominem attacks and precipitated strident counter-critiques, especially in online forums. A common response to his allegations is that they rest upon distorted characterizations of scholars of note and their claims. Thus, Hughes's Theorizing Islam: Disciplinary Deconstruction and Reconstruction (Abingdon: Routledge, 2012) focuses on a critique of what he sees as uncritical, and even "insular and apologetic" (p. 2), tendencies in the discourse and ideology of the academic study of Islam as practiced in North America, especially in circles of scholars associated with the American Academy of Religion. For an unvarnished evaluation of this book and its allegations, see Devin J. Stewart, "A Modest Proposal for Islamic Studies," in Identity, Politics and the Study of Islam: Current Dilemmas in the Study of Religions, ed. Matt Sheedy, 157-200 (Sheffield: Equinox, 2018). Notably, this edited volume was itself a response to a public controversy between Hughes and Omid Safi and the discussions that followed; see the interview with the editor, "Identity, Politics, and the Study of Islam," available online at https://edge.ua.edu/nota-bene/identity-politics-and-the-study-of-islam-an-interview-with-matt-sheedy/. Hughes reiterated many of the critiques of Theorizing Islam even more strenuously in Islam and the Tyranny of Authenticity: An Inquiry into Disciplinary Apologetics and Self-Deception (London: Equinox, 2016). 
significant ongoing debates that are directly relevant to his argument. I cannot say whether his questionable interpretations and misleading representations of texts stem from an indifference to philology or an insensitivity to historical matters, but at various junctures in both of the books under consideration here, one is confronted with perplexing oversights and misprisions, especially (but not solely) pertaining to early and classical Islam.

\section{A Skeptical Religionist Peers into the Darkness: The "Aporia" of Islam's Origins}

Of course, one cannot expect a scholar's research interests to be bounded perpetually by their original or primary area of expertise. Naturally, scholars grow intellectually, foster expanding or divergent interests, and apply their knowledge and methods to new problems. But acknowledgment of Hughes's disciplinary location and background-and the constraints they seem to impose on his project-seems to me to be justified not only because the issue is directly relevant to an evaluation of his work, but also because the author actually foregrounds the question of disciplinary specialization and orientation himself. At the beginning of Shared Identities, Hughes explicitly asserts that his work is not grounded in a historical or philological approach but rather is conceived as operating in a separate (and seemingly higher?) realm, that of the scholar of religion or "religionist." 24 This perhaps explains why his "suggestive and critical intervention" 25 is most effective when Hughes is critiquing the established scholarship on his subject, deftly dissecting the presuppositions and implications of much of the previous work on the Jews of the Islamic world; much contemporary work in religious studies operates in this Foucauldian mode of genealogical and discourse analysis. However, Hughes overlooks much current scholarship that is pertinent to his subject and sometimes seems to be operating at a sharp disadvantage in his handling of relevant, even indispensable, primary evidence as well.

In chapter 1 of Shared Identities, Hughes somewhat blithely critiques a number of recent contributions to the field of Judeo-Islamic/Islamo-Judaic studies (both premodern and modern) as being mainly or solely historical or philological in nature and so failing to achieve a broader synthesis or to reach deeper and more theoretically insightful conclusions. Hughes is correct that the works he mentions here focus on specific subjects pertaining to the Muslim-Jewish encounter-dismissed rather derisively as "micro topics"26-and aim at more specifically contextualized types of insights and conclusions. However, it seems rather unfair, as well as inaccurate, to disparage these authors for not reflecting on broader issues of specific concern to scholars of religion or for failing to explicitly invoke theoretical language or models that are conventional or fashionable in some circles in religious studies.

24. Further, Hughes is explicit that he is not concerned with bringing new evidence per se to the table but rather seeks to operate synthetically and critically, interrogating and critiquing the established literature. The implication often seems to be that the main task of the scholar of religion is to perform second-order analysis on data yielded by other, lower-level types of study that generally do not aim at or achieve true critical insights. This both sells scholarship generated in other disciplines short and effaces the significant work in critical, methodologically oriented religious studies done by scholars who directly engage the historical or contemporary phenomena they study, integrating both types of research activity.

25. Shared Identities, $\mathrm{x}$.

26. Ibid., 2. 
Further, needless to say, even absent such explicit reflection on the part of these scholars, the kind of second-order theoretical analysis Hughes wishes to engage in would not be possible without the more historically grounded or philologically rigorous research into the sources conducted by the scholars he disparages here. ${ }^{27}$

In chapter 2 of Shared Identities ("Origins"), Hughes interrogates past and contemporary scholarship on the Jews of the Prophet Muhammad's time. ${ }^{28}$ Since the foundational work of Abraham Geiger (d. 1874), scholars have persistently explored the question of these Jews' identity and religious orientation, a question of great significance for our understanding of the Quran and the emergence of Islam. In particular, as Hughes notes, the "strong Judaic cast" of proto-Islam induced Geiger and others to speculate regarding the possible Jewish background of the Prophet's career and milieu, as the impact of the Jews of Muhammad's time on the Quran was often explained via a unidirectional movement of ideas and practices from these Jews to the fledgling community. I have elsewhere dubbed this the influence paradigm, though Hughes for some unspecified reason favors the language of "larceny." 29 The logic behind this coinage escapes me, since the scholars of past generations who posited this unidirectional movement of cultural goods from the Jews to Islam almost always utilized the language of debt and borrowing and seldom, if ever, characterized this movement of ideas as theft per se. ${ }^{30}$

27. In the note in which he specifies the historical-philological studies he is talking about, Hughes explicitly states: "None of them . . . are interested in larger questions supplied by the study of religion" (ibid., 152, n. 3). This is a stunningly misleading characterization of the work of the scholars in question (Mark Cohen, Marina Rustow, David Freidenreich, Jessica Goldberg, Arnold Franklin, Shai Secunda, and Phillip Ackerman-Lieberman). It is possible that Hughes simply means to distinguish himself from these scholars, identifying them (in contrast to himself) as historians or philologists by training and method rather than scholars of religion per se. However, the point of such a distinction is lost on me, and it is simply incorrect in at least one case, that of Freidenreich, whose work is squarely located in religious studies and deeply embedded in its critical discourses. I will address the question of methodology, and what Hughes specifically claims to bring to the table as a "religionist," further below.

28. Moving into Hughes's treatment of particular subjects in his books, I should note that on many occasions material from Shared Identities is repeated verbatim in Muslim and Jew; on others, the older material is synopsized but the takeaway is the same, while in a few other cases, Muslim and Jew offers a substantially different approach to a specific topic. I will sometimes note the parallels and divergences between the books below, though I have not attempted to do so systematically.

29. See Shared Identities, 43-53 passim. Hughes cites my early article on Geiger ("The Hebrew Bible and the Quran: The Problem of the Jewish 'Influence' on Islam," Religion Compass 1 [2007]: 643-659) in Shared Identities (166, n. 41), but I did not characterize the language shared between the Quran and contemporaneous varieties of Judaism as "Semitic" in nature there, as he seems to suggest (p. 48). For a more up-to-date version of my argument about the concept of "influence" as it has historically been deployed in discussions of the background to the Quran, see my The Golden Calf between Bible and Qur'an: Scripture, Polemic, and Exegesis from Late Antiquity to Islam (Oxford: Oxford University Press, 2020), esp. 34-41.

30. Hughes appears to attribute the language not only of borrowing but also of theft to Abraham Geiger (Shared Identities, 48), but I have not found a single reference to Muhammad's relationship to Judaism as Diebstahl in Geiger's Was hat Mohammed aus dem Judenthume aufgenommen?, rev. ed. (Leipzig: Kaufmann; New York: Bloch, 1902), whereas references to Aufnahme or Ableitung are ubiquitous. Hughes is certainly correct in noting the extremely widespread impact of Geiger's approach among scholars of the late nineteenth and early twentieth centuries (Shared Identities, 48-49), but my overarching impression of this literature is that 
Be that as it may, Hughes effectively unpacks the conspicuous and problematic political and ideological commitments that have so often informed scholarship in this area. In particular, he emphasizes that many attempts to resolve the question of the origins and pedigree of the Jews of the Hijāz reflect a deep-seated-and ultimately defensive and apologetic-concern with continuity. By asserting the antiquity of this Jewish community, as well as its basically rabbinic orientation, Geiger and his many followers establish not only the privileged and more original status of the Jews vis-à-vis Islam, but also forge an important link in a chain that stretches from Jewish antiquity to the Middle Ages, rooting the culture of European Jewry in the legacy of ancient Israel. However, as Hughes recognizes, the notion of a teleological spread of normative Judaism in this period-and the monolithic hegemony of rabbinic Judaism, in particular-has fallen out of favor among most scholars, as numerous studies have shown that rabbinic authority was only gradually constructed and established in diasporic Jewish communities in the high Middle Ages. ${ }^{31}$

The main impression one gets from Hughes's approach to both Islamic origins in general and the Jewish background to Islam specifically is that of a pervasive agnosticism. In discussing older trajectories of scholarship, Hughes problematizes the idea that the Jews of Muhammad's time were straightforwardly rabbinic and thus that their beliefsand consequent impact on the Quran and formative Islam-conform to the supposedly "traditional" Judaism naturalized as authoritative in the classical rabbinic canon. He concludes this discussion by stating: "[T] he problem remains: What did Judaism look like on the Arabian Peninsula in the sixth and seventh centuries? Since we have no idea, how and why do we continue to claim that a normative rabbinic Judaism was present at the 'birth' of Islam" (p. 46). It is true that the array of questionable presuppositions and ideologically suspect answers scholars working on the "Jewish question" in Islamic origins have sometimes produced suggests that, like views on the historical Jesus, any conclusion one might draw about the Jews of Muhammad's time ultimately reflects only the image of the beholder. In other words, from the time of Geiger to the present day, scholars have gazed eagerly into the darkness, striving to catch a glimpse of historical reality, but have often just spotted their own reflection and so in the end merely confirmed their own

Geiger's followers have similarly favored the language of transaction and indebtedness rather than that of theft, and that the most prevalent characterization of the situation is not one of Jews being victims of "larceny," but rather of Muslims being pervasively indebted to exemplary Jewish models. This is one of the most fundamental ways in which Geiger's work impacted approaches to the Quran and Islamic origins in the Anglo-European tradition. In any event, Hughes presents the term "larceny" in quotation marks (e.g., in the heading “'Larceny”: The History of an Idea," 50) as if he is quoting someone else's coinage, but I have been unable to discern any precedent for it. None is indicated by direct citation.

31. See, e.g., Talya Fishman, Becoming the People of the Talmud:Oral Torah as Written Tradition in Medieval Jewish Cultures (Philadelphia: University of Pennsylvania Press, 2011). Hughes productively makes use of-dare I say "borrows"?-Bulliet's metaphor of the "spreading inkblot" to describe ingrained conceptions of the spread of Islam after the Arab conquests-ineluctable, natural, and homogeneous. Hughes suggests, quite rightly in my view, that this is also how the spread of normative rabbinic Judaism in Late Antiquity is commonly imagined (Shared Identities, 8; cf. 53). 
presuppositions and biases..$^{32}$ Here Hughes, too, gazes into the abyss, but what he sees is rather different from what previous generations managed to glimpse.

To be clear, I absolutely share Hughes's skepticism of overly positivistic studies on the subject of the Jews of late antique Arabia and the Jewish social and religious context of the Quran. Most notably, we concur in our evaluations of the 2014 monograph of Haggai Mazuz, who argues on the basis of a highly problematic negotiation of the evidence that the Jews of Medina were thoroughly rabbinic in orientation. ${ }^{33}$ Similarly, it is difficult to disagree with Hughes's assertion that Islam could not have been-as Geiger and his followers postulated-the product of a unilateral communication of "influences" from a stable, well-defined Judaism to the Prophet and his fledgling Muslim community. As already noted, Hughes favors an alternative position, conjecturing that a host of diverse, but by and large unknowable, expressions of Jewish identity in the late antique milieu contributed to the precipitation of early Islam out of a variegated matrix, with what became the mature, normative forms of both traditions gradually emerging only over the course of centuries through a complex dynamic of mutual exchange and coevolution.

However, I am not confident that a position of complete agnosticism is merited or that it is the current consensus position among contemporary scholars working in this area. For one thing, considerable progress has been made in the study of Arabian Jewry on the basis of epigraphic evidence, in particular. In the case of South Arabia, the massive output of Christian Julien Robin and other scholars over the last two decades might allow us to draw some conclusions, however provisional, about the development and spread of some form of Judaism on the peninsula in Late Antiquity. In Shared Identities, Hughes briefly cites a single piece by Robin, his long article "Himyar et Israël" from 2004, but he does not take into account the substantial development of Robin's thinking in the fifteen years since in his numerous subsequent contributions, nor the more recent and complementary work of Iwona Gajda and others. Granted, we cannot directly ascertain anything about how normative the Judaism of the Jewish tribes of Medina was-the main question of interest to Hughes-by studying the rather earlier Judaization of Himyar, quite far afield from the Hijāz, though linked to it through trade and other networks maintained by the highly

32. This tendency is, of course, true of scholarly engagements with Muhammad himself; for an incisive investigation of the complex investments Western scholars have brought to inquiry into the biography of the Prophet, see Kecia Ali, The Lives of Muhammad (Cambridge, MA: Harvard University Press, 2014). Hughes himself asserts that contemporary professors of Islamic studies have produced an image of Muhammad of a particularly apologetic bent by projecting their own values upon the founder of Islam (Theorizing Islam, 34).

33. Haggai Mazuz, The Religious and Spiritual Life of the Jews of Medina (Leiden: Brill, 2014). Compare Hughes's review in the Journal of the American Academy of Religion 83 (2015): 580-82 and my "The Jews of Medina and the Challenge of Early Islamic Historiography," Review of Qur'anic Research 2, no. 2 (2016), https:// lockwoodonlinejournals.com/index.php/rqr/article/view/332. Hughes efficiently exposes the problems with Mazuz's methodology, focusing particularly on the latter's problematic reliance on the principle of mukhālafa and positing that early Muslims' insistence on acting in a fashion dissimilar to Jews in fact signals self-consciousness about the original similarity, or even identity, of the groups. Hughes's criticism of the shortcomings of Mazuz's methodology is spot on, but his critique would have been strengthened considerably by engagement with the major discussion of mukhālafa in Ze'ev Maghen, After Hardship Cometh Ease: The Jews as Backdrop for Muslim Moderation (Berlin: de Gruyter, 2006), which he overlooks. 
mobile population at the time. Nevertheless, the case of Himyar provides an important precedent for the similar (and far more successful) project of monotheization pursued by Muhammad in the Hijāz. Moreover, considering what scholars have learned about "Judaism" and how it can or should be defined in the Yemenite milieu is surely informative for similar questions of definition as they might pertain to the later Hijāzì milieu. I am not suggesting that the example of Himyar contradicts any of the conclusions Hughes draws here, only that given its direct relevance to the questions Hughes is asking, I would have imagined this case would have merited far greater consideration in his theoretical investigation in Shared Identities. ${ }^{34}$ Presumably Hughes came to recognize this lacuna himself, because Muslim and Jew includes a slightly more robust discussion of the Himyarite evidence, where Hughes briefly notes its utility for corroborating the fluid and heteronormative nature of the "Judaism" to which the Yemenite kingdom supposedly converted in Late Antiquity. ${ }^{35}$

We might also consider the significant contributions to the question of the Jewish background to Islam that have been made recently by scholars in Quranic studies. It is true that many scholars working on the Quran in a textualist-philological vein are generally reticent to advance more sweeping hypotheses of a positivist historical sort. ${ }^{36}$ Nevertheless, much of the work done in Quranic studies over the last decade is extremely pertinent to the topic of the Jewish impact on the Quran and Muhammad, yet Hughes almost completely neglects this literature here, engaging it only as it relates to more peripheral topics. ${ }^{37}$

34. On the other hand, the case of Himyar is not relevant for the reason Hughes explicitly adduces here, namely that Muhammad sent some of his followers to seek refuge in Yemen "among other communities of monotheists" when he was being persecuted in Mecca (Shared Identities, 44). Hughes is likely thinking of the so-called first hijra to Axum, in which a small group of the Prophet's followers fled to Ethiopia under the leadership of Ja'far b. Abī Țālib, Muḥammad's cousin.

35. Muslim and Jew, 14-16, citing a much broader body of secondary literature, including recent or relatively recent work by G. W. Bowersock, George Hatke, Norbert Nebes, and Iwona Gajda alongside somewhat older studies by Reuben Ahroni and Joseph Naveh (curiously, Robin continues to be represented by only the single article from 2004). Hughes has recently devoted a longer piece to the subject that more adroitly navigates the relevant primary and secondary sources: “South Arabian 'Judaism,' Himyarite Rahmanism, and the Origins of Islam," in Remapping Emergent Islam: Texts, Social Settings, and Ideological Trajectories, ed. Carlos A. Segovia, 15-43 (Amsterdam: Amsterdam University Press, 2020). Here Hughes aptly conjectures that Himyarite monotheism may have been a combination of elements, "a thin overlay of some type of non-normative Judaism over a type of autochthonous Arabian monotheism," and implies that a similar synthesis of elements may have been behind the rise of Islam in the Hijāz far to the north (pp. 37-38).

36. See my discussion of the problematic disjunction between contemporary Quranic studies and current historical perspectives on the late antique milieu in which Islam emerged in "Positivism, Revisionism, and Agnosticism in the Study of Late Antiquity and the Qur'ān," Journal of the International Qur'anic Studies Association 2 (2017): 169-99.

37. Thus, the monographs of Holger Zellentin (The Qur'ān's Legal Culture:The Didascalia Apostolorum as a Point of Departure [Tübingen: Mohr Siebeck, 2013]) and Emran El-Badawi (The Qur’ān and the Aramaic Gospel Traditions [Abingdon: Routledge, 2014]) appear in a note concerning Jewish Christianity in the early Islamic milieu (Shared Identities, 175, n. 64), though one readily imagines that they are, or should have been, much more central to Hughes's discussion. Patricia Crone, "Jewish Christianity and the Qur'ān (Part One)," Journal of Near Eastern Studies 74 (2015): 225-53 appears here as well (though not its sequel from the following year). This is the only one of Crone's more recent articles Hughes cites, although her notorious early study with Michael Cook, Hagarism: The Making of the Islamic World (Cambridge: Cambridge University Press, 1979) is cited in both 
Ignoring the substantial discussions of the Quran among specialists is a peculiar decision given their relevance to the question of what reliable information about the Prophet's milieu may be discerned in or extrapolated from the corpus, broadly recognized as the most important primary source for the rise of Islam. To be fair, Wasserstrom did not engage with contemporary debates on the Quran at all either, but he published Between Muslim and Jew at a time when Quranic studies was a far less active field of inquiry than it is today. If one had to judge by Hughes's bibliography, one would conclude-quite wrongly-that not much of significance had been happening in this area of research over the last fifteen years or so. ${ }^{38}$

Admittedly, much contemporary work on the biblical currents or subtexts in the Quran trends against the idea of a direct impact of rabbinic Judaism on the prophetic milieufavoring, for example, Syriac Christian literature as a more pervasive and proximate literary context. ${ }^{39}$ However, there is no shortage of other research that would tend to ratify the conclusion of Geiger and others that the Quran directly reflects the stamp of late antique

Shared Identities and Muslim and Jew, and her Meccan Trade and the Rise of Islam (Princeton, NJ: Princeton University Press, 1987) appears in the former. Stupendously, there is no reference to Angelika Neuwirth at all except as coeditor of the collection in which the previously mentioned article of Nebes appears. The works of John Wansbrough receive some attention in Shared Identities, for example in dialogue with the work of Boyarin (pp. 85-86). Hughes is certainly correct in discerning Wansbrough's analogous significance for inducing skepticism about the received narratives of Islam's origins, but however instrumental Wansbrough may have been in triggering major changes in our understanding of formative Islam and the emergence of the Quran, his work is hardly reflective of where the field is today. The Quran features somewhat more prominently in Hughes's article "Religion without Religion: Integrating Islamic Origins into Religious Studies," Journal of the American Academy of Religion 85 (2017): 867-88, though much of the relevant research of the last decade is again ignored.

38. There is a brief discussion of the Quran in Muslim and Jew, 18-19, that seems to reflect some minor improvement in the author's awareness of issues of significance in the field today, such as the possible impact of the Quran on Jewish literature rather than vice versa as Geiger et al. asserted, but no secondary sources other than Geiger and James Kugel on midrash (In Potiphar's House: The Interpretive Life of Biblical Texts [Cambridge, MA: Harvard University Press, 1990]) are cited here. The reader is given the impression that Hughes's insights on chronology are original, which they are not. This is hardly the only place in either book in which welltrodden arguments are presented as if ex novo, or current scholarship is neglected. Another striking example is the discussion of Jewish Sufism in chapter 6 of Shared Identities; this topic has recently benefited from a significant uptick in scholarly interest, but judging by Hughes's bibliography on the subject, one might conclude that very little had been published on it since the 1980 s.

39. In this connection, it should be noted that most scholars working on the origins of Islam and the background to the Quran today would emphasize that both were undoubtedly the products of complex interactions and dialogues between multiple communities in Late Antiquity, in which not only Jews but also Christians and pagans participated along with the Quranic community; this multifaceted dynamic continued well into the early and medieval periods of Islamic history. Hughes's work reflects and responds to a particular trajectory in the historical scholarship, and so he emphasizes the Jewish-Muslim dialogue to the exclusion of other participants. For a model study that often succeeds in capturing the polyvalent complexities of social and religious interactions among Jews, Christians, Muslims, and others from Late Antiquity to the high Middle Ages, see Uriel Simonsohn, A Common Justice: The Legal Alliances of Christians and Jews under Early Islam (Philadelphia: University of Pennsylvania Press, 2011). The aforementioned work of Lassner, Jews, Christians, and the Abode of Islam, likewise succeeds at triangulating between the traditions both theoretically and in the case studies it considers. 
Jewish thought, though this is now conceived and articulated in a more sophisticated, less reductive way than it has been in the past.

Here a conspicuous problem presents itself. On the one hand, the archaeological and epigraphic data suggest that a form or forms of Judaism prevailed in both Himyar and the Hijāz that we can characterize at most as diffuse and heteronormative (at least relative to rabbinic normativity, an entirely problematic construct in the late antique context). On the other hand, some contemporary work on the Quranic evidence suggests that textual traditions rather close to those that survive either in the standard rabbinic corpus or in "pararabbinic" corpora (such as the piyyutim) supply the most plausible literary precursors for the Quran. ${ }^{40}$ It is not clear whether and how these trajectories can be reconciled. As with the case of Himyar, it is striking that Hughes almost entirely ignores them.

It is a shame that Hughes generally overlooks recent work on the Quran, because there is much here that would enrich his perspective and perhaps move his argument forward out of the foggy state of agnosticism that he dwells in when discussing this critical period. In acknowledging the presence of Jews in and around the Arabian milieu, Hughes briefly mentions Himyar but also refers to the famous community settled at Elephantine in Egypt during the Persian period; since the papyrus remains of the Jewish colony there date to the fifth century BCE, one wonders if this datum is really a relevant comparandum for illuminating the situation in Late Antiquity. ${ }^{41}$ What is surely more relevant is Crone's work on the belief system the Quran attributes to the mushrikūn, Muhammad's "pagan" opponents. In a number of publications before her untimely death in 2015 , Crone argued that the evidence of the Quran itself militates in favor of a view of the Prophet's interlocutors as themselves informed by-and so presumably acculturated to-a worldview that is fundamentally "biblical." Neither the tradition nor the Quran identifies the mushrikūn as Jews, and Crone opts for the hypothesis that at some point, presumably through direct contact with "Israelites"-a population somehow anchored in and defining itself in relation to some register of ancient biblical tradition-the Hijāzì Arabs of Muhammad's time had become strongly assimilated to monotheism of an Israelite-Judaic stripe. ${ }^{42}$ As in the case of Himyar, the evidence of the Quran suggests gradual acculturation to a diffuse form of Israelite monotheism rather than conversion to a formally defined rabbinic or quasirabbinic Judaism. This way of understanding the milieu and Muhammad's contemporaries

40. On the question of canonical rabbinic or pararabbinic precursors to Quranic material, see now my "The Two Sons of Adam: Rabbinic Resonances and Scriptural Virtuosity in Sūrat al-Māidah," Journal of the International Qur'anic Studies Association 6 (2021) (forthcoming) and the bibliography therein.

41. Shared Identities, 44. One could argue that the case of Elephantine is in fact relevant since the form of Judaism reflected in the papyri sometimes diverges quite acutely from what we know of the "normative" or "mainstream" Judaism of the time as evidenced in the literary (that is, biblical) sources for the period. Moreover, Karel van der Toorn has proposed that the Elephantine community was originally Samarian in origin and only gradually acquired a diasporic Jewish identity in response to changing circumstances in Egypt; see his Becoming Diaspora Jews:Behind the Story of Elephantine (New Haven, CT: Yale University Press, 2019). These points seem to me to be quite relevant for Hughes's argument, but the case of Elephantine is raised only as evidence of a Jewish presence in the Arabian (or at least Eastern Roman) environs in the pre-Islamic period.

42. Most of the studies collected in Patricia Crone, The Qur'ānic Pagans and Related Matters, vol. 1 of Collected Studies in Three Volumes, ed. Hanna Siurua (Leiden: Brill, 2016) are pertinent to this theme. 
is surely pertinent to Hughes's main point of interest in the proto-Islamic period, namely, the presence and status of Jews-or "Jews"-in the milieu, and his work would have been considerably enriched by engaging with Crone and other scholars working in the field of Quranic studies. ${ }^{43}$

Intriguingly, Crone's approach dovetails with a strand in older scholarship that postulated that the Jewish tribes of Muhammad's time were "converts"-Judaized Arabs rather than Arabized Jews, as it were. ${ }^{44}$ It is emblematic of Hughes's agnosticism about the Jews of the Hijāz that he is skeptical both of claims of the ancient Palestinian origins of the community and of the thesis that they were converts, as earlier scholars such as Hugo Winckler and D. S. Margoliouth held. ${ }^{45}$ However, although some of their ideas are now problematic, the approach of these older scholars is in some sense vindicated by contemporary research on the spread of some form of Israelite or Jewish identity in both Yemen and the Hijāz in the pre-Islamic period. Hughes's objection to this approach centers on the fact that he sees conversion itself as a problematic notion in this context. Given the lack of doctrinal and institutional coherence Hughes sees as typical of most (all?) varieties of late antique Judaism, he justifiably asks what such putative converts are thought to be converting to; surely we cannot take for granted any kind of formal process of conversion signifying a decisive movement from one clearly delineated system of belief and practice to another. Another strange lacuna in Hughes's work confronts us in this connection, for there is an established, and considerable, scholarly literature on conversion, expressions of communal belonging, and nominal-symbolic or practical boundary-crossing between communities in Late Antiquity, much of which would surely have been relevant to his interests here.

Be that as it may, if we accept the notion that the "Jews" of Muhammad's time were neither rabbinic in orientation nor formal converts but rather Arabs who assimilated to some form of Judaic or Israelite cultural identity-Crone's "God-fearers" 46 -we again face the question that is central to Hughes's enterprise: what was Judaism in the late antique, protoIslamic milieu anyway? The evidence of the Quran, at least as read by Crone, corroborates Hughes's thesis of a diffuse, poorly defined, heteronormative Judaism in this environment. And yet we must ask how diffuse membership in the Jewish community (or Banū Isrā's̄l, or

43. As noted, one of the most striking omissions is the work of Neuwirth, who for many years, in a massive corpus of publications, has articulated an extremely sophisticated approach to the genesis of the Quranic revelation, rejecting the influence paradigm that prevailed in the past in favor of a sophisticated, nuanced presentation of the Prophet and his community as deeply engaged with a Judaic literary and social environment. This is extremely relevant to the "Jewish question" as it pertains to Islamic origins, and so Neuwirth's absence from Hughes's discussion is especially glaring.

44. In his discussion of the origins of Arabian Jewry in his classic A History of the Jews of Arabia from Ancient Times to Their Eclipse under Islam (Columbia: University of South Carolina Press, 1988), Gordon Newby strikes a judicious balance between the accounts of ancient Jewish migration into Arabia-which he seems to perceive as grounded in historical reality despite the obvious ideological commitments of many scholars positing this model of origins-and the numerous traditions that suggest that many of the Jews of Arabia were converts. Trenchantly, Newby observes pre-Islamic Arab conversion to Judaism as a foreshadowing of Islamization (p. 53).

45. Shared Identities, 51-53.

46. Patricia Crone, "Pagan Arabs as God-fearers," in Islam and Its Past: Jahiliyya, Late Antiquity, and the Qur’an, ed. Carol Bakhos and Michael Cook. 140-64 (Oxford: Oxford University Press, 2017). 
Ahl al-Kitāb, all floating signifiers) could really have been in Muhammad's time, since it was cogent enough to be a major criterion of social distinction in the Quran itself. Quranic discourse presupposes that individual and communal identity are determined by the path one follows, and so we must infer from this that the criteria of distinction between the prophetic community of Believers and the Jews (yahūd, sometimes styled alladhina hādū, "those who profess Judaism") were substantial enough to be both legible and meaningful to the Quran's audience. It is difficult to imagine that when the Quranic revelation insinuates that the Jews merit both worldly sanction and eschatological punishment for their misdeeds, the Prophet's followers were uncertain about who was meant or how they differed from members of their own community. Though the distinctions may have been rudimentary and the social boundaries blurry at times, they must have been basically coherent; to be a Jew, whatever that meant, was something significant to the Quran's audience. Nor could such distinctions have been ideal or abstract, unless one imagines-contrary to the consensus-that the Quran was revealed in a vacuum and that its message had no direct social implications. I assume Hughes would agree with this overall appraisal, but to me this all underscores the pertinence of the Quranic evidence to arguments about the Jewish context of Islam's origins.

Those of us who work in this area are well accustomed to abiding in the shadowy realm of conjecture, and so we typically aim at probability and plausibility rather than absolute certitude. However, it is debatable whether a position of total agnosticism is still warranted today and whether we should be content to throw up our hands and claim that the attempt to reach any conclusions about the varieties of Judaism represented in the ambit of the proto-Islamic community is hopeless. There are surely some arch-revisionists still out there who would share Hughes's supposition that we have no idea what was happening in the Hijāz in this period, but to present this as the status quaestionis seems like a rather nihilistic mischaracterization of the field as it now stands. Although this subject must surely be treated with caution and approached with skepticism, Hughes's repeated emphasis on the "aporia" of the Jews of Late Antiquity and early Islam in our historical understanding-an extreme, though at times selective, revisionism-is conspicuously uninformed by contemporary debates. ${ }^{47}$ It is clear we cannot go back to the unreflective and unselfconscious positivism of the nineteenth century; but the Jewish presence in pre-Islamic Arabia is hardly a total black box either, and recent approaches have rehabilitated the perspectives of at least some of the scholars of past generations, though these approaches are largely overlooked by Hughes.

\section{Among the Believers: From the Prophetic to the Early Islamic Period}

A pervasive ambiguity regarding the reliability of the available sources for the protoIslamic period runs throughout Hughes's work. While he generally adopts a skeptical pose, at times he equivocates and becomes more sanguine regarding what exactly we can know

47. The term aporia (literally a disjunction or impasse) recurs several times in Shared Identities; Hughes employs it to signify what he alleges to be the current state of our historical understanding (or lack of understanding) of the nature of Jewish-Muslim relations in periods for which we either have no sources or our sources cannot answer the kinds of questions we wish to pose to them. 
about the prophetic milieu (or at least what questions we can ask and plausibly answer on the basis of the sources). His perspective on the so-called Constitution of Medina is instructive in this regard. Hughes initially sounds a rather pessimistic note about this document given that it survives only in a source dating to more than a century after the time of the Prophet, the Sirrat Rasūl Allāh of Ibn Ishāq (d. 150/767). He observes that both Michael Lecker and Uri Rubin have sought to address the question of the identity (and specifically the tribal affiliations) of the document's Jewish signatories and concludes that even if we judge it reliable, what it primarily attests to is the fuzziness of the boundaries delineating Jewish groups from others in the milieu: "[T] he contours of these 'Jewish' groups ... are impossible to ascertain with any historical clarity." 48 He thus reads the document as an imperfect approximation of a complex reality in which "Jews," however they might have been defined or identified themselves, were incorporated into or accommodated by the early umma. However, one might object that in the end, it is clear that the Jews are not reducible to simply one of several tribal configurations among the others mentioned in the Constitution of Medina; rather, these groups are exceptional among its signatories. Pace Hughes, one wonders what the basis of that exceptionalism is if it is not somehow religious in nature.

One senses a kind of revisionist sleight of hand here: the text of the pact, like the vast majority of extant traditions on the rise of Islam, is preserved in a source that dates from at least a century after the event and so is asserted to be intrinsically suspect; but at the same time, insofar as it is reliable, what it supposedly signals for Hughes is the blurry boundaries of the early umma and the impossibility of determining what "Jewish" identity could have meant in this context. ${ }^{49}$ Although Hughes does not cite him in this passage, one senses Fred Donner's well-known thesis about the fluidity of the early movement of the Believers (as he dubs the primitive community under the guidance of the Prophet) in the background here..$^{50}$ Donner, according to whom muslim was not a distinct, formal religious identity per se but rather a designation limited to Arab converts lacking a previous monotheistic communal identity, is acknowledged elsewhere in Shared Identities, however; for example, he is cited as corroborating Hughes in emphasizing the vagueness of the terms qualifying someone as a member of the early community (p. 9), though in a footnote to this passage, Hughes actually criticizes Donner for characterizing the early movement as specifically "religious" in nature (p. 153, n. 21).

48. Shared Identities, 60. Stunningly, this is the only reference to Uri Rubin's important work in either book. This is perhaps the apposite place to observe that Hughes chronically undercites works and authors relevant to his argument throughout both books; sometimes the omissions are quite startling, as when Hughes ignores studies that are indispensable to a responsible handling of the topic at hand. The problem is especially acute in Muslim and Jew.

49. This ambiguity is characteristic of Hughes's approach to the Isawiyya as well, where late and problematically ideological sources are by and large assumed to represent historical verities when they confirm Hughes's basic thesis about the blurring of boundaries and the ambiguity of identities. In this, Hughes follows Wasserstrom, who struggles to negotiate a critical approach to heresiography while relying on such works for his revisionist historiography. See the discussion of the Isawiyya and messianism below.

50. Fred M. Donner, Muhammad and the Believers: At the Origins of Islam (Cambridge, MA: Belknap Press, 2010). 
However, it is not clear to me that Hughes has apprehended the real point of Donner's argument. Donner's project in Muhammad and the Believers is to show-primarily on the evidence of the Quran itself-that the early umma was far more ecumenical than has been previously recognized, and specifically that the first followers of Muhammad welcomed pious Jews and Christians alongside muslim or "submitting" Arabs in a common pietistic and apocalyptic movement. ${ }^{51}$ To Donner, the Prophet was not founding a new, formally bounded and well-defined "religion" in the modern sense (and so here he and Hughes are in agreement), or even in the sense according to which Muslims would assert categorical prerogatives over Jews and Christians as an imperial ruling class only a few decades after his death. This does not mean, however, that markers of identity and distinction were not operative in the early community, or that they did not quickly come to predominate in the conceptual repertoire shared by various groups in the caliphal period-points Hughes fails to appreciate..$^{52}$

It is noteworthy that Hughes acknowledges Lecker more substantially in his discussion of the Constitution of Medina..$^{53}$ In numerous studies published over the course of decades, Lecker has shown through methodical and at times ingenious interpretation of data provided in the oft-maligned traditional Muslim sources on the formative Islamic period that we can actually discern much useful and plausibly reliable historical information in those sources. Much of Lecker's work pertains to the Jews of the Hijāz, and although he is predominantly interested in questions of tribal affiliation, diplomatic relations, genealogy, and so forth, he has also offered various conjectures pertinent to the subject of the Jewish tribes' religion and its impact upon the formative Muslim tradition. However, most of Lecker's titanic output is dismissed or simply overlooked by Hughes; there is no acknowledgment, for example, of his major 2014 monograph on Muhammad and the Jews. ${ }^{54}$ One might imagine that Lecker's work was of limited benefit to Hughes's project because Lecker by and large seems to assume that the Jewish tribes of Arabia were aligned with the rabbinic Judaism of Palestine and Babylonia; his conclusion that aspects of the Medinan Jews' culture reflected a hegemonic rabbinic normativity contradicts Hughes's argument on a fundamental level. ${ }^{55}$ More broadly, it is possible that Lecker's disposition toward drawing

51. See now also Stephen J. Shoemaker, The Apocalypse of Empire: Imperial Eschatology in Late Antiquity and Early Islam (Philadelphia: University of Pennsylvania Press, 2018), emphasizing apocalyptic piety both as the basis of the "ecumenism" of Muhammad's movement and as the common denominator shared with many other communities in the late antique and early Islamic period.

52. Donner's thesis is cited more straightforwardly in Muslim and Jew, but again as demonstrating the indistinctness of the categories "Muslim" and "Jew" rather than the ecumenism of the umma, which I take to be the real thrust of Donner's argument.

53. See Shared Identities, 59-60; a briefer discussion appears in Muslim and Jew, 30.

54. Michael Lecker, Mûhammad ve-ha-Yehûdîm [Muhammad and the Jews] (Jerusalem: Makhon Ben-Tzvi, 2014). Lecker's extensive scholarly output in English from the last twenty years is readily available in a number of collected volumes.

55. Alternately, we might imagine that not enough of Lecker's work addresses the religion of the Jews of Medina per se, although-as Hughes himself would remind us-it is supposedly impossible to isolate religion from other categories of identity and behavior at this time (this is the crux of his critique of Donner, which strikes me as somewhat misplaced). 
positivistic conclusions about the primitive Islamic milieu on the basis of the later Muslim sources is simply unappealing to Hughes, as it seems to be to many scholars of a revisionist bent; Hughes is hardly the only contemporary scholar who seems at best indifferent to Lecker's numerous contributions to the field, whether published in Hebrew or in English.

The problematic nature of other aspects of Hughes's navigation of the early historiographic tradition becomes apparent as he transitions from the prophetic period to the early centuries of the Islamic dominion. Aspects of Hughes's treatment of the Sira of Ibn Ishāa in Muslim and Jew are strong, as when he recognizes that sira traditions function exegetically, anchoring the interpretation of the Quran in episodes in the life of the Prophet rather than conveying objectively reliable historical information. He also notes that some aspects of the sira serve to cast Muhammad as the fulfillment of biblical prophecy, a wellestablished argument in the field. ${ }^{56}$ However, he veers into somewhat dubious territory when he asserts that the first section of Ibn Ishāq's work, the so-called mubtada', which collects traditions on Muhammad's prophetic precursors, was sheared off by Ibn Hishām (d. 218/833) and other transmitters specifically because of Ibn Ishāà's copious reliance upon isrāinliyyāt, which had fallen into "disrepute" by this time. ${ }^{57}$

Although the abridgment of the Sirrat Rasūl Allāh has been much discussed, the claim that it was judged to be necessary on the basis of on the work's proliferation of isrā'iliyyāt already in the third/ninth century (as Newby, Hughes's source here, avers) is no longer tenable. For one thing, insofar as Ibn Hishām's motivations for his interventions into Ibn Ishāq's work may be thought to be dogmatic in nature, this perception more likely stems from problematic narratives such as the famous Satanic Verses episode. ${ }^{58}$ As regards the mubtada' specifically, most scholars would understand the truncation of the work as reflecting the rapid obsolescence of an approach to the sira that anchored it in pre-Islamic prophetic tradition. The wide circulation of Ibn Ishāq's material on pre-Islamic history in other sources of the period-the basis of Newby's reconstruction of the mubtada'demonstrates that the supposedly censorious attitude toward that material that Hughes attributes to Ibn Hishām and other transmitters of the sīra could hardly have been widespread in the early centuries of Islamic history. Insofar as objections to the inclusion in the Sira of material on the pre-Islamic prophets arose in this period, they were more likely based on evolving conceptions of genre than an aversion to reliance on materials of a Jewish or quasi-Jewish ambience such as would prevail in some circles much later on.

56. These statements (Muslim and Jew, 21-22) reflect a nuanced understanding of the nature of sira and how it functioned in the early period; however, they are rather familiar ones in contemporary scholarship, and Hughes fails to cite a single corroborating source here.

57. Hughes's source is the introduction to Gordon Darnell Newby, The Making of the Last Prophet: A Reconstruction of the Earliest Biography of Muhammad (Columbia: University of South Carolina Press, 1989). Newby's account of the evolution of the Ibn Ishāq corpus was stridently criticized at the time of its publication (see the review of Lawrence I. Conrad, "Recovering Lost Texts: Some Methodological Issues," Journal of the American Oriental Society 113 [1993]: 258-63) and is quite out of date today.

58. On the complex history of Ibn Ishāq's account of this episode, see Shahab Ahmed, Before Orthodoxy: The Satanic Verses in Early Islam (Cambridge, MA: Harvard University Press, 2017). 
Hughes's position here demonstrates a clear misunderstanding of the history and development of isrāinliyyāt as a concept. The copious preservation of Ibn Ishāa's material on pre-Islamic history itself suggests that the kind of censorial activity Hughes attributes to Ibn Hishām, based on the material's "disreputable" association with Jews, is plainly anachronistic for the third/ninth century. But more to the point, much critical investigation of isrā'iliyyāt has shown that this construct should not be taken at face value or understood to be operative in the early centuries of Islamic tradition, as is still sometimes assumed. Numerous studies have shown that the concept of the isrāinliyyāt is an ideological tool that developed quite late in the history of the tradition, but the notion of a categorical opposition to this material because of its questionable authenticity and association with Jews and Judaism has often been projected back and nativized as an aspect of Muslim scholarship early on, a position that simply does not hold up to critical scrutiny. ${ }^{59}$ The motivation to censor the mubtada' as part of a concerted effort to suppress material of a Judaic cast can only fancifully be ascribed to authors and transmitters of the early centuries $\mathrm{AH}$.

Hughes's approach to the question of the isrā'illiyyāt is unfortunate because this phenomenon is undoubtedly significant for his larger project; as a discourse, isrā̄iliyyāt is a preeminent example of an ideologically freighted form of traditional Muslim engagement with Judaism. The idea of the isrā̄iliyyāt as a corpus of traditions that contaminated and undermined a pure, genuinely "Islamic" form of knowledge handed down from the Prophet and the salaf is one component of an ideology of separation or boundary-drawing between Sunnism and various supposed heterodoxies that developed in the post-Mongol eraassuming, as many would, that the Mamluk-era jurist Ibn Taymiyya (d. 728/1328) should be recognized as the watershed figure in that development. Asserting that there was authentic hostility to supposed Jewish intrusions into the pure stream of prophetically validated religious knowledge from Islam's very beginnings, or even in the early centuries AH, or that a corpus of so-called isrā̄iliyyāt could be objectively demarcated and partitioned off from genuinely Muslim lore, is to naturalize and validate a much later, conspicuously polemical, conception of the received tradition. Concerned as he is with the dynamics of differentiation and separation that have contributed to false ideas of a coherent distinction between Judaism and Islam-a distinction Hughes repeatedly avers was objectively lackingone would imagine that he would be more sensitive to the function of the very category of isrāinliyyāt as an ideologically motivated discursive tool used to promote a myth of pristine origins for the received tradition of Islamic religious knowledge. (One also imagines that Hughes should have been more sensitive to anachronistic arguments, given his propensity to target them in others' works.) Curiously, when Hughes discusses the importance of such origin myths elsewhere, no reference to the discourse of isrāisliyyāt is to be found, though it would have augmented his argument considerably. I will return to this point presently.

59. See Roberto Tottoli, “Origin and Use of the Term Isrā̄iliyyāt in Muslim Literature," Arabica 46 (1999): 193-210 and Michael Pregill, "Isrā̄̄liyyāt, Myth, and Pseudepigraphy: Wahb b. Munabbih and the Early Islamic Versions of the Fall of Adam and Eve," Jerusalem Studies in Arabic and Islam 34 (2008): 215-84, esp. $237-41$. Hughes cites the latter article in his bibliography in Shared Identities but seems to miss the import of my argument. 
Hughes's approach to other primary sources for the period and their interpretation is similarly problematic. ${ }^{60}$ One of these is the Doctrina Jacobi nuper baptiziati, a complex text in the Christian adversus iudaeos tradition that has attracted scholarly attention both for its putatively accurate attendance to actual Jewish beliefs on the eve of Islam and for certain statements it makes about Muhammad, in particular its seeming attestation of Jewish belief in Muhammad as a herald of the Messiah. Notably, the date of the text has been disputed: some see it as genuine contemporary testimony to early Jewish support for Islam as a messianic movement, while others note that at least some of the claims made in the text clearly reflect later conceptions ${ }^{61}$ Hughes repeatedly cites the text (consistently referring to it as the Doctrina Iacoba) as evidence of the interconnection and porousness of the three monotheisms at the time, seeing groups from each community genuinely marshaled together under the apocalyptic banner of early Islam: "a rather generic late antique apocalypticism encompasses Jews, Christians, and Muslims." ${ }^{2}$ However, the most cautious reading of the Doctrina is that it has conflated the Jewish belief that the rise of Islam is a harbinger of the coming of the Messiah (a plausible claim borne out by other sources) with the notion of actual active Jewish support for Islamic dominion (a rather less plausible one). It is more problematic, in my view, to read the text as evidence that Jews widely embraced Islam, that the movement was perceptible from the outside as "ecumenical" and friendly to Jews, or-the notorious reading of Patricia Crone and Michael Cook's Hagarism-that protoIslam was rooted in a kind of Jewish messianic revolt. (I would judge all of these claims to be rather farfetched, as they seem to me to misconstrue what are at most polemical assertions about Jews in the Doctrina, but again, I admit that there is disagreement about all this.) At most, what the Doctrina seems to testify to is the coincidence of Jewish and Christian apocalyptic expectations on the eve of Islam, and that the mission of Muhammad and the subsequent Arab conquests appeared to validate those expectations in the eyes of both. ${ }^{63}$

60. In Muslim and Jew Hughes raises the subject of "non-canonical" sources that shed light on early Islam (p. 26), though what he actually seems to mean are references to the Prophet and the rise of Islam found in early non-Muslim sources. These texts are indeed technically "non-canonical" from the Islamic perspective, in distinction to the Quran and hadith, but this strikes me as a rather idiosyncratic way to characterize them. I infer that the choice of label is motivated by Hughes's desire not to project confessional categories onto the sources, his whole point being that we should not reify the distinctions between Islam and other traditions in this period.

61. The established consensus among scholars of Late Antiquity is that the text is genuinely dateable to the 630s. Among Islamicists, this dating is accepted by Robert Hoyland and Shoemaker (Robert G. Hoyland, Seeing Islam as Others Saw It: A Survey and Evaluation of Christian, Jewish and Zoroastrian Writings on Early Islam [Princeton, NJ: Darwin Press, 1997], 55-61; Shoemaker, A pocalypse of Islam, 87-89, and compare his treatment in A Prophet Has Appeared: The Rise of Islam through Christian and Jewish Eyes [Oakland: University of California Press, 2021], 37-44). However, Sean Anthony favors a later date of composition sometime around the 670s (Sean W. Anthony, "Muhammad, the Keys to Paradise, and the Doctrina Iacobi: A Late Antique Puzzle," Der Islam 91 [2014]: 243-65, now reiterated in Muhammad and the Empires of Faith: The Making of the Prophet of Islam [Oakland: University of California Press, 2020], 41-58).

62. Muslim and Jew, 27. As Hughes himself acknowledges, much of this chapter recycles material from his article "Religion without Religion," and so this passage recapitulates the mishandling of the Doctrina found there (pp. 877-78).

63. Hughes's main source for his discussion of the Doctrina is Shoemaker's The Death of a Prophet: The End 
It seems like a significant overreading to suggest that the text is proof that "the three monotheisms are not separate from one another at this point in history." 64

Hughes's discussion of the Doctrina is closely linked to the subject of the sect of the Isawiyya; Hughes views both that movement and the "polythetic and inclusive" messianic literary works of the period as reflecting the spirit of an age in which Jewish, Christian, and Muslim groups circulated, absorbed, and operationalized numerous ideas and claims that would later be branded as heterodox. ${ }^{65}$ For Hughes, as for Wasserstrom before him, this shadowy sect is particularly valuable as prime evidence of the reciprocity of messianic developments among Muslims and Jews in the early period. ${ }^{66}$ Muslims drew on Jewish traditions about the Messiah in articulating their own ideas about the imminence of the eschaton, while "hybrid" or "syncretic" groups such as the Isawiyya seem to have remained oriented toward a publicly Jewish identity as they articulated a theology that strongly overlapped with emergent forms of early Shicism. The Isawiyya apparently combined Muslim and Jewish terms, concepts, and practices in such a way as to be legible to both communities; their theology was Muslim, but their rituals were Jewish (Jewish enough that they apparently intermarried with Rabbanites, according to Shahrastānī). As Hughes cleverly puts it, the group appears to have operated in that liminal space "on the margins of the hyphen in the phrase "Jewish-Muslim." ${ }^{67}$ For him, they epitomize (to again invoke his terms) the type of the Muslimjew or Jewmuslim that ultimately challenges the conceptual stability of the terms Jew and Muslim, which scholars have only artificially naturalized as antipodes. As I read them, a crucial difference between Wasserstrom and Hughes seems

of Muhammad's Life and the Beginnings of Islam (Philadelphia: University of Pennsylvania Press, 2011), who here sees both the Doctrina and the Secrets of Shim'on bar Yohai as testifying to Jewish believers (or Believers) aligned with Muhammad's community (pp. 20-33), though Shoemaker seems rather more cautious about such claims in his more recent Apocalypse of Empire.

64. Muslim and Jew, 27, reiterating "Religion without Religion," 878.

65. Shared Identities, 70-75; the reference to "polythetic and inclusive messianic works" (specifically the Doctrina and the Secrets of Shim'on bar Yohai) is on p. 74. Hughes's reliance on Wasserstrom is particularly strong here.

66. Hughes here attributes a peculiar claim to Shlomo Pines, stating that Pines argued that the Isawiyya were directly "influenced" by apocalyptic sources such as the Doctrina; Hughes critiques this view as reducing the complex dynamics that gave rise to the sect to mere "borrowing" facilitated by the circulation of texts (Shared Identities, 71-72). The Pines piece cited here is "The Jewish Christians of the Early Centuries of Christianity according to a New Source," Proceedings of the Israel Academy of Sciences and Humanities 2, no. 13 (1966), which discusses the then-recently discovered Tathbit dalā'il al-nubuwwa of Qāḍī 'Abd al-Jabbār and advances the controversial thesis that this eleventh-century Mu'tazilite text preserves evidence of the endurance of Jewish Christianity well into the Islamic period. Pines briefly mentions the founder of the Isawiyya, Abū 'īsā al-Ișfahānī, at 44-45; however, the textualist argument for "influence" of apocalyptic texts on the movement decried by Hughes is nowhere to be found in Pines's long article. Nor is there any reference here to the Doctrina or any other apocalyptic text. The gist of Wasserstrom's critique of Pines is not that the latter overstates processes of "influence" in the emergence of the Isawiyya but rather that he mistakenly insists that the group is a late survival of an authentically ancient Jewish Christianity and not a reflex of contemporary Islamic phenomena (Wasserstrom, Between Muslim and Jew, 37-38, and cf. the comparison with the approach of Israel Friedlaender at 82).

67. Shared Identities, 73. 
to lie in how typical each imagines the Isawiyya and other "hybrid" groups to be. For Wasserstrom, such groups are provocative because they are so anomalous, compelling us to interrogate our theoretical and phenomenological assumptions (particularly the absence of Jewish sectarianism between the Second Temple period and the Karaites). For Hughes, by contrast, the Isawiyya seem to be exemplary, demonstrating an ambiguity in the distinction between Jew and Muslim that he sees as chronic, pervasive, and persistent. ${ }^{68}$

In Shared Identities, Hughes's discussion of the Isawiyya segues to the Secrets of Shim'on bar Yohai, a Jewish apocalyptic text dated to around the mid-eighth century CE; Hughes holds that this work is significant for his argument because it "identifies Muhammad as the fulfillment of Jewish messianic speculation." ${ }^{69}$ Hughes is correct in noting that the work is evidence of a kind of feedback loop between Jewish and Muslim communities in this period, as the Secrets "recycles Muslim apocalyptic speculation, some of which had already been paradoxically recycled from Jewish sources by early Muslims." ${ }^{\prime 0}$ He elegantly describes the creative process that generated the text as an example of "collective world-making in an environment wherein ideas moved freely between porous boundaries," but perplexingly, he concludes the paragraph by stating: "The result is that it is impossible to know what is 'Jewish' and what is 'Muslim."'71 This verdict seems farfetched to me, since what this source testifies to is the availability of shared symbolic and imaginative resources to diverse communities operating in the early Islamic period, a kind of messianic-apocalyptic koine, but one whose meaning was clearly contested by the various participants who appropriated and deployed this koine for their own ends.

I imagine that Hughes would likely see this as an oversimplification, but to me it seems rather evident that the deployment of this koine to advance an argument for Islam as the final prophetic dispensation may simply be called "Muslim," while its deployment as a prophecy of the imminent redemption of Israel may be called "Jewish." The specific origins of particular aspects of the koine may be ambiguous, but as operationalized in the Secrets, it is not evidence of blurred boundaries; it is evidence of the articulation of a specific communitarian and sectarian orientation through contesting the meaning of the aforementioned shared symbolic and imaginative resources. I am not even sure that "collective worldmaking" is really an accurate characterization of this dynamic, since this "collective worldmaking" was pursued in the service of mutually incompatible worldviews. This is abundantly clear in the Secrets, because the text as redacted contains at least two strata: an early one that presents the Ishmaelite kingdom as a divine instrument used to deliver the Jews from Rome and thus as a harbinger of the redemption-a clear endorsement

68. Another significant difference in their approaches is highlighted by Hughes himself: whereas Wasserstrom presents the Isawiyya and other contemporary Jewish groups as reacting to Islamicization, Hughes sees them as "caught up in" that very process-embedded and participating in larger religious, political, and cultural trends that ultimately shaped both traditions (Shared Identities, 77).

69. Shared Identities, 76. To be fair, this characterization is Shoemaker's, who uses almost the exact same phrasing, "the fulfillment of Jewish messianic expectations" (Death of a Prophet, 24), though he is not cited here.

70. Shared Identities, 77. It is unclear to me why the "paradoxically" should be necessary here.

71. Ibid. 
of and participation in the imperial eschatology seemingly embraced by the Umayyad dominion in the first/seventh century-and a later one that is considerably more negative regarding that dominion. But neither stratum should really be understood as presenting the Prophet as the "fulfillment of Jewish messianic speculation." 72 At best, the coming of Muhammad is here interpreted as a positive sign of the imminence of the messianic era; at worst, it is understood as the beginning of the Messiah's birth pangs, a time of extreme, though portentous, suffering for Jews. As extant, the Secrets testifies to both viewpoints, and neither represents Islam as anything but instrumental.

At most, one might argue that the Secrets contains evidence that some Jews in the Umayyad period saw the caliphate favorably and even assimilated it into older schemes of the imperial succession that would precede the advent of the messianic age, though this view would be tempered not long after. It is peculiar that Hughes does not recognize the composite nature of the text of the Secrets and thus the disparate perspectives that inform it, given that he quotes the text according to a witness from the Cairo Geniza that actually refers to Muhammad disparagingly as "a crazy man possessed by a spirit . . . [who] speaks lies about the Holy One"; this is seemingly an emendation of an originally pro-Umayyad tradition in the text that brings it into line with the later tradition that is here redacted together with it. One would think that all this signals a text that is clearly Jewish in outlook-though perhaps complicating our ideas of the boundaries of Judaism-and not by any means identifiable as Muslim. ${ }^{73}$ Overall, Hughes is right to emphasize that messianism provides us with a distinctive basis for studying Jewish-Muslim engagements, as messianic groups "draw upon sets of decentralized messianic narratives to carve out ontic space for themselves"-a clear improvement over prevailing approaches to the traditions as cleanly defined binaries. ${ }^{74}$ But in the end, Hughes overstates the degree to which the messianic enthusiasms shared by Jews and Muslims in the early Islamic period really represent some kind of collective enterprise. Apocalypticism may have been a common discourse legible to different groups, but that discourse was deployed to articulate utterly dichotomous truthclaims. There was nothing "generic" about its expressions at all.

There are numerous other sources and phenomena from the early Islamic period that would have further supported or nuanced Hughes's argument in both works yet curiously remain unmentioned in either book. ${ }^{75}$ These omissions are sometimes rather perplexing;

72. On the Secrets and imperial eschatology, see Shoemaker, Apocalypse of Empire, 98-100; on the redactional strata in the text, see the discussion, translation, and commentary of John C. Reeves in Trajectories in Near Eastern Apocalyptic: A Postrabbinic Jewish A pocalypse Reader (Leiden: Brill, 2006), 76-89.

73. Hughes's source for the text of the Secrets is the classic discussion of Bernard Lewis ("An Apocalyptic Vision of Islamic History," Bulletin of the School of Oriental and African Studies, 13 [1950]: 308-38), who actually takes note of both the original and the pejorative readings registered in the witnesses, though Hughes oddly does not acknowledge the original reading that supports his argument. Compare Reeves, Trajectories, 79, n. 20. Hughes's discussion in Muslim and Jew, 28-29, an abbreviation that makes the same points and cites the same source, likewise acknowledges only the pejorative reading.

74. Shared Identities, 81.

75. As just one example, Hughes is aware-again following Wasserstrom-that the interface between the early Shica and contemporary Jewish movements represents a productive site of inquiry regarding his concerns, 
for example, though he is concerned with boundary construction and the delineation of discourses about the other, Hughes never mentions the word dhimmi and omits any reference to the Pact of Umar or the narratives about 'Umar b. al-Khațāab's interactions with Jews, though these are crucial for understanding the normative discourse surrounding social and religious boundaries between Muslims and non-Muslims through the premodern period. ${ }^{76}$ Further, the study of Jews and Christians as imperial subalterns in the caliphal period into the Middle Ages flourishes in contemporary scholarship, yet Hughes ignores much of the recent secondary literature relevant to his arguments. Overall, one gets the sense that Hughes overstates his case for the blurriness of categorical distinctions between Jews and Muslims in the early period, and that this misprision is exacerbated by his chronic misreading of texts and lack of attention to critical debates in the scholarly literature. Although social configurations and religious orientations certainly mapped differently in the early Islamic period than they would later and were no doubt characterized by some fluidity in certain circumstances, the claim that boundaries were totally porous and that distinctions did not matter at all in this period seems like a clear exaggeration to me. It is especially implausible because of the evident propensity in this period for identity markers to be used strategically and ideologically as critical signifiers in apologetic and polemical discourse, beginning with the Quran itself.

\section{Was “Islamic Judaism" Invented?77}

It is important not to lose sight of Hughes's wholly admirable agenda of adopting a more theoretically sophisticated approach to the Muslim-Jewish relationship and critiquing the taxonomies and frameworks typically applied to the study of these communities in their formative period, with the ultimate goal of interrogating the nature of religious identity itself. Putting aside the various issues of specialist concern that Hughes's treatment of particular bodies of evidence and areas of scholarship raises, we might ask whether his work succeeds overall as an exercise in the critical study of religion. That is, does Hughes attain a more theoretically nuanced approach to the material, especially one that is of probative value for larger questions in the discipline of religious studies per se?

From the outset, one might note that Hughes's inconsistent approach to historical evidence demonstrates why his explicit location of his own work at a supposedly higher level of theoretical conjecture and insight is problematic. Aside from that, we might ask exactly how such an Archimedean positioning of oneself as a theorist or religionist above

but this possibility is barely fleshed out in either book, despite the significant research that has been done on the early Shi'a over the last two decades (e.g., Hughes cites Wasserstrom on Ibn Saba' but totally overlooks the important study of Sean W. Anthony, The Caliph and the Heretic: Ibn Saba' and the Origins of Shï 'ism [Leiden: Brill, 2012]). Hughes's treatment of Shicism is particularly idiosyncratic (if not erroneous) at times, as when he refers to the Kharijites as pro-'Alid and subsumes them under the rubric of ghulät (Shared Identities, 71).

76. See the robust treatments in Lassner, Jews, Christians, and the Abode of Islam and Milka Levy-Rubin, Non-Muslims in the Early Islamic Empire (Cambridge: Cambridge University Press, 2011). Both studies are ignored by Hughes. Lassner's book, in particular, overlaps in many ways with the concerns of Shared Identities.

77. With apologies to Brian Pennington for the shameless pastiche of his book title: Was Hinduism Invented? Britons, Indians, and the Colonial Construction of Religion (Oxford: Oxford University Press, 2005). 
and apart from the narrow details of historical or textual specifics is ideally meant to work. What methodology should religionists follow in order to transcend the conventional limitations of overly detail-oriented "micro study," and what are the rules of the game? Can such an attempt at achieving a god's-eye view of the phenomena under discussion actually yield cogent insights?

I agree wholeheartedly with Hughes's basic diagnosis of the problem: much historical and contemporary scholarship on premodern Muslims and Jews still labors under overly positivistic and sometimes anachronistic assumptions that project the stable and welldefined categories of a later age back to the formative period and reify ethnic, religious, cultural, national, or even racial essences as the basis of premodern identities. These reified essences often come into play when scholars seek to imagine intercommunal relations transactively, positing that groups have reciprocally "influenced" one another through different phases in which one "loans" elements that the other "borrows." All of this is ripe for reexamination and reevaluation. Adopting a more nuanced perspective, we may recognize that it is the phenomenon of engagement and exchange across permeable and even purely notional boundaries that is itself definitive for various groups exhibiting highly contingent and fluid characteristics profoundly shaped by the particulars of specific social and cultural circumstances. Thus, to overcome anachronistic essentialisms, we should attempt to understand the posture and attitude of groups as they engage in moments of dynamic interaction as the most salient means of apprehending how communities construct themselves and their others-or rather, construct themselves by means of constructing their others. Hughes foregrounds this perspective when he asserts, in Boyarinesque mode, that his goal is to show how Judaism and Islam-like Judaism and Christianity in a previous age-"emerged dialectically with and from one another."78

However, when we scrutinize the specifics of Hughes's approach to the Muslim-Jewish encounter-epitomized by his statement (again strongly echoing Boyarin) that "the 'history' of the border between Judaism and Islam has primarily been interpretive and that what brings it into existence is a set of imaginative acts"79-one wonders whether this perpetual insistence on fluidity, blurry boundaries, and lack of clear definitions is perhaps at times misplaced. ${ }^{80}$ Following Wasserstrom, Hughes sees the early Islamic period as characterized by an abundance of "manifold and overlapping Muslim and Jewish subcultures that shared a common vocabulary and set of taxonomies," a diversity that supposedly persisted into the Middle Ages.$^{81}$ For Hughes, as for Wasserstrom, this diversity is epitomized by the aforementioned sect of the Isawiyya, but-as already noted-one often gets the impression

78. Shared Identities, 5.

79. Ibid., 18.

80. Hughes's debt to Boyarin is acknowledged explicitly (e.g., Shared Identities, 4), though perhaps not often enough. One detects other theoretical precursors lurking in the background, for example Bruce Lincoln's work on discourse and authority; Lincoln is credited once in this role alongside J. Z. Smith and Russell McCutcheon (ibid., 3) but not again. Judith Butler's germinal thought on the performative nature of identity seems to me to be quite relevant here as well, though their work is not cited by Hughes in either book (and only once in Boyarin's Border Lines).

81. Shared Identities, 19. 
that Hughes sees this diversity, manifest in a plenitude of overlapping social formations, as both pervasive and persistent. Thus, the Isawiyya are not an anomalous case that tests our assumptions about norms; rather, Hughes sees fluidity itself as the norm, in numerous settings, for quite some time.

I readily admit that such an approach is a refreshing alternative to the prevailing view in much of the classic scholarship in the field, in which Judaism and Islam are perceived as wholly separate and integral monoliths that are largely unchanging in their historical essences, with the occasional moments of interface between them characterized as isolated instances of exchange (the transactive movement of some quantum from one to the other group), convergence (the metaphorical intersection of two discrete bodies moving in parallel courses throughout time), or hybridity (the exceptional grafting of two originally discrete species together to make a third entity distinct from both). ${ }^{82}$ As Hughes skillfully demonstrates, this approach, especially common among Jewish historians of the nineteenth and twentieth centuries, was particularly motivated by an emphasis on Jewish distinctiveness, predicated upon the notion of an unchanging ethical core eternally at the heart of Judaism across the centuries, as well as an anxiety about that Jewish core being contaminated by external factors, especially aspects of Arab and/or Muslim culture. ${ }^{83}$ Such a conception of the Jewish-Muslim encounter, constructed as an apologetic for Jewish distinction, significantly underestimates the dynamism and vitality of both communities, as well as effacing the integral role that encounter played in their mutual development.

Scholars of religion have long recognized that boundary construction and maintenance not only are traditional obsessions of religious authorities but have often been replicated in various ways in the modern field of religious studies itself. Previous generations of scholars implied or explicitly asserted that various religious phenomena can be neatly organized and cleanly demarcated, in theory and in practice; in directing considerable amounts of intellectual labor toward this goal, scholars often inadvertently recapitulated the normative and prescriptive discourses indigenous to the very traditions they sought to objectively describe. As scholars' primary means of access to information about traditions, especially premodern ones, has been the literature generated through such normative discourses, in whatever cultural milieu and historical setting, the field has unfortunately often exhibited a characteristic confusion of prescriptive claims with lived religious realities, which more often than not tend to be messy, diverse, and inchoate (like most realms of human endeavor).

82. Another familiar metaphor is intertwining, made famous as a metaphor for Jewish-Muslim engagements by the influential monograph of Hava Lazarus-Yafeh, Intertwined Worlds: Medieval Islam and Bible Criticism (Princeton, NJ: Princeton University Press, 1992). Intertwining implies that two separate things have come together to make up a single strand, balancing the notion of unity with that of distinctiveness and separability. It is the latter aspects that Hughes would likely find objectionable in the metaphor.

83. This theme is a familiar one in religious studies, the quest for pristine origins of religious traditions having been thoroughly exposed by contemporary scholars such as Russell McCutcheon (Manufacturing Religion: The Discourse on Sui Generis Religion and the Politics of Nostalgia [Oxford: Oxford University Press, 1997]) and Tomoko Masuzawa (In Search of Dreamtime: The Quest for the Origin of Religion [Chicago: University of Chicago Press, 1993]), both of whom Hughes cites in Shared Identities. 
The main analytical payoff of work exposing the underlying ideologies and unacknowledged blind spots of the field is the insight that the idealizing perspectives of religious authorities preserved in canonical texts and other literary sources should not be confused with the elusive historical realities of social configurations, quotidian practice, and non-elite worldviews. That said, it is ironic that throughout Hughes's work, which emphasizes the fluidity of phenomena and the artificiality of attempts at boundary construction, the distinction between lived realities and normative discourse is itself blurred.

In chapter 4 of Shared Identities ("The Manufacture of Orthodoxy"), Hughes transitions to a discussion of what he repeatedly terms "Islamic Judaism," a form or forms of Jewish discourse in the high Middle Ages that sought to construct a new Jewish normativity while operating in the realm of-and thus being fundamentally shaped by-Islamic (or Islamicate) discourse ${ }^{84}$ Here Hughes deliberately moves to counter older scholarly approaches and biases: thus, he explains "Islamic Judaism" as a mode in which Jews "think Arabically and Islamically," though Goitein and others characterized the work of such figures as Sa'adya Gaon and Maimonides as reflecting only a superficial Islamic "influence" on Judaism. ${ }^{85}$

One can certainly sympathize with Hughes's desire to overcome the reified categories and essentialism that constrain earlier studies of these major intellectual figures of the Islamic Middle Ages. But we might also note a particular tension surrounding notions of identity and distinction that emerges here and subsequently recurs throughout both of Hughes's books. One imagines that by the period under discussion, both Judaism and Islam had developed enough to be readily distinguishable, at least in theory if not always in practice-though the juridical prescriptions enforcing social distinctions would have made the boundary between Muslims and Jews real enough. Islam, in particular, was culturally, politically, and legally dominant in the Abbasid era, and so the Jews of Muslim lands constituted a subculture, but one that was so thoroughly shaped by prevailing Islamic patterns, norms, and frameworks that it came to be fundamentally "Islamic" in character, orientation, and articulation. ${ }^{86}$ This would actually seem to imply much less blurriness than

84. A condensed summary of Hughes's perspective on the phenomenon of "Islamic Judaism" that emphasizes its emergence out of the dazzling variety of expressions of Jewish identity that prevailed during the geonic period is found in his "Messianism and the Shadow of History: Judaism and Islam in a Time of Uncertainty," in Islamic Studies Today: Essays in Honor of Andrew Rippin, ed. Majid Daneshgar and Walid Saleh, 145-63 (Leiden: Brill, 2017). Here again the familiar leitmotifs of Hughes's books abide: the importance of normative rabbinic Judaism has been overstated, boundaries between Judaism and Islam were blurred or nonexistent in the formative period, and many forms of Jewish belief and practice were functionally indistinguishable from their Muslim counterparts in the early Islamic milieu.

85. Shared Identities, 83. The phrase "Islamic Judaism" appears a number of times in both Shared Identities and Muslim and Jew and should be understood as central to Hughes's thinking on the subject at hand.

86. Whether minority groups impacted by Islamic cultural patterns may be thought to have performed Islam within the contours of their own traditions is a question usefully provoked by Shahab Ahmed's muchdiscussed What Is Islam? The Importance of Being Islamic (Princeton, NJ: Princeton University Press, 2015), where he gives the example of Sikh wrestlers who ritually invoke 'Ali before competing (pp. 445-46). (Ahmed's conception of Islam as performative itself strongly echoes Butler, who is ignored by Ahmed as well as Hughes.) Of the numerous scholars overlooked by Hughes, Ahmed is one of the most conspicuous, as many of his theoretical 
purportedly prevailed in the earlier period discussed by Hughes, and yet he often discusses the major figures of this era-Sa'adya, Maimonides, Abraham ibn Ezra, Bahya ibn Paquda, and others-as if they were still dwelling in the earlier era of foggy indeterminacy. ${ }^{87}$

Whether there was actually anything like an "Islamic Judaism" and whether the phantasmal "Jewmuslims" or "Muslimjews" Hughes posits ever actually existed are still, to my mind, unanswered questions. But we certainly must acknowledge the reality of potent discourses of separation and distinction that operated throughout the history of the JewishMuslim encounter from the very beginning. It was certainly the case, for many if not most insiders, that the boundary between Judaism and Islam was very real, regardless of whether those constructs corresponded exactly to the doctrinally coherent and largely orthopractic varieties that prevailed later on. As we have already seen, a distinction between Judaism and Islam is basic to the Quran; that the differences between them had yet to be fleshed out dogmatically, institutionally, and otherwise seems to me to be beside the point. Likewise, even if the distinctions between the traditions were irrelevant to some in the early centuries of Islam-whoever they may have been-many others were certainly keenly aware of them, and it is these others who tended to be responsible for the surviving cultural productions of the period that allow us our shadowy glimpses of the past.

I do not think that this point is immaterial, yet it frequently appears to be a blind spot in Hughes's analysis. He often seems to overstate his case in repeatedly asserting that boundaries and distinctions were largely artificial and themselves the products of a long, drawn-out historical process of engagement between Jews and their Muslim counterparts/ others/doppelgängers-that the entire history of the encounter between "Muslimjews" and "Jewmuslims" is a "genealogy of indeterminacy." 88 The problem comes to the fore in his approach to the "Islamic Judaism" of the high Middle Ages. He asserts that modern scholars largely invented the idea of Judaism and Islam as discrete and autonomous entities, noting that narratives of boundaries and distinctions "were manufactured in scholarly workshops." ${ }^{89}$ But if this were really the case, what should we make of our normativizing

insights seem quite germane to Hughes's argument. One might suppose that Ahmed's book, which was published in 2015 and widely discussed in 2016, appeared too close to the publication of Shared Identities for Hughes to take it into account, but I observe several books and articles from 2016 cited in Hughes's bibliography (e.g., the aforementioned monograph of Webb, cited a number of times in the book), so the omission is not circumstantial. Hughes did address Ahmed's work in a short review published on the blog of the American Academy of Religion on September 8, 2017 (https://readingreligion.org/books/what-islam).

87. As just one example, see Shared Identities, 134-35, where Hughes evocatively describes the Avicennian echoes in a poem by Ibn Ezra as reflecting an attempt at "producing a Judaism that conformed to the intellectual and aesthetic sensibilities of Arab-Islamic culture" (p. 135). However, this enterprise was hardly novel in Ibn Ezra's time, by that stage having already been centuries in the making. Further, Hughes's conclusion simply does not follow from the evidence: "This could only be done . . . if Judaism was a lot more unstable than the likes of Goitein would have us believe" (ibid.). By this logic, Judaism is perpetually unstable, being redefined at every historical moment, in every era. Perhaps this is Hughes's intention, but if that is the case, there is nothing exceptional about the Jewish-Muslim engagements of the Middle Ages, and Hughes's project in these books threatens to collapse.

88. Shared Identities, 86.

89. Shared Identities, 18. It is clear from the context that Hughes here refers to the work of modern 
sources for the period, which seem quite conspicuously concerned with erecting boundaries and enforcing distinctions from early on, virtually from the dawn of Islam? At times-again following the Boyarin approach-Hughes recognizes that the work of partition is exactly what the communal spokesmen who furnish us with our primary sources for the period are doing. That is, we can plainly see that figures such as Sa'adya Gaon and Maimonides seek to articulate Jewish orthodoxy in Islamic terms-a project that is novel in their time, though not entirely innovative, as Hellenistic Jews had sought to do much the same in seeking to define Judaism according to the canons and categories that dominated the philosophical discourse of their day..$^{90}$ Yet the "manufacturing" of orthodoxy is repeatedly asserted to be a modern phenomenon.

Hughes's approach to Sa'adya Gaon epitomizes some of these tensions. He locates Sa'adya's work in the context of the contemporaneous project of hadith collectors, jurists, and Quran commentators to define and articulate Islamic norms; thus, Sa'adya usefully comes into focus as a Jewish analogue to Muslim peers who formulated the doctrinally cogent expressions of identity that eventually produced the mature forms of classical Islam. ${ }^{91}$ But this does not mean that a coherent conception of Judaism did not precede Sa'adya, just as a coherent conception of Islam surely preceded al-Țabarī. ${ }^{92}$ Yet Hughes

scholars, the "genealogies of terms and narratives" (p. 19) that continue to have repercussions in contemporary scholarship, though somewhat earlier on he refers to the "workshops" in which the Babylonian rabbis sought to develop a normative Judaism in Late Antiquity (p.14). The metaphor of the scholarly workshop is reminiscent of Masuzawa's discussion of Max Müller in In Search of Dreamtime, which appropriates the metaphor from Müller himself: the latter titled his multivolume collection of philological essays Chips from a German Workshop (1867-75). As Masuzawa and Hughes depict Müller and various other scholars of the nineteenth and twentieth centuries, the metaphor seems to me to be meant to evoke a kind of idealizing imaginative work divorced from reality.

90. It is one thing to suggest that a broadly imposed rabbinic normativity was still novel in this era and only beginning to be widely diffused throughout the Jewish world-this, to me, is the crux of work on rabbinization by Seth Schwartz, Hayim Lapin, Talya Fishman, and others. It is entirely another to claim that there was no stable sense of Jewish identity prior to the time of Sa'adya at all, which is the impression one gets (albeit somewhat inconsistently) from Hughes's approach.

91. As with his discussions of the early Islamic period, there are numerous aspects of Hughes's treatment of the Islamic Middle Ages that cry out for elaboration, and many scholars whose work I would consider indispensable to consider in this context are almost entirely ignored. The short shrift given to such major scholars as Camilla Adang, Haggai Ben-Shammai, Ross Brann, Lassner, Lazarus-Yafeh, and Meira Polliack in both books is surprising, but Hughes either mentions these scholars only in passing in notes or includes them in the bibliography without comment. Much contemporary work of relevance is simply ignored, which is especially surprising given that Shared Identities is a work of historiography directed at the critical evaluation of scholarly trends.

92. In his approach to major thinkers of the Islamic Middle Ages, Hughes is clearly deeply influenced (so to speak) by Boyarin's work on figures such as Justin Martyr, whom Boyarin spotlights as a major architect of Christian difference and distinction. Hughes is of course correct in casting Sa'adya as a seminal figure in the emergence of a doctrinally and halakhically coherent form of normative Judaism that would have a wide impact on Jewish communities throughout the Islamic world, the Mediterranean, and Europe. But Hughes often writes as if Sa'adya worked in the religious and social environment of the second century CE, in which the distinctions between Jews, Christians, and others were rudimentary (at least according to Boyarin's model), and not in the rather different milieu of the tenth. 
seems to imply exactly this at times, for example in characterizing Sa'adya as the originator of a Jewish normativity that was only beginning to be imagined in the high Middle Ages. Reimagined, perhaps; but surely Sa'adya did not invent what became normative Judaism ex nihilo.

Further, at other times Hughes seems to insinuate that Sa'adya and Maimonides were not simply proposing an Islamically inflected conception of Judaism-using Islam as an instrument to refine and reorient that prevailing conception-but were in some substantial way "doing" Islam and reshaping it into Judaism. ${ }^{93}$ Is this what Sa'adya and Maimonides perceived themselves to be doing? It is one thing to say there is no firm categorical or phenomenological difference between their activity and that of their Muslim peers. But was it not precisely their intention to impose a distinction between the traditions through implementing those very shared discourses that positions them on the boundary between Judaism and Islam? They surely did not believe they were inventing Judaism from whole cloth; rather, they were using Islam, the well-defined and socially dominant creed and culture in their environment, to reshape another creed and culture that they understood as distinct, even though Hughes as a critical religionist may insist that the distinctions are fuzzy, ephemeral, artificial, or illusory. I myself prefer the formulation that Sa'adya was "doing" Judaism by selectively appropriating aspects of Islam, through an instrumental engagement with Islam as a primary resource available to him in articulating his vision of Judaism. ${ }^{94}$ We must concede that boundaries and definitions are at least at times emic and not etic; if we do not, we adopt the position that spokesmen like Sa'adya and Maimonides were wholly alienated from the tradition they sought to uphold and the community whose integrity they aspired to defend.

Again, from the outside, it may be productive for us to recognize that Sa'adya was functionally a mutakallim or Maimonides a faylasūf, essentially no different from their contemporary Muslim counterparts, without any need to impose the adjective "Jewish" to make such characterizations cogent or convincing. ${ }^{95} \mathrm{I}$ believe this is the main insight Hughes means to express through his treatment of these figures. However, the key point as I see it is that these people participated in a common discourse with their Muslim peers despite seeing themselves as categorically different; wholly apart from the question of whether their work was in any substantial sense distinct from that of their peers, it seems obtuse to suggest that they themselves did not conceive of such a difference or actually invented it themselves. Objectively speaking, the boundary between Judaism and

93. Again, insofar as we might imagine Sa'adya “doing” Islam in his mode as mutakallim (and not a specifically Jewish kind of kalām), both Butler and Ahmed seem indispensable to Hughes's approach here.

94. I would thus object to the aforementioned account of Ahmed portraying Sikh wrestlers as "doing" Islam. It rather seems to me that if we take their intentionality into account-intent and agency being central to Ahmed's understanding of what it means for Muslims to "do" Islam-then these Sikh wrestlers are actually "doing" Sikhism through or with Islam, appropriating aspects of Islam in their articulation of their Sikhism.

95. For example, in introducing the "Islamic Judaism" of Maimonides in Shared Identities (p. 109), Hughes emphasizes that the creed of Maimonides "betrays no sense of the hyphen" imposed in such formulations as "Jewish-Muslim," by which I believe he means that it is misleading to think of his Judaism as somehow hybrid or syncretic. Is this "Islamic Judaism" then simply a form of Islam? Here Hughes's meaning is rather unclear. 
Islam might have been all in their heads, but is it not the case that religious activity is commonly, if not exclusively, constituted by imaginative acts? On some level, it is always all in our heads, and the perception and intentionality of a Sa'adya or Maimonides-let alone of the rank-and-file religious subjects who lived the messy realities we as historians or religionists aspire to capture and convey-is surely as significant as any phenomenological reconstruction we might generate for the sake of analysis. In seeking to avoid overly reified conceptions of Judaism and Islam, we perhaps run the risk of overstating the evanescence of categories and distinctions that were entirely real for historical religious subjects. Of course their categories and distinctions were different from ours, but likely no less "real" from their perspective; even if Sa'adya and Maimonides merely crafted these categories and distinctions in their own "scholarly workshops," they had to have some plausible claim of facticity to have any traction for their coreligionists.

Hughes's constant emphasis on the blurriness of the boundaries between Judaism and Islam results in some misrepresentation of the major figures who stood at the interface of the traditions, and this seems to me to be the real danger we face in imposing the heuristic of the phenomenologist (for whom distinctions seem ephemeral) upon historical subjects (for whom distinctions appear conceptually, practically, and affectively real). For example, he presents Sa'adya as if he differs from his Muslim mutakallim counterparts simply in citing biblical prooftexts for his arguments instead of Quranic ones and even clims that "it is difficult to know how 'Jewish' someone like Saadia regarded his thinking to be." 96 But the point, I think, is that kalām was a shared discourse that did not differ substantially whether it was a Jew or a Muslim (or a Christian) who employed its techniques, and thus that kalām was essentially, for lack of a better term, nondenominational. The point is surely not that the mutakallim abandoned any sense of their own or their tradition's particularism by engaging in it. It is hard for me to imagine that Sa'adya regarded his thinking as anything but Jewish.

I wholeheartedly agree that Hughes's approach presents a much-needed corrective to a prevalent view of Sa'adya that insulates his religious views-his "essential" Jewish identity-from his Islamic milieu, an approach that has historically dominated the study of Maimonides as well. ${ }^{97}$ But Hughes seems to me to go too far in effacing the critical element of Sa'adya's self-perception in the formation of his religious ideas and ideals; he certainly did not see himself as a mutakallim first and foremost and as a Jew second, which is the impression one might get from Hughes's presentation. To presume that Jewish authors did not operate with a strong sense of the distinction between their tradition and Islam, despite the de facto proximity between the traditions, strips them of agency. It should not

\footnotetext{
96. Shared Identities, 100.

97. A sterling example of this trend is Robert Brody's biography Sa'adyah Gaon (Oxford: Littman Library of Jewish Civilization, 2013), a rich and nuanced treatment of Sa'adya's background in and contributions to contemporary Judaism that almost completely ignores his Islamic cultural and intellectual context. Sa'adya's work is ripe for a revisionist corrective along the lines of what has transpired in the rethinking of Maimonides and his significance in the twenty-first century; see, e.g., Joel L. Kraemer, Maimonides: The Life and World of One of Civilization's Greatest Minds (New York: Doubleday, 2008) and Sarah Stroumsa, Maimonides in His World: Portrait of a Mediterranean Thinker (Princeton, NJ: Princeton University Press, 2009).
} 
be impossible for us to balance a recognition of the phenomenological similarity, or even points of practical identity, between Judaism and Islam in the formative period of both with an acknowledgment of these figures' self-conception and intentional appropriation of Islamic ideas in the shaping and reframing of what they considered to be the wholly unique reality of Judaism..$^{98}$

Time and again Hughes depicts the thought of Islamicate Jews, especially in the Middle Ages, as evidence of the persistent lack of a stable core to the Jewish tradition and the anxieties this produced-try as they might, they could not find any essential aspect of their religion to "fall back on or turn to in solace." ${ }^{99}$ I am sympathetic to the work of reframing that such a characterization is meant to do, but I remain deeply skeptical that it accurately captures the attitude of Sa'adya, or Maimonides, or any of the other figures Hughes discusses. The thought of these figures seems to me to reflect medieval Jewish acculturation to Islam-the deliberate or inadvertent conforming of a previous assemblage of beliefs, practices, and attitudes to that of the dominant, and quite distinct, communal formation in the environment. Hughes often seems to be at war with himself on this score: sometimes Sa'adya is unprecedented in creating a normative Judaism of the sort we might recognize as a distinct religious tradition; at other times, as when Hughes says Sa'adya's accomplishment is his framing Judaism in terms of Islam, or rather "the creation of an Islam recast as a Judaism," he seems to concede that some notion of Judaism must have preceded Sa'adya (otherwise, what was it that guided this "recasting"?). ${ }^{100}$ Would that older heritage of Judaism not be exactly what Sa'adyah or others would "fall back on or turn to in solace"? And yet Hughes's overattention to semantics brings us to a point of near-incoherence: "Rather than characterize Saadya as a 'Jewish mutakallim,' we should envisage him simply as a mutakallim who was Jewish. ... [This] avoids the religio-ethnic signifier and instead sees Saadya as but another Arab-speaking mutakallim ..." ${ }^{101}$ But what, then, did his Judaism consist of? How does this leave us with any trace of his significance for Judaism-or better, of the significance of Judaism for him, which was surely considerable?

We can (and should) continue to consider whether and to what degree the twinned traditions of Judaism and Islam were really distinct in theory or practice; we might even entertain the notion that the Islamicate civilization of this time actually constituted a

98. Hughes's exaggeration of the porousness and indefiniteness of the boundary between Judaism and Islam in this period is epitomized by his depiction of the famous Muslim polemicist Ibn Hazm, who made use of contemporary Jewish writings in his polemics. Astoundingly, what this represents for Hughes is that "Jewish and Muslim mutakallimūn do not neatly and simply bifurcate into . . . religious adjectives. The border ... is not yet closed" (Shared Identities, 100). Once again, one senses Boyarin's approach to Justin Martyr in the background here, but it seems unimaginable to me that we can understand the Andalusian context in the eleventh century as anything like that of Palestine in the second. The availability of Jewish writings to Ibn Hazm by no means implies the kind of indeterminacy Hughes eagerly seeks here; social intimacy and intellectual proximity do not equate to porous boundaries. In many cases, intimacy and proximity lead to anxiety about boundaries, and so to efforts to shore them up.

99. Muslim and Jew, 65 (a curiously vague passage that implies that medieval Jews were cognizant of the historical flux and development that shaped their tradition).

100. Shared Identities, 99.

101. Ibid. 
single shared tradition expressed in two separate idioms, one Jewish and one Muslim. ${ }^{102}$ But it seems exceedingly unlikely to me that Muslims or Jews of the time would have seen it that way, and it is dangerously anachronistic to suggest that the distinction between Islam and Judaism was only heuristic, or merely a distant convention to premodern members of either community. ${ }^{103}$ Put another way, although we might see the difference between them as epiphenomenal, from the inside the perceived difference must have been monumental. Otherwise, what would have been the point of all the intellectual work of definition and differentiation that these medieval thinkers undertook? And yet somehow Hughes concludes that "such towering medieval thinkers did not see a clear boundary between Judaism and Islam ..." ${ }^{104}$ In insisting on characterizing the situation this way, Hughes seems to confuse the persistent permeability between Islam and Judaism in the Middle Ages with the fluidity he asserts to have been the norm in earlier centuries. ${ }^{105}$

\section{Modern Politics, Representations, and Realities}

As noted above, Hughes adopts a more explicitly political agenda in Muslim and Jew, suggesting that the critical study of the dynamics of Jewish-Muslim engagements in the past may help to address and somehow ameliorate our contemporary political situation. Asserting that the tensions surrounding the Israeli-Palestinian conflict are "structurally similar to that produced by earlier iterations of Muslim-Jewish cohabitation" (p. viii), Hughes claims that examining significant aspects of the historical Jewish-Muslim relationship can illuminate the current version of the "dialectic of self-definition and other-abnegation" (p. ix) that continues to have repercussions today.

Although this is a perfectly admirable intention, one cannot fail to notice that something important appears to have been elided here. Despite the significant infusion of conspicuously

102. Or that Jews constituted a Muslim subculture, with all that that implies. I borrow the metaphor of Judaism and Islam as dialects or idioms from Boyarin, who applies it (with some reservations) to Judaism and Christianity in their formative period; see Border Lines, 17-22. Marshall Hodgson's widely influential concept of the "Islamicate" has been criticized in recent years, particularly for the way in which it segregates "religion" as a special category of cultural production and meaning-making (see, e.g., Ahmed, What Is Islam?, 157-75), but it remains a salient category for many scholars in Islamic studies.

103. Admittedly, one might cite the famous Averroist conception of the double truth to support exactly the claim that at least some medieval Jewish and Muslim philosophers would have embraced the idea that rationally apprehended truth is unitary and the distinctions between creeds are ultimately irrelevant. Without delving into this possibility here, I will note only that Hughes himself does not invoke this concept to vindicate his claims, so I do not feel obligated to stage a defense on his behalf on this basis either.

104. Shared Identities, 19.

105. See also Hughes's discussion of Bahya ibn Paquda as "but one iteration of how Jews used the dominant narrative of Islam to actively create Judaism” (Shared Identities, 138; cf. Muslim and Jew, 52-54)-not recreate? Compare the discussion of Ibn Kammuna (Shared Identities, 100-102; Muslim and Jew, 45-46), where Hughes avers that labels such as "Jewish" and "Muslim" are anachronistic and unhelpful in characterizing him, though it seems equally accurate to represent him as a rationalist Jew who was particularly openminded about Islam (and "Jewish" and "Muslim" were surely not anachronistic categories in thirteenth-century Ilkhanid Baghdad). Chapter 2 of Muslim and Jew improves on this situation somewhat by concluding with a discussion of the Sabbateans, to whom talk of porous boundaries and blurred categories seems rather more applicable. 
religious ideologies into both the Palestinian resistance and mainstream Zionism since the 1980s, Arab opposition to Israel is by no means reducible to "Islamic" factors, nor are Zionist positions or Israeli state policy simply translations of Jewish outlooks. Hughes is surely aware of this, but he sometimes effaces what seem to me to be important distinctions, and the continuities he asserts are often left implicit and not carefully explained or justified.

Hughes recognizes, of course, that not all Palestinians are Muslim, but he nevertheless holds that significant elements of older Jewish-Muslim dynamics of engagement are recapitulated in the modern conflict, in particular the tendency for each group to evoke ideas about the antipodal other as a means of shaping conceptions of an ideal self. Echoing one of the leitmotifs of Shared Identities, Hughes provocatively suggests that the selfconsciousness and anxiety triggered by social and religious proximity in the past has in the modern period been triggered by actual physical proximity instead; thus, contemporary struggles are only "the latest attempt on behalf of Jews and Muslims to invoke their religious traditions to make sense of an encounter fraught with the nearness and concomitant apprehension of the other." 106 But although anyone who teaches Jewish-Muslim relations in broad perspective surely has to address the impact of the rise of Zionism and the conflict over Palestine on both groups in the modern period, the overly neat way in which Hughes dovetails the past into the present here seems too clever by half. The proposition that the political conflict between Arabs and Jews in the modern era refracts and reconfigures aspects of the tensions between Jews and Muslims in premodern Islamicate societies is intriguing, but as executed in the brief chapters of Muslim and Jew (especially chapter 3, dedicated to the modern period), Hughes's argument is barely substantiated and relies on vague and at times misleading suggestions. At worst, it rests on a conspicuous misrepresentation of the textual evidence, recapitulating some of the problems that recur throughout Shared Identities.

It is true that spokesmen on both sides of the Israeli-Palestinian divide have often positioned themselves as heirs to a perpetual struggle that long preceded Arab or Jewish nationalist ambitions, and so both groups have repeatedly invoked what Hughes terms "nostalgic" and "lachrymose" paradigms-Arabs alluding to the glorious heritage of Islamic dominion and cultural achievement, Jews to the centuries of oppression, discrimination, and violence to which they were perennially subjected under Muslim rule. ${ }^{107}$ In order to

\footnotetext{
106. Muslim and Jew, 66.
}

107. In Muslim and Jew, 3, "lachrymose" is presented as if it is Hughes's own coinage, though it is not. As noted by Mark Cohen, Baron characterized the negative conceptions of Jewish life in Christian Europe prevalent in late nineteenth- and early twentieth-century historiography in this way; in turn, Cohen adapts this characterization and applies the term "neo-lachrymose" to the pessimistic view of Jewish history under Islamic rule that became popular in certain circles after the Six-Day War in 1967 (Cohen, Under Crescent and Cross: The Jews in the Middle Ages [Princeton, NJ: Princeton University Press, 1994], ch. 1). Hughes acknowledges Cohen's "neo-lachrymose" terminology once in Shared Identities (p. 34). The citational problems are distinctly more acute in Muslim and Jew than they are in Shared Identities, but they appear repeatedly in both books. Note, e.g., the references to "epistemic space" (Muslim and Jew, 5, 86), which I read as allusions to Neuwirth, who has used exactly this terminology in her work (e.g., "Locating the Qur'ān in the Epistemic Space of Late Antiquity," in Books and Written Culture of the Islamic World: Studies Presented to Claude Gilliot on the Occasion of His 75th Birthday, ed. Andrew Rippin and Roberto Tottoli, 159-79 [Leiden: Brill, 2015]), but who is absent from both 
substantiate this point in chapter 3, Hughes might have adduced examples of modern ideologues from both the Arab and Zionist camps drawing upon particular aspects of traditional thinking-nationalist arguments on either side rehearsing the terms of older religious polemic-or evoking the ideas and ideals of a previous age to explain modern conditions. I infer that this is what Hughes meant to do in the chapter of Muslim and Jew he dedicates to the modern period. However, for the most part what he offers us here is a basic overview of major political developments from the rise of Zionism to contemporary times. This survey is occasionally punctuated by substantial quotations from primary sources that are presumably intended to support his contentions but are actually of questionable probative value for his argument.

Here the contradiction between the evident significance of texts and the meaning Hughes imputes to them-a chronic problem in both books-seems particularly acute. Early on in the chapter, Hughes suggests that both sides in the modern conflict invoke ancient history as a way of alleviating tensions and anxieties; both Jews and Palestinians take recourse to narratives of a sacred past as an explanatory mechanism that endows the present struggle with meaning. As an example, he refers to Arafat's famous 1974 address to the United Nations, claiming that it "appeals indirectly to the past, to the shared destiny of Jews and Muslims in places like the Arabian Peninsula and Muslim Spain." However, this subtext is wholly absent from the passage Hughes quotes here, which actually speaks to the distinction between Judaism and Jewish colonialism and warns of the threat to international security posed by Zionist "terrorism." 108 Similarly, a long quotation from Jabotinsky is cited as foreshadowing the idea of a transfer of the Palestinian population out of Israel to other Arab territories, but the whole point of the quoted passage is that the Arabs would be allowed to remain on the land (and might actually become even more numerous) but would eventually have to accommodate the reality of becoming a minority with the continuing migration of Jews to Palestine. Jabotinsky notes explicitly that forced relocation would not be necessary for the future Zionist state ("there is no question of ousting the Arabs")the opposite of the point Hughes claims the passage makes. ${ }^{109}$ Still further, one would imagine that discussion of Hamas would be especially productive for Hughes, as the group's political discourse explicitly capitalizes on older narratives representing the Jews of Muhammad's time as subversive, perfidious, and treacherous; this technique would seem to epitomize, as Hughes puts it, the use of a past "selectively remembered to make a political point in the present." 110 But the texts from Hamas he subsequently quotes simply do not demonstrate this. ${ }^{111}$ Hughes then goes on to mention the importance of an idealized unity

books, as noted above. Admittedly, Boyarin also refers to the "epistemic" in Border Lines. In any event, Hughes is hardly original in applying the Foucauldian notion of the episteme to the exchanges and confrontations between Jews, Christians, and the Quranic community in Late Antiquity.

108. Muslim and Jew, 79.

109. Ibid., 75.

110. Ibid., 82 .

111. The long quotation from article 8 of the Hamas charter (ibid., 82) discusses the Zionist conspiracy throughout modern history; the subsequent long quotation from article 28 (ibid., 82-83) discusses Zionist infiltration of modern institutions; and the next quotation, from article 31 (ibid., 83), portrays the Hamas vision 
under the caliphate to modern Muslim ideologues-another apposite theme-but does not support this claim in any way. ${ }^{112}$

The maladroit, partial, and inadequate nature of the evidence Hughes offers in support of his argument is rather conspicuous in this chapter. In the end, the arguments he proposes to make at the beginning simply do not manifest; at best, we are presented with a conspicuously circular logic, in which texts in which Arabs and Zionists express their anxieties about the other are cited as proof that Arabs and Zionists experience anxieties about the other. There is certainly an important point to be made about the persistence of certain ideas about the past and their deployment for ideological and political gain in the propaganda of hardline religious groups in both the Jewish and Palestinian camps, but Hughes's continuing misrepresentation of texts and their meaning in this chapter impairs and overshadows his discussion. This is to say nothing of the numerous conspicuous omissions: as noted previously, Hughes's argument would have been well served if he had addressed the question of the isrā'iliyyāt in this context, as this would have provided a compelling example of a modern Muslim discourse that conflates the distant Islamic past and present political realities. Moreover, one cannot fail to notice that two of the most important thinkers germane to Hughes's argument-Sayyid Qutb and Meir Kahane-receive no mention here, though the type of ideologically burdened evocations of history that Hughes wishes to highlight are central to the intellectual projects of both.

Hughes's arguments are less effective than they should be in other respects as well. In both Shared Identities and Muslim and Jew, the distinction between representation and reality is not always evident. At times Hughes seems entirely cognizant that our available sources, especially Muslim depictions of Jews, serve an ideological function, each group's portrayal of the other serving to address internal communal issues. (This is exactly the argument he purportedly wishes to make in chapter 3 of Muslim and Jew.) Such awareness aligns Hughes's project with a number of important studies from the last decade, particularly those of Ze'ev Maghen, David Freidenreich, and most of all David Nirenberg, concerning what we might term the imaginative politics of Christian and Muslim representations of Jews. ${ }^{113}$ But at other times Hughes cites his sources as evidence of the blurriness or

of Islamism as a creed promoting justice and peaceful coexistence. These passages touch on themes familiar from traditional sources, such as Jewish corruption and subversion, but none refers to premodern history.

112. Ibid., 84. On this important topic, see, e.g., Mona Hassan, Longing for the Lost Caliphate: A Transregional History (Princeton, NJ: Princeton University Press, 2016).

113. As noted above, Maghen's work is overlooked by Hughes, while that of Freidenreich is casually dismissed in Shared Identities. An older monograph by Nirenberg is briefly cited in Shared Identities, but Hughes does not engage with his magnum opus, Anti-Judaism: The Western Tradition (New York: Norton, 2013), at all in either book, another puzzling omission. Strangely, in Muslim and Jew Hughes coins the term "theology" for the primary "prism" framing his analysis, by which he means the various expressions of a religious community thinking about itself through representations of the other, providing "the script whereby a group situates itself, ideally and theoretically, within a social space" (p. 6). It is unclear to me why "theology" should be the preferred term for such strategies of representation. The term is also used according to its more conventional sense (e.g., for the discourse of kalām) in this book, and in Shared Identities it is used solely in the conventional sense (e.g., "Theology represents the systematic articulation of what are imagined as religious truths-the nature of God, the relationship between God and humans, providence ..."; p. 89). 
fluidity he so frequently seeks to discern in various historical periods, when what those sources actually attest to is the proclivity of Jews and Muslims across the centuries to invoke the other in constructing an ideal self or promoting myths of communal origins. His two arguments thus seem to be unhelpfully conflated.

For example, in chapter 1 of Muslim and Jew, Hughes once again foregrounds the question of "decentralized pluralism," the blurred boundaries he asserts were typical of the era in which Islam emerged, but the texts quoted here sometimes seem to attest instead to later authors' concern with solidifying the boundaries between groups and with sanctifying and sanitizing Islam's origins by emphasizing Jewish difference and distinction from the followers of Muhammad. ${ }^{14}$ This is particularly striking as later in the chapter he explicitly recognizes that identities are not only maintained but actually defined at (imagined or real) borders as sites of encounter through the negotiation of (imagined or real) difference in dialectic with the other. In chapter 2, which focuses on the Middle Ages, Hughes begins by claiming that the subject to be discussed is the tendency among both Muslims and Jews to deploy portrayals of the other as "literary stand-ins" in discourses of self-reflection. Here he will supposedly focus on the use of a fictive Jew as a foil by Muslim authors to construct an image of the ideal Muslim, marginalize certain varieties of Islam as illegitimate (by reclassifying them as Jewish), and enforce the boundary between Islam and Judaism. ${ }^{15}$ I agree wholeheartedly that this is exactly what many Muslim depictions of Jews and Judaism throughout the centuries, especially in classical and medieval Islamic texts, are intended to do. However, this agenda quickly recedes into the background in the chapter and is never directly discussed again. Instead, most of the chapter actually discusses the impact of Islam on Jewish thinkers and movements, first addressing major medieval figures and then groups such as the Sabbateans. Despite this, at the end of the chapter, Hughes emphasizes that in this era, when Muslims talked about Jews, they were really talking about Islamic orthodoxy. One can readily agree with this contention, which has been established in a number of other studies published over the last decade, but not on the strength of the foregoing discussion by Hughes himself. This incongruity is paralleled in Shared Identities. In the final chapter of that book (chapter 6, "Re-Frame") Hughes initially seems acutely aware of the function of literary texts in manipulating representations for various ideological ends, as he discusses the antipodes "Muslim" and "Jew" as sites for self-fashioning in each community's discourse. ${ }^{116}$ But by the end of the chapter he veers back into his favorite subject, the persistent blurred boundaries between groups across the centuries, and the question of the political and ideological aspects of representation unfortunately recedes into the background again. ${ }^{117}$

114. E.g., the quotation from the Sīra of Ibn Ishāa concerning Jewish opposition to Muhammad and hypocrisy (Muslim and Jew, 20).

115. Ibid., 36.

116. Once again, this section feels like a reformulation of the insights of other scholars who remain unacknowledged in the discussion, such as Rubin and Nirenberg.

117. It is difficult to account for the multiple disconnects between Hughes's framing and summative statements in both books and the actual subject matter dealt with in his chapters. Hughes acknowledges that the first two chapters of Muslim and Jew rework previously published articles, and much of the material here 


\section{Conclusion}

In sum, Hughes's recent offerings in the area of Jewish-Muslim exchanges and engagements raise numerous important issues, but specialists may find these works to be of limited value for advancing the field. As noted, Hughes criticizes Wasserstrom for interrogating the construct of "symbiosis" without going far enough in proposing a coherent alternative. The same critique may be leveled at Hughes himself; he problematizes many aspects of the established scholarship-and rightly so-but falls short of moving the field forward substantially in terms of offering a coherent methodology, let alone in achieving anything like the paradigm shift at which he aims.

It is certainly true that Hughes has performed a significant service to the field simply by raising these issues and indexing the abiding and persistent problems that chronically haunt explorations of the intersections between Judaism and Islam. As he himself has noted, Jewish studies, in particular, has long been insulated from other fields and so has often been quite slow to accommodate new perspectives not anchored in the traditional commitments of insiders. This has had an array of implications for the field, not least regarding approaches to the study of Jewish-Muslim relations. ${ }^{118}$ Anyone familiar with the discipline, at least in North America, will recognize that however much the field has changed over the last decades, there is still considerable work to be done in broadening the scope of its scholarly purview. The impact of traditional commitments and orientations on the study of the Jews of Late Antiquity, in particular, has long been noted, especially the double hegemony that the rabbinic tradition enjoys in many institutional and scholarly contexts: first, it is still frequently-and anachronistically-assumed to have been the de facto reality for the vast majority of Jews in the Mediterranean and Middle East by the time of the emergence of Islam (despite numerous critiques arguing against this position); and second, it is all too readily naturalized as the default object of study in conversations about Judaism in antiquity after the Greco-Roman period, which is still often assumed to be largely synonymous with the Judaism of the Palestinian and Babylonian academies.

I remain skeptical regarding Hughes's near-total agnosticism about what we can or cannot know about the Judaisms of Late Antiquity and the early Islamic period. However, we can readily recognize the corrective value of such a posture in dislodging many of the still-regnant axioms and assumptions enshrined in various institutional contexts in the field of Jewish studies. I do not think it unfair to say that inquiry into the intersections between Islam and Judaism, especially in the era before the full flowering of the Judeo-Arabic culture of the Middle Ages, remains marginal to mainstream Jewish studies despite the important implications of such research. ${ }^{119}$ Hughes positions himself as a scholar of religion first and

seems condensed and repurposed (or simply taken over verbatim) from Shared Identities as well. That being the case, one wonders whether the incongruities and redactional seams are an unfortunate result of the author's compositional process.

118. Aaron W. Hughes, "Jewish Studies Is Too Jewish," Chronicle of Higher Education, March 24, 2014. For a recent reevaluation of Hughes's argument, see Sarah Imhoff, "Jews, Jewish Studies and the Study of Islam," in Sheedy, Identity, Politics and the Study of Islam, 121-37.

119. As one means of indexing this marginality, one might peruse the conference schedules and archived 
foremost, but his main academic appointment is in Jewish studies, and so his books address numerous problematic approaches and conceptions that remain conspicuous in the latter field: the persistent emphasis on rabbinic normativity; the perennial quest to discern the original roots of an essentialized Judaism; the corresponding neglect of the complex and, yes, fluid nature of Jewish identity at various points in Late Antiquity; and the consequent foreclosure of the possibility that the historical dialogue between Jews and Muslims exerted a significant impact on integral aspects of both.

Seen in this light, Hughes's attempt to revive Wasserstrom's project is laudable, renewing the call for a more vigorous investigation of this supposedly obscure period in Jewish history and especially for more scholarly activity in this area on the model of the ample attention now paid to the Jewish-Christian "symbiosis" of the early centuries CE. Especially given the progress in the field of Jewish-Muslim exchanges and encounters since the early 1990s, Hughes's theoretical intervention is timely, and succeeds in provoking and sustaining important questions even if his books fail to deliver in other respects, especially in providing a reliable and cogent point of entry to this area of research for students and nonspecialists.

abstracts from the past two decades of the annual conference of the Association for Jewish Studies, available at https://www.associationforjewishstudies.org/2020-annual-conference/past-conferences. Even a cursory search of the programs of past meetings demonstrates that only a tiny number of panels and presentations have addressed Jewish-Muslim engagements in any period, especially earlier phases. 


\section{Bibliography}

Ahmed, Shahab. Before Orthodoxy: The Satanic Verses in Early Islam. Cambridge, MA: Harvard University Press, 2017.

- - What Is Islam? The Importance of Being Islamic. Princeton, NJ: Princeton University Press, 2015.

Ali, Kecia. The Lives of Muhammad. Cambridge, MA: Harvard University Press, 2014.

Anidjar, Gil. The Jew, the Arab: A History of the Enemy. Stanford, CA: Stanford University Press, 2003.

Anthony, Sean W. The Caliph and the Heretic: Ibn Saba' and the Origins of Shī 'ism. Leiden: Brill, 2012.

---. "Muhammad, the Keys to Paradise, and the Doctrina Iacobi: A Late Antique Puzzle." Der Islam 91 (2014): 243-65.

---. Muhammad and the Empires of Faith: The Making of the Prophet of Islam. Oakland: University of California Press, 2020.

Boyarin, Daniel. Border Lines: The Partition of Judaeo-Christianity. Philadelphia: University of Pennsylvania Press, 2004.

Brody, Robert. Sa'adyah Gaon. Oxford: Littman Library of Jewish Civilization, 2013.

Bulliet, Richard W. The Case for Islamo-Christian Civilization. New York: Columbia University Press, 2004.

Choueiri, Youssef M. Review of Imagining the Arabs: Arab Identity and the Rise of Islam, by Peter J. Webb. Journal of Near Eastern Studies 76 (2017): 377-79.

Cohen, Mark. Under Crescent and Cross: The Jews in the Middle Ages. Princeton, NJ: Princeton University Press, 1994.

Conrad, Lawrence I. "Recovering Lost Texts: Some Methodological Issues" (review of Gordon D. Newby, The Making of the Last Prophet: A Reconstruction of the Earliest Biography of Muhammad). Journal of the American Oriental Society 113 (1993): 258-63.

Crone, Patricia. "Jewish Christianity and the Qur'ān (Part One)." Journal of Near Eastern Studies 74 (2015): 225-53.

-_-. Meccan Trade and the Rise of Islam. Princeton, NJ: Princeton University Press, 1987.

---. "Pagan Arabs as God-fearers." In Islam and Its Past: Jahiliyya, Late Antiquity, and the Qur'an, edited by Carol Bakhos and Michael Cook, 140-64. Oxford: Oxford University Press, 2017. 
---. The Qurānic Pagans and Related Matters. Volume 1 of Collected Studies in Three Volumes. Edited by Hanna Siurua. Leiden: Brill, 2016.

-- - and Michael Cook. Hagarism: The Making of the Islamic World. Cambridge: Cambridge University Press, 1979.

Donner, Fred M. Muhammad and the Believers: At the Origins of Islam. Cambridge, MA: Belknap Press, 2010.

Drory, Rina. Models and Contacts: Arabic Literature and Its Impact on Medieval Jewish Culture. Leiden: Brill, 2000.

El-Badawi, Emran. The Qur'ān and the Aramaic Gospel Traditions. Abingdon: Routledge, 2014.

Fishman, Talya. Becoming the People of the Talmud: Oral Torah as Written Tradition in Medieval Jewish Cultures. Philadelphia: University of Pennsylvania Press, 2011.

Geiger, Abraham. Was hat Mohammed aus dem Judenthume aufgenommen? Rev. ed. Leipzig: Kaufmann; New York: Bloch, 1902.

GhaneaBassiri, Kambiz, and Paul Robertson, eds. All Religion Is Inter-Religion: Engaging the Work of Steven M. Wasserstrom. London: Bloomsbury Academic, 2019.

Goitein, S. D. Jews and Arabs: Their Contacts through the Ages. 3rd rev. ed. New York: Schocken, 1974.

Hassan, Mona. Longing for the Lost Caliphate: A Transregional History. Princeton, NJ: Princeton University Press, 2016.

Hoyland, Robert G. Seeing Islam as Others Saw It: A Survey and Evaluation of Christian, Jewish and Zoroastrian Writings on Early Islam. Princeton, NJ: Darwin Press, 1997.

Hughes, Aaron W. Islam and the Tyranny of Authenticity: An Inquiry into Disciplinary Apologetics and Self-Deception. London: Equinox, 2016.

-_-. "Jewish Studies Is Too Jewish." Chronicle of Higher Education, March 24, 2014. https:// www.chronicle.com/article/jewish-studies-is-too-jewish/.

-_-. "Messianism and the Shadow of History: Judaism and Islam in a Time of Uncertainty." In Islamic Studies Today: Essays in Honor of Andrew Rippin, edited by Majid Daneshgar and Walid Saleh, 145-63. Leiden: Brill, 2017.

-_-. Muslim and Jew. Abingdon: Routledge, 2019.

--—. "Religion without Religion: Integrating Islamic Origins into Religious Studies." Journal of the American Academy of Religion 85 (2017): 867-88.

-- - Review of The Religious and Spiritual Life of the Jews of Medina, by Haggai Mazuz. Journal of the American Academy of Religion 83 (2015): 580-82. 
--- Review of What Is Islam? The Importance of Being Islamic, by Shahab Ahmed. Reading Religion: A Publication of the American Academy of Religion, Sept. 8, 2017. https://readingreligion.org/books/what-islam.

-- - Shared Identities: Medieval and Modern Imaginings of Judeo-Islam. Oxford: Oxford University Press, 2017.

---. "South Arabian 'Judaism,' Himyarite Rahmanism, and the Origins of Islam." In Remapping Emergent Islam: Texts, Social Settings, and Ideological Trajectories, edited by Carlos A. Segovia, 15-43. Amsterdam: Amsterdam University Press, 2020.

---. Theorizing Islam: Disciplinary Deconstruction and Reconstruction. Abingdon: Routledge, 2012.

Imhoff, Sarah. "Jews, Jewish Studies and the Study of Islam." In Identity, Politics and the Study of Islam: Current Dilemmas in the Study of Religions, edited by Matt Sheedy, 121-37. Sheffield: Equinox, 2018.

Kraemer, Joel L. Maimonides: The Life and World of One of Civilization's Greatest Minds. New York: Doubleday, 2008.

Kugel, James L. In Potiphar's House: The Interpretive Life of Biblical Texts. Cambridge, MA: Harvard University Press, 1990.

Lassner, Jacob. Jews, Christians, and the Abode of Islam: Modern Scholarship, Medieval Realities. Chicago: University of Chicago Press, 2013.

Lazarus-Yafeh, Hava. Intertwined Worlds: Medieval Islam and Bible Criticism. Princeton, NJ: Princeton University Press, 1992.

Lecker, Michael. Mûhammad ve-ha-Yehûdîm [Muḥammad and the Jews]. Jerusalem: Makhon Ben-Tzvi, 2014.

Levy-Rubin, Milka. Non-Muslims in the Early Islamic Empire. Cambridge: Cambridge University Press, 2011.

Lewis, Bernard. The Jews of Islam. Princeton, NJ: Princeton University Press, 1984.

Maghen, Ze'ev. After Hardship Cometh Ease: The Jews as Backdrop for Muslim Moderation. Berlin: de Gruyter, 2006.

Masuzawa, Tomoko. In Search of Dreamtime: The Quest for the Origin of Religion. Chicago: University of Chicago Press, 1993.

Mazuz, Haggai. The Religious and Spiritual Life of the Jews of Medina. Leiden: Brill, 2014.

McCutcheon, Russell. Manufacturing Religion: The Discourse on Sui Generis Religion and the Politics of Nostalgia. Oxford: Oxford University Press, 1997. 
Neuwirth, Angelika. "Locating the Qur'ān in the Epistemic Space of Late Antiquity." In Books and Written Culture of the Islamic World: Studies Presented to Claude Gilliot on the Occasion of His 75th Birthday, edited by Andrew Rippin and Roberto Tottoli, 159-79. Leiden: Brill, 2015.

Newby, Gordon Darnell. A History of the Jews of Arabia from Ancient Times to Their Eclipse under Islam. Columbia: University of South Carolina Press, 1988.

-- - The Making of the Last Prophet: A Reconstruction of the Earliest Biography of Muhammad. Columbia: University of South Carolina Press, 1989.

Nirenberg, David. Anti-Judaism: The Western Tradition. New York: Norton, 2013.

Penn, Michael Philip. Envisioning Islam: Syriac Christians and the Early Muslim World. Philadelphia: University of Pennsylvania Press, 2015.

Pennington, Brian. Was Hinduism Invented? Britons, Indians, and the Colonial Construction of Religion. Oxford: Oxford University Press, 2005.

Pines, Shlomo. "The Jewish Christians of the Early Centuries of Christianity according to a New Source." Proceedings of the Israel Academy of Sciences and Humanities 2, no. 13 (1966).

Pregill, Michael E. The Golden Calf between Bible and Qur' an: Scripture, Polemic, and Exegesis from Late Antiquity to Islam. Oxford: Oxford University Press, 2020.

- - . "The Hebrew Bible and the Quran: The Problem of the Jewish 'Influence' on Islam." Religion Compass 1 (2007): 643-59.

- - " "Isrā̄illiyyāt, Myth, and Pseudepigraphy: Wahb b. Munabbih and the Early Islamic Versions of the Fall of Adam and Eve." Jerusalem Studies in Arabic and Islam 34 (2008): 215-84.

- - . "The Jews of Medina and the Challenge of Early Islamic Historiography" (review of Haggai Mazuz, The Religious and Spiritual Life of the Jews of Medina). Review of Qur'anic Research 2, no. 2 (2016). https://lockwoodonlinejournals.com/index.php/ rqr/article/view/332.

- - . "Positivism, Revisionism, and Agnosticism in the Study of Late Antiquity and the Qur’ān.” Journal of the International Qur'anic Studies Association 2 (2017): 169-99.

--_. "The Two Sons of Adam: Rabbinic Resonances and Scriptural Virtuosity in Sūrat al-Mā'idah." Journal of the International Qur'anic Studies Association 6 (2021) (forthcoming).

Reeves, John C. Trajectories in Near Eastern Apocalyptic: A Postrabbinic Jewish Apocalypse Reader. Leiden: Brill, 2006. 
Sheedy, Matt. "Identity, Politics, and the Study of Islam." Culture on the Edge:A Peer Reviewed Blog, February 25, 2019. https://edge.ua.edu/nota-bene/identity-politics-and-thestudy-of-islam-an-interview-with-matt-sheedy/.

Shoemaker, Stephen J. The A pocalypse of Empire:Imperial Eschatology in Late Antiquity and Early Islam. Philadelphia: University of Pennsylvania Press, 2018.

-- . The Death of a Prophet: The End of Muhammad's Life and the Beginnings of Islam. Philadelphia: University of Pennsylvania Press, 2011.

---. A Prophet Has Appeared:The Rise of Islam through Christian and Jewish Eyes. Oakland: University of California Press, 2021.

Simonsohn, Uriel. A Common Justice: The Legal Alliances of Christians and Jews under Early Islam. Philadelphia: University of Pennsylvania Press, 2011.

Stewart, Devin J. "A Modest Proposal for Islamic Studies." In Identity, Politics and the Study of Islam: Current Dilemmas in the Study of Religions, edited by Matt Sheedy, 157-200. Sheffield: Equinox, 2018.

Stillman, Norman. The Jews of Arab Lands: A History and Sourcebook. New York: Jewish Publication Society of America, 1979.

Stroumsa, Sarah. Maimonides in His World: Portrait of a Mediterranean Thinker. Princeton, NJ: Princeton University Press, 2009.

Toorn, Karel van der. Becoming Diaspora Jews: Behind the Story of Elephantine. New Haven, CT: Yale University Press, 2019.

Tottoli, Roberto. "Origin and Use of the Term Isrā̄̄liyyāt in Muslim Literature." Arabica 46 (1999): 193-210.

Wasserstrom, Steven M. Between Muslim and Jew: The Problem of Symbiosis under Early Islam. Princeton, NJ: Princeton University Press, 1995.

-_-. "The Moving Finger Writes: Mughīra b. Sa'īd's Islamic Gnosis and the Myths of Its Rejection." History of Religions 25 (1985): 1-29.

---. Religion After Religion: Gershom Scholem, Mircea Eliade, and Henry Corbin at Eranos. Princeton, NJ: Princeton University Press, 1999.

-_-. "Species of Misbelief: A History of Muslim Heresiography of the Jews." PhD dissertation, University of Toronto, 1987.

Webb, Peter J. Imagining the Arabs: Arab Identity and the Rise of Islam. Edinburgh: Edinburgh University Press, 2016.

Zellentin, Holger M. The Qur'ān's Legal Culture: The Didascalia Apostolorum as a Point of Departure. Tübingen: Mohr Siebeck, 2013. 


\title{
Review Essay
}

\section{Feeling Bad about Emotional History: The Case of Andalucismo}

\author{
Charles Hirschkind. The Feeling of History: Islam, \\ Romanticism, and Andalusia (Chicago: University of \\ Chicago Press, 2021). ISBN 978-02-2674-695-1. Price: \\ $\$ 27.50$ (paper), \$95.00 (cloth).
}

\section{Alejandro García-SAnjuÁN \\ University of Huelva (Spain)}

(sanjuan@uhu.es)

\begin{abstract}
This article presents a critical review of The Feeling of History, a recent work by the American anthropologist Charles Hirschkind. In this book, the author treats Andalucismo, a political movement that arose in modern Andalusia early in the twentieth century and was chiefly characterized by an extremely positive view of the Islamic Iberian past (al-Andalus)-a tendency that is certainly unusual in Spain and goes against the prevalent Spanish nationalism. In his book, Hirschkind not only develops an uncritical view of Andalucismo and its intrinsically emotional reading of the past but also legitimizes a rather farfetched conflation of modern Andalusia and al-Andalus. Moreover, he offers an extremely shallow and unnuanced reading of current Spanish scholarship on the Middle Ages, branding it wholesale as an heir to Francoism. He also lends legitimacy to those who call into question the origin of al-Andalus in the Islamic conquest of 711 CE-representatives of an unscholarly approach that has been largely dismissed by academic outlets since the 1970s. Burdened by heavy ideological prejudices and hampered by the author's limited knowledge of the most recent academic historiographic debates in the field of Iberian medieval studies, the book represents a failed attempt to present the Anglophone readership with a consistent introduction to Andalusian nationalism together with a critical appraisal of the Andalusian nationalist interpretation of the medieval Iberian past.
\end{abstract}

"What does it matter the story is false, if the feeling it raises is true?"1

\section{Introduction}

As in many other modern states, diverse national feelings coexist in today's Spain. Although many Spaniards would be reluctant to admit it, Spanish identity shapes the mainstream nationalist feeling in the country. Spanish nationalism reached its most radical expression during the forty years of Francoist dictatorship (1936-1975), when the regime

1. "Qué importa que la historia sea falsa, si el sentimiento que provoca es verdadero?" El Roto, El País, April 9, 2014.

(c) 2021 Alejandro García-Sanjuán. This is an open access article distributed under the terms of the Creative Commons Attribution-NonCommercialNoDerivatives License, which allows users to copy and distribute the material in any medium or format in unadapted form only, for noncommercial purposes only, and only so long as attribution is given to the original authors and source. 
sought to turn Spain into "one, great, and free" nation, as its official motto declared. Francoist nationalism, usually known as National Catholicism, banished any other form of collective identity in the country. Small wonder, then, that in August 1936, upon the outbreak of the Civil War, Francoist forces arrested and killed in Seville the founder of Andalusian nationalism (Andalucismo), Blas Infante.

Franco's demise in 1975 and the passing of the 1978 constitution ushered Spain into its current democratic period, which brought with it a new territorial structure, made up of so-called autonomous communities. With their own parliaments and institutions, the new autonomías emerged as a suitable framework in which different local national feelings, marginalized and harshly repressed by the Franco regime, could thrive. Although Andalucismo reached its peak in the years of the Spanish "transition" to democracy (197582), it never achieved strong popular support or significant scholarly legitimacy. To the best of my knowledge, Hirschkind's The Feeling of History: Islam, Romanticism, and Andalusia (Chicago: University of Chicago Press, 2021), represents the most substantial academic legitimation so far of this local form of nationalism in Spain.

In what follows, I lay out why I find this book deeply troublesome and disappointing. Before proceeding any further, however, I have to make clear my specific goals in this essay. Virtually every book is open to criticism from different perspectives; I will limit myself here to issues that concern me as a historian and a medievalist. More specifically, I wish to draw the reader's attention to Hirschkind's misguided and distorted portrayal of Spanish scholarship on the Middle Ages and to the way his book, in line with recent precedents, lends legitimacy to an old and well-known academic fraud about the origins of al-Andalus.

\section{From al-Andalus to Andalusia: Andalucismo}

The case of Andalucismo is peculiar insofar as it represents the only form of Iberian nationalism that looks to al-Andalus for the historical grounding of its collective identity. Drawing on the etymological connection between Andalusia and al-Andalus, Blas Infante sketched a historical account according to which the Castilian conquerors (the "Spaniards") had stripped the "Andalusians" of their country and their national identity since the thirteenth century. It goes without saying that al-Andalus and Andalusia are radically different historical realities, and therefore that conflating the people of al-Andalus with modern Andalusians represents a serious mistake. But such conflation is part of any national narrative's mythology.

Like any other nationalism, Andalucismo looks at the past through a rather emotional lens. Analyzing and explaining its relationship to the past represents a relevant scholarly subject that helps us answer significant questions about the reception of al-Andalus and the medieval Iberian past in modern Spain and Andalusia. However, studying, explaining, and understanding a phenomenon is very different from assuming and legitimizing particular theories about it. Here lies one of the the main problems with The Feeling of History: it is a book that not only examines but fully embraces Andalucismo. What it offers, therefore, is not just a scholarly presentation of Andalucismo but a study that draws on the Andalusian nationalist approach to the past. In other words, Hirschkind embarks on a full legitimation 
of the Andalusian nationalist envisioning of al-Andalus and endorses this approach as a valid and legitimate counternarrative to the traditional Spanish nationalist account of medieval Iberia. Far from shattering myths, however, The Feeling of History proves that there is no valid alternative to carefully crafted historical knowledge when it comes to dismantling deeply ingrained myths about the past.

Drawing on the writings of the philosopher and activist W. E. B. Du Bois (1868-63), the philosopher Ludwig Wittgenstein (1889-1951), and Ananda Abeysekara (an expert on Buddhist studies), the book's introduction develops a methodological framework intended to justify emotional history as a valid and legitimate academic approach to the past as historical knowledge. Hirschkind points out that "our relation to a given past may not be one of indifference or neutrality ... it may rather be affectively structured in a way that asks of us a unique attunement and response." 2

Emotional envisionings of the past are radically opposed to the academic study of history: historical knowledge is built not on feelings but on documents, data, and sources. Emotions and feelings are legitimate objects of study for historians, but not legitimate methodological approaches for the academic study of history. In other words, the history of emotions is one thing, and emotional history is another. A twenty-first-century academic work by a social scientist (certainly not a historian) endorsing and justifying an emotional and therefore nonacademic approach to the past is not just a striking novelty but an indication of a much more worrying issue: unscientific tendencies are making their way into academia.

I intend to show below that lending academic legitimacy to an emotional approach to the past represents a huge scholarly mistake. Arguably the most glaring evidence for this in The Feeling of History lies in Hirschkind's ideas about current Spanish historiography and, in particular, in his utterly uncritical approach to negationism.

It has been frequently said that nationalism could not exist without a particular historical narrative. In this respect, Andalucismo suffered from extreme intellectual indigence until the mid-1970s. A notary by training, Infante was never able to produce a well-grounded presentation of the Andalusian people's historical evolution. But building a suggestive national project requires a consistent national account, and this is where Ignacio Olagüe's (1903-74) outlandish narrative about the origins of al-Andalus came in handy for Andalusian nationalists. ${ }^{3}$

The story of this amateur historian has been told many times, ${ }^{4}$ especially after the 2006 book Historia general de Al Ándalus lent, for the first time, scholarly legitimacy to his ideas. ${ }^{5}$ This review is not the right place to retell that story at length:

2. Hirschkind, Feeling of History, 23.

3. I. Olagüe, Les arabes n'ont jamais envahi l'Espagne (Paris: Flammarion, 1969); idem, La revolución islámica en occidente (Madrid: Fundación Juan March, 1974).

4. A. García-Sanjuán, "Denying the Islamic Conquest of Iberia, a Historiographical Fraud," Journal of Medieval Iberian Studies 11, no. 3 (2019): 306-22.

5. E. González Ferrín, Historia general de Al Ándalus (Córdoba: Almuzara, 2006); idem, Cuando fuimos árabes (Córdoba: Almuzara, 2017). See also González Ferrín's rather enthusiastic presentation of Olagüe’s work in a recent online interview: https://www.youtube.com/watch?v=hdrqef9ViGE. 
seasoned specialists from Spain (P. Martínez Montávez), France (R. Le Tourneau, P. Guichard), and the United States (J. T. Monroe) have unequivocally refuted Olagüe's claims. ${ }^{6}$ In a nutshell, Olagüe argued (only rarely attempting to prove his claims) that the Arab and Islamic conquest of Iberia in 711 CE never happened. Instead, he contended, after a civil war that destroyed the Visigothic kingdom early in the eighth century, a slow, smooth, and rather unnoticeable process gradually turned the local unitarian Arians into fullfledged Muslims. Therefore, according to Olagüe, al-Andalus was the product of local, not foreign, forces. This nativism made Olagüe's approach irresistible to Andalusian nationalists in the 1970s and 1980s. It also explains why, as Hirschkind acknowledges, ${ }^{7}$ Olagüe's thesis fascinated the many local Andalusian converts to Islam in the late 1970s: he provided them with a local Islam of their own.

An English-language book on Andalucismo could have been an excellent opportunity to offer an international scholarly audience a clear picture of the origins and evolution of this peculiar form of nationalism. It could likewise have provided a suitable framework for developing a more nuanced and historically contextualized understanding of how the brainchild of Olagüe, a follower of fascism, could, many decades later, thrive in a radically different ideological context-in other words, how Olagüe's negationism (that is, denial of the historicity of the 711 Islamic conquest of Iberia) ended up legitimizing a reading of the past narrowly associated with a form of nationalism that was diametrically opposed to the kind of radical Spanish nationalism that had originally inspired Olagüe. Let us remember that Infante, the founder of Andalucismo, died at the hands of Francoist fascists, and that Olagüe's fascist beliefs in the 1920s and the 1930s played a key role in shaping his revisionist approach to Spanish history. ${ }^{8}$ It is no wonder that Olagüe's closest friends, who were fascists, enthusiastically welcomed his earliest historical contribution, which included a moving personal dedication to his beloved friend Ramiro Ledesma Ramos (1905-36), the founder of the oldest Spanish political fascist organization who was killed in Madrid upon the outbreak of the Civil War9.

Nothing of this history, however, is to be found in Hirschkind's book. Instead of adopting a critical approach to Infante's thinking and Olagüe's fantasies (which survive in their academic proxies), the book is even more explicit and unapologetic in its legitimation of negationism than its American precedents were. ${ }^{10}$ In 1975, J. T. Monroe described Olagüe's

6. For an extensive review of the opinions of the aforementioned authors as well as others, see A. GarcíaSanjuán, La conquista islámica de la península ibérica y la tergiversación del pasado, 2nd ed. (Madrid: Marcial Pons, 2019), 138-54.

7. Hirschkind, Feeling of History, 86.

8. M. Fierro, "Al-Andalus en el pensamiento fascista español: La revolución islámica en Occidente, de Ignacio Olagüe," in Andalus, España: Historiografías en contraste, siglos XVII-XXI, ed. M. Marín (Madrid: Casa de Velázquez and CSIC, 2009), 325-50.

9. A. García-Sanjuán, "Ignacio Olagüe y el origen de al-Andalus: Génesis y edición del proyecto negacionista”, Revista de estudios internacionales mediterráneos 24 (2018): 173-98.

10. K. B. Wolf, "Negating Negationism," Pomona Faculty Publications and Research 394 (2014), http://scholarship.claremont.edu/pomona_fac_pub/394; idem, "Myth, History, and the Origins of al-Andalus: 
Les arabes n'ont jamais envahi l'Espagne as "not a scholarly work" and branded Olagüe's approach anti-Semitic. ${ }^{11}$ As an amateur historian, Olagüe could not be expected to possess full command over either the historical sources or the extant scholarship about the origins of al-Andalus. However, the same lenience cannot be extended to his current scholarly followers, and this is why in 2013 I went a step further than Monroe did and called the reengineering of Olagüe's original negationism not just unscholarly but a scholarly fraud. It is striking, then, that this new negationism has continued to gain traction in sectors of American scholarship over the past years.

\section{Misunderstanding Spanish Historical Writing}

A few words of clarification concerning the notion of negationism are in order. In my 2013 monograph I gave the name "negationism" to Olagüe's ideas. Being aware of the Nazi parallel, I declared explicitly that I did not mean to draw a moral equivalence between the two phenomena. ${ }^{12}$ Ignoring this explicit statement, Hirschkind claims: "In comparing González Ferrín's work to the discourse of Holocaust denial, the term negationism's primary referent, García Sanjuán invites us to view the text as a morally reprehensible act of historical distortion." ${ }^{13}$ Like others before him, ${ }^{14}$ Hirschkind is here rehearsing an extremely simplistic argument. Although there is an obvious moral difference between doubting the Holocaust and calling into question historical events twelve centuries ago, it is indisputable that the term negationism has over the last few years been applied to positions on many issues other than the Nazi genocide. According to the sociologist Keith Kahn-Harris,

in recent years, the term has been used to describe a number of fields of "scholarship," whose scholars engage in audacious projects to hold back, against seemingly insurmountable odds, the findings of an avalanche of research. They argue that the Holocaust (and other genocides) never happened, that anthropogenic (human-caused) climate change is a myth, that Aids either does not exist or is unrelated to HIV, that evolution is a scientific impossibility, and that all manner of other scientific and historical orthodoxies must be rejected. ${ }^{15}$

A Historiographical Essay," Journal of Medieval Iberian Studies 11, no. 3 (2019): 378-401; H. Fancy, “The New Convivencia," Journal of Medieval Iberian Studies 11, no. 3 (2019): 295-305.

11. J. T. Monroe, review of Les Arabes n'ont jamais envahi l'Espagne, by I. Olagüe, International Journal of Middle East Studies 6, no. 3 (1975): 347-48.

12. García-Sanjuán, La conquista islámica, 80: "No pretendo establecer una equiparación moral entre ellos."

13. Hirschkind, Feeling of History, 91.

14. Wolf, "Negating Negationism"; J. Lorenzo, review of La conquista islámica de la península ibérica y la tergiversación del pasado, by A. García Sanjuán, Medieval Encounters 20 (1014): 273-75. See my reply to Lorenzo: A. García-Sanjuán, "Response to: Jesús Lorenzo," Medieval Encounters 21 (2015): 136-38.

15. K. Kahn-Harris, "Denialism: What Drives People to Reject the Truth," Guardian, August 3, 2018, https://www.theguardian.com/news/2018/aug/03/denialism-what-drives-people-to-reject-the-truth. 
In other words, "negationism" refers to all challenges to knowledge that is based on the interpretation of empirical and reliable evidence through recognized methodologies. Calling into question such well-researched and well-known historical processes as the Islamic conquest of Iberia fits this label well. Indeed, Wikipedia deems the denial of the Islamic conquest of Iberia a form of historical negationism alongside denial of the Holocaust and other episodes in more recent history. ${ }^{16}$

Let us now focus on Hirschkind's reading of current Spanish historical writing. According to him, by rejecting negationism, Spanish historians today ironically share views held by Francoists. The second chapter of the book ("The Difficult Convivencia of Spanish History") opens with the bold statement that medieval Iberian studies is "a field entrusted to maintain order over the inconvenient and unwieldy eight hundred years of Muslim rule on the peninsula." 17 Even more explicitly, when discussing Maribel Fierro's approach to negationist literature, Hirschkind declares: "Spanish Arabism remains haunted by early associations with and accommodations made under National Catholicism."18

I am anything but uncritical of my own discipline. In fact, over the last ten years, I have made academic outlets that continue to cling to the Francoist tradition a focal point of my scholarship. ${ }^{19}$ I firmly believe that we are currently witnessing in Spain an insufficient academic reaction to an all-out offensive by the far right to resuscitate the Francoist, National Catholic narrative of the Reconquista. However, Hirschkind's unnuanced tarring of the entire field of Spanish medieval and Arabic studies with the same brush is a gross oversimplification. A close reading of the book shows that Hirschkind's grim outlook on Spanish historical writing is the result not of a careful and comprehensive appraisal but of a reckless and dramatically mistaken decision: taking negationism as a reliable map for his journey through medieval Iberian scholarship's troubled waters.

\section{Misinterpreting Negationist Academic Literature}

The unfortunate consequences of this decision are not difficult to ascertain. First and foremost, Hirschkind's perception of negationism is unrealistic and farfetched. The informed reader will be surprised by the claim that González Ferrín's writings on the origins of al-Andalus are "based on a rereading of the limited historical evidence currently

16. "Historical Negationism," https://en.wikipedia.org/wiki/Historical_negationism.

17. Hirschkind, Feeling of History, 69.

18. Ibid., 88.

19. A. García-Sanjuán, "La persistencia del discurso nacionalcatólico sobre el medievo peninsular en la historiografía española actual," Historiografías: Revista de historia y teoría 12 (2016): 132-53; idem, “Al-Andalus en la historiografía nacionalcatólica española: Claudio Sánchez-Albornoz," eHumanista 37 (2017): 305-28; idem, "Rejecting al-Andalus, Exalting the Reconquista: Historical Memory in Contemporary Spain," Journal of Medieval Iberian Studies 10-11 (2018): 127-45; idem, “Cómo desactivar una bomba historiográfica: La pervivencia actual del paradigma de la Reconquista," in La Reconquista. Ideología y justificación de la guerra santa peninsular, ed. C. de Ayala and S. Palacios, 99-119 (Madrid: La Ergástula, 2019); idem, "Weaponizing Historical Knowledge: The Notion of Reconquista in Spanish Nationalism," Imago Temporis: Medium Aevum 14 (2020): 133-62. 
available." ${ }^{20}$ Hirschkind exhibits both a complete ignorance of the historical sources and a gullible attitude toward negationist literature, as when he reports uncritically that "according to González Ferrín, the conflicting views in this particular debate devolve almost entirely on the interpretation of two coins." 21

Like any other form of negationism, denial of the Islamic conquest of Iberia relies on disregard of the empirical evidence, and an overriding disdain for historical sources thus represents its most salient feature. Much ink has been spilled over the last fifty years on exposing the sham that this approach represents. Although Hirschkind ignores most of the academic literature on negationism, he draws extensively on Fierro's 2009 article and on my 2013 monograph. ${ }^{22}$ Consequently, his appraisal of González Ferrín's alleged "rereading" of the sources suggests that he either has decided to ignore the critics he cites or simply does not understand what negationism really is.

Hirschkind's further remarks confirm his strikingly shallow understanding of negationism. He writes, for example: “While González Ferrín's downplaying of the military dimension of the arrival of Islam in Iberia is certainly unconventional, many parts of his narrative on the porosity and slow consolidation of Islam during the eighth and ninth centuries have gained increasing acceptance in recent decades." ${ }^{23}$ For starters, casting as merely "unconventional" a scholarly fraud consistently and explicitly rejected by professional historians for the past half-century points to a clear failure to grasp the true nature of negationism. Second, claiming that denialist literature "downplays" the military dimension of the arrival of Islam is inaccurate, as González Ferrín actually denies it altogether. Further, the latter claims that what arrived in Iberia in 711 was not Islam but something that he calls, in his distinctly abstruse and pretentious style, "another variety of unmistakable prior recognition" ("otra variedad de indudable reconocimiento previo") - a phrase that sounds as meaningless in English as it does in its original Spanish. ${ }^{24}$ This is just one of many examples of the empty verbiage that characterizes negationism.

I wonder whether scholars would dare to indulge and legitimize negationism so openly in connection with a different historical event, such as the 1620 arrival of the Pilgrims in what is today Massachusetts. The possibility of such absurdity was raised already forty-five years ago by Monroe in his review of Olagüe:

The reader, left exhausted and suspicious over the political and chauvinistic motives of the author, is likely to wonder whether Mr Olagüe will continue in this line of research, and eventually show that the Romans never conquered the Mediterranean basin, that the Normans never invaded England, and so on. Will he perhaps even show that the Spanish never conquered an empire in America? ${ }^{25}$

\footnotetext{
20. Hirschkind, Feeling of History, 74.

21. Ibid., 177.

22. Ibid., 86-95.

23. Ibid., 95.

24. González Ferrín, Historia general de Al Ándalus, 185.

25. Monroe, review of Olagüe, 348.
} 
On the other hand, I would have been grateful to Hirschkind for taking the trouble to clarify which specific parts of scholarly negationism have gained "increasing acceptance" in recent decades and what the evidence for this acceptance is. I am not aware of any specialist in early Islam or the history of al-Andalus ready to endorse González Ferrín's claim that Islam "as such," or "full-fledged" Islam (whatever that means), did not exist before the year $800^{26}$ (in Hirschkind's words, "before the ninth century, Islam has yet to coalesce into a distinct civilization"27); that the Arab governor of Qayrawan, Mūsā b. Nușayr, was a mere "personification" ("una personificación"), ${ }^{28}$ or that the name Muhammad does not appear in the 98/716-17 bilingual dinar struck in Spania/al-Andalus, ${ }^{29}$ to mention just a few of the most blatantly unfounded negationist claims. For Hirschkind, however, my pointing out of these features serves to make my account of negationism "highly distorted." 30

One is similarly left to wonder which precise parts of negationism "cohere with current historical research." ${ }^{31}$ If we look at the most recent and reliable revisionist academic literature about early Islam, negationism clearly does not fit in. Fred Donner, for example, has argued that "during the late first century AH/seventh century C.E. and early second century AH/eighth century C.E., the Believers' movement evolved into the religion we now know as Islam." ${ }^{32}$ Largely in accordance with the traditional account, Donner asserts that what he calls "the Believers' movement" expanded rapidly upon Muhammad's demise through military conquests, and he devotes a full chapter ("The Expansion of the Community of Believers") to these conquests. The mainstream nonrevisionist academic literature pleads for an even earlier origin of Islam; indeed, in 1981, Donner himself devoted a book-length study to the early Islamic conquests. So it is difficult to identify any part of the academic denialist literature that would "cohere with current historical research" on early Islam, whether revisionist or nonrevisionist. The reason is simple: as pointed out years ago by Guichard, Monroe, and others, and much to the chagrin of its current proponents and followers, negationism does not meet academic standards.

The same applies to negationist claims about the process of the Quran's canonization. González Ferrín recently published an article in a volume edited by Carlos Segovia in which

\section{González Ferrín, Cuando fuimos árabes, 235.}

27. Hirschkind, Feeling of History, 82.

28. González Ferrín, Historia general de Al Ándalus, 179. According to the dictionary of the Royal Spanish Academy, "personificación" entails the attribution of the features of rational beings to things that are irrational, inanimate, disembodied, or abstract. It is not clear in which of these categories González Ferrín means to place Mūsā b. Nușayr. The latter three do not fit well an entity mentioned by his personal name in written documents, literary sources, and coins; see the recent article by Y. Benhima and P. Guichard, "Mûsâ ibn Nusayr: Retour sur l'histoire et le pouvoir d'un gouverneur omeyyade en Occident musulmán," Bulletin d'études orientales 66 (2017): 97-116. Nor is it evident on what grounds Mūsā b. Nuṣayr could be branded an irrational being.

29. González Ferrín, Historia general de Al Ándalus, 194.

30. Hirschkind, Feeling of History, 92.

31. Ibid., 93.

32. F. Donner, Muhammad and the Believers: At the Origins of Islam (Cambridge, MA: Belknap Press, 2010), 194-95. 
he argued that the Quran was compiled only after $800 \mathrm{CE}$. In a Twitter thread, Marijn van Putten exclaims that the article "makes me feel like we have stepped into a time machine, all progress of the past decades is ignored." 33 Reviewing González Ferrín's handling of the relevant manuscript evidence, van Putten concludes that "it's rather clear that he has never actually looked at any of these manuscripts, otherwise he would not suggest something so absurd. And indeed, his discussion on early manuscripts makes it quite clear he is utterly clueless about them." ${ }^{34}$. Segovia and González Ferrín are close collaborators, and Nora K. Schmid's review of Segovia's The Quranic Noah (2015) indicates that Segovia and González Ferrín share the same ungrounded approach to the origins of Islam. ${ }^{35}$ Both Van Putten and Schmid point out that even as negationism gains visibility through international scholarly outlets, its pushing of standard academic boundaries is becoming increasingly clear. ${ }^{36}$

As noted earlier, academic negationism regarding the Islamic conquest of Iberia first surfaced in Spain, and consequently Spanish scholars were the first to address it. Their work, however, has not always been duly acknowledged, at least not as much as in other cases. In this regard, it is worth recalling the enthusiastic reaction provoked by the "surgical dissection" of van Putten's thread. ${ }^{37}$ By contrast, when dealing with the much more exhaustive and comprehensive rebuttals of negationism written by Spanish critics and published in scholarly venues (not on social media), Hussein Fancy was much more lukewarm in his response. ${ }^{38}$ The justification for this stark contrast is not evident.

Not being a specialist in medieval studies, Hirschkind appears unable to understand a scholarly debate largely alien to his professional training. As a result, he is forced to rely on others' opinions. His main guide in navigating the choppy waters of Iberian medieval historiography is Kenneth B. Wolf's review of my 2013 monograph, in which Wolf offered a largely uncritical portrait of González Ferrín's negationism. ${ }^{39}$ Wolf's role needs to be carefully considered, since he not only introduced academic negationism to American scholarship but did so by granting González Ferrín the academic credentials that most specialists have never accorded him. To set the record straight: negationism has never

33. M. van Putten (@PhDniX), Twitter thread, December 6, 2020, https://twitter.com/PhDniX/ status/1335676197498478593. Van Putten is referring to E. González Ferrín, “What Do We Mean by the Qur’ān: On Origins, Fragments, and Inter-Narrative Identity," in Remapping Emergent Islam: Texts, Social Contexts, and Ideological Trajectories, ed. C. A. Segovia, 221-44 (Amsterdam: University of Amsterdam Press, 2020).

34. Van Putten, Twitter thread, December 6, 2020.

35. N. K. Schmid, review of The Quranic Noah and the Making of the Islamic Prophet: A Study of Intertextuality and Religious Identity Formation in Late Antiquity, by C. A. Segovia, Der Islam 97, no. 2 (2020): 617-22.

36. González Ferrín, Cuando fuimos árabes, 62, disingenuously complains about the Spanish academe’s positivism and lack of openness to what he calls "interpretive novelty" ("novedad interpretativa").

37. https://twitter.com/PhDniX/status/1335676197498478593.

38. Fancy, "New Convivencia."

39. See Wolf, "Negating Negationism" and "Myth, History, and the Origins of al-Andalus," as well as my reply to Wolf: A. García-Sanjuán, "La tergiversación del pasado y la función social del conocimiento histórico," Revista de libros, July 9, 2014: https://www.revistadelibros.com/discusion/la-tergiversacion-del-pasado-yla-funcion-social-del-conocimiento-historico. Hirschkind ignores this latter publication. 
been regarded as a valid academic approach in Spanish scholarship, and there is no debate on this point. ${ }^{40}$ For its part, academic negationism has never responded to its critics. Its sole response has consisted of scorning them as promoters of a smear campaign aimed at discrediting Olagüe's followers. Given the unambiguous rejection of negationism by the experts, one wonders about the reason behind the growing number of American scholars (Wolf, then Fancy, and now Hirschkind) willing to take seriously negationism as an academic approach. It is galling to witness the scholarly legitimation of telling of the past that no expert has ever considered worthy of the slightest academic credit.

Contradicting this consensus of nearly fifty years and following the precedent set by Wolf in 2014, Hirschkind argues that however questionable it is, negationism nonetheless merits academic consideration. Addressing my critique, he alleges that my "determination to demolish González-Ferrín's credibility" has led me to "misrepresent or too readily dismiss the serious aspects of the latter's work." 41 I do not believe that González Ferrín needs my help to demolish his scholarly credibility, but I do wonder what those "serious aspects" are. Luis Molina, a seasoned and highly regarded Arabist and one of the leading experts on Andalusi Arabic, went so far as to dismiss González Ferrín's work as "bullshit"42 an exceptionally harsh public assessment by one scholar of another's work, and one that conveys the vehemence with which Spanish scholars reject negationism's academic pretensions.

Strikingly, Hirschkind ignores not only almost the entirety of Spanish academic literature about negationism but likewise much of the recent and rich Anglophone scholarly production on Andalucismo. For instance, he never mentions the books of Christina Civantos ${ }^{43}$ and Jose Luis Venegas, ${ }^{44}$ and his references to Eric Calderwood's important work ${ }^{45}$ are not particularly substantive. Because he avoids dialogue with these authors, Hirschkind does not pay sufficient attention to political Andalucismo and, as a result, downplays the

40. The same is true also of other European scholarly traditions, especially the French; apart from the pioneering work of P. Guichard, “Les Arabes ont bien envahi l'Espagne: Les structures sociales de l'Espagne musulmane," Annales: Histoire, Sciences Sociales 6 (1974): 1483-513, see the much more recent article by P. Guichard and P. Sénac, "Les débuts d'al-Andalus: Des textes, des monnaies et des sceaux," Le Moyen Âge 128, no. 3-4 (2020): 511-37, where, quoting González Ferrín, they decry the "inanity" of publications casting doubt on the reality of the Arab conquest.

41. Hirschkind, Feeling of History, 92.

42. L. Molina, review of La conquista islámica de la península ibérica y la tergiversación del pasado, by A. García-Sanjuán, Medievalismo 25 (2015): 455-59. Hirschkind ignores both this review and a previous contribution by the same author on the same topic: L. Molina, "La conquista de al-Andalus, tergiversada: ¿Mala ciencia, ensayo, ficción?,” Revista de libros, September 1, 2014, https://www.revistadelibros.com/ discusion/la-conquista-de-al-andalus-tergiversadamala-ciencia-ensayo-ficcion.

43. C. Civantos, The Afterlife of al-Andalus: Muslim Iberia in Contemporary Arab and Hispanic Narratives (Albany: State University of New York Press, 2017).

44. J. L. Venegas, The Sublime South: Andalusia, Orientalism, and the Making of Modern Spain (Evanston, IL: Northwestern University Press, 2018).

45. E. Calderwood, Colonial al-Andalus: Spain and the Making of Modern Moroccan Culture (Cambridge, MA: Belknap Press, 2018). 
fact that the Andalucistas are responding to Spanish nationalism and complex regional dynamics (e.g., the competitive relationship between Andalusia and Catalonia).

\section{Misinterpreting National Catholic Scholarship}

Another claim put forward in Hirschkind's book is that the mere fact of acknowledging the 711 Islamic conquest of Iberia, and therefore rejecting negationism leads, in effect, to National Catholicism: ${ }^{46}$

García Sanjuán's campaign to discredit every aspect of the negationist thesis leads him not only to undervalue the parts of the thesis that cohere with current historical research but to seemingly embrace much of the conventional account propounded by National Catholicism, a view that García Sanjuán explicitly rejects as a nationalist myth. ... The fact that scholars who are acutely attuned to the dangers of Spanish nationalism end up reaffirming some of the more problematic tenets of nationalist historiography (Islam as a violent intruder into Iberia, erasure of the Arab contribution to building what eventually becomes Europe) points to the political and ideological pressures under which historians of the period labor. ${ }^{47}$

It is true that Vox, the new brand of the Spanish far right, has slammed González Ferrín for questioning the Islamic conquest, called him "Muslim-friendly," and charged him with "whitewashing Spain's history." 48 But that does not absolve negationism of its scholarly weaknesses. In fact, the narrative of Andalucismo, just like its apparent antipode, the traditional conservative account, relies on the perception of an unbroken historical continuity; from its perspective, in Hirschkind's words, al-Andalus and modern Spain and Portugal "cohere in a single continuous development." ${ }^{49}$ On the other side, Claudio Sánchez-Albornoz, the main proponent of traditional Spanish nationalist historical writing, once declared that Ibn Hazm represents "the Moorish link in the chain binding Seneca

46. González Ferrín, Cuando fuimos árabes, 237: “The Islamic conquest of the Iberian Peninsula is not just a historicist dogma but also a National Catholic requirement" ("La conquista islámica de la península ibérica no es sólo un dogma historicista, es también un requerimiento nacionalcatólico”).

47. Hirschkind, Feeling of History, 93.

48. On March 5, 2018, Vox tweeted, "The islamophile Emilio González Ferrín, falsifying the history of Spain, whitewashing Islam, and asserting in @el_pais [newspaper] that there was neither an Islamic invasion of the Iberian Peninsula in 711 nor a Christian reconquest ... Post-truth = the new lie" ("El islamófilo Emilio González Ferrín falseando la historia de España, blanqueando el islam y defendiendo en @el_pais que ni hubo invasión islámica de la península Ibérica en el año 711 ni tampoco una reconquista cristiana . . . La posverdad = la nueva mentira"); https://twitter.com/voxnoticias_es/status/970653678289018881. Vox was reacting to a report in E1 País about González Ferrín's Cuando fuimos árabes: P. Rodríguez Blanco, “Cuando fuimos árabes: La posverdad sobre Al Andalus," El País, March 6, 2018, https://elpais.com/elpais/2018/03/04/hechos/1520120370_739370. html. The same newspaper, however, later took a more critical stance: P. Rodríguez Blanco, “El 'fraude' que intenta tergiversar la historia de al-Andalus," El País, April 9, 2018, https://elpais.com/elpais/2018/04/06/ hechos/1523043230_705992.html.

49. Hirschkind, Feeling of History, 1. 
and Unamuno." ${ }^{50}$ Emotional history is the hallmark of every nationalist approach to the past. Although Andalucismo and National Catholicism obviously diverge in their respective approaches to medieval Iberia, at core they are more alike than they are different, which can hardly be seen as just a fluke.

The suggestion that rejecting negationism amounts to endorsing National Catholicism is absurd. Are Guichard, Monroe, and all the scholars who rejected negationism fifty years ago to be seen as National Catholic proxies? What is to be done with the Islamic conquests of, say, Syria, Egypt, or the Sassanid empire, to mention just a few of the territories targeted by the Arab conquerors before their 711 arrival in Iberia? Are these conquests likewise just part of a National Catholic myth? Should Walter Kaegi, ${ }^{51}$ Hugh Kennedy, ${ }^{52}$ and Robert Hoyland, ${ }^{53}$ among other highly regarded specialists on the early Islamic conquests, also be considered advocates of National Catholicism? The origin of al-Andalus is inextricably intertwined with the seventh-century Islamic expansion, so questioning part of the process entails questioning all of it.

Portraying the Islamic conquest of Iberia as merely an element of a National Catholic narrative exemplifies the potentially toxic effects of the uncontrolled consumption of emotional history, especially by nonspecialist audiences but even by scholarly ones. But this is not the most serious problem raised by The Feeling of History.

\section{Concealing the Islamic Past: A Conspiracy Theory}

Hirschkind's book opens with the following statement: "The argument I explore here can be simply stated: medieval Muslim Iberia did not disappear from history with the seizure of Granada in 1492 by Christian armies, as our history books have it. Rather, forced into hiding, it continued on as an invisible warp within the fabric of Spanish society" (emphasis mine). Later, in the conclusion, Hirschkind argues that Andalucismo deserves our attention, among other reasons, "for the way it brings to light a past left in darkness" (emphasis mine). ${ }^{54}$

Early in the nineteenth century, Spanish scholars of Arabic studies inaugurated a strong scholarly tradition focused almost exclusively on the history of al-Andalus, and since that time, thousands of publications have appeared, in Spain and elsewhere, on this topic. Although it is true that medieval studies in Spain has largely ignored (but not concealed) al-Andalus, a growing number of historians and archaeologists currently work in this academic field. Over the last four decades, public authorities have funded dozens of research projects in Spain aimed at producing deeper and more refined knowledge of al-Andalus.

50. C. Sánchez-Albornoz, El Islam de España y el Occidente (Madrid: Espasa-Calpe, 1965), 113.

51. W. Kaegi, Byzantium and the Early Islamic Conquests (Cambridge: Cambridge University Press, 1992); idem, Muslim Expansion and Byzantine Collapse in North Africa (Cambridge: Cambridge University Press, 2010).

52. H. Kennedy, The Great Arab Conquests: How the Spread of Islam Changed the World We Live In (London: Weidenfeld and Nicolson, 2007).

53. R. G. Hoyland, In God's Path: The Arab Conquest and the Creation of an Islamic Empire (Oxford: Oxford University Press, 2015).

54. Hirschkind, Feeling of History, 1 and 159. 
A good number of Islamic monuments in Spain are open to visitors, and public exhibitions displaying all kinds of objects and artifacts crafted in al-Andalus are held regularly in different countries. In light of all this activity, how and when has the Islamic Iberian past been "forced into hiding"?

To the best of my knowledge, there is a single instance of a deliberate plan to conceal the Islamic Iberian past: the Mosque of Córdoba. In the last few years, especially since the 2006 claim on the building's legal ownership made by the Catholic Church, the bishopric of Córdoba has taken a series of decisions clearly aimed at blurring the building's Islamic past, chief among them attempts to remove the word "Mezquita" from its official name..$^{55}$ Some of the scholars scorned by Hirschkind as mere National Catholic proxies (see below) have been among the most vocal in condemning this trend. This is particularly true of the historian Eduardo Manzano of the Consejo Superior de Investigaciones Científicas (CSIC), who authored a remarkably insightful op-ed pointing out that "the misappropriation of the building has prompted the kidnapping of its memory." 56 Not long after its publication, Manzano's opinion piece turned into a manifesto for the public ownership of the building, and it was signed by more than one hundred scholars from more than thirty research institutions. ${ }^{57}$ Unsurprisingly, Hirschkind overlooks both Manzano's contribution and its scholarly repercussions. ${ }^{58}$ Readers may decide for themselves whether this omission amounts to concealment or reflects simple ignorance.

Beyond the singular case of the Mosque, Hirschkind's opening remark points to the realm of conspiracy theories. The same approach lay at the heart of Olagüe's denialist ideas: he repeatedly suggested that historians had deliberately decided to ignore issues that would force reconsideration of the existing knowledge about al-Andalus. ${ }^{59}$ In fact, however, it was Olagüe himself who concealed historical evidence that contradicted his fantasies, as I have shown in detail elsewhere. ${ }^{60}$

More recently, González Ferrín, Olagüe's most outstanding pupil, has taken up this line of argument, referring repeatedly to an "official" history-presumably juxtaposed with a concealed "real" one. ${ }^{61} \mathrm{He}$ has also proven willing to apply this approach beyond the limits

55. E. Calderwood, “The Reconquista of the Mosque of Córdoba," Foreign Policy, April 10, 2015, https:// foreignpolicy.com/2015/04/10/the-reconquista-of-the-mosque-of-cordoba-spain-catholic-church-islam/.

56. E. Manzano, “El affaire de la Mezquita de Córdoba," El País, April 14, 2015, https://elpais.com/ elpais/2015/02/05/opinion/1423137778_840752.html.

57. C. Morán, “Cien expertos critican la situación de la Mezquita de Córdoba," El País, November 3, 2015, https://elpais.com/politica/2015/11/03/actualidad/1446553126_305752.html.

58. Hirschkind, Feeling of History, 59-63.

59. Olagüe, La revolución islámica, 16 ("Ignorándolos y no hablando de ellos, en un común y tácito acuerdo, han preferido los historiadores dejar a los españoles dormir durante varios siglos"); 274 ("La mayoría de los historiadores han generalmente olvidado o se han cuidado muy mucho de recordar"); 451 ("Los historiadores no habían tenido la valentía de declarar").

60. García-Sanjuán, La conquista islámica, 243-63.

61. E. González Ferrín, "Historiología del Islam y al-Andalus, entre el post-orientalismo y la Historia Oficial," Imago crítica 3 (2011): 71; idem, “711: Historiología de una conquista," in Al-Andalus y el mundo árabe (711-2011): Visiones desde el arabismo, 67-90 (Granada: Sociedad española de estudios árabes, 2012 ), 70. 
of the Islamic Iberian past: a few years ago, he expressed support for the most unhinged conspiracy theory in recent Spanish history, according to which the 2004 bombings in Madrid were the work not of al-Qaeda but of the Basque terrorist organization ETA. ${ }^{62}$ It is thus hardly surprising that González Ferrín would promote the idea of a conspiracy against himself in order to explain the heavy scholarly criticism to which he has been subjected.

González Ferrín's allegation of a conspiracy is based on two false claims. First, he claims that his critics label him a fascist because of his support for ideas originally put forward by the fascist Olagüe. ${ }^{63}$ As evidence of this claim he cites four authors-but none of them in fact calls him a fascist. ${ }^{64}$ To the contrary, two of them, Rodríguez-Mediano ${ }^{65}$ and Fierro, ${ }^{66}$ explicitly distinguish him ideologically from Olagüe.

The second false claim is that the CSIC is a National Catholic institution and leads the smear campaign against González Ferrín: "Spanish medievalism is fed by the CSIC, a Francoist construction that has inherited National Catholic sentiment." ${ }^{67}$. Here, too, Hirschkind uncritically accepts González Ferrín's arguments and freely endorses the idea of a National Catholic plot led by the CSIC: "Numerous authors have insinuated that despite González Ferrín's long-standing support for leftist causes, he is a Falangist in disguise. Much of the campaign against him (though not all, by any means) has been waged by the Department of Jewish and Islamic Studies at CSIC in Madrid." 68

Who are these "numerous authors," and where is the evidence of their "campaign"? Accusing some scholars of plotting against another is a extremely serious step, and it is

62. E. González Ferrín, "El 11-M fue un atentado de ETA," ABC, June 20, 2004. The conservative government led by Jose Maria Aznar first advanced this theory in the aftermath of the attacks, and ever since it has been consistently upheld by most far-right outlets in Spain.

63. E. González Ferrín, "El islam y su expansión en Occidente: Efectos tomados como causas," in Frontera inferior de al-Andalus: La Lusitania tras la presencia islámica (713-756 d.C./94-138 H), ed. B. Franco Moreno, 29-52 (Mérida: Consorcio ciudad monumental histórico-artística y arqueológica, 2015), 37: “Since Olagüe was a Falangist and denied the invasion, everyone who denies the invasion is a Falangist" "Como Olagüe era falangista y negó la invasión, todo aquel que niegue la invasión es falangista”).

64. F. Rodríguez-Mediano, "Culture, Identity and Civilization: The Arabs and Islam in the History of Spain," in Islam and the Politics of Culture in Europe: Memory, Aesthetics, Art, ed. F. Peter et al., 41-60 (Bielefeld: Transcript, 2013); Fierro, "Al-Andalus en el pensamiento fascista"; E. Manzano, "Algunas reflexiones sobre el 711," Awraq 3 (2011): 3-20; García-Sanjuán, La conquista islámica.

65. Rodríguez-Mediano, "Culture, Identity and Civilization", 56: "From a viewpoint clearly opposed to the fascist ideology of Olagüe, Ferrín postulates a similar argument about the nonexistence of the conquest" (emphasis mine).

66. M. Fierro, “Al-Andalus, convivencia e islam: Mucho ruido y pocas nueces," Revista de Libros, October 17, 2018: "No one doubts that González Ferrín is inspired by Olagüe's book, but this does not imply that he shares his political ideas: as he himself affirms, ideas often travel along unexpected paths" ("Nadie duda que González Ferrín se inspirase en el libro de Olagüe, y ello no implica que comulgara con sus ideas políticas: como él mismo afirma, las ideas viajan a menudo por caminos insospechados").

67. J. López Astilleros, "González Ferrín: Mi única idea sobre Al Andalus es su continuidad cultural," Público, November 2, 2018, https://blogs.publico.es/otrasmiradas/16363/gonzalez-ferrin-mi-unica-ideasobre-al-andalus-es-su-continuidad-cultural/.

68. Hirschkind, Feeling of History, 175. 
more serious still when done without providing any names a single piece of evidence in support of the allegation.

Meanwhile, even if the CSIC had started out as a Francoist institution (it was founded in 1941), the large group of medievalist historians, Arabists, and Islamicists currently working under its auspices in Madrid, Barcelona, and Granada can hardly be described as Francoist proxies. ${ }^{69}$ Some of its members are not just uncritical of the origins of their own institution but among the most vocal critics of conservative scholarship in general. ${ }^{70}$ Casting them as inheritors of National Catholicism involves an obvious untruth and represents another clear indication of the extremely problematic relationship of negationism with actual evidence. Obviously, the problem here is not the Francoist origin of CSIC but the fact that some CSIC members (especially Fierro, Manzano, and Molina) are among the most vocal critics of negationism. ${ }^{71}$

González Ferrín's denunciation of CSIC fits uneasily with his declared commitment to Karl Popper's maxim of "understanding the world as a sum of individuals, not of collectivities." 72 By scorning the CSIC as a whole, he declines to extend the basic privilege of being seen as individuals to the members of the CSIC. And by insisting that the CSIC remains captive to its National Catholic origins more than forty-five years after Franco's demise, he provides a convenient explanation for its members' rejection of his ideas: its members necessarily hate González Ferrín, like they hate Américo Castro. ${ }^{73}$

The contradiction inherent in González Ferrín's claims is quite obvious: if the CSIC were indeed a Francoist and National Catholic institution, why would its members wage a campaign to denounce someone as a fascist? It simply makes no sense. In any case, none of his critics at the CSIC has ever described González Ferrín as a fascist, nor is there any campaign to discredit him as one. Instead, as noted earlier, some of his critics have explicitly highlighted the ideological differences between him and the fascist Olagüe.

69. Ibid., 77: "An institution founded by the Franco regime and still subject to its looming shadow."

70. E. Manzano, "La construcción histórica del pasado nacional," in La gestión de la memoria: La historia de España al servicio del poder, ed. J. S. Pérez Garzón et al., 33-62 (Barcelona: Crítica, 2000); idem, review of Al-Andalus contra España, by S. Fanjul, Hispania 61/3, no. 209 (2001): 1161-64; idem, "De cómo la historia se ha convertido en una disciplina al servicio de los intereses conservadores," in Hispania, Al-Ándalus, España: Nacionalismo e identidad en el medievo peninsular, ed. M. Fierro and A. García-Sanjuán, 47-56 (Madrid: Marcial Pons, 2020); F. Rodríguez-Mediano, "Al-Ándalus y la batalla del presente," in Fierro and GarcíaSanjuán, Hispania, Al-Ándalus, España, 23-32; Fierro, "Al-Andalus, convivencia e islam”; idem, review of The Myth of the Andalusian Paradise: Muslims, Christians, and Jews under Islamic Rule in Medieval Spain, by D. Fernández-Morera, Al-Qanțara 39, no. 1 (2018): 248-53. Hirschkind ignores all of these publications.

71. See Fierro, "Al-Andalus en el pensamiento fascista”; Molina, review of García-Sanjuán, La conquista islámica; idem, "La conquista de al-Andalus, tergiversada"; E. Manzano, "De como los árabes realmente invadieron Hispania,” Al-Qanțara 35, no. 1 (2014):311-19; idem, “¿Realmente invadieron los árabes Hispania?," El País, February 13, 2014, https://blogs.elpais.com/historias/2014/02/invasionhispania.html.

72. González Ferrín, Cuando fuimos árabes, 86: "Mi convencido seguimiento de Karl R. Popper y la necesidad de comprender el mundo como suma de individualidades, no de colectividades."

73. González Ferrín, Cuando fuimos árabes, 85: "El odio del CSIC a la obra de Castro.” See the recent article by M. García-Arenal, “Américo Castro en Estados Unidos,” Boletín de la Institución libre de enseñanza 119-20 (December 2020): 287-300, the latest evidence of the steady interest in Castro among CSIC scholars. 
González Ferrín's academic peers do not "have it in for him"; the reason for the torrent of criticism he has been subjected to in Spain for fifteen years now ${ }^{74}$ is not that he has adopted the ideas of a fascist pseudo-historian but that by advocating them he-like Hirschkind after him-has lent academic legitimacy to a well-known (and well-worn) scholarly fraud.

\section{Final Remarks}

The Feeling of History is an academic book that gives international support to pseudoacademic ideas largely discredited among specialists over the last forty-five years and that makes sweeping and simplistic overgeneralizations about Spanish scholarship that include glaring untruths and false accusations.

Hirschkind does not limit himself to exposing and analyzing the historical and social phenomenon of Andalucismo. Instead, he fully embraces it (as he is well aware, noting that "the result may appear to some as partisan"). The most compelling evidence of the partisan nature of his approach lies in his unmitigated scorn for historical knowledge as a form of rational understanding of the past. Hirschkind alleges an intentional cover-up of al-Andalus, denigrates historians as Francoist proxies, and gives fuel to a well-known historiographical fraud. Science and scholarship promote rationality, not emotions, in order to understand human societies. Disregarding his obligations as a scholar and a social scientist, Hirschkind subscribes to a deeply reactionary tendency that promotes an emotional approach to the past as the basis for the construction of collective identity.

Hirschkind's legitimation of emotional appeals to the past raises the question whether he would be willing to take the same stance on phenomena similar to Andalucismo. For instance, would he legitimize the highly emotional envisioning of the medieval Christian past currently advocated by far-right organizations and groups in the USA and elsewhere? Or would he argue that emotional approaches to the past must be allowed only selectively? Once Pandora's box is open, who can control or close it? History is a highly flammable product, and the least a social scientist should do is handle it very carefully.

Lending academic legitimacy to emotional (nationalist) views of the past is not only a huge scholarly mistake that involves unacceptable distortion of the past but also a dangerous and thoughtless frivolity. As a scholar and a historian, I must confess that The Feeling of History left me feeling really bad.

74. A. García-Sanjuán, review of Historia general de Al Ándalus, by E. González Ferrín, Medievalismo 16 (2006): 327-32. 


\section{Bibliography}

Benhima, Y., and P. Guichard. "Mûsâ ibn Nusayr: Retour sur l'histoire et le pouvoir d'un gouverneur omeyyade en Occident musulmán." Bulletin d'études orientales 66 (2017): 97-116.

Calderwood, E. Colonial al-Andalus: Spain and the Making of Modern Moroccan Culture. Cambridge, MA: Belknap Press, 2018.

--C. "The Reconquista of the Mosque of Córdoba." Foreign Policy, April 10, 2015. https:// foreignpolicy.com/2015/04/10/the-reconquista-of-the-mosque-of-cordoba-spaincatholic-church-islam/.

Civantos, C. The Afterlife of al-Andalus: Muslim Iberia in Contemporary Arab and Hispanic Narratives. Albany: State University of New York Press, 2017.

Donner, F. The Early Islamic Conquests. Princeton, NJ: Princeton University Press, 1981.

-- . Muhammad and the Believers: At the Origins of Islam. Cambridge, MA: Belknap Press, 2010.

Fancy, H. “The New Convivencia.” Journal of Medieval Iberian Studies 11, no. 3 (2019): 295-305.

Fierro, M. “Al-Andalus, convivencia e islam: Mucho ruido y pocas nueces.” Revista de libros, October 17, 2018.

- - . "Al-Andalus en el pensamiento fascista español: La revolución islámica en Occidente, de Ignacio Olagüe." In Andalus, España: Historiografías en contraste, siglos XVII-XXI, edited by M. Marín, 325-50. Madrid: Casa de Velázquez and CSIC, 2009.

-- - Review of The Myth of the Andalusian Paradise: Muslims, Christians, and Jews under Islamic Rule in Medieval Spain, by D. Fernández-Morera. Al-Qanțara 39, no. 1 (2018): 248-53.

García-Arenal, M. “Américo Castro en Estados Unidos." Boletín de la Institución libre de enseñanza 119-20 (December 2020): 287-300.

García-Sanjuán, A. "Al-Andalus en la historiografía nacionalcatólica española: Claudio Sánchez-Albornoz.” eHumanista 37 (2017): 305-28.

-_-. "Cómo desactivar una bomba historiográfica: La pervivencia actual del paradigma de la Reconquista." In La Reconquista. Ideología y justificación de la guerra santa peninsular, edited by C. de Ayala and S. Palacios, 99-119. Madrid: La Ergástula, 2019.

--- La conquista islámica de la península ibérica y la tergiversación del pasado. 2nd ed. Madrid: Marcial Pons, 2019.

-_- "Denying the Islamic Conquest of Iberia, a Historiographical Fraud." Journal of Medieval Iberian Studies 11, no. 3 (2019): 306-22. 
--_. "Ignacio Olagüe y el origen de al-Andalus: Génesis y edición del proyecto negacionista." Revista de estudios internacionales mediterráneos 24 (2018): 173-98.

--_. "La persistencia del discurso nacionalcatólico sobre el medievo peninsular en la historiografía española actual." Historiografías: Revista de historia y teoría 12 (2016): 132-53.

- - . "Rejecting al-Andalus, Exalting the Reconquista: Historical Memory in Contemporary Spain." Journal of Medieval Iberian Studies 10-11 (2018): 127-45.

-_-. "Response to: Jesús Lorenzo." Medieval Encounters 21 (2015): 136-38.

---. Review of Historia general de Al Ándalus, by E. González Ferrín. Medievalismo 16 (2006): 327-32.

- - . "La tergiversación del pasado y la función social del conocimiento histórico." Revista de libros, July 9, 2014. https://www.revistadelibros.com/discusion/la-tergiversaciondel-pasado-y-la-funcion-social-del-conocimiento-historico.

-_- “Weaponizing Historical Knowledge:The Notion of Reconquistain Spanish Nationalism." Imago Temporis: Medium Aevum 14 (2020): 133-62.

González Ferrín, E. “El 11-M fue un atentado de ETA.” ABC, June 20, 2004.

--_. "711: Historiología de una conquista." In Al-Andalus y el mundo árabe (711-2011): Visiones desde el arabismo, 67-90. Granada: Sociedad española de estudios árabes, 2012.

-_- Cuando fuimos árabes. Córdoba: Almuzara, 2017.

-—-. Historia general de Al Ándalus. Córdoba: Almuzara, 2006.

-—-. "Historiología del Islam y al-Andalus, entre el post-orientalismo y la Historia Oficial." Imago crítica 3 (2011): 57-73.

-—-. "El islam y su expansión en Occidente: Efectos tomados como causas." In Frontera inferior de al-Andalus: La Lusitania tras la presencia islámica (713-756 d.C./94-138 H), edited by B. Franco Moreno, 29-52. Mérida: Consorcio ciudad monumental históricoartística y arqueológica, 2015.

-—-."What Do We Mean by the Qur’ān: On Origins, Fragments, and Inter-Narrative Identity." In Remapping Emergent Islam: Texts, Social Contexts, and Ideological Trajectories, edited by C. A. Segovia, 221-44. Amsterdam: University of Amsterdam Press, 2020.

Guichard, P. “Les Arabes ont bien envahi l'Espagne: Les structures sociales de l'Espagne musulmane." Annales: Histoire, Sciences Sociales 6 (1974): 1483-513.

-- - and P. Sénac. "Les débuts d'al-Andalus: Des textes, des monnaies et des sceaux." Le Moyen Âge 126, no. 3-4 (2020): 511-37. 
Hirschkind, C. The Feeling of History: Islam, Romanticism, and Andalusia. Chicago: University of Chicago Press, 2021.

Hoyland, R. G. In God's Path: The Arab Conquest and the Creation of an Islamic Empire. Oxford: Oxford University Press, 2015.

Kaegi, W. Byzantium and the Early Islamic Conquests. Cambridge: Cambridge University Press, 1992.

---. Muslim Expansion and Byzantine Collapse in North Africa. Cambridge: Cambridge University Press, 2010.

Kahn-Harris, K. "Denialism: What Drives People to Reject the Truth." Guardian, August 3, 2018. https://www.theguardian.com/news/2018/aug/03/denialism-what-drivespeople-to-reject-the-truth.

Kennedy, H. The Great Arab Conquests: How the Spread of Islam Changed the World We Live In. London: Weidenfeld and Nicolson, 2007.

López Astilleros, J. "González Ferrín: Mi única idea sobre Al Andalus es su continuidad cultural.” Público, November 2, 2018. https://blogs.publico.es/otrasmiradas/16363/ gonzalez-ferrin-mi-unica-idea-sobre-al-andalus-es-su-continuidad-cultural/.

Lorenzo, J. Review of La conquista islámica de la península ibérica y la tergiversación del pasado: Del catastrofismo al negacionismo, by A. García Sanjuán. Medieval Encounters 20 (1014): 273-75.

Manzano, E. “El affaire de la Mezquita de Córdoba.” El País, April 14, 2015. https://elpais.com/ elpais/2015/02/05/opinion/1423137778_840752.html.

-_- "La construcción histórica del pasado nacional." In La gestión de la memoria:La historia de España al servicio del poder, edited by J. S. Pérez Garzón et al., 33-62. Barcelona: Crítica, 2000.

--_. "De cómo la historia se ha convertido en una disciplina al servicio de los intereses conservadores." In Hispania, Al-Ándalus, España: Nacionalismo e identidad en el medievo peninsular, edited by M. Fierro and A. García-Sanjuán, 46-56. Madrid: Marcial Pons, 2020.

- - . "De como los árabes realmente invadieron Hispania." Al-Qanțara 35, no. 1 (2014): 311-19.

-_-. ¿Realmente invadieron los árabes Hispania?” El País, February 13, 2014. https://blogs. elpais.com/historias/2014/02/invasionhispania.html.

--_. Review of Al-Andalus contra España, by S. Fanjul. Hispania 61/3, no. 209 (2001): 1161-64. 
Molina, L. "La conquista de al-Andalus, tergiversada: ¿Mala ciencia, ensayo, ficción?” Revista de libros, September 1, 2014. https://www.revistadelibros.com/discusion/la-conquistade-al-andalus-tergiversadamala-ciencia-ensayo-ficcion.

-- - Review of A. La conquista islámica de la península ibérica y la tergiversación del pasado, by A. García-Sanjuán. Medievalismo 25 (2015): 455-59.

Monroe, J. T. Review of Les Arabes n'ont jamais envahi l'Espagne, by I. Olagüe. International Journal of Middle East Studies 6, no. 3 (1975): 347-48.

Morán, C. "Cien expertos critican la situación de la Mezquita de Córdoba." El País, November 3, 2015. https://elpais.com/politica/2015/11/03/actualidad/1446553126_305752.html.

Olagüe, I. Les arabes n'ont jamais envahi l'Espagne. Paris: Flammarion, 1969.

-_- La revolución islámica en occidente. Madrid: Fundación Juan March, 1974.

Rodríguez Blanco, P. “Cuando fuimos árabes: La posverdad sobre Al Andalus.” El País, March 6, 2018. https://elpais.com/elpais/2018/03/04/hechos/1520120370_739370.html.

-_-. "El 'fraude' que intenta tergiversar la historia de al-Andalus." El País, April 9, 2018. https://elpais.com/elpais/2018/04/06/hechos/1523043230_705992.html.

Rodríguez-Mediano, F. “Al-Ándalus y la batalla del presente.” In Hispania, Al-Ándalus, España: Nacionalismo e identidad en el medievo peninsular, edited by M. Fierro and A. GarcíaSanjuán, 23-32. Madrid: Marcial Pons, 2020.

- - . "Culture, Identity and Civilization: The Arabs and Islam in the History of Spain." In Islam and the Politics of Culture in Europe: Memory, Aesthetics, Art, edited by F. Peter et al., 41-60. Bielefeld: Transcript, 2013.

Sánchez-Albornoz, C. El Islam de España y el Occidente. Madrid: Espasa-Calpe, 1965.

Schmid, N. K. Review of The Quranic Noah and the Making of the Islamic Prophet: A Study of Intertextuality and Religious Identity Formation in Late Antiquity, by C. A. Segovia. Der Islam 97, no. 2 (2020): 617-22.

Venegas, J. L. The Sublime South: Andalusia, Orientalism, and the Making of Modern Spain. Evanston, IL: Northwestern University Press, 2018.

Wolf, K. B. "Myth, History, and the Origins of al-Andalus: A Historiographical Essay." Journal of Medieval Iberian Studies 11, no. 3 (2019): 378-401.

-_-. "Negating Negationism." Pomona Faculty Publications and Research 394 (2014). http:// scholarship.claremont.edu/pomona_fac_pub/394. 


\title{
Conference Report
}

\section{Pre-Modern Comparative Literary Practice in the Multilingual Islamic World(s) (Oxford Comparative Criticism and Translation Research Centre/OCCT, University of Oxford, 22-24 July 2021)}

\author{
Conference Organizers: \\ Huda Fakhreddine, David Larsen, and Hany Rashwan \\ Report by: \\ Clarissa Burt \\ United States Naval Academy \\ (burt@usna.edu)
}

$\mathrm{T}$

his three-day virtual conference, organized by Huda Fakhreddine (University of Pennsylvania), David Larsen (New York University), and Hany Rashwan (University of Birmingham) and hosted by the University of Oxford's Comparative Criticism and Translation research centre (OCCT), delivered a splendid set of twenty-two papers by scholars from all over the world, examining a broad variety of multilingual texts from Islamic history. In October 2020, the organizers called for papers examining the web of literary practices and critical theories of multilingual writers working in Urdu, Persian, Turkish, Arabic, Kurdish, and other languages of Asia and Africa, which fall outside the Eurocentric purview of modern Comparative Literature. The respondents, including individuals from fourteen countries, fulfilled the ambitious scope of the call for papers.
Thanks to the efforts of Rawad Wehbe (University of Pennsylvania), the logistics of the conference proceeded smoothly. The conference started on Thursday, July 22 at 10 a.m. ET (3 p.m. British Summer Time) with Matthew Reynolds, chair of the OCCT, who welcomed attendees with some opening remarks in support of the conference's mission of challenging Eurocentric approaches to the discipline.

Hany Rashwan then introduced the first keynote speaker, Fatemeh Keshavarz (director of the School of Languages, Literatures, and Cultures at the University of Maryland), whose address, "Multilingual Poetry, the Information Highway of the Medieval Muslim World," focused on poetry's transmission along the "Silk Road of literary distribution and understanding," with the Persian Sufi Fakhr al-Dīn 'Irāqī (1213-1289 CE) as a prime example. With a review of 'Irāqī's life, travels, and

(c) 2021 Clarissa Burt. This is an open access article distributed under the terms of the Creative Commons Attribution-NonCommercial-NoDerivatives License, which allows users to copy and distribute the material in any medium or format in unadapted form only, for noncommercial purposes only, and only so long as attribution is given to the original authors and source. 
texts, supplemented with references to Rūmī, Sa'dī of Shiraz, and several others, Keshavarz argued convincingly for cosmopolitan multilinguality in elite Sufi circles, where linguistic and cultural diversity was embraced and celebrated.

Thursday's first session, entitled "Multilingual Scholars and Scholarly Practice" and chaired by David Larsen, followed Kesharvarz's keynote. Larsen introduced Claire Gallien (Université Montpellier 3), whose presentation was entitled "Multilingual Commentary Literatures of the Islamicate and Their Role in Early Modern Orientalism." In this sophisticated piece, Gallien examined the disposition of manuscripts (including Quranic commentaries and other works of Islamic science) in Arabic, Persian, and Turkish that were gathered as artifacts by Great Britain in the seventeenth and eighteenth centuries and remain unedited. She argues that the selection of materials for translation and publication in English fed Orientalist conceptions and prejudices and ignored the intellectual engagement that multilingual commentaries represent. Gallien gave the example of Richardson's 1774 translation of Hāfiz, and its reliance on the commentary by Ahmed Sudi Bosnevi (an Ottoman scholar of the sixteenth century (E), which eclipsed more mystical commentaries by Sururi and Shem $i$ in the Orientalist reception.

Ali Karjoo-Ravary (Bucknell) gave a paper entitled "A Brocade of Many Textures: Literary Trilingualism in 14th Century Anatolia, Iran and Beyond," in which he displayed stunning examples of trilingual literary production from the court of Kadi Burhâneddin of Sivas (d. 1398). Pointing to mulamma' and talmī ${ }^{c}$ as critical terms for multilingual stylistics in Islamic poetry, Karjoo-Ravary argued for a hierarchical theory of language use in constructing texts for the community of scholars and saints and traced its continued use in trilingual texts with reference to nineteenth-century works from Iran, eastern Anatolia, and central Asia.

Zeynep Oktay-Uslu (Boğaziçi University) presented "Sufi Metaphysics as Literary Theory: Şeyh Gālib's Beauty and Love." Sketching the life and works of the multilingual Ottoman Sufi Şeyh Gālib (d. 1798 CE), Oktay-Uslu focused on Gālib's Turkish mathnavī poem Hüsn $\ddot{u}$ 'Aş̧ (Beauty and love), in which she found three layers of allegory: a mystical cosmology, a Sufi pathway to the divine, and the writing process. Oktay-Uslu considered this layered analogical tale using its relationship with Ibn 'Arabī's doctrine of the oneness of being and its interaction with Rūmī's work, arguing that only such multidimensional analysis opens complex layers of meaning in Gālib's text.

Christopher Livanos (University of Wisconsin at Madison) chaired the second Friday session, "Translinguistic Adaptations of Genre and Form." Maryam Fatima (University of Massachusetts at Amherst) presented "Ibrat for an Islami Pablik: Nineteenth-Century Historical Novel in Urdu," in which she examined the historical novels through which Abdul Halim Sharar (1860-1926) navigated his own form of colonial modernity. These contain a unique mix of Islamic scholarship and Western-style rich paratextual notes, revealing Sharar's control of Islamic historiography.

Next, Alaaeldin Mahmoud (American University of the Middle East in Kuwait) presented "Rethinking the Art of 
Composition (Inshāe ) in Arabic and Persian Maqāmāt: Badī‘ al Zamān al-Hamadhānī and al-Harīrī in Dialogue with Hamīd al-Dīn Balkhī." Using theoretical terms from al-Shaybānī (d. 298/910-11) and Qalqashandī (d. 821/1418), Mahmoud engaged with the Arabic maqāmāt of al-Hamadhānī and al-Harīì and the Persian maqāmāt of Hamīd al-Dīn Balkhī (d. 599/1202-3) as multimodal productions. Mahmoud looked specifically at the use of the Persian term sabk for the "stylistics" expounded by Muhammad Taqī Bahār in his Sabkshināsī, yā tārīkh $-i$ tațavvur-i nasr-i Fārsī (Stylistics, or the history of change in Persian prose), questioning the crosslingual relationship of sabk with tașannu' (artfulness).

Simon Leese (Utrecht University) presented the panel's third paper, entitled "Refrains of Comparison: Bringing the Persian Radif into Arabic Poetry in Eighteenth Century India." Focusing on the multilingual poetry of Ghulām 'Alī “Āzād” al-Bilgrāmī (d. 1786) and Muḥammad Bāqir “Āgāh” al-Madrāsī (d. 1806), Leese demonstrated how these poets incorporated the Persian stylistic radif (refrain) into their Arabic poetic compositions and engaged in theoretical disputes using the terms 'Arab, 'Ajam, and Hindi to signify relationships between languages and literary practices in Arabic, Persian, and the languages of India as a critical apparatus for their multilingual poetics.

In the last presentation of the day, Orhan Elmaz (University of Saint Andrews) gave a paper entitled "Contrasting Masculine and Feminine Poetic Voices in Wine Poetry: Cases from Arabic and Ottoman Poetry." Using selections from pre-Islamic Arabic poetry through sixteenth-century Ottoman poetry, Elmaz sketched the wine-song tradition in Arabic and Turkish with its contrasts in poetic conventions, attitudes, and social functions and its occasional overlaps with love poetry. Elmaz highlighted selections from the Ottoman poets Fużûlî (1483-1556) and Bâkî (1526-1600), in which abstemious attitudes toward wine contrast with the fakhr of wine songs in pre-Islamic poetry. Elsewhere, the female Ottoman poet Mihrî Hatun (1460-1506/1512) composed wine poetry that Elmaz compared, in imagery and sentiment, to the poetry of al-A'shā (d. $627 \mathrm{CE}$ ).

When the conference resumed on Friday July 23, Hany Rashwan chaired the day's first panel, "Translation and Non-translation in the Islamic World," and introduced the first speaker, Peter Webb (Leiden University), who presented a paper entitled "Arabic Texts as Ottoman Literary Phenomena: The Multilingual Lives of Sarh al- 'Uyūn (Pasturing at the Wellsprings of Knowledge)." Webb traced the dissemination of al-Risāla al-hazaliyya (The witty letter) by the Andalusian poet Ibn Zaydūn (1003-1071) and the fourteenth-century commentary on it composed by the Egyptian poet Ibn Nubāta (1287-1366), Sarh al-'uyūn, which exploded in popularity in the subsequent centuries as attested by the sheer number and geographical range of extant manuscripts of the work. Webb followed Ibn Nubāta's use of a Persian phrase across manuscripts to see how scribes understood it (or not) across time, space, and linguistic difference. On the basis of the content of Sarh al-'uyūn, Webb posits that the Ottoman popularity of the work derived from its presentation of succinct narratives of classical pre-Islamic Arabic 
figures, which summarized the cultural traditions of Arab lands under Ottoman control.

In "Islam in the Vernacular: The World(s) of Arabi Malayalam, and Multilingual Imaginaries in Kerala, South India," Muneer Aram Kuzhiyan (Aligarh Muslim University) examined literary production in Arabi Malayalam, a form of Malayalam in Arabic script with lexical borrowings from Arabic, Tamil, Persian, Urdu, and Sanskrit. Kuzhiyan focused on Muhyiddin Mala by Qādī Muhammad (d. 1616), a praise poem for the twelfth-century Sufi master Shaykh 'Abd al-Qādir al-Jīlānī (d. 1166), which contributed to "translating Islam" for the Muslims of Kerala. Kuzhiyan spoke of anthologies of other "sabina songs," as devotional texts in Arabi Malayalam were called. He offered several etymologies for the term but focused more on translations into Arabi Malayalam in the second half of the eighteenth century, situating Arabi Malayalam as a locus for multilingual comparative studies in relation to its many languages and cultures of contact.

Ayelet Kotler (University of Chicago) presented "Translation as a Poetic Point of Departure: Persianizing the Rāmāyana in Early 17th-Century India." In this wellargued paper on Maśnavīi Rām u Sìtā, a Persian verse translation of the Sanskrit epic Rāmāyaña by the seventeenthcentury north Indian poet Masīh $\mathrm{Sa}^{\mathrm{c}} \mathrm{d}$ Allāh Pānipatī, Kotler analyzed Masīh's faithfulness to the Sanskrit original and his creative process in building the Persian poetic text to argue for analytical criticism of premodern Persian translations through the values inherent in such compositions as Moghul mediations of Indian culture in Persian.
Simon Leese chaired the second Friday session, "Minorities, Shibboleths and Polyglossia." Nasim Basiri (Oregon State University) offered the first paper, entitled "Rethinking Queering in the Pre-modern Persian Poetry: A Dialogue between Rūmī and Hāfez-e Shīrāzī." In her paper, Basiri addressed modern scholarship of premodern Persian poetry and its neglect of LGBTQ+ identities. Through her readings of Rūmī and Hāfiz, Basiri aimed to "save pre-modern queer poetry from marginalization" and "read queerness" into the study of Persian poetry, in the process breaking open Eurocentric, white, cisgender, male-centered comparative literary analysis.

Talya Fishman (University of Pennsylvania) turned her attention to multilingual medieval Jewish scholarly culture in her paper, "Echoes of Arabic Linguistic Theory, Practice and Muslim Doctrine in Jewish Writings of the Medieval Islamicate World." Focusing on Rabbanite and Qaraite authors of the ninth through eleventh centuries, Fishman related the Hebrew dictionaries of Saadia al-Fayyumi (882-942 CE), the gaon (leader) of the Babylonian Talmudic academy of Sura in Iraq, to Arabic lexicographical scholarship on rare lexemes in the Quran. Similarly, her analysis of the tenth-century Aramaic epistle of Sherira (a subsequent gaon of the Suran yeshiva) pointed to the application of the Islamic doctrine of inimitability (i j jāz) to rabbinic tradition.

Seerwan Ali Hariry (Soran University in Iraqi Kurdistan) ended the panel with his fascinating paper, "Poetics of Multilingualism in Medieval and Pre-modern Kurdish Poetry: Rethinking Macaronic Verses in Classical Kurdish 
Poetry." In one of the most delightful examples of multilingualism in the conference, Hariry presented selections of mixed-language macaronic verses by the Kurdish poets Aḥmad-ī Khānī (1651-1707), Nālī (1797-1877), and Mahwī (1830-1909) in which each group of verses were composed in Arabic, Persian, Turkish, and Kurdish in turn, signaling the poet's virtuosity and requiring a similar multilingualism on the part of the audience. Although Kurds at the geographic crossroads between AraboIslamic, Safavid, and Ottoman empires used hegemonic languages in their writings to the detriment of their own, these poets added Kurdish to crown their literary canon with compositions that broaden the definition of macaronic verse for comparative purposes.

Nasim Basiri convened the third Friday session, titled "Catachresis and Creative Misreadings." Christopher Livanos opened the session with his paper, "Reading Christian Heresy into the Qur'an in the Latin Fathers, the Medieval Translators and the Modern Academy." Citing Bloom's "anxiety of influence," Livanos argued that Western criticism of the Quran has centered on a heresiological approach seeking to uncover distorted Christian and biblical sources for the Quranic text, an approach he finds in the "Syriac turn" in Quranic scholarship. In contrast, Livanos hopes for new academic approaches to the Quran to account for its literary and religious significance.

Colinda Lindermann (Freie Universität Berlin) came next with her "Loanwords from Within: Debating Ta'rīb in the Multilingual Ottoman Environment," in which she traced the history of Arabic theory concerning ta'rīb (Arabicizing) loanwords from other languages, from
al-Khalīl b. Aḥmad (d. ca. 170/786) to al-Jawālīqī's (d. 540/1144) treatise al-Mu'arrab min al-kalām al-a jamī 'alā ḩurüf al-mu'jam. Lindermann traced the debate from early scholars to al-Suyūtī (d. 1505), through the treatise of Kemalpaşazāde (d. 1534), al-Risāla fi taḥīq ta'rīb al-kalima al-'ajamiyya, and al-Munshī (d. 1592) to al-Khafājī (d. 1659), who mentions the slang of Ottoman gender-benders under the rubric of lughat al-mukhannathīn. Lindermann argued that this scholarly discourse was clearly engaged with the living linguistic and sociocultural Ottoman milieu.

Mehtap Ozdemir (University of Massachusetts at Amherst) presented Friday's last paper, "Debating Belagat: The Poetics of (Af)filiative Translation in late Ottoman Literary Modernity." Ozdemir pointed to the wave of nineteenth-century translations from Arabic and French that imported literary values into Turkish and its impact on late Ottoman literature. Ozdemir analyzed Recaizade Ekrem's 1882 Talim-i Edebiyat (Teaching of literature) and the controversy that followed its publication, with Hac1 İbrahim Efendi arguing over the legacy of belagat (poetics) from Arabic in balance with or in contrast to French-oriented literary theory. This literary-theoretical debate reflects the tension between a necessary rupture with the past to build Ottoman modernity and the preservation of traditional devices as encased in belagat so as to create a unique, self-possessed Ottoman literature.

Huda Fakhreddine chaired the first Saturday session, "Multilingual Lexicology and Exegesis." Leila Chamankhah (University of California at San Diego) presented a paper entitled "Mapping Ibn 'Arabī's Teachings in the 
Premodern Persian Sufi World: 'Abdul Razzāq Kāshānī's Lexicons and Their Literary Importance in Formalizing Sufi Terminology." She detailed 'Abdul Razzāq Kāshānī's (d. 1335) prolific dissemination of Ibn 'Arabī's teachings in Ilkhanid Iran (1256-1353) and his own contributions to Sufi literature. The paper focused on three lexicons by Kāshānī: Ișțilāhāàt al-șūfiyya (Technical terms of Sufism), Rashḥ al-zulāl (Distilling pure water), and Lațāif al-i' lām (The niceties of imparting knowledge).

Next, Salour Evaz Malayeri (University of Saint Andrews) presented "Religion and Literature in Dialogue: Nāṣir-i Khusraw's Reception of the Quran and Hadith." A well-traveled Persian bilingual (Persian and Arabic) poet, Nāṣir-i Khusraw (10041076 CE) contributed widely to Persian literature. The paper focused on the poet's religious and exegetical thought as revealed in his Jam' al-hikmatayn (Reconciling the two wisdoms). The two sources of wisdom were falsafa/philosophy and Isma'ili doctrine/ta'wìl. By comparing the Quran and Hadith with Nāṣir's use of rhetorical devices and philosophical propositions, Malayeri showed that the poet used the Quran and hadith to support his own argument.

This paper was followed by that of Abdul Manan Bhat (University of Pennsylvania), "Prophethood in Poetic Wisdom: Beginnings, Adab and Muhammad Iqbal." The paper examined PersianUrdu diglossia in Muhammad Iqbal's (d. 1938) concept of payām as inspirational impetus for poetic and prophetic discourse. Tentatively translating payām as "message," Bhat showed that payām for Iqbal is both what prophets deliver to humanity and the poetic yearning that poets channel to construct poetic texts.
After discussion, Ali Karjoo-Ravary convened the final panel of the conference, "Textual Practice, Media, and Reception." Suheil Laher (Hartford Seminary) presented an intriguing paper, "Arabic Prayer or Persian or Both? Abū Hanīfa's View and Its Legal Reception." Laher traced the history of translation of the Quran into Persian (starting with Salman the Persian, d. 33/654), and its recitation in prayer. Abū Hanīfa (d. 150/767), unlike other legal scholars, allowed the use of Persian in ritual prayer, perhaps as accommodation for non-Arab converts. The question points to the historical dispute over whether the Quran consists in its meanings qua meaning, or in the meanings of the Arabic; the majority of scholars of Islamic law ultimately settled on the latter position. Citing a range of legal opinions from Abū-l-Layth al-Samarqandī (d. 376/983) to Burhān al-Dīn al-Marghīnānī (d. 593/1197), Laher showed that Hanafi jurists tolerated the use of Persian in ritual prayer and supplication and faced a consequent antiShu' $\bar{u}$ bi backlash, which enforced the use of Arabic alone in devotional practice across the Muslim world.

Fayaz A. Dar and Zubair Khalid (Jawaharlal Nehru University, New Delhi, India) offered a joint paper, "Sheikh Nuruddin's Koshur Quran: Translinguistic Poetry of a Fourteenth century Kashmiri Saint." The authors detailed the legacy and Kashmiri mystical poetry of Sheikh Nuruddin (1378-1440 CE). Venerated as the saint and founder of a mystical order, Nuruddin incorporated Quranic references, figures, and verses in Arabic into his shrukh poetry, to the point that his poetry has been described as Koshur Quran, or "the Quran in Kashmiri." His verse also refers to such Sufi figures as al-Ḥallāj and 
Rūmì, making his poetry an addition to Sufi mystical Kashmiri literature, which combines Arabic, Kashmiri, and Sanskrit values.

Aqsa Ijaz (McGill University) gave the conference's last paper, "Shaping the Language of Love: The Afterlife of Nizami's Khusrau u Shīrin in Persianate India," in which Ijaz considered three north Indian versions (Persian, Urdu, and Punjabi) of Nizami Ganjavi's (1141-1209) celebrated poem. Ijaz explored intertextuality among the different versions, which articulated the poetics of love and desire in Khusrau $u$ Shìrin across cultures, languages, and time.

Huda Fakhreddine introduced the closing keynote speaker, Michael Cooperson (UCLA), whose delightful talk, "Learning Arabic in Pre-modern Times," was a consolation for anyone who struggles with a second, third, or fourth language. As Muslims conquered non-Arab lands, Cooperson asked, how did the 'Ajam, those who were linguistically "othered," submit to and function in Arabic as a hegemonic language? In answer, he offered several texts that were used as primers for non-Arabs to learn Arabic, including Tafsir Muqātil b. Sulaymān (d. 150/767) and Maqāmāt al-Harīrī (mentioning a Gilaki interlinear commentary) for acquiring vocabulary and mastering grammatical intricacies. He shared anecdotes of Bishr al-Ḥāfì (d. 227/841) and 'Alī b. 'Abd Allāh al-Ghuzūlì (d. 815/1412) and the linguistic challenges they encountered, suggesting that the formal and rule-bound nature of Arabic and its literary devices was a source of empowerment for non-Arabs that allowed them to excel and contribute broadly to the Arabo-Islamic cultural heritage.

Concluding this amazing range of papers, David Larsen offered closing remarks, reviewing the salient points of many papers and encouraging scholars to follow up on avenues for further research. The conference closed with mutual thanks and greetings from all.

Overall, the event was a sterling example of an intimate seminar in which participants benefit hugely from the papers and feedback of their peers. The online format did not detract at all; instead, it made possible the geographic range of the participating scholars. Rawad Wehbe curated an extraordinary video record of the conference, which can now be seen on YouTube (https://www.youtube. $\mathrm{com} /$ playlist? 1 ist $=$ PLv1dO-ubwbqhW zO6fRTdQ5M28L-1YxZY). An edited volume of the conference proceedings is much to be hoped for. 


\title{
Book Review
}

\author{
Julián M. Ortega Ortega. La conquista islámica de la Península \\ Ibérica: Una perspectiva arqueológica. Serie Arqueología y \\ Patrimonio 14 (Madrid: Ediciones de la Ergástula, 2018), 414 \\ pp, 9 figs. ISBN 978-84-16242-30-6. Price: $€ 28.00$ (paper).
}

\author{
Xavier Ballestín \\ Universitat de Barcelona
}

(xballestin@ub.edu)

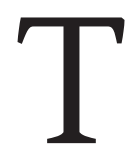

his work offers the first comprehensive archaeological analysis of the Islamic conquest of the Regnum Gothorum/Spania, from the landing of Țāriq b. Ziyād in Gibraltar at the westernmost tip of Algeciras Bay in $92 / 711$ to the consolidation of the Iberian Peninsula's conquest around 100/718-19, which eventually brought the Islamic armies to Narbonne, Septimania, Northern Catalonia, and neighboring areas. Julián Ortega takes the Islamic conquest of 92/711 as the watershed moment marking the inception of a new society, a new country, and a new culture-al-Andalus. Understanding this set of changes requires a close reading of settlement patterns and material culture, the main research fields of archaeologists. The meticulous and thorough attention to detail that Ortega invests to provide a clear explanation of this process is one of the main strengths of this book. The reader should not expect a book infused with textual criticism, warranted or unwarranted, of the Arabic or Latin sources-notwithstanding the author's knowledge of the postmodern approach to written sourcesnor one that tackles the Sisyphean task of collating a cogent and plausible account of the conquest from the available source material-a task that has not yet been accomplished. Rather, Ortega has used the archaeological remains of material culture to detect and understand the Islamic conquest and the distinctive appearance of al-Andalus.

The book begins with an introduction, which is followed by eleven chapters and a conclusion, a bibliography, and analytical indexes. The chapters' titles are quite straightforward and explanatory, even for a readership not used to the history of al-Andalus or the High Middle Ages: chapter 1 (pp. 25-35), "(De)limiting the scope of the sources"; chapter 2

(C) 2021 Xavier Ballestín. This is an open access article distributed under the terms of the Creative Commons Attribution-NonCommercial-NoDerivatives License, which allows users to copy and distribute the material in any medium or format in unadapted form only, for noncommercial purposes only, and only so long as attribution is given to the original authors and source. 
(pp. 37-58), "Prolegomenon"; chapter 3 (pp. 59-87), "The conquest (al-fath) without rhetoric: Toward a calibration of military operations"; chapter 4 (pp. 88-108), "The spoils"; chapter 5 (pp. 109-28), "The treasury and coinage"; chapter 6 (pp. 129-60), "The urban imprint of the conquest"; chapter 7 (pp. 161-72), "The territorial arrangement of the occupation"; chapter 8 (pp. 173-222), "Migration and colonization"; chapter 9 (pp. 223-54), "Taking root: Green revolution or agrarian reform?"; chapter 10 (pp. 255-90), Aristocracies, tribes, and slaves"; and chapter 11 (pp. 291-328), "The people of the conquest: Ethnogenesis and islamization." The main issues treated in these chapters are discussed below.

The introduction starts with the anonymous Crónica del 754, written by a cultured priest whose acquaintance with Byzantine and early Islamic history is extensive and who considered the demise of the Visigothic kingdom an unparalleled tragedy. The dramatic, almost apocalyptic account of the disappearance of the realm and the Islamic conquest found in this highly sophisticated Latin source is followed by the account that prevailed amongst historians of the treatment meted out by the Muslim conquerors-a tale also infused with overtones of catastrophe, upheaval, radical change, destruction, loss of life and property, and the end of times. Ortega manages to show clearly not only how Spanish medieval and Arabist scholarship has dealt with the existence of al-Andalus but also how heavily knowledge of the conquest and the inception of Andalusi society relies on a full and thorough grasp of the changes taking place in what we can label early Islam in the Middle East, Arabia, and Egypt, and how the issues scholars and archeologists have raised about these changes should be used to develop a balanced and nuanced approach to the High Middle Ages in the Iberian Peninsula. In the closing remarks of the introduction, Ortega acknowledges explicitly that intellectual production, including this very book, must be conceived of as a collective endeavor; this statement allows the author to present the names of the scholars and other people to whom he is indebted for their help and advice.

After his up-to-date and astonishingly rich appraisal of Islamic historiography on the two ends of the Mediterranean, Ortega comes to grips with the nature, availability, and reliability of the written and material sources. Two points inform the author's approach to both kinds of sources. The first, made by Th. Glick and F. Curta (p. 23), is the capital contribution of medieval archaeology to the knowledge of al-Andalus's early history-the second/ eighth to fifth/eleventh centuries-which is unparalleled in the fields of medieval history and Spanish Arabism. The second is that the recent prominence of archaeology is directly related to the changes taking place in the study of Late Antiquity, the end of the Roman empire, and the successor states, a development that has come to encompass the Umayyad caliphate in the East and that A. Giardina in 1999 labeled the "explosion of Late Antiquity" (p. 24, n. 41). Within this framework, Ortega proceeds to consider the relevant data that can be obtained from different layers of the source material, with particular attention to texts, toponymy, numismatics and, in a more detailed way, archaeological research and fieldwork. 
Ortega's approach to original sources shows his expertise with the issues associated with the Arabic sources. These are plentiful but late and beset by contradictions, and their reliability and trustworthiness, both for Islamic history in the Middle East and for the central and eastern Mediterranean, are questionable. Ortega argues that the age in which archaeologists try to illustrate and elucidate source data by means of data from the field has come to an end. Literary and annalistic source scholarship and the archaeological fieldwork of surveys and excavations each follow their own paths, and the search for historical truth should not be guided exclusively by written sources. Nevertheless-and this is a major asset of the book-Ortega never loses sight of the written sources and constantly checks the raw data, even if scarce and inconclusive, yielded by the Latin and Arabic sources against the data provided by excavations, field surveys, and the theoretical field of anthropology.

Toponymy has received a good deal of scholarly attention, as it provides clues about the settlement of Arabic and Berber groups in the countryside after the conquest. Their presence left an imprint in toponyms containing the word Beni, analyzed for the first time by Jaime Oliver Asín in 1973 and thoroughly investigated by Pierre Guichard in 1976. Juan Zozaya has studied the imprint of toponyms formed or derived from the Latin or Romance word for "five"-Quintana, Quintos, Quintanilla, Quinto-which had a direct relationship with the fifth (khums) of war spoils and landed property that was allotted to the state in the wake of the conquest. And Manuel Acién has researched toponyms related to qal'a (pl. qilā'; fortress, stronghold, citadel), such as Calatañazor, Calatayud, Calatrava, and Alcalá la Real, which were conceived as new settlements in the conquered countryside. Ortega also devotes attention to the research of Ramon Martí, who has traced the names of palaces and lighthouses in Catalunya and Septimania. If the attention that Ortega gives to toponymy-a single page (pp. 27-28)-might profitably have been expanded, he is nonetheless truly aware in his work of the issues associated with the data provided by toponyms and advocates for a study of place-names that relies more on geography and fieldwork than on dictionaries and bibliographies (p. 28).

Numismatics has long since left the traditional field of antiquarianism and joined the areas of historical and archaeological research. The production, supply, and circulation of coins and their stratigraphic distribution in excavations and fieldwork are now the mainstays of numismatic research. The problem is that the lifespan of a coin in the High Middle Ages, whether Arabic, Greek, or Latin, stretches beyond the chronological strata in which it may be found; this fact requires a very nuanced approach to the information afforded by excavations. The data provided by archaeological research show that the second/eighth century witnessed the utter decay and even cessation of the elite's ability to exert power. This means that the footprint of the Regnum Gothorum in material culture, architecture, and symbolic expressions of power in this period becomes very weak and rather difficult to identify in the field, a trend that does not change until the Umayyads' arrival in al-Andalus in the second half of the second/eighth century. Ortega argues that powerful states 
allow the development of a traditional archaeology, with historicist overtones, well suited for tracing the exercise of power and furnished with index fossils and clear and well-coded pottery typologies. This approach is poorly suited, however, to the age of the Islamic conquests in the Mediterranean basin and the last years of the Regnum Gothorum (p. 31). Besides the problems associated with what may be called the poverty of the material culture of the elite, and despite the advances in ceramics typology and geochronological $\mathrm{C}^{14}$ dating, there is neither a cohesive chronological framework nor a clear-cut typology for the first half of the second/ eighth century. Notwithstanding these challenges, Ortega offers the reader a list of index fossils for a wide range of daily use pottery, tableware, metal tableware, glass, and clothing accessories. He concludes with a remark about the use of radiocarbon dating and the issues associated with it for a period that covers half a century. He notes, wisely, that medieval archaeology is best placed to assess what are the pertinent questions and issues to be addressed, and these should be considered not only by archaeologists but also by scholars working on written sources.

After a detailed appraisal of the nature of the source material, easily readable even by non-archaeologists (a trait that numbers amongst the main strengths of the book), Ortega gives due attention to the context of the Islamic conquest. This brings to the fore his critical explanation of the relationship between the Umayyad caliphate in Damascus, the leadership of the conquest armies, the ideology of jihād, and the governance and control of the conquered areas, which can also be seen through the lens of the almost dialectical relationship between center and periphery. Ortega emphasizes the fluid and changing nature of the administrative arrangements made during the consolidation of Umayyad power in the Middle East. This fluidity went hand in hand with the autonomy enjoyed by the conquerors, who benefited from a wide network of clientship (walā') and, in the case of the conquest of the Islamic West, the systematic inclusion of Berbers/ Amazigh in the conquering armies of Mūsā b. Nușayr. The reader should be aware that the Islamic conquest of the Regnum Gothorum followed administrative reforms ascribed to 'Abd al-Malik b. Marwān (r. 65-86/685-705) and their consolidation under the aegis of his son and successor al-Walìd b. 'Abd al-Malik (r. 86-96/70515). It would therefore be very difficult to ascertain which instructions were followed by the armies of Tāariq b. Ziyād and Mūsā b. Nușayr, if there was a set of centrally sanctioned conquest practices at all. In fact, even if we acknowledge that the degree of centralization and control exerted by the Umayyads of Damascus remains debated, there does not seem to have been a clear policy to be followed for every eventuality, as indicated by the variegated formulae and legends that appear on the Islamic coinage, whether Latin or Arabic or mixed, minted shortly before and immediately after the conquest of 92/711.

Ortega's next step in narrating the Islamic conquest and the creation of al-Andalus is to outline the military conquest by the armies of Țāriq b. Ziyād and Mūsā b. Nuṣayr. The main lines developed are the building of fortified settlements (amșār) and their relationship with the progress of the conquering armies, the use of the standing network of ancient Roman roads, the role of city walls in the defense 
of resisting local communities, the remains of violence that have been found, and the development of an archaeological reading of surrender covenants (p. 59). Ortega, whose knowledge of current debates on the Islamic conquest is considerable, concludes that the few data points in the material record pointing conclusively to destruction, loss of life, and war can be explained only in the framework of a very careful and well-conceived strategy that he qualifies with the very contemporary word "surgical." According to Ortega, violence and the clash of the Islamic armies with the inhabitants of the Regnum Gothorum was restricted to selected strategic locations-mostly citieswhile the countryside was left to its own devices except for the wealthiest and most protected settlements. In fact, even if the written sources and field surveys point to at least two amșār (one, near Écija, has not yet been located, and the other, located near Huesca, awaits a full excavation campaign), these temporary army camps built to house besieging armies never became true amșār, which are not to be found in either the Maghreb or al-Andalus. The lack of amșār in the latter could be explained by a very fast conquest followed by a comprehensive settlement pattern.

The Islamic conquest fueled itself and maintained its pace, Ortega argues, with substantial amounts of booty and spoils, both human and material. This statement appears contradictory with his earlier claim about the poverty of the material culture of the elite. But members of the Regnum Gothorum elite measured their own status and social relevance in the kingdom by the gold and treasure that they were able to store. Accordingly, in addition to the official thesaurun
Regnum Gothorum, there were abundant treasures, lay and ecclesiastical, with varying degrees of complexity, richness, and sumptuousness; some have been lost altogether, others have been recovered, and a small handful are seemingly datable to the aftermath of the Islamic conquest because they were found in conditions and contexts that indicate hurried and haphazard efforts to hide them. These treasures have received a great deal of attention in Arabic sources. The Solomon table-the most valued item of the state treasury-and the lead seals of Septimania, mostly from the settlement at Ruscino and other areas, were found during field surveys or rediscovered in museums and on antiquarians' shelves. They show that the distribution and allotment of booty and spoils was a matter of concern, and accordingly it was regulated from the beginning. Although the inscriptions on the lead seals are sometimes difficult to read and lacking some words, and the locations at which the seals were found are mostly unknown, they show that the booty and the spoils were allotted following a previously established set of fiscal practices. As far as the human booty is concerned, Ortega acknowledges that finding archaeological evidence of slavery is very difficult, but he argues that the brief upsurge in cave settlements, which ended around the third/ninth century and was concentrated in the northern areas of Cantabria, Aragón, Euskadi, and Catalunya, may point to a need for shelters and hideaways for people fleeing the awful prospect of slavery (pp. 97-100). Such escapees would have been part of the human booty of the conquest in the Maghreb, in the Iberian Peninsula, and the Middle East. 
The inevitable corollary to a treatment of booty and spoils is a discussion of tributary practices and coinage, the tools par excellence of state building, booty distribution, and wealth accumulation. Ortega takes up these topics and thoroughly discusses the production, use, distribution, and currency of golden coinage (dīnār), silver coinage (dirham), and copper coinage (fals). The distribution patterns of hoards and single coins found and dated to the first half of the second/ eighth century show, on the one hand, the geography of the power exerted by the Islamic governors of al-Andalus, reflected in the amount of coinage found in each region, and, on the other, that those governors managed to build an efficient and working fiscal system shortly after the events of $92 / 711$.

Ortega continues with an analysis of the imprint the conquest made on the urban landscape of the country, providing an updated and minute study of housing, household items, mosques, city ramparts, and pottery. The rural landscape, which is not restricted to the hinterland of cities and receives detailed attention, is the theater of hilltop fortified settlements, new fortresses (qilāc) built in the first years of the conquest, and a network of lighthouses (fars) and settlements (balāt), mostly located in Catalunya and Septimania, whose purpose was to enhance the authority and control of the conquerors over the countryside.

The Islamic conquest involved the arrival of conquering armies and settlers from the Maghreb, Ifrīiya, Egypt, and the Middle East. Ortega studies their settlement patterns, the areas where they settled, and their relationships with the new landscape and with the Iberian
Peninsula's native people, both Christian and Jewish. There has not been enough field research or excavations to produce a detailed and thorough map of even the settlements that have been identified, and most settlements await discovery. In fact, the existing research on the settlement and distribution patterns of the first wave of settlers, the so-called baladiyyün, who arrived in al-Andalus during and shortly after the conquest, and of the second wave, the so-called shāmiyyūn, who arrived with the defeated Syrian army of Balj b. Bishr around 123-124/741-742, allows only a sketch of general features established mainly through a close reading of the available written sources, which offer a consistent and credible account. From the vantage point of material culture, both waves, when they settled in rural areas, left few traces of radical change or of a substantial and distinct material culture. Instead, one finds a novel rearrangement of the late antique settlement tissue, which was clearly disrupted by the disappearance of a sizeable number of settlements and the creation of others.

The next subject Ortega deals with is the ability and resources of the new settlers to adapt and change the landscape to their own ends. Ortega addresses here A. Watson's controversial theory of an "Islamic agricultural revolution" in order to determine whether there really was a such a transformation from an agriculture adapted to a "Mediterranean ecotype" to one suited to a "hydraulic ecotype" and, if there was, how it would have been reflected in material culture (pp. 223-24). According to Watson, this transformation was brought about by the conquerors through a panoply of new techniques, plants, and practices and the allegedly 
widespread diffusion of small settlements closely associated with irrigated areas. This is not the place to review this theory and the critical responses that it has occasioned. Suffice it to say that such a "revolution" has often been understood as a direct and lasting result of the Islamic conquest. Ortega holds, however, that there was no green revolution, but the innovations introduced between the second/eighth and third/ninth centuries nevertheless radically altered the Iberian landscape for the remainder of the Middle Ages (p. 253).

The author then turns to the social organization of the newcomers and their relationships with the original Iberian population. This topic prompts a discussion of segmentary lineages/ tribes, the vocabulary used to identify them in the Arabic sources (mostly the term qawm), the relationships among tribes and lineages and between them and political authorities, and the problem of recognizing segmentary arrangements in material culture and settlement structure, as well as of identifying their influence, or lack thereof, on the original Iberian population.

The book's last chapter is a proposal to use ethnogenesis as a conceptual tool for understanding the full array of changes triggered by the Islamic conquest, the demise of the Regnum Gothorum, and the settlement of Arabs and Berbers in a postimperial and late antique milieu. Ortega also gives full attention here to the meaning and use of the concept of Islamization, its relevance, and the ways it can be assessed in material culture. Settlement structures, the building of mosques over either functioning or deserted churches, the layout of cemeteries, and the orientation and placement of corpses in graves show that the pace of Islamization reflected in Islamic burials was as fast as it was heterogeneous and early. In fact, Ortega contends that it would not be surprising if future excavations were to uncover mosques in the countryside besides those already found and excavated, especially in places quite far from cities. If so, Bulliet's thesis about the incompleteness and slowness of Islamic conversion in al-Andalus will need a thorough review (pp. 309-10).

To readers well versed in scholarship on al-Andalus, Ortega's concluding remarks may appear a set of truisms, devoid of novelty and imbued with anthropological jargon. Yet this is the kind of judgment that, not so long ago, would have been encountered in book reviews written by classical archaeologists and punctilious armchair scholars about new publications in archaeology. Ortega offers the reader a refreshing and readily verifiable set of assertions about the Islamic conquest: it was well conceived, cohesively arranged, and the expected result of a proven previous strategy. It was not, in other words, the lucky outcome of a single and decisive battle or of some hypothetical factionalism among the potentes in the Regnum Gothorum. It entailed a rural and urban colonization by Arab and Berber peoples, who developed a set of agrarian practices but not a colonial regime. Above all, Ortega's book shows that the study of the conquest is in need of renewed and fresh approaches. My recommendation to potential readers of Ortega's book will thus come as no surprise: the book must be read with the care and attention due to true scholarship and to long-term, careful, detailed, and difficult research, usually 
done neither in the best of institutional frameworks nor with the required funding.

At the end of the book, Ortega provides an analytical index of persons and placenames, a very welcome and rather unusual addition that enables readers to look for and trace the settlements and the people, whether historians, archaeologists, or historical actors, mentioned in the body of the text. In addition, the book contains ninety-five figures, maps, and graphs, clear proof of Ortega's exhaustive knowledge of the difficult and costly archaeological research done in the field. I do not understand why this book has not been published also in PDF, EPUB, or another digital format, a step that has been taken by other publishing houses. The paperback with jacket format, the typeface, and the quality of the images is not as good as one would have expected, and these shortcomings would have been averted in a digital edition. I strongly recommend, therefore, that the book receive a new edition that takes into account the archaeological expeditions, field surveys, and rescue excavations undertaken between 2018 and 2021. The new edition should also correct the unexpected error of the claim that the seven-branched candelabra (menorah) and Solomon's table can be seen in Trajan's column (p. 88); in fact their location is the Arch of Titus. Some spelling and agreement mistakes and some inadequate references that lack page numbers could also be corrected in the new edition that this book deserves. Overall, Ortega's work is an outstanding masterpiece that must be read by everyone concerned with an accurate understanding of the Islamic conquest of the Iberian Peninsula. 


\title{
Book Review
}

\author{
Eneko López Martínez de Marigorta. Mercaderes, Artesanos y \\ ulemas: Las ciudades de las coras de Ilbira y Pechina en época omeya. \\ Arqueologías, Serie Medieval, 2 (Jaén: UJA Editorial, 2020), 432 pp. \\ ISBN 978-84-9159-298-3. Price: $€ 50.00$ (paper), $€ 17.00$ (e-book).
}

\author{
Aurélien Montel \\ CIHAM (UMR 5648) \\ (France)
}

(aurelien.montel@gmail.com)

B ecause the history of al-Andalus has mostly been written from a capital-centered perspective, the historical trajectory of the provinces has elicited only slight historiographical interest. Eneko López Martínez de Marigorta's book, which is based on his $\mathrm{PhD}$ dissertation written under the supervision of Professors Eduardo Manzano Moreno and Manuel Acién Almansa and defended at the Consejo Superior de Investigaciones Cientificas (CSIC) in 2017, fills this gap in an excellent way.

The book is dedicated to the study of the cities of southeastern al-Andalus, nominally the küras ("provinces") of Elvira and Pechina. These correspond roughly to the modern provinces of Granada and Almeria, which are very different in their topographical and cultural characteristics. The book's temporal scope is the Umayyad era (second/eighth to fifth/eleventh centuries), set within a longue durée perspective that sees the author make frequent reference to the Visigothic and Taifa periods. This is an ambitious approach, since the objective of the book is to identify the historical trajectory of the region by looking at both cities and people, especially the progress of urbanization (p. 13).

The author has collected information from a wide range of sources, employing all the classical chronicles and geographical treatises while also making good use of the biographical literature (țabaqāt) and of some Latin Christian texts. With respect to the documentation, one of the strengths of the study is the systematic use of archaeological reports from recent investigations in the region, mostly in Pechina and madinat Elvira, though some

(c) 2021 Aurélien Montel. This is an open access article distributed under the terms of the Creative Commons Attribution-NonCommercial-NoDerivatives License, which allows users to copy and distribute the material in any medium or format in unadapted form only, for noncommercial purposes only, and only so long as attribution is given to the original authors and source. 
rural settlements are documented, too. Methodologically, that study does a fine job connecting textual sources and material evidence, both of which are meticulously examined and cross-checked. The study's methodological rigor contributes to both the ambition and the innovativeness of the conclusions.

The book is divided into seven chapters. It also contains twenty-three maps, which greatly assist the reader in understanding the discussion; nineteen color figures; and twenty black-and-white figures of various kinds (here we must also commend the editor for the high-quality product). The list of sources occupies a six-page section (pp. 371-77), which shows their breadth, and an extensive bibliography of fortyeight pages likewise gives the reader insight into the wide range of materials used (pp. 377-415). Although the chapters are arranged to follow a chronological progression, in fact they also reflect three geographical scales: local, Iberian, and Mediterranean.

Focused on the küra of Elvira-Granada, chapters 1 ("The articulation of the province of Ilbira before the creation of its madina," pp. 19-65) and 2 ("The madina of Ilbīra and territorial hierarchical organization," pp. 67-108) investigate how the transition from the Visigothic era to Umayyad rule affected the southeastern portion of the Iberian Peninsula-in other words, how it inflected the course of Late Antiquity in the region. After reviewing the narratives of the Islamic conquest at the beginning of the second/eighth century, the author proposes an interesting synthesis regarding the settlement of the Arab ajnād (military divisions), whose territorial distribution, which partly differs from that of the Visigothic aristocracy, he precisely delineated (p. 32). Another interesting facet of this first chapter is the data the author has gathered regarding the administration of the region; such information is rare for al-Andalus because of the scarcity of sources for the first centuries of the Islamic era. It is notable that in this peripheral region, the Arab ajnād continued to hold the most prominent administrative positions; Umayyad power seems to have been very limited here, although the küra of Elvira was one of the provinces that contributed the most to the treasury due to the dynamism of its economic life.

It seems that Islamic Elvira-a place distinct from late antique Illiberisbecame the capital city of the küra in the middle of the third/ninth century, when it was inhabited by Syrian Arabs, whose importance can be seen in the tabaqāt, especially in the tribal nisbas. Elvira gradually managed to polarize its hinterland, especially from a fiscal point of view. It was also a major vector for transmitting Islamic scholarship, since many of the local scholars traveled east for a rihla fi talab al-cilm (journey in search of knowledge). The author notes that Elvira produced more such traveling scholars than most other cities. This indicates that in peripheral spaces, Islamization must be seen as a local initiative, with only slight interference from the capital. Because of the influence of the Syrian ajnād, Umayyad emirs had only a limited role in the city; their one attempt to appoint a judge, for example, ended in failure. Although Elvira was deeply affected by the fitna in the late third/ninth century, these effects had highly specific local features. It seems that the proportion of rebels belonging to the social group of the muwalladūn (Muslims 
of local descent) was smaller in Elvira than it was anywhere else in al-Andalus; the most important local rebels were in fact Syrians.

In this context, the first appearance of the toponym Granada, at the end of the third/ninth century, is quite remarkable. That toponym had, of course, a storied career after the end of the fourth/tenth century, as shown in chapter 6 ("The madina of Granada and the substitution of the Shāmiyyūn by stipendiary troops," pp. 277-95). Under the Umayyad caliphate, Elvira experienced a major disturbance after hājib al-Manșūr recruited a great number of mercenaries from the Maghrib. During the fitna that ended the caliphate of Cordoba, madinat Ilbira was destroyed and its inhabitants moved into the highlands, where they settled at the site of late medieval Granada. There, a lineage belonging to the Banū Zìri family took over and ruled over an independent taifa until the end of the fifth/eleventh century. Thus the fitna appears to have been a real watershed, in some regards much more important than the Muslim conquest of the Iberian Peninsula, for it completely changed the territorial configuration of the region.

The Mediterranean orientation of the southeastern Iberian Peninsula is investigated in chapters 3 ("The madina of Pechina and the connection to the Mashriq," pp. 109-61) and 5 ("The madina of Almeria and the Umayyad maritime influence," pp. 231-75), with an emphasis on Pechina and Almeria. The main focus of chapter 3 is the foundation of Pechina, which has been discussed in many earlier publications and is regarded as convincing proof of the increased openness of al-Andalus to the Mediterranean in the middle of the third/ninth century. An important partner in that opening was the Maghrib, where, the author underscores, many Andalusians from the peninsula's southeast settled and formed a diasporic network. Their communities included one in al-Qayrawān (in modern-day Tunisia), which was at that time the "mother city" of the Islamic West, and another in Tenes (today's Algeria), which is presented in medieval sources as an Andalusian foundation. This chapter clearly shows how Pechina was shaped by its very specific opening to the sea. It became a major hub of western Mediterranean trade but also one of the most dynamic peripheral cities of al-Andalus in terms of Islamic scholarship because of its links with the Maghrib and the East. The author's use of the Andalusian tabaqāt literature here is very convincing. He extracts from this corpus extensive information regarding local 'ulamā' who traveled to the Maghrib and/or to the East, studied there, and brought back Islamic knowledge. These data thus illustrate clearly the social and cultural construction of a city founded by Muslims. The author makes good use of archaeological reports from a material and economic perspective.

Chapter 5 presents the consequences of the foundation of Almeria, which was chosen as the harbor of the Umayyad navy in the middle of the fourth/tenth century and quickly overshadowed Pechina. Here, the reader may regret that the conflict between the Umayyad and Fatimid caliphates is passed over so quickly, since medieval authors argued that 'Abd al-Raḥmān III founded Almeria specifically in response to a Fatimid attack in 344/955; that moment was as traumatic as it was foundational. Apart from this aspect, 
the chapter continues the reflections of the previous one, looking into the Mediterranean functions of Almeria from an Iberian perspective. Founded as a caliphal initiative, the city followed a very specific trajectory, increasingly guided by central political power. The author observes that notables from Pechina continued to play a political role within the administration of the caliphate, especially in its navy, until al-Manșūr managed to curb their influence. From an economic point of view, Almeria became the most important city on the Mediterranean shore of al-Andalus, receiving considerable investment from the caliphs, who acted as traders in their own right. The city's two functions-military and economic-had a direct influence on its urban arrangement, which featured the unique association of a qayșariyya (public market) and a dār al-șināa (arsenal) in the center. Because of the macro-development of Almeria, Pechina experienced a long decline. The pages dedicated to the Taifa period (fifth/eleventh century) are especially interesting, since the author shows that the fitna, traditionally considered to have represented a breakdown, did not hamper urban development in this area. In addition to functioning as the main Mediterranean harbor of al-Andalus-its "door to the East" (bāb al-sharq)-Almeria also became one of the peninsula's most powerful cities, and its population was still growing during the Taifa period, when several new suburbs were established.

Indeed, economic life at the local level is the subject of chapters 4 ("The artisanal and mercantile environment of the madinat Ilbīra and Pechina," pp. 163-229) and 7 ("The flourishing of production and trade in the cities of the provinces of Ilbira and
Pechina," pp. 297-359). Here, the author adopts a double perspective, analyzing first manufacturing activities and then trade.

Regarding the production of goods, archaeological investigations have clearly shown that products such as luxury ceramics and glass are well represented in the archaeological record as early as the third/ninth century. Within the city, the textual sources document also other luxury products, including items made of iron, copper, and brass; leather goods; marble carvings; and perfumes. Textiles seem to have been very important within local economic networks, and specific, renowned items such as silk (harīr) became key products for the local economy, sold in Mediterranean markets. Later, silk ensured the wealth of the Nasrid emirate of Granada. Local linen (kattān) was also prized. The consumption of such goods, which clearly increased in the fourth/tenth century, can be related to the expansion and refinement of the urban way of life. The author develops a very interesting approach to the study of production, combining archaeological findings and textual data, such as professional nisbas extracted from the tabaqāt literature. By doing so, he manages to circumvent the silence of the medieval authors on economic matters and to reconnect the products to their makers, who are usually invisible.

These cities were also major hubs of trade, at different scales. The author demonstrates, through archaeological studies, that the cities' inhabitants lived on the agro-pastoral products of their own hinterland. More important, however, were their regional trading functions. Open to the Mediterranean, they were also tightly connected with the capital 
city of Cordoba, the node of all economic networks in Umayyad al-Andalus. For the first time, Pechina seems to have been connected to Cordoba by a route that remains partly unknown; following the foundation of Almeria, it seems that the road between Cordoba and the new harbor was one of the most important. At this point, Granada became the node that connected the two segments of the route.

Through the vast sweep of his scholarship, Eneko López Martínez de Marigorta delivers with this book an insightful reflection on the construction and resilience of a territory. The book's merging of spatial and cultural approaches, using a wide range of very different sources of information, proves both generative and innovative. By demonstrating the true importance of territories that are normally considered peripheral from a political perspective, this book makes an important contribution to the history of the Islamic West. It shows that the kurras of Elvira and Pechina were crucial in the creation and development of relations with the opposite shore of the Mediterranean and with the East, an important source of both trade goods and scholarship. Another important conclusion is that academic periodization is open to discussion and debate. In this region the most important period seems to have been not the Islamic conquest of the early second/eighth century but rather the middle of the fifth/ eleventh century, which saw such important changes as the emergence of Granada and the ascendancy of Almeria at a Mediterranean level. These developments produced a very different pattern from that seen in Visigothic Iberia.

One may note several weaknesses in the section on the book's sources. First, most of the sources are referenced only in an Arabic edition, and not always the edition preferred by scholars. This can be disconcerting for readers in search of translated texts. Moreover, some references are mistaken; for instance, the Mafākhir al-Barbar is said to have been edited and translated by Muhammad Yaclā, but in fact it was only edited by him. In terms of historiography, it is unfortunate that the bibliographical references consulted do not include more works from the French scholars who have dedicated important studies to Andalusian cities and especially Pechina-Almeria (such as Christine Mazzoli-Guintard, Mohamed Meouak, and Christophe Picard). ${ }^{1}$

Yet these observations concerning the bibliography do not detract from the high quality of the analysis or of the book overall, and its abundant pictorial documentation will be of great help to readers. Original in its methodology, this very erudite book should certainly be welcomed, read, and discussed.

1. See, for instance, Christine Mazzoli-Guintard, “Almería, ¿ciudad-mundo en los siglos XI y XII?,” in Carolus: Homenaje a Friedrich Edelmayer, ed. Francisco Toro Ceballos, 241-49 (Alcalá la Real: Ayuntamiento de Alcalá la Real, 2017); Christophe Picard, "Pechina-Almeria aux IX ${ }^{\mathrm{e}}-\mathrm{x}^{\mathrm{e}}$ siècles: La naissance d'un port omeyyade en Méditerranée," in Villes méditerranéennes au Moyen Âge, ed. Élisabeth Malamut and Mohamed Ouerfelli, 163-76 (Aix-en-Provence: Presses universitaires de Provence, 2014); Mohamed Meouak, "Les Banū-1-Rumāhis et les Banū Ṭumlus, fonctionnaires au service de l'état hispano-umayyade," in Familias Andalusíes: Estudios Onomástico-Biográficos de al-Andalus V, ed. Manuela Marín and Jesús Zanón, 273-88 (Madrid: CSIC-Instituto de Cooperación con el Mundo Árabe, 1992). 


\title{
Book Review
}

\author{
Challenging the Historiography of Philosophy, Science, and Religion \\ through Greek-into-Arabic Translations from Eleventh-Century Antioch

\begin{abstract}
Alexandre M. Roberts. Reason and Revelation in Byzantine Antioch: The Christian Translation Program of Abdallah ibn al-Fadl (Oakland: University of California Press, 2020), xiii $+357 \mathrm{pp}$. ISBN 978-0-520-34349-8. Price: $\$ 95.00$ (cloth), $£ 74.00$ (e-book).
\end{abstract}

\author{
Alberto Bardi \\ Tsinghua University \\ (alberto.bardi@live.com)
}

$\mathrm{R}$ eason and Revelation in Byzantine Antioch: The Christian Translation Program of Abdallah ibn al-Fadl, by Alexandre M. Roberts, is a remarkable achievement. To fully understand the importance of the book's contributions, it is worth briefly introducing the scholarly fields with which the volume engages.

In recent times, scholarship has focused on the relationships between the Islamicate and Byzantine worlds by examining manuscripts that provide traces of exchanges between the two. Benefiting from nineteenth- and twentieth-century catalogs and surveys of translations from Arabic into Greek and vice versa, new approaches to manuscript analysis, codicology, and paleography have allowed scholars to reach a deeper understanding of the historical dimension of translations. They have revisited old conclusions, undertaken new surveys, and arrived at a new state of the art. Yet scholarship has yet to provide a fine-grained, comprehensive account of the complexity of historical phenomena related to these translations. The working questions include the following: To what extent are Arabic-into-Greek translations of philosophical and scientific texts connected to the translations undertaken in ninth-century Baghdad? What kinds of exchanges (if any are traceable) took place between translators from Arabic into Greek working in Byzantine territories in the tenth and eleventh centuries and translators of Christian textual materials from Greek into Arabic? And what impact did translators' religious beliefs have on the translation processes? The nature of

\footnotetext{
(c) 2021 Alberto Bardi. This is an open access article distributed under the terms of the Creative Commons Attribution-NonCommercial-NoDerivatives License, which allows users to copy and distribute the material in any medium or format in unadapted form only, for noncommercial purposes only, and only so long as attribution is given to the original authors and source.
} 
the demand for translations from Arabic on the Byzantine side and the impact of these translations on Byzantine intellectual history and politics are currently under exploration; it remains to be fully established what strategies were employed to absorb Arabic-into-Greek translations into the Greek curricula. Moreover, it is still unclear whether religious concerns and struggles-such as the emergence of iconoclasm-were responsible for what is usually deemed a loss of scientific and philosophical heritage in the Byzantine world, a heritage whose transmission is ordinarily assumed to have been kept alive thanks to Arabic or Syriac translations.

To tackle such questions is difficult not only because a scholar faces problems of ethnocentrism, such as the Hellenophilia implicit in the narrative of the rebirth of Greek philosophy and science in the Renaissance, but also because she or he must deal with several crystallized-and still popular-theses having to do with Byzantine and Islamicate civilizations. Prominent among these is the view of Voltaire and Edward Gibbon, of Byzantium as a period of general decline, and the repercussions of this thesis in modern scholarship. Under the influence of this thesis, the rises of Christianity and Islam are usually deemed (e.g., by Karl Popper) to be responsible for the decline of philosophy and science as cultivated by the Greeks.

In this wide and complex scholarly frame, Roberts's contribution, as presented in the book under review, is relevant for at least two reasons. First, it provides a step forward in understanding the intellectual networks that linked the Byzantine and Islamicate worlds and the connections between Arabic and Greek scholarship after Late Antiquity. Second, it shows, through textual evidence from unpublished sources that the author has often edited and translated for the first time, how the narrative of the decline of Greek philosophy and science needs to be urgently readdressed in the historiography of science and philosophy between Late Antiquity and early modernity.

Roberts's volume is arranged in two parts. The first part, "Translation," reconstructs the content and social context of the translation program of the deacon Abdallah ibn al-Fadl. The section contains three chapters: chapter 1 "A Scholar and His City"; chapter 2 "A Translation Program"; and chapter 3 "A Byzantine Ecclesiastical Curriculum." Working in the multicultural setting of eleventh-century Antioch, Ibn al-Fadl faced a unique Arabic-speaking milieu whose intellectual features he had to accurately apprehend in order to select fundamental theological (patristic), philosophical, and scientific texts and translate them from Greek into Arabic in such a way that the content could be delivered effectively and received within those frames (faith, style, language, rhetoric). The Greek corpus that the Antiochene deacon worked on for his translations appears at first glance to be strictly religious, but a closer examination proves the superficial reader wrong. In the first part of the book, one learns to put aside modern and contemporary categorizations of knowledge fields and to adopt the lens of a historico-critical approach. As a matter of fact, Basil's Hexaemeron-whose time-consuming translation Ibn al-Fadl undertookconcerns itself with matters of philosophy, astronomy, and cosmology. Undoubtedly, 
Ibn al-Fadl needed what we would consider a scientific and philosophical background to understand Basil and the other authors with whom he engaged for his translations, such as Isaac the Syrian, John Chrysostom, John of Damascus, John of Thessaloniki, and Maximos the Confessor.

In the second part of the book, "Philosophy," the reader can all but see Ibn al-Fadl's program through the eyes of the translator himself, for Roberts offers an aesthetic experience of immersion in the Antiochene deacon's philosophy of translation. This section, in continuity with the first part, covers the textual typologies and topics the Antiochene scholar dealt with, and it contains the following chapters: chapter 4 "Purpose in the Prefaces"; chapter 5 "Education in the Margins"; chapter 6 "Logic"; chapter 7 "Physics"; chapter 8 "Cosmology"; chapter 9 "Astronomy"; and chapter 10 "A Shared Scholarly Culture." The author provides editions and English translations of prefaces and other relevant texts, including marginalia, authored by Ibn al-Fadl or taken from his sources. Primary sources are reproduced in the original Arabic or Greek, with significant variant readings in footnotes (the sigla of all manuscripts are given in the bibliography). A translation is placed below each original text. In the case of text portions with unintuitive interpretations in English, the reader finds between brackets transliterations of the relevant words or sentences. Accordingly, Roberts's choices are explained either in footnotes or in the commentary that accompanies the source. All of this material reveals the rationales behind Ibn al-Fadl's translation choices in fields ranging from theology and moral philosophy to logic, natural philosophy, cosmology, and astronomy. With the primary sources presented in such detail, it is possible to grasp how the translator deploys rhetoric and style to present the content of the translated texts within the Aristotelian framework that was familiar to the Arabic-speaking elite of Antioch. By reading Ibn al-Fadl's own texts alongside Roberts's commentary, the reader learns an essential trait, one that is decisive to understand the importance of the author's intellectual labor. Many of the texts that Ibn al-Fadl translated into Arabic and commented upon were already available in that language before him. From that point of view, there would appear to be nothing new about his work. Nevertheless, the Arabic elites whom Ibn al-Fadl was addressing needed to be approached with proper stylistic codes that would sound appropriate to them. Herein lies the importance of rhetoric to the educational purpose of Ibn al-Fadl's translation program. Greek theological, philosophical, and scientific texts would not have been received without the prefaces, the rhetoric, the corrections, and the stylistic improvements that Ibn al-Fadl adopted and whose traits are reconstructed and displayed in part two of Roberts's book. The reader is further aided by Arabic and Greek indexes at the end of the volume, which prove useful in consulting the sources presented in the book.

Ibn al-Fadl's skills in the art of translation can be fully appreciated in the cases in which Roberts has identified, in addition to the Greek original, the Arabic sources that the Antiochene scholar had at his disposal. The reader can even compare the different Arabic versions of a text thanks to Roberts's decision to print 
in boldface those textual portions that are identical in Ibn al-Fadl's own version and in the source he used. An emblematic case is his reworking of a passage from Basil's Hexaemeron concerning cosmology, which we can find both in an anonymous Arabic version in MS Sinai arabicus 270 and in Ibn al-Fadl's translation in MS Damascus OP arabicus 142 (see pp. 200-221). Reading the overlapping passages presented in user-friendly boldface not only readily reveals the translator's choices but also sheds new light on his conceptual and terminological background. The relevance of Ibn al-Fadl's reworked version-as Roberts's commentary accurately explains (pp. 221-30)-is manifold. Among others, (1) the general terminology is kept unmodified: Cilla stands for the Greek aitia (cause), al-kull for ta hola (universe, all things, the whole), (ālam for kosmos (the world), and al-mubșarāt for ta horata (the visible things); (2) the specific Aristotelian terminology does not change: al-asbāb al-hayūlāniyya stands for hylikai hypotheseis (material causes) and isțiqsāt/ istiqșāt for stoicheia (elements); and (3) Ibn al-Fadl translates the Greek aitia emphrona (intelligent cause) with 'illa (ãqila, while the previous translator had chosen cilla mafhüma (intellected cause). This choice not only proves the value of Ibn al-Fadl's philosophical background but also gives a radically different meaning, as Roberts points out: "Aside from making God, usually considered beyond comprehension, into something that can be 'understood,' the Anonymous Translation had missed, or at least, weakened, the point of the passage, which is that the world did not arise out of mindless matter, but rather out of a First Cause with mental capacity" (p. 222). On the basis of this and many other critical examinations of the sources presented in his volume, Roberts argues convincingly for the importance of retranslations (which he explains in detail on p. 289) in educating the Arabic elites of Antioch, who shared a distinctive style of thought and were accustomed to receiving content in a specific rhetorical style. Retranslations by Ibn al-Fadl show that questions about the transmission of Greek science and philosophy into a Christian context were not solved once and for all thanks to the reasoning of Church Fathers such as Basil, Chrysostom, and Gregory and that the efforts of previous translators from Greek into Arabic in Arabic-speaking contexts needed to be revisited. Churchmen like Ibn al-Fadl understood that science and philosophy are not independent of the stylistic codes of the language in which they are conveyed. On this account, Roberts has shown not only that translating science and philosophy from Greek into Arabic preserved those branches of knowledge but also that being Christian played an essential role in challenging the receiving culture and in starting a process of appropriation and transformation of Greek science and philosophy. In light of cases such as Ibn al-Fadl's, it is evident that the old-fashioned thesis concerning the rebirth of Greek science in the Renaissance after its decline in Byzantium breaks down. On the contrary, it was thanks to "religious" scholars such as Ibn al-Fadl that Greek science and philosophy thrived. Further discussions on the historiography of science and philosophy between Late Antiquity and early modernity must consider translation processes more accurately by analyzing the social context in which they occurred and by taking manuscript analysis into account and 
studying texts as entities embodied in their transmission and in the flux of history, rather than as abstract entities as in old-school philology.

In sum, Roberts has produced not only an impressive work of intellectual and social history but also an accomplished exemplar of the exploration of unpublished sources with insightful philological and linguistic examinations. Since his book does not deal with the translation program alone, the title does not entirely capture the relevance of the topics contained in the volume. This is a minor problem, of course, but readers should be aware that the book goes beyond the focus on translation suggested by the subtitle and also engages extensively with the practice and philosophy of translations (especially in its second part), as summarized above.

Most of the chapters contain introductory parts, which provide an almost encyclopedic survey of the literature on a given topic. Although this enhances the clarity of the author's arguments for nonexperts and provide a helpful guide to novices, they could have been condensed, as the relevant literature is cited in the footnotes. In my opinion, as Roberts has demonstrated his talent in dealing with unpublished sources and conveys his discoveries in a detailed manner, even the omission of these introductory sections would have detracted little from his achievements.
Despite these minor issues, the volume manages to strike a balance between the reconstruction of unpublished sources, the translations, and discussion of the extant literature (primary and secondary sources).

The practice of translating works of science and philosophy in an Arabicspeaking context has shed new light on the nature of the transmission of science and philosophy and on the nexus between transmission and its historical context. The topic of retranslations, in my view, has strong potential to foster future scholarship and might bring philology into dialogue with the histories of science, philosophy, and religions, and with the philosophy of science and religion. Indeed, Ibn al-Fadl's retranslations reveal the necessity of shaping scientific and philosophical content according to expected styles in order to communicate that content to a specific community (in this case an Arab elite within a Christianized Aristotelian framework) so that it can be received, accepted, and transformed. Such a view is not so distant from reflections on the role of language and styles with reference to the nature of science as elaborated by philosophers such as Ludwik Fleck, Thomas Kuhn, and Ian Hacking. To what extent are retranslations connected to the communication of scientific discoveries and their acceptance or rejection? This is just one of the many questions that arise upon reading Roberts's book. 


\title{
Book Review
}

\section{Konrad Hirschler. A Monument to Medieval Syrian Book Culture: The Library of Ibn 'Abd al-Hādi. Edinburgh Series in Classical Islamic History and Culture (Edinburgh: Edinburgh University Press, 2020), $\mathrm{X}+612$ pp. ISBN 978-14-7445-156-7. Price: $£ 85.00$ (cloth).}

\author{
Caterina Bori* \\ Università di Bologna \\ (caterina.bori@unibo.it)
}

$\mathrm{I}$ n his new book, Konrad Hirschler continues his research on the history of libraries and catalogs. After studying the catalog of the Damascene Ashrafiyya Library, ${ }^{1}$ Hirschler remains in Damascus but this time turns his gaze to the books of the Hanbalī scholar Yūsuf Ibn 'Abd al-Hādī (840-909/1437-1503). Ibn 'Abd al-Hādī, also known as Ibn Mibrad, was a minor scholarly personality. He belonged to the Maqdisī branch of local Hanbalism, and like many members of that branch, he lived in the Damascene neighborhood of Șālihiyya, on the slopes of Mt. Qāsiyūn, west of the old city's walls. ${ }^{2}$ Ibn 'Abd al-Hādī traveled little and wrote a lot-an estimated 800 works according to Hirschler-but not many of his works enjoyed wide dissemination. He was a precise and dedicated bibliophile equipped with a strong sense of himself and of the prestigious scholarly tradition to which he belonged. Accordingly, he compiled several autobibliographies, one of which has just been published by Said Aljoumani and Hirschler. ${ }^{3}$ Most importantly, for the purposes of the book under review, Ibn 'Abd al-Hādī also accumulated a collection of some 3,000 works

\footnotetext{
* Cecilia Palombo read and discussed with me the last version of this text. I would like to thank her here for her sensible suggestions.

1. Konrad Hirschler, Medieval Damascus: Plurality and Diversity in an Arabic Library; The Ashrafiya Library Catalogue (Edinburgh: Edinburgh University Press, 2016).

2. Sālihiyya has been at the center of recent scholarly attention: see Toru Miura, Dynamism in the Urban Society of Damascus: The Șālihiyya Quarter from the Twelfth to the Twentieth Centuries (Leiden: Brill, 2016).

3. Said Aljoumani and Konrad Hirschler, Mu’allafāt Yūsuf b. Hasan b. 'Abd al-Hādī wa-musāhamatuhu fí hifz al-turāth al-fikrī (Leiden: Brill, 2021). The book is more than a translation of the English one presented here, especially chapters 4 to 6. It will not be discussed here. I thank Mohamed Merheb for drawing my attention to it.

(c) 2021 Caterina Bori. This is an open access article distributed under the terms of the Creative Commons Attribution-NonCommercial-NoDerivatives License, which allows users to copy and distribute the material in any medium or format in unadapted form only, for noncommercial purposes only, and only so long as attribution is given to the original authors and source.
} 
contained in almost 600 manuscripts that, toward the end of his life, he endowed to the 'Umariyya Madrasa along with their fihrist (catalog). The fihrist survived, and so did a substantial portion of his book endowment. Both lie at the heart of this study.

The research carried out by Hirschler combines two main dimensions that are already explicit in the title of the book. One focuses on Ibn 'Abd al-Hādī's project of constructing a large corpus of books that he itemized in his fihrist and donated to a madrasa that was particularly prominent in the history of Syrian Hanbalism. With a special emphasis on materiality (here "material philology"), Hirschler explores how and why Ibn 'Abd al-Hādī assembled his collection. ${ }^{4}$ Hirschler argues that Ibn 'Abd al-Hādi conceived of this corpus of books as a monument to the heyday of the local culture of hadith transmission, an activity whose literary outcomes, social mechanics, and cultural implications have recently been at the center of a growing scholarly trend. ${ }^{5}$ The second and more ambitious dimension that Hirschler intends to illuminate through the case study of Ibn 'Abd al-Hādī's fihrist and his extant books is the social and cultural significance of owning and endowing books in the late medieval period (p. 2). In this regard, Ibn 'Abd al-Hādī's fihrist and endowment are presumably treated as representative of a larger book culture, although-as will be pointed out below-his collection bore the marks of a highly distinctive personal and individual project. Hirschler explains that Ibn 'Abd al-Hādī's collection deserves to be studied because "it is surrounded by an outstandingly dense documentation" (ibid.). The book unfolds as a close examination of this documentation.

Without being explicitly divided into two parts, A Monument to Medieval Syrian Book Culture is in fact organized in two sets of chapters. The first one consists of four narrative chapters that cover Ibn 'Abd al-Hādī's life and his book endowment: its material aspects, aims, and history. ${ }^{6}$ The second one consists of two chapters and is bulkier. ${ }^{7}$ It comprises an edition of Yūsuf Ibn 'Abd al-Hādī's fihrist, preceded by identification of the items mentioned in it. The single works are also matched-when possible-with Ibn 'Abd al-Hādī's extant manuscripts and modern editions. Two sections of plates, at the end of chapters 4 and 6 , allow the reader to follow the argument and to visualize the sources and

4. For nonspecialists, a clarification of the differences between "material philology" and "codicology" may have been appropriate. The reference is to Stephen Nichols, "Philology in a Manuscript Culture," Speculum: A Journal of Medieval Studies 65, no. 1 (1990): 1-10, but see also, slightly later, idem, "Why Material Philology? Some Thoughts," in Philologie als Textwissenschaft: Alte und neue Horizonte, ed. Helmut Tervooren and Horst Wenzel, special issue, Zeitschrift für deutsche Philologie 116 (1997): 10-30. A useful overview can be found in Lena Rohrbach, "Material Philology," in Handbook of Pre-modern Nordic Memory Studies: Interdisciplinary Approaches, ed. Jürg Glauser, Pernille Hermann, and Stephen A. Mitchell, part 1: Disciplines, Traditions and Perspectives, 210-16 (Berlin: de Gruyter, 2018).

5. In English, see, above all, Garret Davidson, A Social and Intellectual History of Hadith Transmission across a Thousand Years (Boston: Brill, 2020) and before him the seminal article by Eerik Dickinson, "Ibn al-Ṣalạ̄ al-Shahrazūrī and the Isnād," Journal of the American Oriental Society 122, no. 3 (2002): 481-505.

6. Chapters 1 to 4 with introduction and conclusion, pp. 1-170.

7. Chapters 5 and 6, pp. 171-554. 
much of the information provided by the author. In addition to the general index and bibliography, the provided indexes of titles, authors, thematic categories, and identified manuscripts of Ibn 'Abd al-Hādī's books (pp. 582-612) are necessary ancillary tools to make the best of the catalog.

The book is rich and informed by a variety of approaches with a strong penchant for material history. It starts by providing context for Ibn 'Abd al-Hādī's scholarly background, his ancestors and descendants, and more generally his family branch-the Maqdisīs-that was renowned for its commitment to hadith transmission. ${ }^{8}$ Hadith transmission is also the field of which Ibn 'Abd al-Hādī was most fond, as is clear from his own book collection. Despite his impressive written production, biographies of Ibn 'Abd al-Hādī are not very informative. Yet close inspection of Ibn 'Abd al-Hādī's books (i.e., manuscripts) allows Hirschler to uncover details about this scholar's real-estate and professional activities, details that are omitted by biographical sources. This is one of the main points the book seeks to make: that documentary and manuscript sources are essential for bringing to light information that remains below the radar of normative and narrative texts. At the end of the first chapter, two topics are tangentially touched upon (pp. 59-63). They are peripheral to
Hirschler's agenda but deserve to be mentioned here since they are important for a complete understanding of late medieval Syrian Hanbalism. The first is Ibn 'Abd al-Hādī's Sufism, which raises the broader issue of the relationship of hadith scholars and transmitters with local forms of tașawwuf. As Hirschler observes (p. 59), the mutual permeability of the boundary between these trends has been repeatedly pointed out in recent research. ${ }^{9}$ Nonetheless, its full configuration has yet to be understood. One significant step in this direction has been taken by Arjan Post in his book on the tradition-oriented tasawwuf of the Taymiyyan Sufi 'Imād al-Dīn al-Wāsițī (d. 711/1311). ${ }^{10}$ At some point at the beginning of the seventh/thirteenth century, 'Imād al-Dīn al-Wāsiṭi became a student of Ibn Taymiyya (d. 728/1328) in Damascus and the Sufi teacher of Ibn Taymiyya's circle of followers, many of whom were devoted to hadith transmission and scholarship. Al-Wāsiți devised a sober, scripturalist, prophet-centered tașawwuf.

Like many of his peers, Ibn 'Abd al-Hādī was the author of a booklet on the khirqa (the initiatory Sufi cloak) in which he professes to have received the cloak of the Qādirī brotherhood via a lineage featuring the names of the authoritative Hanbalīs Ibn Rajab (d. 795/1392), Ibn Qayyim al-Jawziyya (d. 751/1350), and Ibn Taymiyya. ${ }^{11}$

8. See Stefan Leder, "Charismatic Scripturalism: The Hanbalī Maqdisīs of Damascus," Der Islam 74, no. 2 (1997): 279-304.

9. Too often overlooked is Denis Gril, "De la khirqa à la țarīqa: Continuité et évolution dans l'identification et la classification des voies," in Le soufisme en Égypte et dans le monde musulman à l'époque ottomane, ed. Rachida Chih and Catherine Mayeur-Jaouen, 58-81 (Cairo: IFAO, 2009), esp. 63-72, 80 with n. 75. Gril makes important points about the meaning of khirqa treatises written in the Ayyubid and Mamluk periods.

10. Arjan Post, The Journeys of a Taymiyyan Sufi: Sufism through the Eyes of Imād al-Dīn Ahmmad al-Wāsiți (d. 711/1311) (Leiden: Brill, 2020).

11. Hirschler, Monument, 60-61; Yūsuf Ibn 'Abd al-Hādī, Bad' al-'ulqa bi-lubs al-khirqa, in Lubs al-khirqa 
He also reports, from the Shāfi ${ }^{C} \overline{1}$ hadith specialist Ibn Nāṣir al-Dīn al-Dimashqī (d. 842/1438), a famous statement in which Ibn Taymiyya describes the Qãdiri path as "the greatest path among the well-known ones." 12 All these elements are duly noted by Hirschler, but it remains unclear what boasting of having worn the Qãdirī khirqa meant to Ibn 'Abd al-Hādī and, overall, what the implications of claiming such spiritual affiliations were. In what senses and ways a scholar like Ibn 'Abd al-Hādī was a Sufi is a big question that remains to be answered. ${ }^{13}$

The mention of Ibn Taymiyya's name leads to the second issue-namely, Ibn Taymiyya's marginal position in Ibn 'Abd al-Hādî's library. The broader issue at stake is, of course, the (not so obvious) relationship of late medieval Syrian Hanbalism to the legacy of the towering and controversial Ibn Taymiyya. Although quite a few of Ibn Taymiyya's occasional writings are recorded in Ibn 'Abd al-Hādī's fihrist, none of his big treatises is.
According to Hirschler, this is due to Ibn Taymiyya's scant engagement in hadith transmission, which is corroborated by his minor role in the Index of Damascene Audition Certificates when compared to the Maqdisis. ${ }^{14}$ Although there is certainly some truth in this claim, it is equally true that the samā'āt excerpts reported by Ibn Nāṣir al-Dīn al-Dimashqī in his defense of those who acknowledged Ibn Taymiyya as shaykh al-islām do attest to some involvement on Ibn Taymiyya's part in local hadith transmission. ${ }^{15}$ This element alerts us to remain vigilant about the limits of the Index of Damascene Audition Certificates and not to give up exploring literary sources as repositories of documentary ones. ${ }^{16}$

Hirschler suggests that there were two local trends of Hanbalism: a Șāliḥiyyacentered, hadith-focused Hanbalism, and a Taymiyyan Hanbalism concentrated within the city walls (p. 63). It is an interesting suggestion that deserves to be taken up in the future. The boundary

fi al-sulūk al-ṣūfi, ed. 'Āṣim Ibrāhīm al-Kayālī, 45-75 (Beirut: Dār al-Kutub al-'Ilmiyya, 2008), 72-73.

12. Yūsuf Ibn 'Abd al-Hādī, Bad' al-'ulqa, 28. Famously, these materials were noticed by George Makdisi in "Ibn Taimìya: A Șūfi of the Qādiriya Order," American Journal of Arabic Studies 1 (1974): 118-29, at 124; idem, "The Hanbalī School and Sufism," Boletín de la Asociación Española de Orientalistas 15 (1979): 115-26, at 123, 125. See also idem, "L'isnād initiatique de Muwaffaq al-Dīn Ibn Qudāma," Cahiers de l'Herne 13 (1970): 88-96.

13. While writing this review, I became aware of Daphna Ephrat, Sufi Masters and the Creation of Saintly Spheres in Medieval Syria (Leeds: ARC Humanities Press, 2021) which may provide answers to some of these questions.

14. Stefan Leder, Yāsīn M. al-Sawwās, and Ma’mūn al-Șāgharjī, Múcjam al-samācāt al-dimashqiyya: Les certificats d'audition à Damas, 550-750/1155-1349, 2 vols. (Damascus: Institut français d'études arabes de Damas, 1996-2000).

15. I make this point in "Hadith Culture and Ibn Taymiyya's Controversial Legacy in Fifteenth Century Damascus: Ibn Nāṣir al-Dīn al-Dimashqī and His al-Radd al-Wāfir (d. 842/1438)," in The Presence of the Prophet in Early Modern and Contemporary Islam: The Prophet between Doctrine, Literature and Arts; Historical Legacies and Their Unfolding, ed. Denis Gril, Stefan Reichmuth, and Dilek Sarmis, vol. 1 (Leiden: Brill, 2021). The work of Ibn Nāṣir al-Dīn in question is al-Radd al-wāfir 'alā man za'ama anna man sammā Ibn Taymiyya shaykh al-islām kāfir, ed. Zuhayr al-Shāwīsh (Beirut: al-Maktab al-Islāmī, 1393 [1973 or 1974]; 2nd rev. ed. 1400/1980).

16. Well argued by Fozia Bora with regard to historiography in Writing History in the Medieval Islamic World: The Value of Chronicles as Archives (London: I. B. Tauris, 2019), 1-7, 12-27. 
between these groups was probably more fluid than one might think. A good illustration of this point is Muhammad b. Aḥmad Ibn 'Abd al-Hādī (d. 744/1343), one of Yūsuf's ancestors. Muhammad, too, was a Șālihiyya-based Hanbalī who was committed to hadith. He studied with the great hadith scholars of the day, al-Dhahabi (d. 748/1348) and al-Mizzī (d. 742/1341), taught in the Șālihịiyya (at al-Ṣadriyya madrasa), and was close to Ibn Taymiyya, whose life he recounted and documented in the most voluminous and important biography of Ibn Taymiyya we possess. ${ }^{17}$ Not only is Muhammad's work well represented in Yūsuf Ibn 'Abd al-Hādī's library, ${ }^{18}$ but Yūsuf also compiled two bibliographies of his ancestor's writings. Yet Muhammad's al-'Uqūd al-durriyya, so important for us, is not included in the fihrist. ${ }^{19}$ Hirschler's book is thus a good reminder of the difficulty we face in figuring out the relationship between these close but diverse groups within the same school of law, a relationship we generally tend to depict as neater than it effectively was. This first chapter also performs a service by reminding us that little has yet been done on post- and extraTaymiyyan Hanbalism.

The book continues by approaching Ibn 'Abd al-Hādī's collection and fihrist from different angles. Chapter 2 addresses the purpose of Ibn 'Abd al-Hādī's project, which was-according to the author-the creation of a monument, or "museum of texts," commemorating Șālihiyya's great legacy of hadith scholarship and transmission (p. 113). Chapter 3 adds to the monumentalization argument by examining the materiality of Ibn 'Abd al-Hâdī's books: the shape of his manuscripts, the layout of their notes, and Ibn 'Abd al-Hādī's archival practices. Chapter 4 retraces the afterlife of Ibn 'Abd al-Hādi's collection. It is here that the exquisite local flavor of Ibn 'Abd al-Hādī's books enters into conversation with the broader history of the nineteenth-century European book trade in the Arab Middle East, through which many of the Oriental manuscript collections of Western libraries took shape. Hirschler convincingly shows that Ibn 'Abd al-Hādì's collection was saved from dispersal by its unattractive character together with the foundation, in 1878, of the Public Library in Damascus, where Ibn 'Abd al-Hādì's corpus was transferred. In the last chapter (chap. 5), the author unpacks the logic of the fihrist and presents the difficulties involved in identifying the works it mentions. The identification of the works, authors, subjects, extant editions, and/or manuscripts for each of the titles listed in the catalog covers the rest of the book and forms its most voluminous part (pp. 198-511).

The argument running throughout the book revolves around the idea that Ibn 'Abd al-Hādī's collection and endowment constituted an attempt to "monumentalise a bygone era of scholarly practices, namely post-canonical hadith transmission" (p. 4). This argument is validated through several

17. Muḥammad b. Aḥmad Ibn 'Abd al-Hādī, al- 'Uqūd al-durriyya min manāqib shaykh al-islām Aḥmad b. Taymiyya, ed. Muhammad al-Hāmid Fiqī (Cairo: Maṭba'at al-Hijāz, 1938). On his life, see Ibn Rajab, al-Dhayl ‘alā țabaqāt al-Ḥanābila, ed. 'Abd al-Raḥmān b. Sulaymān al-CUthaymīn, 5 vols. (Mecca: Maktabat al-'Ubaykān, 2005), 5:117-23.

18. See Hirschler, Monument, 603 for references to the fihrist's entries.

19. Hirschler, Monument, 94, and entries 511-12, 514-15. 
indicators originating from Hirschler's insightful reading of his materials: Ibn 'Abd al-Hādì's careful construction of a corpus of books that consisted mainly of small-scale hadith booklets with a strong Hanbalī-Șāliḥ̂ bent in terms of their transmission history; his transmission notes, which drew renewed attention to booklets that had gone unread for a hundred years; the fihrist itself, which was meant to accompany the books and framed itself as a guide to the (monument's?) visitor; and the repeated readings to which Ibn 'Abd al-Hādì subjected his household in order to bid farewell to his books right before their endowment in 897/1492. Finally, the choice of the endowment's destination-the 'Umariyya Madrasawas not accidental. As the madrasa that embodied the origins of Sāâlihì Hanbalism, it would have been particularly meaningful for somebody like Ibn 'Abd al-Hādī.

Materially speaking, Hirschler argues that Ibn 'Abd al-Hādī's project was reinforced by his creation of a significant set of new books by binding small booklets together into new, largescale composite manuscripts. On these newly bound books, Ibn 'Abd al-Hādī left evidence of his presence by means of distinctive "legalized" transmission notes that functioned, according to Hirschler, as stamps. Contrary to the norm, Ibn 'Abd al-Hâdi wrote his notes on the title page. His presence on his books was thus highly visible and distinctive. Finally, Ibn 'Abd al-Hādì used his newly bound books as archives by sewing into them a significant amount of his paperwork.
For Hirschler, these are all strong markers of Ibn 'Abd al-Hādī's "conscious project of monumentalising what was for him the the glorious past of his hometown" (p. 67).

This book is part of a trend of growing interest in the history of libraries, catalogs, and book collections. ${ }^{20}$ It participates in a wider documentary and material wave that studies archival practices rather than archives and manuscripts as objects rather than as texts, with their own life cycles, specific agencies, and performative functions. It is from this perspective, and not so much from that of intellectual history, that the book approaches the fihrist as well as Ibn 'Abd al-Hādī's extant corpus. In this regard, Hirschler's achievements are manifold. His book illustrates the fascinating historical trajectory of Ibn 'Abd al-Hādī's books, which passed from book markets to Ibn 'Abd al-Hādī's home and then through the 'Umariyya Madrasa, the modern al-Maktaba al-'Umūmiyya, and the Zāhiriyya Library before ending up in the present-day al-Asad National Library, where they sit today. The book makes the long afterlife of this book collection extraordinarily alive. In so doing, it succeeds in showing the debt that a modern-day manuscript library owes to the personal project of a single seventh/ fifteenth-century scholar of middling rank. Equally impressive is the amount of information Hirschler can extract from his material inspection of the manuscripts. It will also be important for scholars who work with Damascene samā'ät to know that 94\% of the manuscript notes that Leder, al-Sawwās, and al-Ṣaghārjī indexed in

20. One significant title among others is Gülru Necipoğlu, Cemal Kafadar, and Cornell H. Fleischer, eds., Treasures of Knowledge: An Inventory of the Ottoman Palace Library (1502/3-1503/4), 2 vols. (Leiden: Brill, 2019). 
their Mu'jam come from Ibn 'Abd al-Hādī's collection (p. 67). Finally, Ibn 'Abd al-Hādī's very personal self-inscription on his books and Hirschler's skillful grasp of it allow the latter to track the provenance of Ibn 'Abd al-Hādī's books even though some of them are now scattered around the world. It is thus a relief to observe that the loss of historical information that normally accompanies unprovenanced objects or manuscripts is significantly reduced here. ${ }^{21}$

I have one further point to raise and one complaint to make. Let me start with the former. As anticipated above, part of Hirschler's agenda is demonstrating that manuscript and documentary sources and their material inspection can yield much information that literary sources do not divulge. In this vein, the contribution of Hirschler's work in general has been influential. Yet at the same time, the book under review also shows how much scholars can gain not by turning away from the dominance of narrative and normative sources ${ }^{22}$ but by activating a fruitful interplay between different types of sources. It is only thanks to Ibn Ṭūlūn that chunks of Ibn 'Abd al-Hādì's history of Șālihiyya have come down to us (pp. 48, 58). And it is Ibn Ṭūlūn, too, who tells us that at some point Ibn 'Abd al-Hādi endowed his books to the al-'Umariyya Madrasa (p. 97). "In fact," writes Hirschler, "we do not have a single note stating that any of his books were endowed to the "Umariyya madrasa" (p. 96). The work on material and documentary sources carried out by Hirschler and others is innovative, refreshing, and inspiring. Now that these materials have begun to receive the attention they deserve, and their value has accordingly begun to be appreciated, serious critical reflection is needed not only on their potential but also on their limitations, if we are to make the most of them.

As for the complaint, it regards the heuristic term devised by Hirschler to explain the aim of Ibn 'Abd al-Hādì's project-namely, the idea, repeated many times throughout the book, that Ibn 'Abd al-Hādī's purpose was to erect a monument to commemorate a golden past of thriving hadith transmission that was focused on the Saalihiyya neighborhood and was on the brink of disappearance by Ibn 'Abd al-Hādì's time. Given the prominence of this argument in the book, ${ }^{23}$ it is surprising that the concept of "monument" as a heuristic tool is never discussed. The absence of such a discussion in an otherwise theoretically rich study has the consequence of making the monument argument not fully convincing. In related literature, monuments are defined as "built forms erected to confer meanings on space." ${ }^{24}$ Recent approaches emphasize that a monument bears multiple meanings

21. Charming discussions by Cecilia Palombo on working with (unprovenanced) collections can be read on the website of the Embedding Conquest project: https://emco.hcommons.org/2021/03/19/it-belongs-in-amuseum-or-does-it/ and https://emco.hcommons.org/2020/12/21/working-with-collections/.

22. Hirschler, "From Archive to Archival Practices," Journal of the American Oriental Society 131, no. 1 (2016): $1-28$, at 3 .

23. See, for example, pp. 4, 67, 72, 80, 83, 87, 89, 92, 94, 95, 111, 112, 117, 138, 140, 141, 145, 149, 152, 155, 156, 157,158 , and 167.

24. Federico Bellentanti and Mario Panico, in "The Meanings of Monuments and Memorials: Toward a Semiotic Approach," Punctum 2, no. 1 (2016): 28-46, advocate a semiotic approach to monuments but also 
that stem from the interplay among its designers, its users, the monument itself, and the surrounding environment. ${ }^{25}$ The spatial dimension of a monument is a central aspect of it. ${ }^{26}$ The issues of space and users are too important to be overlooked. Where and how in the al-'Umariyya Madrasa were Ibn 'Abd al-Hādī's books placed? Were they displayed and thus visually accessible? Hirschler discusses the significance of the 'Umariyya location for Ibn 'Abd al-Hādī in a paragraph titled "Placing the monument" (pp. 103-12), yet the monument is not the "Umariyya building but the collection of books itself. It is thus the spatial positioning of the collection within the "Umariyya with its ensuing consumption "as a monument" that one expects to find discussed here. One might assume that Hirscher uses the word "monument" metaphorically to mean "a tribute to." This does not seem to be the case, however, because the word occurs in the title of the book and too often thereafter to be just a suggestive metaphor. Furthermore, the paragraph on "placing the monument" just mentioned shows that the word is not intended figuratively. Ibn 'Abd al-Hādī's endowment is also referred to as a "museum of texts" (p. 113). Preservation, conservation, and safeguarding are perhaps implicit dimensions here. Yet a museum-like a monument-is also, and above all, a place of visual accessibility and display.

On the contrary, what emerges with great force throughout the book is the highly individual character of Ibn 'Abd al-Hādī's enterprise. In putting together his book collection, in binding insignificant booklets into larger ones, in signing his notes and styling them in a strikingly distinctive fashion, in placing them on the first rather than the last page of his books, in sewing his own paperwork into his manuscripts, and finally in endowing all of this to a famous Hanbali madrasa, this littleknown Hanbali scholar exhibited a robust sense of self. This is a self that appears inextricably tied to his books, which in turn bespoke the scholarly profile of the community Ibn 'Abd al-Hādì belonged to and its chosen place (Șāliḥiyya). In other words, a conscious and deliberate personal project surfaces from Hirschler's material study of Ibn 'Abd al-Hādī's library and catalog. Ibn 'Abd al-Hādī's self-inscription into these materials is so pervasive that both the fihrist and the books could almost be read as material ego documents. This is precisely what strikes the present reader, and it is here that material philology as advocated and practiced by Konrad Hirschler performs at its best.

\footnotetext{
illustrate the main approaches to the subject.

25. Ibid.

26. Henri Lefevbre, The Production of Space (Oxford: Blackwell, 1991), 220-26 (originally published in French in 1974 as La production de l'espace).
} 


\title{
Book Review
}

Mā lidhdhat al-ishq illā li-1-majānīn [Love Is Only for Fools]. Edited by Philip Kennedy, Bilal Orfali, and Maurice Pomerantz. Library of Arabic Literature Young Readers Series (Abu Dhabi: University Bookshop, 2019). ISBN 978-99-4885-880-5.

Hilyākat al-kalām [Weaving Words]. Edited by Philip Kennedy, Enass Khansa, and Bilal Orfali. Library of Arabic Literature Young Readers Series (Abu Dhabi: University Bookshop, 2019). ISBN 978-99-4836-916-5.

Lima ishtadda 'ishq al-insān li-hādhā al-călam? [Why Did Humanity So Love This World?]. Edited by Philip Kennedy, Enass Khansa, and Bilal Orfali. Library of Arabic Literature Young Readers Series (Abu Dhabi: University Bookshop, 2020). ISBN 978-99-4825-962-6.

\author{
Philip Raad \\ American University of Beirut
}

(pjr01@mail.aub.edu)

$\mathrm{T}$ he Library of Arabic Literature (LAL)'s Young Readers (YR) Series offers collections of selected excerpts from premodern Arabic literary texts (https://www.libraryofarabicliterature.org/ar/young-readers). All texts in the series are presented exclusively in Arabic and made available for free online. In their accessible format and their minimal scholarly footnotes and references, the collections are similar to the LAL's parent series of monograph Arabic editions and English translations. In something of a departure into new territory, however, the YR series takes up the LAL's goal of expanding Arabic literature's readership and focuses it on younger readers of Arabic.

The series editors seek to highlight the brilliance of original Arabic texts from the fourth/tenth century while also making them accessible to younger readers. The editors have also involved contemporary visual artists as coeditors in their project. The most visible product of this collaboration is the stimulating complement of interpretive illustrations. A limited number of excerpts from Hiyākat al-kalām (Weaving Words) have also been adapted into audio recordings in Levantine

(c) 2021 Philip Raad. This is an open access article distributed under the terms of the Creative Commons Attribution-NonCommercial-NoDerivatives License, which allows users to copy and distribute the material in any medium or format in unadapted form only, for noncommercial purposes only, and only so long as attribution is given to the original authors and source. 
Arabic by the storyteller Shalabiya Hakawatiya (https://soundcloud.com/lal_ nyuad).

The series contains three titles thus far. Bilal Orfali and Maurice Pomerantz made selections for Mā lidhdhat al-'ishq illā li-1majānin (Love Is Only for Fools), while selections for Lima ishtadda 'ishq al-insān li-hadhā al-cālam? (Why Did Humanity So Love This World?) and Weaving Words were made by Bilal Orfali and Enass Khansa. All three works acknowledge Philip Kennedy as general editor. Illustrations for Love Is Only for Fools, the sole work illustrated in color, and Why Did Humanity So Love This World? were provided by Ward Khalaf. Those for Weaving Words were provided by Jana Traboulsi.

For Love Is Only for Fools, the editors have selected excerpts from Ibn Habīb al-Naysābūrī's (d. 406/1016) 'Uqalā' al-majānīn (Wise Madmen). ${ }^{1}$ The collected selection of anecdotes, lexical treatises, and poetry, even in this abridged form, captures a complex meditation on junūn (folly) and its prominent exemplars in premodern Arabic literature. The editors begin with selections that briefly reconstruct al-Naysābūrī's exposition of the general meaning of junūn. This is followed by a colorful recounting of the tales of prominent majānīn (wise fools). Throughout, al-Naysabūrī withholds judgment and fosters an appreciation of the often humorous or poignant capacity of the majnūn to expose hypocrisy and symptoms of social contradiction. Despite the author's apparent neutrality, readers are led to revel in the fecundity of the wise fool's words and actions. The anecdotes selected suggest that wise fools such as Buhlul and Majnun Layla became important for their capacity to expose the limits of the social imagination, to pierce through appearances, and to expose the essence of social forms. Read in tandem with works of disability history, such as Kristina Richardson's Difference and Disability in the Medieval Islamic World: Blighted Bodies or Sara Scalenghe's Disability History in the Ottoman Arab World, 1500-1800, the excerpts in Love Is Only for Fools allow access to stories of the historical person of the majnün that point to the variety in approaches to social difference across history. ${ }^{2}$ An appreciation of the history of difference can lead to creative thought: How do our own societies treat nonconformity with predominant social norms? And can we imagine, perhaps with Buhlul's help, a society whose formal mechanisms imply a more just treatment of all?

Weaving Words consists of selections from al-Muhassin b. 'Alī al-Tanūkhī's (d. 384/994) anthologies al-Faraj ba'd al-shidda (Deliverance Follows Adversity) and Nishwār al-muhādara wa-akhbār al-mudhākara (The Table-Talk of a Mesopotamian Judge). ${ }^{3}$ The text contains

1. The editors of the YR series drew their selections from the following manuscript: MS New Haven, Beinecke, Beineck-L600 (740/1340). For additional information on this work, see Shereen el-Ezabi, “Al-Naysaburi's Wise Madmen," Alif: Journal of Comparative Poetics 14 (1994): 192-205.

2. Kristina Richardson, Difference and Disability in the Medieval Islamic World (Edinburgh: Edinburgh University Press, 2012); Sara Scalenge, Disability in the Ottoman Arab World, 1500-1800 (New York: Cambridge University Press, 2014).

3. The editors of the series made their selections from the following manuscripts of al-Faraj ba'd al-shidda: MS Istanbul, Fatih Millet Kütüphanesi, Fatih 4013 and MS Istanbul, Nuruosmaniye Kütüphanesi, Nuruosmaniye 
twenty-one selected anecdotes, each two to nine pages in length. Some of these fall within the faraj ba'd al-shidda ("deliverance after adversity") genre, which centers on the tropes of piety in the face of hardship and serendipitous, if at times implicitly divine, deliverance. Those anecdotes that do not fall within the faraj genre are no less enthralling. Read in tandem with academic works such as Julia Bray's article "Reading 'the Exotic' and Organising the Production of Knowledge" or Philip Kennedy's chapter on the faraj genre in Recognition in the Arabic Narrative Tradition, the collected anecdotes might be discussed in a classroom setting in terms of recurring formal components such as the structure of the isnād and the organization of the text around the element of recognition. ${ }^{4}$ Such discussions might also take their cues from the titles given to the three sections by the editors. The first section is entitled Tirḥāl: al-Kashf wa-1-wa'd wa-l-manām ("Travel: Recognition, Oath, and Dream"); the second, Faḍ̄āàt mutashābika: al-Ṣawt wa-1-hajar wa-1-qadar ("Interconnected Spaces: Voice, Stone, and Fate"); and the third, Liqā'āt wa-aqni'a wa-adwār mutaghayyira ("Encounters, Masks, and Changing Roles").

Lima ishtadda 'ishq al-insān li-hādhā al-'̄alam? (Why Did Humanity So Love This World?) contains selections from al-hawāmil wa-1-shawāmil, a collection of correspondence between two prominent contributors to intellectual life in the Islamicate world in the fourth/tenth century. ${ }^{5}$ The first of these is the adīb Abu Hayyān al-Tawhīìī (d. 414/1023), who poses questions (including that which gives the work its title) to the second author, the philosopher-historian Abū 'Alī Miskawayh (d. 412/1030), who answers them. The collection includes thirty-four questions and their answers, separated into three sections under the titles As'ila muqārina ("Comparative Questions"), al-Insān: al- Ishq wa-l-naqș ("Humanity: Love and Lack"), and Masā'il jadaliyya ("Controversial Issues"). The dialogue between the two authors touches on philosophy, religion, science, and language. The text is presented as a reflection of the debates and interests of its time and a mirror of the spirit of rationality that defined it, which found its common thread in a celebration of humanity's desire for understanding. A reading of the text may be supplemented by a discussion of the genre of risāla in early Arabic prose and enriched by comparison with other epistolary works and dialogues of the time.

The LAL Young Readers Series makes a timely suggestion: that the re-presentation of works of premodern writing, in this case in abridged, curated, and illustrated form, might facilitate and enhance an invigorated practice of reading in the present. In making this suggestion, the series has set

4135. For selections from the Nishwār, the editors turned to the printed edition: al-Muhassin b. 'Alī al-Tanūkhī, Nishwār al-muhāạara wa-akhbār al-mudhākara, ed. 'Abbūd al-Shāljī (Beirut: Dār Șādir, 1971).

4. Julia Bray, "Reading 'the Exotic' and Organising the Production of Knowledge: Al-Tanūkhī on Indians and Their Elephants," Asiatische Studien / Études asiatiques 71, no. 3 (2017): 833-56, https://doi.org/10.1515/asia2017-0003; Philip Kennedy, Recognition in the Arabic Narrative Tradition (Edinburgh: Edinburgh University Press, 2016).

5. The editors of the YR series drew their selections from the following manuscript: MS Istanbul, Süleymaniye Kütüphanesi, Ayasofya 2476. 
itself at odds with contemporary culture, which considers premodern literary texts eccentric. The series defiantly asserts the value of premodern Arabic writing for projects of self-reflection and creativity today.

However, without significant pedagogical scaffolding, the difficulty of the texts will likely pose a significant obstacle to the types of reading practices the series editors hope to encourage. Perhaps another way of putting this is that the series has yet to define exactly what it wants to be, preferring instead to be many things at once. The editors of the YR Series will do well to ask themselves the following questions: Is the YR Series in fact a more a valuable contribution to the Arabic classroom than it is to "story time" at home? And if so, could the benefits of an editing process more intimately in touch with pedagogy justify a departure from the LAL's customary evasion of a pedagogical routine, perhaps in the form of investment in the development of lesson plans or other material to supplement the YR texts? In an environment of staunch competition from publishers of children's books and young adult fiction, could the energies of the YR Series be more effectively spent on a concerted effort to facilitate Arabic language and literature pedagogies, or perhaps even multiliteracy and digital social reading? 


\title{
Book Review
}

\author{
Alejandro García Sanjuán. Yihad: La regulación de la \\ guerra en la doctrina islámica clásica (Madrid: Marcial \\ Pons Historia, 2020), 366 pp. ISBN 978-84-17945-10-7. \\ Price: $€ 26.60$ (paper).
}

\author{
Javier Albarrán \\ RomanIslam, Universität Hamburg
}

(j.albarran.iruela@gmail.com)

A s its title points out, this book by Alejandro García Sanjuán, professor of medieval history at the University of Huelva and one of the most prominent scholars of the history of alAndalus, deals with jihād in classical Islam from a very specific angle: the legal-doctrinal one. ${ }^{1}$ This perspective is already evident in the introduction, where García Sanjuán defines jihād as "legitimate war from the Islamic perspective" (p. 17). ${ }^{2}$ And indeed, the sources on which García Sanjuán bases his book are predominantly legal and doctrinal treatises. In the introduction, the author also makes clear his position on the link between violence and religion-namely, that the latter has been an essential factor in the legitimation of the former, another important element of the idea of jihād. This point introduces one of the vitally important topics treated in the book: the significance of not including the idea of jihād within the concept of holy war.

In addition to outlining his selection of sources, García Sanjuán specifies in the introduction how he will address the study of jihād. Compared to other approaches, especially those adopted by nonspecialists who "proclaim themselves 'ulama $\bar{a}$ ' and determine the meaning of these texts by establishing whether the Quran is belligerent or not, and whether Muhammad promoted war or peace" (p. 22), García Sanjuán sets out to let the sources speak for themselves. In this way, he complies with a principle that is consciously present throughout his

1. The book is thus in dialog with works such as Majid Khadduri, War and Peace in the Law of Islām (Baltimore: Johns Hopkins University Press, 1955) and A. M. Al-Dawoody, The Islamic Law of War: Justifications and Regulations (New York: Palgrave Macmillan, 2011).

2. The English translations of the quoted passages are mine.

(C) 2021 Javier Albarrán. This is an open access article distributed under the terms of the Creative Commons Attribution-NonCommercial-NoDerivatives License, which allows users to copy and distribute the material in any medium or format in unadapted form only, for noncommercial purposes only, and only so long as attribution is given to the original authors and source. 
work: "Islam belongs to its believers, who are responsible for defining the meaning of their own beliefs" (p. 22). As we will see later, despite its utility as a maxim with which to establish the meaning of a concept in the sources, this is a somewhat risky statement.

The first chapter, titled "Las bases textuales" (The textual bases), constitutes an excellent analysis not only of the concept of jihād in the Quran, the Sunna, and the biography of the Prophet but also of the main works of Islamic law. After a careful examination of the Quranic vocabulary related to combat, violence, and warfare, García Sanjuán addresses the complex question of whether there is a Quranic doctrine on war, understood as a set of clear, systematic, and wellarticulated norms. His answer, derived from the study of the Quranic text itself as well as of the opinions of various specialists such as Patricia Crone ${ }^{3}$ and Asma Afsaruddin, ${ }^{4}$ is that the more warlike readings of the Holy Book emerged after the establishment of the Quranic text. By analyzing the opinions of medieval scholars, García Sanjuán illustrates in a simple but forceful way how classical thinkers took into account the ambiguous meaning of many Quranic verses, thus giving voice, as the author has proposed to do, to the sources themselves.

Also of great interest is the section devoted to the deeds of Muhammad and the formation of the prophetic tradition, where García Sanjuán analyzes the importance of hadith, but also that of the sìra and the maghāzī, for the establishment of the doctrine of jihād. Like his discussion of the Quranic text, this part includes a brilliant introduction to these genres and the debates around them. The same can be said of the section devoted to the elaboration of fiqh, which also serves as an introduction to the sources used by the author.

The second chapter aims to answer the question posed by its title: “¿Qué es el yihad?" (What is jihād?). García Sanjuán's answer is clear and accurate: despite the diversity of concepts and practices, there is a hegemonic vision within the Muslim tradition of how to engage in jihād, and this centers on its connection with war. As García Sanjuán says, "there are justified reasons to speak of an intense sacralization of the martial dimension of jihad, which allow us to place it [jihād] within the framework of the concept of holy war" (p. 106). One of the main reasons is the direct relationship between the practice of jihād and the salvation of the soul. This does not prevent the author from also discussing, in detail, the nonviolent forms of jihād, which are mainly related to Sufism. However, as García Sanjuán states, it is not possible to establish a dichotomy between the warlike jihād of the 'ulamā' and the spiritual jihād of the Sufis, since war remained, in works such as that of Ibn al-Mubārak, conceptualized as a form of asceticism (pp. 109-10).

This chapter also discusses the important relationship between hisba and jihād through the practice of takfir. Here, García Sanjuán studies what he calls "sectarian jihād," jihād carried out

\footnotetext{
3. Patricia Crone, "Jihad: Idea and History," Open Democracy (2007).

4. Asma Afsaruddin, Striving in the Path of God:Jihād and Martyrdom in Islamic Thought (New York: Oxford University Press, 2013).
} 
against other Muslims. He illustrates this section with examples from the Islamic West, such as the case of the Almohads, and compares this reality with that of the crusades launched against Christians who were considered heretics. This interesting cross-cultural perspective could have been developed by the author also in other cases.

Next, García Sanjuán analyzes a recurring but necessary theme in this type of work: that of the place of jihād in the hierarchy of Islamic beliefs, and what type of duty it is. He also addresses another key issue, which is that the notion of holy war in Islam should not be limited to the idea of jihād but should also encompass other concepts, such as ribāt, fath, and shahāda. This point is relevant for future research on the idea of holy war in the Islamic world from a holistic perspective. García Sanjuán concludes that the notion of fath (divinely sanctioned conquest) constitutes the highest expression of the sacralization of war in Islam, even more so than jihād, since this notion casts God as the subject of the action. However, and despite agreeing with the author on the importance of fath to the sacralization of war in Islam, one may object that the agent of fath is not always God. As just one example, Ibn Abi Zar', in his Rawd al-qirțās, reports that the Almohad caliph 'Abd al-Mu'min conquered (fataha) all of the Maghrib. ${ }^{5}$ Conversely, God appears as the subject of warfare also in other concepts, such as nașr (divine aid). ${ }^{6}$ What we find in the sources, to return to García Sanjuán's approach, is a concept of the sacralization of war manifested through various complementary terms. Undoubtedly, the manifestation of God in the contexts of jihād, especially through "His help" (nașr), is one of the main features of holy war. ${ }^{7}$ This chapter ends with another interesting terminological analysis focused on the interruption of hostilities.

The third chapter, titled "¿Cuáles son los límites de la práctica del yihad?" (What are the limits to the practice of jihād?), focuses on the significant Islamic legal corpus related to ius in bello, that is, the behavior of combatants in war. As García Sanjuán says, the limits imposed on the practice of jihād are a fundamental element of the classical notion of jihād. The chapter analyzes, in depth and with an impeccable use of sources, issues such as the distinction between combatants and noncombatants, protected groups, the treatment of prisoners, the use of weapons of indiscriminate destruction, destruction of property, and self-harm and martyrdom. The extensive elaboration of these issues in Islamic legal and doctrinal treatises leads García Sanjuán to consider fiqh the first great legal system to contain a specific doctrine of ius in bello, thus anticipating modern public international law by several centuries. Here a brief reference to the theory of just war, at the time under development and revision in both

5. Ibn Abī Zar', Kitāb al-anīs al-muțrib rawḍ al-qirțās fî akhbār mulūk al-Maghrib wa-ta’rīkh madīnat Fās (Rabat: Dār al-Manșūr, 1972), 204.

6. See, for example, M. A. Makki, "Wathā’iq ta’rījiyya yadīda 'an 'aṣr al-murābiținn (Documentos inéditos de la época almorávide)," Revista del Instituto de Estudios Islámicos 7/8 (1959-60): 109-98 (letter no. 2).

7. See, for example, Dominique Urvoy, "The Question of Divine Help in the Jihād," in Violence in Islamic Thought from the Qur'ān to the Mongols, ed. Robert Gleave and István Kristó-Nagy, 27-32 (Edinburgh: Edinburgh University Press, 2015). 
the Greco-Roman and Western medieval traditions as well as in Islamic thought, ${ }^{8}$ would have been of interest to demonstrate that just-war theory also developed a ius in bello doctrine, even though it did not reach the level of normative development present in fiqh. Frederick Russell's definition of this theory highlights the overlap: "Content with the achievement of more concrete political objectives, the just war stops short of countenancing the utter destruction of the adversaries and tends to limit the incidence of violence by codes of right conduct, of non-combatant immunity and by other humanitarian restraints."

The fourth and final chapter of the book is the most innovative of all, at least from the point of view of the posed question: "¿Por qué el yihad ha sido un concepto polémico y tergiversado?" (Why has jihād been a controversial and distorted concept?). This chapter-which is connected to other seminal works of historiographical criticism written by the author ${ }^{10}$-analyzes the different ways in which the conceptualization of jihād has been adulterated, especially as a result of the fall of the Iron Curtain, the appearance of the theory of clash of civilizations, and the growing accentuation of the role of Islamist radicalism in international politics. García Sanjuán denounces the mainstream media's identification of Islam with terrorism through a manipulation of the idea of jihād, evident in the writings of nonspecialists who "proclaim themselves Islamic scholars," such as Antonio Elorza, ${ }^{11}$ and he traces the genealogy of this Islamophobic perspective from the medieval polemic tradition, paying special attention to the Spanish case-an example of great importance due to the Islamic past of the Iberian Peninsula.

Following the approaches laid out in the introduction, García Sanjuán emphasizes that "the role of religious texts in the analysis of violence should not be placed on the level of causes, but rather on that of its justification or legitimation" (p. 294), a point that serves as a preamble to a refutation of what he calls "the fallacy of Islamic exceptionalism" (pp. 294-95), that is, the erroneous idea that Islam is a violent religion per se. However, it would have been interesting if, when dismantling this fallacy, the author had referred to some of the studies that have tried to contextualize the rise of Islam within the framework of Late Antiquity and the ideas of religious violence that were circulating at the time. ${ }^{12}$ Likewise, inserting García Sanjuán's considerations into the broader debate on the relationship between violence and religion would have been fruitful. ${ }^{13}$ Within

8. See, for example, James Turner Johnson and John Kelsay, eds., Just War and Jihad:Historical and Theoretical Perspectives on War and Peace in Western and Islamic Traditions (Westport, CT: Greenwood Press, 1991), and John Kelsay, Arguing the Just War in Islam (Cambridge, MA: Harvard University Press, 2007).

9. Frederick Russell, The Just War in the Middle Ages (Cambridge: Cambridge University Press, 1975).

10. See, for example, Alejandro García Sanjuán, La conquistaislámica de la Península Ibérica yla tergiversación del pasado: Del catastrofismo al negacionismo (Madrid: Marcial Pons Historia, 2013).

11. Antonio Elorza, "Anatomía de la yihad en el Corán y los hadices," in El nuevo terrorismo islamista:Del 11-S al 11-M, ed. Fernando Reinares and Antonio Elorza, 269-94 (Madrid: Temas de Hoy, 2004).

12. See, for example, Thomas Sizgorich, Violence and Belief in Late Antiquity: Militant Devotion in Christianity and Islam (Philadelphia: University of Pennsylvania Press, 2009).

13. See, for example, Jan Assmann, Die Mosaische Unterscheidung oder der Preis des Monotheismus 
his discussion of the misrepresentation of jihād, García Sanjuán also rightly includes those authors who, from a confessional and apologetic perspective, have tried to separate the "historical" idea of jihād from any warlike vision. ${ }^{14}$

This book is, therefore, an exceptional exercise in close reading, scholarship, and historiographical practice. As such, it raises a series of questions for the interested reader that, more by way of dialogue than minor criticism, I would now like to point out. In the first place, although García Sanjuán reiterates throughout the book the conclusion that the historically hegemonic aspect of jihād is undoubtedly that of holy war, sometimes it seems that he is reluctant to use this notion of sacralized violence, preferring to employ definitions such as the abovementioned "legitimate war from the Islamic perspective" (p. 17). Without being wrong, this framing is, in the view of the present reviewer, not entirely clear, since jihād is not the only "legitimate" war within the Islamic tradition. ${ }^{15}$ More precisely, within the Islamic tradition it is the sacralization of jihād that differentiates it from other types of legitimate wars (such as those waged against rebels), through, for example, its salvific character, as García Sanjuán rightly establishes.

Second, as noted earlier, the principle established by García Sanjuán in the introduction-that Islam belongs to its believers, who ought to be the ones to define their beliefs-is somewhat risky. I believe that the interpretation, for example, of the Quran in its historical context is not incompatible with the analysis of what the medieval 'ulama $\bar{a}$ ' said about the Quranic text, even though such interpretation can yield results that differ from those enunciated by Muslim believers. Following García Sanjuán's premise, many of the studies on early and medieval Islam that he quotes would be invalid. For example, reaching a conclusion such as Afsaruddin's, when she says that the warlike reading of jihād constitutes a "considerable deviation" from its Quranic meaning, could not be deemed methodologically valid. ${ }^{16}$ How can she correct and judge the medieval 'ulamā'? The problem with authors such as Elorza is not their "self-proclamation" as 'ulamā'

(Munich: Carl Hanser Verlag, 2003) and William T. Cavanaugh, The Myth of Religious Violence:Secular Ideology and the Roots of Modern Conflict (Oxford: Oxford University Press, 2009).

14. A clear example is the work of Louay Fatoohi, who analyzes the Quran exclusively, highlighting the spiritual vision of jihād and ignoring the fact that it was the medieval 'ulamā' themselves who interpreted the idea within a warlike framework: L. Fatoohi, Jihad in the Qur'an: The Truth from the Source (Birmingham: Luna Plena, 2009).

15. See, for example, Khaled Abou El Fadl, Rebellion and Violence in Islamic Law (Cambridge: Cambridge University Press, 2001).

16. On the other hand, Afsaruddin's work, focused on Quranic exegesis, could be used as another example of studies that have misrepresented the notion of jihād, in this case to downplay its warlike character. See Christopher Melchert's review of Afsaruddin's book in Review of Middle East Studies 49, no. 2 (2015): 175-78. As Melchert states, "a natural concern of an historian is what Islam has been like, of a theologian what Islam ought to be like. This book tries to enlist an historical survey in aid of a theological argument. Perhaps theologians will find it unusually scholarly. As an historian, I find it disappointingly unrigorous." On the early Quranic exegetical sources regarding jihād, see Andrew Rippin, "Reading the Qur’ān on Jihād: Two Early Exegetical Texts," in Gleave and Kristó-Nagy, Violence in Islamic Thought, 33-48. 
and their interpretation of the Quran despite not being Muslims, but rather the decontextualized way in which they carry out their interpretation and their lack of training and specialization for this task, as most of them lack any knowledge of the Arabic language or the Islamic exegetical tradition.

Third, and given the legal-doctrinal approach of the book, it presents a perspective that could be further nuanced, at some points, by the use of other sources, such as chronicles or biographical dictionaries. A clear example concerns the limits to the practice of jihād, which are greatly blurred if we depart from the purely legal approach. A wide selection of sources and different perspectives is essential in a study on a broad notion such as jihād, and thus brief reference to the multidimensional perspective provided by other sources could have been helpful to the reader. In the same vein, sometimes a better contextualization of the authors and sources analyzed could have been useful for a better understanding of the approaches and meanings they propose. An illustrative example is that of Ibn Hazm, whose vision of jihād should, I think, be attributed not only to his Zāhirism but also to the threatening situation that al-Andalus was facing in the eleventh century. García Sanjuán rightly highlights this issue when talking, for example, of how pilgrimage and jihād are equated in the texts of Ibn Rushd al-Jadd.

These points notwithstanding, this is an outstanding book written by one of the leading Spanish scholars of Islamic studies and Islamic history, and its publication is undoubtedly a milestone in the analysis of jihād, for three main reasons. The first is the book's indubitable meticulousness and accuracy in approaching its sources, not an easy task considering the amount and complexity of Islamic legal-doctrinal literature. In this sense, it is also worth mentioning the author's comprehensive use of secondary literature. The second reason is that the author adds to his rigor a clarity of expression and explanation as well as a capacity for synthesis, allowing the book to be directed to a wider public, in line with the commitment to society that García Sanjuán has always exhibited in his work as a historian. ${ }^{17}$ Third, and relatedly, this work fills in a rather astonishing gap: it is the first academic monograph in Spanish to systematically address the concept of jihād. Fortunately, in the last year other books on the topic, likewise written from a historical perspective, have been published, thus beginning to fill this gap. ${ }^{18}$ García Sanjuán's book, therefore, has opened a line of research that will hopefully be followed in the coming years.

17. For example, he is one of the creators and editors of the open access online magazine on Andalusi history Al-Andalus y la Historia: https://www.alandalusylahistoria.com/. He is also a regular contributor to many newspapers; see, for example, https://www.infolibre.es/noticias/opinion/plaza_publica/2021/02/15/ convivencia_invasion_genocidio_pasado_peninsular_116649_2003.html.

18. See, for example, Javier Albarrán, Ejércitos benditos: Yihad y memoria en al-Andalus (siglos X-XIII) (Granada: Universidad de Granada, 2020) and Josep Suñé, Guerra, ejército y fiscalidad en al-Andalus (ss. VIIIXII):De la hegemonía musulmana a la decadencia (Madrid: La Ergástula, 2020). 


\title{
Book Review
}

\author{
Ana Labarta (with Carmen Barceló). Anillos de la \\ Península Ibérica, 711-1611 (Valencia: Editorial \\ Angeles Carrillo Baeza, 2017), 324 pp. ISBN 978-84- \\ 9464-375-0. Price: $€ 85.00$ (cloth).
}

\author{
Maribel Fierro \\ Consejo Superior de Investigaciones Científicas \\ (Madrid, Spain)
}

(maribel.fierro@cchs.csic.es)

$\mathrm{T}$ his book collects information on the rings found in or originating from the Iberian Peninsula that are linked to the three religious communities (Jewish, Christian, and Muslim) that lived there from 711 to 1611. This was, of course, the period of Islamic presence in the Iberian Peninsula down to the expulsion of the Moriscos.

Following the study (pp. 1-92), the catalog (pp. 93-320)-which features data about where and how the rings were found, their present locations, their material features, their epigraphy (if any), and the relevant academic literature, along with images-is divided into three main sections. These are devoted, respectively, to rings found in Islamic, Jewish, and Christian contexts. The rings listed are made overwhelmingly of silver with a few of gold, which raises a number of questions that the author discusses (p. 51): Were there no gold rings? Were gold rings reused, and would such reuse explain their disappearance? Did the gold rings preserved belong to women or to Jews, given that Muslim men were forbidden to use them? Rings made of other materials (black jet, glass, ivory, or bone) are dealt with in the following sections. The catalog ends with sections on other circular objects that were not used as rings, anomalous cases, a group of Basque-Navarrese rings that present peculiar features, and cases on which there is incomplete information. One index lists the rings' places of origin and another the places where they are now preserved.

The author is Ana Labarta, professor of Arabic and Islamic studies at the University of Valencia and a scholar known for her research on subjects as varied as astrology, magic, chancery letters, seals, Arabic place-names, food,

(c) 2021 Maribel Fierro. This is an open access article distributed under the terms of the Creative Commons Attribution-NonCommercial-NoDerivatives License, which allows users to copy and distribute the material in any medium or format in unadapted form only, for noncommercial purposes only, and only so long as attribution is given to the original authors and source. 
and clothing. Together with Carmen Barceló (her collaborator in this book), she has also worked on the Arabic poetry written in the Iberian Peninsula during the fifteenth and sixteenth centuries, and on the Arabic texts produced by the Muslim minority in Valencia from 1401 to 1608. The two scholars have produced fascinating books on these topics, ${ }^{1}$ all of which were published, like the bulk of Labarta's solo research, in Spanish. This means that the books' circulation has not matched their scholarly importance.

Labarta's interest in rings started in 2013, when she was asked to read the Arabic epigraphy inscribed on eight carnelians, some held in rings, found in graves from caliphal Cordoba. To gain a broader perspective, she looked for previous studies on rings and found that rings have seldom been included in studies devoted to metals. Indeed, the extant bibliography was scarce, scattered, and fragmentary. This monograph, therefore, is a most welcome addition to our knowledge of the material culture of the three religious communities that lived in the Iberian Peninsula.

Labarta begins her study by reviewing what we know about the pre-Islamic situation, paying attention to Roman and Visigothic rings. I learned from this section that there is no evidence for the presence of people who dressed in Visigothic styleand used Visigothic rings-in the southern regions of the Iberian Peninsula (the Betica). The Islamic conquest introduced noticeable formal and other changes (p. 53). The earliest dated rings are all made of silver and are inscribed with Arabic legends in negative, which indicates their use as seals (p. 54). The Almohad period appears also to have prompted changes (p. 55). The medieval religious, legal, and cultural norms related to the use of rings-whatever such norms there wereare dealt with in an illuminating section that highlights the Māliki dislike of men's using gold or iron rings; as mentioned, this prohibition is to be related to the almost complete prevalence of silver rings found in Islamic contexts (p. 51). A few rings have even been recovered from Muslim graves. For example, a Muslim woman buried in caliphal Cordoba had two rings with gemstones on her hands and another gem in her mouth, all of them inscribed with the complete Islamic profession of faith. Such cases, as noted by Labarta, are exceptional, and we have to date no explanation for them, given the general Islamic insistence on burying the dead without any grave goods. Especially thought-provoking are rings found in burials that seem to challenge religious boundaries, such as one in which the corpse had a ring with a cross in one hand and in the other a ring with the Arabic inscription "There is no god but God." Equally interesting is the fact that rings associated with Jewish contexts are dated between 1350 and 1492, which suggests that before 1350 the rings used by Jews were indistinguishable from others (p. 32). The inscriptions in Arabic used in the early Islamic period include the Quranic expression hasbi Allāh ("God is enough

1. Carmen Barceló Torres and Ana Labarta, Cancionero morisco:Poesía árabe de los siglos XV y XVI (Valencia: Editorial Angeles Carrillo Baeza, 2016); Carmen Barceló Torres and Ana Labarta, Archivos moriscos: Textos árabes de la minoría islámica valenciana 1401-1608 (Barcelona: Publicacions de la Universitat de València, 2009). 
for me"), present on rings found in funerary contexts. The same formula reappears later, in Almoravid times, but on coins. ${ }^{2}$ Sometimes the inscriptions also include names, information that enriches our knowledge of Iberian onomastics; one of the fascinating contributions of Labarta's study concerns a ring found in Ecija on which a member of the Berber Banū Tājìt-well attested in chroniclesis mentioned (p. 125). Labarta also pays attention to the moulds used for casting the rings, some of which have appeared in archaeological excavations, and to forgeries. A useful appendix on the inscriptions used, according to literary sources, by Andalusi rulers and others on their seals is also included.

Labarta sounds cautionary notes regarding the interpretation of the materials she has collected, such as the (in fact extremely limited) extent to which modern North African jewellery continues Andalusi practices (p. 58). She is also not shy in stating the limits of her knowledge as regards, for example, the reasons for the choice of certain gemstones (p. 61).
Labarta's study is concise but rich in insights and also in questions for which there are no easy answers. It also includes much more than just her research on rings. When dealing with the issue of how to explain the presence of objects in Muslim graves, she points out that we similarly have no explanation for the presence of corpses buried in non-Islamic bodily positions in Muslim cemeteries (p. 31). One can only hope that this comment is a signal that she may be considering preparing a monograph on Islamic burial practices in the Iberian Peninsula. Al-Andalus is a region of the Islamic world for which we have studies on a considerable variety of topics, but there are still lacunae that need to be filled through the type of rigorous and innovative scholarship at which Labarta excels and that allows for wellgrounded and significant advances in our understanding of the religious and cultural landscape of medieval Iberia. When reading any study by Labarta, one can be sure that most of what one encounters is new evidence, something that is often as rare as medieval Iberian gold rings.

2. Miguel Vega Martín and Salvador Peña Martín, "Allah hasbi, lema coránico (IX:129) en una moneda meriní hallada en Granada,” Miscelánea de Estudios Arabes y Hebraicos: Sección Arabe-Islam 51 (2002): 327-38. 


\title{
Book Review
}

\begin{abstract}
Daniella Talmon-Heller. Sacred Place and Sacred Time in the Medieval Islamic Middle East: A Historical Perspective. Edinburgh Studies in Classical Islamic History and Culture (Edinburgh: Edinburgh University Press, 2020), $x+279$ pp, 28 illustrations, 1 map, index. ISBN 978-14-7446-096-5. Price: \$105.00 (cloth), \$24.95 (paper).
\end{abstract}

\author{
Kader Smail \\ University of Maryland, College Park
}

(ksmail@terpmail.umd.edu)

O ver the last two decades, Daniella Talmon-Heller has published widely on religion and social practices in the medieval Islamic world. Recently, she edited a remarkable volume that sought to integrate material and textual evidence for the study of the medieval and modern Middle East. ${ }^{1}$ The book under review inaugurates a new theme. At the intersection of history, anthropology, and religion, Sacred Place and Sacred Time in the Medieval Islamic Middle East examines the dual issues of sacred place and sacred time while surveying the development of rites associated with them. The book is divided into two parts. The first part studies the sanctification of the martyrdom of al-Husayn, Muhammad's grandson and 'Alī's second son, through the construc- tion of two shrines, in Ascalon and in Cairo, that purportedly hold the head of the martyr. The second part investigates the month of Rajab, the seventh month of the Islamic calendar, whose sanctity, both acknowledged and disputed by generations of scholars, was characterized by truces, pilgrimage to the sanctuary of Mecca, ritual slaughter, fasting, prayers, and supplications. The geographical scope of the book is for the most part restricted to Egypt and Palestine; the period considered extends from Fatimid Ismā'īlī rule (358-567/969-1171) to the Mamluks (548923/1250-1517).

The author convincingly demonstrates how the shrines of al-Husayn and the month of Rajab were venerated, how the rites performed in public were promoted

1. See Daniella Talmon-Heller, Islamic Piety in Medieval Syria:Mosques, Cemeteries and Sermons under the Zangids and Ayyūbids (1146-1260), Jerusalem Studies in Religion and Culture 7 (Leiden: Brill, 2007); Daniella Talmon-Heller and Katia Cytryn-Silverman, eds., Material Evidence and Narrative Sources: Interdisciplinary Studies of the History of the Muslim Middle East, Islamic History and Civilization 108 (Leiden: Brill, 2015).

C 2021 Kader Smail. This is an open access article distributed under the terms of the Creative Commons Attribution-NonCommercial-NoDerivatives License, which allows users to copy and distribute the material in any medium or format in unadapted form only, for noncommercial purposes only, and only so long as attribution is given to the original authors and source. 
by rulers, and, most importantly, how old beliefs and practices were adjusted to fit changing historical circumstances. Talmon-Heller draws on a large variety of narrative sources, both Sunni and Shi $i$, and frequently combines them with material ones. Authors such as Nāșir-i Khusraw (d. between 465/1072 and 471/1078), al-Bīrūnī (d. ca. 440/1050), Ibn Țāwūs (d. 664/1266), and Ibn Taymiyya (d. 728/1328), to name but a few, provide a broad spectrum of travelogue, historical, and legal literature. In a detailed historiographical discussion ("The State of the Art"), Talmon-Heller offers a survey of modern scholarship, especially on sacred spaces. She notes the relative scarcity of works on time; most such works, according to her, deal primarily with scientific computation of the hijri calendar rather than with calendars as cultural artifacts (p. 19).

This discrepancy is also reflected in the book's structure, which raises a few issues. While its two parts are roughly of the same length, the first contains eleven chapters, five of them excursuses, whereas the second consists of seven chapters and three excursuses. As the author explains, the excursuses aim to "supplement the narrative of each part of the book, digressing from the main plotlines in order to elaborate on a number of themes" (p. 6). Yet, given their similarities, two excursuses could have been merged with the preceding chapters (chaps. 4-5 and 6-7). Two others merely list treatises in praise of Ascalon and the sacred months in Islam without building on what might have constituted a solid working basis for a more substantial discussion (chaps. 9 and 20). Finally, an excursus on Saladin and al-Husayn in Palestinian folklore teleports the reader from medieval times to the twentieth century but contributes little to the general discussion (chap. 11). Inevitably, this organization creates a serious imbalance between the two parts, which is exacerbated by the eight excursuses.

With regard to content, the book's epistemological framework is well defined and particularly welcome in an often theory-poor field. For the reasons explained above, the emphasis here is exclusively on sacred spaces. TalmonHeller considers what a sacred space is and what can be inferred from its geographical location. In response to the first question, she offers an overview of Mircea Eliade's concept of axis mundi: "Every microcosm, every inhabited region has a center, that is to say, a place that is sacred above all," says Eliade, and this place symbolizes the connection between heaven and earth or the higher and lower realms. ${ }^{2}$ TalmonHeller then turns to the second question and discusses Victor Turner's theoretical model of pilgrimage, commonly referred to as "the center out there." Turner noticed the remoteness and distinctness of many popular pilgrimage sites from sociopolitical centers. ${ }^{3}$ Finally, Talmon-Heller presents and largely adopts Erik Cohen's continuum approach between Eliade's and Turner's centers, which throws new

2. Mircea Eliade, Images and Symbols: Studies in Religious Symbolism, trans. Philip Mairet (New York: Sheed \& Ward, 1961), 39-51.

3. Victor Turner, “The Center Out There: Pilgrim's Goal," History of Religions 12, no. 3 (1973): 191-230. 
light on the anthropological study of pilgrimage. ${ }^{4}$ Succinctly, according to Cohen, pilgrimage sites are either "formal" or "popular" centers, and several criteria determine where they are to be placed on the spectrum. In Talmon-Heller's words, these criteria are

the observance of formal Islamic devotions vs. the use of relics and ritual objects; sponsorship by the political or religious establishment vs. initiatives "from below"; and the availability (vs. absence) of entertainment and commerce at or near the site. The "excessive" presence of women was often regarded-especially by men of religion, and sometimes also by ruling authorities-to indicate a deviation from proper and "serious" religious activity (p. 11).

In the case of al-Husayn's shrine, the pilgrimage site is initially a popular center, then eventually becomes a formal one.

Talmon-Heller argues that the shrine where al-Husayn's head was buried in Ascalon was possibly a burial place of decapitated Christian martyrs in the early fourth century CE (p. 62). Little is known about Ascalon between the fourth and eleventh centuries CE; churches were built and destroyed, and a mosque was constructed in 155/771-72. More than three centuries later, in 484/1091, the Fatimid vizier Badr al-Jamālī (d. 487/1094) commissioned a long inscription on a minbar found among the ruins in Ascalon that commemorates the discovery of al-Husayn's head (p. 46). Apart from this source, the evidence associating
al-Husayn's head with Ascalon postdates the Fatimid-era inscription. Talmon-Heller acknowledges this lack of evidence. What is also lacking from her audacious and fascinating history in the longue durée is twofold: on the one hand, there is no historicization of al-Husayn's memory; on the other, there is no attempt to make sense of any of the twelve sites the book identifies that commemorate the voyage of the head throughout the Middle East. Both of the ignored phenomena are connected to the Battle of Karbalā' and, more specifically, with the shaping of the memory of this tragic episode.

In an article on the memorialization of Karbalā', Antoine Borrut demonstrated that this episode, which was "often reduced, in fact, to a police operation directed against a rebel refusing to acknowledge caliphal authority," was remembered differently under the Umayyads and the Abbasids. During the reign of the former, historical information circulated primarily in Medina and Kufa, where the 'Alids' memories were preserved. The traumatic memory of the defeat and assassination of the grandson of the Prophet Muhammad was subjected to caliphal repression of the 'Alids, while pro-Umayyad discourses favored strategies to silence the episode or deflect blame onto local actors. During the reign of the Abbasids, the 'Alids became the victims and martyrs in whose name the Abbasids were "seeking vengeance and legitimacy" and whose memory was to be gradually revived. The redemption of 'Alid memory, as recalled by Borrut, seems to have followed the paradigm suggested by Stephen Humphreys: covenant, betrayal,

4. Erik Cohen, "Pilgrimage Centers: Concentric and Excentric," Annals of Tourism Research 19, no. 1 (1992): 33-50. 
and redemption. Thus, "the redemption process starts early, chiefly with the Tawwābun, but is not complete until Husaynid memory has been redeemed in "Abbāsī sources," after nearly two centuries. ${ }^{5}$

To return to the book under review, it seems clear that a shrine visited by Sunnis and Shicis alike must commemorate something meaningful for both. The history of the process leading to this shared practice is missing from the book. ${ }^{6}$ Similarly, with respect to the numerous shrines commemorating the voyage of al-Husayn's head, one wonders to what extent these sacred places, which are de facto sites of memory, are part of the long process of redemption and of the sacred geography contributing to Ascalon's prestige.

In the second part of the book, the author examines the month of Rajab, the rites associated with it, and their evolution between the first/seventh and ninth/fifteenth centuries. Celebrated in Arabia before the rise of Islam, Rajab was connected to the springtime festivities of the peninsula and the ban on warfare. Although it goes beyond the scope of the present work, this phenomenon is somewhat reminiscent of the "peace and truce of God" (Pax et treuga Dei) in
Europe during the Middle Ages, a topic that has generated a rich scholarship. ${ }^{7}$ A comparison of the two environments (and other non-Western contexts) remains to be done. For several generations, Talmon-Heller argues, the Rajab visitation of Mecca was an individual practice. In the fourth/tenth century under the Fatimids, however, it became a formal public commemoration in Egypt and northern Syria. The Fridays of the month were marked by special sermons given in the presence of the ruler (p. 155). From this point onward, Rajab took on a new dimension. A new communal devotion, the prayer of great rewards (salāt al-raghāìib), surfaced in Jerusalem around the fifth/ eleventh century (p. 183). The Mamluk sultan Baybars (d. 676/1277) incorporated the procession of the kiswa and the mahmal into the annual caravan that left Cairo for Mecca in Rajab 661/1263 (p. 206). Liturgical texts were produced to frame religious practices during Rajab. As in the case of al-Husayn's shrines, some medieval scholars-exclusively Sunnisargued against the sanctity of Rajab; in this specific case, they pointed out the absence of evidence designating certain days as "special." Besides the very descriptive approach of this second part, its main weakness lies in its disconnection from

5. Antoine Borrut, "Remembering Karbalā’: The Construction of an Early Islamic Site of Memory," Jerusalem Studies in Arabic and Islam 42 (2015): 249-282 (quotations from pp. 249, 269, 271); R. Stephen Humphreys, "Qur'ānic Myth and Narrative Structure in Early Islamic Historiography," in Tradition and Innovation in Late Antiquity, ed. Frank M. Clover and R. Stephen Humphreys (Madison: University of Wisconsin Press, 1989), 271-90.

6. On the same topic, see Stephennie Mulder, The Shrines of the 'Alids in Medieval Syria: Sunnis, Shi' is and the Architecture of Coexistence (Edinburgh: Edinburgh University Press, 2014), chap. 2.

7. See Hartmut Hoffmann, Gottesfriede und Treuga Dei, Schriften der Monumenta Germaniae Historica 20 (Stuttgart: A. Hiersemann, 1964); Thomas Head and Richard Landes, The Peace of God: Social Violence and Religious Response in France around the Year 1000 (Ithaca, NY: Cornell University Press, 1992); Dominique Barthélemy, L'an mil et la paix de Dieu: La France chrétienne et féodale, 980-1060 (Paris: Fayard, 1999). 
the first one. Indeed, visiting al-Husayn's shrines in Rajab confers no additional merit. The Karbalā' episode, for instance, offers the opportunity of studying the case of Muharram, which is, like Rajab, one of the four sacred months of the Islamic calendar. The month of Ramaḍān could also have been an excellent choice.

Yet this potential weakness is also, paradoxically, a strength insofar as the reader can read one part or the other without losing the common thread of the book. In the "Final Comment" (i.e., general conclusion), Talmon-Heller points out that sacred place and time both aim to promote and develop humans' sanctity through rites. This element is what links the two parts of the book. On another level, the author identifies new avenues of research to be studied: on the one hand, the social dimension of festivities associated with sacred space and time creates numerous opportunities for philanthropy; on the other, large-scale patronage by rulers and members of the elite redefines the contours of local identities.

This book contributes another element to the field of sanctity in Islam alongside the contributions of Arezou Azad (2013), Yaron Friedmann (2013), Harry Munt (2014), and Stephennie Mulder (2014). ${ }^{8}$

8. Arezou Azad, Sacred Landscape in Medieval Afghanistan: Revisiting the "Fad̄āil-i Balkh" (Oxford: Oxford University Press, 2013); Yaron Friedmann, “Kūfa Is Better': The Sanctity of Kūfa in Early Islam and Shī'ism in Particular," Le Muséon 126, no. 1-2 (2013): 203-37; Harry Munt, The Holy City of Medina: Sacred Space in Early Islamic Arabia (New York: Cambridge University Press, 2014); Mulder, Shrines of the 'Alids. 


\title{
Book Review
}

\author{
Wendy M. K. Shaw. What Is "Islamic" Art? Between Religion and \\ Perception (Cambridge: Cambridge University Press, 2019), xix + \\ 366 pp. ISBN 978-11-0847-465-8. Price: $\$ 28.85$ (cloth).
}

\author{
Sarah Slingluff \\ University of Edinburgh
}

(S.E.Slingluff@sms.ed.ac.uk)

A s Wendy Shaw states in her introduction, What Is "Islamic" Art? Between Religion and Perception aims to provide readers with a new episteme to approach the field of Islamic art. Shaw hopes, she writes, to move the conversation from the production of Islamic art to its reception, emphasizing commonalities across time and space. Above all, What Is "Islamic" Art?, recipient of the 2020 Albert Hourani Book Award Honorable Mention from MESA and the $28^{\text {th }}$ Iran's World Book Award, advocates for a philosophy that understands Islamic art as experiential and interactional, something she finds lacking in current scholarship. Shaw's book has enjoyed a mixed reception thus far, perhaps unsurprisingly, given its ambitious title.

Readers should approach this book with the understanding that it does not offer an answer to the question "What is Islamic art?" Rather, Shaw interrogates the question itself, and the title should be understood as challenging the boundaries of the discipline, encouraging her audience to think about whether the Western-defined field of art history is an appropriate model for conceiving of non-Western cultural production. Her working title, Fortress of Form, Robber of Consciousness ( $p .221$ ), far better encompasses the book, and one is curious as to what considerations in the publishing process led to the title under which the book ended up being distributed. Although Shaw's book does challenge what constitutes the field of Islamic art and, interestingly, pushes scholars away from visual understandings toward aural and performative ones, the book does not review historiographical debates about Islamic art, nor does it provide the type of

(C) 2021 Sarah Slingluff. This is an open access article distributed under the terms of the Creative Commons Attribution-NonCommercial-NoDerivatives License, which allows users to copy and distribute the material in any medium or format in unadapted form only, for noncommercial purposes only, and only so long as attribution is given to the original authors and source. 
analysis that its clear comparand, Shahab Ahmed's What Is Islam?, does. Reading it with this understanding, one can appreciate the novel arguments Shaw has to offer.

What Is "Islamic" Art? eschews the geographical and temporal organization that typically dominates introductory books in the field, and for that it deserves commendation. ${ }^{1}$ Instead of centering a particular place and time, Shaw chooses a structure that focuses on how the individual receives "art," then moves outward in considering reflections of the self before looking at how poets, philosophers, and makers conceived of "the image." Shaw begins with a discussion of "the Islamic image" (chapter 1) and then transitions from visual perception to audial reception in chapter 2 , "Seeing with the Ear." Chapters 3 ("The Insufficient Image") and 4 ("Seeing with the Heart") emphasize the importance of understanding the role of the divine in artistic production, arguing that Islamic art cannot be understood outside of an inspired tradition. At this point, Shaw moves the discussion away from the individual to a more relational approach, looking at the whats, hows, and whys of artists and their production. Chapters 5 through 8 explore the various webs and networks of makers, looking at what those who create are interacting with, how artists and patrons express their works in a variety of forms, and why art in Islamic traditions manifests in different genres. The book ends with discussions on geometry and perspective, which seem not to fit the flow of the narrative; instead, they read as addenda of issues not covered elsewhere. At times it is unclear why a particular topic follows another, an aspect that is particularly evident in the lack of transition between "Seeing through the Mirror" (chapter 5) and "Deceiving Deception" (chapter 6). On a macro level, this feature could be challenging for beginning scholars attempting to understand the field that Shaw intends to introduce. One is left with the feeling that this work could just as well have been published as a series of articles or, alternatively, as a much longer book that fully engages with all the issues upon which it touches.

Shaw's strongest chapter is her first, in which she joins a chorus of scholars, most recently Shahab Ahmed and Christiane Gruber, in attempting to debunk myths about the prohibition of figural imagery in Islamic art. ${ }^{2}$ Although many of her arguments are not novel, this concise look at the subject benefits from her unique voice. One's view of Shaw's writing style, with its abundant opinions and generalizations mixed with academic jargon, is a matter of preference. Her writing is often polarizing-frustrating for those who find it too casual or opinionated, energizing for those who appreciate her passion-and readers may grapple with both reactions while reading her work.

1. For a summary of historiographical approaches to survey texts of Islamic Art, see Sheila Blair and Jonathan Bloom, "The Mirage of Islamic Art: Reflections on the Study of an Unwieldy Field," Art Bulletin 85, no. 1 (2003): 152-184.

2. See Shahab Ahmed, What Is Islam? The Importance of Being Islamic (Princeton, NJ: Princeton University Press, 2016); Christiane J. Gruber, ed., The Image Debate: Figural Representation in Islam and across the World (London: Gingko, 2019); eadem, The Praiseworthy One: The Prophet Muhammad in Islamic Texts and Images (Bloomington: Indiana University Press, 2018). 
Yet for Islamic art historians, her willingness to be candid and clear about the supposed prohibition of figural image in Islamic art is welcome. Chapter 1 is masterful and should be required reading for every Introduction to Art History course, and perhaps for any course that touches on Islamic culture. Shaw's exasperation at the unending repetition of such an easily refutable myth echoes that felt by anyone who has had to teach and continuously explain its erroneousness-to both students and the general public-and her willingness to express these sentiments openly and forcefully in an academic text is long overdue. Though the chapter runs through the early history of Islam and the development of the Quran, hadith, and Sunni schools of jurisprudence at a breakneck pace that might leave those new to Islamic studies feeling overwhelmed, the overall arc of the chapter is well conceived and delivered. For those for whom the history moves too fast, the appropriate references are available for further investigation and study. For specialists, the coherent weaving together of seminal works on imagery in Islam is unmatched in current scholarship. Finally, Shaw's discussion of the ways in which twentiethcentury popular culture contributed to a modern understanding of an aniconic Islam is new and well argued.

Another novel contribution to the field is Shaw's focus on the role that poetry has played and continues to play in "express[ing] cultural roles for perception" of Islamic art (p. 25). As a result, poetry and the arts of the book form the core source base for her argument. What Is
"Islamic" Art? elucidates philosophies in Islamic poetry to explicate a theory of perceptual culture in Islamic art. This is a major shift in considering Islamic art as both a field and a corpus, a choice perhaps driven by Shaw's aim to integrate poetry as the progenitor of the illustrated manuscript tradition more fully into the study of Islamic art as well as by her stated goal of demonstrating the ubiquity of figural imagery in the arts of Islam. However, the choice to exclude other forms of Islamic art, including architecture, metalwork, ivories, and ceramics, from a book titled What Is "Islamic" Art? implies that readers have a working knowledge of the field prior to engaging with this work. In short, Shaw assumes her readers know that up until this point, Islamic art has not been defined the way she chooses to do in this book.

As Lawrence Nees has pointed out, the book's source base is surprisingly limited to the "Persianate" world. ${ }^{3}$ With the exception of one picture of the Sasanian Taq-e-Bustan and illustrations on her discussion of geometry in chapter 8 , all illustrations date to after the thirteenth century, and the majority were produced within the "Balkans-to-Bengal complex" as defined by Ahmed. Coverage of many areas, including North Africa and Southeast Asia, is almost nonexistent. As a result, many scholars of Islamic art can read the book without ever recognizing themselves or their area of research in its pages. There is a pronounced lack of images for an art-historical text, and despite the discussions of Islamic art as object, only the forms of painting and carved stucco

3. Lawrence Nees, review of What Is "Islamic" Art? Between Religion and Perception, by Wendy Shaw, CHOICE: Current Reviews for Academic Libraries 57, no. 10 (2020): 1081. 
appear in the work. Of course, to some extent this is Shaw's point: that Islamic art need not be defined by what we see with our eyes, and that there is far more to consider in terms of experiencing art than just what we process visually.

Shaw's least successful chapters are those in which she attempts to generalize about Islamic art history and its development in relation to the Late Antique and Early Medieval periods (chapters 4, "Seeing with the Heart," and 10, "Perspectives on Perspective"). It is clear that this is not her area of expertise, and her depiction of postNicene Creed (325 CE) Christianity as a monolith does to Christianity what she argues we must not do to Islam: paints it as an unnuanced, singular faith (p. 106). This is the greatest fault of the book: Shaw's unfamiliarity with Late Antique culture leads her to see differences as "Christian"/"Christianate"/"Western" versus "Islamic," and while she convincingly argues that this dynamic began in the late Middle Ages with "Renaissance" and "Enlightenment" thought and was later entrenched in European hegemony and colonization, this binary simply does not work as a framework for the Late
Antique and Early Medieval periods. ${ }^{4}$ Shaw's unfamiliarity with this time period and the scholarship on it reveals a lack of understanding of methods in and approaches to premodern "art." In chapter 10 , she repeatedly states that Christian art lacks a "multi-centered mode of viewing the world," seemingly unaware that for the first one thousand years of "Christian" art, makers depicted expressions of space from "an infinite network of focal points" in both two-dimensional and three-dimensional pieces (pp. 314, 325). ${ }^{6}$ This seems a missed opportunity; readers wait for a discussion that never comes on how theoretical approaches tied to pre-perspectival theories of medieval art might be useful in the study of Islamic cultural perception.

Similarly, the discussion in her longest chapter, "The Transgressive Image" (chapter 7), inhabits this Christian vs. Islamic dynamic that she criticizes in her assessments of early scholars in the fields of art history and Islamic art, particularly Alois Riegl, Erwin Panofsky, Ernst Kühnel, Oleg Grabar, and Owen Jones. In this chapter, Shaw regularly juxtaposes Islam and Christianity, forcing comparisons that may not be appropriate.

4. It is also of some concern that Shaw never explains why she accepts Ahmed's definition of "Christianate" but rejects the use of "Islamicate," referring the reader only to Ahmed's work in a footnote. This sets up a strange tension between Christianate vs. Islamic art, which is never fully explained. Though many scholars have discussed the problems with projecting nineteenth- and twentieth-century cultural dynamics onto the medieval period, perhaps the most succinct discussion of works in the field of Ottoman studies, and thus the Balkans-to-Bengal complex, can be found in Alan Mikhail and Christine M Philliou, "The Ottoman Empire and the Imperial Turn," Comparative Studies in Society and History 54, no. 4 (2012): 721-45.

5. For further reading on challenging approaches to medieval art, see Miriam Schild Bunim, Space in Medieval Painting and the Forerunners of Perspective (New York: Columbia University Press, 1940) and Meg Boulton, “The End of the World as We Know It': The Eschatology of Symbolic Space/s in Insular Art," in Making Histories: Proceedings of the Sixth International Insular Arts Conference, ed. Jane Hawkes, 279-90 (Donington: Shaun Tyas, 2013).

6. For similar essentializing assertions about the perspectival nature of Christian art, see pp. 300, 301, 305, 306,319 , and 321. 
The crux of this chapter revolves around Islamic artistic renderings of the story of Joseph, Zuleikha, and Potiphar, dominant in the poetic and artistic corpus of Islam, and their comparison with Christian depictions of the same story. Although one sees why she chose this story as representative for Islam, the Potiphar story has relatively little importance in the Christian tradition and as such provides a poor example from which to make sweeping generalizations about Christian art. One wonders why the comparison to Christian art is necessary, given the strength of her argument concerning the indivisibility of painting and poetry evinced in her chosen exemplar.
Ultimately, a tension between defining and interrogating the field of Islamic art persists throughout the book. The attempt to explain the field to a novice audience, coupled with the deep theoretical discussions that could only make sense to those well versed in both art history and Islamic art history, results in a lack of cohesion. However, one should not dismiss the questions that Shaw begs us to consider. Despite its shortcomings, the book is a valuable contribution. What Is "Islamic" Art? seeks to answer a question, but perhaps more importantly, it challenges readers to think about what questions we ask and why. 


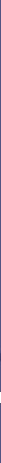

\section{EDITORS}

Antoine Borrut, University of Maryland

Matthew S. Gordon, Miami University Alison Vacca, University of Tennessee, Knoxville

\section{MANAGING EDITOR}

Christiane-Marie Abu Sarah, Erskine College

Al-`Ușūr al-Wusțā (Editorial Office)

Antoine Borrut, Editor

Department of History, University of Maryland

2115 Francis Scott Key Hall,

College Park, MD 20742-7315 USA

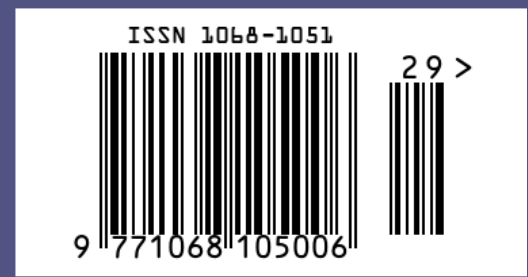

